\title{
REFERENCE COPY
}

ERDAZ4

\section{GULF COAST}

\section{PROGRAMMATIC ENVIRONMENTAL ASSESSMENT GEOTHERMAL WELL TESTING .}

\section{THE FRIO FORMATION OF TEXAS AND LOUISIANA}

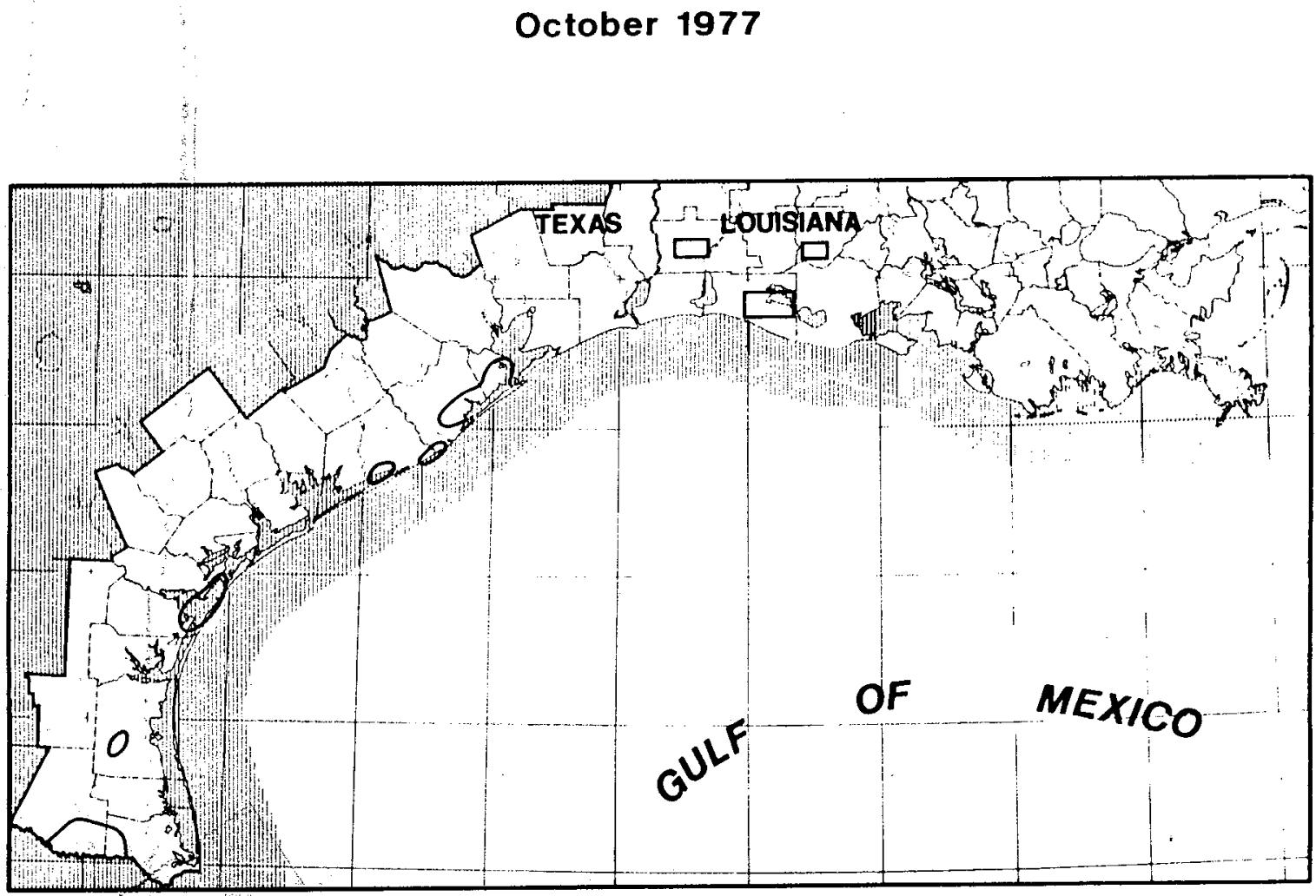

DIVISION OF GEOTHERMAL ENERGY

ENERGY RESEARCH AND DEVELOPMENT ADMINISTRATION 


\section{DISCLAIMER}

This report was prepared as an account of work sponsored by an agency of the United States Government. Neither the United States Government nor any agency Thereof, nor any of their employees, makes any warranty, express or implied, or assumes any legal liability or responsibility for the accuracy, completeness, or usefulness of any information, apparatus, product, or process disclosed, or represents that its use would not infringe privately owned rights. Reference herein to any specific commercial product, process, or service by trade name, trademark, manufacturer, or otherwise does not necessarily constitute or imply its endorsement, recommendation, or favoring by the United States Government or any agency thereof. The views and opinions of authors expressed herein do not necessarily state or reflect those of the United States Government or any agency thereof. 


\section{DISCLAIMER}

Portions of this document may be illegible in electronic image products. Images are produced from the best available original document. 
GULF COAST

PROGRAMMATIC ENVIRONMENTAL ASSESSMENT

GEOTHERMAL WELL TESTING

THE FRIO FORMATION OF TEXAS AND LOUISIANA

DIVISION OF GEOTHERMAL ENERGY

ENERGY RESEARCH AND DEVELOPMENT ADMINISTRATION

This EA exists in two volumes, this one and an Atlas. The Plate numbers in this volume refer to the Atlas. 
TABLE OF CONTENTS

PAGE NUMBER

LIST OF.FIGURES . . . . . . . . . . . . . . . . . vi

LIST OF TABLES. . . . . . . . . . . . . . . . . . ix

CHAPTER ONE - DESCRIPTION OF THE PROPOSED ACTION. . . . . . . 1-1

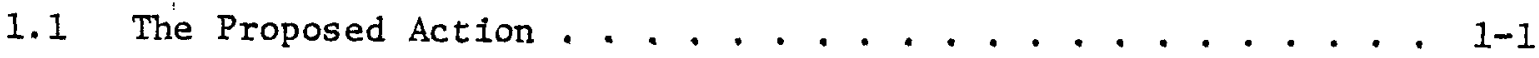

1.1.1 Objectives of Proposed Action . . . . . . . . . . 1-1

1.1.2 Scope of Project. . . . . . . . . . . . . . . 1-2

1.2 Location. . . . . . . . . . . . . . . . . 1-8

1.2.1 The Region. . . . . . . . . . . . . . . . 1-8

1.2.2 The High Potential Zone. . . . . . . . . . . 1-8

1.3 Known Environmental Issues. . . . . . . . . . . . . 1-9

1.3.1 The Physical and Biological Issues - A Summary

of Adverse Impacts. . . . . . . . . . . . . . . 1-9

1.3.2 The Cultural Issues - A Sumary of

Adverse Impacts . . . . . . . . . . . . . . . 1-10

1.3.3 The Economic Issues - A Summary of

Adverse Impacts . . . . . . . . . . . . 1-11

CHAPTER TWO - DESCRIPTION OF THE EXISTING ENVIRONMENT . . . . . . 2-1

2.1 Geology .................... . . 2-1

2.1 .1 Geomorphology .................. 2-1

2.1.2 Geology ..................... 2-3

2.1.3 Tectonic Activity . . . . . . . . . . . . 2-6

2.1.4 Mineral Resources .. . . . . . . . . . . . . . 2-8

2.1.5 Geology of the Geothermal-Geopressured Belt . . . . 2-9

2.2 Hydrology and Water Use . . . . . . . . . . . . 2-12

2.2.1 Groundwater Hydrology and Use........... 2-12

2.2.2 Surface Water................. 2-19

2.3 Terrestrial Ecology . . . . . . . . . . . . . 2-20

2.3.1 Wetlands. .................. $2-21$

2.3.2 Pleistocene.................. 2- 2 23

2.4 Aquatic Ecology .. . . . . . . . . . . . . . . 2-25

2.4.1 Wetlands. . . . . . . . . . . . . 2-25 
TABLE OF CONTENTS

(Continued)

PAGE NUMBER

2.5 Endangered Species,. . . . . . . . . . . . 2-33

2.5.1 Terrestrial ............... 2-33

2.5.2 Aquatic................ 2-33

2.6 Land Use. . . . . . . . . . . . . . . . 2-36

2.7 Climate and Air Quality .............. . . 2-38

2.7 .1 Climate................ 2-38

2.7.2 Regional Air Quality. . . . . . . . . . . . 2-39

2.7.3 Atmospheric Inversion Potential . . . . . . . . 2-40

2.7.4 Emission Inventory. .............. . 2-40

2.8 Cultural Resources. . . . . . . . . . . . . . . 2-41

2.9 Socioeconomic Characteristics . . . . . . . . . . . 2-42

2.9.1 Employment. . . . . . . . . . . . . . 2-42

2.9.2 Economy .. . . . . . . . . . . . . . 2-42

2.9.3 Population, Demography, Ethnic Make-up. . . . . . 2-43

2.10 Prime Areas of Geopressure-Geotherma1 Interest. . . . . . 2-45

2.10 .1 Southwest Louisiana . . . . . . . . . . . . 2-45

2.10.2 Brazoria and Galveston Counties, Texas. . . . . . 2-55

2.10.3 Matagorda County. . . . . . . . . . . . . 2-63

2.10.4 Nueces, San Patricio, and Aransas Counties. . . . 2-68

2.10 .5 South Texas ............... 2-73

CHAPTER THREE - POTENTIAL ENVIRONMENTAL IMPACTS . . . . . . . . 3-1

3.1 Installation and Maintenance of Well. . . . . . . . . 3-1

3.1.1 Physical and Biological Issues. . . . . . . . . 3-1

3.1.2 Cultural Issues .. . . . . . . . . . . . 3-6

3.1.3 Economic Impacts. . . . . . . . . . . 3-10

3.2 Normal Effluents from Operation of Well . . . . . . . . 3-12

3.2.1 Biological Issues . . . . . . . . . . . 3-22

3.2.2 Cultural Issues... . . . . . . . . . . 3-23

3.3 Accidents . . . . . . . . . . . . . 3-25

3.3.1 Physical and Biological Issues. . . . . . . . 3-25

3.3.2 Cultural Issues........ . . . . . . 3-44 
TABLE OF CONTENTS

(Continued)

PAGE NUMBER

3.4 Impact Contro1 Program Including Restoration

of Well Site. . . . . . . . . . . . . . . . 3-45

3.4.1 Blological Issues .. . . . . . . . . . . 3-47

3.4.2 Cultural Issues... . . . . . . . . . 3-49

CHAPTER FOUR - COORDINATION WITH FEDERAL, STATE, REGIONAL AND LOCAL LEVELS OF GOVERNMENT .......... . 4-1

4.1 Federal Regulation and Permitting Requirements. . . . . . . 4-1

4.1.1 Geothermal Leasing on Federal Lands . . . . . . . 4-1

4.1.2 Degradation of the Environment. . . . . . . . . . 4-1

4.1.3 Act1vities on Navigable Waters. . . . . . . . . 4-5

4.2 State Plans and Policies. . . . . . . . . . . 4-6

4.2.1 State Land Use Plans. . . . . . . . . . . . 4-6

4.2.2 Coastal Zone Management Plans............ 4-6

4.2.3 State Well Drilling Procedures. . . . . . . . . 4-6

4.2.4 State Archeological and Historic

Survey Requirements ..... . . . . . . . . 4-7

4.2.5 State Environmental Requirements - Waste

Fluid Disposal. . . . . . . . . . . . . 4-7

4.2.5.1 Surface and Subsurface Permitting

Procedures at the State Level . . . . . . 4-7

4.2.5.2 Air Emission Regulatory and Permitting

Procedures at the State Leve1... . . 4-7

4.3 Regional and Local Plans and Policies........... . 4-7

APPENDIX A - DESCRIPTION OF THE EXISTING ENVIRONMENT. . . . . . A-1

2.1 Geology .. . . . . . . . . . . . . . . . $\mathrm{A}-1$

2.1.1 Geomorphology . . . . . . . . . . . . . A-1

2.1 .2 Geology ..................... $\mathrm{A}-14$

2.1.3 Tectonic Activity . . . . . . . . . . . A-20

2.1 .4 Mineral Resources .............. . . . A-24

2.1.5 Geology of the Geothermal-Geopressured Belt . . . . A-25

2.2 Hydrology and Water Use . . . . . . . . . . . . A-28

2.2.1 Groundwater Hydrology and Use . . . . . . . . A-28

2.2.1.1 Horizontal and Vertical Extent

of Aquifers . . . . . . . . . . . A-28 
TABLE OF CONTENTS

(Continued)

PAGE NUMBER

2.2.2 Surface Water. . . . . . . . . . . . A-43

2.2.2.1 General Hydrology .......... A-43

2.2.2.2 Drainage Basins and Rivers, . . . . . . A-46

2.2.2.3 Precipitation and Runoff. . . . . . . A-47

2.2.2.4 Physical Characteristics of

Regional Hydrology. . . . . . . . . A-49

2.2.2.5 Water Quality Characteristics...... A-50

2.2.2.6 Water Resource Development. . . . . . A-57

2.3 Terrestrial Ecology . . . . . . . . . . . . . A-59

2.3.1 Wetlands.................. A-60

2.3.2 Pleistocene.............. A-68

2.4 Aquatic Ecology . . . . . . . . . . . . . A-73

2.4.1 Wetlands. . . . . . ......... A-73

2.5 Endangered Species. . . . . . . . . . . . . . A-97

2.5.1 Terrestrial . . . . . . . . . . . . A-97

2.5.2 Aquatic.................. A-102

2.6 Land Use. . . . . . . . . . . . . . . A-108

2.7 Climate and Air Quality .............. A-117

2.7.1 Climate... . . . . . . . . . . . . A-117

2.7.2 Regional Air Quality. . . . . . . . . . . . . A-120

2.7.3 Atmospheric Stability Classes... . . . . . . . A-124

2.7.4 Atmospheric Inversion Potential . . . . . . . . A-126

2.7 .5 Emission Inventory. . . . . . . . . . . A-129

2.8 National Landmarks. . . . . . . . . . . . . . A-129

2.8.1 State Landmarks . . . . . . . . . . . . . A A-131

2.8.2 Cultural Resources. . . . . . . . . . . . . A-132

2.8.3 Survey Standards. . . . . . . . . . . A-133

2.9 Socioeconomic Characteristics . . . . . . . . . . A-135

2.9.1 Employment. . . . . . . . . . . . . . A-135

2.9.2 Economy . . . . . . . . . . . . . . . . A-135

2.9.3 Population, Demography, Ethnic Make-up. . . . . . A-140 
TABLE OF CONTENTS

(Continued)

PAGE NUMBER

APPENDIX B - POTENTIAL ENVIRONMENTAL IMPACTS, , , , , . . B-1

3.1 Installation and Maintenance of Well, ., ., , , . , B-1

3.1.1 Physical and Biological Issues, ........... B-1

3.2 Normal Effluents from Operation of Well , , , , , . , B-4

3.2.1 Biological Issues,................. B-4

3.3 Accidents . . . . . . . . . . . . . B-4

3.3.1 Physical and Biological Issues, ., . . . . . B-6

3.4 Impact Control Program Including Restoration of Well Site , B-16

3.4.1 Biological Issues . . . . . . . . . . B-16

APPENDIX C - COORDINATION WITH FEDERAL, STATE, REGIONAL AND

LOCAL GOVERNMENTS. . . . . . . . . . . . . C-1

4.1 Federal Regulation and Permitting Requirements. ........ C-1

4.2 State Plans and Policies. . . . . . . . . . . . C-14

4.2.1 State Land Use Plans - Parks, Refuges, etc. . . . . C-15

4.2.2 Coastal Zone Management Plans . . . . . . . . . . C-18

4.2.3 State Well Drilling Procedures. . . . . . . . . . . C-18

4.2.4 State Archeological and Historic Survey

4.2 .5 Requirements. . . . . . . . . . . . . C-20

State Environmental Requirements. . . . . . . . C-21

4.2.6 Other State Permitting Procedures... . . . . C-24

4.3 Regional Plans and Policies..., . . . , , . . C-25

4.4 Local Plans... . . . . . . . . . . . C-26

REFERENCES, , , , , , , , , , , , , , , , , R-1 


\section{LIST OF FIGURES}

FIGURE NUMBER

PAGE NUMBER

2-1 Geologic section across south Texas coastal plain showing fault systems in major Cenozoic delta deposits, and their relation to the top of the Geopressure Zone . . . . . . . . . , 2-7

2-2 Types of reservoir seals necessary to preserve abnormal pressures. . . . . . . . . , 2-11

2-3 Location map showing the extent of the assessed geopressured zones and their division into subareas. . . . . . . . . . . . 2-13

2-4 Geohydrologic section from southeastern Texas to eastern St. Martin Parish, Louisiana . . . 2-48

2-5 Geohydrologic section from northern Beauregard Parish to southern Cameron Parish, Louisiana. . 2-49

2-6 Altitude of Piezometric surface in the ChicotAtchafalaya Aquifer in southwestern Louisiana, April, 1956 . . . . . . . . . . 2-50

2-7 Hydrologic section $A-A^{\prime}$, Harris and Brazoria Counties. . . . . . . . . . . . 2-57

2-8 Classification of irrigation waters in Brazoria County, Texas... . . . . . . . 2-59

2-9 Land-surface subsidence in the Houston area, Texas, 1943-1964............ , 2-61

2-10 Active surface faults and surface traces of extrapolated subsurface faults, Harris and Galveston Counties, Texas . . . . . . . 2-62

2-11 Profile of land-surface subsidence in Matagorda County, Texas, 1918-1951. . . . . 2-67

A-1 The deltaic plain of the Mississippi characterized by meander belts, natural levees, point bars, distributary systems, and interdistributary swamps and marshes. . . . . . . . . . . . $\mathrm{A}-2$

A-2 The generalized morphology of the Pleistocene surface of southeast Texas. . . . . . . . . A-5

A-3 Detailed morphology of the Pleistocene fluvial facies in the Beaumont-Port Arthur Area, Southeast Texas .. . . . . . . . . . A-6 


\section{LIST OF FIGURES}

(Continued)

FIGURE NUMBER

PAGE NUMBER

A-4

Prime or unique soils of Louisiana. . . . . . . A-12

A-5 Thickness of Cenozoic deposits in the Gulf

Coast Geosyncline.... . . . . . . . A-15

A-6 Generalized cross-section of the Gulf Coast

Geosyncline . . . . . . . . . . . A-16

A-7 Diagrammatic dip section through the Rio Grande embayment showing strata thickening across growth faults.... . . . . . . . . . A-18

A-8 Typical regional cross-section of formations under the study area. . . . . . . . . . . . A-19

A-9 Geologic section across south Texas coastal plain showing fault systems in major Cenozoic delta deposits, and their relation to the top of the Geopressure Zone . . . . . . . . . . A-21

A-10 Structure contour map of Dickinson, Gillock, and South Gillock fields, Galveston County, Texas, showing central graben and complex radial fault pattern. . . . . . . . . . . A-22

A-11 Collapse fault system associated with the Chacahoula salt-dome of Assumption Parish, Louisiana . . . . . . . . . . . A-23

A-12 Types of reservoir seals necessary to preserve abnorma1 pressures. . . . . . . . . A-26

A-13 Location map showing the extent of the assessed geopressured zones and their division into subareas. . . . . . . . . . . . . A-29

A-14 Changes in total dissolved solids concentrations of produced waters from sandstones with depth, from wells where high pressure is present and not present............. A-40

A-15 Plot of measured temperatures versus depth which shows increased temperature gradient at top of high-pressure zone. . . . ., . . . . , A-40

A-16 Isohaline map of the Louistana coast, , , . A-45

A-17 Average annual precipitation, inches, . . . . A-47 


\section{LIST OF FIGURES \\ (ContInued)}

FTGURE NUMBER

PAGE NUMBER

A-18

Normal annual runoff, inches.,. . . .. : A-48

A-19.

Gulf of Mexico shrimp fishing zones , , . . . A-88

A-20

Historic range (a) and present known range (b)

of the red wolf (Canis rufus)......... . A-99

A-21 Migration route of whooping crane . . . . . A-107

A-22 Breakdown of land use types with in the study

area. . . . . . . . . . . . . A $\mathrm{A}-112$

A-23 Earliest and latest tropical cyclone occurrences

for the period 1886-1970, . . . . . . . . A-119

A-24 Cyclone probabilities for coastal sector along

Gulf and Atlantic Seaboard. . . . . . . . . A-120

A-25 Isopleths of nighttime (A) Winter, (B) Spring,

(C) Summer, (D) Fal1, (E) Annua1. . . . . . . A-127

A-26 Inversion frequency (percent of total hours)

(A) Winter, (B) Spring, (C) Summer, (D) Fall,

(E) Annual. . . . . . . . . . . A-128

A-27 U.S. emission density maps for various

parameters. . . . . . . . . . . . A-130 


\section{LIST OF TABLES}

TABLE NUMBER

PAGE NOMBER

2-1 Geologic Column for the Study Area, . , . . . 2-5

2-2 Area1 Extent and Average Pressure, Temperature, and Salinity Conditions in Each Subarea . . . . 2-14

2-3 Geopressured Manchester Field Compared with

Normal Pressured Hackberry Field, . : . . . 2-15

2-4 Groundwater Pumpage in Southwest Louisiana. . . 2-47

2-5 Water Quality Characteristics of Selected

Streams in the Study Area...,...., , 2-53

2-6 Geologic and Hydrologic Units of the Texas and Louisiana Coastal Plain . . . . . . . 2-58

2-7 Methods and Quantity of Saltwater Disposed in 1961, Matagorda County, Texas . . . . . , 2-65

2-8 Records of Brine Injection and Disposal Wells

in Matagorda County, Texas. . . . . . . . 2-65

2-9 Water Chemistry of Geopressured Zone in the

Middle Texas Gulf Coast Areas . . , . . . , , 2-69

2-10 Methods of Disposal and Quantity of Saltwater

Disposed in Nueces and San Patriclo Counties

in 1961 . . . . . . . . . . . . 2-71

2-11 Methods of Disposal and Quantity of Saltwater

Disposed in Aransas County in 1961. . . . . . 2-72

2-12 Water Chemistry of Geopressured Zone in the

South Texas Gulf Coast Area . . . . . . . . 2-75

3-1 Estimated Disturbance Due to Installation of the Well. . . . . . . . . . . . . . 3-3

3-2 Noise Criteria Not to be Exceeded for Geotherma1Related Activities. . . . . . . . . . 3-9

3-3 Water Chemistry of Geopressured Zone in the South and Middle Texas Gulf Coast Area, . . . . 3-14

3-4 Water Chemistry of Geopressured Zone in the Manchester Field, Calcasieu Parish, Southwest Louisiana ... . . . . . . . . . . 3-15

3-5 Concentrations of Dissolved Ions in Sea Water , . 3-17 
LIST OF TABLES

(Continued)

TABLE NUMBER

PAGE NUMBER

3-6

EPA Suggested Water Quality Criteria, , . . . 3-18

3-7 Relative Hazard of Known Geothermal Fluid

Constituents, ., . . . . . . . . . 3-19

3-8 Total Dissolved Solids Concentration of Surface

Waters that Have Been Used as Sources for

Industrial Water Supplies . . . . . . . , 3-20

3-9 Some Constituents Used in Drilling Fluids

and Muds, : . . . . . . . . . . . , . 3-24

3-10 Constituents in Geopressured Brines of

Environmental Concern . , , , . , , , 3-32

3-11 Factors Tending to Influence Geothermal

Subsidence. . . . . . . . . . . , 3-38

3-12 Aquifer, We11, and Fluid Data for the

Hypothetical Problem. . . . . . . . . . 3-39

3-13 Fluid Withdrawal Rates and Geopressure.

Responses . . . . . . . . . . . . 3-40

4-1 Matrix of Federal and State Actions on Geopressure-Geothermal Well Testing Activities

and Related $0 i 1$ Activities. . . . . . . . 4-2

A-1 Recognized Pleistocene Terraces in Louisiana

and Texas . . . . . . . . . . . . $\mathrm{A}-4$

A-2 Soils Groups of the Texas Study Area, . . . . . . A-7

A-3 Soils Groups of the Louisiana Study Area, . . . A-10

A-4 Geologic Column for the Study Area. . . . . . . A-18

A-5 Areal Extent and Average Pressure, Temperature,

and Salinity Conditions in Each Subarea . . . A $\mathrm{A}-30$

A-6 Geopressured Manchester Field Compared with

Normal Pressured Hackberry Field, . . . . . . A-31

A-7 Geologic and Hydrologic Units of the Texas and

Louisiana Coastal Plain.... . , . . . . A-33

A-8 Geologic Formations and Their Water-bearing

Characteristics in the Texas Coastal Region . . A-35 
$A-9$

Geologic Formations and their Water-bearing Characteristics tn the Mississippi River Area, Loulsiana . . . . . . . . . . , . . A-37 Major Drainage Basins and Rivers. . . . . . . A-46 Runoff as a Percent of Precipitation on Various Surfaces. . . . . . . . . . . . A-49 Physical Characteristics of Drainage Basin, . . A-51 Water Quality Characteristics of Selected Streams in the Study Area . . . . . . . . . . . A-53 Water Quality Criteria for Selected Variables , A-55

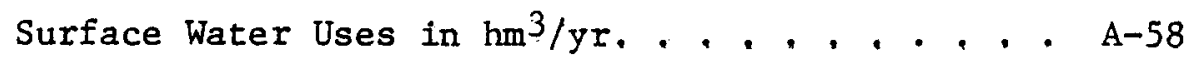

Type and Number of Major Industrial Discharges by State. . . . . . . , . . . . . A-59 Vegetation of the Study Area, . . . . . . . A-64 Distribution of Diving and Dabbling Ducks as Indicated by Harvest Trends, Louisiana and Texas Coast - 1961-1970. . . . . . . . A-76

Mammals Occurring in Study Area of Louisiana and Texas (Excluding Marine Mammals). . . . . A-81 Average Annual (1970-1973) Louisiana and Texas Landings from Marine and Coastal Waters.... A-85 Areas of Marsh and Water with Percentages of the Northern Gulf Shrimp Catch by Fishing Zones . . A-89

Terrestrial Vegetation - Proposed Endangered Species , . , . , . . ., . , , , A-98

Endangered or Threatened Specles List of Coastal Louisiana and Texas... . . . . . A-100 Aquatic Vegetation - Proposed Endangered Species . . . . . . . .. . . . . A-103 Areas of Land Use in Louisiana Parishes in the Study Region, , . . . , . : . , , A-110 
LIST OF TABLES

(Continued)

TABLE NUMBER

PAGE NUMBER

$\mathrm{A}-26$

Areas of Land Use in Texas Counties in the

Study Region, : , , , , , , , , , , A-111

A-27 State Parks in the Loulsiana and Texas Study

Area, . . . . . . . . . , , . A-115

A-28 National Wildlife Refuges in Coastal Louisiana

and Texas....., . . . . . . . . , A-116

A-29 State Wildlife Management Areas and Preserves . A-116

A-30 National Audubon Society Sanctuaries in Texas

and Loulsiana. . . . . . . . . . . . A-117

A-31 Summary of National Ambient Air Quality

Standards . . . . . . . . . . . . A-121

A-32 Air Quality Data for Particulate, Micrograms

per Cubic Meter... . . . . . . . . A-122

A-33 Stability Classes and Wind Speed Measured Near

Taft, Louisiana, from May 1972 through April

1973. . . . . . . . . . . . . . A-125

A-34 Stability Classes and Wind Speed Measured Near

Houston, Texas, from August 1972 through July

1973. . . . . . . . . . . . . . A-126

A-35 Total Employment and Employment in Selected

Occupations . . . . . . . . . . . . . A-136

A-36 Population, Median Family Income, and Median

Number of School Years by Parish. . . . . . . A-138

A-37 Population, Median Family Income, and Median

Number of School Years by County. . . . . . . A-139

A-38 Total Population, Percentage of Population by

Race and Also Percentage of Spanish Speakers

by Parish . . . . . . . . . . . . . A-141

A-39 Value of Agricultural and Mineral Production in

Louisiana by Parish . . . . . . . . . . A-144

A-40 Value of Agricultural and Mineral Production in

Texas by County... . . . . . . . . . A-145

C-1 List of Federal Agencies Contacted Regarding

Coordination of the Proposed Action . . . . . C-2 


\section{LIST OF TABLES}

(Continued)

TABLE NUMBER

PAGE NUMBER

$\mathrm{C}-2$

Matrix of Federal and State Actions on Geopressure-Geothermal Well Testing Activities and Related Oil Activities, . . . . . . . C -5 
CHAPTER ONE - DESCRIPTION OF THE PROPOSED ACTION

\subsection{The Proposed Action}

\subsubsection{Objectives of Proposed Action}

In accordance with the requirements of 10 CFR Part 711 , environmental assessments are being prepared for significant activities and individual projects of the Division of Geothermal Energy (DGE) of the Energy Research and Development Administration (ERDA). This environmental assessment of geopressure well testing addresses, on a regional basis, the expected activities, affected environments, and possible impacts in a broad sense. The specific part of the program addressed by this environmental assessment is geothermal well testing by the takeover of one or more unsuccessful oil wells before the drilling rig is removed and completion of drilling into the geopressured zone.

Along the Texas and Louisiana Gulf Coast (Plate $I$ and Overlay) water at high temperatures and high pressures is trapped within Gulf basin sediments. The water is confined within or below essentially impermeable shale sequences and carries most or all of the overburden pressure. Such zones are referred to as geopressured strata. These fluids and sediments are heated to abnormally high temperatures (up to $260^{\circ} \mathrm{C}$ ) and may provide potential reservoirs for economical production of geothermal energy.

The obvious need in resource development is to assess the resource. Ongoing studies to define large-sand-volume reservoirs will ultimately define optimum sites for drilling special large diameter wells to perform large volume flow production tests. In the interim, existing well tests need to be made to help define and assess the resource. 


\subsubsection{Scope of Project}

The project addressed by this environmental assessment is the performance of a geothermal well test in high potential geothermal areas. Well tests involve four major actions each of which may or may not be required for each of the well tests. The four major actions are: site preparation, drilling a saltwater disposal well, actual flow testing, and abandonment of the well.

(1) Site Preparation - The use of existing oil wells for yielding geopressured resource information is essential at this time. Because the wells are presently in existence, road construction and most site preparation will have been accomplished although some modification may be required to perform geopressured formation testing (e.g., disposal well drilling). Most of these prior actions will have been in compliance with environmental regulations as followed by the oil and gas industry. Certain modifications may need to be made to make use of high pressure gas separators to measure the natural gas entrained in geopressured fluids. Inasmuch as existing well sites may be on land, in marshes or adjoining inland waterways, these minor modifications may be of different forms. In all cases, the rig should be on location and dredging, reserve pits, etc., will have been completed and no additional significant site preparation will need to be done other than the possible site preparation, drilling and completion of disposal wells.

(2) Drilling - Two drilling operations are possible during the proposed action. First, the well which is selected for the flow test may be deepened to penetrate a more desirable formation. This will require using the existing drill pad, structure, and avenues of access. There should be no additional land or other resources needed for this action. 
Second, existing saltwater disposal wells will be used if they are available. If no disposal wells are available, one well will be drilled to a suitable brine disposal depth. Each well tested will produce approximately 300,000 barrels of geopressured fluid that may have salinities ranging from 10,000 to $80,000 \mathrm{mg} / 1$. The water will be disposed of in a saltwater-bearing sand formation with salinities ranging from 20,000 to $60,000 \mathrm{mg} / 1$ at approximate depths of $763 \mathrm{~m}$ to $915 \mathrm{~m}(2,500$ to $3,000 \mathrm{ft})$. If a disposal well is required, it will be drilled and tested prior to the testing of the production well. A possible alternative arrangement is that an existing adjacent well may be available for the disposal of residue brines.

Drill-pad construction requires that an area of about 0.4 to 0.8 ha (one to two acres) be levelled and cleared of vegetation. The pad area will provide space for the drilling rig and accessories, temporary structures, parking, and maneuvering room for service and delivery vehicles. The pad may be surfaced with rock or gravel. A reserve pond of several square meters to several hundred square meters (several hundred to several thousand square feet) in area and 2 to $3 \mathrm{~m}$ ( 5 to $10 \mathrm{ft}$ ) deep, depending on the depth of the hole, will contain waste fluids and drill cuttings. The pond will be lined with impervious material to reduce leaching and groundwater contamination. Portable sanitary facilities will be provided for construction crews, and construction wastes will be disposed of at suitable spoil sites. Approximately 6 to 15 persons may be present on the site at any particular time.

Some $297,360 \mathrm{~m}^{3}\left(10.5\right.$ million $\left.\mathrm{ft}^{3}\right)$ of gas will result from the production testing and will be flared at the site. Flaring of gas at such operations is a frequently occurring action and no monitoring of resultant air pollution has been done. 
(3) Flow Testing - After the drilling and completion of the disposal well, tests will need to be conducted to test well integrity and to determine the volume of water the disposal well will accept. The production well, which may need to be deepened if it has not penetrated geopressured formation, will be used for flow tests designed to determine the capacity of the geopressured reservoir and the rates at which the reservoir can be produced. For these flow tests, the water will flow from the formation through the casing to surface test equipment because of the difference in pressure. At the surface, the water will go into a separator to separate natural gas, condensate, and water. The natural gas w111 be burned; the condensate stored; and the water possibly used, prior to its being reinjected in the disposal well, to drive a geopressured hydraulic turbine-generator. The turbine-generator, if it is used at all, will convert hydraulic energy of the water into electrical power in very limited tests of conversion techniques and equipment. One or more geopressured aquifers may be tested at each well for flow characteristics, fluid composition, temperature and gas content, depending on the geopressured formations penetrated. During well testing the well is vented to the surface, causing noise and the release of geothermal effluents. Noise may be abated by venting through a muffler system. The geothermal flow to the surface from a geopressured system will be a mixture of steam, noncondensable gases, liquid, and methane. During flow testing, the geothermal fluid will pass through a three-phase separator that will separate the fluid into non-condensable gas and methane; liquid; and condensate. Each effluent may then be disposed of in an appropriate manner. The duration of testing for each formation is not expected to exceed two weeks. If more than one formation is tested in a well, the total existing well test period is not anticipated to exceed four weeks. The total water production will be approximately 300,000 barrels for 
each well. This will be reinjected into the disposal well. The natural gas volume will be approximately $297,360 \mathrm{~m}^{3}$ (10.5 million $\left.\mathrm{ft}^{3}\right)(23-35$ standard cubic feet per barrel) which will be flared.

Equipment Test Facilities - Only limited testing of specialized equipment such as high pressure turbine-generators is considered in association with the well testing described in previous sections. Such equipment will be provided at the site and no effluent release or waste disposal is anticipated in addition to what has been previously described.

Construction - Because existing wells are to be used, the site will have been prepared with the necessary excavations and construction accomplished for the drilling operation. Minor site modification may need to be done to prepare. areas for the separator, fluid disposal piping and the disposal well. Land use and water use considerations will have been taken care of during the initial planning for the drilled well done by the commercial operator. The rig and its ancillary equipment will be self-contained with power provided by two or more diesel-electric or turbo-electric power units. All material required for the operation will be brought to the site and no indigenous materials will be used. Temporary structures will be those normally used in commercial oil and gas well operations. Waste disposal will be handled as described in previous sections. Noise production will be associated with the drilling of the disposal well, with workover and testing of the existing well and with plugging of the test well. Noise levels for a typical drilling rig have been measured to be $90 \mathrm{dBA}$ at 6 meters (20 feet) from the engine room. Existing wells typically will be remote from habitation, and well activities in the Gulf Coast have taken place for a 
number of decades. Additional noise sources may be dredging; crew boat, helicopter, and turbine operation; and the use of tools. Such sources are already temporarily present in the oil field area. The work force employed at the well site may range from six to twenty, depending on the activity taking place. Services such as logging, cementing, and perforating may require the presence of the higher number of personnel. During the testing phase, approximately ten people will be on site.

Well Maintenance - The presence of qualified personnel at the well site during testing will insure monitoring and control of production conditions. Since operator and industry-management personnel are all qualified and experienced in all phases of drilling, testing, and production operations, adequate well maintenance is assured. In the event of leaks or spills, detection and control should occur quickly and remedial action be taken immediately.

We11 Blowouts - Other than the flaring operation and exhaust gases from combustion engines described above and possible small volume gas venting associated with testing and sampling; the only possible exhaust of contaminants into the atmosphere could occur from accidental well blowouts. A number of safety precautions will be used in an attempt to exclude such occurrences. The following items typically are used as precautions against the hazards of blowout:

1) blowout preventers (several may be in a stack) will be rated at 10,000 pounds per square inch (psi) working pressure or greater to be safely above the anticipated surface pressures of geopressured formations; 
2) production tubing with pressure rating to 20,000 psi working pressure;

3). test tree with 10,000 psi working pressure and containing safety valves and kill lines for controlling high pressures;

4) safety valves capable of being closed from a remote location;

5) use of weighted mud and high pressure mud pumps capable of pumping mud into the well to control high pressures;

6) use of special high pressure engineers and mud engineers to monitor and evaluate test conditions;

7) means for monitoring and controlling sand erosion problems that may develop during flow tests;

8) equipment with high working pressure ratings to handle the pressures expected to be encountered. Adequate safety valve will also be specified in the system design; and

9) if the site is in a water area, a drilling rig with spill prevention control and counter-measure plan as required by Federal law.

(4) We11 Abandonment - With completion of the well tests, and subject to the operator's plan for production well disposition, the source well and the disposal well will be abandoned and the surface location cleaned up. Mud pits and reserve pits will be drained of free water and this water pumped in to the disposal well prior to its abandonment. The pits will be filled and the area will be left in as natural a condition as possible. The production well and disposal wells will be plugged and abandoned in compliance with appropriate state rules and regulations. 


\subsection{Location}

\subsubsection{The Region}

This environmental assessment considers only geopressured wells of opportunity in the Frio Formation of Texas and Loulsiana (Overlay). The study area extends from the Louisiana-Mississippi state line on the east to the Mexican border on the west. In Louisiana, the area of study is south of an east-west line which is 100 to $160 \mathrm{~km}$ (60 to $100 \mathrm{mi}$ ) inland from the Gulf of Mexico. In Texas, the study area is the first tier of counties inland from the Gulf of Mexico except at the western extreme in lower Texas where the study area extends inland from the shoreline two counties.

\subsubsection{The High Potential Zone}

Within the region are selected areas of particular interest to the well-testing program. Each zone covers a large area; temperatures are high; sands are sufficiently thick; and the subsurface fluid pressures significantly exceed the normal hydrostatic pressure to warrant special consideration. There are three of these zones in southwestern Louisiana, one each in Calcasieu, Acadia and Cameron Parishes (Overlay). In Texas, there are six areas, one covering parts of Brazoria and Galveston Counties, two in Matagorda County, one covering sections of Nueces, San Patricio, and Aransas Counties, one in Kenedy County, and one in Hidalgo and Cameron Counties. Special emphasis is directed to these areas in this environmental assessment because of their nature and the high probability of their having a well site selected during this testing program. 


\subsection{Known Environmental Issues}

1.3.1 The Physical and Biological Issues - A Summary of Adverse Impacts

(1) Upgrading of roads or canals to provide better access to the welltest site and the reinjection well will destroy vegetation. In some cases the vegetation removed will be wildlife, waterfowl, or fish habitat, or nursing grounds. The areal extent, degree, and length of time of the impacts will vary from one well site to another.

(2) Installation of a reinjection well will require clearing or dredging of about 1.2 hectares ( 3 acres) of land or wetland.

(3) Removal of vegetation and construction activities will result in increased runoff, erosion, and sediment concentration in streams.

(4) Contaminants will be introduced into the environment such as lubricants from vehicles and equipment and chemicals from spills and accidents. The degree of impact will depend on the type, amount, and duration of the spill or accident. Some species of flora will not be able to tolerate these occurrences and may be destroyed. Toxins may be picked up in the food chain and passed to herbivores and carnivores.

(5) Wildlife may be displaced by the human activity, noise, or accidents.

(6) Blowouts or other accidents may introduce chemical and thermal pollutants into surface and ground waters.

(7) Leakage from around casings may contaminate aquifers with chemical and thermal pollutants.

(8) Well testing may result in land subsidence. 
(9) Air quality will be adversely affected by the introduction of dust, vehicular emissions, and motor emissions assoclated with the well test program.

(10) There is the possibility of air pollution in the vicinity of the well-test site should a blowout occur. The intensity of pollution depends on the nature and volume of the emitted fluids and gases.

(11) Noise from machines and vehicles operating at the test site will raise the ambient noise level.

(12) There will be an odor associated with the release of $\mathrm{H}_{2} \mathrm{~S}$ into the atmosphere.

1.3.2 The Cultural Issues - A Summary of Adverse Impacts

(1) Some land use changes may occur as a result of the well test program. The area used for the reinjection well will be modified from its present status to an energy related use.

(2) Noise from the drilling and testing operation will affect the use of surrounding areas.

(3) If there should be residue left from operations or accidents at the site, selected future land uses may be limited.

(4) Some archeological sites may be located in the area needed for the test program. These sites will be surveyed and evaluated for mitigation.

(5) The aesthetic value of an area will be reduced by the presence of a drilling operation. 
1.3.3 The Economic Issues - A Summary of Adverse Impacts Adverse economic impacts will occur if there should be an accident or a massive spill of some kind. Should either of these two events occur, there may be a resulting land use change or contamination of a water supply. 
CHAPTER TWO - DESCRIPTION OF THE EXISTING ENVIROMMENT

\subsection{Geology}

\subsubsection{Geomorphology}

The Quaternary surfaces of the Gulf coastal plain of Texas and Louisiana are all clastic deposits transported to the study area by nine major rivers. From the Mississippi River to the Rio Grande, the coast described below is a series of deltaic and inter-deltaic plains (Plate 2).

Along the coast, the largest deltaic plain is a result of Mississippi River migration across southeast Louisiana. The deltaic plain is composed of distributary meander belts of natural levee, point bar, and channel fill deposits. Between the meander belts are interdistributary basins of inland swamps and - fresh to saline marshes grading toward the coast. Throughout the basins are lakes and bays connecting to the open gulf through a series of meandering tidal channels. Natural water movement across the deltaic plain is from the principal channels over the natural levees during flood or down the levee backslopes as a result of precipitation. Water moves by sheet flow over the natural levees and through the swamps and marshes until it is concentrated into sluggish channels feeding lakes and bays.

West of the Mississippi delta is the chenier plain of Louisiana and Texas. The chenier plain is a marsh wetland which is segmented by a series of abandoned beach ridges (Plate 2). Cheniers are formed during a transgressive (raising of sea level relative to land) phase when sediment is available to be transported and deposited along the shore because of the eastward migration of the Mississippi River. Water circulation, controlled by tides and winds, moves into and out of the area by tidal channels and across the marshes by sheet flow. 
From the chenier plain westward, the coast may be divided into relict deltaic plains, the barrier island complex, and the Rio Grande delta plain. Delta system physiography is similar to that described for the Mississippi River, but on $\dot{a}$ smaller scale and in proportion to the channel size. The inter-deltaic plain or the barrier island plain is composed of barrier islands and spits of sand dunes, beach ridges, swales, and tidal deposits. Behind the barriers are bays and lagoons which may be partially filled by mud and sand tidal flats. Smaller rivers are building deltas into the drowned river valleys in the older Pleistocene surfaces, slowly filling in the valleys as they advance into the bays. Water circulation through the bay-lagoon system is a product of tides and winds. Tidal channels cross the marshes and mudflats fringing the basins.

The higher lands in the study area are for the most part Pleistocene surfaces which lie between the Recent deposits along the shoreline and the youngest Tertiary outcrops. The depositional surfaces represent interglacial stages and are present along the coasts and up the river valleys as terraces which are very flat. Bernard and Leblanc (1965) describe the Quaternary of Texas and Louisiana as "a series of coalescing alluvial, deltaic and coastal inter-deltaic plains, developed principally by the major river systems..." (Plate 2).

One area along the south Texas coast which is different from the Pleistocene terraces is eolian plain. Sand dunes and clay-silt dunes veneer a $80 \mathrm{~km}(50 \mathrm{mi})$ stretch of the coast, and extend approximately $120 \mathrm{~km}(75 \mathrm{mi})$ inland. Farther inland in south Texas the Goliad formation (Pliocene) forms the uplands in the Rio Grande valley. The Goliad is a marine formation of poorly consolidated sands, silts, clays, pebbles, cobbles, and caliche.

Soils

The soil groups and unique solls of the study area are shown on Plate 3 and are described in Appendix . Overall, the soils of the study area are the product 
of deltaic progradation and retreat and subsequent weathering. Along the Texas coast, the soils range from the sandy loams underlain by caliche layers of the Rio Grande plain in the more arid areas near the Rio Grande, to calcareous clay loams and clays of the Gulf coast prairies in the more humid central part of the coast. Farther north along the Texas coast are the Gulf coast marshes, a little-developed clay soil with white sand ridges. Inland from the southern coast of Texas, the soils remain sandy and underlain by a caliche layer. Northwest from the Gulf coast prairies, the soils are sandy loams over a dense clayey subsoil in the commonly referred to "Post Oak Belt." The area is mainly in the subhumid climatic zone. Along the Texas-Louisiana border, the soils grade from marsh to prairie to Southern coastal plain. Soils are sands and sandy loams on the gently rolling areas, and alluvium in the valleys.

Soils along the Louisiana coast are organic clays. In the southwest these are crossed by cheniers (stranded beach ridges) of sand and shell paralleling the coast. In the Mississippi deltaic plain of the southeast, the soils are crossed by natural levees of silts and fine sands. Proceeding north from the chenier plain, the first soils crossed are the Coastal Prairie group of silt loam and clay and the second group are the Flatwoods of silt loam and fine sandy loam. Along the northern edge of the study area are the Coastal Plain soils of sandy loam. Pleistocene terrace soils and loess border the Mississippi River alluvial valley. The loess soils are silty and sandy while the terraces are silt loams over fragipans. The Recent Alluvium of the Mississippi valley is a series of meander belts of gravels, sands, and silts in a larger backswamp area of silts and clays.

\subsubsection{Geology}

The study area is in the northwest quadrant of the Gulf of Mexico, a region dominated by the Gulf coast geosyncline. The axis of the geosyncline extends 
just seaward of the present shoreline from the northeast Gulf to northern Mexico while the landward limits are the updip edge of the basal Tertiary deposits and the southern limit is probably near the Sigsbee Escarpment (Antoine, J. W. et al., 1974) on the seaward side. The regional strike of the geologic beds under Louisiana is east to west with the oldest beds being exposed farther inland. All of the beds dip as a monocline toward the axis of the geosyncline. Under the upper Texas Gulf Coast, the Tertiary and Quaternary beds strike northeast-southwest, or roughly parallel to the existing shoreline, and then gently dip toward the geosyncline. Through the middle and south coast of Texas, the coastal plain beds parallel the axis of the geosyncline and dip as a monocline toward it. Middle Texas is underlain by the gulfward plunging anticline, the San Marcos Arch, while south Texas is underlain by a broad, gulfward plunging syncline, the Rio Grande embayment (Landes, 1970).

The updip sections of the sedimentary wedges are fluvial deposits of backswamp material, predominantly thin shales. Throughout the shales are meander belt deposits of natural levees, point bars, and channel fill sands. Gulfward of the fluvial sequence are the deltaic deposits or depocenters of the formation, continuing thick sands and thick shales. Strandplain and barrier-bar systems of thin shales and thin sands are found in and adjacent to the deltaic system. Downdip from the deltaic sequence are the prodelta and shelf deposits of thick shales. Some thin, restricted sand bodies are present (Holcomb, 1964; Boyd and Dyer, 1964).

Accumulating sediment since the Cenozoic, the geosyncline has become a huge prism of clastic sediments derived from the north and northwest. The stratigraphy is a sequence of thick transgressive and regressive sections of Tertiary and Quaternary sediments deposited in off-lapping wedges. From the Tertiary to 
the present, the depocenters have migrated eastward from south Texas to Louisiana as a result of the shifting influence of river systems discharging into the basin. The beds dip and thicken into the geosyncline. Diapiric shale structures, salt stocks, regional faults, and local faults disrupt the beds. Table 2-1 shows the geologic column for the study area and Plate 5 shows regional crasssections through the study area.

Table 2-1. Geologic Column for the Study Area. (After Bebout et al. , 1976)

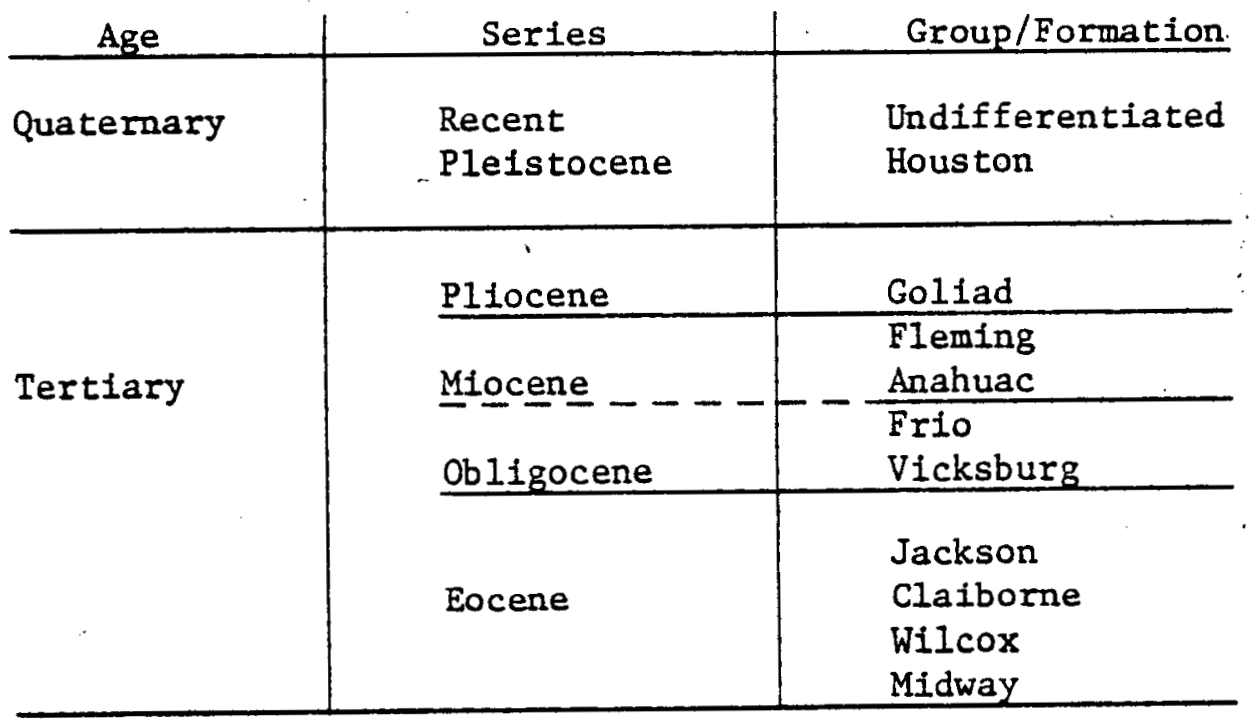


The Frio wedge of clastic sediments is the formation of concern because it has the desired vertical, areal, and temperature characteristics which make geothermal well-testing feasible. Vicksburg sediments of marine sands and shales mark the bottom limit of the Frio while the Anahuac sediments mark the top of the Frio (Bebout et al., 1976). Anahuac sediments represent a complete transgressive and regressive marine cycle (Holcomb, 1964). The Frio is composed of numerous overlapping deltaic and inter-deltaic systems which were built into the Gulf geosyncline. There is an interfingering of sands, silts, and clays deposited as part of deltas, strandplain systems, and barrier islands. The relation of the Frio formation to geothermal activity is described in detail by Bebout, Dorfman, and Agagu, 1975a, 1975b; Bebout et al., 1976; Jones, 1968c, 1968b, 1969a, 1969b, 1970a, 1970b, 1975; Jones et a1., 1974; Jones and Wa1lace, 1973; and Wallace, 1969.

\subsubsection{Tectonic Activity}

The Gulf coast geosyncline is a huge tectonically subsiding basin, which has been active since Mesozoic time. At the base of the Mesozoic sequence are the Jurassic Louann salts. Deposited on top of these salts are the Cenozoic deltas which have been filling the basin from the north. Rapid, thick deltaic sedimentation has resulted in normal growth faults along the boundary between the sand and clay units (Figure 2-1). When these faults intersect across the study area, they form regional faults. A second response to rapid subsidence and the weight of accumulated sediment has been the intrusion of salt stocks and shale diapirs into the overlying sedimentary beds. Structural features associated with the salt stocks form the traps for most petroleum in the study area.

Four types of faults are common in the Tertiary and Quatemary formations of the Gulf coast: regional faults, salt dome faults, embayment faults, and collapse 


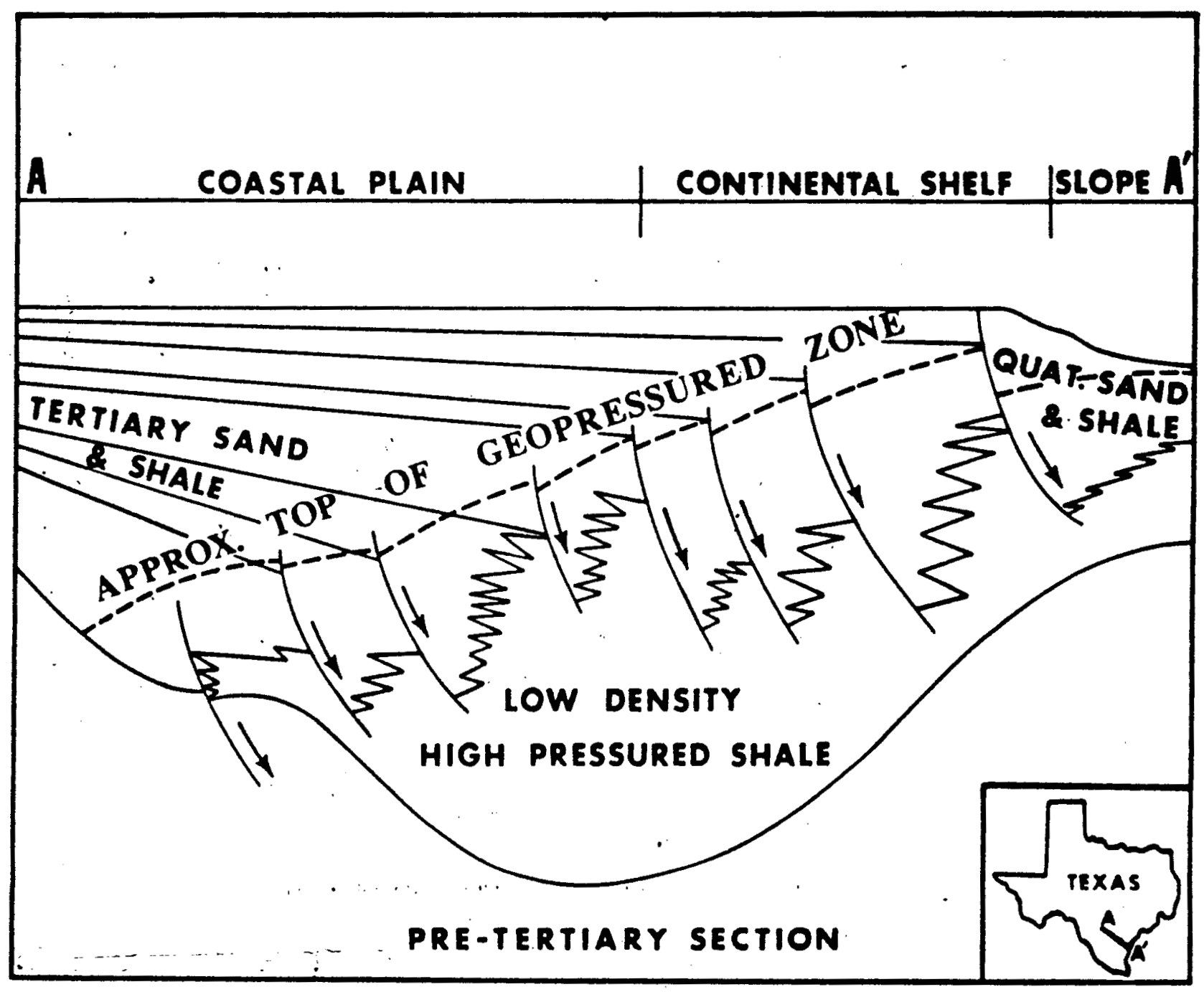

Fig. 2-1. Geologic section across south Texas coastal plain showing fault systems in mafor Cenozolc delta deposits, and their relation to the top of the Geopressure Zone (After Jones, 1975). 
faults (Seglund, 1974). Regional faults, described as growth or contemporaneous faults when there is active sedimentation, are normal faults which strike parallel to the reglonal strike and are downthrown on the Gulf side (P1ate 4). Beds are thicker on the downthrown side; vertical displacement increases with depth and may be as great as $1 \mathrm{~km}$. Jones (1970) estimates the dip of the fault to be about $50^{\circ}$ near the surface and to decrease to low angle faults in the deep subsurface. Salt dome faults are directly associated with the numerous salt stocks of the Upper Texas coast and the Louisiana coast. Faults may be peripheral, radial, graben, or horst. Embayment faults are parallel to ancient embayment shorelines such as along the Nodosaria embayment of southwest Louisiana. Collapse faults are downthrown toward the center of salt withdrawal areas formed when salt migrates from these areas to form salt stocks. The faults are nearly en echelon. The stratigraphy of the study area is complicated by the faulting patterns across the coastal plains.

Even with all of the faulting throughout the coastal plain, seismic hazard in Texas and Louisiana is very low to non-existent (Algermissin, 1969, Algermissen and Perkins, 1976). The potential for seismic risk is described on a scale of 0 to 3 where Zone 0 means no damage, Zone 1 means minor damage, Zone 2 means moderate damage, and Zone 3 means major damage. The scale is based on historical data which considers only the intensity of the earthquake, not its frequency. Both Texas and Louisiana have a seismic potential of zero. (Algermissin and Perkins, 1976).

\subsubsection{Mineral Resources}

The Gulf of Mexico coastal plain is a major supplier of petroleum, and natural gas for the United States. In south Louisiana, oil fields are concentrated in a belt $112 \mathrm{~km}$ ( $70 \mathrm{mi}$ ) wide, from the shoreline inland and from the Texas border 
to Mississippi. Landes (1970) estimates that "over four-fifths of the estimated ultimate resources of oil and two-thirds of the gas and condensate" has accumulated in the supercap, cap rock, and flank traps associated with salt stocks. Other oil traps occur along normal growth faults, collapse faults, or in sandstone pinchouts. Wells along the coast are deep, reaching to between $3050 \mathrm{~m}$ $(10,000 \mathrm{ft})$ and $6710 \mathrm{~m}(22,000 \mathrm{ft})$. Another mineral in the coastal zone is sulfur. It is associated with the cap rock of salt stocks and has been commercially produced by the Frasch process. Finally, salt is commercially mined from salt domes in Louisiana.

Texas is the leading oil producing state in the country. Along the upper Texas coast, the most productive belt is three counties inland from the shoreline. Within the belt is the most productive district, the Frio formation, $64 \mathrm{~km}$ ( $4 \mathrm{mi}$ ) to $97 \mathrm{~km}$ (60 mi) wide and extending from Mexico to Louisiana. Most of the mineral resources are associated with salt dome traps (Landes, 1970). The next most productive areas are traps associated with growth faults and finely lenticular sands. In south Texas, oil field trends are parallel to the shoreline and major fault zones, and extend inland five or six counties.

\subsubsection{Geology of the Geothermal-Geopressured Belt}

The geothermal-geopressured belt of the Louisiana and Texas Gulf coast follows seaward dipping beds of the Gulf coast geosyncline. The narrow belt is composed of Tertiary sediments of interfingering beds of sands and shales. The study area extends from the Rio Grande in Texas to the Pearl River in Louisiana, extending inland 20 miles along the Texas coast and $97 \mathrm{~km}(60 \mathrm{mi})$ to $161 \mathrm{~km}$ (100 mi) inland in Louisiana. Six prime areas of interest are in Texas and three are in Louisiana (Overlay). Selection was based on two criteria: the sand bodies had a volume of greater than $12.5 \mathrm{~km}^{3}\left(3 \mathrm{mi}^{3}\right)$ and uncorrected fluid temperature in 
excess of $121^{\circ} \mathrm{C}\left(250^{\circ} \mathrm{F}\right)$. Within the segments underlying these areas are the high temperature and high pressured waters containing dissolved natural gases which are to be tested by this program.

Geopressure reservoirs, those beds where the pore pressure exceeds hydrostatic pressure $\left(0.0106\right.$ meganewtons $/ \mathrm{m}^{3}$ or $\left.0.465 \mathrm{psi} / \mathrm{ft}\right)$, are associated with either the downthrown blocks of normal growth faults which are subparallel to the axis of the geosyncline or with sand lenses which pinch out (Bebout, 1976) (Figure 2-2). The "pinched out" beds are the result of deltaic and inter-deltaic sedimentary processes associated with a migrating shoreline. These beds occur in the Frio formation along the Gulf Coast where the geopressure-hydropressure interface occurs at a depth between $3000-4000 \mathrm{~m}(10,000-12,000 \mathrm{ft})$. Below this interface, pressure steadily increases with depth in the geopressure zone.

Fluids in the geopressure zone originate from two major sources. Most of the interstitial fluid consists of water confined during initial deposition. Second, free water is liberated by the alteration of montmorillonite to the less hydrous clay illite.

Heat in the reservoirs is from the earth's mantle. The sands and shales of the geopressure zone act as a barrier and prevent heat transfer to the overlying sediments. Above the high-pressure strata, temperature gradients are normal but increase sharply below the geopressure interface, from $2.3^{\circ} \mathrm{C} / 100 \mathrm{~m}\left(1.3^{\circ} \mathrm{F} / 100 \mathrm{ft}\right)$ to $3.8^{\circ} \mathrm{C} / 100 \mathrm{~m}\left(2.1^{\circ} \mathrm{F} / 100 \mathrm{ft}\right.$ ) (Schmidt, 1973) and from $2.7^{\circ} \mathrm{C} / 100 \mathrm{~m}\left(1.5^{\circ} \mathrm{F} / 100 \mathrm{ft}\right.$ ) to $5.5^{\circ} \mathrm{C} / 100 \mathrm{~m}\left(3.0^{\circ} \mathrm{F} / 100 \mathrm{ft}\right.$ ) (Dorfman and Deller, 1976). Temperatures range from below $200^{\circ} \mathrm{F}$ to above $300^{\circ} \mathrm{F}$. 


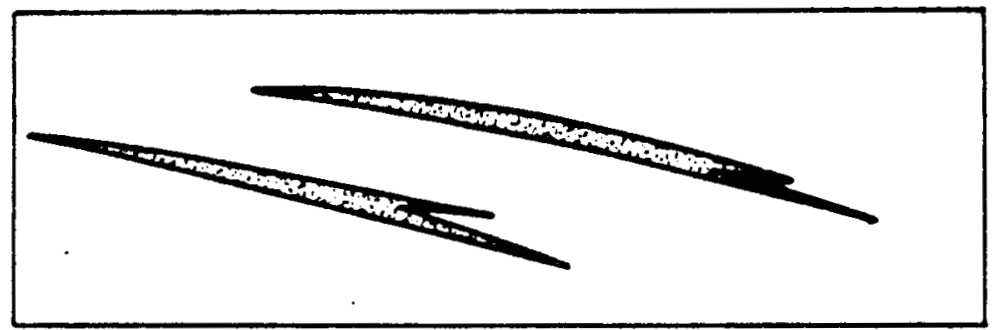

(A) SMALL RESERVOIR SEALED BY PINCHOUT

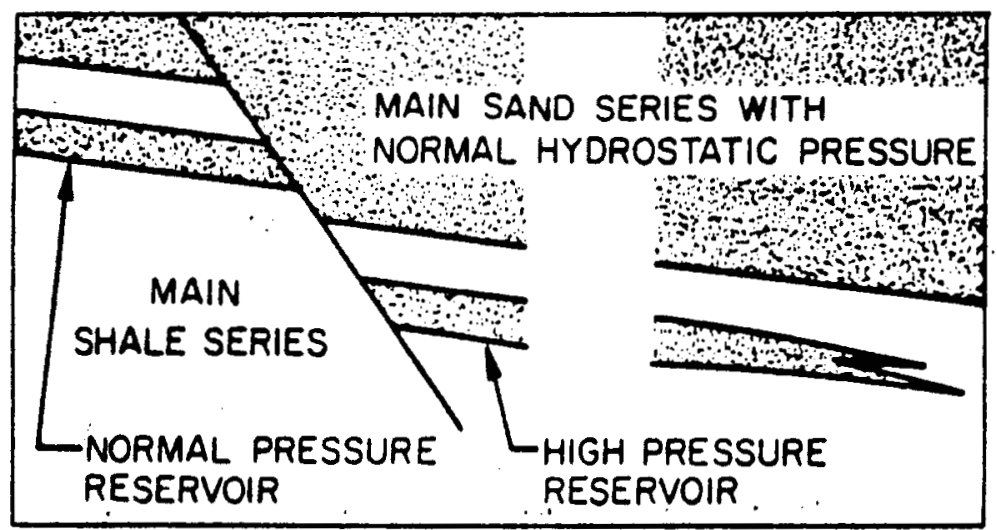

(B) LARGE RESERVOIR SEALED UPDIP BY FAULTING DOWN AGAINST THICK SHALE SERIES, SEALED DOWNDIP BY REGIONAL FACIES CHANGE

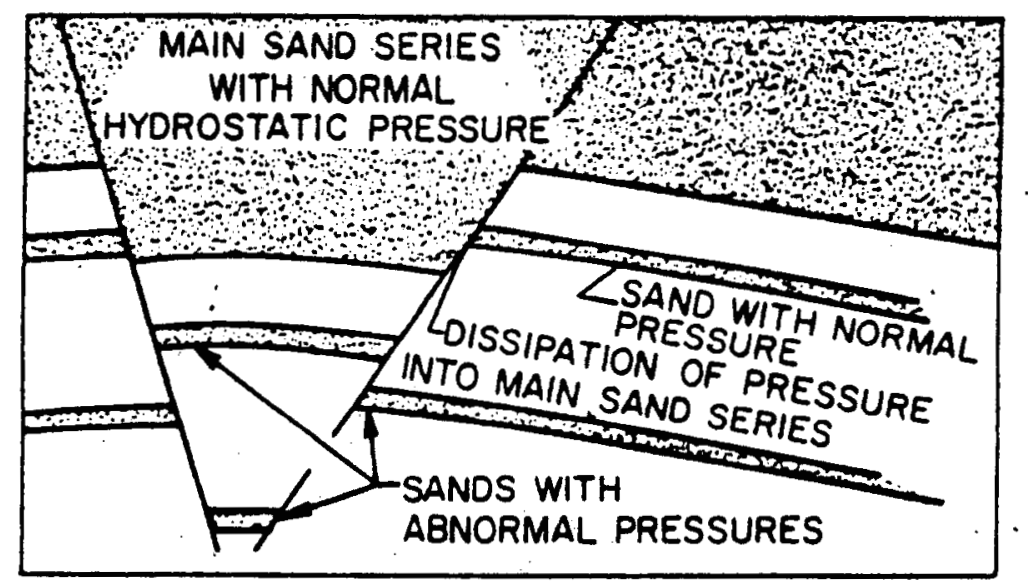

(C) RELATIVE POSITION OF FAULT SEALS IN UPTHROWN AND DOWNTHROWN BLOCKS

F1g. 2-2. Types of reservolr seals necessary to preserve abnormal pressures (After Dickinson, 1953). 
Shale beds are essentially impermeable. Porosity varies within a single shale bed, but generally decreases from the shale's central zone to its outer contacts with sand aquifers. Permeability of the sands averages $29 \mathrm{md}$ (Papadopulas et al., 1975) while porosity ranges from $12-22 \%$ by volume.

In the Gulf Coast, most of the hydrocarbon originates in the Cenozoic shales. The hydrocarbons in the geopressure fluids are nearly all natural gases, primarily methane; but ethane and propane are present in minute amounts. There is little or no evidence of hydrogen sulfide $\left(\mathrm{H}_{2} \mathrm{~S}\right)$ or other contaminants and only minimal concentrations of heavier hydrocarbons (Dorfman and Deller, 1976). Natural gas is presumed to exist at saturation levels in the reservoirs. Quantities range from $.2 \mathrm{~m}^{3}\left(7 \mathrm{ft}^{3}\right)$ per barrel of fluid to $1.13 \mathrm{~m}^{3}\left(40 \mathrm{ft}^{3}\right)$ per barrel.

The sand lenses act as excellent reservoirs for geopressured fluids because of their porosity, permeability, and enclosure by shales or faults, Reservoir fluids are high in methane but vary in salinity when compared to the composition of formation fluids above the geopressured zone. In the geopressured zone, dissolved solids may range to and above 100,000 ppm. Figure 2-3 shows the subareas of geothermal potential on the Gulf coast. Table 2-2 gives the characteristics of each of the subareas of the Gulf coast area. Table 2-3 compares the water composition between a geopressured formation and a normally pressured formation in southwest Louisiana.

\subsection{Hydrology and Water Use}

\subsubsection{Groundwater Hydrology and Use}

The groundwater resources of the coastal plain of Texas and Louisiana are contained in gulfward dipping and thickening wedges of Quatemary and Tertiary age 


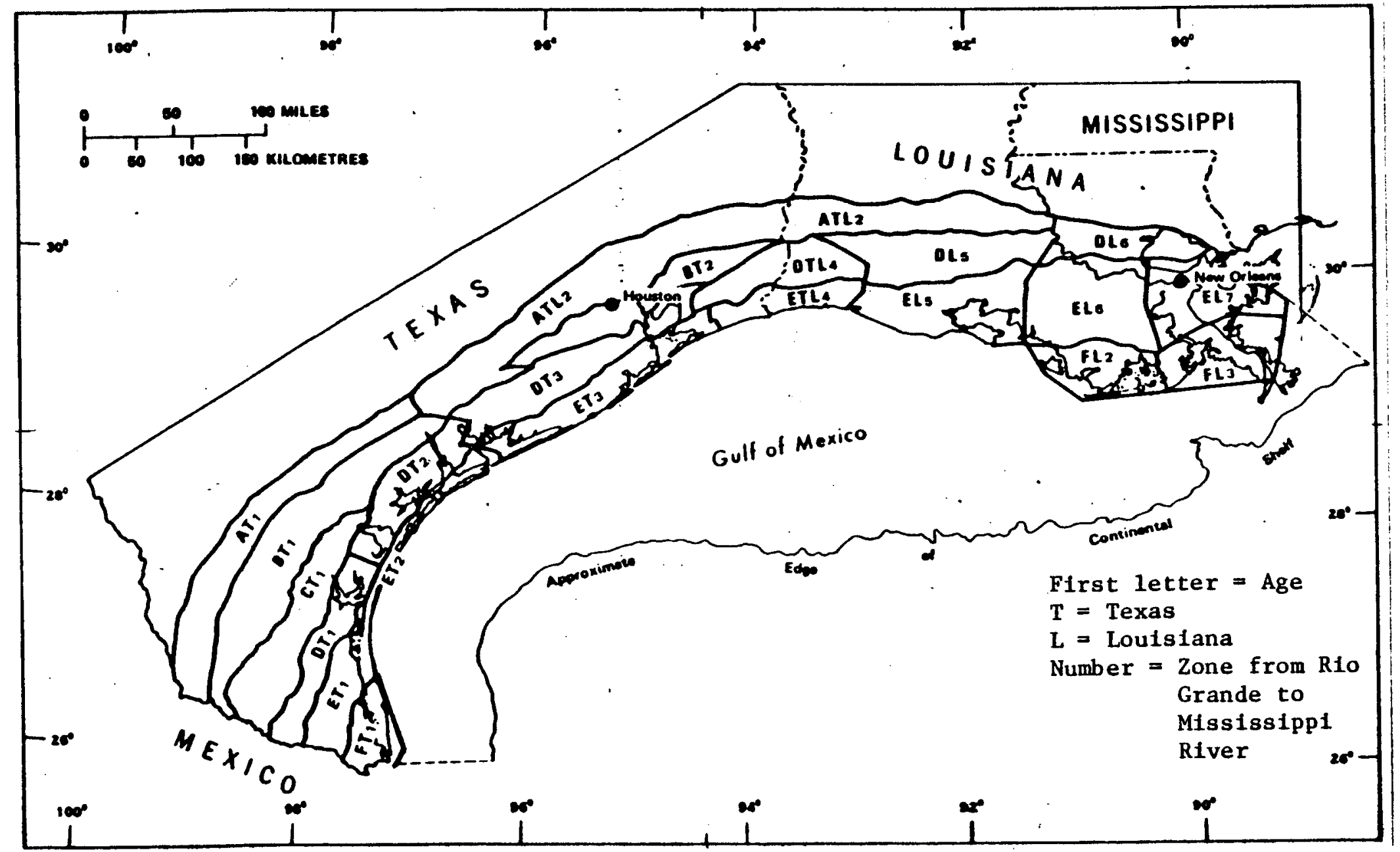

F1g. 2-3. Location map showing the extent of the assessed geopressured zones and their division Into subareas (After Papadopulas et al., 1975). 
Table 2-2. Areal Extent and Average Pressure, Temperature, and Salinity Conditions in Each Subarea (After Papadopulas et a1. 1975).

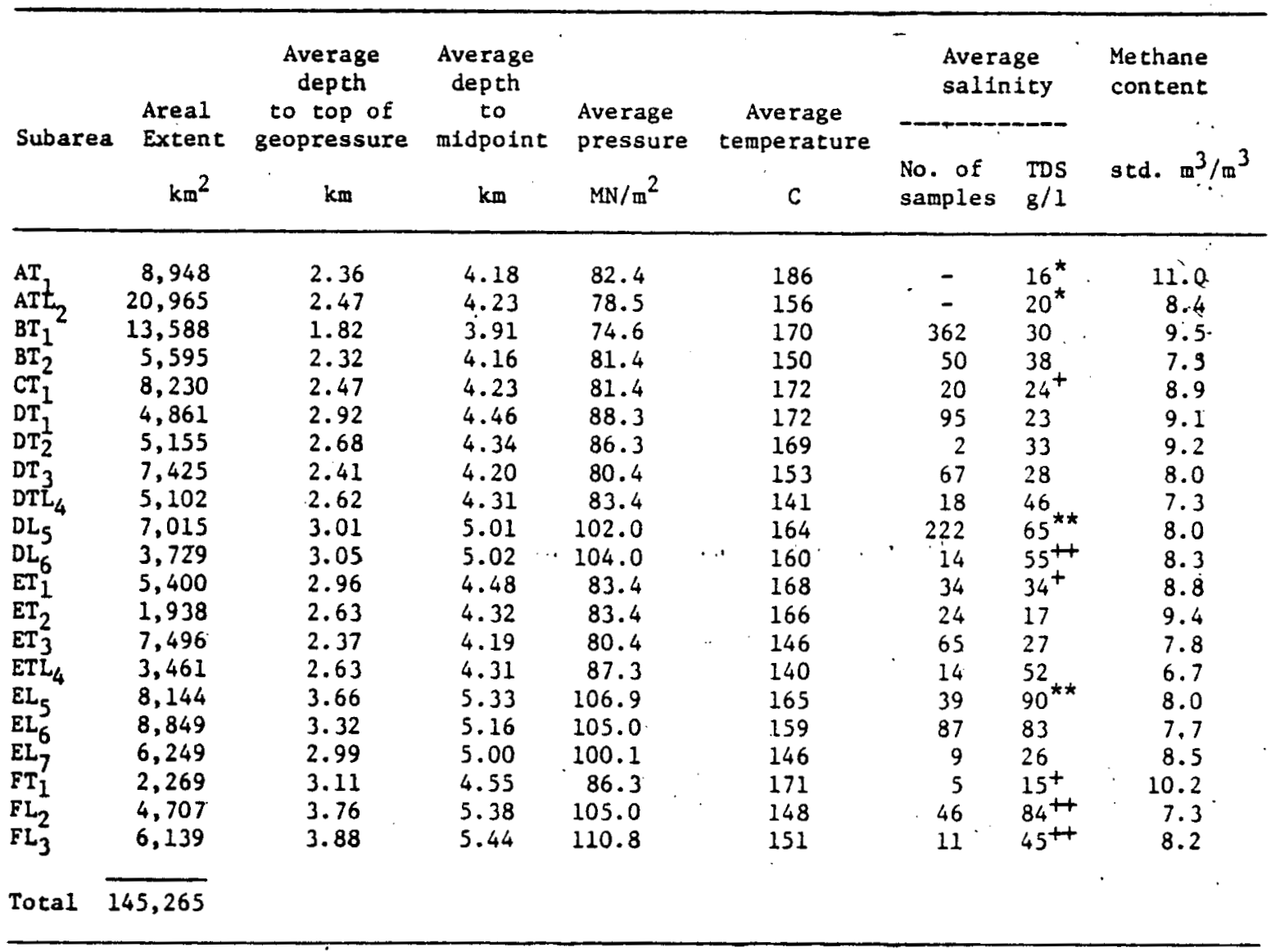

* Estlmated; samples not available.

+ Salinity as $\mathrm{NaCl}$ calculated from spontaneous potential of well logs; number of samples refers to number of well logs.

* Only few samples from deep zones are included.

+ No samples from deep zones are included. 
Table 2-3. Geopressured Manchester Field Compared with Normal Pressured Hackberry Field

\begin{tabular}{lcc}
\hline & Calcasieu Parish & Acadia Parish \\
\hline & Manchester & Hackberry \\
No, 1 W. H. McBurrey & No. 51 Gulfland \\
& $12,670-12,677$ & 11,500 \\
Composition & & \\
& & \\
& 680 & 49,100 \\
138 & 5,850 \\
18 & 903 \\
86 & 309 \\
9,950 & 92,100 \\
1,330 & 286 \\
175 & 37 \\
& 3.1 & 4.5 \\
0 & 0.6 \\
& 5.3 & 0 \\
33 & 569 \\
27 & 183 \\
0 & 5.3 \\
18,300 & 23 \\
& & 149,000 \\
\hline
\end{tabular}

Source: Schmidt, 1973 and Schmidt et al., 1976. 
sediments ranging in composition from clay and silt to sand and gravel. The sediments increase in age from Recent along the coast to Eocene inland. Generally, the sedimentary wedges are coarsest inland becoming thicker and grading to silt and clay some distance gulfward. The aquifers are recharged by precipitation inland at the elevated outcrop areas.

The deepest fresh water resources are in the northeast Texas and Louisiana areas. The coastward dipping aquifers are confined by clay layers above and below creating artesian conditions. Thus in wells tapping these aquifers, water rises above the confining layers in the wells. Unconfined aquifers (water table conditions) exist only along the major river valleys and at the outcrop areas. The important geologic and hydrologic units in the Texas and Louisiana study area are 1isted in Appendix A, aquifer outcrops are shown on Plate 5.

Outcrop areas for the important fresh water aquifers of the Texas and Louisiana coastal plain are shown on Plate 5. Coastal artesian aquifers receive recharge in their inland outcrop areas. Large areas of the Texas and Louisiana coasts are covered with relatively impermeable deposits of Recent alluvium and Pleistocene terraces. In these areas precipitation can only recharge nearsurface water table aquifers. Major streams crossing these areas are in hydraulic contact with alluvial aquifers and, in some cases, with deeper artesian aquifers. Thus, even though surface deposits prevent recharge by precipitation, aquifers can receive important amounts of recharge from these streams.

In the coastal plain fresh groundwater is confined to the sands and clays of the Pleistocene and Pliocene age. The depth of occurrence of fresh to slightly saline 
water (near 0 to 1000 parts per million total dissolved solids) is shown graphically in Plate 6 and in cross-sections of the Tertiary formations of the Texas coast in Plate 6. Generally, fresh water is more abundant in Louisiana and the northeast Texas coast than in the southwest Texas coast. The maximum depth of fresh water within the region considered in this report is approximately $732 \mathrm{~m}(2400 \mathrm{ft})$ below sea level near Houston, Texas. In Louisiana the maximum depth of fresh water occurrence is approximately $610 \mathrm{~m}$ (2000 ft) below land surface in northern Calcasieu Parish. Generally, the depth of occurrence of fresh water increases inland from a minimum at the coast. Below the fresh water aquifers and down dip from the fresh water/saltwater interface in a given aquifer, saline water ranging from $10,000 \mathrm{ppm}$ to $130,000 \mathrm{ppm}$ dissolved solids occurs. Below $2440 \mathrm{~m}$ to $3660 \mathrm{~m}$ (8000 ft to $12,000 \mathrm{ft}$ ) the water usually decreases in salinity to below 10,000 ppm dissolved solids (Jones, 1969).

In Texas the largest center of groundwater development is the Houston area. This is one of the most heavily pumped areas in the United States (McGuinness, 1963). Groundwater was pumped from the Chicot and Evangeline aquifers at a rate estimated at about 2,176 million liters per day ( 575 million gallons per day) in 1975 (Jorgenson, 1975). Two important irrigation areas in Texas are the Rio Grande valley and a broad area between the Guadalupe and Sabine Rivers. In the Rio Grande valley, vegetables, citrus fruit and cotton are irrigated with water supplied from the river and wells in the alluvium. Between the Guadalupe and Sabine Rivers approximately 68,758 hectares $(417,000$ acres) of rice were irrigated in 1960 (Wood, Gabrysch, and Marvin, 1963). Approximately 40\% of the irrigation water came from groundwater sources.

In Louisiana the most important area of groundwater use within the report area is Lake Charles. Daily offtake in 1963 was $152 \mathrm{mgd}$ with $92 \%$ of all water 
pumped from the "500 ft" sand of the Chicot aquifer (Harder et al., 1967). In the parishes surrounding Lake Charles and to the east, approximately 242,817 hectares $(600,000$ acres) of rice land is irrigated for rice production. In 1960 , approximately 74,909 hectares $(185,100$ acres) was irrigated using water from the Chicot and Evangeline aquifers (Kilburn and Whitman, 1962).

Two main problems are associated with groundwater development in the Gulf coast -saltwater encroachment and land subsidence. Saltwater encroachment results from the landward advance of saltwater, which exists downdip and near the coast in all aquifers, in response to fresh water withdrawals.

Land subsidence due to groundwater withdrawals is a more significant problem. Subsidence due to groundwater use has been reported in Baton Rouge (Wintz, Kazmann, and Smith, 1970), New Orleans (Kazmann and Heath, 1968), and the Houston, Texas area (Gabrysch and Bonnet, 1975). Land subsidence in these areas is the result of compaction of aquifers and the surrounding fine-grained sediments as water pressure in the aquifer is lowered. Generally, maximum subsidence occurs near the centers of pumpage. In Houston, where the grestest subsidence has occurred, pumping has affected an area of about $12,945 \mathrm{~km}^{2}\left(5000 \mathrm{~m}^{2}\right)$ and the area of greatest subsidence, about $2.29 \mathrm{~m}(7.5 \mathrm{ft}$ ) measured between 1943 and 1973 , is coincident with the location of greatest water level declines (Jorgensen, 1975).

Consequences of subsidence include: (1) increased areas subject to innundation during floods and storms, (2) changes in surface water channel performance (canals, irrigations systems), (3) fault activation (Kreitler, 19772, Gustavson and Krietler, 1976), and (4) damage to buildings, roads, utilities and other man-made improvements (Earle, 1976). 


\subsubsection{Surface Water}

The network of drainage and tidal streams in the coastal zone basins conducts surface water through a complex, multi-faceted system. Routing of the surface runoff is through distributaries, fresh swamps and marshes, intermediate marshes (brackish), and natural estuarine ponds, lakes, and tidal streams. Basin boundaries form constraints to flow in upper parts of the basins, but much interbasin transfer occurs in the lower wetlands parts, both naturally and through man-made structures and devices. Weather parameters introduce variable influences on surface flow as well. Because the processes and interactions of the hydrologic cycle are so complex and so diverse throughout the Gulf coast of Louisiana and Texas, detailed and technical data assessing the hydrologic regime of the region are presented in Appendix A.

The major drainage basins and main streams draining each are mapped on Plate 7 . These delineations constitute the principle hydrologic features of the geopressured region. Physical characteristics of these basins are detailed in Appendix A, including pertinent information on climatic gradients, basin size, runoff amounts and ranges, and seasonal variations of stream regime. Hydrographs of representative streams (located on Plate \&) are used to illustrate the distribution of these physical parameters across the region. A distinct eastwest gradient is clearly evident, with runoff $\left(\mathrm{hm}^{3} / \mathrm{km}^{2}\right)$ ranging from 1.5 in the Baratoria basin to 0.1 in the Nueces-Rio Grande basin.

Water quality varies substantially from basin to basin throughout the region owing the variations in geomorphic, geologic, and climatic factors as well as man's activities. Water quality parameters are characterized in Appendix Average discharge, dissolved chlorides, dissolved sulfates, total dissolved 
solids, and water temperatures are used to illustrate the range of water quality across the region. For example, TDS concentrations vary from $30 \mathrm{mg} / \mathrm{I}$ in the Tickfaw, Louisiana, to $2790 \mathrm{mg} / 1$ in the Mission River.; Water quality criteria are tabulated to present a basis for comparison among the various streams. Streams with designated water quality problems are mapped on Plate 7.

Municipal, industrial and agricultural uses of surface water are tabulated in Appendix A, along with major types of industries discharging into surface streams. Surface sources of domestic water supply are mapped on Plate 7. Recreational use of the streams is discussed in Appendix A and scenic/recreational waterways are mapped on Plate 7.

\subsection{Terrestrial Ecology}

The distribution of coastal vegetation of Louisiana and Texas ia a result of both geologic events and historic and current land uses. Before man's influence the Pleistocene and older deposits were mainly covered with shortleaf pine, longleaf pine, hartwoods, swamps and marshes (Penfound, 1944). In historic times the shortleaf and longleaf pines have decreased in favor of the 1oblolly pine-hardwoods forest type. The prairies have been largely replaced with agricultural and range lands.

On the accompanying vegetation map (Plate 8), the areas that have been changed to intensive human uses such as agriculture, range, or urban centers, are blank and are discussed in Section 2.6, Land Use. All other lands are divided into the appropriate vegetation type and a discussion follows in sections 2.3 and 2.4. The species composition and solls of the vegetation types are summarized in Appendix A. 
A discussion of the fauna is presented in detail in Appendix A. Most of the animals occur in more than one vegetation type. Some may spend their entire lives within one type while others of the same species may occupy an entirely different type and still others utilize several habitat types. Therefore, this section contains a discussion of only the better known animals.

\subsubsection{Wetlands}

Deciduous Forest - The deciduous forests in the study area are found on Pleistocene terraces, alluvial ridges, cheniers, beach ridges, salt domes, Indian middens, and spoil areas. Those associated with Pleistocene sediments will be discussed in Section 2.3.2.

Bottomland hardwoods are deciduous forests found on better drained alluvial areas with moist soil, near seasonally flooding streams and on some abandoned river courses. They thrive in areas with short, occasional flooding. The hydroperiod and soil moisture conditions determine what kind of vegetation will be present and generally it is a highly productive ecosystem (Conner and Day, 1976).

The bottomland ecosystem supports a diverse fauna with many species reaching their maximum density in this habitat type.. The white-tailed deer finds its best habitat in bottomland forests with a mixture of age classes because it provides them with highly nutritious browse, mast and fruits as well as adequate cover. Deer also occupy loblolly-shortleaf pine, upland hardwood, swamp forests and longleaf-slash pine ecosystems, but with fewer animals per unit of area than is the case with the bottomland hardwood type. Swamp rabbits are also found in this ecosystem but their range extends westward only to the upper twothirds of the Texas coast. 
Bottomland hardwoods support more squirrels per unit of area than any other habitat type. The Eastern gray squirrel and the fox squirrel (Davis, 1974, and Lowery, 1974a) require trees as a component of their habitat and so are absent from the extensive marshes, prairies and brushlands.

The deciduous forest vegetation may also occur in scattered localities within a swamp or marsh. This increases their importance to wildlife that uses woody cover for resting, nesting or denning and forages for food into the marshes. Their presence marks an elevation rise of perhaps only a few inches. These rises were formed by a variety of physical and human processes. Scattered mounds mark former habitation sites of Indians who built up areas with shells to form middens. Other scattered and often circular rises were formed by the diapiric movement of salt domes. In western Louisiana, the process of storms and changing Mississippi River courses formed parallel ridges and islands which are remnants of former dune ridges. In Texas, similar processes formed fluvial and distributary sand bodies called the strandplain. Farther south, the elevation rises are the basis for the oak mottes. All of these elevated areas are the base for a live oak association of limited diversity which contrasts sharply with surrounding marshes or prairies. Most of these areas are too small a scale to show up on the vegetation map (Plate 8).

Swamp Forest - Baldcypress once occurred in almost pure stands in the wetter alluvial river bottoms in Louisiana and Texas. Cypress was extensively logged in the early 1900's leaving an expanse of rotting stumps and logs which provided a base for germination of red maple (Acer rubrum), pumpkin ash (Fraxinus tomentosa), and water tupelo. The resultant forest was a more diverse association of cypress, tupelogum, and maple. The largest carnivore in the study area 
is the American black bear (Ursus americanus). It occurs in the Atchafalaya Basin of Louisiana (Lowery, 1974) and has been reported in Willacy and Kleberg Counties of Texas (Davis, 1974).

\subsubsection{Pleistocene}

Deciduous Forest - Only a small portion of the deciduous forest in the study area would be considered upland hardwoods or blufflands. This type occurs in western Livingston, East Baton Rouge, St. Landry, and Lafayette Parishes. It is found on the Mississippi terrace and Loessial hill soils, a brown, silty loam. Its unique association is characterized by a highly diverse flora of which over $50 \%$ of the species present are upland oak and hickory (Carya spp.) (U.S. Department of Agriculture, 1969a). Other common associates include gum, elm, and maple, with an understory of palmetto (Sabal minor), greenbriar (Smilax spp.), and poison ivy (Rhus radicans). Much of this vegetation type has been converted to farmland or pasture.

One of the most valuable furbearers is the neartic river otter (Lutra canadensis) which occurs in aquatic habitats across the entire Louisiana area (Lowery, 1974a) and along the upper and middle Texas coast (Davis, 1974).

Coniferous Forest - Longleaf pine (Pinus palustris) and slash pine (Pinus elliotti, var. elliottii) make up more than $50 \%$ of the stand and are associated with other southern pines, oak, and gum. Coniferous forest occurs on coastal plain or flatwoods soils which are sandy loams or sandy clay loams, medium to strongly acid and low in organic matter. The association grows best on soils with poor surface drainage. Plant and animal communities in this type are adapted to thrive with periodic fires. 
Mixed Forest - The mixed forest in Louisiana and northeast Texas is a loblolly pine (Pinus taeda) - shortleaf pine (Pinus echinata) forest, which is associated with hardwoods, brushy understory and grasses. It occurs on acid clayey and loamy soils such as Mississippi terrace and flatwoods and it colonizes disturbed areas. Of the pines, loblolly prefer moist sites. Over $50 \%$ of the stand is made up of loblolly, shortleaf, and other southern pines, the remaining trees are mainly oak, hickory and gum. Pines are less shade tolerant than the associated hardwoods. This forest type is a mid-successional type.

Prairie-Grasslands - Prairies once occupied extensive areas of western Louisiana and coastal Texas. They occurred on coastal prairie soils which are a silt loam or silty clay surface soil with underlying silty clay, moderate organic matter and neutral to slight acidity. Original species included bluestem (Andropogon spp.), broomsedge (Andropogon virginicus), and switch grass (Panicum virgatum). Rice, soybeans, cotton and sugarcane have replaced much of the prairie. Overgrazing has caused a shift in species and many less desirable plants such as ragweed (Ambrosia spp.), tumblegrass (Schedonnardus spp.), broomsedge and mesquite. There is no native prairie left in Louisiana.

As one moves westward the climate is drier and this is reflected in the vegetation. In Texas, prickly pear cactus (Opuntia spp.), mesquite and huisache (Acacia farmesiana) become part of the association. Below Nueces County, the inland portions of the coastal counties are part of the south Texas plain vegetation area (Texas Agricultural Extension Service, 1975). This area is known as brushy country or chaparral. The principle plants are mesquite, small live oak, prickly pear cactus, catclaw (Acacia greggii), huisache, and blackbrush (Acacia rigidula). Originally, this area was warm season bunchgrass (Sporobolus spp.), in post oak (Quercus stellata), live oak, and mesquite 
savannas. But years of cattle grazing have caused brush to predominate. Untouched grasslands are a vanishing type. They are being quickly converted to human uses.

Associated with the grasslands and drier areas are the ocelot (Felis pardalis), the cougar (Felis concolor stanleyana), and the jaguarundi (Felis yagouaroundi). The ocelot is most numerous in the dense chaparral thickets of the brushland adjacent to the lower Texas coast. The cougar has recently ranged from about Galveston Bay north and westward. Of the four counties of Texas within the range of the jaguarundi, three, Cameron, Hidalgo and Willacy, are within the study area.

\subsection{Aquatic Ecology}

\subsubsection{Wetlands}

Coastal Wetlands - Louisiana and Texas have a large percentage of the marsh area of the United States. The coasts of Louisiana and Texas are bordered by nutrient-rich estuarine water and productive marshes which provide organisms with food, habitat, favorable growth conditions and protection from predators. Fish, furbearers, waterfowl and alligators are the most commercially important wetlands fauna.

Coastal estuaries and marshes serve as nursery grounds for the Gulf fishery resources. Estuarine dependent species comprixe $97.5 \%$ of the total catch of the Gulf states. The highly productive estuaries and marshes are responsible for making Louisiana the leading state in commercial fisheries yeild.

The shrimp fishery is the most economically valuable single fishery in LouisianaTexas coastal waters, followed by menhaden, oysters, and blue crabs (Appendix A). 
These four species account for $96 \%$ of the total weight and $97 \%$ of the total value of all fishery products landed in Louisiana and Texas. Menhaden and shrimp occupy estuaries for a large portion of their life cycles; the oyster and blue crab fisheries are almost entirely inshore or estuarine. In addition to providing for the major commercial species, these estuaries and marshes support hundreds of organisms which have no immediate economic value, but are important in the food chain upon which commercial species depend.

Louisiana is one of the leading fur producing states in the nation. Fur resources of Louisiana and the Upper Texas coast are concentrated in the marshes. Nutria (Myocastor coypus) and muskrat (Ondatra zibethicus) are the most valuable pelt products. The Northern raccoon (Procyon lotor) is the third most valuable fur in Louisiana and the most valuable in Texas. Muskrat are most abundant in the intermediate marsh while nutria are most abundant in the fresher marshes.

Several other fur bearers are listed in Louisiana and Texas catch records in the coastal area of one or both states. These are North American mink (Mustela vison), Virginia opossum (Didelphis virginiana), Eastern spotted skunk or "civet" (Spilogale putorius), striped skunk (Mephitis mephitis), bobcat (Lynx rufus), American beaver (Castor canadensis), red fox (Vulpes fulva), gray fox (Urocyon cinereoargenteus), coyote (Canis latrans) (Lowery, 1974a, and Davis, 1974), and in Texas only, the ringtail (Bassariscus astutus), and badger (Taxidea taxus) (Davis, 1974).

The study area also comprises the terminal ends of the major administrative "flyways." Louisiana is in the Mississippi Flyway and Texas is in the Central Flyway. While many birds that use these flyways spend portions of the winter south of the United States border, the wetlands, especially the coastal wetlands, play a major role in the maintenance of the Continental waterfowl population. 
The marshes are dominated by grasses, sedges, and rushes (Palmisano, 1971 and Chabreck, 1970). The marsh community composition reflects the age of the marsh and its soil and water environment. Water ranging from fresh to saline connects the marsh types. Salinity is determined by the level and frequence of flooding from both the upland fresh waters and the Gulf saltwater. An east to west precipitation gradient also exists which affects the annual water surplus, and, thus, the areal extent of the coastal marshes.

Saline Marsh - Saline marsh is found on the borders of saline bays, lagoons, bayous, and lakes. The principal vegetation is a combination of oyster grass (Spartina alterniflora), black rush (Juncus roemerianus), batis (Batis maritima), black mangrove (Avicennia nitida), and saltgrass (Distichlis spicata). This is the least diverse marsh type.

As one moves westward, marshes become less dominated by oyster grass and have a greater percentage of sea ox-eye (Borrichia frutescens), salt grass, sea bite (Suaeda spp.), and glasswort (Salicornia spp.). Black mangroves occur in infrequent clumps, but are limited by cold temperatures.

Intermediate Marsh - Intermediate marsh occurs between the fresh and saline marsh or bordering medium salinity bays and tidal lakes and includes both the brackish and intermediate types of Chabreck, 1970. In more saline areas, marsh cord grass (Spartina patens); big cord grass (Spartina cynosuroides), salt grass, and widgeon grass (Ruppia maritima) predominate. Sedges, such as threecorner grass (Scirpus olneyi) occupy early plant successional stages of intermediate marshes and sometimes occur in extensive stands that support large muskrat populations and also provide food for waterfowl. 
The fresher areas are generally more diverse and include the above association plus deer pea (Vigna repens), arrowhead (Sagitarria spp.), and roseau cane (Phragmites communis). The once common sawgrass (Cladium jamaicense) died off extensively in the late $1950^{\prime}$ 's (Valentine, 1974).

Fresh Marsh - Fresh marsh occurs between the intermediate marshes to the south and the coastal prairie or river alluvium to the north. It receives no salinity flux and is primarily dependent on upland runoff, streams, and rainfall input for water supply. Principal species present are maidencane (Panicum hermitomon), bulltongue (Sagittaria falcata), roseau cane, pickerel weed (Pontederia cordata), and paspalum (Paspalum spp.). Mos of the species in this association will not tolerate salinity, although some intermediate marsh species may be interspersed in a fresh marsh. Plant species are more diverse here than in brackish or saline marshes (Palmisano, 1971).

The American alligator (Alligator mississippiensis), recently classed as "endangered" throughout its range, has been reclassified as "threatened" in portions of its range including the entire coastal area of Louisiana and Texas (Federal Register, 1977, Vol. 42, No. 6, p. 2071-2077). The alligator occurs in fresh to brackish marsh habitats and river swamp systems ( $0^{\prime} \mathrm{Ne} i \mathrm{I}$ and Linscombe, 1975). The total coastal population of Louisiana and Texas is estimated at about 214,000 alligators with 100,000 of these found in Calcasieu, Cameron, and Vermilion Parishes, Louisiana (U.S.'Department of the Interior, 1977).

The Louisiana-Texas coastal area can be divided into a number of zones. The active delta zone of Louisiana contains a roseau cane-alligator weed (Alternanthera philoxaroides) association; the inactive delta, a maiden cane 
association; and the chenier plain, a bulltongue-alligator weed association (Palmisano, 1970). Texas can be divided into the coast from Louisiana to Matagorda Bay and then the southern section generally bordered by barrier islands. The northernmost fresh marshes are predominantly black rush, bullrush (Scirpus spp.), cattail (Typha spp.), and slough grass (Spartina pectinata). Below Matagorda Bay they become a mix of coastal sacahuista, seacoast bluestem (Andropogon scoparius), balsam grass (Elyonurus tripsacoides), paspalum, and huisache. In the drier areas of the marsh there is mesquite, hackberry (Celtis laevigata), and oaks.

Lakes and Streams - The vegetation of lakes and streams is closely related to the chemistry of the water (see Section 2.2.2). In shallow waters with a current and low nutrient levels, submergent and emergent attached grasses predominate. Fresh water phytoplankton are found in deeper waters and where currents are greater. If an area becomes heavily polluted or stagnant, green algae, blue-green algae, duckweed (Lemna minir), water hyacinth (Eichornia crassipes), or alligator weed predominate and may cause further deterioration of water quality due to the oxygen demand of decomposing organic matter and respiration.

Other common plants found in the area are wild celery (Vallisneria americana), skunk weed (Chara vulgaris); water lettuce (Pistia spp.), arrowhead, coontail (Ceratophyllum demersum), bladderwort (Urtricularia spp.), fanwort (Cabomba spp.), duckweed, pennywort (Hydrocotyl spp.), white water 1ily (Nymphaea odorata), and waterfern (Azolla caroliniana).

Fresh water sport fishing is provided by several species of fish. Various bream (Lepomis spp.), crappie (Proxomis spp.), and bass (Micropterus spp.) are 
all popular with sport fishermen. Bream and crappie are found in waters ranging from fresh to slightly brackish. Largemouth bass (Micropterus salmoides) inhabit lakes, ponds, fresh to slightly brackish estuarine areas, overflow swamps and rivers of the area. Spotted bass (Micropterus punctulatus) inhabit the flowing streams that bisect the terrace lands and are taken there along with largemouth bass. While the largemouth occurs throughout the study area the range of the spotted bass extends southwestward only to the middle Texas coast. During 1974 , over thirty-five million fresh water fishing days participation were estimated for all of Louisiana (Louisiana Department of the State, 1977).

Beaches and Dunes - Beaches and dunes is a broad classification which includes sandy beaches, dunes, barrier flats, sandflats, eolian ridges, berms along bay margins, and subaerial or slightly inundated mud flats. In Louisiana, the barrier islands such as the Chandeleur Islands, Timbalier and Isles Dernieres Islands, and Grand Terre and Grand Isle have beach and dune habitat, although the area of these that is covered with beach and dune vegetation is too small to be detectable on the vegetation map (Plate 8 ). In Texas the beach and dune areas are more extensive and appear on the vegetation map.

The dominant vegetation of beaches and dunes is marsh hay cordgrass, saltgrass, oyster grass, sea ox-eye, batis, camphorweed (Heterotheca subaxillaris), morning glory (Ipomoea spp.), seaside heliotrope, sedge (Cyperaceae), poor man's pepper (Lepidium virginicum), and saltbush (Atriplex arenaris). The sand flats have a sparse cover of glassworts and saltgrass. Other vegetation which joins the association in Texas includes seacoast bluestem, sandbur (Cenchrus incertus), beach tea (Craton punctatus), salt cedar (Ramarix gallica), seaside croton (Croton maritima), and mesquite. 
Estuaries, Bays, and Coastal Waters - Estuaries, bays, and coastal waters is another broad classification which includes medium salinity bays, slightly brackish to nearly saline estuaries, transitional bays, tidal creeks, restricted bays and hypersaline lagoons. In general, medium salinity bays run perpendicular to the coast while restricted and hypersaline bays run parallel to the coast.

Shallow areas have brackish and marine submergent grasses such as celery grass, widgeon grass, eelgrass (Zostera marina), turtle grass (Thalassia testudinum), manatee grass (Syringodium filiforma), Cuban shoal weed (Halodule wrightii), and water nymph (Jajas guadalupensis). This vegetation follows a yearly cycle and experiences a winter die-back, when algaes, especially red algaes (Rhodophyta), become more abundant.

Hypersaline lagoons experience a very wide range of temperature, $\mathrm{pH}$, and salinity. Blue-green algae mats are the dominant vegetation along with turtle grass and Cuban shoal weed.

Diving ducks make heavy use of bays, lakes, and near-shore waters, especially the lesser scaup (Aythya affinis) in Louistana and the redhead (Aythya americana) in Texas. Dabbling ducks greatly outnumber diving ducks, with the largest percentage of dabbling ducks being in the chenier plain of Texas and Louisiana. Geese are also found in the study area with the snow goose (Chen caerulescens) being found in the marsh grubbing for roots and rhizomes and the white-fronted goose (Anser albifrons) and Canada goose (Branta canadensis) being assoctated with agricultural fields. Coastal sea and wading bird rookeries are shown on P1ate 9. 
Saltwater fishery resources are considerable with the spotted seatrout or speckled trout (Cunoscion nebulosus), red drum or redfish (Sciaenops ocellata), and the Atlantic croaker (Micropogon undulatus), as three of the more important saltwater sportfish. Each is estuary dependent and provides fishing in the marsh bayous and canals, the estuarine bays, and in the Gulf itself. The blue crab (Callinectes sapidus) provides a great deal of sport crabbing.

Unique Wildlife - The Audubon's caracara (Caracara cheriway) is a common bird near the middle and lower coasts of Texas (Oberholser, 1974) but is known as a Louisiana breeding bird only from Gum Cove (Lowery, 1974a). Caracaras are members of the falcon family but subsist largely on carrion.

The black francolin (Francolinus francolinus asiae) is well-established as a breeding bird on the Gum Cove ridge and $16 \mathrm{~km}$ to $24 \mathrm{~km}$ (10 $\mathrm{mi}$ to $15 \mathrm{mi}$ ) from the initial release area (Palermo and Doster, 1970). According to Murray (personal communication) this bird has withstood considerable adversity in becoming established and appears to have found a niche in that particular habitat.

Mammals of both states that occur or have recently occurred in our area of interest are 1isted in the Appendix, adapted from Lowery, 1974a, and Davis, 1974. Omitted are marine mammals, exotic mammals either stocked or escaped from captivity (the nutria excepted), unusual records of animals that have apparently arrived as stowaways on foreign vessels, and domestic and feral animals. 


\subsection{Endangered Species}

\subsubsection{Terrestrial}

\section{VEGETATION}

Species that are either endangered or threatened are listed in Appendix Information on location, habitat preference, status, state where the status is in effect, and references are included. Those species whose present location is a very restricted geographic area are also indicated on the vegetation map (Plate 8).

\section{ANIMALS}

The ranges of endangered or threatened species for Louisiana are shown on Plate 8 and are discussed in more detail in Appendix

\subsubsection{Aquatic} VEGETATION

Threatened and endangered plant species which are located in wetlands environments are listed in Appendix A. Any species of very restricted range also appears on the vegetation map (Plate 8 ).

\section{ANIMALS}

Five species of reptiles are currently classifled by the U.S. Fish and Wildlife Service as "endangered" or "threatened," including the American alligator (Alligator mississippiensis), Atlantic Ridley turtle (Lepidochelys kempii), Hawksbill turtle (Eretmochelys imbricata), leatherback turtle (Dermochelys coriacea), and the Houston toad (Bufo houstonensis), (U.S. Department of the Interior, 1976a). The Sabine map turtle (Graptemys pseudogeographic sabinensis), a distinctive subspecies confined to the drainage of the Sabine, Calcasieu, and Mermentau Rivers, was being considered for inclusion on the endangered 
species list, but has recently been withdrawn (Dr. C. K. Dodd, Jr., U.S. Fish and Wildlife Service, personal communication). Also to be considered is the black pine snake (Pituophismelanoleucus lodingi), a melanistic subspecies that just enters the study area along the Pearl River on the Louisiana-Mississippi border (Dr. C. K. Dodd, Jr., personal communication). The Atlantic green turtle (Chelonia mydas), and the Atlantic loggerhead (Caretta caretta), have been proposed to receive "threatened" status because of the similarity of their appearance to the other endangered sea turtles (U.S. Department of the Interior, 1976b).

The brown pelican (Pelecanus occidentalis) once occurred on all coasts of North America below the latitude of $36^{\circ} \mathrm{N}$. Large numbers were year-around residents along the northern Gulf of Mexico. Widescale mortalities and reproduction failures have caused alarm about the welfare of these birds (Allen, 1935; King et al., 1977; Simmons, 1974; Winn, 1975). The brown pelican is listed as endangered by the U.S. Fish and Wildlife Service.

Approximate locations for southern bald eagle (Haliaeetus leucocephalus) nests observed in Louisiana and Texas during 1977 are shown on Plate 9. Bald eagles will often change nest sites year-to-year and utilize a nest which may have gone unused for one or more previous breeding seasons. Therefore, care should be taken to preserve currently inactive nests. A total of nine active eagles nests were observed in Louisiana in 1977 (Ray Aycock, U.S. Fish and Wildlife Service, Baton Rouge, personal communication), and in Texas seven nests were recorded from six different countles (William Brownlee, Texas Parks and Wildlife Department, personal communication). 
The whooping crane (Grus americana) once nested over a wide area from Lake Michigan to the Peace River area in Alberta, Canada, with scattered colonies throughout the Mackenzie River system and northward to the Axctic coast (Canada Wildlife Service, 1968). Currently, the breeding range of the whooping crane occupies $1300 \mathrm{~km}^{2}\left(500 \mathrm{mi}^{2}\right)$ in Wood Buffalo National Park in Northwest Territories, Canada. Their present winter range is limited to about $40 \mathrm{~km}^{2}$ (15 $\mathrm{mi}^{2}$ ) in the Aransas National Wildlife Refuge located on the Blackjack Peninsula in Aransas County, Texas.

The ivory-billed woodpecker (Campephilus principalis) was last confirmed in Louisiana in 1942, and in Texas in 1904. Based on photographs, Lowery (1974b) believes that a pair of birds were present in an unspecified location "...south of U.S. Highway $90 \ldots "$ in 1971.

Bachman's warbler (Vermivora bachmanni) was apparently fairly numerous in the eastern part of the study area during the latter part of the nineteenth century. Today it is the rarest warbler in this country and is to be looked for in heavily wooded swamp areas.

The peregrine falcon (Falco peregrinus) is a regular winer visitor to the coastal area. During its sojourn here it is highly mobile and tends to locate near concentrations of sandpipers, coots, ducks, or other prey species.

The red-cockaded woodpecker (Dendrocopos borealis) is classified as endangered because modern forest management practices eliminate pines that are infected with a fungus called "red heart" that occurs only in older, heavily-stressed pines, primarily longleaf. 


\subsection{Land Use}

Existing land use along the Louisiana and Texas coast is illustrated on Plate 10. Five general categories have been designated which encompass the major land use types of the region. The categories which are discussed below include developed land, agricultural land, woodlands, swamps, and marshes.

Developed land includes residential, commercial, industrial and extractive uses. Cultivated land, orchards, pasture and acreage presently out of cultivation have been grouped together as agricultural land. Wooded land is characterized by deciduous and hardwood forests which may be present either on Pleistocene soils or on floodplains of modern streams. Continually wet forested floodplains are designated as swamp lands. Saline, brackish, and freshwater marshes, as well as other coastal features such as barrier islands and some spoil areas, have all been included in the marsh category. Parks, refuges, federal highways and major waterways are presented separate from the other land uses on Plates 1 and 11.

The statistics on land uses in Louisiana parishes and Texas counties is presented in Appendix A. For Louisiana, these data represent land use in square kilometers for every parish that lies either totally or partially within the study region. Land use for the entire parish has been included even if only a portion of it falls within the project area boundaries. In Texas counties, the information included reflects only those areas covered in the Environmental Geologic Atlas, Texas Coastal Zone, mapped by the Bureau of Economic Geology at the University of Texas in Austin. This atlas covers only those counties or portions of counties which are considered to be in the coastal zone. Therefore, the data represent land use information for partial counties as well as whole counties. 
The dominant land use in the region is clearly agricultural. Approximately $49 \%$ of the land is either presently used for crops and range lands or has recently been under cultivation. Range land vegetation is similar to that found in prairie grasslands.

Agricultural lands extend over a large part of the Texas coast and continue into Louisiana along the Pleistocene terrace as far as the Atchafalaya Basin. Other agricultural land in Louisiana is along the fertile natural levees of the rivers and: bayous .

Major regions of developed land in the study area include the urban and industrial areas associated with Corpus Christi, Galveston, the southern part of Houston, Beaumont, and Port Arthur in Texas; and Lake Charles, Lafayette, New Orleans, and Baton Rouge in Louisiana. Other urban and industrial areas in Texas mainly occur along major highways and railroads and inland waterways. In southern Louisiana the secondary developed areas tend to follow the higher. land along the natural levees of bayous and rivers.

Extensive wooded areas in the Texas coastal region occur west of Boffin Bay as oak mottes, and in the Brazos River Basin and near the Texas-Louisiana border. These forests of eastern Texas continue into Louisiana north of the marshes and prairies. More forested areas in Louisiana occur in the uppermost parts of the Atchafalaya Basin.

Nearly all of the swamp and marsh land in the two state regions falls in Louisiana. Swamp land comprises $7164 \mathrm{~km}^{2}\left(2765 \mathrm{mi}^{2}\right)$ of the land in the study area. Approximately $97 \%$ of the total swamp land is within Louisiana, mostly in the Atchafalaya Basin and west of Lake Pontchartrain. The major part of the 
marsh area also occurs in Louisiana. A total of $16,536 \mathrm{~km}^{2}$ (6385 $\left.\mathrm{mi}^{2}\right)$ along the Louisiana coast has been categorized as marsh land. Only $1844 \mathrm{~km}^{2}\left(710 \mathrm{mi}^{2}\right)$ of the marsh land in the study area occurs in Texas. Primary uses are for grazing, open space, and wildlife habitat.

State and federally owned lands in the region include numerous parks and refuges along the coast (Plate 11 and Appendix A).

\subsection{Climate and Air Quality}

2.7.1 Climate

From Pearl River, Louisiana, to the Rio Grande, Texas, there are significant variations in climate both from north to south and from east to west. The climate of southern Louisiana and upper Texas coasts east of Galveston may be classified as humid subtropical. Climate is influenced to a large degree by. the many water surfaces provided by lakes and streams and by the proximity of the Gulf of Mexico. Throughout the year, these water areas modify the relative humidity and temperature regime by decreasing the range between extremes. During periods of southerly wind flow, these effects are increased, imparting the characteristics of a marine climate. Temperatures seldom fall below $0^{\circ} \mathrm{C}$ $\left(32^{\circ} \mathrm{F}\right)$ in winter, and daily maxima above $32^{\circ} \mathrm{C}\left(90^{\circ} \mathrm{F}\right)$ are common in summer.

The climate of south Texas west of Houston-Galveston is also subtropical but grading toward the west becomes progressively drier and more continental. Along the Rio Grande annual rainfall drops off to less than $500 \mathrm{~mm}$ (20 in), with very low humidities, and the region is characteristically semi-desert in nature. Annual rainfall along the Texas coast varies significantly from north to south. Compare Houston's $1150 \mathrm{~mm}$ (45.26 in) annually, and Brownsville's $678.5 \mathrm{~mm}$ $(26.75 \mathrm{in})$. More detailed information about climate in the study area is given 
in Orton (1964), about local wind regimes in Hsu (1969, 1970), and their relationship to air quality in Hsu (1977).

Tropical cyclones (hurricanes) are the largest and most destructive storms affecting the study area. They form between June and October over the warm waters of the Central Atlantic, Caribbean Sea, and Gulf of Mexico (Browner et al., 1972). Early in the season, hurricanes generally approach land from the south. As the tropical storm approaches land, sea level rises as a response to wind driven storm surge; wind velocities increase to in some cases an estimated $324 \mathrm{~km} /$ hour $(200 \mathrm{mi} / \mathrm{hr})$, precipitation increases in intensity and amount, more than $50 \mathrm{~cm}(20 \mathrm{in})$ in 24 hours; and barometric pressures in the eye of the storm may drop as low as $68 \mathrm{~cm}$ (26.5 in) of mercury (McGowen et al., 1970; and U.S. Army Corps of Engineers, 1973). Damage from hurricanes results from storm surge along the coastal areas and from flooding resulting from precipitation in the more inland areas. Depth of flooding from storm surge depends on the configuration of the coast, the bottom topography and the intensity of the storm. In some cases, surge heights may exceed $10 \mathrm{~m}(33 \mathrm{ft}$ ) and reach $160 \mathrm{~km}$ (100 mi) inland. Wind damage is common to inland and coastal areas, but is less a cause of damage than is water. Wind damage may be intense in isolated zones impacted by tornadoes which precede the eye of the storm.

\subsubsection{Regional Air Quality}

From Pearl River to the Rio Grande, several pollutants were measured simultaneously. Some generalizations about the air quality of the area are:

(1) for particulate matter, two areas, namely. Harlingen and Houston, exceeded national standards in geometric mean, one area in Harlingen exceeded the maximum observation which is not to be exceeded more than once per year. 
(2) for sulfur dioxide, there were no areas in our study region which exceeded national standard both in arithmetic and maximum value not to be exceeded more than once per year.

(3) for nitrogen dioxide, measurements showed that they were all below national standard.

(4) for ozone, from sparse data from Corpus Christi and Houston, both areas exceeded maximum value of $160 \mathrm{mg} / \mathrm{m}^{3}$ for one hour readings, not to be exceeded more than once per year.

It is concluded from air quality measurements in the study area from Pearl River to Rio Grande, that except in Houston (for particulate and $O_{3}$ ), Corpus Christi (for $\mathrm{O}_{3}$ ), and Harlingen (for particulate), the measurements did not exceed national standards.

\subsubsection{Atmospheric Inversion Potential}

While temperature normally decreases with height, inversions are not infrequent, especially near the ground. They occur particularly at night, when the ground is cooled because of the outgoing radiation not being compensated by incoming radiation from the sun. It is clear that in our study area from the coastal region to inland, the gradient of these inversion frequencies is large. In general, however, there is slightly less frequency (40\% vs. $50 \%$ during nightime and $25 \%$ vs. $30 \%$ for total hours) for the inversion to form between Galveston and Corpus Christi than other regions in our study area.

\subsubsection{Emission Inventory}

Natural emissions density maps have been compiled for the United States (Bach and Daniels, 1975). In the study area, density of suspended particates decreases from east to west. Sulfur dioxide, nitric oxides, hydrocarbons, and carbon 
monoxide are highest in the north Texas Gulf coast air quality control region. The density of input decreases to the east and west from this region with the south and central Texas coast having the lowest pollution levels in the study region. The suspended particles, $\mathrm{NO}_{\mathrm{x}}$ emissions, and $\mathrm{SO}_{\mathrm{x}}$ emissions are largely the result of industrial and power plants in the heavily populated areas. Hydrocarbon and carbon dioxide are the result of transportation facilities and industrial processes. Bach and Daniels (1975) issue a word of caution on using these maps:
Finally, a word of caution is appropriate when interpreting these emission density maps. It is clear that the magnitude of the emission density is critically dependent not only upon the magnitude of the emission tonnage, but also upon the size of the area to which it is related.

The maps show the relative differences between areas.

\subsection{Cultural Resources}

Archeology in Louisiana and Texas includes prehistoric and historic Indian sites, historic European sites, and shipwrecks. The sites date from 10,000 B.C. to ca. A.D. 1900. Although there are concentrations of different cultures within the project area there is also a scattering of sites representing all time periods throughout the area. The circles on Plate 12 represent concentrations of sites. A concentration is five or more sites within a small area. On the map is a number next to each concentration representing the approximate number of sites within the area. The concentrations do not reflect the true site distribution within the area since they have usually been located through small, local surveys or they are in presently easily accessible locales. In addition, the location of many of the sites in Louisiana have been lost due to the subsidence of the land. 
Most of the sites are on high ground that is located near water. These landforms are called high probability areas; other high probability areas include modern and relict natural levees, crevasse channels in backswamp areas, and floodplains and stream confluences.

Many archeological and historical sites are National Landmarks, or are in the National Register of Historic Places, or are Louisiana or Texas State landmarks.

Survey Standards and related federal and state legislation are in Appendix A.

\subsection{Socioeconomic Characteristics}

\subsubsection{Employment}

The major employment categories, agriculture, mining, construction, and manufacturing, and the number of people employed in each of these groups by county (parish) are listed in Appendix A. Both Louisiana and Texas are below the 1970 national per capita income of $\$ 3,910$. The Texas 1970 per capita income was $\$ 3,515$ (U.S. Bureau of the Census, 1973) while the Louisiana 1973 per capita income level was $\$ 3,825$ (U.S. Bureau of Mines, 1976). For comparison within the project area, the median family income is listed for each county or parish within the area (Appendix A). Also for reference, the median number of years of school for each county (parish) is listed (Appendix A).

\subsubsection{Economy}

The economy of the project area is diversified. Agriculture, mining, construction, and manufacturing are the four largest employers, but retailing, medical services, as well as other occupations, are also important, especially in urban areas. 
Agriculture includes forestry, wildlife, and fishing (U.S. Bureau of Census, 1973). The value of agricultural crops in Louisiana in 1974 was $\$ 1,193,722,000$, $55 \%$ of this came from southern Louisiana. Texas had $\$ 3,292,627,000$ worth of agricultural products in $1974 ; 11 \%$ was from the project area.

The fishing industry is very important in the project area. In Texas, $(98 /$ million pounds of fish and shellfish brought in $\$ 91$ million in 1973 . Louisiana harvested 1,029 million pounds with a value of $\$ 95$ million in 1973 . In 1974 , the value of shellfish was $\$ 253$ million in Louisiana and $\$ 91$ million in Texas.

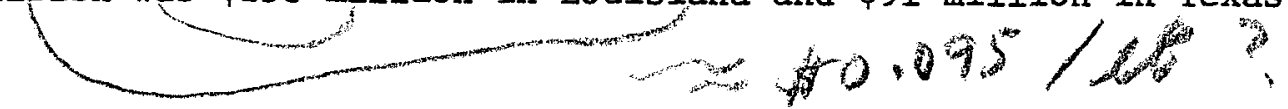

Minerals contribute much to the economy of both states. Petroleum, natural gas, sulfur, salt, and other minerals are mined in both states. The production of natural gas and petroleum is the most important in the project area. The value for natural gas alone in Louisiana and Texas was $\$ 3,581,534,000$ in 1973 (U.S. Bureau of Mines, 1976). The importance of minerals can be seen in Appendix A.

\subsubsection{Population, Demography, Ethnic Make-up}

Louisiana and Texas have a wide variety of ethnic and racial groups (P1ate 13). Many small groups are scattered throughout the area but there are three large groups (AppendixA). These groups are Blacks, Mexican-Americans, and Acadian French. In Louisiana, Blacks constitute $33.3 \%$ of the population. The percentage of Blacks decreases in western Louisiana. In Texas, Blacks compose 12.5\% of the population. The percentage of Blacks decreases in south Texas (U.S. Bureau of Census, 1973).

Mexican-Americans and people with a Spanish surname are the second large group. Spanish-speaking people make up $18.4 \%$ of the Texas population. The small 
percentage of Spanish-speaking people in Louisiana (1.9\%) are not necessarily Mexican-American (U.S. Bureau of Census, 1973).

The third large group is the Acadian French. These people are centered in central and western Louisiana (Bertrand, 1976) and eastern Texas (Nesmith, 1977).

In Louisiana, two Indian reservations are located within the project area. The Chitimacha Reservation is centered at Charenton in St. Mary Parish and contains 115 hectares (283 acres). The Coushatta Reservation contains 58 hectares (143 acres) and is centered at Elton, Louisiana, in Allen Parish. Other Indian centers are Houma Alliance in Terrebonne, the Houma Tribe in Lafourche (Mora, 1977) and the Choctaws in St. Tammany (Bertrand, 1976). Only in Terrebonne and Plaquemines Parishes does the Indian population exceed 1\% (U.S. Bureau of Census, 1973). No Indian reservations or communities are located in Texas counties in the study area (Jordan, 1970).

Several European ethnic communities are located in the project area (Plate 13). German communities are the most numerous, espeically in Texas. Only one German community is in Louisiana and it is located in Acadia Parish.

Louisiana is dominated by ethnic groups different from those found in Texas (Plate 13): Italians, Dalmatian-Slovonian, and Mennonites. For additional details, see Appendix .

Some of the most interesting communities in Louisiana are the racial hybrid communities. Often, these groups are a tri-racial mixture of Black, Whites and Indians. Very little is known about these groups because the people are very sensitive about their racial heritage (Bertrand, 1976). 
The total population of Louisiana is $3,641,306 ; 62 \%(2,251,771)$ live in the project area. There are four Standard Metropolitan Statistical Areas (SMSA's) in south Louisiana. They are Baton Rouge $(285,167)$, Lafayette $(109,716)$, Lake Charles $(145,415)$, and New Orleans $(1,045,089)$. Seventy percent of the population lives in these four areas.

The Texas state population is $11,195,431 ; 30 \%(3,410,144)$ live in the project area. In the five SMSA's, Beaumont-Port Arthur-Orange $(315,943)$, Corpus Christi $(284,832)$, Galveston-Texas City $(169,812)$, Houston $(1,985,031)$, and BrownsvilleHarlingen-San Benito $(140,368)$, live $85 \%$ of the people in the project area.

\subsection{Prime Areas of Geopressure-Geothermal Interest}

There are three prime areas of geopressure-geothermal interest in Louisiana and six areas of interest in Texas. The three areas in Louisiana surround Lake Charles in the southwest quarter of the state; there is one each in Calcasieu, Acadia, and Cameron Parishes. Texas sites are more or less evenly spaced along the coast from the Louisiana state line to the Mexican border. The northernmost fairway is in Brazoria and Galveston Counties, southwest of Houston. Southwest of the first site are two fairways in Matagorda County. Farther south, Corpus Christi is surrounded by a fourth fairway in Nueces, San Patricio, and Aransas Counties. A small fairway is located on the Rio Grande in Hidalgo and Cameron Counties. In this summary section of the baseline chapter, each of the fairways is briefly described.

\subsubsection{Southwest Louisiana}

There are three prime areas of interest in southwest Louisiana, one each in Calcasieu, Acadia, and Cameron Parishes. In Calcasieu, the average depth to. the top of the geopressure zone is $2.62 \mathrm{~km}(8600 \mathrm{ft})$ and the average temperature 
is $141^{\circ} \mathrm{C}\left(285^{\circ} \mathrm{F}\right)$. The study area is approximately $332 \mathrm{~km}^{2}\left(128 \mathrm{mi}^{2}\right)$. In Acadia Parish, the average depth to the geopressure zone is $3.01 \mathrm{~km}(9875 \mathrm{ft}$ ) and the average temperature is $141^{\circ} \mathrm{C}\left(285^{\circ} \mathrm{F}\right)$. The study area is approximately $248 \mathrm{~km}^{2}$ $\left(96 \mathrm{mi}^{2}\right)$. In Cameron Parish, the top of the geopressure zone is $2.63 \mathrm{~km}$ (8625 ft) below the surface and the average temperature is $140^{\circ} \mathrm{C}\left(285^{\circ} \mathrm{F}\right)$. The total study area is approximately $435 \mathrm{~km}^{2}\left(168 \mathrm{mi}^{2}\right)$.

The chemical constituents of the geothermal fluids varies from reservoir to reservoir.

Soils under the prime areas of interest vary from one area to the other. In southwest Louisiana, the Calcasieu Parish study area lies under flatwood, poorly drained forest soils of Pleistocene origin and coastal prairie soils. Runoff is slow to moderate and shrink-swell potential is low to high. The flatwoods soils may have excess seepage from dugouts, whereas the prairie soils are suitable for water impoundment. The Acadia Parish site is on coastal prairie soils similar to those found at the Calcasieu Parish site. The southernmost site in Cameron Parish is on organic soils and cheniers (abandoned beach ridges) of Recent geologic origin. The area for the most part is covered by standing water and runoff is very slow. The shrink-swell potential is very high. Suitability for ponds and reservoirs is low because of the high:: water table and standing water.

The three Louisiana sites are geohydrologically similar in that the Chicot is the principal fresh groundwater source in each area. In Calcasieu and Acadia Parishes the Chicot aquifer contains fresh water to depths of 214 to $305 \mathrm{~m}$ (700 to $1000 \mathrm{ft}$ ) (Harder et al., 1967). Nearer the coast in southeastern 
Cameron Parish, fresh groundwater is limited to the upper $214 \mathrm{~m}$ (700 ft) of the upper sands of the Chicot aquifer. The deeper Evangeline aquifer contains only saltwater except in the northernmost parts of Calcasieu and Acadia Parishes. Fresh water in the Chicot aquifer is generally characterized as a calcium magnesium to calcium sodium bicarbonate type (Harder et al., 1967).

An east-west cross-section through the Calcasieu and Acadia sites demonstrates the massive nature of the Chicot sands and gravels and the saltwater present in the base of the sand (Figure 2-4). Figure 2-5 shows the nature of the gulfward dipping sands of the Chicot, Evangeline and Jasper aquifers in a north-south cross-section and the abrupt change from fresh to saltwater in the aquifers near the coast.

The two major uses of groundwater in southwest Louisiana are (1) industrial pumping at Lake Charles and (2) irrigation pumping, principally in Acadia Parish. The following table lists the total amount of pumping in the three parishes of interest and the principal water uses (Table 2-4).

Table 2-4. Groundwater Pumpage in Southwest Louisiana

\begin{tabular}{|c|c|c|c|c|c|c|c|c|}
\hline \multirow[t]{2}{*}{ Parish } & \multicolumn{2}{|c|}{ Total } & \multicolumn{2}{|c|}{ Irrigation } & \multicolumn{2}{|c|}{ Industrial } & \multicolumn{2}{|c|}{ Municipal } \\
\hline & $\mathrm{m} 3 / \mathrm{d}$ & (mgd) & $\mathrm{m} 3 / \mathrm{d}$ & (mgd) & $\mathrm{m} 3 / \mathrm{d}$ & (mgd) & $\mathrm{m} 3 / \mathrm{d}$ & (mgd) \\
\hline Acadia & 525,358 & 138.8 & 492,050 & 130.0 & 11,734 & 3.1 & 12,112 & 3.2 \\
\hline Calcasieu & 574,185 & 151.7 & 228,614 & 60.4 & 288,796 & 76.3 & 39,743 & 10.5 \\
\hline Cameron & $57,1.54$ & 15.1 & 39,364 & 10,4 & 12,112 & 3.2 & 2,650 & 0.7 \\
\hline
\end{tabular}

Source: Harder et al., 1967. 


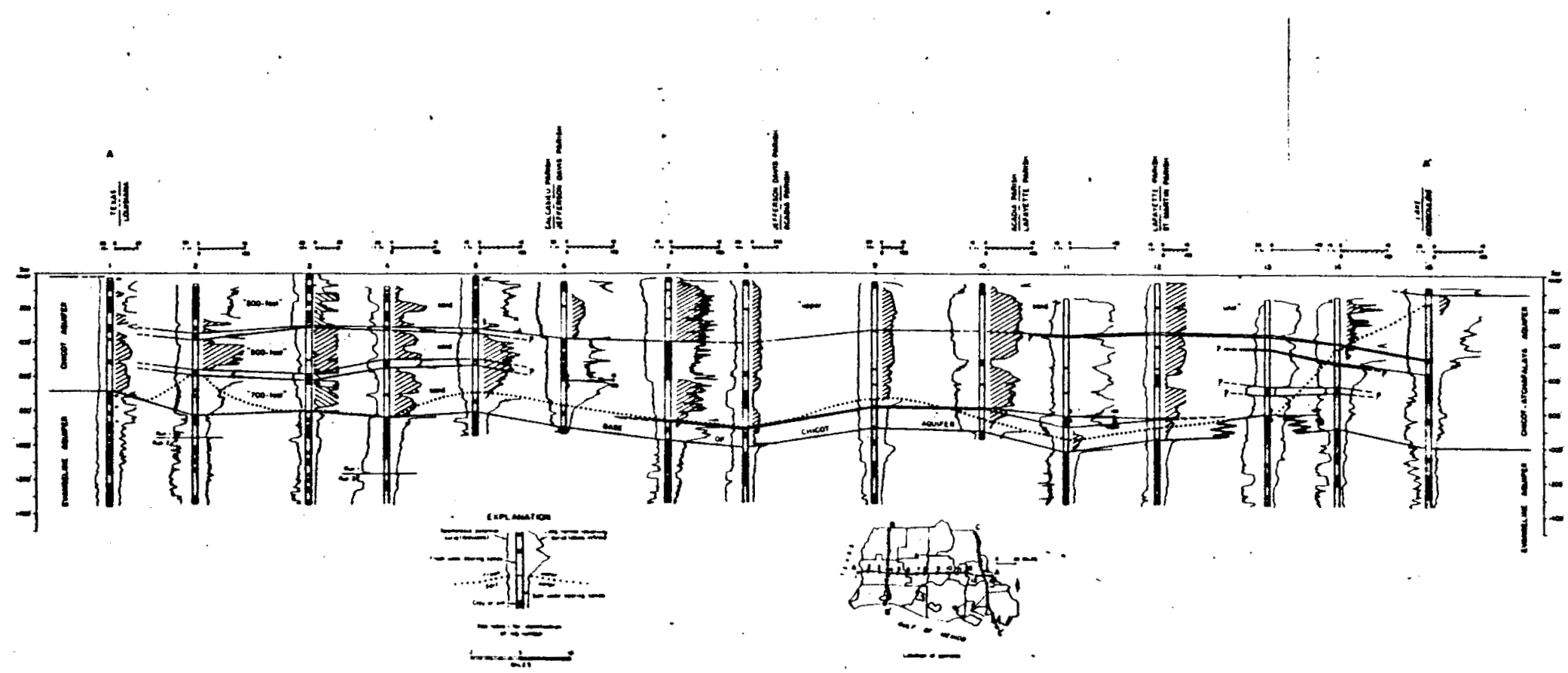

F1g. 2-4. Geohydrologic section from southeastern Texas to eastern St. Martin Par1sh, Louisiana (After Harder et al., 1967). 


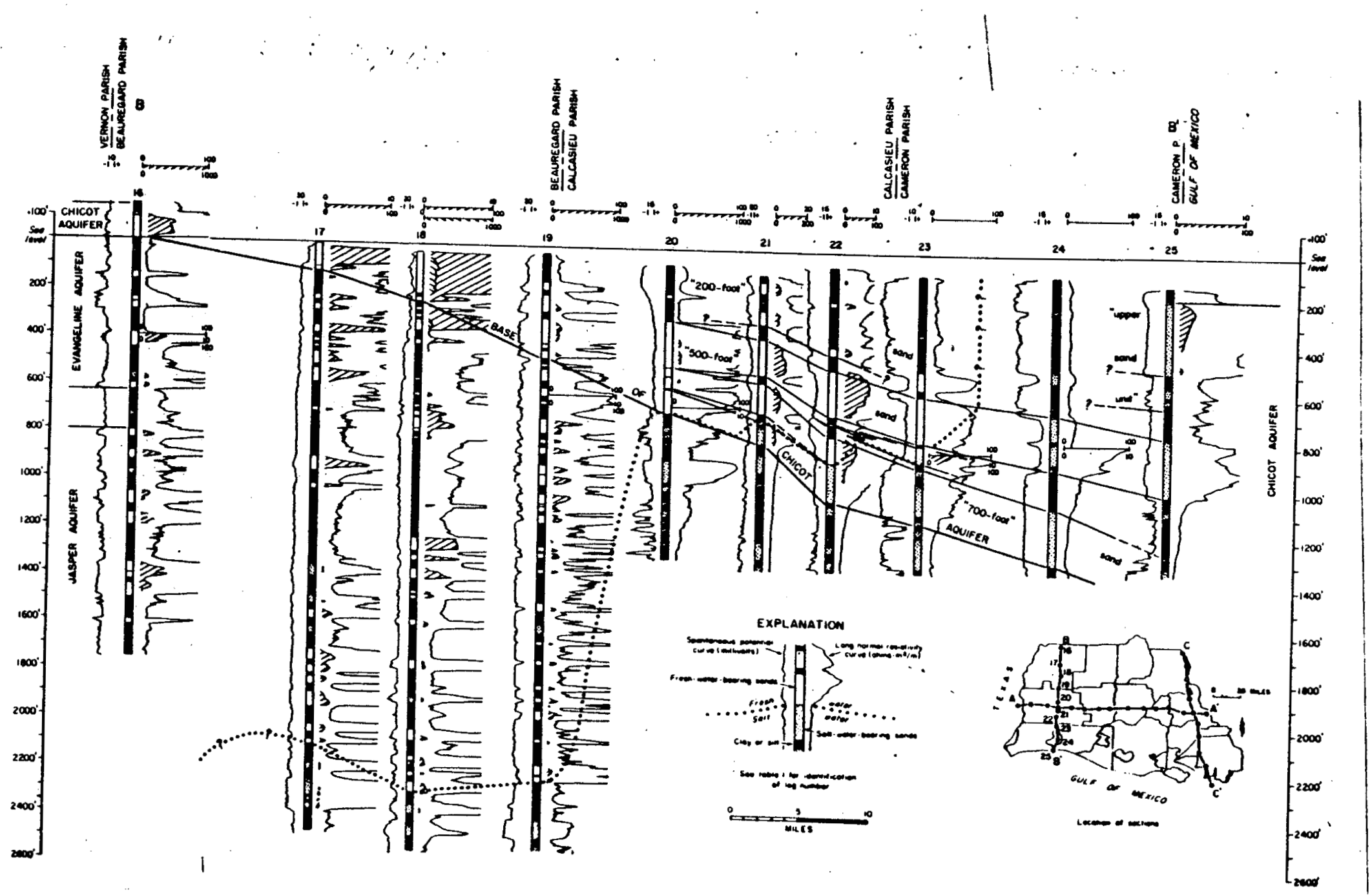

F1g. 2-5. Geohydrologic section from northern Beauregard Parlsh to southern Cameron Par1sh,
Louisiana: (After Harder et al., 1967). 


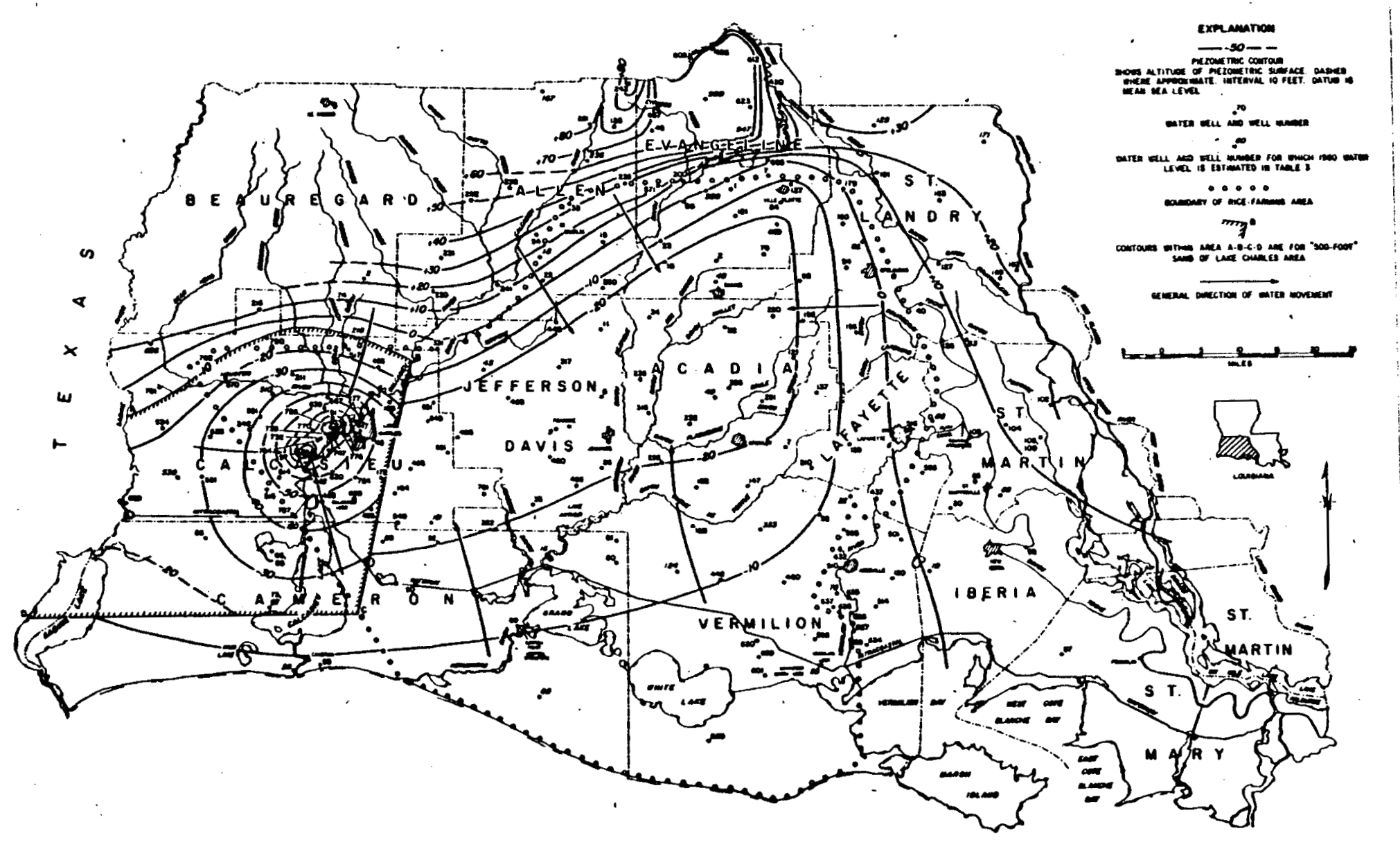

Fig. 2-6: Alt1tude of Plezometric surface In the Chicot-Atchafalaya Aquifer In southwestern Loulsiana, Apr11, 1956 (After Harder et al., 1967). 
Figure 2-6 is a map of water levels in the Chicot aquifer. The center of maximum drawdown is at Lake Charles. A broad trough of water level decline extends east and northeast from Lake Charles into Acadia Parish where thousands of irrigation wells pump water from the Chicot aquifer causing a reversal of the normal gulfward flow of groundwater. Water now moves northward from the coast in the Chicot aquifer at a rate of 9 to $61 \mathrm{~m}$ (30 to $200 \mathrm{ft}$ ) per day (Harder et al, , 1967). The same authors conclude that future water development will not lead to serious problems of saltwater encroachment except for wells located near the present saltwater/fresh water interface. Although water level declines greater than $36 \mathrm{~m}$ (100 ft) have occurred at Lake Charles and declines of several tens of feet occur in parishes east of Lake Charles, land subsidence due to groundwater offtake in the area has not been reported.

The thick and abundant saline sands below the fresh water aquifers are ideal reservoirs for oil field brine disposal. Information regarding brine disposal wells is recorded with the Louisiana Department of Conservation (Louisiana Department of Conservation, 1975). No adverse environmental impacts associated with injection well disposal of brine have been reported in southeastern Louisiana.

The Calcasieu Parish site is situated in the Calcasieu drainage basin, drained by the polluted Calcasieu River (P1ate 1), No domestic water supply is taken from streams in the area and no scenic streams are located downstream of the potential site, Water for irrigation is taken from surface sources in the basin.

The Acadia Parish site is located in the Mermentau drainage basin. Though not designated by the Environmental Protection Agency as a polluted stream, the 


\begin{abstract}
Mermentau River has an average chlorides concentration of $1963 \mathrm{ppm}$ and an average sulfates concentration of $267 \mathrm{ppm}$ (Table 2-5). Therefore, the water quality. is already less than excellent. The surface water is used for irrigation at times. No domestic water supply is taken from streams in the basin, and there are no designated scenic streams (Plate 7):
\end{abstract}

The Cameron Parish site is also in the Mermentau Basin. However, this site is in the lower part of the basin in the wetlands. Water circulation is less confined and more subject to weather and tidal events and diffusion of effluents is more pervasive than on upland sites. Commercial fisheries, oysters, shrimp, and trapping activities which are dependent on existing surface water conditions are prevalent in this location. Recreational and aesthetic use of the surface waters are considerations in the area, but no domestic water supply sources or scenic streams are located here.

In Calcasieu Parish the majority of the study area is agriculture, with perhaps $10 \%$ in mixed or coniferous forest. In the Acadia Parish area there is mostly agricultural land. Near the southern and northern borders of the area are swamp forest and bottomland hardwood (deciduous) vegetation. In Cameron Parish the majority of the area is intermediate marsh, with some fresh marsh at the northern limits of the area around Grand Lake, Some ridge vegetation occurs in this area but the extent is so slight that it does not show up on the vegetation map (Plate 8 ). In the Acadia Parish site, there are no especially significant fish and wildife resources. 
Table 2-5. Water Quality Characteristics of Selected Streams in the Study Area.

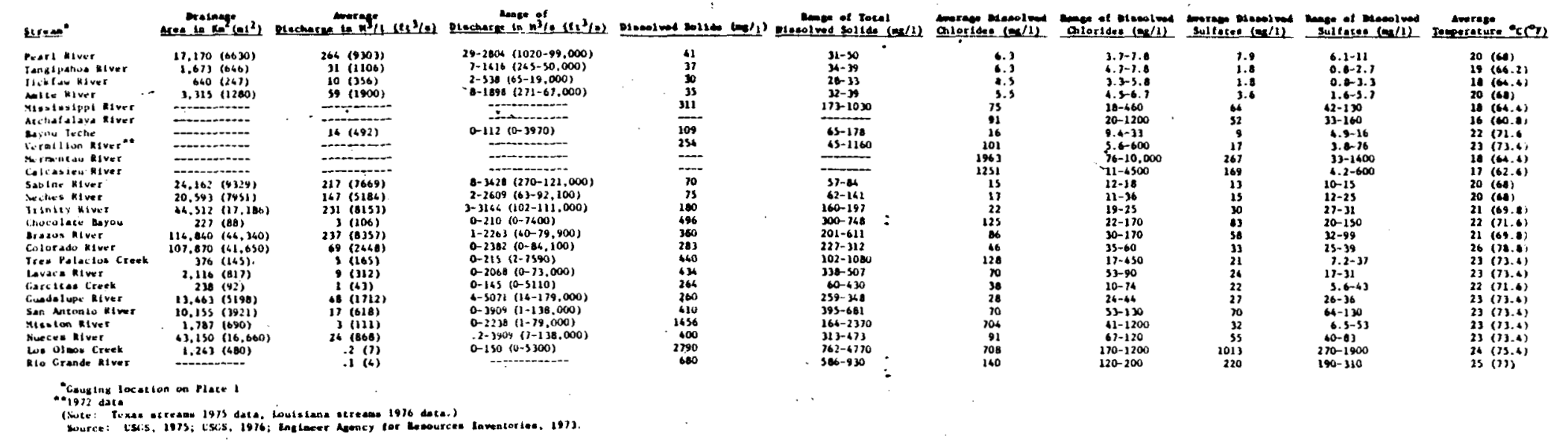


The Cameron Parish site contains an area that is within the boundaries of the Lacassine National Migratory Waterfowl Refuge. Outside of the refuge most of the extensive marsh lands are used for oll and gas extraction, cattle grazing, fur and alligator propogation and harvest, and for waterfowl hunting leases. Considerable sport and commercial fishing occur there. The Cameron site also covers Little Chenier State Park.

The western edge of this fairway is near the eastern part of the recently occupied range of the endangered red wolf, but site selection here poses no threat to the wolf's welfare. Five wading bird rookeries are present and are in active use from March through July. Developments during the season that nests are inactive should be planned so as to not alter vegetative cover or normal water levels.

The Calcasieu Parish site contains wetlands, bottomland hardwoods, pinelands, urban development and agriculture. The red-cockaded woodpecker occurs here in residual pine trees (Pinus palustris) that have survived earlier logging. Woodpecker colonies are not mapped for all of this area but many industrial forest owners have noted colonies that occur on their lands. No specific maps of bird rookeries are available this far from the coast but they do occur throughout the area.

Land use in southwest Louisiana is directly related to physiography. The Pleistocene terraces of Calcasieu and Acadia Parishes are cultivated and for the most part are in rice, Bottomlands along streams remain in hardwoods and serve as flood areas and wildlife zones, Cameron Parish on the other hand is coastal wetland and is a wildlife, waterfowl, recreation zone which has for the most part 
remained undeveloped. The greatest user impact on the area is related to oil canals and petroleum activities.

From the cultural viewpoint, there is a concentration of archeological sites along the Calcasieu River in Calcasieu Parish. In Acadia Parish, there is a small zone of sites along the Mermentau River while in Cameron Parish, archeological sites occur around Grand Lake. Acadians are found throughout the parishes which contain the fairways.

\subsubsection{Brazoria and Galveston Counties, Texas}

The northernmost fairway in Texas is in Brazoria and Galveston Counties and appears to be the most promising for a well testing site. Sand bodies total approximately $244 \mathrm{~m}$ (800 ft) thick in thin interfingering sands and shales deposited as marine sediments. The top of the geopressure zone is between 2745 to $3660 \mathrm{~m}$ ( 9000 to $12,000 \mathrm{ft}$ ) below sea level. Temperatures are greater than $121^{\circ} \mathrm{C}\left(250^{\circ} \mathrm{F}\right)$ (Bebout, Loucks, Bosch, and Dorfman, 1976).

The Brazoria-Galveston County, Texas, geothermal area of interest is covered by six soils groups. Saline soils occur along the Gulf coast and along Galveston Bay. Runoff is slow to very slow and has a very high to high shrinkswell potential. Such soils are not suitable for ponds or reservoirs. Inland from the coast are clays and clayey loams of the Pleistocene terraces which have slow to very slow runoff characteristics. The shrink-swell potential for all of the soils is moderate to very high. For the most part, the soils are not suitable for pond or reservoir use. 
The groundwater resources of the Brazoria-Galveston area are described in reports by Sandeen and Wesselman (1973) and Pettit and Winslow (1957). A detailed cross-section of the fresh to saline aquifers is given in Figure 2-7. The relationship between the geopressured reservoirs and the occurrence of fresh and slightly saline water is shown in the Tertiary cross-section of Bebout, Luttrell and Seo (1976) in Plate 5.

Only the Quatemary alluvium and Beaumont Clay outcrop at the surface receive recharge in the Brazoria-Galveston area (Plate 5). The deeper and older formations come to the surface and are recharged north of the area. Hydrologic characteristics of the main aquifers of the area are listed in Table 2-6. Wesselman (1973) includes a detailed discussion of water quality varations and lists chemical analysis of all wells sampled in Brazoria County. The classification of groundwaters for irrigation use from various aquifers in Brazoria County is shown in Figure 2-8.

Major pumping centers of groundwater in Galveston County are the Alta Loma area (13 mgd in 1972) and the Texas City area (14 mgd in 1972) (Gabrysch and Bonnet, 1975). In Brazoria County the largest center of groundwater pumpage is Freeport. The total groundwater pumpage for the county was $162,755 \mathrm{~m} 3 / \mathrm{d}$ (43 mgd) in 1967 and the majority of water was used for irrigation.

An important additional component affecting the groundwater situation in the Brazoria-Galveston area is the pumpage of groundwater in the Houston area, The Houston area includes five separate sub-areas outside of Brazoria and Galveston Counties which pump a total of approximately $490 \mathrm{mgd}$ (Gabrysch and Bonnet, 1975). 


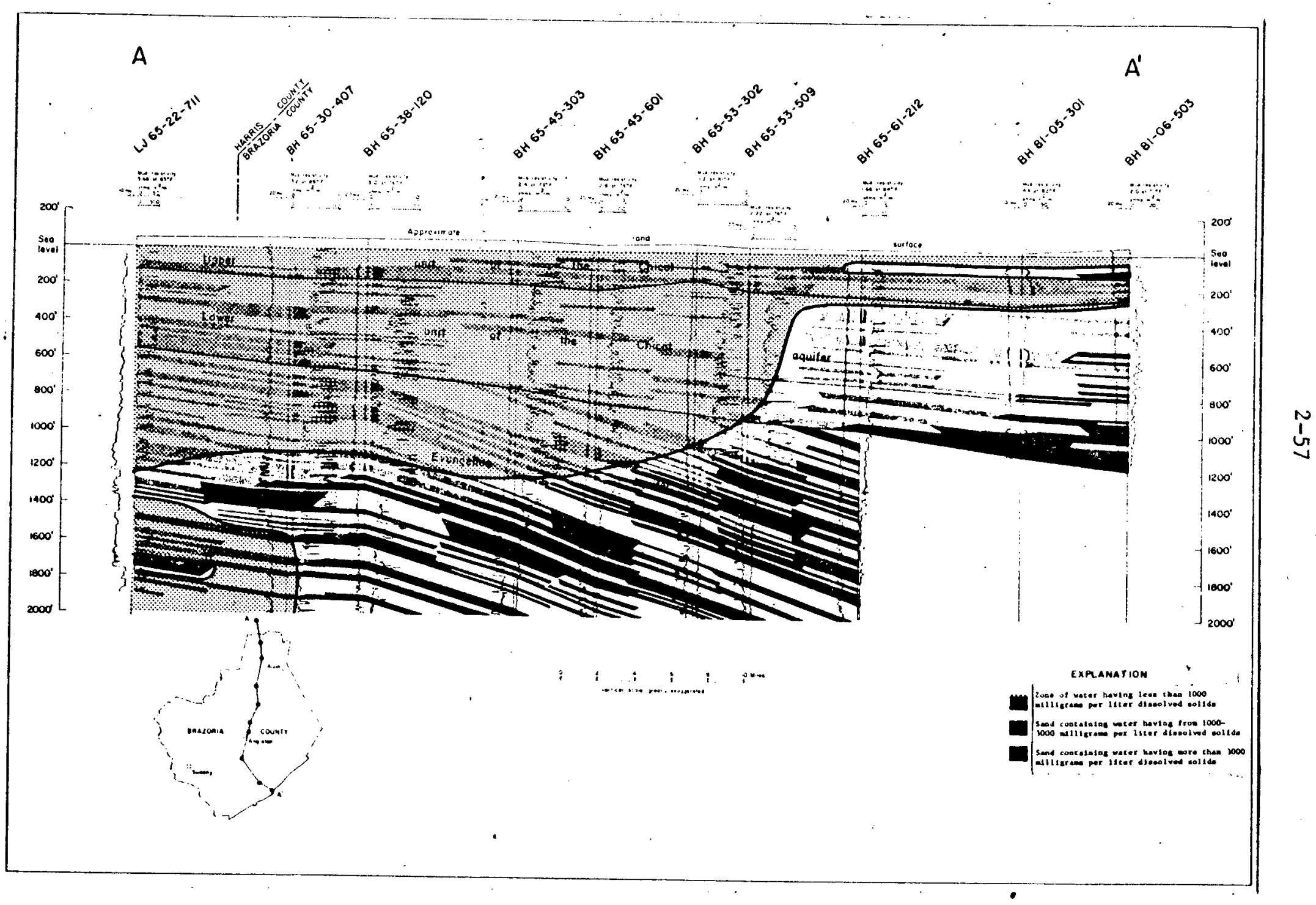
Fig. 2-7. Hydrologic section A-A', Harris and Brazoria Counties (After Sandeen and Wesselman,
1973). 
Table 2-6. Geologic and Hydrologic Units of the Texas and - Louisiana Coastal Plain.

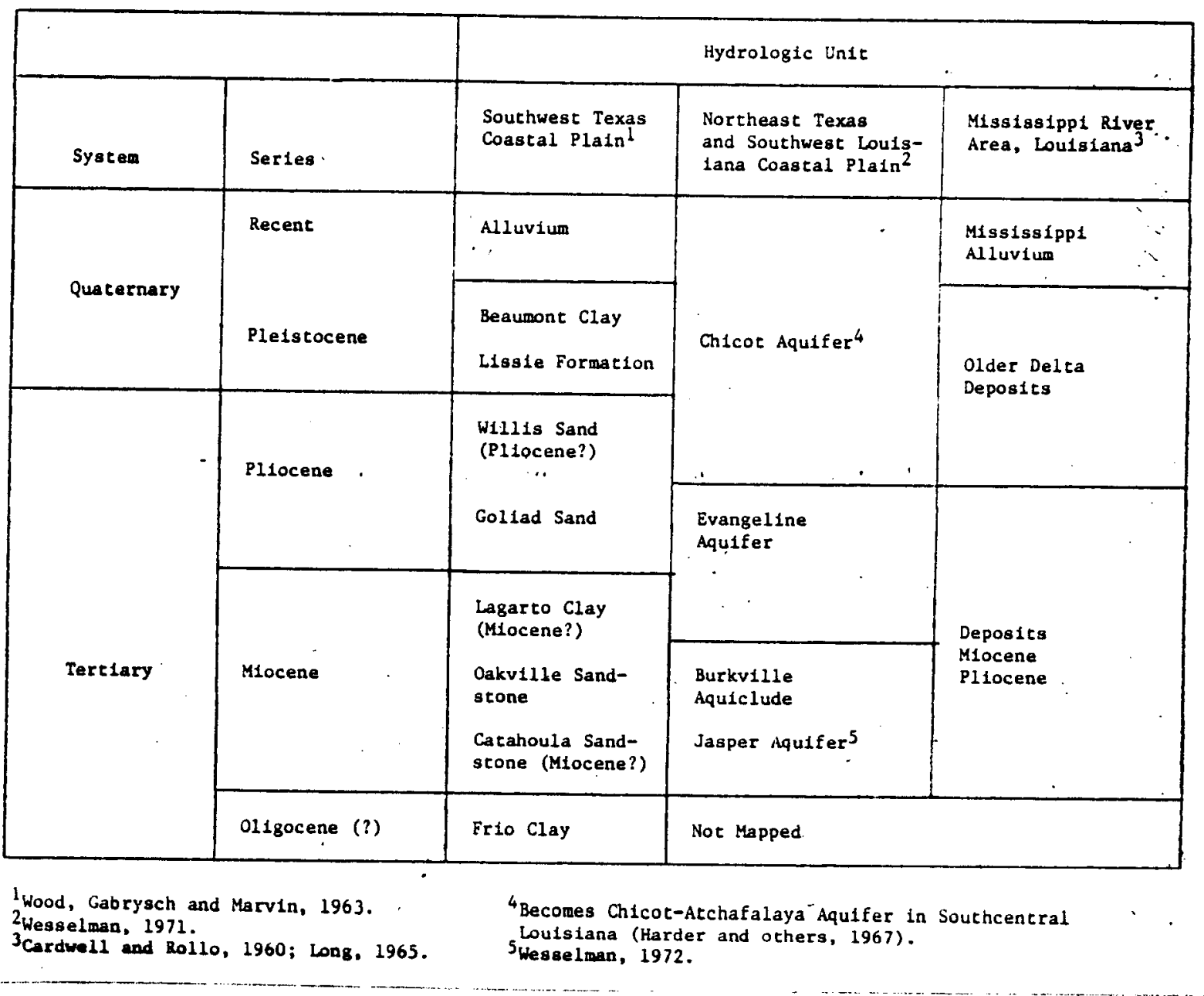




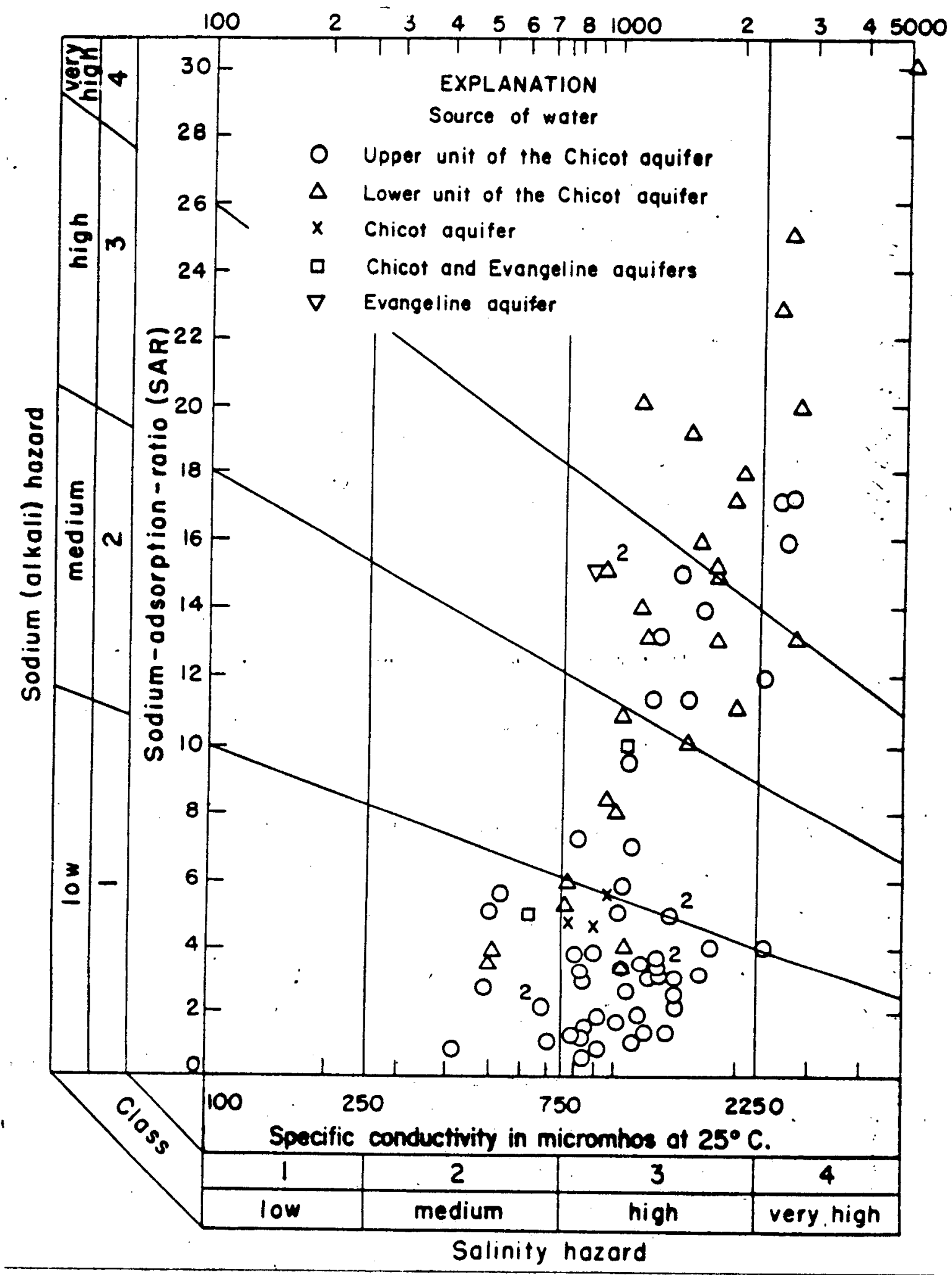

F18. 2-8. Classification of 1rrigation waters in Brazorla County, Texas (After Sandeen and Wesselman, 1973). 
As a result water levels have declined more than $61 \mathrm{~m}(200 \mathrm{ft})$ in the Chicot aquifer and $92 \mathrm{~m}(300 \mathrm{ft})$ in the Evangeline aquifer. The natural coastward flow of groundwater has been reversed in a broad area resulting in the landward encroachment of the saltwater/fresh water interface along the coast. In addition the decline of artesian pressure in the coastal aquifers has resulted in land subsidence over a wide area. Subsidence measured between 1943 and 1964 is shown in Figure 2-9. Figure 2-10 shows active surface faults and surface traces extrapolated from subsurface faults in Galveston and Harris Counties. Kreitler (1977) concluded groundwater: withdrawals activate some faults by differential compaction and that faults can restrict water level declines and land subsidence.

The Brazoria County site is located in the San Jacinto-Brazos drainage basin. Water quality in the basin is relatively good, and some domestic water is supplied from surface sources in the basin. No polluted streams or scenic streams are in the area. Surface water is used for irrigation in the basin.

Most of the fairway has been cleared of its natural vegetation, except for the bottomlands along the streams and the saline and intermediate marshes along the bay.

The Galveston-Brazoria County area includes recently occupied bald eagle nest sites. Nesting territories should be protected by not conducting any developments within $1.6 \mathrm{~km}(1 \mathrm{mi})$ of the nest tree from October through April. Developments at other times should not allow destruction of the nest trees or similar trees in the vicinity of the nest. 


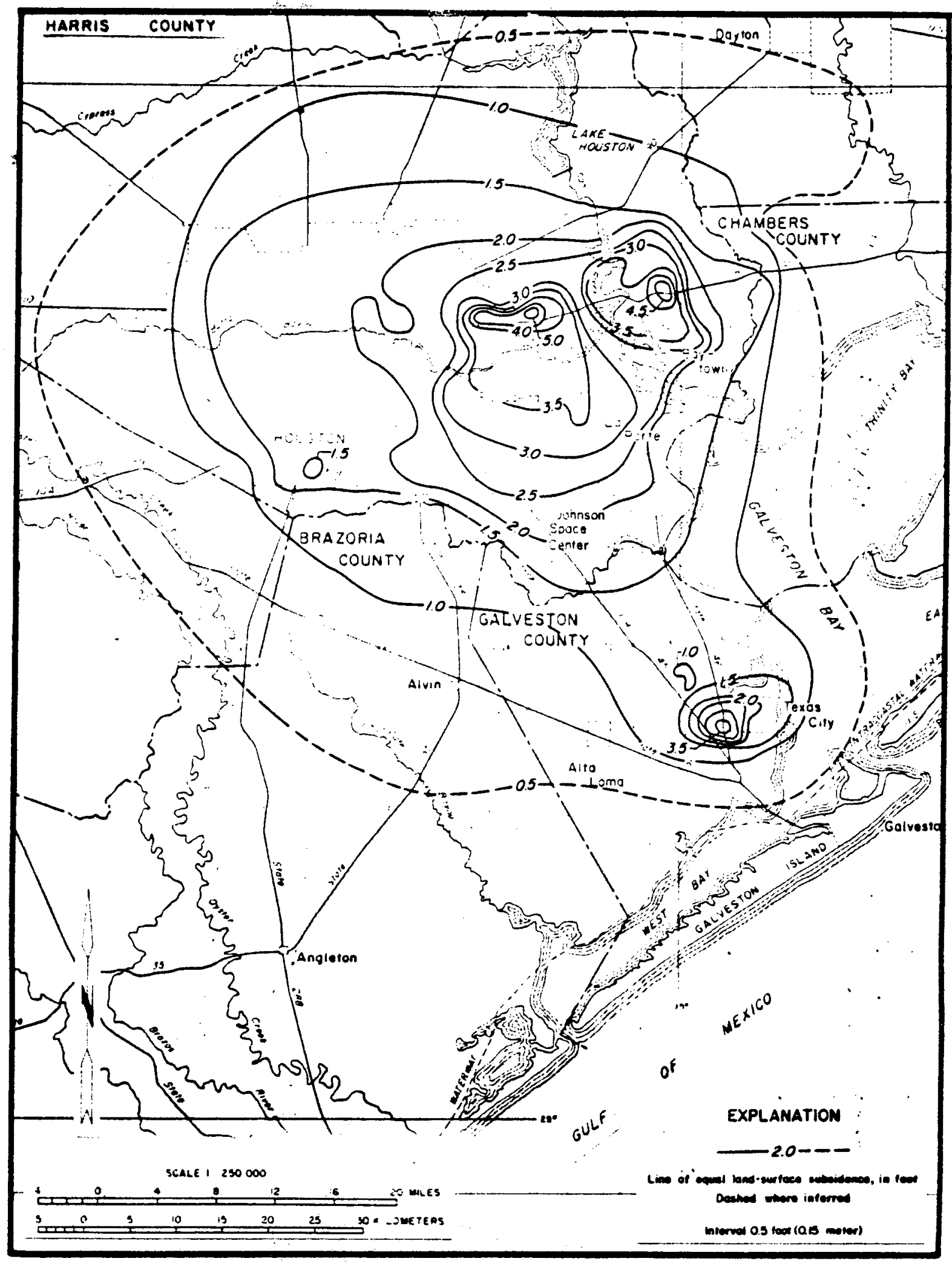

F1g. 2-9... Land-surface subsidence in the Houston area, Texas, 1943-1964 (After Jorgensen, 1975). 


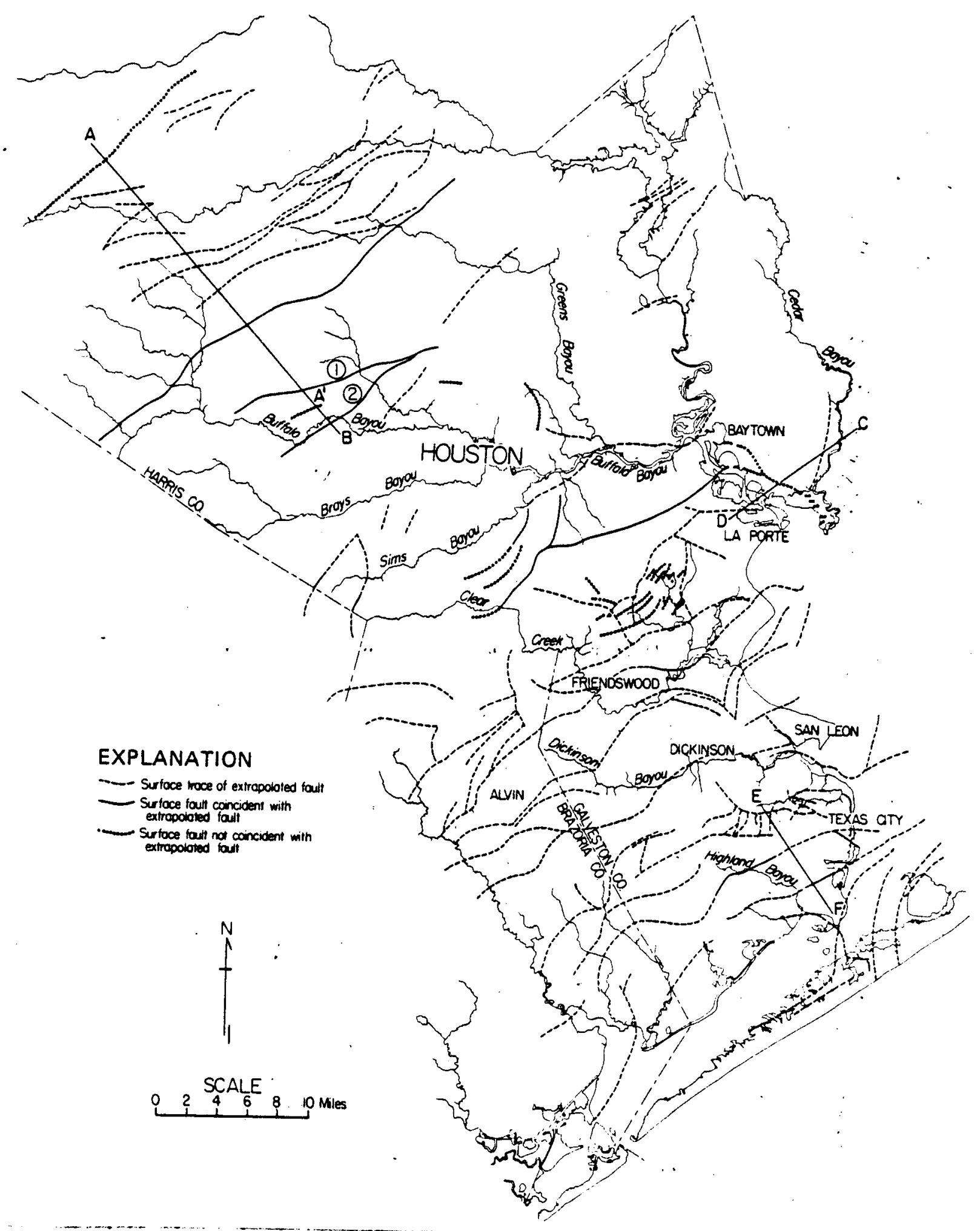

Fig. 2-10.- Active surface faults and surface traces of extrapolated subsurface faults, Harris and Galveston Counties, Texas (After Kreitler, 1977). 
The Attwater's prairie chicken occurs in small colonies in Brazoria and Galveston Counties. The prairie chicken uses bluestem prairie vegetation on or adjacent to the presently occupied ranges. Any developments within agricultural lands may infringe upon the relatively small range of this bird.

The fairway infringes on the range of the red wolf, the cougar, and the ocelot. A major concentration of bird nesting colonies is found along Galveston Bay.

Land use on the Pleistocene surfaces in this fairway grades from agricultural cultivated lands in Galveston County to range land in Brazoria County. Along the margins of the bays and barrier islands, saline marshes and beaches serve as recreation areas and wildlife habitat. The urban centers of Galveston and Texas City and numerous small towns border Galveston Bay at the eastern extreme of the fairway.

In the goepressure-geothermal fairway in Brazoria County, there are three concentrations of archeological sites. In addition, there is one National Register site, the Frank Davidson House (Plate 12 and Overlay).

\subsubsection{Matagorda County}

The fairway in south-central Matagorda County is over $161 \mathrm{~km}$ (100 mi) in area and lies at a depth of $4790 \mathrm{~m}(15,700 \mathrm{ft})$. The strandplain sands are more than $61 \mathrm{~m}$ (200 ft) thick and the fluid temperature exceeds $149^{\circ} \mathrm{C}\left(300^{\circ} \mathrm{F}\right)$. The area of the fairway in northeast Matagorda County is unknown becasue of lack of control, but it occurs at $-4180 \mathrm{~m}(-13,700 \mathrm{ft})$. The sands are $46 \mathrm{~m}$ (150 ft) thick and the fluid temperatures are approximately $149^{\circ} \mathrm{C}\left(300^{\circ} \mathrm{F}\right)$ (Bebout, Agagu, and Dorfman, 1975). 
The Matagorda County site has soils similar to the Brazoria-Galveston site. Runoff is slow to very slow. The shrink-swell potential is moderate to very high and the area is generally not suitable for water impoundments.

The groundwater resources of Matagorda County have been evaluated by Hammond (1969). Generally, the occurrence of fresh and saline groundwater here is similar to the Brazoria-Galveston area. Fresh water is available in the Gulf coast aquifer (equivalent of the Chicot aquifer in Brazoria County) as deep as $305 \mathrm{~m}$ (1000 ft), except within 8 to $16 \mathrm{~km}$ (5 to $10 \mathrm{mi}$ ) of the coast where the fresh water zone thins to less than $153 \mathrm{~m}$ (500 ft). Approximately $64,345 \mathrm{~m} 3 / \mathrm{d}$ (17 mgd) was pumped during 1966 and nearly 60\% of that was used for irrigation. Because groundwater development is less in Matagorda County than in the neighboring counties to the east, the problems of land subsidence and saltwater encroachment are similarly reduced. Land subsidence has amounted to less than $10 \mathrm{~cm}$ (0.3 ft) since 1918 (Figure 2-11). Saltwater encroachment may be important only in one local area where groundwater levels have been lowered more than $31 \mathrm{~m}$ (100 ft) at 01d Gulf salt dome during the sulphur production process.

Subsurface injection of oil field brines is the principal means of brine disposal in Matagorda County as indicated in Table 2-7. Table 2-8 1ists brine injection wells reported by Hammond (1969). The brine injection zones ranged from 4514 to $2166 \mathrm{~m}(1,480$ to $7102 \mathrm{ft})$ below land surface. Approximately 15,077,427 barrels of brine or $93 \%$ of the brine produced was reinjected during 1961 at pressures varying between 0 to $4882 \mathrm{kgs} / \mathrm{m}^{2}\left(0\right.$ to $\left.10001 \mathrm{bs} / \mathrm{in}^{2}\right)$. 
Table 2-7. Methods and Quantity of Saltwater Disposed in 1961, Matagorda County, Texas (After Hammond, 1969).

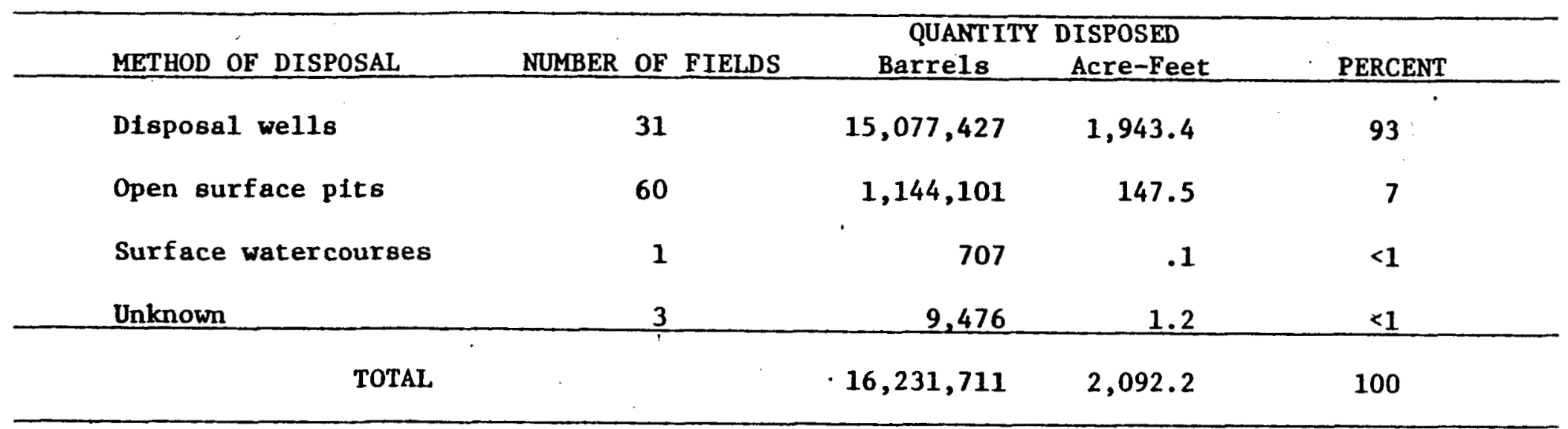

Table 2-8 Records of Brine Injection and Disposal Wells in Matagorda County, Texas (After Hammond, 1969).

\begin{tabular}{|c|c|c|c|c|c|c|c|c|c|c|c|c|c|c|c|c|}
\hline Last & $m$ & 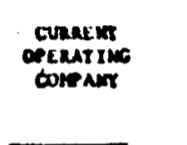 & 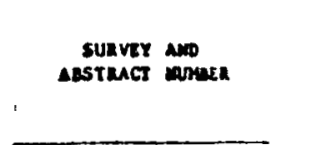 & $\begin{array}{l}\text { INULCT LOW } \\
\text { 2ONE (FERT } \\
\text { LEW LWND } \\
\text { SURF ACE) }\end{array}$ & $\begin{array}{l}\text { siger } \\
\text { (IN.) }\end{array}$ & 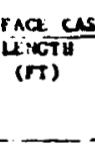 & 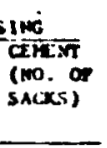 & $\begin{array}{l}\frac{\operatorname{lng} c e}{\operatorname{sizh}} \\
\text { (1M.) }\end{array}$ & 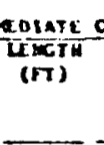 & $\begin{array}{l}\text { CAsthe } \\
\text { CERe } \\
\text { (No. of } \\
\text { sACas) }\end{array}$ & $\begin{array}{l}8 \frac{\text { LONC }}{i z} \\
(\therefore .)\end{array}$ & 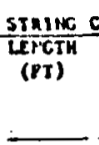 & 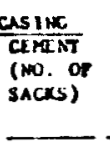 & $\begin{array}{l}\text { TY." } \\
\text { INUECT ION }\end{array}$ & $\begin{array}{l}\text { CURAENT } \\
\text { OAILY VOLUTE } \\
\text { OF BRINE } \\
\text { INJECTED } \\
\text { (BBLS) } \\
\end{array}$ & $\begin{array}{l}\text { SLNGACE } \\
\text { INUETI IOW } \\
\text { PRESSURE } \\
\text { (PAL) }\end{array}$ \\
\hline 1. J. Plerce, et al. & 2 & A. Selth & J. W. E. Mallace, A-94 & $1,510-1,6: 9$ & *. & $\cdots$ & $\cdots$ & $\cdots$ & $\cdots$ & $\cdots$ & $5-1 / 2$ & 1,700 & 300 & $\begin{array}{l}\text { Tubling with } \\
\text { packer }\end{array}$ & 600 & Cravity \\
\hline W. J. rulhertson & 1 & Eupertor & Burnet Sojourner, $A-13$ & $1,920-1,962$ & $13-3 / 8$ & 1,441 & 800. & .. & $\cdots$ & -- & 7 & a,516 & 500 & do & 2,000 & 450 \\
\hline r. C. CuLb "s" & 40 & Skelly & M. Cuesen $(n a, A-2)$ & $1,052-1,714$ & 1 & 1,796 & 680 & -. & -- & $\because$ & .. & .. & $\cdots$ & do & 6,000 & 800 \\
\hline c. Laurence & 1 & do & Burnect \& Sojourber, A-1] & $2,920-3,010$ & 7 & 3,061 & 650 & -. & $\cdots$ & -- & -- & -. & $\cdot \cdot$ & do & 750 & 300 \\
\hline D. Mourtze "8" & 了 & Texan Pactlic & ISCN Ma, $1-2=19$ & $2,360-2,380$ & $8-5 / 8$ & 616 & 205 & *. & -- & $\cdot-$ & $3-1 / 2$ & 2,479 & 335 & do & 1,500 & 800 \\
\hline $\begin{array}{l}\text { Soweri Texsen } \\
\text { Devel opseser co. }\end{array}$ & 1 & Iruln o suck & $\begin{array}{l}\text { Detles etryt } \\
\text { willides, } a-3\end{array}$ & $1,610-3,640$ & $13+3 / 8$ & 1,690 & 250 & $9-5 / 8$ & 6.849 & $\cdots$ & $?$ & 10,380 & 1,000 & Anevulus: & 100 & 200 \\
\hline L. V. Scoddard & 1 & Nade & c. A. A. $\cot (0, a-1\}$ & $2,312 \cdot 2,290$ & $13-5 / 8$ & 2,516 & 276 & $9.3 / 8$ & 9,580 & 1,000 & $5-1 / 2$ & $10,131$. & .00 & Tubling & 600 & 900 \\
\hline M. E. Crouch & 1 & $\begin{array}{l}\text { Siteward } \\
\text { Couger }\end{array}$ & John Criex, A-19 & $6,360-6,350$ & $10-3 / 4$ & 1,337 & 835 & $\cdots$ & -- & $\cdots$ & $4-1 / 2$ & 7,121 & 295 & Lone atring & 100 & $\begin{array}{c}\text { Grevsly } \\
600\end{array}$ \\
\hline M. C. Cornellues & 3 & $\begin{array}{l}\text { Moteri:- } \\
\text { whicson }\end{array}$ & M. H. Morrison, A-96 & $1,689-9,200$ & $9-5 / 8$ & 1,609 & 350 & $\cdots$ & $\cdots$ & $\cdot \cdot$ & $4-1 / 2$ & 9,870 & 400 & Aanulus & $200-400$ & 600 \\
\hline D. V. Trull Unlt Well & 1 & Crown Centrial & IsCK an, a-289 & $2,226-2,290$ & $10-3 / 4$ & 1,110 & 673 & $\cdots$ & $\cdots$ & $\cdots$ & $5-1 / 2$ & 0,553 & 200 & Cos Ing & $250-300$ & 300 \\
\hline Eeinke.est. & i & Kirby & Joha Mer (1D, A-J3) & $2,300-6,210$ & $10-314$ & 2,300 & 1,350 & 1 & 10,980 & 600 & 5 & 11,350 & 113 & aranulue & $70-80$ & -. \\
\hline P. M. Cornelives & 1 & a. A. Inc. & Isew $24, N-209$ & $2,262-2,293$ & $10-3 / 4$ & 1,122 & 335 & $\cdots$ & $\cdots$ & $\because$ & $3-1 / 2$ & $B, 746$ & 425 & Tubins & $500-800$ & $150=-100$ \\
\hline mockeye & 1 & Monsanto & c. A. M. $\operatorname{Cot}\left\{00, A^{A-1]}\right.$ & $2,506-1$ & $13-5 / 8$ & 2,506 & 1,350 & $0-5 / 6$ & 9,526 & 500 & 7 & 15,000 & 700 & $\therefore$ Anoulue & 30 & Grevlty \\
\hline D. M. orsmen " $\mathrm{C}$ " & 2 & sun & nowle, A-4! & $1,900-3,200$ & $9-3 / 8$ & 30 & 20 & -. & -- & $\cdots$ & ' & 3,250 & 230 & Tub lng & 2,800 & 300 \\
\hline D. W. O'Conner "A" & 1 & Cont imencel & town to Reese, At & $1,358-8,000$ & $9-5 / 8$ & 1,558 & cos & $\cdots$ & $\cdots \prime$ & $\cdots$ & $3-1 / 2$ & 9,914 & 300 & Annul ise & $.90-200$ & 250 \\
\hline J. A. Wheeler & $3-k$ & Gandy-Heauley & ICCM NR, a-209 & $1,102-1,133$ & $10-3 / 4$ & $\because$ & $-\cdot$ & $\cdots$ & $-\cdot$ & $\cdot \cdot$ & $2-7 / 6$ & 7,935 & 400 & cesines & $500-1,000$ & $130-1,000$ \\
\hline Aicherde vati & $\mathbf{1 1}$ & crom ceatral & Iace an, A-2w9 & $1,3 \times-1,390$ & $\cdot$ & $\cdot$ & $\cdots$ & $\because$ & -- & $\cdots$ & $\because$ & $\because$ & $\cdots$ & $\cdots$ & $\because$ & erevlsy \\
\hline
\end{tabular}


Table 2-8. Records of Brine Infection and Disposal Wells In Matagorda County, Texas (After Hammond, 1969).
Continued.

\begin{tabular}{|c|c|c|c|c|c|c|c|c|c|c|c|c|c|c|c|c|}
\hline LEASE & n. & $\begin{array}{l}\text { CURMENT } \\
\text { UPERATINC } \\
\text { COMPAST } \\
\text { - }\end{array}$ & $\begin{array}{l}\text { SLRVIT AND } \\
\text { ABSTRACT MATBiK }\end{array}$ & 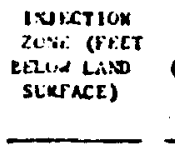 & $\frac{s ! w r}{s i k t}$ & $\begin{array}{l}\text { PACECAS } \\
\text { Livitit } \\
\text { (FT) }\end{array}$ & $\begin{array}{l}\frac{\lim }{\operatorname{cin} \overline{\operatorname{sint}}} \\
\text { (WN. UF } \\
\text { SAcKS) }\end{array}$ & 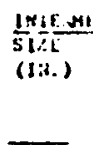 & 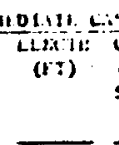 & 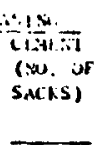 & 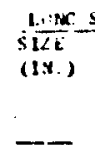 & $\frac{\operatorname{sinjixc}}{\substack{\text { LLxidii } \\
\text { (fil }}}$ & $\begin{array}{l}\text { ASINE } \\
\text { CENET } \\
\text { (:D. of } \\
\text { SACKS) }\end{array}$ & $\begin{array}{r}\text { Thet } \\
\end{array}$ & 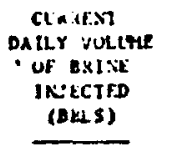 & $\begin{array}{l}\text { Sunfack } \\
\text { iNuEction } \\
\text { puessiak } \\
\text { (pai) }\end{array}$ \\
\hline J. S. Morets & 2 & Weat liced & $\operatorname{lng} 2 x,-132$ & $1,50-2,010$ & $-5 / 1$ & $1, \operatorname{ses}$ & $\infty$ & $\cdots$ & - & $\cdots$ & $2-1 / 0$ & 2,000 & $\rightarrow$ & $200 x$ & 300 & 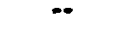 \\
\hline v. U. creect undt & 1 & M. P. s. Fod. & Wurnate \& Sojourner, $A-13$ & $1,400-1,675$ & $9-310$ & 1,470 & 590 & $\cdots$ & $\cdots$ & $\cdots$ & $3-1 / 2$ & $\bullet, 077$ & 450 & ماسman & $60-60$ & $20-100$ \\
\hline A. Spencer & 2 & Superior & 1. Rectue, $A-7)$ & $2,000-2,100$ & $\because$ & $\because$ & -- & -- & $\cdots$ & $-\cdot$ & s & 2,100 & $\cdots$ & $\begin{array}{l}\text { Tublag wlth } \\
\text { pecter }\end{array}$ & 1,300 & 100 \\
\hline Ineall cas Unte & 1 & Pon Mexicen & El laste mall, ats & $2,730-2,780$ & $10-3 / 4$ & 2,326 & 2,000 & 1 & 10,230 & 300 & $s$ & 10,620 & 150 & Anaulus & 600 & .00 \\
\hline A. A. Aoxt ls, & $\mathbf{1}$ & cult & IEFH MA, A-290' & $1,914-2,019^{\prime}$ & $\cdots$ & $\cdots$ & 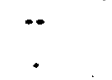 & $\cdots$ & $\cdots$ & $\cdots$ & $a-3 / 2$ & 2,113 & 325 & Tublias & 120 & Grevity \\
\hline villie - Gee Unit & 2 & Pan curican & Ellobe Hall, Ats & $2,095-2,840$ & $10-3 / 4$ & 2,753 & 1,350 & 1 & 9,223 & 300 & 3 & 10,549 & 123 & anoulios & 800 & 100 \\
\hline Eny Cley Unde 16 & 1 & $\infty$. & $\because$ & $2,670-2,646$ & $10-3 / 4$ & 2,532 & 2,000 & $\because$ & $\cdots$ & $\cdots$ & ' & 10,10 & 1,100 & ఎొ & 800 & 200 \\
\hline -. P. moxe LST & 1 & U. M. Morrtean & A. P. T. Stone, A-92 & $2,050 \rightarrow, 455$ & $10-3 / 4$ & 2,050 & 1,010 & $\cdots$ & $\cdots$ & $\because$ & $3-1 / 2$ & 20,605 & 356 & do & 60 & Gravl'; \\
\hline Dienstop-plerce & $\mathbf{1}$ & Texeco & ISCM EN, A-209 & $1,950-2,700$ & $10-3 / 4$ & 1,553 & $\$ 25$ & $\cdots$ & $\cdots$ & $\because$ & 1 & 0,363 & 400 & Tubins & 10,000 & 300 \\
\hline J. C. Lewils & 1 & Munble. & c. c. $\cos , a-10$ & $2,000 \cdot 3,430$ & $8-5 / 0$ & 2,000 & 300 & $\because$ & $\cdots$ & $\because$ & $4-1 / 2$ & 3,500 & 223 & Lone string & $50-250$ & Cravity. \\
\hline $\begin{array}{l}\text { a. c. Mullitcon } \\
\text { cat untt }\end{array}$ & 1 & Pan Aoseritcan & $186 \times 2 \pi, 1-276$ & $1,100-2,600$ & 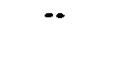 & .. & $\cdot \cdot$ & $\cdots$ & $\cdots$ & $\because$ & $s$ & 2,630 & $\cdots$ & do & 110 & 800 \\
\hline d. Wh Doss Unile "A" & 1 & Temixus & A. I. Jacquen, A-32 & $2,615-2,480$ & $13-1 / 0$ & 1,625 & 100 & $\cdots$ & $\cdots$ & $\cdots$ & $9-3 / 8$ & 0,019 & $4 \infty$ & Twblage & 500 & 100 \\
\hline J. R. Camp & 3 & $\begin{array}{l}\text { Drsper, cuwl. } \\
\text { sic + Co. }\end{array}$ & $\operatorname{tatan} 201,1-336$ & $1,625 \cdot 1,700$ & $10.11:$ & 1,567 & Bds & $\cdot-$ & $\cdots$ & .. & $3.1 / 2$ & 6.345 & 300 & Annulus & 200 & 30.100 \\
\hline a. H. Cluver Unll & $=$ & Atlantie Refs. & J. T. S.1knar, A-11 S & $3,600 \cdot 4,100$ & $10-3 / 4$ & .1 .242 & 223 & $\cdots$ & $-\cdot$ & $\cdots$ & $3-1 / 2$ & 4.211. & 125 & Lung sering & 3045 & Gravity \\
\hline d. S. Glllens, at al. & $2-c$ & Desens & $O K D, A-182$ & $4,283-4,287$ & $3-5 / 4$ & 1,014 & 427 & $\cdots$ & $\cdots$ & $\cdots$ & $4-1 / 2$ & 4,350 & 624 & annulus & $\therefore 0$ & 100 \\
\hline J. 8. Brld & 1 & Mound & LSCS RR, A-339 & $2,515-.1$ & $.10-3 / 4$ & 2,315 & $1, \div 00$ & -- & $-\cdot$ & -. & $5 \cdot 1 / 2$ & 10,503 & 100 & do & 150 & 800 \\
\hline Ciorse Krueser & 1 & ज. P. S. Prod. & A. W. Magnum, A-362 & $2,460-2,560$ & $8-5 / 8$ & 606 & .235 & $\cdots$ & $-\cdot$ & 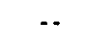 & $4-1 / 2$ & 6,911 & 430 & do & 130 & $150-200$ \\
\hline D. *. Trull Estate & 1 & Mubil & Susaa Perkins, A-3)I & $2,050-2,168$ & $9-5 / 8$ & 1,122 & 400 & $\cdots$ & $\cdots$ & $\because$ & 1 & $9,2: 0$ & 2ss & Lon: $\sin \ln x$ & 1,000 & .900 \\
\hline Sallle Juhason & 6 & Skelly & Maris Cumolns, a.22 & $1,534-1,746$ & $\cdot-$ & .. & 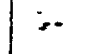 & $\cdots$ & $\cdots$ & $\cdots$ & $3.5 / 8$ & 1,801 & 473 & Twbing & 2,023 & 0.250 \\
\hline moure est. & 13 & - do & $16 C M R, A-10$ & $1,004-1,718$ & $10.3 / 4$ & 163 & 125 & $\cdots$ & $\cdots$ & $\cdots$ & ' & 1,893 & 475 & Do & 1,288 & 0.230 \\
\hline A. U. Irull & 1 & Hiznland & Munly Sexton, A-495 & $1,580-1$ & $\cdot \cdot$ & $-\cdot$ & $\cdots$ & $\cdots$ & $\cdot \cdot$ & 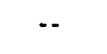 & $-\cdot$ & $\cdots$ & $\cdot \cdot$ & do & -. & $\cdots$ \\
\hline $\begin{array}{l}\text { Midfield Tounstie } \\
\text { Unit }\end{array}$ & 1 & R. A. Gardner & LCCX RR, A-289 & $1,513 \cdot 6,888$ & $10-3 / 4$ & 1,313 & 610 & $\cdots$ & -. & $-\cdot$ & $3-1 / 2$ & 8,830 & 520 & Annulus & 500 & $500-700$ \\
\hline Texas Culf Mlaerals & $!$ & H. H. Howe 11 & LSCM \&R, A-21J & $5,120-5 ; 275$ & $10.3 / 4$ & 175 & 140 & $\cdots$ & $\cdots$ & $\therefore$ & $4-1 / 2$ & 6,353 & 60 & Lons icsins & 100 & $\cdots$ \\
\hline Sthet Cormeltus & 1 & nobil & J. C. Peycon, A.74 & 1.690 .2 .865 & $10-3 / 6$ & 3,062 & 1,635 & $\cdots$ & $\cdot \cdot$ & -. & -. & .. & 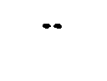 & $\begin{array}{l}\text { Tubing vich } \\
\text { pecker }\end{array}$ & 1,000 & 200 \\
\hline M. A. Cuess. & 1 & $\begin{array}{l}\text { Brition: } \\
\text { Aacrican }\end{array}$ & A. H. villiteax: A-10s & $2,982 \cdot ?$ & $10-3 / 4$ & 2,982 & 3,000 & $7-5 / 8$ & 12,452 & ¿ & $.3-1 / 2$ & 14,266 & 35.2 & Amoulus & 30 & 500 \\
\hline Crege Lourence & 7 & Sket1ly & Durnets \&ojourner, $A-1\}$ & $1.850 .3,030$ & .. & $\cdot \cdot$ & $\cdots$ & $\cdot \cdot$ & $\cdots$, & .. & , & 3,075 & $\cdots$ & $\begin{array}{l}\text { Tubing vith } \\
\text { packef }\end{array}$ & .. & $\cdot \cdot$ \\
\hline Cooke "a" & 3 & do & do & $1,053.2,166$ & 1 & 2,826 & 625 & $\cdot \cdot$ & $\cdots$ & $\cdots$ & $\cdots$ & $\cdot-$ & -- & do & 2,200 & 500 \\
\hline
\end{tabular}


Open surface pits have been used at 60 oil fields for disposal of brines in Matagorda County. Shallow groundwater contamination is documented in three areas where brine seeped into fresh water sands underlying surface pits (Hammond, 1969).

The Matagorda County sites are located in parts of the Brazos-Colorado, Colorado, and Colorado-Lavaca basins. Surface water quality is good in the basins (Table 2-5). Domestic water is supplied from streams in all these basins, as well as

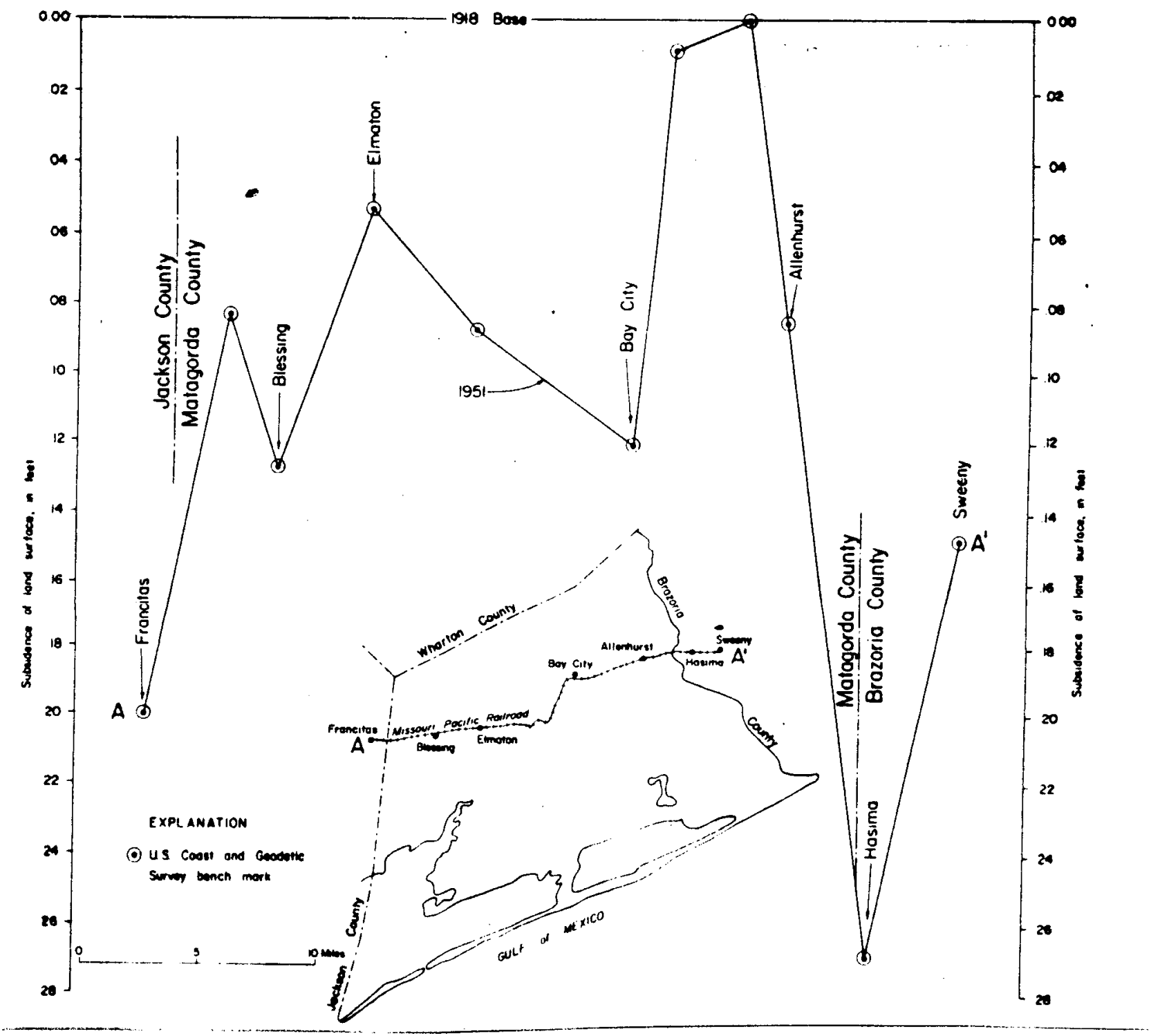

Fig. 2-11. Profile of land-surface subsidence in Matagorda County, Texas, 1918-1951 (After Hammond, 1969). 
water for irrigation. The San Bernard River is a designated scenic stream (Plate 7). No polluted streams are found within these basins.

The wildlife in the Matagorda fairways is significantly modified by the agricultural and urban development of the area. Of principal concern are the eagles' nests located in Matagorda County. Hunting territories may extend into the two fairways. The fairways are also part of the recent ocelot and cougar ranges and contain some major inshore fishing areas.

The dominant land use in Matagorda County is for range and pasture. Interspersed throughout the range lands are cultivated fields. Hardwoods, found along the stream bottoms as they cross the Pleistocene surfaces, serve as wildlife habitat and possible recreation areas. Along the coast are saline marshes, sand dunes, and beaches which are recreation and wildlife habitat zones. The San Bernard National Wildlife Refuge is right in the center of the eastern fairway.

In the two study fairways in Matagorda County, archeological sites are concentrated along major rivers and streams (Plate 12). There are no known National Register sites or ethnic centers in either of the two fairways.

\subsubsection{Nueces, San Patricio, and Aransas Counties}

The geopressure-geothermal fairway under Nueces, San Patricio, and Aransas Counties is more than $322 \mathrm{~km}^{2}\left(200 \mathrm{mi}^{2}\right)$. The top of the geopressure zone is between 3050 and $4880 \mathrm{~m}(10,000$ and 16,000.ft) and appears as a strandplain sand over $153 \mathrm{~m}$ (500 ft) thick. Bottom-hole temperatures are between 149 and $160^{\circ} \mathrm{C}$ $\left(300\right.$ and $320^{\circ} \mathrm{F}$ ). Table 2-9 gives the water chemistry of the geopressured zone of this area. 
At the Nueces, San Patricio, Aransas Counties sites, the soils are sandy and saline along the Gulf and bay and clayey inland. Runoff on these soils is slow to very slow and the shrink-swell potential is low on the sandy soils and very high toward the interior. The clayey soils are suitable for ponds or reservoirs, but the sandy soils along the coast are not.

Table 2-9. Water Chemistry of Geopressured Zone in the Middle Texas Gulf Coast Areas. All concentrations expressed as mg/e (ppm).

\begin{tabular}{lc}
\hline Name & $\begin{array}{c}\text { Seven wells in Aransas, } \\
\text { Nueces, Refugio and San } \\
\text { Patricio Counties }\end{array}$ \\
\hline $\mathrm{Na}+\mathrm{K}$ & $2,000-20,000$ \\
$\mathrm{Ca}$ & $10-8,000$ \\
$\mathrm{Mg}$ & $20-200$ \\
$\mathrm{Cl}$ & $3,500-46,000$ \\
$\mathrm{SO}_{4}$ & $1-1,600$ \\
$\mathrm{CO}_{3}$ & $1-450$ \\
$\mathrm{CO}_{2}$ & $7-1,000$ \\
$\mathrm{Ca}, \mathrm{Mg}$ Hardness & $30-20,000$ \\
$\mathrm{TDS}$ & $8,000-72,000$ \\
$\mathrm{Cu}$ & Not Available (NA) \\
$\mathrm{Zn}$ & $\mathrm{NA}$ \\
$\mathrm{B}$ & $\mathrm{NA}$ \\
$\mathrm{As}$ & $\mathrm{NA}$ \\
$\mathrm{Cr}$ & $\mathrm{NA}$ \\
$\mathrm{Hg}$ & $\mathrm{NA}$ \\
$\mathrm{Pb}$ & $\mathrm{NA}$ \\
$\mathrm{Cd}$ & $\mathrm{NA}$ \\
$\mathrm{Ba}$ & $\mathrm{NA}$ \\
$\mathrm{Fe}$ & $\mathrm{NA}$ \\
$\mathrm{SiO}$ & $\mathrm{NA}$
\end{tabular}

Source; Gustavson and Kreitler 1976.

Schafer (1968) describes the groundwater resources of Nueces and San Patricio Counties and Aransas County (1970). The principal fresh water aquifers are the Beaumont Clay, Lissie Formation and the Goliad Sand (collectively referred to in this area as the Gulf Coast Aquifer). The depth of fresh water occurrences in these sands is shown in Plate 5 (cross-section $\mathrm{H}-\mathrm{H}$ and Table 2-9). 
Generally, water levels are at or slightly above sea level in most areas. An exception is southwestern Nueces County where industrial pumping has lowered the pontentiometric surface of the Gulf Coast Aquifer to nearly $46 \mathrm{~m}$ ( $150 \mathrm{ft}$ ) below sea level. Approximately 16 million gallons of groundwater was pumped daily in Nueces and San Patricio Counties in 1964 (Shafer, 1968). Half of this water was used for Irrigation. In Aransas County during 1966 approximately 1.4 million gallons of groundwater was pumped of which the largest portion (42\%) was used for public supply (Shafer, 1970).

Like other coastal areas, groundwater development has resulted in some inland movement of the fresh water-saltwater interface. Land subsidence has not been reported in this area.

Shafer reported saltwater disposal from oil and gas operations in the three counties was largely accomplished using open surface pits and surface streams as late as 1961. Tables 2-10 and 2-11 from his reports list the methods and quantities of brine disposal. Surface disposal has probably resulted in some contamination of shallow fresh waters (Shafer, 1970).

The Aransas-San Patricio-Nueces site is located in the San Antonio-Nueces and Nueces basins. The Mission River, though not designated a polluted stream, has an average TDS content of $1456 \mathrm{mg} / 1$ (Table 2-5), The Nueces River is of good quality and is used as a source of domestic water. Water for irrigation is supplied from surface sources in parts of the area. Parts of Corpus Cbristi Bay are designated polluted from industrial effluents. 
Table 2-10. Methods of Disposal and Quantity of Saltwater Disposed in Nueces and San Patricio Counties in 1961 (After Shafer, 1968).

Neuces County

\begin{tabular}{lccc}
\hline Methods of Disposal & \multicolumn{2}{c}{ Quantity disposed } & Percent \\
\cline { 2 - 4 } & Barrels & Acre-feet & \\
Injection wells & $15,059,462$ & 1,940 & 23.9 \\
Open-surface pits & $21,228,164$ & 2,730 & 33.6 \\
Surface watercourses & $26,632,120$ & 3,430 & 42.2 \\
Miscellaneous & 76,467 & 98 & .1 \\
Unknown & 101,340 & 130 & .2 \\
\hline
\end{tabular}

San Patricio County

\begin{tabular}{lccc}
\hline Methods of Disposal & \multicolumn{2}{c}{ Quantity disposed } & Percent \\
\cline { 2 - 3 } & Barrels & Acre-feet & \\
Injection wells & $9,703,070$ & 1,250 & 9.0 \\
Open-surface pits & $25,334,257$ & 3,265 & 23.4 \\
Surface watercourses & $72,837,557$ & 9,390 & 67.4 \\
Miscellaneous & 1,095 & .14 & 0.0 \\
Unknown & 248,213 & 320 & .2 \\
\hline
\end{tabular}

Very little natural vegetation remains in this fairway. Along the bays are some saline marshes and beach and dune vegetation on the barrier islands. Inland there are swamps and fresh marshes along some of the rivers.

The Aransas-Nueces fairway contains brown pelican nesting sites, a recently used eagle nest and the wintering area of the whooping crane. Numerous colonial and 


\begin{tabular}{|c|c|c|c|c|c|c|c|}
\hline \multirow[b]{2}{*}{ Field } & \multirow[b]{2}{*}{$\begin{array}{c}\text { Brine Production } \\
\text { (Barrels) }\end{array}$} & \\
\hline & & $\begin{array}{c}\begin{array}{c}\text { Inject } \\
\text { (Barrels) }\end{array} \\
\end{array}$ & $\begin{array}{l}\text { on Well } \\
\text { (Percent) }\end{array}$ & $\begin{array}{c}\text { Open Sur } \\
\text { (Barrels) }\end{array}$ & $\begin{array}{l}\text { ace Pit } \\
\text { (Percent) }\end{array}$ & $\begin{array}{l}\text { Surface-Wa } \\
\text { (Barrels) }\end{array}$ & $\begin{array}{l}\text { er Course } \\
\text { Percent). }\end{array}$ \\
\hline Aransas Pass. & 842,115 & -- & -- & 842,115 & 100 & -- & -- \\
\hline Aransas Pass, Eust & 4,100 & -- & - & 4,100 & 100 & - & - \\
\hline Aransas Pass, North & 400 & -- & -- & 400 & 100 & -- & -- \\
\hline Black jack & 15,490 & -- & -- & 15,490 & 100 & - & - \\
\hline Fulton Beach & $2,407,472$ & -- & - & 795,850 & $33: 1$ & $1,611,522$ & 66.9 \\
\hline Fulton Beach, East & 110,853 & 500 & 0.5 & 62,235 & 56.1 & 48,118 & 43.4 \\
\hline Fulton Beach, North & 118,907 & -- & - & 61,857 & 52.0 & 57,050 & 48.0 \\
\hline Fulton Beach, West & 555,396 & -- & -- & -- & - & 555,396 & 100 \\
\hline Coose Island & 575 & -- & $-\cdots$ & 575 & 100 & -- & -- \\
\hline Half Moon Reef & 14,000 & $\rightarrow$ & -- & -- & -- & 14,000 & 100 \\
\hline Lamar & 10,750 & -- & -- & 10,750 & 100 & -- & -- \\
\hline Mud Flats & 5,041 & -- & -- & 5,041 & 100 & - & - \\
\hline Puerto Bay & 242,609 & - & -- & 10,000 & 4.1 & 232,609 & .95 .9 \\
\hline Rockport, West & 346,692 & - & - & - & -- & 346,692 & 100 \\
\hline Salt lake & 144.831 & -- & -- & 105,230 & 72.7 & 39,601 & 27.3 \\
\hline Sam Wilson & 7,300 & -- & - & 7,300 & 100 & -- & - \\
\hline St. Charles & 58,438 & -- & -- & 58,438 & 100 & -- & -- \\
\hline St. Charles Bay & 2,198 & $=$ & $=$ & 2,198 & $\underline{100}$ & - & - \\
\hline Totals & $4,887,167$ & 500 & 0.5 & $1,981,679$ & 40.5 & $2,904,988$ & 59.4 \\
\hline
\end{tabular}

Table 2-11. Methods of disposal and quant1ty of saltwater disposed in Aransas County in 1961 (After Shafer, 1968). 
wading birds nest here. All of these habitats can be avoided with careful planning. The pelican nesting sites should be avoided fom February through June. Shore bird nesting colonies should be avoided from March through July. Finally, the fairway covers some major inshore fishing areas,

Land use in the Nueces, San Patricto, Aransas Counties fairway is dominated by the city of Corpus Christi. Surrounding the city are cultivated fields on the Pleistocene surface and wildlife habitat and recreation areas on the margins of the bays and on the barrier islands. Range land and woodlands occur along the larger streams which cross the area. The fairway contains two National Audubon Society Sanctuaries, Mustang Island State Park, and Corpus Christi Naval Air Station.

Throughout the area of this fairway, archeological sites are located along the embayments and streams (Plate 12). In addition, two Register sites (Plate 12), the Fulton Mansion and the T. H. Mathis House, are located on Live Oak Peninsula, and two sites, the Courthouse and the Centennial House, are located in Corpus Christi. Two ethnic centers, one German and the other Czech, are located just south of Corpus Christi.

\subsubsection{South Texas}

In Hidalgo and Cameron Counties, the geopressure-geothermal zone has temperatures over $107^{\circ} \mathrm{C}\left(225^{\circ} \mathrm{F}\right)$ and occurs at the depth of 2135 to $2745 \mathrm{~m}(7000$ to $9000 \mathrm{ft})$. The lower Frio sand bodies are 31 to $183 \mathrm{~m}$ (100 to $600 \mathrm{ft}$ ) thick in a high destructive delta deposit (Bebout, Dorfman, and Agagu, 1975). A smaller area of local difference is in Kenedy County, Texas, at a depth of 2135 to $2745 \mathrm{~m}$ (7000 
to $2000 \mathrm{ft}$ ), and sands are 3 to $31 \mathrm{~m}$. (10 to $100 \mathrm{ft}$ ) thick and are interfingered with thin shales. Formation was probably the result of strandplain deposits (Bebout, Dorfman, and Agagu, 1975). Table 2-12 gives the water chemistry of the geopressured zones in Kenedy County,

The soils of the Kenedy County site are sandy and loamy throughout, Runoff is slow to very slow and there is a moderate shrink-swell potential. Some locations may be used for ponds or reservoirs.

The most southern site is along the Rio Grande in Hidalgo and Cameron Counties. Along the Rio Grande and in the alluvial valley, the soils are clayey. The upland soils are loamy. Runoff from the clayey soils is slow to very slow. Runoff from the loamy soils is slow to moderate.

The Kenedy County site is in the Nueces-Rio Grande basin. The surface water quality in this area is generally low because of the nature of climate and terrain. Little surface water surplus is available for use. No domestic supply from surface streams is designated. There are no polluted or scenic streams in the basin.

The Hidalgo County site is also in the Nueces-Rio Grande basin. This area is representative of the most arid in the entire region. Most surface water supply sources are entirely ephemeral. No domestic water is supplied from streams within the basin. The Rio Grande does provide domestic water, and all the water is committed. No designated polluted or scenic streams are located in the area of proposed testing. 
Table 2-12. Water Chemistry of Geopressured Zone in the South Texas Gulf Coast Area. All concentrations expressed as $\mathrm{mg} / 1$ (ppm)

\begin{tabular}{lc}
\hline \multicolumn{1}{c}{ Name } & $\begin{array}{c}\text { Fifteen wells in } \\
\text { Kenedy County }\end{array}$ \\
\hline $\mathrm{Na}+\mathrm{K}$ & $7,000-12,000$ \\
$\mathrm{Ca}$ & $20-4,000$ \\
$\mathrm{Mg}$ & $10-200$ \\
$\mathrm{CI}$ & $300-2,500$ \\
$\mathrm{SO}_{4}$ & $1-550$ \\
$\mathrm{CO}_{3}$ & Not Available (NA) \\
$\mathrm{CO}_{2}$ & $18,000-40,000$ \\
$\mathrm{Ca}, \mathrm{MG}$ Hardness & $150-9,000$ \\
$\mathrm{TDS}$ & $18,000-40,000$ \\
$\mathrm{Cu}$ & Not Available (NA) \\
$\mathrm{Zn}$ & NA \\
$\mathrm{B}$ & NA \\
$\mathrm{As}$ & NA \\
$\mathrm{Cr}$ & NA \\
$\mathrm{Hg}$ & NA \\
$\mathrm{Pb}$ & NA \\
$\mathrm{Cd}$ & NA \\
$\mathrm{Ba}$ & NA \\
$\mathrm{Fe}$ & NA \\
$\mathrm{SiO}$ & NA
\end{tabular}

(Source: Gustavson and Kreitler, 1976)

The Kenedy County area is covered with eolian plain deposits which yield small quantities of slightly saline water. Fresh water is unknown in these sands (Shafer and Baker, 1973). The Goliad sand, beneath the eolian deposits, yields the only fresh groundwater in the county. An eastward-thinning wedge of fresh groundwater occurs in the Goliad sand in the western half of the county, generally between 61 and $214 \mathrm{~m}$ (200 and $700 \mathrm{ft}$ ) below the surface. Water above and below this zone is slightly saline to saline. Artesian conditions exist in the Goliad sand and pressures are sufficient to cause wells to flow in many low areas of the county. 
Groundwater from the Goliad sand supplies $98 \%$ of industrial water and $95 \%$ of water for rural-domestic and livestock use, which are the principal water uses in the county (Shafer and Baker, 1973). Use of groundwater for irrigation and public supply is insignificant.

The potential geothermal test area is coincident with the eastern limit of fresh groundwater in Kenedy County. This area is part of the area listed as most favorable for future groundwater developments by Shafer and Baker (1973). Because of the limited fresh water resources of the area, geothermal test activities must be designed to assure the fresh water of the Goliad sand is not contaminated.

The potential geothermal test site in Hildago and Cameron Counties, like the area in Kenedy County, is coincident with the area of best groundwater resources. The principal aquifers are the alluvium of the Rio Grande River, the Goliad Sand, Lissie Formation and Beaumont Clay. The alluvium provides an important hydraulic connection between several aquifers creating the lower Rio Grande groundwater reservoir (Baker and Dale, 1964). This reservoir provides an important source of irrigation water in southern Cameron and Hidalgo Counties. The pumpage for irrigation fluctuates widely with variations in rainfall and no quantitative estimates of pumpage are available.

The lower Rio Grande groundwater reservoir is generally a water table aquifer with only limited area of artesian conditions. The major sources of recharge to the aquifer is the Rio Grande River and precipitation. 
The best water in the aquifer occurs within about $4.8 \mathrm{~km}(3 \mathrm{mi})$ of the Rio Grande River between 15 and $76 \mathrm{~m}$ (50 and $250 \mathrm{ft}$ ) deep. Mineralization of water increases with depth and distance from the river. Even the best water has a high salinity hazard for irrigation (Baker and Dale, 1964).

Vegetation in Kenedy County is predominantly grass and scrub-covered eolian sand sheet. In Hidalgo and Cameron Counties, the area is cultivated so there is little if any natural vegetation remaining.

The Kenedy County site is within the recent ocelot and cougar ranges.

The Hidalgo-Cameron fairway is within the range of the jaguarundi, and the ocelot which is classed as endangered by Texas. These cats are due special consideration because of their peripheral distribution in the United States. Both inhabit dense brushland and are chiefly nocturnal in their traveling and feeding. Their secretive nature makes specific avoidance difficult, but the requirements of the proposed project is such that very little potential habitat will be modified in the event that the site is selected in a brushland vegetative community. It is also within the range of the cougar.

Land use in Kenedy County is limited to range and pasture. Land use is the Hidalgo and Cameron site is range ard pasture and cultivated fields where irrigation is practiced.

There are no known archeological sites or National Register sites in either of the two fairways. The zones are in the Spanish-speaking area of south Texas. 
CHAPTER THREE - POTENTIAL ENVIRONMENTAL IMPACTS

\subsection{Installation and Maintenance of We11}

Well testing will occur on existing well sites that are modified by oil activities. No additional land clearing will be necessary for the test well, but a disposal well for fluid reinjection may require drilling. Roads may need upgrading or constructing to the reinjection site. The drill pad requires 0.4 to 0.8 hectare (one to two acres); a reserve pond requires 0.4 hectare (one acre) or less. The disposal well will be as close as possible to the test well. Reinjection wells will be drilled approximately $915 \mathrm{~m}(3,000 \mathrm{ft})$ into saltwaterbearing sand formations. The gas which is expected to result from the production testing will be flared at the site. Test duration for each formation is not expected to exceed two weeks. The total water produced will be approximately 300,000 barrels.

\subsubsection{Physical and Biological Issues}

Flora - Environmental impacts due to the installation and maintenance of geothermal wells are mitigated by the use of existing well sites. The reopening of an old site and possible drilling of a disposal well may involve building roads, dredging or redredging canals, disposing of spoil, building drill pads, transportation of on-site drill crews to and from the site, and building of a reserve pond to hold drilling wastes.

There will be a net productivity loss due to a permanent commitment of 2 to 3 hectares for roads or canals and drill pads. The loss in organic matter (dry weight) will range from $0 \mathrm{mt} / \mathrm{yr}$ in unvegetated dunes to a possible $100 \mathrm{mt} / \mathrm{yr}$ in submerged Thalassia beds. 
Operations in the high slope areas may cause changes in drainage that would increase the area of permanent change. The maximum impact from roads, canals or ponds will occur in vegetation types of limited abundance where loss in acreage will threaten the system and where alteration will affect large areas. The bluffland forest, small marshes in Texas and submerged grass beds are of limited abundance.

Dune topography and stablilizing vegetation make up an important storm buffer for inland marsh, estuary and bay systems. Care must be taken to align roads parallel to dune ridges where possible because breaks across dunes may cause accelerated erosion leading to loss of storm buffer and possibly the making of a new pass or waterway. This could alter salinity levels and flushing rates of inland areas, especially in south Texas.

If new canals are dredged and spoil banks deposited in swamp forest and marshes, the drainage pattern may be changed and result in salinity and community composition changes. These are long-term impacts.

The site preparation activities may increase turbidity in nearby waters and affect the flora and fauna, but the effect will be short-term.

High noise levels and air pollution and dust are not expected to be of high enough magnitude to cause environmental harm during site preparation. Many of the above-mentioned activities will not be necessary if a suitable disposal 
Table 3-1. Estimated Disturbance Due to Installation of the We11

\begin{tabular}{|c|c|c|c|c|c|c|c|c|c|c|}
\hline \multirow[b]{2}{*}{$\begin{array}{c}\text { Veget at 1on } \\
\text { Iype }\end{array}$} & \multirow[b]{2}{*}{$\begin{array}{l}\text { Net Primary } \\
\text { Productivity } \\
\text { (mt/ha·yr) }\end{array}$} & \multicolumn{6}{|c|}{ Product1vity Lose Per Well Site; $P$ - Permanent, $I$ - Temporary } & \multirow[b]{2}{*}{$\begin{array}{c}\operatorname{Max} \\
P \\
(\operatorname{mr} / y r) \\
\end{array}$} & \multirow{2}{*}{$\begin{array}{l}\text { Compounded } \\
\text { difficulty } \\
\text { due to hilly } \\
\text { Terrain }(X) \\
\end{array}$} & \multirow{2}{*}{$\begin{array}{l}\text { Long Time } \\
\text { Necessary } \\
\text { for Recov- } \\
\text { exy }(x) \\
\end{array}$} \\
\hline & & $\begin{array}{c}\text { Road or } \\
\text { Canal } \\
(\times 2 \text { ha }) P \\
\end{array}$ & $\begin{array}{c}\text { Dr111 Pad } \\
(\times .4-.8 \mathrm{ha}) \mathrm{P} \\
\end{array}$ & $\begin{array}{c}\text { Total } \\
\mathbf{P} \\
(\mathrm{mt} / \mathrm{yr}) \\
\end{array}$ & $\begin{array}{l}\text { Reserve } \\
\text { Pond } \\
(\times .05-.1 \text { ha }) \mathrm{T} \\
\end{array}$ & $\begin{array}{l}\text { Evaporation } \\
\text { Pond } \\
(\mathbf{x} 2 \mathrm{ha}) \mathrm{T} \\
\end{array}$ & $\begin{array}{c}\text { Total } \\
T \\
\text { (mt/yr) }\end{array}$ & & & \\
\hline $\begin{array}{l}\text { Dec1duous Porest' } \\
\text { (Up1 and and Wetland) }\end{array}$ & 15.7 & 31.4 & 6.3-12.6 & $37.7-44$ & $.8-1.6$ & 31.4 & $32.2-33$ & 44 & $\mathbf{x}$ & $\mathbf{x}$ \\
\hline Swamp Foreat $1,2,5$ & 13 & 26 & $5.2-10.4$ & $31.2-36.4$ & $.7-1.3$ & 26 & $26.7-2-.3$ & 36 & $\mathbf{x}$ & $\mathbf{x}$ \\
\hline Con1ferous Poreat ${ }^{4}$ & $4.8-12.8$ & $9.6-25.6$ & $1.9-10.4$ & $11.5-35.8$ & $.2-1.3$ & $9.6-25.6$ & $9.8-26.9$ & 36 & $x$ & $\mathbf{x}$ \\
\hline Mixed Porest ${ }^{2}$ & 9.8 & 19.6 & $3.9-7.8$ & $23.2-27.4$ & $.5-1.0$ & 19.6 & $20.1-20.6$ & 27 & $\mathbf{x}$ & $\mathbf{x}$. \\
\hline Pra1rie-Grassland 6,7 & 6 & 12 & $2.4-4.8$ & $14.4-16.8$ & $.3-.6$ & 12 & $12.3-12.6$ & 17 & & \\
\hline Salt Marsh ${ }^{2}$ & 24 & 48 & - & 48 & $1.2-2.4$ & 48 & $49.2-50.4$ & 48 & & \\
\hline Intermediate Marsh ${ }^{2}$ & $27-29$ & $54-58$ & -- & $54-58$ & $1.4-2.9$ & $54-58$ & $55.4-60.9$ & 58 & & \\
\hline Fresh Marsh ${ }^{2}$ & 14 & 28 & - & 28 & $.7-1.4$ & 28 & $28.7-29.4$ & 28 & & \\
\hline $\begin{array}{l}\text { Lakes and Streams } 10 \\
\text { Clear Lake or Stream } \\
\text { Bayou }\end{array}$ & 14 & $\overline{-}$ & $\overline{-}$ & $\overline{-}$ & $\overline{-}$ & $=$ & - & $\overline{-}$ & & \\
\hline Beaches and Dunes ${ }^{11}$ & $0-6$ & $0-12$ & $0-4.8$ & $0-16.8$ & $0-.6$ & $0-12$ & $0-12.6$ & 17 & & \\
\hline $\begin{array}{l}\text { Eat uar1es, Baye, Open Yater } \\
\text { Subme gged Grans Beds } \\
\text { Other }\end{array}$ & $2.3-7.5$ & $\stackrel{32-100}{-}$ & $=$ & $32-100$ & $\overline{-}$ & $\overline{-}$ & - & $\begin{array}{r}100 \\
6\end{array}$ & & $\mathbf{x}$ \\
\hline $\begin{array}{l}1 \text { Conner and Day, } 1976 \\
2 \text { Coner } \\
3 \text { Cosselink and Beck, } 1976 \\
4 \text { Odum and Hoskins, 1959; Qa } \\
\text { 5Re1ch1e, et } 11.1973 \\
\text { O1son, ig75 }\end{array}$ & 2810 and & 1 1.1, 1971 & $\begin{array}{l}6 \text { Odum, } 1971, \\
7 \text { Coupland, } 197 \\
8_{\text {Rod1n, ec a1, }} \\
9 \text { Day, et al, } \\
10_{\text {Day, et al, }}\end{array}$ & $\begin{array}{l}\text { after Leich, } \\
75 \\
1975 \\
1973 \\
1977\end{array}$ & $\begin{array}{l}11 \text { These } \\
\text { shife } \\
\text { tat10 } \\
\text { al gi }\end{array}$ & $\begin{array}{l}\text { e sttes may a } \\
\text { ting gande, b } \\
\text { on they are a } \\
\text { ranslands und }\end{array}$ & $\begin{array}{l}\text { oot have veg } \\
\text { put where th } \\
\text { assumed to b } \\
\text { ler opt fmal }\end{array}$ & $\begin{array}{l}\text { tation d } \\
\text { y suppor } \\
\text { sa prod } \\
\text { ondition }\end{array}$ & $\begin{array}{l}\text { lue to } \\
\text { it vege- } \\
\text { luctive } \\
\text { a. }\end{array}$ & \\
\hline
\end{tabular}


well already exists. It is assumed that waste products related to the construction and maintenance crew will be disposed of off the site.

Any of these activities would adversely affect the threatened or endangered species present. Given a choice among well sites, those for which impacts in Table 3-1 are less and which are not near endangered species (Plate 9) would be favored.

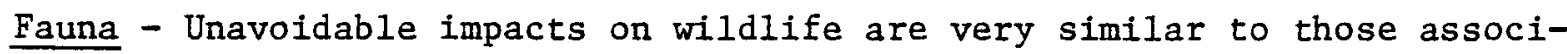
ated with oil and gas drilling activities that have long been common throughout the study area. As the oil and gas industry has developed and become more efficient in locating and extracting petroleum products they have been made aware of numerous environmental concerns regarding industry impacts upon fish and wildlife resources. Because of these concerns and because of the monitoring of their activities by federal, state and local government agencies, the industry has developed a body of knowledge that allows a great reduction of impacts. Some impacts, however, cannot be entirely avoided, such as eliminating the wildlife support ability of the area invested in site for the drilling pad, the access road and the reserve pond. This total habitat loss is of difference duration for different wildlife species.

In the swamp or forest, squirrel habitat would be influenced for a longer period of time. Most producing oaks would require 30 years after site abandonment to become prolific producers of acorns. Since hollows suitable for mammal denning or bird nesting are characteristic of older trees, this component of forest cover would be lost for a greater period of time. Other wildlife forms would be most seriously impacted during construction and operation of the facility. 
The species of prairie chicken in the project area (Attwater's) is classified as rare and endangered primarily because of habitat shrinkage caused by changing land uses. The occupied areas of chicken range are delineated on Plate 9. Modification of additional land for this testing program will further reduce their habitat but not by a significant amount. Site development on a booming ground would likely disrupt historic mating patterns.

The whooping crane is a winter resident of marshes of the Aransas National Wildlife Refuge. Its habitat is guarded against human disturbance during the period of time that the birds are present (October through March). While policy prohibits geothermal exploration on the refuge, such activities in crane habitat in adjacent marshes should be avoided during those months the birds are present.

The southern bald eagle habitually returns to the same nest each fall. Egg laying begins as early as October and fledglings are still present around some nest sites into April. Known nest sites are indicated on Plate 9. No development should be allowed within $1.5-\mathrm{km}$ of a nest site between October and April.

The endangered red wolf recently occurred over much of the projected area. The occupied range has shrunk, and the resident wolves have hybridized with coyotes and domestic dogs. The recent wolf range is delineated on Plate 9 but this contains local areas of animals with purer bloodlines surrounded by larger areas where genetic dilution is so great that the animals are no longer considered to be wolves. Extinction throughout the study area is anticipated in the near future even though a breeding program is underway. 
The effect of noise on wildlife under natural conditions is largely unknown. Most studies have dealt with the effects of noise on domestic animals confined to the laboratory. Noise generators of various types have been utilized successfully to frighten animals, such as deer or birds, from areas where they are feeding on crops or creating a nuisance. The general effect of project noise on terrestial animals is likely to be one of the animals' avoidance of the immediate project area.

The quality of the air in the immediate vicinity of the activities associated with the well testing program will be adversely affected. Dust will be generated by vehicles used during the installation of an injection well. However, this will be kept to a minimum through treating roads and construction sites by surfacing appropriate areas and watering other areas. In addition, vehicle and power source emissions will contribute to the total air-quality degradation. The newer engines will meet EPA guidelines for reduced emissions. All of the above air quality impacts are in association with existing well drilling activities so that no new impacts will result from the well-testing program. The duration of these emissions will be extended by this program, but such emissions are not considered to add significantly to ambient levels of air pollution.

\subsubsection{Cultural Issues}

As much as 4 ha (10 acres) of land may be directly changed by construction and maintenance activities associated with the test well. Since all efforts will be made to return the land to its original condition and since the test wells will be on abandoned oil well sites, major land use impacts are not anticipated in the developed and agricultural land categories. Minor impacts may result 
from 1) construction noise which may be a temporary nuisance if the well site is near a residential or commercial area, 2) residue left in the reserve pond, evaporation pond or drainage ways which may make revegetation difficult and affect the reuse of these areas for agriculture and rangeland, and 3) construction machinery, drilling rigs, and other equipment which may result in temporary visual impacts if the test site is near residential, commercial or recreational areas.

Since the work crews are to be in an area for a short time with a maximum of 15-20 people, then there will be little or no effect on the population. Ethnic areas have maintained their solidarity for many years with similar work in oil fields being done there. In Louisiana, however, there are several multi-racial communities that are very sensitive about their mixed racial heritage. Animosity could develop very quickly between the community and the workers on the project. Care should be taken to see this does not happen.

The development of geothermal energy may have a great impact on archeology. Disturbance of the earth's surface can destroy many sites that are only located on the surface. Disturbance of this kind can also destroy the top layers of a stratified site. This could happen during grading, dredging or during other types on preparation for the project. Often sites are buried beneath the surface or extend several meters below the ground surface. Augering or test pits can determine if subsurface deposits are in the area. Any excavations or drilling on a'site could severely damage or destroy a site. This is especially true where large evaporation basins are used, as they could destroy all traces of a site. 
Since archeological sites are scattered throughout the project area, there is a good possibility that many of the wells are near or on sites. Many of the wells were probably drilled before federal regulations concerning archeological and historical sites were enacted. These wells may have already disturbed the area and further construction may destroy the rest of the site. This destruction should be avoided. Surveys of the well sites will be required and the results must be approved by the State Historic Preservation Officer (SHPO). Contact with the SHPO well in advance of the proposed work will keep problems and delays at a minimum and will be given a high priority.

Highest noise production will be from the drilling rig of the disposal well, workover of the existing well, and plugging of the test well. The noise level for a typical drilling rig at a distance of 20 feet from the engine room was measured to be $90 \mathrm{dBA}$ (data from Atlantic Richfield Oil Company, Mr. Roy McKay). Recognizing flatness of the terrain and absence of sound barriers, reduction of A-scale sound level $\left(R_{d}\right)$ can be expressed as a function of distance from a point source relative to $6.1 \mathrm{~m}(20 \mathrm{ft})$ distance, using the drop-off rate of 6 . dBA per double distance and taking into account molecular absorption ( $1 \mathrm{dBA} / 305 \mathrm{~m})$ and atmospheric effects $(1 \mathrm{dBA} / 305 \mathrm{~m})$ after the first $610 \mathrm{~m}(2000 \mathrm{ft})$ and $305 \mathrm{~m}$ $(1000 \mathrm{ft})$, respectively.

If, for example, the nearest house is $1,830 \mathrm{~m}(6,000 \mathrm{ft})$ from the well test site, the noise level from the operation would be $31.4 \mathrm{dBA}$. If the nearest house is $3,660 \mathrm{~m}(12,000 \mathrm{ft})$ from the drilling $\mathrm{rig}$, the noise level would be reduced to $13.4 \mathrm{dBA}$. In both cases, the anticipated noise levels are well below daytime 
criteria proposed by the federal government with regard to geothermal operations and very close to night time levels at $1,830 \mathrm{~m}(6,000 \mathrm{ft})$ (U.S. Dept. of Interior, 1975). Since drilling is typically conducted 24 hours a day, the proposed 30 dBA night time criterion would be exceeded if drilling was carried out within less than $1,800 \mathrm{~m}(5,940 \mathrm{ft})$ of an occupied residence or recreation area. These criteria are shown in Table 3-2. Night and daytime levels for uninhabited areas (marsh) are exceeded up to distances of $193 \mathrm{~m}(630 \mathrm{ft})$ and $61 \mathrm{~m}(200 \mathrm{ft})$, respectively.

Table 3-2. Noise Criteria Not to be Exceeded for Geothermal-Related Activities (U.S. Dept. of Interior, 1975)

\begin{tabular}{llll}
\hline Land Use & Daytime & Evening & Night \\
\hline Residential (Rural) & $45 \mathrm{dBA}$ & $40 \mathrm{dBA}$ & $30 \mathrm{dBA}$ \\
Agricultural & $70 \mathrm{dBA}$ & $65 \mathrm{dBA}$ & $55 \mathrm{dBA}$ \\
Recreational & $45 \mathrm{dBA}$ & $40 \mathrm{dBA}$ & $30 \mathrm{dBA}$ \\
$\begin{array}{l}\text { Uninhabited or } \\
\text { Rangelands }\end{array}$ & $70 \mathrm{dBA}$ & $65 \mathrm{dBA}$ & $60 \mathrm{dBA}$ \\
\end{tabular}

Noise from additional or alternate sources during various phases of the operation include that of the dredge (one day), small crew boats $(6.1 \mathrm{~m})$, helicopters, turbine, flow of pressured fluids through piping, and other lesser sources such as tools. Each of these sources would already have been temporarily present in the general area as a result of oil and gas development. Their contribution to the overall noise level of the area and to that of the test site during drilling operations can be considered acceptable for the period of the test duration. 
In the case of an accident, an unmuffled venting geothermal well may cause noise levels of $120 \mathrm{dBA}$ at $30.5 \mathrm{~m}(100 \mathrm{ft})$.

\subsubsection{Economic Impacts}

It is clear that the direct and indirect impact of work crews on the local economies in any given case is determined by the size of the crew, their level of earnings at the site, the duration of their stay at the site, whether they are transient or establish residences at or near the site, whether they are provided quarters at the site or must find housing in the local private community, the proportion of their earnings which are spent in the community, whether the food and other supplies which are provided for them at the rig are purchased locally or shipped in from some central point, and the multiplier effect of all of these expenditures on the total economic activity in the community.

The size of the workover crew can be expected to vary with the complexity of the job. In most cases, however, the crew is likely to consist of about five or six people, with total weekly earnings of some $\$ 1,500$ to $\$ 2,000$. The impact that these earnings will have on the local economy, however, will depend on the proportion of that income which is spent there.

The following scenario represents the case of maximum economic impact: All members of the work crew are permanent residents in the community and maintain homes there. Moreover, it is assumed here that the earnings of these people represent a net increase in earnings to the community, i.e., in the absence of the workover there would be no work for these people in the community and no earnings. 
Given the assumptions outlined, the direct increase in income in the community is from $\$ 1,500$ to $\$ 2,000$ per week. To evaluate the indirect and induced impact resulting from the spending of this income within the community, it is necessary to estimate 1) the precent of income which is spent for current consumption, 2) the fraction of that which is spent locally by the workover crew, and 3) the multiplier effect of further spending and respending within the community by those people to whom the initial expenditures become income. According to data published annually in the Survey of Current Business and reprinted in the U.S. Statistical Abstract, over the period from 1970 through 1976 the American people spent approximately 92 percent of their disposable income for current consumption and saved the rest. Disposable personal income is defined to be total income less state and federal income taxes, social security payments, and the like. The average of such taxes is likely to be in the neighborhood of 20 to 24 percent of total income. Thus, total consumption expenditures of the crew members would probably be in the neighborhood of $(.92) \times(.78) \times 100=72 \%$ of gross earnings. For the whole crew, then, total consumption expenditures would most likely be between about $\$ 1,100$ and $\$ 1,450$ per week. The next question is how much of this is likely to be spent for locally produced goods and services. What is important here is not only that part which is spent in local retail and service establishments but also that part which is likely to be respent in the community in both salaries for retail and service personnel and also for production of the products that are sold in those establishments. There are no data for this which are fully reliable for present purposes but according to the Texas input-output study about $68 \%$ of consumer expenditures in Texas stay in Texas; i.e., go for Texas-produced goods and services. This is probably 
about the same or a little less in Louisiana. It is likely then that in a sma11 community this percentage could not be more than $25 \%$. Thus it is likely that the $\$ 1,100$ to $\$ 1,450$ of consumer expenditures of the crew, not more than $\$ 275$ to perhaps $\$ 360$ would enter further into the income stream of the community. Considering the multiplier effect of the total flow of income that might result, however, from a part of each person expenditures becoming income to someone else this is likely to amount to no more than a total of perhaps $\$ 2,800$ to $\$ 3,500$ a week, including the original payroll.

\subsection{Normal Effluents from Operation of Well}

Impacts to surface water from routine operation of test wells result from disposal of water brought to the surface either purposefully or accidentally, and from possible environmental changes such as land surface subsidence or seismic activity. Thermal and chemical pollution could alter surface water quality by introducing produced fluids of unknown consistency into drainage basins. Elevation changes could alter surface flow patterns, disrupting existing environmental systems dependent on established surface water regimes and increasing saltwater encroachment in wetlands.

Produced geothermal fluids range in average temperatures from $150^{\circ} \mathrm{C}\left(300^{\circ} \mathrm{F}\right)$ to $260^{\circ} \mathrm{C}\left(500^{\circ} \mathrm{F}\right)$ in the region (Dorfman, 1976). Temperature distributions are entirely dependent on formation structure, making accurate prediction impossible (Jones, 1975). The highest recorded temperature is $273^{\circ} \mathrm{C}\left(520^{\circ} \mathrm{F}\right)$ at a depth of $5,859 \mathrm{~m}(19,223 \mathrm{ft}$ ) (Dorfman, 1976). Introduction of these temperatures into surrounding waters will create conditions that could disrupt the local ecology, impacting both terrestrial and aquatic wildlife and vegetation adversely. 
Chemical composition of the produced fluids varies from formation to formation, but there are a number of inferences that can be drawn based on the information availabie from samples in the Gulf Coast geopressured zone (Tables 3-3 and 3-4). Brines contain inorganic ions that have adverse effects on plant and animal life. Additionally, fluids sampled contained nonionic substances such as oil, dissolved organics and dissolved gases (methane, hydrogen sulfide). Data on the occurrence and concentrations of toxic trace elements such as $\mathrm{Hg}$, $\mathrm{Pb}$ and $\mathrm{As}$ are not presently available. Because of the ability of certain plants and animals to concentrate these elements, and because of the resulting toxicity and environmental detriment, total water quality analyses of the produced waters are needed to determine concentrations of these constituents as well as to detect any unusual constituents. Sabadell and Axtmann (1975) report a high probability of environmental pollution by trace heavy metals from geothermal sources.

Formation waters sampled from $3,350 \mathrm{~m}(11,000 \mathrm{ft})$ south of Corpus Christi in the Chapman Ranch geopressured field showed boron concentrations ranging from 19 to $42 \mathrm{mg} / 1$ (Gustavson and Kreiller, 1976). These concentrations are similar to those found by Collins (1975) for formation waters in Louisiana. High concentrations of this constituent alone will pose constraints on use and disposal of the produced waters. 
Table 3-3. Water Chemistry of Geopressured Zone in the South and Middle Texas Gulf Coast Areas. All concentrations expressed as mg/1 (ppm).

\begin{tabular}{|c|c|c|}
\hline Name & $\begin{array}{l}\text { Seven wells in Aransas, } \\
\text { Nueces, Refugio and San } \\
\text { Patricio Counties }\end{array}$ & $\begin{array}{l}\text { Fifteen wells in } \\
\text { Kenedy County }\end{array}$ \\
\hline $\mathrm{Na}+\mathrm{K}$ & $2,000-20,000$ & $7,000-12,000$ \\
\hline $\mathrm{Ca}$ & $10-8,000$ & $20-4,000$ \\
\hline $\mathrm{Mg}$ & $20-$ & $10-$ \\
\hline $\mathrm{Cl}$ & $3,500-46,000$ & $300-2,500$ \\
\hline $\mathrm{SO}_{4}$ & $1-1,600$ & $1-$ \\
\hline $\mathrm{CO}_{3}$ & $1-\quad 450$ & Not Available (NA) \\
\hline $\mathrm{CO}_{2}$ & $7-1,000$ & $18,000-40,000$ \\
\hline Hardness, ( $\mathrm{Ca}$, & $30-20,000$ & $150-9,000$ \\
\hline TDS & $8,000-72,000$ & $18,000-40,000$ \\
\hline $\mathrm{Cu}$ & Not Available (NA) & Not Available (NA) \\
\hline $\mathrm{Zn}$ & NA & NA \\
\hline B & NA & $\mathrm{NA}$ \\
\hline As & NA & $\mathrm{NA}$ \\
\hline $\mathrm{Cr}$ & $\mathrm{NA}$ & NA \\
\hline $\mathrm{Hg}$ & $\mathrm{NA}$ & $\mathrm{NA}$ \\
\hline $\mathrm{Pb}$ & NA & NA \\
\hline $\mathrm{Cd}$ & NA & NA \\
\hline $\mathrm{Ba}$ & $\mathrm{NA}$ & NA \\
\hline $\mathrm{Fe}$ & NA & NA \\
\hline $\mathrm{SiO}_{2}$ & NA & NA \\
\hline
\end{tabular}

(Source: Gustavson and Kreitler, 1976) 
Table 3-4. Water Chemistry of Geopressured Zone in the Manchester Field, Calcasieu Parish, Southwest Louisiana

\section{Calcasieu Parish}

Field
Name
Depth (ft)
hemical Composition

Manchester

No. 1 W. H. McBurrey

$12,670-12,677$

(ppm)

$\mathrm{Na}$

$\mathrm{Ca}$

$\mathrm{Mg}$

$\mathrm{K}$

C1

$\mathrm{H} \mathrm{CO} 3$

$\mathrm{SO}_{4}$

$\mathrm{CO}_{3}$

$\mathrm{Rb}$

Cs

$\mathrm{Sr}$

$\mathrm{Br}$

I

$\mathrm{Ba}$

TDS

$\mathrm{Cu}$

$\mathrm{Zn}$

$B$

As

$\mathrm{Cr}$

$\mathrm{Hg}$

$\mathrm{Pb}$

$\mathrm{Cd}$

$\mathrm{Ba}$

$\mathrm{Fe}$

$\mathrm{SiO}_{2}$

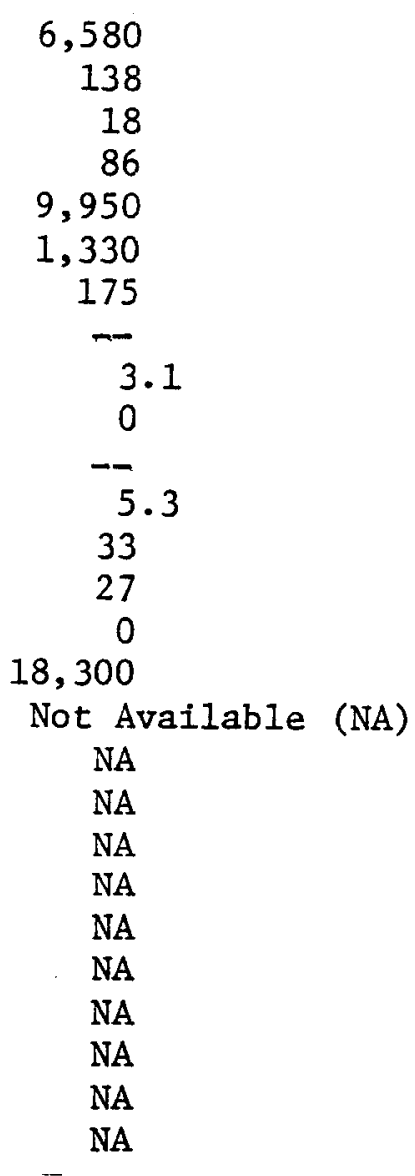

Source: G. W. Schmidt, "Interstitial Water Composition and Geochemistry of Deep Gulf Coast Shells and Sandstones," Am. Assoc. Pet. Geol. Bull. 57(2):321-337 (1973). 
Table 3-5 gives average concentrations of selected elements in sea water. The produced waters (see Tables $3-3$ and 3-4) range from well below to far above average sea water in concentration of most mineral constituents. That great range in consistency will be reflected in the concurrent diversity of environmental impacts that effluents from the proposed testing could produce. Table 3-6 1ists tolerance levels of selected constituents suggested by the Environmental Protection Agency in water for domestic use and for sustaining aquatic 1ife.

Ușing available information on chemical quality of geothermal fluids in the Gulf Coast region (Tables 3-3 and 3-4) and corresponding limits of concentrations for domestic water supply (Table 3-6), range of concentrations of selected constituents are evaluated in terms of relative hazard with respect to public water supply (Table 3-7). When more information is available, similar evaluation can be performed for heavy metals and other possibly hazardous constituents of the produced fluids. The relative hazard is calculated by dividing the minimum and maximum concentration observed by the appropriate limit (Schieler, 1976). This gives a number which indicates how much, if any, a given concentration exceeds the maximum allowable concentration. 
Table 3-5. Concentrations of Dissolved Ions in Sea Water (ppm)

\section{Constituent}

$\mathrm{Na}$

$\mathrm{Mg}$

$\mathrm{Ca}$

$\mathrm{K}$

C1

$\mathrm{HCO}_{3}$

$\mathrm{CO}_{3}^{4}$

$\mathrm{Li}^{3}$

$\mathrm{Rb}$

Cs

$\mathrm{Sr}$

$B r$

I

$\mathrm{Ba}$

TDS

$\mathrm{Cu}$

$\mathrm{Zn}$

$B$

As

$\mathrm{Cr}$

$\mathrm{Hg}$

Pd

Cd

$\mathrm{Ba}$

$\mathrm{Fe}$

$\mathrm{SiO}_{2}$
Average Concentration
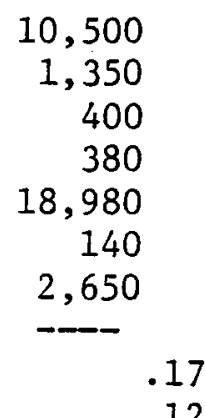

.12

.0005

8

65

.06

.03

34,486

.003

.01

4.6

.003

$-$

.00003

-.-

.03

.01

6.4

(Source: Goldberg, 1965) 
Table 3-6, EPA Suggested Water Quality Criteria

\section{Constituent}

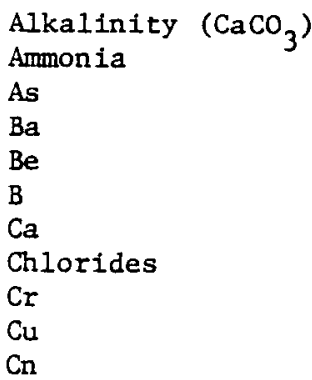

total dissolved gasses

$\mathrm{Fe}$

$\mathrm{Pb}$

$\mathrm{Mg}$

$\mathrm{Hg}$

N1

$\mathrm{N}$

Phenol

$P$

$\mathrm{Se}$

Ag

Sulfates

TDS

Turbidity

$$
\mathrm{H}_{2} \mathrm{~S}
$$

Temperature

$\mathrm{zn}$
Domestic

$$
\begin{aligned}
20 \mathrm{mg} / 1 \\
0.02 \mathrm{mg} / 1 \\
50 \mathrm{ug} / 1 \\
1 \mathrm{mg} / 1 \\
1100 \mathrm{ug} / 1 \\
750 \mathrm{ug} / 1 \\
10 \mathrm{ug} / 1 \\
250 \mathrm{mg} / 1 \\
50 \mathrm{ug} / 1 \\
1 \mathrm{mg} / 1 \\
5 \mathrm{ug} / 1
\end{aligned}
$$

$110 \%$ saturation value $0.3 \mathrm{mg} / 1$

$50 \mathrm{ug} / 1$

$50 \mathrm{ug} / 1$

$2 \mathrm{ug} / 1$

0.01 96-hr. LC 50

$10 \mathrm{mg} / 1$

$1 \mathrm{ug} / 1$

$0.01 \mathrm{ug} / 1$

$10 \mathrm{ug} / 1$

$50 \mathrm{ug} / 1$

$250 \mathrm{mg} / \mathrm{I}$

$500 \mathrm{mg} / \mathrm{I}$

1imit $10 \%$ reduction in photosynthetic activity point $2 \mathrm{ug} / \mathrm{I}$

a) increase in weekly average no greater than $1 \mathrm{C}(1.8 \mathrm{~F})$

b) daily cycle not altered in amplitude or frequency, summer maximum not exceeded $5000 \mathrm{ug} / 1$
Aquatic

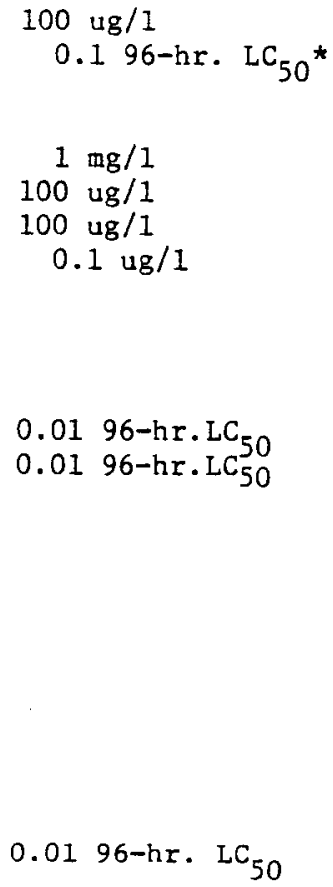

0.01 96-hr. LC 50

$0.0196-\mathrm{hr} . \mathrm{LC}_{50}^{50}$

0.01 96-hr. LC $_{50}$

${ }^{*} \mathrm{LC}_{50}$ - the concentration of a toxicant which is lethal (fatal) to $50 \%$ of the organisms
tested in a specified time.

(Source: EPA, 1976) 
Table 3-7. Relative Hazard of Known Geothermal Fluid Constituents

\begin{tabular}{|c|c|c|c|}
\hline Constituent & $\begin{array}{l}\text { Range of Average } \\
\text { Concentration (ppm) }\end{array}$ & $\begin{array}{l}\text { Tolerance Level for } \\
\text { Domestic Supply (ppm) }\end{array}$ & $\begin{array}{l}\text { Range of Rela- } \\
\text { tive Hazard } \\
\end{array}$ \\
\hline B & $19-42$ & 0.75 & $25-56$ \\
\hline $\mathrm{Na}$ & $2,000-20,000$ & 270 & $7-74$ \\
\hline $\mathrm{Cl}$ & $9-9,950$ & 250 & $0.04-40$ \\
\hline $\mathrm{SO}_{4}$ & $1-1,600$ & 250 & $0.004-6$ \\
\hline Hardness $\left(\mathrm{CaCO}_{3}\right)$ & $30-20,000$ & 300 & $0.1-67$ \\
\hline TDS & $8,000-72,000$ & 500 & $16-144$ \\
\hline
\end{tabular}

On the basis of these available data, total dissolved solids content appears to present the greatest potential hazard. Unknown hazards from toxic trace elements whose concentrations are not known may prove to be far more hazardous, however. All species of fish and other aquatic life must tolerate a range of dissolved solid concentrations in order to survive. Estuarine species are tolerant of changes from fresh to brackish to sea water. Abrupt changes in hydrologic regimes (stream flow, salinity) could result from effects of the excess dissolved solids, primarily through the elimination of food and habitat-forming plants. Rapid salinity changes cause plasmolysis of leaves and stems because of changes in osmotic pressure. The following limits in salinity variation from natural have been recommended to protect wildlife habitats (EPA, 1976):

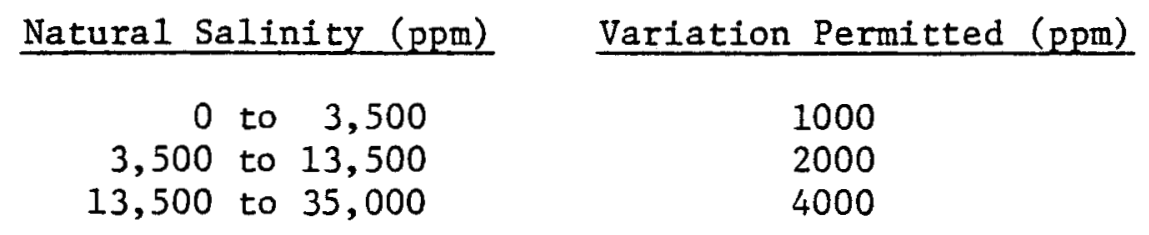

Agricultural uses of water are also limited by excessive dissolved solids concentrations. A general classification of salinity hazards for irrigation has been prepared (EPA, 1976): 


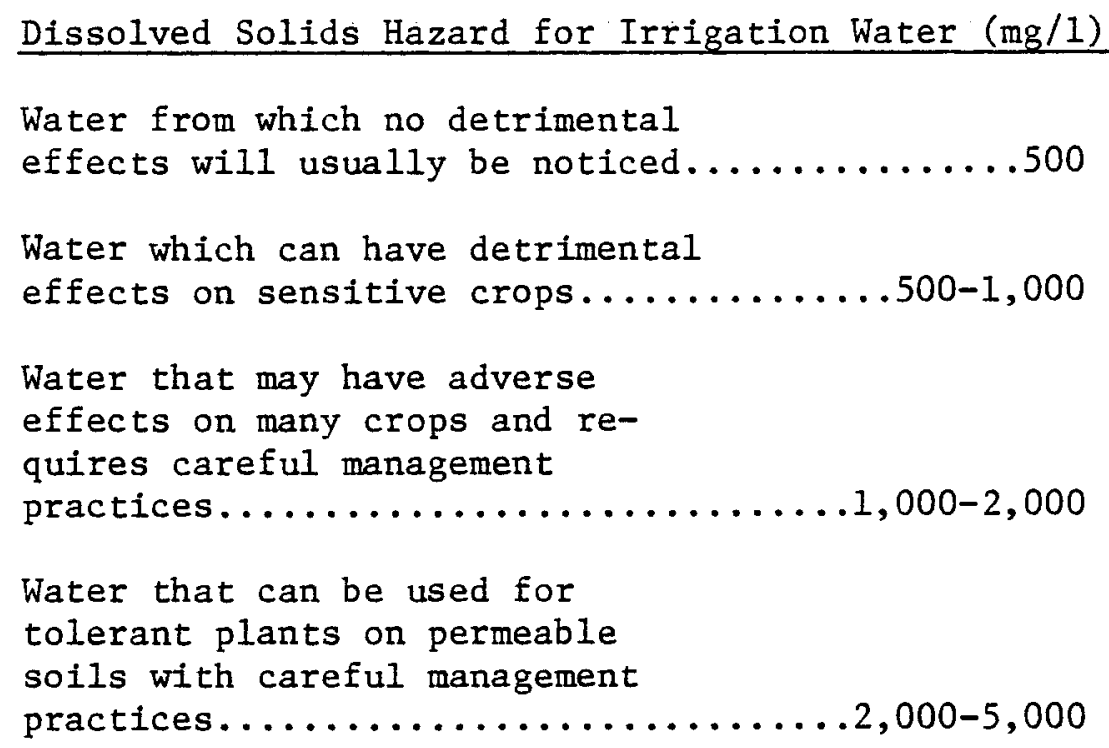

Industrial requirements regarding dissolved solids content of raw waters is quite variable. Table 3-8 indicates maximum values accepted by various industries for process requirements.

Table 3-8. Total Dissolved Solids Concentration of Surface Waters that Have Been Used as Sources for Industrial Water Supplies

Industry/Use Maximum Concentration (mg/1)

Textile 150

Pulp and Paper $\quad 1,080$

Chemical 2,500

Petroleum. $\quad 3,500$

Primary Metals $\quad 1,500$

Copper Mining 2,100

Boiler Make-up $\quad 35,000$

(Source: EPA, 1976)

Brines produced from the geopressured reservoirs differ considerably from brines encountered in drilling through the hydropressured aquifers. Hyperfiltration of water expelled from the geopressured sediments is clearly evident 
in some samples from the geopressured sandstones. Salinities $<5,000 \mathrm{mg} / 1$ and often approximately $1,000 \mathrm{mg} / 1$ are found at depths of $4,750 \mathrm{~m}(15,000 \mathrm{ft})$ or more in contrast to salinities $>200,000 \mathrm{mg} / 1$ in sands overlying the geopressured intervals (Dorfman, 1976). The waters from the geopressured reservoirs may therefore be less hazardous to the environment than brines encountered during drilling down to the geopressured reservoirs, but that assumption is not conclusive owing to the wide range of characteristics inferred from available data.

Although no routine surface disposal is expected to be employed during any of the drilling or testing procedures, injection well shut-down or failure, or perhaps lack of suitable injection well sites in a particular vicinity could necessitate such practice temporarily. If so, potential adverse impacts would occur from alternative methods such as holding ponds, evaporation pits, or overland transport by pipelines, canals, or other surface waterways to bays or open gulf waters. Dorfman and Deller (1976) list the following possible impacts from surface disposal:

1) contamination of shallow groundwater aquifers, recharge areas, and soils from leaks, seepage, or flooding;

2) destruction of non-salt tolerant vegetation adjacent to water courses;

3) interruption of animal migration patterns by hot saline courses;

4) disruption of food chain and ecological balance in bays, estuaries, lagoons, and other coastal waters where discharge is allowed;

5) possible air pollution from release of toxic gases in the brines;

6) thermal pollution; and

7) chemical loading of food fisheries with heavy metals, jeopardizing and possibly closing the fishery. 
Air quality will be slightly affected by the normal effluents from the well. Such effluents include emissions from trucks and boats used to bring materials to the well site, diesel generators operating at the site, and other equipment used during the testing process. These are the same types of equipment used during an oil field operation and they are expected to have minimal impact on the overall air quality of the area.

\subsubsection{Biological Issues}

The normal effluents from operating wells include air pollutants from motor vehicles and diesel-powered equipment, dust from movement of vehicles, noise, runoff from drill pad and boats, fluids contained in the reserve pond and, possibly, where allowed, brine water stored in evaporation or reserve ponds.

In the section treating climatology, it is stated that the possibility of air pollution is very small and restricted to the immediate vicinity of the drilling operation. For this reason it is not felt that normal operation of the well will adversely affect surrounding vegetation, and it will certainly have no greater effect than other oil and gas operations in the same area.

Dust and noise may decrease wildlife use in the area but will probably not adversely affect the flora.

Runoff from the operation which is not routed into the reserve pond and boat effluents may affect local vegetation. They will probably contain oils, organic materials and detergents. Since the operation will be for a short period of time, it is expected that whatever adverse effects these have on vegetation and 
wildlife will be short-lived. The most sensitive populations would include shellfish and other benthos. Activity in coastal areas may result in temporary closing of oyster grounds.

Fluids in the reserve pond may include fuel lubricants, acids, runoff from drill pad, and drill cuttings and drilling muds (Table 3-9). It is possible, but unlikely, that brine might be stored in the reserve pond. Those constituents of drilling muds which have the greatest possible detrimental impact to plants in the area are shown with an " $\mathrm{X}$ " in Table 3-9.

Brine water disposal via drainage or evaporation ponds is considered unlikely. However, if it occurs, once dried the constituents of the brine with the most harmful environmental influence on the vegetation will probably be copper, zinc, lead, manganese and barium (Schieler, 1976). Effects of these on the vegetation will be discussed in section 3.3 .1 .

\subsubsection{Cultural Issues}

Land use impacts resulting from the normal effluents of the well may be as follows:

1) Gases such as hydrogen sulfide could cause problems if the wells are near residences, crops or wooded areas.

2) Vented steam, if not muffled, can cause a jet-like sound audible at a considerable distance from the well which may prove to be a nuisance in developed areas. 
Table 3-9. Some Constituents Used in Drilling Fluids and Muds

Quebracho extract

$X$ Lignosulfonates, calcium and chrome derivatives Acrylonitrites (such as hydrolyzed polyacrylonitrite) Sodium salts of meta and pyrophosphoric acid Natural gums

Tannins

Molecularly dehydrated phosphates

Subbituminous products

Protocatechuic acid

Barite

Lignins (such as humic acids) Bentonite

Sugar cane fibers

Lime

Granular material, such as ground nutshells

Corn starch

Salt water

Soluble caustic/lignin product

Carboxy methyl cellulose

$\mathrm{X}$ Crude oil

$X$ Sulfonated crude oil

$X$ Oil emulsions

Sodium chromate

Anionic and nonionic surfactants

Organophylic clay

Soaps of long-chain fatty acids

Phospholipids (e.g., lecithin)

$\mathrm{X}$ Asbestos

$\mathrm{X}=$ Greatest anticipated potential impact on local vegetation

(Source: Collins, 1975, p. 463) 
3) Fluids which may include incidental spills of fuel, lubricants, or other substances as well as runoff from the drill pad area and muds not contained in the mud pits may adversely affect the soil in the area so that revegetation or reuse as agricultural or rangeland is not possible.

\subsection{Accidents}

Accidents are possible during any engineering operation regardless of how many safety precautions are incorporated into the well-testing program. The problem most likely to occur is a well blowout, the uncontrolled release of geopressuredgeothermal fluids into the subsurface or surface environment. Such a situation may result from failure of drilling equipment to function under adverse conditions of temperature and pressure as designed and failure of safety equipment to properly respond to this emergency. In addition, there is the potential for equipment breakage in response to the shrink-swell character of selected soils in the study area or from wind and storm-surge resulting from hurricanes striking in the vicinity of the well-test site.

Other accidents may occur as a result of well testing. These include land subsidence, fault activation, and cultural impact. All of these hazards are discussed in this section.

\subsubsection{Physical and Biological Issue}

Blow-outs and Brine Spills - Shallow, fresh groundwater resources may be contaminated by brine from a geopressure test well should the well blow out or back flow or if leaks develop in the brine containment system (surface pits and pipelines). Formation plugging in the brine reinjection well could also cause 
excessive system pressures that could lead to leaks and surface spills. Chemical analyses of brines from geopressure zones are listed in Tables 3-3 and 3-4. The greatest impact would probably result from an uncontrolled blowout. The following are among the important factors controlling the severity of the resulting groundwater impacts:

(1) The permeability of the surface sediments. Spills on clayey soils or on impermeable caliche soils will have less impact on local fresh water aquifers than spills on sandy soils.

(2) Surface hydrologic conditions. Flooded land will allow spilled brine to mix with surface waters, reducing the salinity of water reaching shallow aquifers. In dry, permeable areas, a brine spill could seep directly to the underlying aquifer causing significant changes in local water quality.

(3) Local relief. Brine spilled in low, poorly drained areas is more likely to remain at the spill site than spills in areas of significant relief, where brine may be carried away from the spill site by local streams. However, during dry periods stream valleys may be sites for recharge of brine into shallow aquifers.

(4) Native groundwater salinity. Where shallow ground waters are brackish or saline, surface brine spills will have little or no impact on local groundwater quality.

(5) Salinity of brine. The salinity of geopressured brine may vary widely from as 10 as $2,000 \mathrm{ppm}$ TDS to greater than $110,000 \mathrm{ppm}$ TDS as produced in a geothermal test well at Tigre Lagoon in south Louisiana. 
Based on these factors, least damage to the groundwater resources would occur in coastal areas of fine-grained, relatively impermeable sediments occasionally or permanently inundated by brackish or saline surface waters. Thus, in Louisiana the potential test site in southeast Cameron Parish is least likely to be adversely affected by surface brine spills. Surface water salinities in the area range from 15 ppt near the coast to less than 0.5 ppt along the northern boundary of the area (See Figure A-16, Appendix A). The Louisiana sites in Calcasieu and Acadia Parishes are located on soils of the Coastal Prairies. (Lytel and Sturgis, 1962.) which have "very slowly permeable subsoils." The effects of spills in these areas would be limited to near surface sediments. Water wells completed in local water-table aquifers could experience contamination which would increase groundwater salinity, possibly making the water unfit for human consumption and irrigation.

In Texas, the principal area of interest in Brazoria and Galveston Counties is underlain by clayey, poorly drained soils. Additionally, a wide band of saline soils which borders West Bay accounts for about one third of the surface in the area. The shallowest groundwater in the area contains from 1,000 to 3,000 ppm dissolved solids (Sandeen and Wesselman, 1973). Thus, brine spills at the surface will be retained by relatively impermeable soils, which are naturally saline in much of the area. Furthermore, because shallow groundwaters are slightly saline, spills probably would not affect local groundwater use.

The two potential test areas in Matagorda County are much like the BrazoriaGalveston area. Soils are clayey, poorly drained, and slightly permeable. Soils surrounding the inland bays are saline and many areas are subject to 
floods by storm tides. Except for the most inland portions of the area, the shallow groundwater is slightly saline to very saline. The impacts on groundwater of accidental spills of brine from geothermal test wells will be insignificant compared to the natural effects of storm tides and saline waters in the area.

The geothermal area in San Patricio, Nueces, and Aransas Counties is characterized by sandy soils underlain by clayey layers, subject to occasional flood tides. Thus the area is naturally inundated with saltwater. Generally the area is marked by the absence of fresh groundwater resources. The only area containing significant quantities of fresh water is a narrow strip, approximately $4.8 \mathrm{~km}$ ( $3 \mathrm{mi}$ ) wide, extending from Ingleside in San Patricio County to Rockport in Aransas County along the Live Oak Peninsula. Here fresh groundwater occurs to a depth of approximately $30.5 \mathrm{~m}$ (100 ft). Thus, spills in the San Patricio, Nueces and Aransas Counties area would penetrate naturally saline soils and mix with naturally saline groundwaters in most of the area. Spills on the Live Oak Peninsula could adversely affect fresh groundwater supplies for the city of Rockport.

In sumary, brine spills in the potential test areas will produce limited impacts because the soils are generally impermeable and in many areas are naturally saline. Shallow aquifers in the areas contain saline water and are therefore subject to limited use. Deeper and more important artesian aquifers will not be contaminated by surface spills unless the spills occur at inland outcrop areas. 
Brine Disposal - Possible accidents associated with brine disposal include disposal aquifer fracture, loss of brine around the injection well casing and brine leakage through abandoned well casings. Risks of aquifer fracture and leaks of the injection well can be minimized by proper engineering procedures. Proper monitoring of injection well operation will assure that injection pressures do not reach fracture levels causing loss of brine through induced fractures. State regulations governing the construction and completion of injection wells provide for adequate cementing and casing specifications to protect fresh waters from brine leaks.

Saline sands of adequate thickness and having adequate separation from overlying fresh water sands are available in every proposed test area. Tables 3-3 and 3-4 list brine injection wells and also indicate depths of saline sands commonly used for brine disposal.

The volume of brine anticipated for reinjection during these tests $(300,000-b b 1$ per site) is not large by industry standards. Injection of brine during tests could cause significant local pressure increases in disposal aquifers. It is possible that abandoned wells near the injection wells, which are not properly plugged or have leaky casings or no casings, could act as pressure release valves and begin to flow. In this case there is a risk of contamination of fresh water resources, including surface soils and waters. To avoid such possibilities, maps and records of abandoned wells in the area of proposed tests should be reviewed. If unplugged wells exist, decisions regarding selection of disposal depths to avoid possible hydraulic connections with the well or replugging the well may be required. 
Accidental Discharge - Technology for drilling, maintaining, and abandoning wells in the geopressured region is highly advanced because of the ubiquitous oil and gas exploration and the resulting experience gained. However, accidents are always a threat, particularly when dealing with the high temperatures and pressures expected in the proposed testing. Blowouts, thermal well-head and casing cracks, leaks, spills, and human error all could result in venting of geothermal fluids and drilling muds and lubricants to the surface (Tables 3-9 and 3-10 describe constituents). These substances would then join surface waters by natural drainage, seepage, runoff, or flooding.

Once in the natural drainage system, these thermal and chemical pollutants would produce possible adverse impacts throughout the drainage basins, with possibilities of inter-basin spreading in the highly productive wetlands areas common to the bottom of all the coastal basins. Impacts from such contingencies would probably be short-term and localized. Dilution and limiting of the effects would be dependent upon magnitude of the accidental discharge and meteorological and hydrologic conditions present at the site of discharge. Low stream flows coupled with low tides and offshore winds would produce the environmental situation in which greatest threats could occur. These conditions vary geographically and seasonally across the geopressured region.

Undetected or accidental venting of effluents through surface and subsurface faults could occur for several reasons. Faulty installation of casing, choice of hydraulically unsuitable disposal aquifers or reinjection well sites, and improperly monitored plugging of production and disposal wells during abandonment could allow the geopressured fluids to escape undetected at some distance from the test sites through faults or sand lenses with surface outcrops. Con- 
tamination of soils, reduction of water quality, and consequent threats to terrestrial and aquatic biota would result.

The following impacts could be expected from accidental discharges:

1) thermal contamination;

2) alterations to water quality including changes in salinity and $\mathrm{pH}$, and introduction of toxic trace elements;

3) possibility of acid rain, dew or fog which would damage vegetation and wildife locally and enter surface drainage patterns wherein the effect could be spread;

4) possible contamination of surface domestic water supplies which could force importation of drinking water to affected areas;

5) possibly hazardous bio-accumulation of trace elements in food fisheries.

\section{Biological Issues with special reference to flora}

Some of the types of accidents that could occur are a well blowout, evaporation or reserve pond leak, evaporation or reserve pond wash over-due to flooding or storms, vehicle or boating waste spill, plugging of injection aquifer and subsequent breakage of well casings or blowout, fire, breakage of well casings or blowout due to physical conditions such as improper drilling mud pressure or seismic activity and subsidence, earthquakes, or fault reactivation.

Of these, the well blowout will probably have the most detrimental effect on the surrounding vegetation.

Some of the constituents of geopressured brines are listed in Table 3-10. Comparison of concentrations in brines, seawater and acceptable standards are shown. Those ingredients whose level is higher than normal or standard are marked with an "X". Very few data are available on the heavy metals. 
Table 3-10. Constituents in Geopressured Brines of Environmental Concern (ppm)

Pose

Hazard (X)

$\mathrm{X}$

$\mathrm{X}$

$\mathrm{Mg}$

$\mathrm{X} \quad \mathrm{Cl}$

$\mathrm{X}$

$\begin{array}{ll}\mathrm{X} & \text { Hardness, } \mathrm{Ca}, \mathrm{Mg} \\ \mathrm{X} & \mathrm{TDS}\end{array}$

$\mathrm{X}$

X

X

$?$

?

?

$X \quad B a$

$\mathrm{X} \quad \mathrm{Fe}$

? $\quad \mathrm{SiO}_{2}$

$\mathrm{X} \quad \mathrm{Br}$

$X \quad \mathrm{NH}_{4}$

? Ni

$\mathrm{X} \quad \mathrm{H}_{2} \mathrm{~S}$ (gas)

As

$\mathrm{Cr}$

$\mathrm{Hg}$

$\mathrm{Pb}$

Cd

$\mathrm{Ba}$
$\mathrm{Br}_{2}$
$\mathrm{HH}_{4}$

Geothermal

$2,000-20,0001$

10-8,000 1

20-200

$3,500-46,000^{1}$

$150-2,5001$

$1-1,6001$

$1-450$

$7-40,000^{1}$

$30-20,000^{1}$

$8,000-72,000^{1}$

$.08^{3}$

$.42^{3}$

$19-75^{2}, 4$

$50^{2}$
30,500 part .08 sol. ${ }^{3}$

$204-213^{2}$
$282-294^{2}$

3.1
Standard

Acceptable ${ }^{7}$

$270^{10}$

400

1,350

18,980

140

2,650

$250^{10}$

$250^{10}$

$300^{10}$

34,486

.003

.01

4.6

$.003^{6}$

$.0005^{6}$

$.0002^{6}$

.00003

$.0001^{6}$

.03

.01

6.4

65

Unionized

$.007^{6}$
.02

$.025-.6^{14}$
$.009-.4^{15}$

1

0.1

0.1

0.0001

$0.2-515$

$.0004-.005$

Fresh Marine

50

1 $.5-1$
$.3-3$

${ }_{2}^{1}$ See Table Sec. 2-10, this report.

2 Collins, 1975, p. 348

3 Mayer and Ho, 1977

${ }_{5}^{4}$ Gustavsion and Kreitler, 1976

${ }_{6}^{5}$ Goldberg, 1965

${ }_{7}^{6}$ Koons, et al, 1977

7 EPA, $19 \overline{76}$

${ }_{9}^{8}$ CSGPC, 1970, in CEI, 1976

${ }_{10}^{9}$ Thompson and Kats, 1977

10 Tolerance level for domestic supply

11 Necessary for plants

12 These will quickly reach equilibrium if they are discharged in water.

13 Pacific oyster larvae were affected at $0.2 \mathrm{ppm}$.

14 Not rapidly fatal to fish below 0.25 in soft waters; toxic to fish at .6 in hard waters, but may be taken up and concentrated in filter feeders and rise to toxic levels in the food chain at much lower levels.

15.01 of the 96 -hour $\mathrm{TL}_{50}$ for fresh water fish fry or eggs. 
The constituents of the brines which would cause the most detriment to flora and fauna are $\mathrm{Na}, \mathrm{Cl}, \mathrm{SO}_{4}$, hardness, $\mathrm{TDS}, \mathrm{Cu}, \mathrm{Zn}, \mathrm{B}, \mathrm{Ba}, \mathrm{Fe}, \mathrm{Br}, \mathrm{NH}_{4}, \mathrm{Ni}$ and $\mathrm{H}_{2} \mathrm{~S}$ (gas). Other heavy metals may also be in excess of acceptable standards, but their concentration in brines is not known. The major impact in upland areas would likely be within $300 \mathrm{~m}(1,000 \mathrm{ft})$ of the well.

In general, an increase in TDS or ions would cause death of plants listed in Appendix Table A-17 which show 0 0/00 salinity. Only if the blowout continued for a long time would there be a permanent change of community. In the wetland areas the salts would sink to the bottom and mainly affect benthic flora and fauna. Intermediate and saline marsh areas would be least affected. Residual affects would most likely occur in high clay soils. Motile organisms will probably leave the area, and repopulation may be poor if the vegetation community experiences a permanent change. Eventually a new community including flora and fauna would develop.

Heavy metals levels in brine waters have been cited by many authors in the geothermal field (Axtmann, 1975; Collins, 1975; Schieler, 1976; Balashove, 1975; Schmidt, 1975; Sabadel1 and Axtmann, 1975; and Koons et al., 1977). Unfortunately information concerning geopressured brines from the Gulf Coast is sketchy or absent. Table 3-10 summarizes what little is known and uses Mayer and Ho, 1977, as a data source even though the brine they tested was from a geologic formation directly over the geopressured zone but not in it. Details of heavy metal availability are in Appendix B. 
Lead may be concentrated by filterfeeders and even at low levels affect valuable shellfisheries. Similarly, zinc may affect shellfish and fish feeding on benthic invertebrates in the vicinity of a blowout. The greatest impact on plants would be seen in the well-drained upland areas.

Copper levels in the brine may be toxic to plants and animals unless quickly diluted. Its incorporation into the foodchain would mainly affect the carnivores.

Boron levels are reportedly very high in geothermal brines, roughly 19 to 75 times the maximum suggested by EPA, 1976. Upland areas, especially croplands, are most sensitive to boron additions from geothermal fluids.

Mercury levels are unknown in geothermal brines. There may be concentration and cycling of mercury into the estuarine detrital food chains if high levels were spilled near submerged grass beds.

Once in the soil, the $\mathrm{Eh}, \mathrm{pH}$ conditions regulate to a considerable extent heavy metal availability to plants and animals. The oxidized rhizosphere of plants may change the equilibrium and allow plant uptake even in reduced environments. Dredging may under some conditions release a pulse of metals to surface and subsurface waters. Plant uptake may be the first step in a chain of bioconcentration. Much research needs to be done to more accurately assess the environmental impact of geothermal brines, especially in regard to heavy metals. It appears that the intermediate marsh and submerged grass bed vegetation type with high organic matter content, moderately alkaline $\mathrm{pH}$ and proven plant uptake capabili- 
ties may be the most sensitive areas to heavy metal pollution. Rice agriculture, extensively practiced in the chenier plain area, may also be sensitive due to alternate flooding and drying of soils.

Ammonia toxicity will depend on its equilibrium with ammonium. It is most toxic in its un-ionized state, in contrast with heavy metals which are toxic in their free ionic state.

Finally, $\mathrm{H}_{2} \mathrm{~S}$ gas as measured in the field near a geopressured site blowout was at toxic or harmful levels. This was probably only true within a short distance from the well.

In conclusion, there are many constituents in geopressured brines with possible detrimental impacts on the flora and fauna. Mackin, 1971, has shown that the majority of the effects are felt in the benthic communities, and some of these are outlined above. It is apparent that long-term effects may occur if the soil or sediment is subsequently disturbed. Toxicities are further accentuated by high salt concentration of brines (Schneider, 1972) and by high temperatures (Anderson, 1973), both of which cause toxicity to occur at lower concentrations than under normal conditions. Evaporation pond and drainage ditch leaks, breaks or washovers will have the same effect as a blowout, but in a more localized area.

Subsidence, earthquakes and fault reactivation are considered very unlikely to occur and are covered in section 2.1. 
Fire will cause the least damage in the wetland environments where if it occurs in the wet season will not cause root or rhizome damage. In general, fire will have increasing impact toward the west because of increasing arid conditions. If fire occurs in a fresh or brackish marsh when it is not flooded, it has a high probability of burning the rich peat deposits and causing permanent loss of habitat. These areas would change to open water, as has been seen in many areas in the chenier plan (Gosselink and Beck, 1976). Fire could have severe impact on dry grassland. Fire in upland forests will tend to reduce understory but will not be damaging unless it occurs in a dry area that has been artificially protected from fire previously. In those areas, high litter buildup may feed a very hot fire that could permanently damage even larger trees and root layers. Normally, fire is a natural event and a management practice that selects for a pine forest.

This section has tried to outline possible accidents and give an indication of the relative impact each type of accident would have in the different soilvegetation associations. It goes without saying that any of these accidents would be highly detrimental to the threatened and endangered species and care should be taken to protect local populations.

Air Quality - From air quality measurements of particulate, sulfur dioxide, nitrogen dioxide and ozone in the study area from Pearl River to Rio Grande, the levels of pollutants did not exceed national standards except for particulate and ozone in Houston, for ozone in Corpus Christi, and for particulate in Harlingen. If a well blowout occurs, however, the concentration at the same distance downwind from the well will ordinarily be higher in Louisiana than in 
Texas, assuming same emission rate, stability class, and effective source height, because of lower wind speed and higher inversion frequency in Louisiana than Texas. This should be used in association with the stability class and inversion frequency already given in a previous section (2.7). Some odor will be associated with the release of $\mathrm{H}_{2} \mathrm{~S}$ into the atmosphere. However, this should be minimal. It is expected that the impact of geothermal well-testing will have no major adverse impact in air quality in the study area.

Land Subsidence - A major potential environmental impact anticipated in the full-scale development of geothermal energy in the Gulf Coast is land subsidence (Gustavson and Freitler, 1976; Atherton et al., 1976). The potential land subsidence resulting from large-scale geothermal development is the subject of several recent reports (Atherton et al., 1976; Gustavson and Kreitter, 1976; Popadopolus, 1975). Their work and the work of others is summarized in Environmental Assessment of the Geopressure Subprogram of the Division of Geothermal Energy (1976).

Atherton et al. (1976) listed factors which contribute to subsidence susceptibility of geothermal sites (Table 3-11). Important factors in the Gulf Coast include the fact that the aquifers are pressured and highly porous and overlying sediments are unconsolidated. Factors contributing to surface stability include the fact that the produced volume of fluid will be small, fluid levels and pore pressure drops should be small and may be only temporary, and the overburden thickness is great. The Gulf Coast geopressure sites have several characteristics which indicate subsidence is 1ikely if large-scale geothermal development takes place. However, in the limited tests proposed (300,000 bb1 in two weeks) the stablilizing factors, particularly the limited volume of produced fluid, probably outweigh the subsidence factors. 
Table 3-11. Factors Tending to Influence Geothermal Subsidence

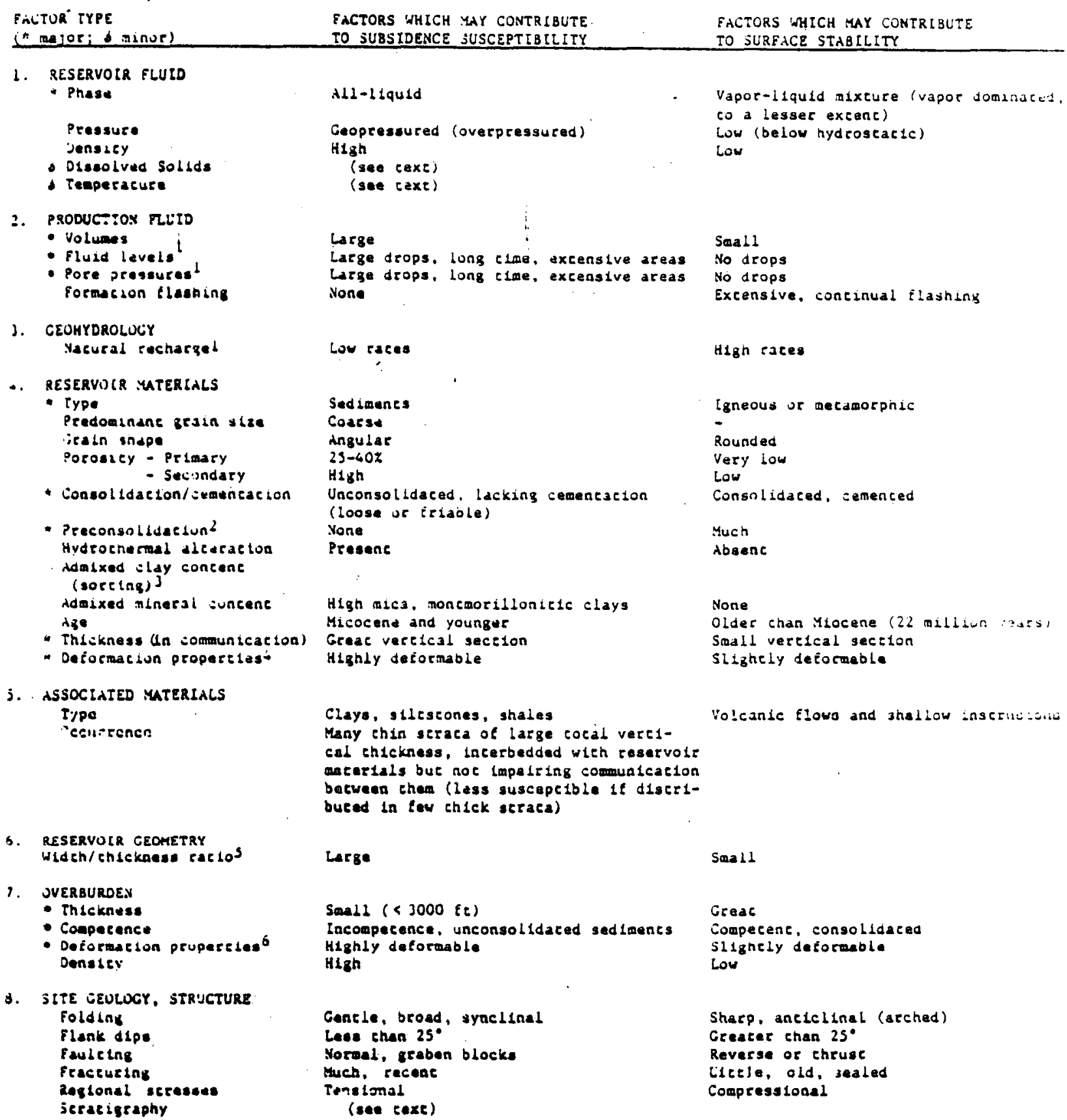

All-1 Lquld

Geopressured (overpressured)

High

(see $(\operatorname{sex} 5)$

(see cext)

Clays, stlestones, shales

Many chin seraca of large coedi vertical ehickness, tacerbedded with reservolt anterials but not Impelring comuntcation botween them (less suscepcible if diacr1buted in tew ehlek ecraca)

Large

Small

Soal1 (s $3000 \mathrm{ft})$

lacompecence, unconsolidaced sedimencs

Hizhly deformable

Hizh

d. SITE EEULUCY, STRUCTURE Folding

Flank dipe

Faublelng

Feacturing

Reglonal scresses

jeracigraphy

(see cexe)

TO SURFACE STABLLITY


An estimate of the amount of pressure reduction anticipated in a brief ( 2 wk) test can be made using the aquifer characteristics and the analysis of reservoir hydraulics presented by Bernard (1975). Table 3-12 1ists hypothetical geopressure reservoir characteristics used in Bernard's calculations.

$\begin{array}{ll}\text { Table 3-12. Aquifer, Well, and Fluid Data for the Hypothetical Problem } \\ \text { Pipe diameter }=9 \text { inches } & \text { Permeability }=0.1 \text { darcy } \\ \text { Initial pressure }=10,000 \mathrm{psig} & \text { Thickness }=200 \mathrm{feet} \\ \text { Temperature }=300^{\circ} \mathrm{F} & \text { Wellbore radius }=0.375 \mathrm{feet} \\ \text { Water viscosity }=0.3 \mathrm{cp} & \text { Compressibility }=10^{-5} \mathrm{psi}-1 \\ \text { Porosity }=20 \text { percent } & \text { Depth }=12,000 \text { feet } \\ \text { Water density }=1.0 \mathrm{~g} / \mathrm{cc} & \text { Aquifer size }=200,000 \text { acres or } \\ & \end{array}$

(Source: Bernard, 1975)

The theoretical pressure loss in this aquifer due to the withdrawal of $300,000-$ bb1 of fluid in fourteen days is shown in Table 3-13. The initial surface pressure, 4,804.0 psig, drops to $4,345.0 \mathrm{psig}$ at the end of the test period. After the test is terminated and the well has been shut in for 100 days, the pressure has recovered to within about 3 pounds of the original pressure. Hence, the effect of the test is short-term and minimal.

Because "wells-of-opportunity" considered in this assessment will produce for a period of approximately only two weeks, the amount of subsidence is expected to be negligible. In the Gulf Coast, where numerous oil and gas fields have produced for several decades, Lofgren (1977, p. 4) stated that there are probably less than a half dozen heavily developed ...fields with direct evidence of land-surface subsidence caused by the fluid withdrawal, and in each of these the correlation with deep withdrawals is not unequivocal. 
Table 3-13. Fluid Withdrawal Rates and Geopressure Responses

\begin{tabular}{|c|c|c|c|c|c|}
\hline $\begin{array}{c}\text { Production } \\
\text { (bb1/day) } \\
\end{array}$ & Days & $\begin{array}{l}\text { Bottom-Hole } \\
\text { Pressure (psi) }\end{array}$ & $\begin{array}{l}\text { Static } \\
\text { Head } \\
\end{array}$ & Friction & $\begin{array}{l}\text { Surface } \\
\text { Pressure (psig) }\end{array}$ \\
\hline 0 & 0 & $10,000.0$ & $5,196.0$ & -19.9 & $4,804.0$ \\
\hline 21,500 & 1 & $9,621.0$ & $5,196.0$ & -19.9 & $4,405.1$ \\
\hline 21,500 & 2 & $9,605.2$ & $5,196.0$ & -19.9 & $4,389.3$ \\
\hline 21,500 & 3 & $9,596.0$ & $5,196.0$ & -19.9 & $4,380.1$ \\
\hline 21,500 & 4 & $9,596.0$ & $5,196.0$ & -19.9 & $4,373.5$ \\
\hline 21,500 & 5 & $9,584.4$ & $5,196.0$ & -19.9 & $4,368.5$ \\
\hline 21,500 & 6 & $9,580.2$ & $5,196.0$ & -19.9 & $4,364.3$ \\
\hline 21,500 & 7 & $9,576.7$ & $5,196.0$ & -19.9 & $4,360.8$ \\
\hline 21,500 & 8 & $9,573.7$ & $5,196.00$ & -19.9 & $4,357.8$ \\
\hline 21,500 & 9 & $9,571.0$ & $5,196.00$ & -19.9 & $4,355.1$ \\
\hline 21,500 & 10 & $9,568.6$ & $5,196.00$ & -19.9 & $4,352.7$ \\
\hline 21,500 & 11 & $9,566.4$ & $5,196.00$ & -19.9 & $4,350.5$ \\
\hline 21,500 & 12 & $9,564.4$ & $5,196.00$ & -19.9 & $4,348.5$ \\
\hline 21,500 & 13 & $9,562.6$ & $5,196.0$ & -19.9 & $4,346.7$ \\
\hline 21,500 & 14 & $9,560.9$ & $5,196.00$ & -19.9 & $4,345.0$ \\
\hline $0 *$ & 15 & $9,938.3$ & $5,196.0$ & 0.0 & $4,742.3$ \\
\hline 0 & 16 & $9,952.6$ & $5,196.0$ & 0.0 & $4,756.6$ \\
\hline 0 & 17 & $9,960.5$ & $5,196.0$ & 0.0 & $4,764.5$ \\
\hline 0 & 20 & $9,972.6$ & $5,196.0$ & 0.0 & $4,776.6$ \\
\hline 0 & 30 & $9,985.7$ & $5,196.0$ & 0.0 & $4,789.7$ \\
\hline 0 & 100 & $9,996.6$ & $5,196.0$ & 0.0 & $4,800.6$ \\
\hline
\end{tabular}

*Test Ends

(Source: C.G. Smith, 1977) 
Lofgren listed the following as the most likely reasons subsidence has not been detected:

1) Data have not been sufficient to monitor and detect subsidence.

2) Pumped reservoirs have been naturally recharged reducing the pressure decline.

3) Horizontal land movement may account for part of the compaction.

4) The reservoirs may be only slightly compressible. Thus compaction and subsidence are small.

Factors 2 and 4 may significantly reduce the potential for land subsidence at sites of limited and even full-scale geothermal development in the Gulf Coast.

For a short-term test of two weeks, a simple approach may be useful in providing a rough estimate of the maximum subsidence attributable to the offtake of $300,000 \mathrm{bbl}$ of fluid. Two examples follow.

First, Herrin, Goforth and Pheasant (1973) evaluated potential subsidence above a model geothermal reservoir bounded by growth faults and facies changes. Assuming a $1,610 \mathrm{~m}(5,280 \mathrm{ft})$ thick reservoir beginning at a depth of $3,660 \mathrm{~m}$ $(12,000 \mathrm{ft})$ below the surface, consisting of half sand and half shale, $32 \mathrm{~km}$ by $48 \mathrm{~km}$ ( $20 \mathrm{mi}$ by $30 \mathrm{mi}$ ) wide, with a daily production rate of $50,000 \mathrm{bbl}$, they estimated surface subsidence would be $3.35 \mathrm{~m}$ (11 ft) after 20 years of production. In this example 3.5 percent of the total water in the reservoir was produced and land subsidence was treated as a direct result of aquifer compac- 
tion due to reduced pore pressure. Using the same reservoir characteristics and the maximum production volume of only 300,000 bbl anticipated at a brief test of an available well, the volume of produced fluid is only 0.00017 percent of the total reservoir volume. Using the same approach the maximum average subsidence would be $0.049 \mathrm{~cm}(0.0016 \mathrm{ft})$.

A second approach is suggested by Lofgren (1977). He reported that the amount of subsidence at Chocolate Bayou oil field in Texas is approximately equal to twice the volume of oil produced (he assumes the volume of gas and water produced was equal to the volume of oil produced). Assuming the area of subsidence was $52 \mathrm{~km}^{2}\left(20 \mathrm{mi}^{2}\right)$, the average amount of subsidence was predicted to be $0.24 \mathrm{~m}$ $(0.8 \mathrm{ft})$, roughly equal to the actual amount of subsidence. This approach can be used to estimate the maximum subsidence produced by a well producing only 300,000-bb1 of fluid. Assuming the change in shear stress is propagated outward at an angle of $45^{\circ}$ from the depth of production [say $3,050 \mathrm{~m}(10,000 \mathrm{ft})$ ], an area of $29,170,600 \mathrm{~m}^{2}\left(3.14 \times 10^{8} \mathrm{Et}^{2}\right)$ [a circle with diamter of $6,100-\mathrm{m}$ $(20,000 \mathrm{ft})]$ would be affected. The predicted average subsidence would be 0.0053 ft. For comparison, the U.S. Coast and Geodetic Survey allows a closure error of $0.0164 \mathrm{~m}(0.0537 \mathrm{ft})$ in a first order survey run over a distance of $16 \mathrm{~km}$ (10 miles) (Brinker, 1969).

Both of the above examples assume 1) no recharge occurs in the reservoir to reduce the effects of pressure drop caused by fluid production, and 2) the 
effects of reservoir compaction are not reduced at the surface by the thick overburden. Both factors would probably reduce the amount of subsidence measured at the surface. Furthermore, in the estimates above, the values of subsidence are average. It is assumed that in large geothermal reservoirs maximum subsidence will occur near the wells at areas of maximum pressure decline.

Subsidence associated with geothermal fluid production is not expected to begin immediately. Although the compaction of the sands of the geopressured reservoirs will be nearly contemporaneous with fluid production, compaction of the interlayered and surrounding clays and silts will require substantially longer periods of time due to the lower permeability of such sediments. According to Atherton et a1., (1976, vo1. 1, p. 4-19):

Because of the differing response rates of sands and clays, it is common to observe a time lag between changes in the rates of pumping and the occurrence of subsidence. This delay may last for days or years, depending on the pumping history and the physical properties of the aquifer system (Lofgren, 1968; Poland, 1969). For the same reason, it is impractical to use short-term pumping tests to measure a field's subsidence potential; and it is even more difficult to predict subsidence rates than the ultimate total amount of subsidence.

Hence the ultimate effects of subsidence may not be established for a test site for months or years after the test is concluded.

Fault Activation - Gustavson and Kreitler (1976) suggest normal faults in the Gulf Coast may be activated by geothermal developments. Differential compaction on one side of a fault can cause fault movement near the surface (Kreitler, 1977). Kreitler and Gustavson cite examples of fault movement due to fluid extraction in Saxet field near Corpus Christi and due to groundwater development in the Houston area. 
Surface fault traces and photo lineations indicate important areas for monitoring of differential ground subsidence in areas of large-scale geothermal development. However, the limited quantities of fluids produced, the anticipated slight declines in reservoir pressures, and the expected lack of subsidence associated with a two-week geothermal test suggest no fault movement will result in tests considered in this assessment.

\subsubsection{Cultural Issues}

Though a well blowout is unlikely because of the extensive precautions taken against such an event, such an accident would result in the exhaustion of hot brine, steam, mud, methane gas and other non-condensable gases into the atmosphere. A blowout could thus result in:

1) a threat to residential and commercial development, and

2) contamination of agricultural, wooded and wetlands with brine and chemicals.

Other accidents which may affect land use relate to mud pits and reserve pits. These pits will be lined with impervious materials, but if this lining is faulty or is fractured, groundwater may be contaminated. This contaminated groundwater may affect growing conditions in both agriculturally and naturally vegetated areas. A second possible problem with these pits deals with overflow of brine or drilling mud. Again this may adversely affect vegetation and prevent restoration of the site to its original condition. 


\subsection{Impact Control Program Including Restoration of Well Site}

Use of existing wells for testing will result in minimal environmental impact. Construction, grading, land clearing, and use of heavy equipment in site preparation will be lessened. Consequent minimizing of physical changes to the land surface will result in less possible adverse impact to water circulation, water quality, wildlife, vegetation, recreational water use, and aesthetic value of surface waters.

Methods of erosion control will be employed to reduce surface runoff and siltation during all phases of the proposed activity. Construction and sanitary wastes will be disposed of at suitable spoil sites. Reserve ponds, evaporation pits, and drainage channels will be lined with impervious material and will have a minimum freeboard height of $1 \mathrm{~m}(3 \mathrm{ft})$ to prevent contamination of soils, surface water, and groundwater recharge areas and aquifers from leaks and seepage.

All the potential impacts from well installation and maintenance have been extensively encountered by the oil and gas industry throughout the region. Although impacts to the environment are still substantial, technology developed through experience in the region is capable of minimizing detriment to the environment from production practices or accidents. Additionally, experienced personnel will be employed in the proposed testing, and numerous regulations governing drilling operations in the region will diminish environmental impacts considerably.

In order to ensure that leaks from the well bore which could contaminate fresh water aquifers or escape to the surface do not occur, each piece of the casing 
will be cemented in place and overlapped with the next piece to a distance of $30 \mathrm{~m}$ (100 ft). Annular space of each well will be cemented completely from the formation to the surface to provide greater stability, to ensure sealing of overlying aquifers and fault zones, and to control pressures. High pressure blowout prevention equipment will be installed and maintained to prevent the threat posed to surface waters by blowouts.

Excess fluids from the reserve pit will be drained off and pumped into the disposal well prior to abandonment. The remaining reserve pond contents will be solidified and buried. Abandoned wells will be plugged in a manner designed to prevent any fluid movement in the well bore. Extensive monitoring by trained and experienced personnel should prevent undetected leaks and should minimize the extent of accidental discharges by allowing rapid recovery. When testing is complete, all structures and equipment will be removed and the site will be reseeded.

These programs should minimize impacts to surface water by controlling erosion, controlling introduction of drilling muds and produced waters to surface drainage, and by restoring the site as closely as possible to its original condition, enhancing rapid recuperation to the previous hydrologic setting. However, buried toxicants and precipitated trace heavy metals will remain in the environment and remain susceptible to re-introduction by future construction, dredging, and natural hazards such as erosion, flooding, storm action, and tectonic activity. The long-term effect of the proposed activity is difficult to evaluate because of the lack of data on effects of the materials involved. 
Location will be important in assessing the magnitude of potential impacts. The diversity of environments across the geopressured region produces spatially varying consequences from any of the potential impacts. For example, brine spills in an area of brackish or saline water or into a drainage network already severely polluted from other sources will probably cause negligible impact. Leaks or discharges into drainage basins with high runoff rates and consequent ample assimilative capacity will be diluted below acceptable levels and will therefore pose no substantial impact on that area. On the other hand, surface venting of brines or chemicals into sensitive aquatic or terrestrial habitats, domestic water supply sources, or aesthetically valuable water courses would produce impacts of magnified intensity. The value of this generic assessment of regional hydrology is in identifying areas of greatest and least potential impact to surface waters from the proposed activity.

\subsubsection{Biological Issues}

Impact control programs and site restoration such as building reserve ponds with berms and impervious linings, pumping reserve pond fluids back down well or taking off the site and covering over reserve ponds and reseeding them and possibly drill pad sites have both positive and negative impacts on the flora.

The reserve ponds protect surrounding areas but also restrict surface water flow. This could change local flora due to soil moisture and salinity changes. After cleaning the pit, filling it in and reseeding, what impacts occur? If the pit is filled with material dredged from canal, lake or stream bottoms in a reduced condition, putting it in an upland site above the water table may result in sediment oxidation and subsequent mobilization and release of heavy metals (Gambrell et al., 1977a). These can be translocated through vegetation to the food chain. 
If the site is not returned to a condition level with surroundings, especially in the marsh, it may not help to reseed it as its increased elevation may cause spoil bank vegetation to out-compete marsh grasses and sedges.

If the site is filled with sandy soil, it may take years for organic matter content to build up and succession, especially to upland forest, may take a very long time.

Since the pit and channels are impervious, they may serve as holding ponds in areas that were once recharge sites. This could cause a local hydric vegetation to develop.

If careful cleaning, return to same elevation and breaks in the impervious lining were made, the areas would have the best chance for a rapid recovery.

It might be noted that the extremely productive submerged grass beds reproduce mainly by vegetative growth in this area. Any channels or dredging may take a long time to recolonize, and seeds are not generally available (Godcharles, 1971).

The early stages of plant succession following site abandonment will provide better rabbit, dove, and deer habitat than the natural pine, pine-hardwood, or swamp forests which may have previously occupied the site. Gravel on disturbed surfaces may attract doves, geese, and other birds. 


\subsubsection{Cultural Issues}

Impact control programs and restoration practices which will ameliorate adverse effects on land use include:

1) extensive precautions against well blowouts,

2) pumping free water from the mud pits and reserve pits

into the disposal well and then filling and restoring these

pits in as natural a condition as possible,

3) abating noise caused by venting geothermal effluents, and

4) restoring, as much as possible, the entire test site to its original condition by regrading, filling and reseeding. 
CHAPTER FOUR - COORDINATION WITH FEDERAL, STATE, REGIONAL AND LOCAL LEVELS OF GOVERNMENT

\subsection{Federal Regulation and Permitting Requirements}

Oil and gas operation, as well as geothermal activities, are subject to regulations at the Federal and state levels of government. A summary of existing policies, regulations and permitting requirements at Federal, state and local levels and a list of Federal Agencles contacted regarding coordination of the proposed action is presented in Appendix $C$.

\subsubsection{Geothermal Leasing on Federal Lands}

The following Federal lands are removed from geothermal leasing by Congress: National Parks, National Recreation Areas, Fish Hatcheries, Wildlife Refuges, Wildlife Ranges, Game Ranges, Wildlife Management Areas, Waterfowl Production Areas, lands acquired or reserved for the protection and conservation of fish and wildlife that are endangered, and tribally or individually owned Indian trust or restricted lands, within or without the boundaries of Indian Reservations (Plate II).

The Bureau of Land Management is the agency responsible for the leasing of mineral resources in the states of Texas and Louisiana.

\subsubsection{Degradation of the Environment}

Several existing Federal programs regulate some aspect of activities which have a potential for adversely impacting the environment (Table 4-1). Discharge of effluents into waters of the United States and releasing pollutants into the air require a permit from the Environmental Protection Agency (EPA). 
Table 4-1. Matrix of Federal and State Actions on Geopressure-Geothermal We11 Testing Activities and Related Oil Activities

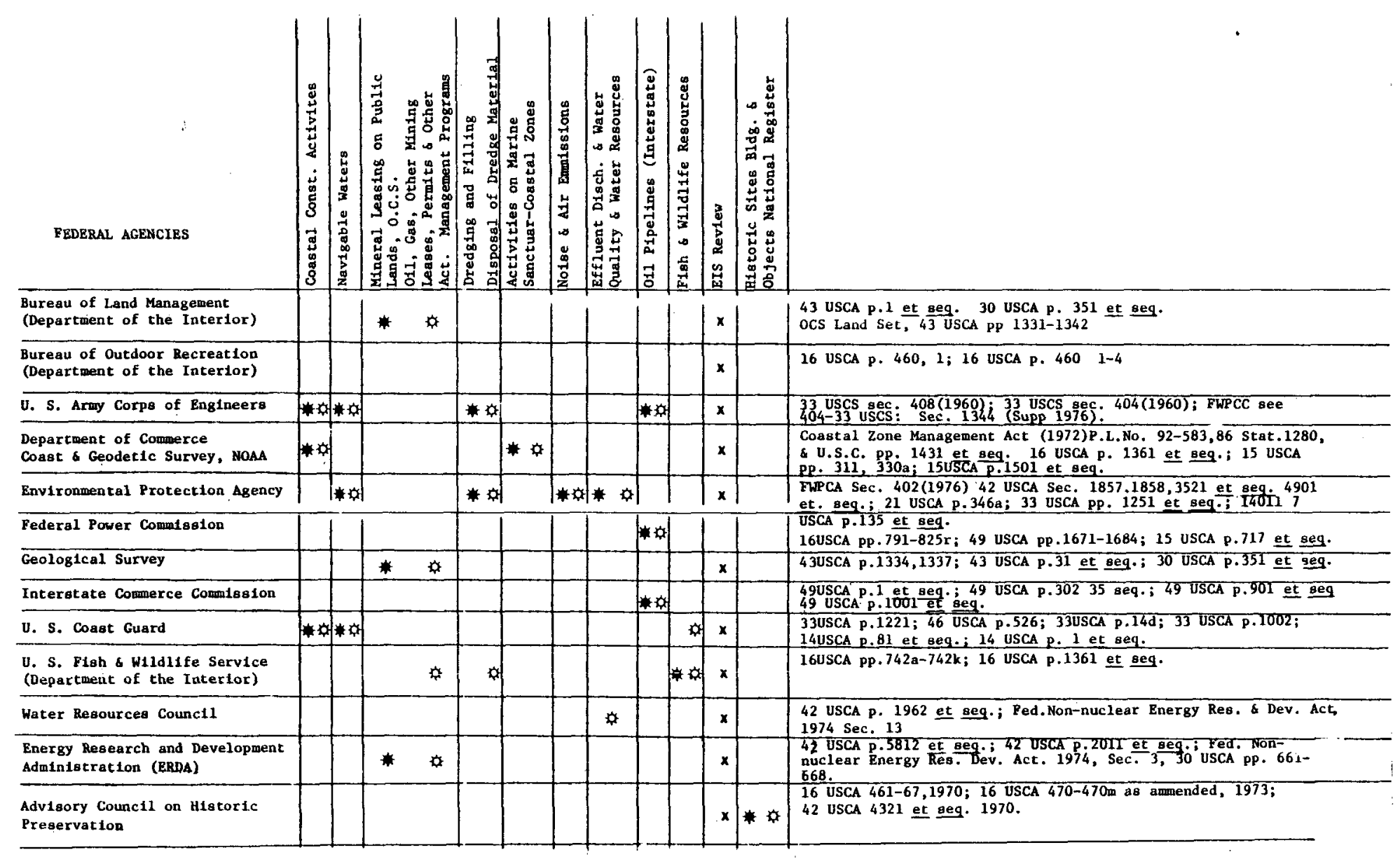

* Agency Requires Permits

\begin{abstract}
Agency has Rules and Regulations Applying to Action
\end{abstract}

x Agency Reviews EIS and EA or Reviews Applications 
Table 4-1. Matrix of Federal and State Actions on Geopressure-Geothermal Well Testing Activities and Related Oil Activities: Continued.

\begin{tabular}{|c|c|c|c|c|c|c|c|c|c|c|c|c|c|}
\hline $\begin{array}{l}\text { State Agencies } \\
\text { Louisiana }\end{array}$ & 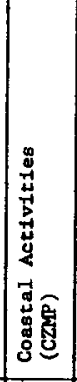 & 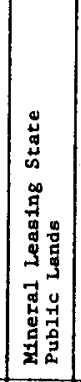 & 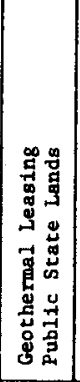 & 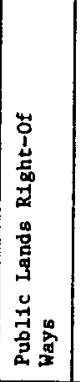 & 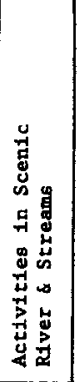 & 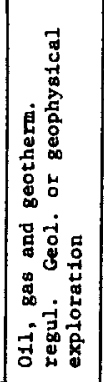 & 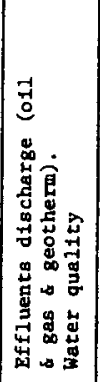 & 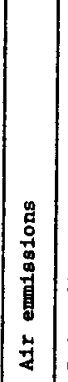 & 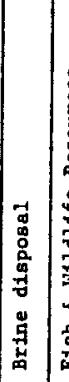 & 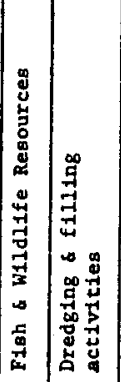 & 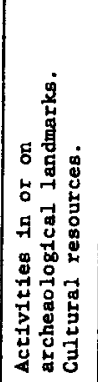 & 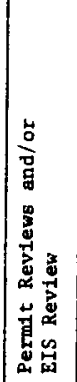 & Authorization \\
\hline State Land of fice & & * & * & $*$ & & & & & & $*$ & & & $\begin{array}{l}\text { La. R.S. 41:1173-1174 Dec. 31, 1974; L.a. R.S. } \\
\text { 41:1262-1268 Ammended by Acts 1970; No. 59; Acts } \\
1974 \text {, No. 611; T1tle 30, p. 171-179.14 }\end{array}$ \\
\hline $\begin{array}{l}\text { Louisiana Wild11fe and } \\
\text { Fisherles Commisston }\end{array}$ & & 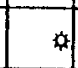 & & & $*$ & & * & & & & & $\mathbf{x}$ & $\begin{array}{l}\text { Ch. 8 of Title 56, La, Rev. Stat. 1950, R.S. 56: } \\
\text { 1841-56:1849. Title 41, p. } 12640\end{array}$ \\
\hline $\begin{array}{l}\text { La. Stream Control } \\
\text { Commisslon }\end{array}$ & & & & & & & $*$ & & 则 & $\not$ & & $\mathbf{x}$ & $\begin{array}{l}\text { La. Rev. Stat. } 56: 1433 ; \text { La. Rev. Stat. 56:1441- } \\
\text { 56:1445 Div. of Wat. Pollution Contr. of L.W.6F.Comm }\end{array}$ \\
\hline $\begin{array}{l}\text { La. State Planning office } \\
\text { Coastal Zone Mang. Prog. }\end{array}$ & $\$$ & & & & & & & & & & & & $\begin{array}{l}\text { B111 } 425 \text { CZMP have not yet been approved by the } \\
\text { Secretary of Comm. }\end{array}$ \\
\hline Department of Conservation & & & & & & $*$ & & & * 蛇 & 0 & & & $\begin{array}{l}\text { Title 30, Order 29-E Act 134, Act 735; Order 25 B } \\
\text { La. Geothermal \& Geopressured Energy Res. \& Dev. } \\
\text { Act, 1975. T1tle 30, Ch. } 7 \text { (Act 735; 1975); Ch. } \\
8 \text { (Act 784; 1975). } \\
\text { An Ad Hoc Committee is prepartng a draft for Rules } \\
\text { and Reg. pertaining to the state's geotherman and } \\
\text { /or geopressured resource }\end{array}$ \\
\hline $\begin{array}{l}\text { La. Archaelogical Survey } \\
\text { and Antiquities Commission }\end{array}$ & & & & & & & & & & & * & $\mathbf{x}$ & $\begin{array}{l}\text { L.R.S. } 41: 1601-1613 \text { as ammended by Act } 378 \text { of } 1974 \\
\text { La. standards for cultural resource surveying is } \\
\text { In draft form. }\end{array}$ \\
\hline La. Alr Control Comm. & & & & & & & & * & & & & $x$ & $\begin{array}{l}\text { Title } 40 \text { Sec. } 2204 \text { of Tftle } 40 \text { of la. Rev. State. } \\
1950 \text {. Tithe } 40 \text {, Sec. } 2201 \text { et geg. Act } 259 \text { of } 1964 \text {. } \\
\text { Has given auth. to La. Dpt. of Health to adulnister } \\
\text { regul. applying to any source of alr eamissions. }\end{array}$ \\
\hline La. Dept. of Health & & & & & & & $*$ & * & & & & & $\begin{array}{l}\text { R.S. } 40: 2204(\mathrm{~A}) \text { Title } 40 \text { Sec. } 2201 \text { et seg. Act } \\
259 \text { of } 1964 \text {. }\end{array}$ \\
\hline State M1neral Board & & * & $*$ & & & $*$ & & & & & & & 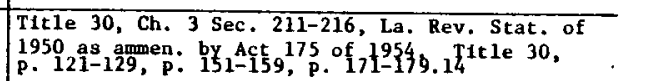 \\
\hline $\begin{array}{l}\text { Dept. of Urban \& } \\
\text { Comomunity Af fairs }\end{array}$ & & & & & & & & & & & & $x$ & Execut lve order 60 A-95 Review \\
\hline
\end{tabular}

* Agency Requires Permits
Agency has Rules and Regulations Applying to Action $x$ Agency Reviews EIS and EA or Reviews Applications 
Table 4-1. Matrix of Federal and State Actions on Geopressure-Geothermal Well Testing
Activities and Related Oil Activities. Continued.

\begin{tabular}{|c|c|c|c|c|c|c|c|c|c|c|c|c|c|}
\hline $\begin{array}{l}\text { STATR AGENCIES } \\
\text { TEXAS }\end{array}$ & 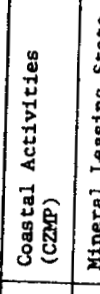 & 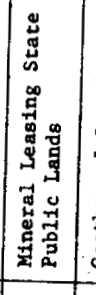 & 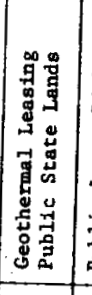 & 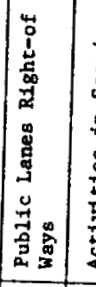 & 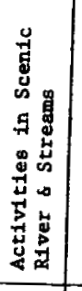 & 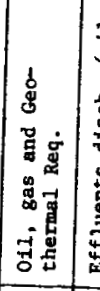 & 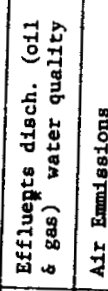 & 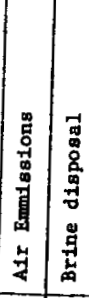 & 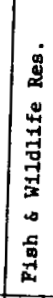 & 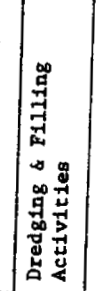 & 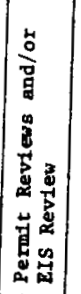 & 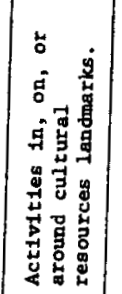 & Auchorization \\
\hline $\begin{array}{l}\text { Texas General Land } \\
\text { Of } f \pm c e\end{array}$ & 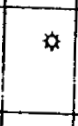 & $*$ & & $* a$ & & & & & & & & & 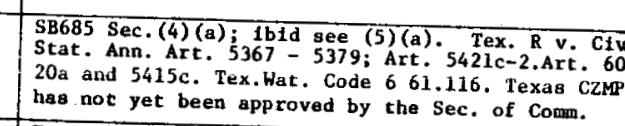 \\
\hline School Land Board & $*$ & & * & $*$ & & & & & & & & & 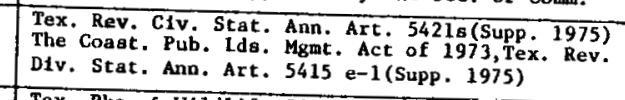 \\
\hline $\begin{array}{l}\text { Texas Park } \delta \text { Hild11fe Dept. } \\
\text { Texas Rallroad Comini ssion }\end{array}$ & . & & & & 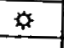 & & 女 & -5 & & - & $x$ & & Tex. Pks. \& W11d1Ife Cde.Ann. Sec. $86.00 \overline{2(a)}(197 \overline{7})$ \\
\hline Texas Rallroad Commission & & & & & & * 女 & $* \$$ & $* 0$ & & & & & $\begin{array}{l}\text { Art. } 6444 \text { et seq.; Art. } 6004 \text { et seq.; Tex. Water } \\
\text { Code, Ch. } \frac{22 .}{2} \text {. }\end{array}$ \\
\hline Texas hater Qual1ty Board * & & & & & & & * & & 虾 & & $x$ & & Texas Water code, ch. 21. \\
\hline Texas Water Developrent Board $d^{*}$ & & & & & & & 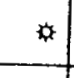 & & $\not 2$ & & $x$ & & $\begin{array}{l}\text { Tex. Water Code, Ah. 11; Tex. Water Code, ch. 57; } \\
\text { Art. 108a }\end{array}$ \\
\hline $\begin{array}{c}\text { State Dept. of Health } \\
\text { Resources }\end{array}$ & & & & & & & a & & 的 & & $x$ & & Art. 4414 a et geg.; Art. $4050 \mathrm{f}$ \\
\hline Texas Antiquities Committee & & & & & & & & & & & $\stackrel{x}{\longrightarrow}$ & $*$ & $\begin{array}{l}\begin{array}{l}\text { Tex. Rev. C1v. Stat. Ann. Art. 6145-9 (1970) as } \\
\text { amminended (Supp. 2975) }\end{array} \\
\end{array}$ \\
\hline Texas Alr Control Board & & & & & & & & * & & & * & & $\begin{array}{l}\text { Art. } 4477-5663.07-5.05 \text {; Tex. Rev. Code, } \\
\text { Art. } 698 \mathrm{~d}\end{array}$ \\
\hline office of the Governor & & & & & & & & & & & $x$ & & $\begin{array}{l}\text { Tex, Rev, C1v. Stat. Ann. Art, 4413(328) (32b); } \\
\text { A-95 Review - State Clearting House }\end{array}$ \\
\hline $\begin{array}{l}\text { Texas Water Wells Drillers } \\
\text { Board }\end{array}$ & & & & & & & & & & $*$ & $x$ & & $\begin{array}{l}\text { Art. 7621e; D1aposal Well Act, Tex. Water Code, } \\
\text { Ch. } 22 .\end{array}$ \\
\hline
\end{tabular}

\section{* Agency Requires Permits}

* These two agencies plus the Texas Water Rights Commission have become the Texas Department of Water Resources

\section{* Agency has Rules and Regulations Applying to Action}
x Agency Reviews EIS and EA or Reviews Applica- tions


Also, under the Safe Water Drinking Act (SWDA), EPA has regulatory jurisdiction over injection wells (December, 1974). There are also Federal Land Use Programs which regulate and control impacts to park and recreation areas in the vicinity of oil, gas and geothermal activities.

\subsubsection{Activities on Navigable Waters}

Any development activities in areas under the definition of navigable waters and unprotected flood areas requires a permit from the Corps of Engineers. Also, the Coast Guard requires permits for certain construction developments over navigable waters (including tidal wetlands) (Appendix C).

If a state has a Coastal Zone Management Program approved by the Department of Commerce, any activity in the coastal zone which requires a Federal permit license must be accompanied by a state's approval.

Several Federal Programs control geothermal resource development activities such as the Non-Nuclear Energy Research and Development Act of 1974 (Public Law 93-557, 88 Stat. 1878), and the Geothermal Energy Research Development and Demonstration Act of 1974 (Public Law 93-410, 88 Stat. 1079).

There are several Federal Acts and Programs which provide for the protection of historic and prehistoric sites, buildings and monuments which might be affected or adversely impacted by a proposed development activity. Federal guidelines and procedures should be taken into account when undertaking Federally required cultural resource surveys. 


\subsection{State Plans and Policies}

Regulations and permitting procedures in the states of Louisiana and Texas regarding oil, gas and geothermal resources development are briefly outlined in Table $4-1$.

\subsubsection{State Land Use Plans}

In Louisiana, the Register of State Lands may lease any public lands belonging to the state. Leases from school board lands can be obtained from the appropriate agency.

In the state of Texas, the General Land Office and the School Land Board regulate activities which take place on the public free school lands of Texas, including coastal public lands.

\subsubsection{Coastal Zone Management Plans}

Neither the state of Texas nor the state of Louisiana has instituted a Coastal Zone Management program approved by the Secretary of Commerce.

\subsubsection{State Well Drilling Procedures}

In the state of Texas the agency which regulates and issues permits regarding oil, gas and geothermal energy developments is the Texas Railroad Commission. Coordinating agencies are: The Texas Department of Water Resources, Texas Parks and Wildife Department and the State Health Department.

In the state of Louisiana the Department of Conservation, Louisiana Geological Survey, is the main regulatory agency for activities concerning oil and gas developments. Rules and regulations pertaining to geothermal resources development are presently being drafted by an ad hoc comittee. 


\subsubsection{State Archeological and Historic Survey Requirements}

Both the states of Texas and Louisiana have set standards for cultural resources surveying in compliance with Federal regulations.

\subsubsection{State Environmental Requirements - Waste Fluid Disposal \\ 4.2.5.1 Surface and Subsurface Permiting Procedures at the State Level}

In the state of Texas, the Texas Department of Water Resources and the Texas Railroad Commission (TRRC), regulate and issue permits regarding waste fluld disposal in association with geothermal resources and with the production of oil and gas. EPA regulates and issues permits at the Federal level. Brine disposal associated with oil, gas and geothermal activities requires a permit from the Railroad Commission of Texas, 011 and Gas Division, which also grants permits for fluid injection into a productive oil, gas or geothermal reservoir.

In Louisiana, the agency regulating brine disposal is the Department of Conservation, Louisiana Geological Survey, $0 i 1$ and Gas Division.

\subsubsection{Air Emission Regulatory and Permitting Procedures at the State Level}

The main regulatory agency in the state of Texas is the Texas Air Control Board (TACB). In the state of Louisiana, the Louisiana Air Control Commission administers regulations concerning air emissions.

\subsection{Regional and Local Plans and Policies}

Regional Planning Commissions in the states of Texas and Louisiana, as well as local planning bodies, exercise controls and have rules and regulations which apply to their particular regional or local area. 
For more detail on the subject and for a list of regional and local agencies contacted and their views and comments, see Appendix C. 


\section{ALTERNATIVES}

The reasonably available alternatives to the proposed action are delayed or no action and to consider a specific site as opposed to a general region.

\subsection{DELAYED OR NO ACTION}

This specific project is designed to supply important information on fluid and flow properties of the geopressured resource by using an unsuccessful oil well. Should this project prove successful, an important tool for geopressured and resource evaluation will have been found while an important use for some unsuccessful oil wells may be realized. Delayed or no action will delay or eliminate the information to be gained on the value of appropriately located, but unsuccessful, oil wells to geopressured resource evaluation.

\subsection{LOCATION}

This environmental assessment is based on a regional location although only one well is to be tested. This is because the oil well must be acquired by ERDA prior to removal of the drilling rig by the oil company. On this basis, it is not possible to pick a specific site since it is not known which wells available to ERDA will be unsuccessful oil wells. The time constraint on removing the drilling rig precludes doing a site specific environmental review after the site is known. Therefore, the regional evaluation is used to provide an adequate assessment of the potential environmental impacts of any likely site in the region. 
APPENDICES

Appendices $A-C$ give detailed information summarized in Chapters 2-4, respectively. 
APPENDIX A - DESCRIPTION OF THE EXISTING ENVIRONMENT

\subsection{Geology}

\subsubsection{Geomorphology}

The Quaternary surfaces of the Gulf coastal plain of Texas and Louisiana are all clastic deposits transported to the study area by nine major rivers. From the Mississippi River to the Rio Grande, the coast described below is a series of deltaic and inter-deltaic plains (Plate 2).

Along the coast, the largest deltaic plain is a result of Mississippi River migration across southeast Louisiana. The deltaic plain is composed of distributary meander belts of natural levee, point bar, and channel fill deposits (Figure $\mathrm{A}-1$ ). Between the meander belts are interdistributary basins of inland swamps and fresh to saline marshes grading toward the coast. Throughout the basins are lakes and bays connecting to the open gulf through a series of meandering tidal channels. Natural water movement across the deltaic plain is from the principal channels over the natural levees during flood or down the levee backslopes as a result of precipitation. Water moves by sheet flow over the natural levees and through the swamps and marshes until it is concentrated into sluggish channels feeding lakes and bays.

West of the Mississippl delta is the chenier plain of Louisiana and Texas. The chenier plain is a marsh wetland which is segmented by a series of abandoned beach ridges (Plate 2). Cheniers are formed during a transgressive phase (raising of sea level relative to land) when sediment is available to be transported and deposited along the shore because of the eastward migration of the Mississippi River. Water circulation, controlled by tides and winds, moves into and out of the area by tidal channels and across the marshes by sheet flow. 


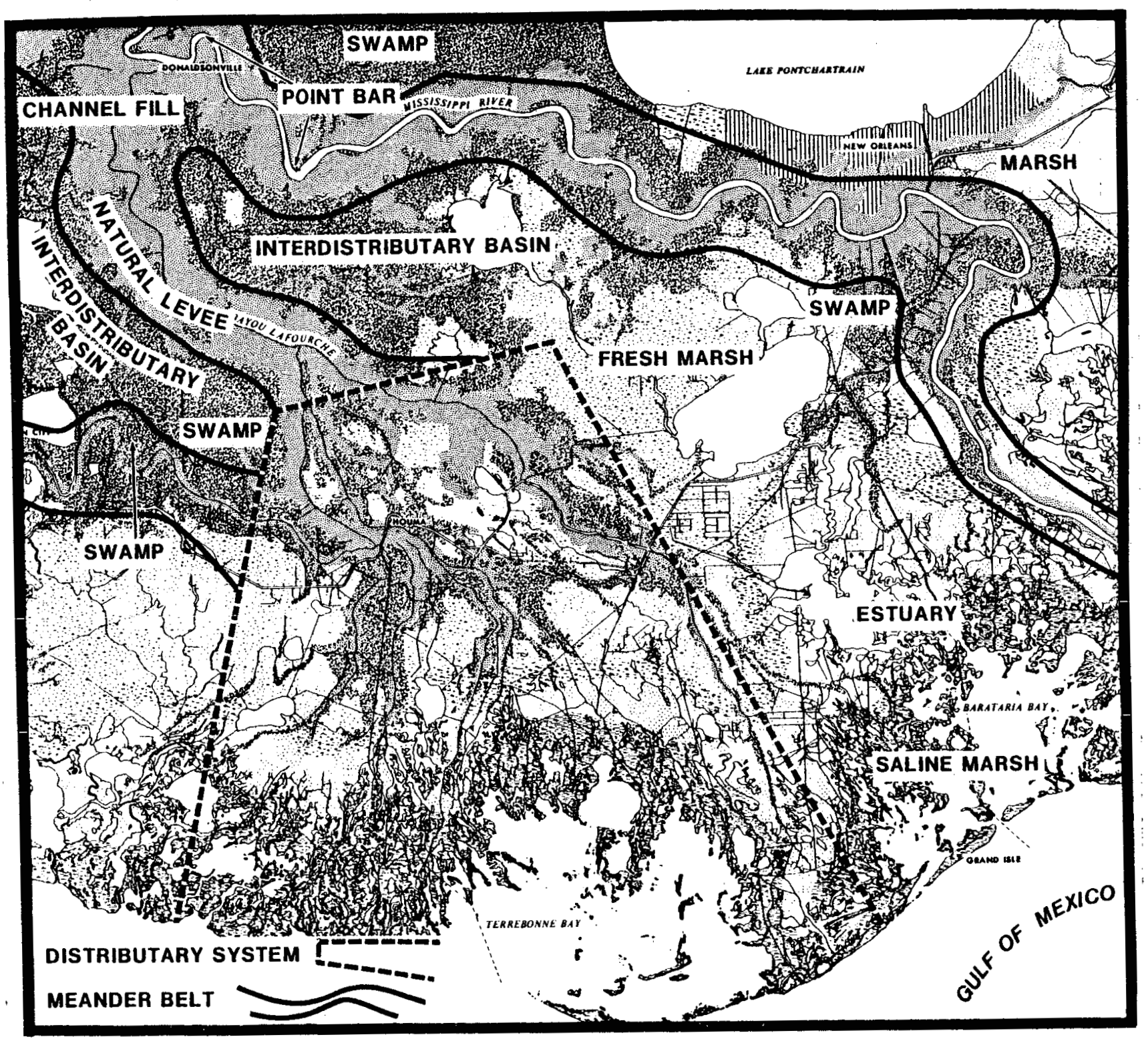

Fig. A-1. The deltaic plain of the Mississippi characterized by meander belts, natural levees, point bars, distributary systems, and interdistributary swamps and marshes (After Gould and Morgan, 1962; Kolb and van Lopik, 1958). 
From the chenier plain westward, the coast may be divided into deltic plains, the barrier island complex, and interdeltaic plains. Delta system physiography is similar to that described for the Mississippi River, but on a smaller scale and in proportion to the channel size. The inter-deltaic plain or the barrier island plain is composed of barrier islands and spits of sand dunes, beach ridges, swales, and tidal deposits. Behind the barriers are bays and lagoons which may be partially filled by mud and sand tidal flats. Smaller rivers are building deltas into the drowned river valleys in the older Pleistocene surfaces, slowly filling in the valleys as they advance into the bays. Water circulation through the bay-lagoon system is a product of tides and winds. Tidal channels cross the marshes and mudflats fringing the basins.

The higher lands in the study area are for the most part Pleistocene terraces and lie between the material along the shoreline from the Recent geological stage and the youngest Tertiary outcrops. The depositional surfaces represent interglacial stages and are present along the coasts and up the river valleys. Table A-1 lists the terraces recognized in Louisiana and Texas and shows their slope as an indication of flatness. Each of the Pleistocene surfaces is underlain by a sequence of alluvial deltaic, coastal inter-deltaic, and marine deposits. Bernard and Leblanc (1965) describe the Quaternary of Texas and Louisiana as "a series of coalescing alluvial, deltaic and coastal inter-deltaic plains, developed principally by the major river systems..." (P1ate 2). Figures A-2 and A-3 show the typical Pleistocene morphology of meander belts, interdistribubary basins, and deltaic systems of the study area and the relation of these to the Recent coastal deposits. The processes which are shaping the present system are the same which formed the older surfaces. 
Table A-1. Recognized Pleistocene Terraces in Loulsiana and Texas

\begin{tabular}{|c|c|c|c|c|c|}
\hline \multicolumn{3}{|c|}{ Central Texas } & \multicolumn{3}{|c|}{ Southeast Texas } \\
\hline \multirow{2}{*}{\multicolumn{3}{|c|}{$\begin{array}{l}\text { Near Brazos River } \\
\text { (Bernard, LeBlanc, and } \\
\text { Major, 1962) } \\
\text { Seaward Slope }\end{array}$}} & \multicolumn{3}{|c|}{$\begin{array}{c}\text { Between Neches and Sabine } \\
\text { Rivers, (Bernard, 1950) } \\
\text { Seaward Slope }\end{array}$} \\
\hline & & & Name & $\mathrm{m} / \mathrm{km}$ & $\mathrm{ft} / \mathrm{mi}$ \\
\hline Name & $\mathrm{m} / \mathrm{km}$ & $\mathrm{ft} / \mathrm{mi}$ & $\overline{\text { Williana }}$ & $1.99-2.65$ & $10.5-14$ \\
\hline$\overline{\text { Willis }}$ & 1.89 & 10 & Bentley & & 5 \\
\hline Bentley & .66 & 3.5 & Montgomery & $.45-.64$ & $2.4-3.4$ \\
\hline Montgomery & .47 & 2.5 & Prairie & $.21-.23$ & $1.1-1.2$ \\
\hline Beaumont & .38 & 2 & Deweyville & $.21-.23$ & $1.1-1.2$ \\
\hline Recent & $.23-.27$ & $1.2-1.4$ & Recent & $0-.27$ & $0.01-1.4$ \\
\hline
\end{tabular}

Central Louisiana

(F1sk, 1939a, 1944)

\begin{tabular}{|c|c|c|}
\hline \multirow{3}{*}{$\frac{\text { Name }}{\text { Williana }}$} & \multicolumn{2}{|c|}{ Seaward Slope } \\
\hline & $\mathrm{m} / \mathrm{km}$ & $\mathrm{ft} / \mathrm{mi}$ \\
\hline & $1.74-1.89$ & 9.2 \\
\hline Bentley & $.81-1.52$ & $4.3-8$. \\
\hline Mon tgomery & $.55-.95$ & $2.9-5$ \\
\hline Prairie & $.23-.45$ & $1.2-2.4$ \\
\hline $\begin{array}{l}\text { High-level flood plain } \\
\text { Recent }\end{array}$ & $\begin{array}{l}0-.19 \\
0-.19\end{array}$ & $\begin{array}{l}0.02 \quad 1.0 \\
0.01-1.0\end{array}$ \\
\hline
\end{tabular}

Source: Bernard and LeBlanc 1965.

One area along the south Texas coast is different from the Pleistocene terraces.

The eolian plain covers abandoned Pleistocene morphology, such as deltas, lagoons, barriers, and other associated features. Sand dunes and clay-silt dunes veneer a $80 \mathrm{~km}(50 \mathrm{mi})$ stretch of the coast, and extend approxinately $120 \mathrm{~km}$ (75. mi) inland. The dunes have become stabilized by vegetation. Farther inland in south Texas the Goliad formation (Pliocene) forms the uplands in the Rio Grande valley. The Goliad is a marine formation of poorly consolidated sands, silts, clays, pebbles, cobbles, and caliche. 


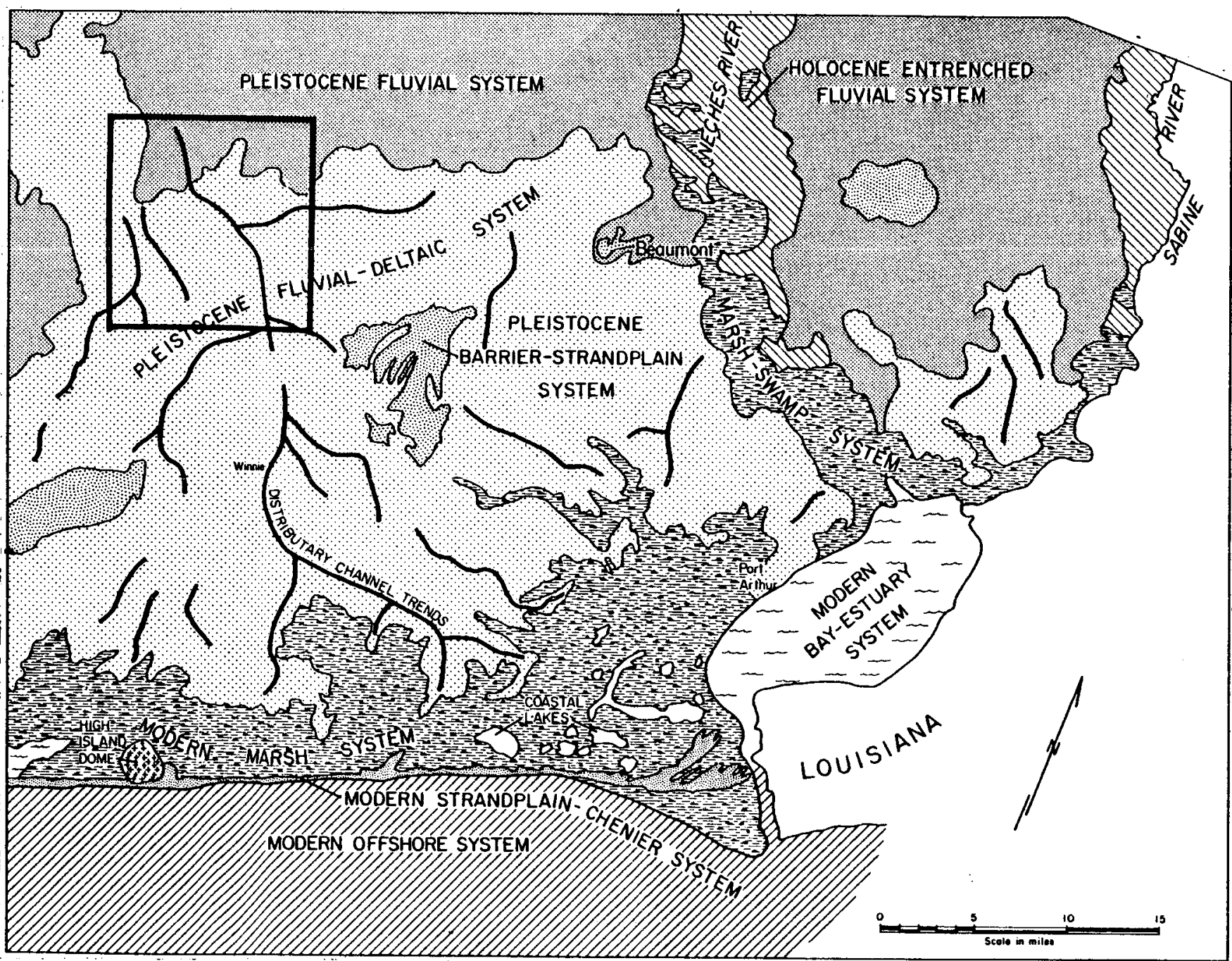

Fig. A-2. The generalized morphology of the Pleistocene surface of southeast Texas (After The Environmental Geology Map of the Environmental Geologic Atlas of the Texas Coastal Zone, Beaumont-Port Arthur, Texas, 1971-1977). 


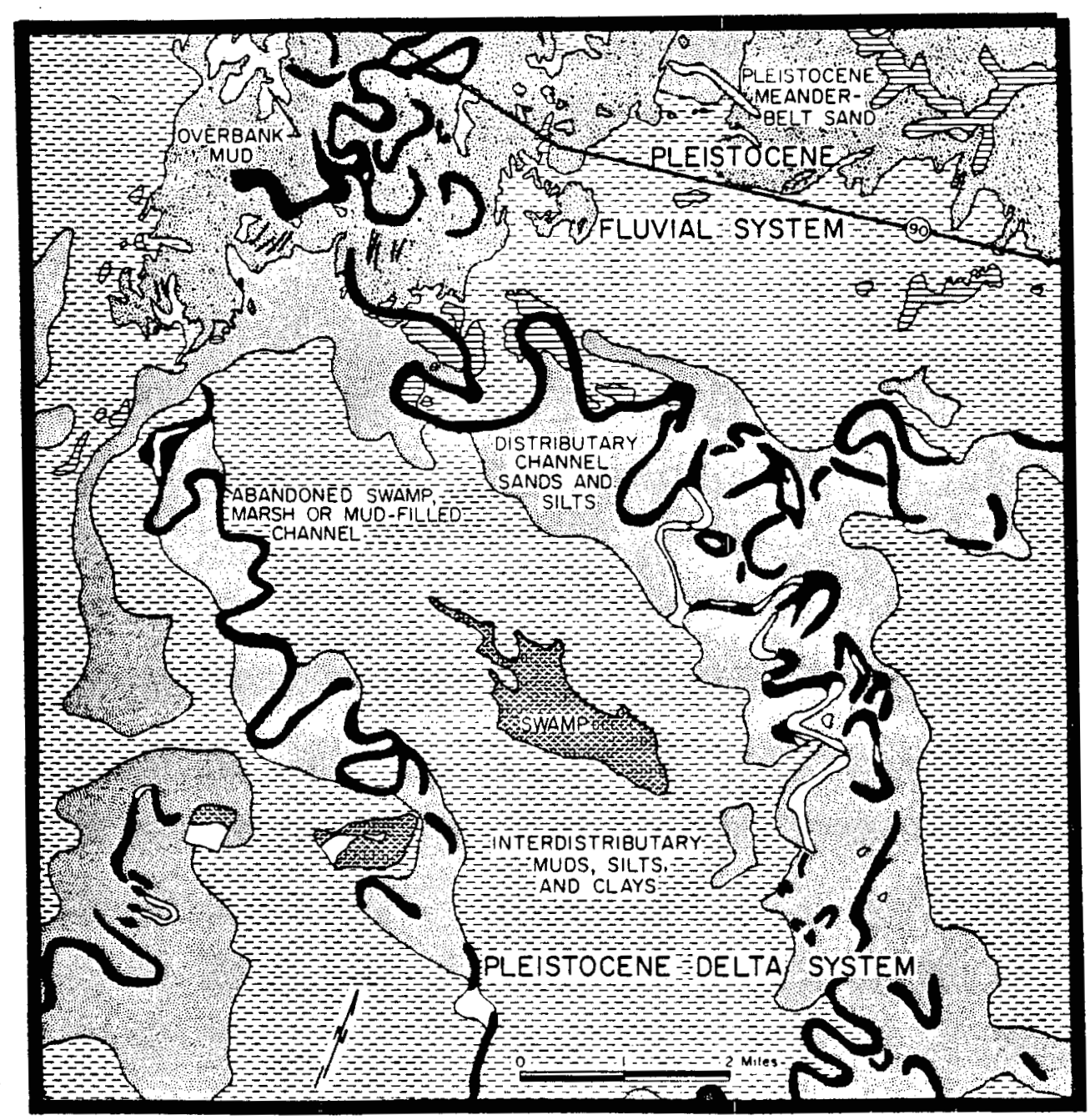

Fig. A-3. Detailed morphology of the Pleistocene fluvial facies in the Beaumont-Port Arthur Area, Southeast Texas.

Source: The Environmental Geology Map of the Environmental Geologic Atlas of the Texas Coastal Zone, BeaumontPort Arthur, Texas, 1971-1977.

\section{SOILS}

The soil groups of the study area are shown on Plate 3 and are described in Tables A-2 and A-3. Soil groups, assemblages of soil associations, are based on generalized similarities as described and mapped by the U.S. Soil Conservation Service. The unique soils of Louisiana are shown on Figure A-4. Similar information is not yet available for Texas. 
Table A-2. Soils Groups of the Texas Study Area (After USDASCS 1969b, 1972).

\begin{tabular}{|c|c|c|c|c|c|c|c|}
\hline Group & Description & Runoff & Permeability & $\mathrm{pH}$ & $\begin{array}{l}\text { Dominant } \\
\text { Use } \\
\text { (over } 50 \% \text { ) } \\
\end{array}$ & $\begin{array}{l}\text { Suitability } \\
\text { for Pond } \\
\text { Reservoir Area }\end{array}$ & $\begin{array}{c}\text { Suitability } \\
\text { for Buildings } \\
\text { and Roads } \\
\end{array}$ \\
\hline $\mathbf{I}$ & $\begin{array}{l}\text { Cracking clayey soils; soils with loamy } \\
\text { surface layers underlain by cracking } \\
\text { clayey layers; and soils loamy through- } \\
\text { out, some of which are compact beneath } \\
\text { the surface layer }\end{array}$ & $\begin{array}{l}\text { slow to very } \\
\text { slow }\end{array}$ & $\begin{array}{l}\text { slow to very } \\
\text { slow }\end{array}$ & $\begin{array}{l}\text { strongly acid } \\
\text { to moderately } \\
\text { alkallne }\end{array}$ & cropland & $\begin{array}{l}\text { sultable for } \\
\text { water } 1 \text { mpoundment }\end{array}$ & $\begin{array}{l}\text { very high shrink- } \\
\text { swell }\end{array}$ \\
\hline II & $\begin{array}{l}\text { Solls with loamy surface layers underlain } \\
\text { by cracking. clayey layers; and cracking } \\
\text { clayey soils }\end{array}$ & very slow & very slow & medium acid & cropland & $\begin{array}{l}\text { sultable for } \\
\text { water fmpoundment }\end{array}$ & high shrink-swell \\
\hline III & $\begin{array}{l}\text { Solls that are sandy or loamy throughout; } \\
\text { or soils with sandy or loamy surface } \\
\text { layers underlain by loamy layers. }\end{array}$ & $\begin{array}{l}\text { slow to very } \\
\text { slow }\end{array}$ & $\begin{array}{l}\text { very slow to } \\
\text { moderately } \\
\text { slow }\end{array}$ & $\begin{array}{l}\text { medium acid } \\
\text { to neutral }\end{array}$ & rangeland & some 1 imitations & $\begin{array}{l}\text { moderate shrink- } \\
\text { swell }\end{array}$ \\
\hline IV & $\begin{array}{l}\text { Solls with sandy or loamy surface layers } \\
\text { underlain by clayey layers most of which } \\
\text { are very slowly permeable; and soils with } \\
\text { thick sandy surface layers underlain by } \\
\text { loamy layers of moderately slow permeabilit }\end{array}$ & $\begin{array}{l}\text { slow to very } \\
\text { slow } \\
\text { ty }\end{array}$ & slow & $\begin{array}{l}\text { slightly to } \\
\text { medium acit }\end{array}$ & rangeland & $\begin{array}{l}\text { sultable for } \\
\text { water impoundment }\end{array}$ & $\begin{array}{l}\text { moderate to high } \\
\text { shrink-swell }\end{array}$ \\
\hline $\mathbf{v}$ & $\begin{array}{l}\text { Deep sandy soils, or solls with sandy sur- } \\
\text { face layers underlain by loamy or clayey } \\
\text { layers; saline clayey and loamy soils -- } \\
\text { all occastonally flooded by storm tides }\end{array}$ & very slow & $\begin{array}{l}\text { rapid to } \\
\text { moderate }\end{array}$ & $\begin{array}{l}\text { medium actd } \\
\text { to neutral }\end{array}$ & rangeland & not suftable & low shrink-swell \\
\hline vI & Solls loamy throughout & $\begin{array}{l}\text { slow to } \\
\text { moderate }\end{array}$ & $\begin{array}{l}\text { moderate to } \\
\text { slow }\end{array}$ & $\begin{array}{l}\text { moderately } \\
\text { alkaline }\end{array}$ & rangeland & some Ifmitaltuus & $\begin{array}{l}\text { moderate shrink- } \\
\text { swell }\end{array}$ \\
\hline VII & $\begin{array}{l}\text { Soils loamy throughout or with loamy } \\
\text { surface layers underlain by clayey } \\
\text { layers. Most of the soils have strongly } \\
\text { cemented caliche beginning at about } 10 \text { to } \\
40 \text { inch depths. }\end{array}$ & $\begin{array}{l}\text { medlum to } \\
\text { rapid }\end{array}$ & moderate & $\begin{array}{l}\text { moderately } \\
\text { alkaline to } \\
\text { neutral }\end{array}$ & range 1 and & not suftable & low shrink-swell \\
\hline VIII & $\begin{array}{l}\text { Solls loamy throughout or with loamy } \\
\text { surface layers underlain by clayey } \\
\text { layers; some clayey throughout. All }\end{array}$ & $\begin{array}{l}\text { slow to very } \\
\text { slow }\end{array}$ & very slow & $\begin{array}{l}\text { strongly to } \\
\text { medium actd }\end{array}$ & $\begin{array}{l}\text { cropland } \\
\text { forest }\end{array}$ & $\begin{array}{l}\text { suitable for } \\
\text { water impoundment }\end{array}$ & $\begin{array}{l}\text { moderate to high } \\
\text { shrink-swell }\end{array}$ \\
\hline
\end{tabular}


Table A-2. Soils Groups of the Texas Study Area. (After USDASCS, 1969b, 1972). Continued

\begin{tabular}{|c|c|c|c|c|c|c|c|}
\hline Group & Description & Runoff & Permeability & pH & $\begin{array}{l}\text { DomInant } \\
\text { Use } \\
\text { (over } 50 \% \text { ) } \\
\end{array}$ & $\begin{array}{l}\text { Sultability } \\
\text { for Pond } \\
\text { Reservoir Area }\end{array}$ & $\begin{array}{l}\text { Sultabllity } \\
\text { for Buildings } \\
\text { and Roads } \\
\end{array}$ \\
\hline IX & $\begin{array}{l}\text { Saline solls clayey or loamy } \\
\text { throughout }\end{array}$ & very slow & slow & $\begin{array}{l}\text { mildly } \\
\text { alkaline }\end{array}$ & $\begin{array}{l}\text { marsh } \\
\text { rangeland }\end{array}$ & not suftable & $\begin{array}{l}\text { high to very high } \\
\text { shrink-swell }\end{array}$ \\
\hline $\mathrm{x}$ & $\begin{array}{l}\text { Solls clayey throughout; or soils } \\
\text { with loamy surface layers underlain } \\
\text { by clayey layers. All are saline solls. }\end{array}$ & very slow & very slow & $\begin{array}{l}\text { slightly acid } \\
\text { to mildly } \\
\text { alkaline }\end{array}$ & $\begin{array}{l}\text { cropland } \\
\text { marsh } \\
\text { rangeland }\end{array}$ & not suitable & $\begin{array}{l}\text { high to very high } \\
\text { shrink-swell }\end{array}$ \\
\hline $\mathrm{XI}$ & $\begin{array}{l}\text { Solls sandy throughout or with sandy } \\
\text { surface layers underlain by loamy layers; } \\
\text { or solls with loamy surface layers under- } \\
\text { latn by clayey layers }\end{array}$ & slow & $\begin{array}{l}\text { slow to } \\
\text { moderate }\end{array}$ & $\begin{array}{l}\text { strongly to } \\
\text { slightly acid }\end{array}$ & forest & some Iimitations & $\begin{array}{l}\text { Low to high shrink- } \\
\text { swell }\end{array}$ \\
\hline XII & $\begin{array}{l}\text { Solls loamy throughout or with loamy sur- } \\
\text { face layers underlain by clayey layers; } \\
\text { and solls with sandy surface layers under- } \\
\text { lain by loamy layers }\end{array}$ & slow & moderate & $\begin{array}{l}\text { strongly to } \\
\text { slightly acid }\end{array}$ & forest & some 1 imftations & $\begin{array}{l}\text { some high shrink- } \\
\text { swell areas }\end{array}$ \\
\hline XIIII & $\begin{array}{l}\text { Solls loamy throughout or solls with } \\
\text { loamy surface layers underlain by clayey } \\
\text { layers. All solls somewhat poorly or } \\
\text { poorly drained. }\end{array}$ & $\begin{array}{l}\text { slow to very } \\
\text { slow }\end{array}$ & $\begin{array}{l}\text { slow to very } \\
\text { slow }\end{array}$ & medium acid & $\begin{array}{l}\text { forest } \\
\text { cropland }\end{array}$ & some limitations & low shrink-swe11 \\
\hline XIV & $\begin{array}{l}\text { Noncalcareous and calcareous, cracking } \\
\text { clayey solls and calcareous loamy soils; } \\
\text { and strongly acid clayey and loamy solls. } \\
\text { All bottom land solls. }\end{array}$ & $\begin{array}{l}\text { slow to very } \\
\text { slow }\end{array}$ & $\begin{array}{l}\text { very slow to } \\
\text { moderate }\end{array}$ & $\begin{array}{l}\text { moderately } \\
\text { alkaline to } \\
\text { very strongly } \\
\text { acid }\end{array}$ & $\begin{array}{l}\text { wooded } \\
\text { rangeland } \\
\text { forest }\end{array}$ & $\begin{array}{l}\text { sultable for } \\
\text { water } 1 \text { mpoundment }\end{array}$ & high shrink-swe11 \\
\hline Xv & $\begin{array}{l}\text { Level loamy soils of floodplains and low } \\
\text { terraces }\end{array}$ & $\begin{array}{l}\text { slow to very } \\
\text { slow }\end{array}$ & $\begin{array}{l}\text { slow to } \\
\text { moderate }\end{array}$ & $\begin{array}{l}\text { moderately } \\
\text { alkaline }\end{array}$ & cropland & & \\
\hline XVI & $\begin{array}{l}\text { Level moderately and slowly permeable } \\
\text { soils of uplands }\end{array}$ & slow & $\begin{array}{l}\text { moderate to } \\
\text { s low }\end{array}$ & $\begin{array}{l}\text { moderately } \\
\text { alkallne }\end{array}$ & cropland & & \\
\hline XVII & $\begin{array}{l}\text { Gently sloping moderately permeable } \\
\text { loamy solls of uplands }\end{array}$ & $\begin{array}{l}\text { slow to } \\
\text { medium }\end{array}$ & moderate & $\begin{array}{l}\text { moderately } \\
\text { alkallne }\end{array}$ & cropland & & \\
\hline XVIII & Gently sloping sandy sotls of uplands & $\begin{array}{l}\text { medium to } \\
\text { slow }\end{array}$ & $\begin{array}{l}\text { moderate to } \\
\text { rapid }\end{array}$ & $\begin{array}{l}\text { neutral to } \\
\text { slightly acid }\end{array}$ & rangeland & & \\
\hline
\end{tabular}


Table A-2. Solls Groups of the Texas Gtudy Area (After USDASCS 1969b, 1972). Continued.

\begin{tabular}{|c|c|c|c|c|c|c|c|}
\hline Group & Description & Runoff & Permeab1lity & $\mathrm{pH}$ & $\begin{array}{l}\text { Dominant } \\
\text { Use } \\
\text { (over 50\%) }\end{array}$ & $\begin{array}{l}\text { Sultablifty } \\
\text { for Pond } \\
\text { Reservolr Area }\end{array}$ & $\begin{array}{l}\text { Suitability } \\
\text { for Buildings } \\
\text { and Roads }\end{array}$ \\
\hline $\mathrm{XIX}$ & $\begin{array}{l}\text { Level, very slowly permeable, high } \\
\text { shrink-swell clayey sofls }\end{array}$ & very slow & very slow & & cropland & & \\
\hline$x x$ & $\begin{array}{l}\text { Level and gently sloping solls of } \\
\text { coastal areas }\end{array}$ & very slow & very slow & & rangeland & & \\
\hline$x X I$ & Saline & very slow & $\begin{array}{l}\text { moderate to } \\
\text { slow }\end{array}$ & $\begin{array}{l}\text { slightly } \\
\text { alkaline }\end{array}$ & rangeland & & \\
\hline XXII & $\begin{array}{l}\text { Undulating shallow gravelly loamy } \\
\text { solls }\end{array}$ & med1um & moderate & & rangel and & & \\
\hline
\end{tabular}


Table A-3. Soils Groups of the Louisiana Study Area (After Lytle and Sturgis, 1962; USACE 1973, 1975).

\begin{tabular}{|c|c|c|c|c|c|c|c|}
\hline Group & Description & Runof $f$ & Permeab111ty & $\mathrm{pH}$ & $\begin{array}{l}\text { Dominant } \\
\text { Use } \\
\text { (over 50\%) }\end{array}$ & $\begin{array}{l}\text { Sultability } \\
\text { for Pond } \\
\text { Reservoir Area }\end{array}$ & $\begin{array}{l}\text { Suttability } \\
\text { for Buildings } \\
\text { and Roads }\end{array}$ \\
\hline XXXI I I & $\begin{array}{l}\text { Hi11 lands of sandy loam surfaces and } \\
\text { sandy clayey loam subsurfaces, from } \\
\text { Pleistocene and Tertiary materials }\end{array}$ & slow & slow & $\begin{array}{l}\text { medium to } \\
\text { strongly actd }\end{array}$ & forest & generally sultable & $\begin{array}{l}\text { low to high shrink- } \\
\text { swe11 }\end{array}$ \\
\hline xxIv & $\begin{array}{l}\text { Loess, well-drained and moderately } \\
\text { well-drained loamy solls which are } \\
\text { gently to steeply sloping }\end{array}$ & $\begin{array}{l}\text { medium to } \\
\text { rapid }\end{array}$ & $\begin{array}{l}\text { slow to } \\
\text { moderate }\end{array}$ & $\begin{array}{l}\text { medium to } \\
\text { strongly acid }\end{array}$ & $\begin{array}{l}\text { cropland } \\
\text { forest }\end{array}$ & $\begin{array}{l}\text { suftable, but } \\
\text { some seepage }\end{array}$ & low shrink-swell \\
\hline$x x v$ & $\begin{array}{l}\text { Loessial Hills solls developed from } \\
\text { a shallow mantle of silty material } \\
\text { over sandy materials of the Pleistocene }\end{array}$ & & $\begin{array}{l}\text { moderately } \\
\text { slow. }\end{array}$ & $\begin{array}{l}\text { medium to } \\
\text { strongly acid }\end{array}$ & eropland & $\begin{array}{l}\text { suitable, but } \\
\text { some seepage }\end{array}$ & low shrink-swell \\
\hline XXVI & $\begin{array}{l}\text { Mississippi Terrace soils developed from } \\
\text { late Pleistocene and Recent sediments, } \\
\text { poorly drained, fragipan layer which } \\
\text { restricts root growth and water pene- } \\
\text { tration; silt loam surface soils }\end{array}$ & slow & slow & $\begin{array}{l}\text { medium to } \\
\text { strongly actid }\end{array}$ & $\begin{array}{l}\text { cropland } \\
\text { and forest }\end{array}$ & suitable & $\begin{array}{l}\text { low to high shrink- } \\
\text { swell }\end{array}$ \\
\hline XXVII & $\begin{array}{l}\text { Flatwood, porrly drained forested soils } \\
\text { developed from Plelstocene and Tertiary } \\
\text { materials; very fine sandy loam surface } \\
\text { solls; low in organic matter }\end{array}$ & $\begin{array}{l}\text { moderate to } \\
\text { slow }\end{array}$ & moderate & $\begin{array}{l}\text { medium to } \\
\text { strongly acid }\end{array}$ & $\begin{array}{l}\text { forest and } \\
\text { grazing }\end{array}$ & $\begin{array}{l}\text { may have excess } \\
\text { seepage from } \\
\text { dugouts }\end{array}$ & $\begin{array}{l}\text { low to high shrink- } \\
\text { swell }\end{array}$ \\
\hline XXVIII & $\begin{array}{l}\text { Coastal prafrie solls with very slowly } \\
\text { permeable subsoils, developed from } \\
\text { Pleistocene sediments; silty loam sur- } \\
\text { face soils to dark clays }\end{array}$ & $\begin{array}{l}\text { slow to } \\
\text { moderate }\end{array}$ & very slow & $\begin{array}{l}\text { alkaline to } \\
\text { slightly acid }\end{array}$ & cropland & $\begin{array}{l}\text { suitable for } \\
\text { water topoundment }\end{array}$ & h1gh shrink-swell \\
\hline $\operatorname{xxIX}$ & $\begin{array}{l}\text { Older alluvial and terrace solls; } \\
\text { natural levees, silt loam and sility } \\
\text { clay loam }\end{array}$ & $\begin{array}{l}\text { slow to } \\
\text { moderate }\end{array}$ & $\begin{array}{l}\text { moderately } \\
\text { slow }\end{array}$ & $\begin{array}{l}\text { medium acid to } \\
\text { alkaline }\end{array}$ & crop land & $\begin{array}{l}\text { sultable for } \\
\text { water impoundment }\end{array}$ & $\begin{array}{l}\text { very high shrink- } \\
\text { swell }\end{array}$ \\
\hline$x x x$ & $\begin{array}{l}\text { Silty and sandy recent alluvial soils } \\
\text { of the Mississippi River, occurring in } \\
\text { better drained areas; silt loams and } \\
\text { very fine sandy loams }\end{array}$ & $\begin{array}{l}\text { medfum to } \\
\text { slow }\end{array}$ & slow & $\begin{array}{l}\text { slightly achd } \\
\text { to neutral }\end{array}$ & $\begin{array}{l}\text { cropland } \\
\text { pasture }\end{array}$ & $\begin{array}{l}\text { may have excess } \\
\text { seepage from dug- } \\
\text { out pond, too flat } \\
\text { for dant type pond }\end{array}$ & $\begin{array}{l}\text { very high shrink- } \\
\text { swell }\end{array}$ \\
\hline
\end{tabular}


Table A-3. Soils Groups of the Louisiana Study Area (After Lytle and Sturgis, 1962; USACE 1973, 1975), Continued.

\begin{tabular}{|c|c|c|c|c|c|c|c|}
\hline Group & Description & Runoff & Permeabllity & $\mathrm{pH}$ & $\begin{array}{l}\text { Dominant } \\
\text { Use } \\
\text { (over S0\%) }\end{array}$ & $\begin{array}{l}\text { Sultability } \\
\text { for Pond } \\
\text { Reservolr Area }\end{array}$ & $\begin{array}{l}\text { Sultability } \\
\text { for Bulldings } \\
\text { and Roads } \\
\end{array}$ \\
\hline xxxI & $\begin{array}{l}\text { Clayey recent alluvial soils of the } \\
\text { Mississippi River, occurring in } \\
\text { poorly drained areas; swamp clays }\end{array}$ & slow & very slow & $\begin{array}{l}\text { neutral to } \\
\text { alkaline }\end{array}$ & forest & $\begin{array}{l}\text { sultable for } \\
\text { water 1mpoundment }\end{array}$ & $\begin{array}{l}\text { very high shrink- } \\
\text { swell }\end{array}$ \\
\hline XXXII & $\begin{array}{l}\text { Alluvial solls derived from recent } \\
\text { sediments of the Red River, very fine } \\
\text { sandy loams and silt loams on levees; } \\
\text { clay and silty clays on backslopes } \\
\text { and in backswamp }\end{array}$ & $\begin{array}{l}\text { slow to } \\
\text { moderate }\end{array}$ & $\begin{array}{l}\text { slow to } \\
\text { moderate }\end{array}$ & $\begin{array}{l}\text { neutral to } \\
\text { alkaline }\end{array}$ & $\begin{array}{l}\text { cropland } \\
\text { forest }\end{array}$ & suftable & $\begin{array}{l}\text { high to very high } \\
\text { shrink-swell }\end{array}$ \\
\hline XXXIII & $\begin{array}{l}\text { Alluvial soils derived from older and } \\
\text { recent sediments of the Mississippi } \\
\text { and Red Rivers, backswamp clays and } \\
\text { silty clays; some sandy loam levees }\end{array}$ & slow & very slow & $\begin{array}{l}\text { strongly acid } \\
\text { to alkaline }\end{array}$ & $\begin{array}{l}\text { swamp } \\
\text { grazing }\end{array}$ & $\begin{array}{l}\text { suitable for } \\
\text { water impoundment }\end{array}$ & $\begin{array}{l}\text { high to very high } \\
\text { shrink-swell }\end{array}$ \\
\hline$x x x r v$ & $\begin{array}{l}\text { Alluvial soils derived from recent } \\
\text { sediments from the coastal plain and } \\
\text { loesslal areas; silty to sandy bottom } \\
\text { lands, frequent flooding }\end{array}$ & $\begin{array}{l}\text { slow to very } \\
\text { slow }\end{array}$ & $\begin{array}{l}\text { slow to } \\
\text { moderate }\end{array}$ & $\begin{array}{l}\text { strongly to } \\
\text { slightly acid }\end{array}$ & swamp & $\begin{array}{l}\text { may have excess } \\
\text { seepage from } \\
\text { dugout ponds }\end{array}$ & high shrink-swell \\
\hline$x x x v$ & $\begin{array}{l}\text { Organic soils, clays, and sandy beaches } \\
\text { derived from recent stream sediments } \\
\text { and marine deposits; high in organic } \\
\text { content }\end{array}$ & very slow & very slow & $\begin{array}{l}\text { acid to } \\
\text { alkaline }\end{array}$ & wildlife & $\begin{array}{l}\text { permanently high } \\
\text { water table and } \\
\text { flooding hazard } \\
\text { precludes use } \\
\text { without major } \\
\text { reclamation }\end{array}$ & $\begin{array}{l}\text { high to very high } \\
\text { shrink-swell }\end{array}$ \\
\hline
\end{tabular}




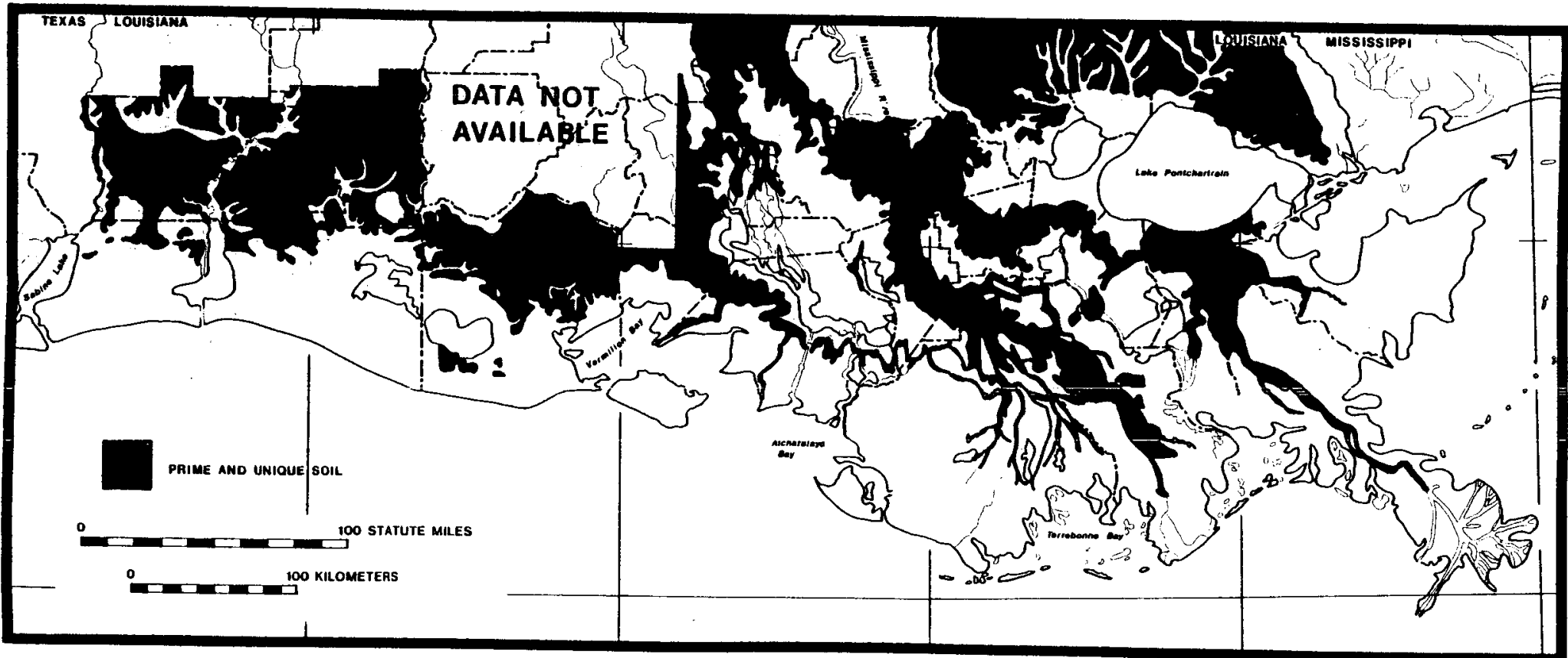

Fig. A-4. Prime or unique soils of Loulsiana. 
Overall, the soils of the study area are the product of deltaic progradation and retreat and subsequent weathering. Along the Texas coast, the soils range from the sandy loams underlain by caliche layers of the Rio Grande plain in the more arid areas near the Rio Grande, to calcareous clay loams and clays of the Gulf coast prairies in the more humid central part of the coast. Farther north along the Texas coast are the Gulf coast marshes, a 1ittle-developed clay soil with white sand ridges. Inland from the southern coast of Texas, the soils remain sandy and underlain by a caliche layer. Northwest from the Gulf coast prairies, the soils are sandy loams over a dense clayey subsoil in the commonly referred to "Post Oak Belt." The area is mainly in the subhumid climatic zone. Along the Texas-Louisiana border, the soils grade from marsh to prairie to Southern coastal plain. Solls are sands and sandy loams on the gently rolling areas, and alluvium in the valleys.

Soils along the Louisiana coast are organic clays. In the southwest these are crossed by cheniers (stranded beach ridges) of sand and shell paralleling the coast. In the Mississippi deltaic plain of the southeast, the solls are crossed by natural levees of silts and fine sands. Proceeding north from the chenier plain, the first soils crossed are the Coastal Prairie group of silt loam and clay and the second group are the Flatwoods of silt loam and fine sandy loam. Along the northern edge of the study area are the Coastal Plain soils of sandy loam. Pleistocene terrace soils and loess border the Mississippi River alluvial valley. The loess soils are silty and sandy while the terraces are silt loams over fragipans. The Recent Alluvium of the Mississippi valley is a series of meander belts of gravels, sands, and silts in a larger backswamp area of silts and clays. 
The general characteristics of the soil groups of the study area are shown in Tables A-2 and A-3. The Soil Conservation Service has defined the following terms which appear in Tables $A-2$ and $A-3$. Permeability is the quality of the soil horizon that enables water or air to move through it. The acidity or alkalinity of the soil is expressed in $\mathrm{pH}$ values. The descriptive terms in the $\mathrm{pH}$ column are:

$\begin{array}{ll}\text { Extremely acid } & \text { below } 4.5 \\ \text { Very strongly acid } & 4.5 \text { to } 5.0 \\ \text { Strongly acid } & 5.1 \text { to } 5.5 \\ \text { Medium acid } & 5.6 \text { to } 6.0 \\ \text { Slightly acid } & 6.1 \text { to } 6.5 \\ \text { Neutral } & 6.6 \text { to } 7.3 \\ \text { Mildly alkaline } & 7.4 \text { to } 7.8 \\ \text { Moderately alkaline } & 7.9 \text { to } 8.4 \\ \text { Strongly alkaline } & 8.5 \text { to } 9.0 \\ \text { Very strongly alkaline } & 9.1 \text { and higher }\end{array}$

The shrink-swell potential is the relative volume to be expected of soil material which changes in moisture content; that is, the extent to which the soil shrinks as it dries or swells when it gets wet. Amount and kind of clay affects the extent of swelling and shrinking.

\subsubsection{Geology}

The study area is in the northwest quadrant of the Gulf of Mexico. The geology of the region is dominated by the Gulf coast geosyncline (a long, narrow trough filled with sediments), the axis of which is just seaward of the present shoreline 
(Figure A-5). The geosyncline extends from the northeast Gulf to northern Mexico while the landward limits are the updip edge of the basal Tertiary deposits and the southern limit is probably near the Sigsbee Escarpment (Antoine, J.W. et al., 1974) on the seaward side, The regional strike of the geologic beds under Louisiana is in bands east to west with the oldest beds being exposed farther inland. A1l of the beds dip as a monocline toward the axis of the geosyncline (Figure A-6). Under the upper Texas Gulf Coast, the Tertiary and Quaternary beds strike northeast-southwest, or roughly parallel to the existing shoreline, and they gently dip toward the geosyncline. Through the middle and south coast of Texas, the coastal plain beds parallel the axis of the geosyncline and dip as a monocline toward it. Middle Texas is underlain by the gulfward plunging anticline, the San Marcos Arch, while south Texas is underlain by a broad, gulfward plunging syncline, the Rio Grande embayment (Landes, 1970).

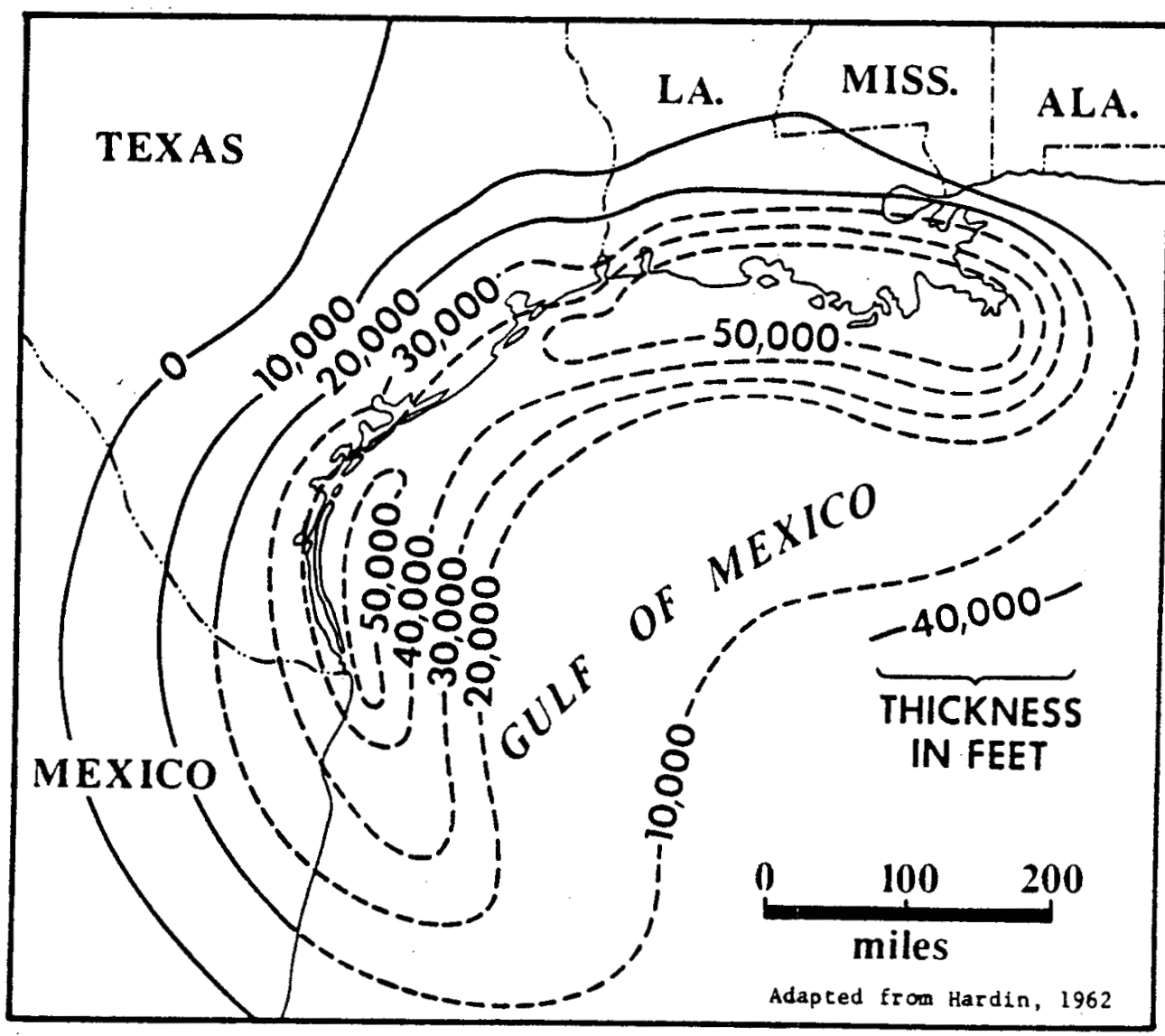

Fig. A-5. Thickness of Cenozoic deposits in the Gulf Coast Geosyncline (After Hardin, 1962). 


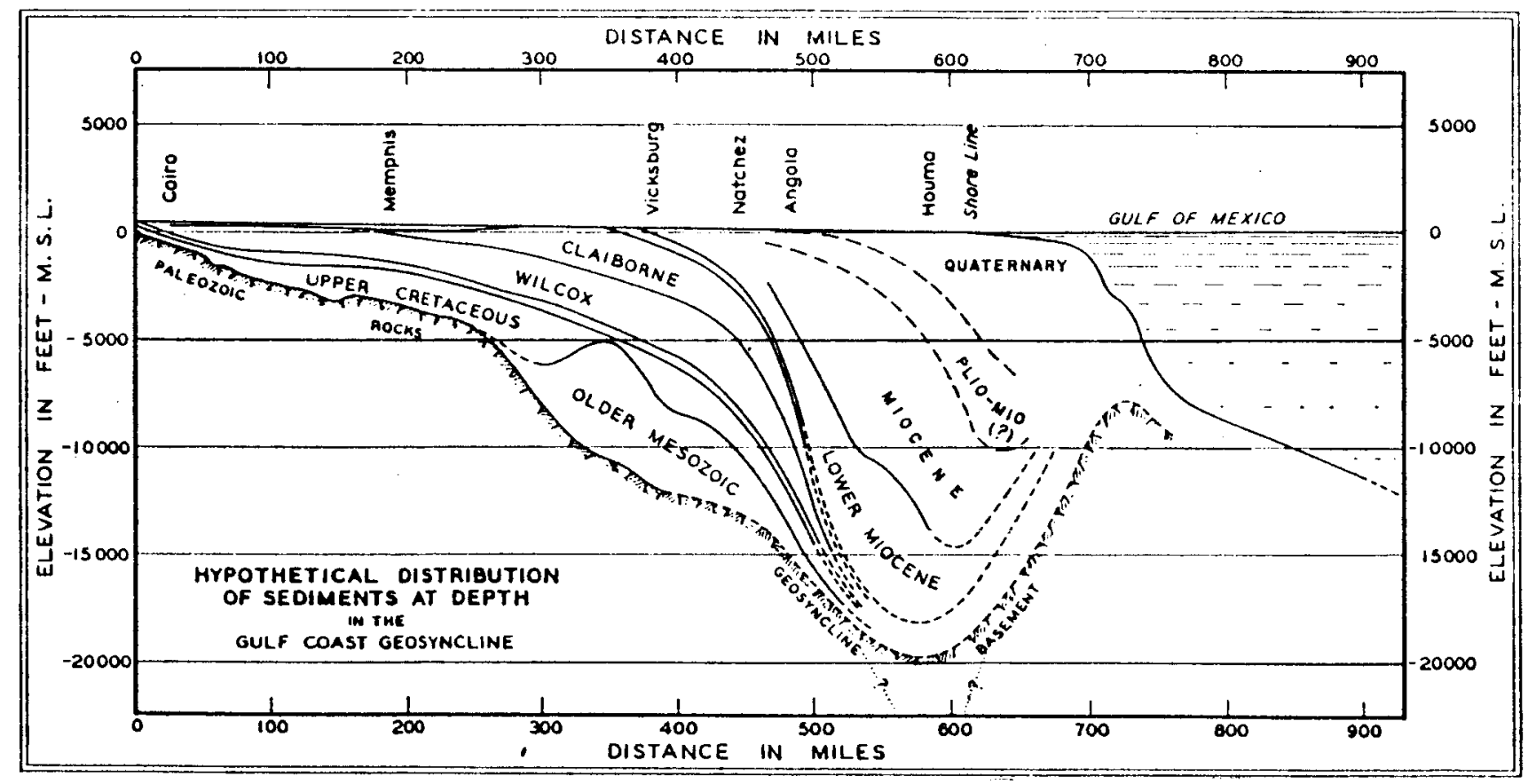

Fig. A-6. Generalized cross-section of the Gulf Coast Geosyncline (After Bernard and Leblanc, 1965). 
The updip sections of the sedimentary wedges are fluvial deposits of backswamp material, predominantly thin shales. Throughout the shales are meander belt deposits of natural levees, point bars, and channel fill sands. Gulfward of the fluvial sequence is the deltaic deposits or depocenters of the formation, continuing thick sands and thick shales. Strandplain and barrier-bar systems of thin shales and thin sands are found in and adjacent to the deltaic system. Downdip from the deltaic sequence are the prodelta and shelf deposits of thick shales. Some thin, restricted sand bodies are present (Holcomb, 1964; Boyd and Dyer, 1964).

Accumulating sediment since the Cenozoic, the geosyncline has become a huge prism of clastic sediments derived from the north and northwest. The stratigraphy is a sequence of thick transgressive and regressive sections of Tertiary and Quaternary sediments deposited in off-lapping wedges. From the Tertiary to the present, the depocenters have migrated eastward from south Texas to Louisiana as a result of the shifting influence of river systems discharging into the basin. The beds dip and thicken into the geosyncline (Figure A-7). Diapiric shale structures, salt stocks, regional faults, and local faults disrupt the beds. Table A-4 shows the geologic column for the study area and Figure A-8 shows a regional cross-section in the vicinity of Galveston and Brazoria Counties, Texas.

The Frio wedge of clastic sediments is the formation of concern because it has the desired vertical, areal, and temperature characteristics which make geothermal well-testing feasible. Vicksburg sediments of marine sands and shales mark the bottom limit of the Frio while the Anahuac sediments mark the top of the Frio (Bebout et al., 1976). Anahuac sediments represent a complete 


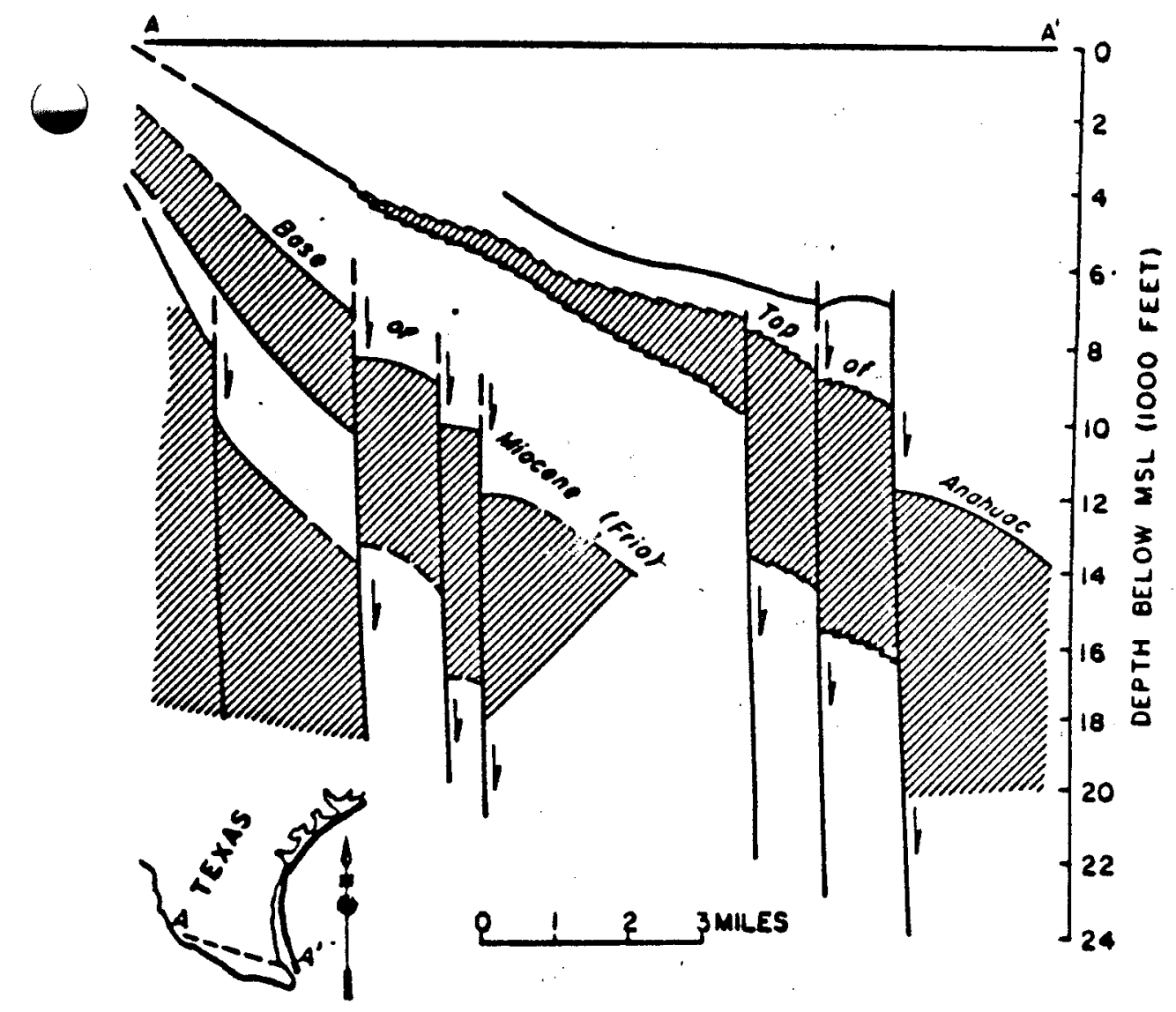

DIAGRAMMATIC DIP SECTION
THROUGH THE

RIO GRANDE EMBAYMENT

SHOWING

STRATA THICKENING ACROSS GROWTH FAULTS

\section{Acepled from Mwroy, 1961}

Fig. A-7. Diagrammatic dip section through the Rio Grande embayment showing strata thickening across growth faults.

Table A-4. Geologic Column for the Study Area (After Bebout et al., 1976)

\begin{tabular}{l|l|l} 
Age & Series & Group/Formation \\
\hline Quaternary & $\begin{array}{l}\text { Recent } \\
\text { Pleistocene }\end{array}$ & $\begin{array}{l}\text { Undifferentiated } \\
\text { Houston }\end{array}$ \\
\hline \multirow{2}{*}{ Tertiary } & Pliocene & Goliad \\
\hline & Miocene $--~$ & $\begin{array}{l}\text { Fleming } \\
\text { Anahuac }\end{array}$ \\
& Obligocene & $\begin{array}{l}\text { Frio } \\
\text { Vicksburg }\end{array}$ \\
& Eocene & $\begin{array}{l}\text { Jackson } \\
\text { Claiborne } \\
\text { Wilcox } \\
\end{array}$ \\
& & Midway \\
\hline
\end{tabular}




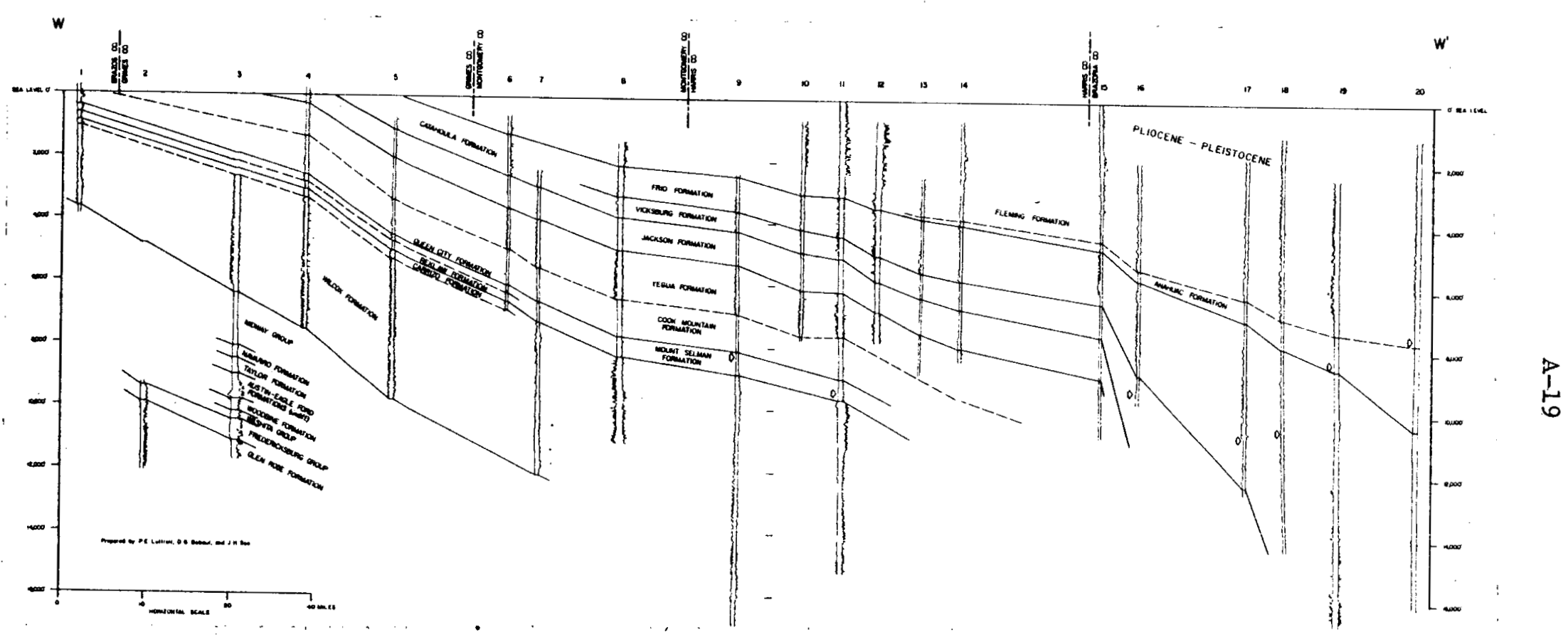

Fig. A-8. Typical regional cross-section of formations under the study area (After Bebout et al., 1976). 
transgressive and regressive marine cycle (Holcomb, 1964). The Frio is composed of numerous overlapping deltaic and inter-deltaic systems which were built into the Gulf geosyncline. There is an interfingering of sands, silts, and clays deposited as part of deltas, strandplain systems, and barrier islands. The relation of the Frio formation to geothermal activity is described in detail by Bebout, Dorfman, and Agagu, 1975a, 1975b; Bebout et al., 1976, Jones, 1968c, 1968b, 1969a, 1969b, 1970a, 1970b, 1975, Jones et al., 1974, Jones and Wallace, 1973, and Wallace, 1969.

\subsubsection{Tectonic Activity}

The Gulf coast geosyncline is a huge tectonically subsiding basin, which has been active since Mesozoic time. At the base of the Mesozoic sequence are the Jurassic Louann salts. Deposited on top of these salts are the Cenozoic deltas which have been filling the basin from the north. Rapid, thick deltaic sedimentation has resulted in normal growth faults along the boundary between the sand and clay units (Figure A-9). When these faults intersect across the study area, they form regional faults. A second response to rapid subsidence and the weight of accumulated sediment has been the intrusion of salt stocks and shale diapirs into the overlying sedimentary beds. Structural features associated with the salt stocks form the traps for most petroleum in the study area.

Four types of faults are common in the Tertiary and Quaternary formations of the Gulf coast: regional faults, salt dome faults, embayment faults, and collapse faults (Seglund, 1974). Regional faults, described as growth or contemporaneous faults when there is active sedimentation, are normal faults which strike parallel to the regional strike and are downthrown on the Gulf side (Plate 4). Beds are thicker on the downthrown side; vertical displacement increases with 


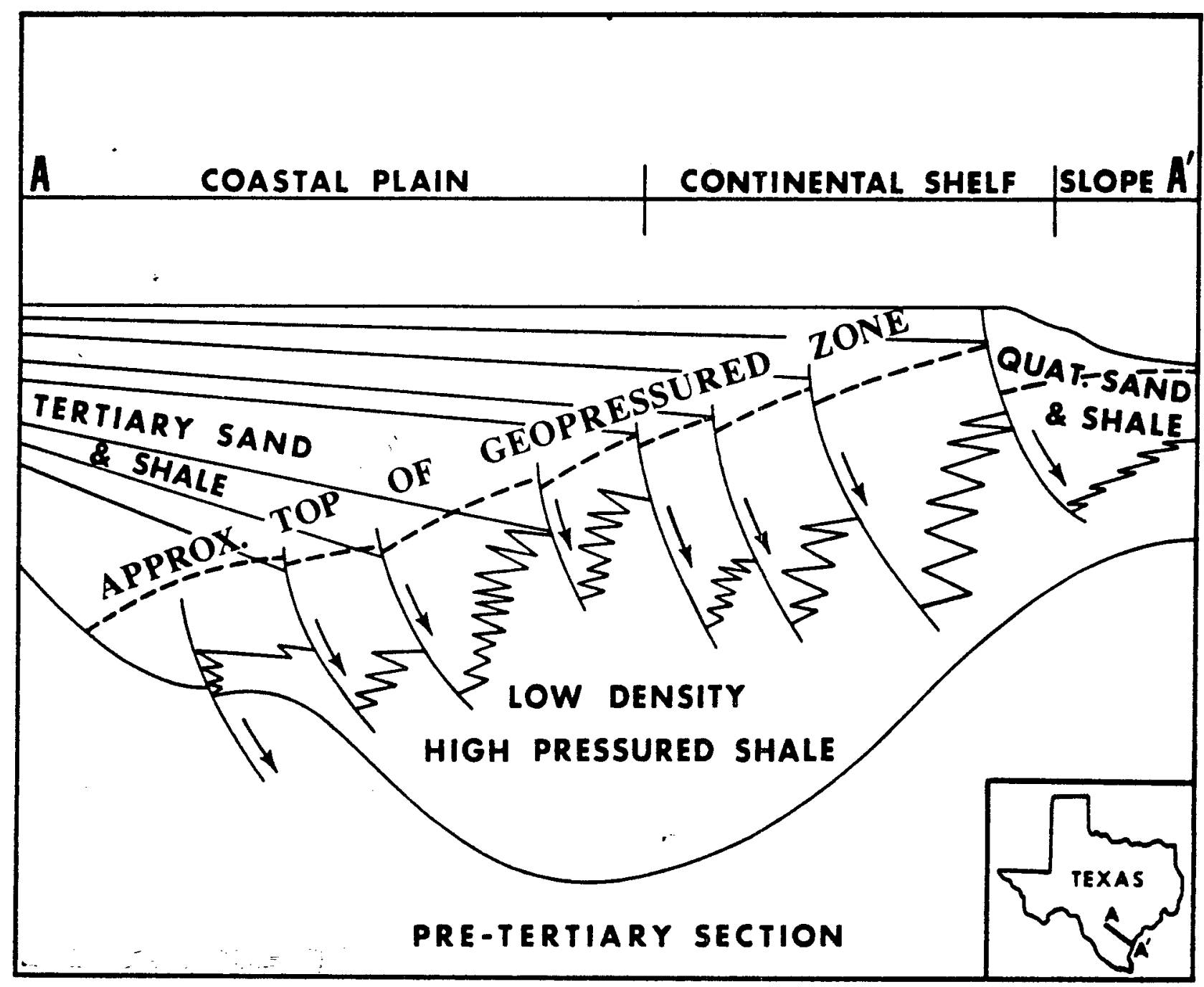

Fig. A-9. Geologic section across south Texas coastal plain showing fault systems in major Cenozoic delta deposits, and their relation to the top of the Geopressure Zone (After Jones, 1975).

depth and may be as great as $1-\mathrm{km}$. Jones (1970) estimates the dip of the fault to be about $50^{\circ}$ near the surface and to decrease to low angle faults in the deep subsurface. Salt dome faults are directly associated with the numerous salt stocks of the Upper Texas coast and the Louisiana coast. Faults may be peripheral, radial, graben, or horst (Figure A-10). Embayment faults are parallel to ancient embayment shorelines such as along the Nodosaria embayment of southwest Louisiana. Collapse faults are downthrown toward the center of salt withdrawal areas formed when salt migrates from these areas to form salt stocks. The faults are nearly 


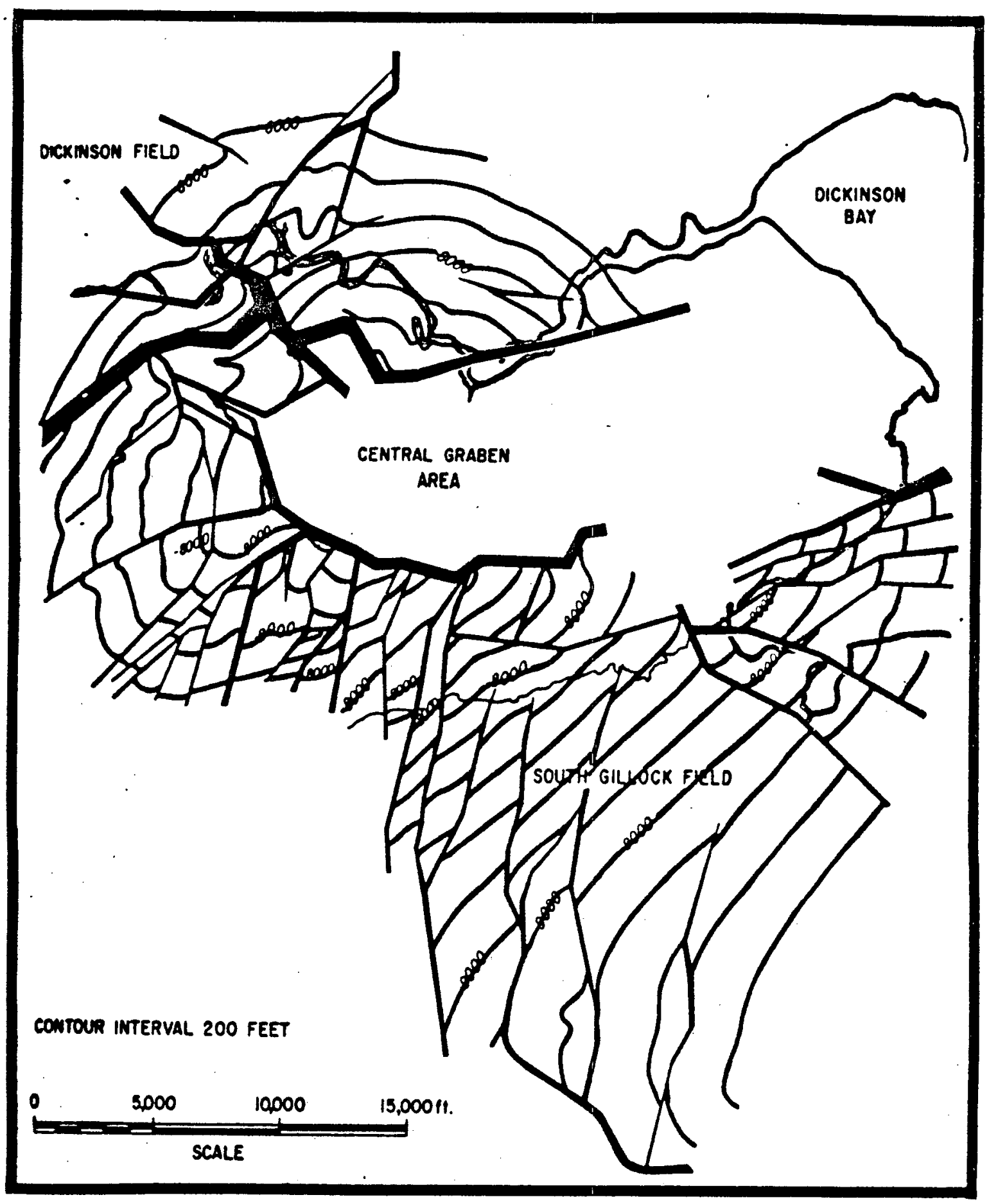

Fig. A-10. Structure contour map of Dickinson, Gillock and South Gillock fields, Galveston County, Texas, showing central graben and complex radial fault pattern. Contours are on top of a producing gas sand (After Gahagan, 1953). 
en echelon (Figure A-11). The stratigraphy of the study area is complicated by the faulting patterns across the coastal plains.

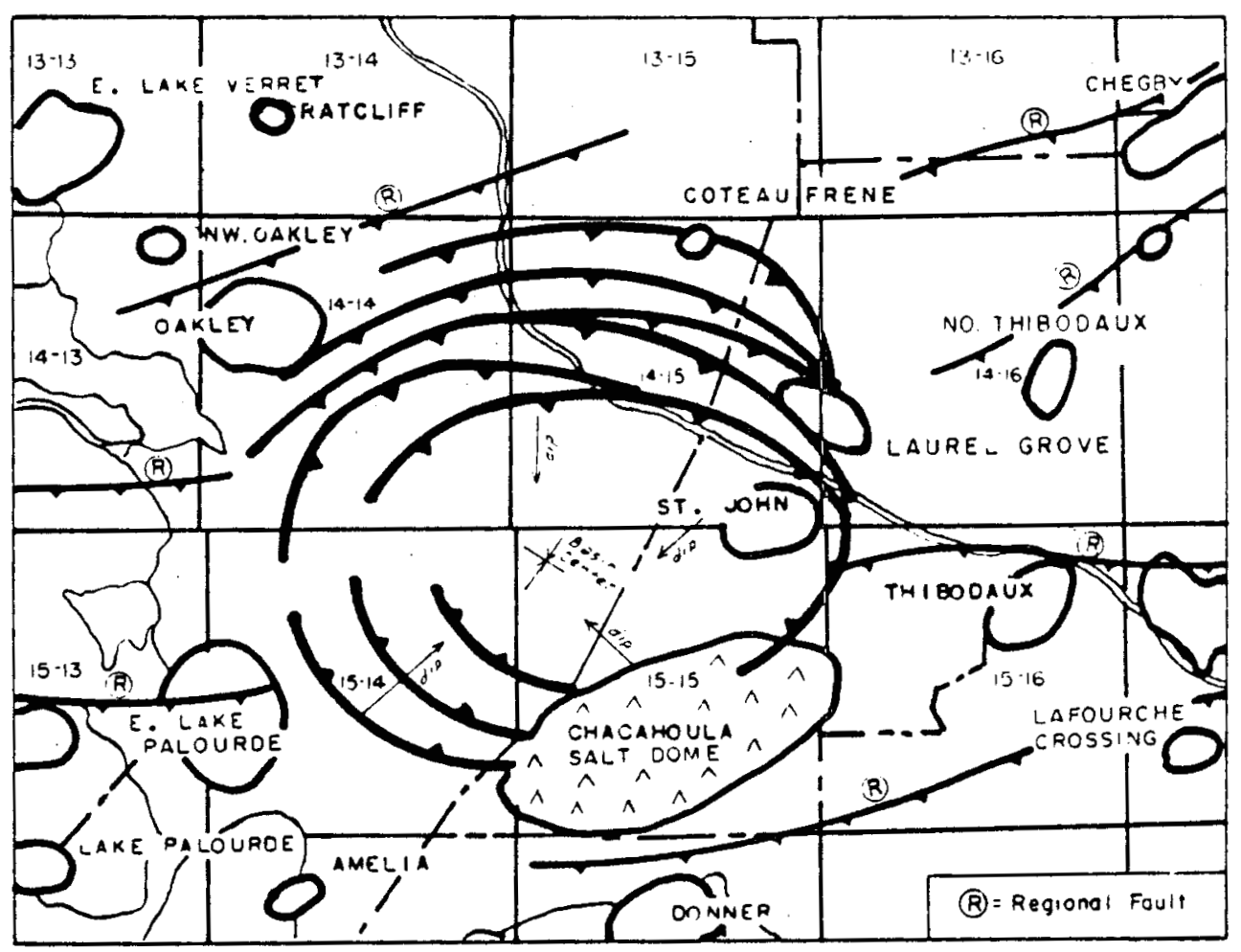

Fig. A-11. Collapse fault system associated with the Chacahoula salt-dome of Assumption Parish, Louisiana (After Seglund, 1974).

Even with all of the faulting throughout the coastal plain, seismic hazard in Texas and Louisiana is very low to non-existent (Algermissen, 1969; Algermissen and Perkins, 1976). The potential for seismic risk is described on a scale of 0 to 3 where Zone) means no damage, Zone 1 means minor damage, Zone 2 means moderate damage, and Zone 3 means major damage. The scale is based on historical data which considers only the intensity of the earthquake, not its frequency. Both Texas and Louisiana have a seismic potential of zero (Algermissen and Perkins, 1976). 


\subsubsection{Mineral Resources}

The Gulf of Mexico coastal plain is a major supplier of petroleum and natural'gas for the United States. In south Louisiana, oil fields are concentrated in a belt $112-\mathrm{km}(70-\mathrm{mi})$ wide, from the shoreline inland and from the Texas border to Mississippi. Landes (1970) estimates that "over four-fifths of the estimated ultimate resources of oil and two-thirds of the gas and condensate" has accumulated in the supercap, cap rock, and flank traps associated with salt stocks. Other oil traps occur along normal growth faults, collapse faults, or in sandstone pinchouts. Wells along the coast are deep, reaching to between $3050-\mathrm{m}(10,000-\mathrm{ft})$ and 6710-m $(22,000-\mathrm{ft})$. Another mineral in the coastal zone is sulfur. It is associated with the cap rock of salt stocks and has been commercially produced by the Frasch process. Finally, salt is commercially mined from salt domes in Louisiana.

Texas is the leading oil producing state in the country. Along the upper Texas coast, the most productive belt is three counties inland from the shoreline. Within the belt is the Frio formation, 64-km (4-mi) to 97-km (60-mi) wide, extending from Mexico to Louisiana. It is the most productive district. Most of the mineral resources are associated with salt dome traps (Landes, 1970). The next most productive areas are traps associated with growth faults and finely lenticular sands. In south Texas, oil field trends are parallel to the shoreline and major fault zones, and extend inland five or six counties. The field trends are named for the ages of the principal reservoirs and proceed from the Miocene along the shoreline to the Cretaceous inland. The Frio trend (Oligocene) is the most productive in the southern part of the state. The most productive traps in the Frio are along the downthrown blocks of normal faults, some closures on the upthrown side of growth faults, and traps associated with salt 
structures. Production along the south and central Texas coast is associated more with growth faults than with salt stocks, exactly the opposite from the upper Texas coast and Louisiana.

\subsubsection{Geology of the Geothermal-Geopressured Belt}

The geothermal-geopressured belt of the Louisiana and Texas Gulf coast follows seaward dipping beds of the Gulf coast geosyncline (Figure A-6). The narrow belt is composed of Tertiary sediments of interfingering beds of sands and shales. The study area extends from the Rio Grande in Texas to the Pearl River in Louisiana, extending inland 20 miles along the Texas coast and 97-km (60-mi) to $161-\mathrm{km}(100-\mathrm{mi})$ inland in Louisiana. Six prime areas of interest are in Texas and three are in Louisiana (Overlay). Selection was based on two criteria: the sand bodies had a volume of greater than $12.5-\mathrm{km}^{3}\left(3-\mathrm{mi}^{3}\right)$ and uncorrected fluid temperature in excess of $121^{\circ} \mathrm{C}\left(250^{\circ} \mathrm{F}\right)$. Within the sediments underlying these areas are the high temperature and high pressured waters containing dissolved natural gases which are to be tested by this program.

Geopressure reservoirs, those beds where the pore pressure exceeds hydrostatic pressure $\left(0.0106\right.$ meganewtons $/ \mathrm{m}^{3}$ or $\left.0.465 \mathrm{psi} / \mathrm{ft}\right)$, are associated with either the downthrown blocks of normal growth faults which are subparallel to the axis of the geosyncline or with sand lenses which pinch out (Bebout, 1976) (Figure A-10). Along the growth faults, sedimentation and subsidence has lead to accumulations of large amounts of clastics on the downthrown blocks (Figure A-10). The "pinched out" beds are the result of deltaic and inter-deltaic sedimentary processes associated with a migrating shoreline. These beds occur in the Frio formation along the Gulf Coast where the geopressure-hydropressure interface occurs at a depth between 3000-4000-m (10,000-12,000-ft). Below this interface, pressure steadily increases with depth in the geopressure zone. 


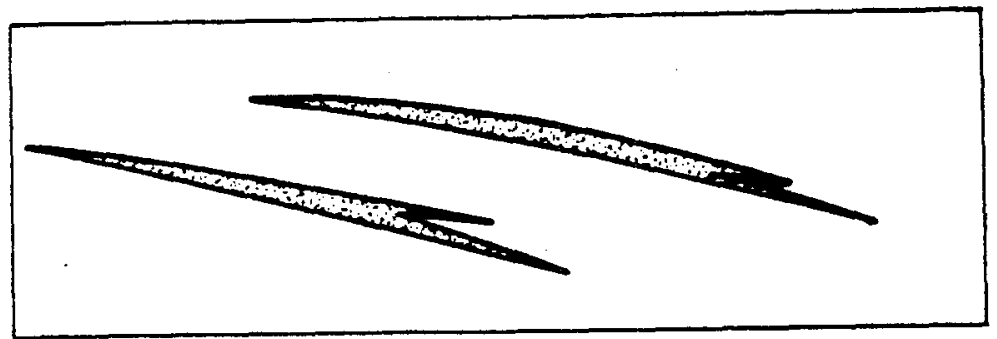

(A) SMALL RESERVOIR SEALED BY PINCHOUT

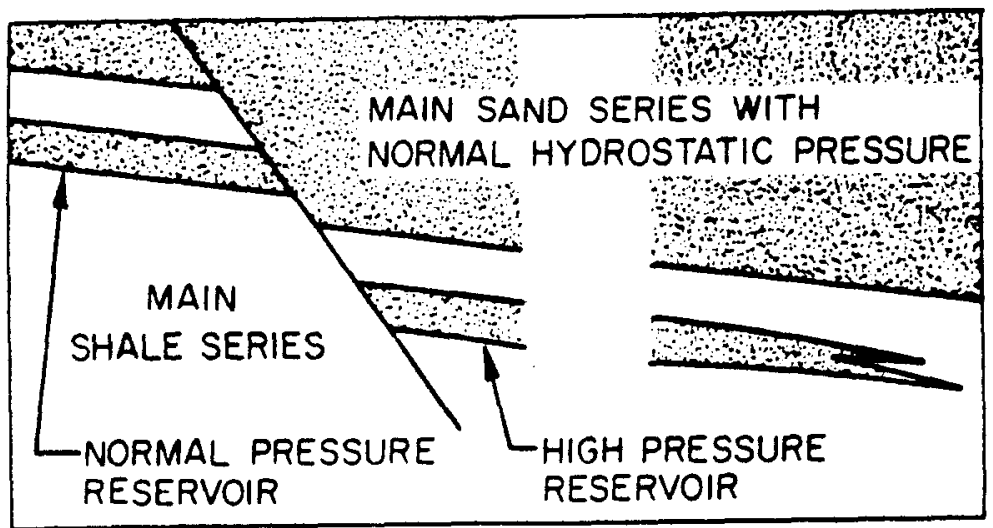

(B) LARGE RESERVOIR SEALED UPDIP BY FAULTING DOWN AGAINST THICK SHALE SERIES, SEALED DOWNDIP BY REGIONAL FACIES CHANGE

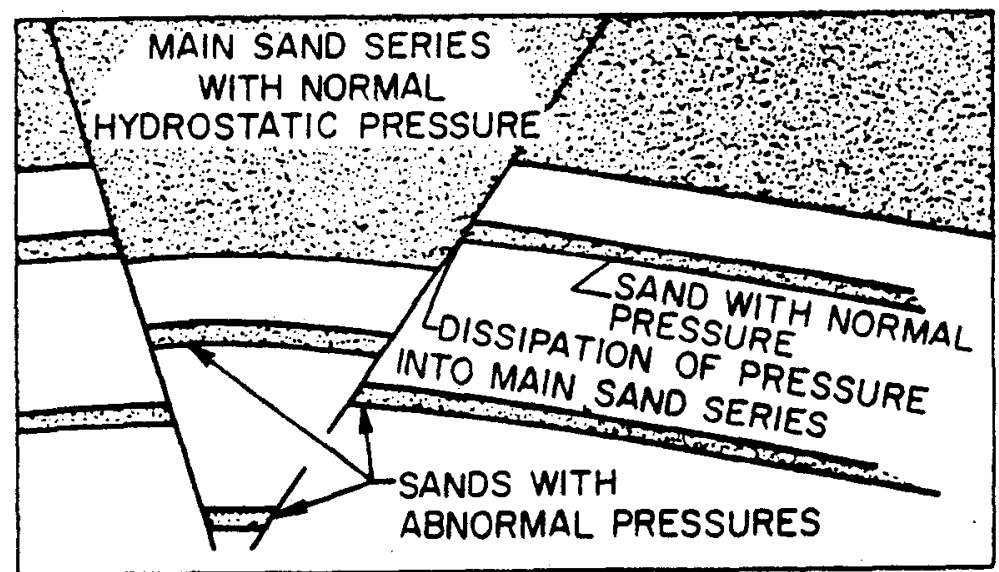

(C) RELATIVE POSITION OF FAULT SEALS IN UPTHROWN AND DOWNTHROWN BLOCKS

Fig. A-12. Types of reservoir seals necessary to preserve abnormal pressures (After Dickinson, 1953). 
Fluids in the geopressure zone originate from two major sources. Most of the interstitial fluid consists of water confined during initial deposition. Second, free water is liberated by the alteration of montmorillonite to the less hydrous clay illite.

Heat in the reservoirs is from the earth's mantle. The sands and shales of the geopressure zone act as a barrier and prevent heat transfer to the overlying sediments. Above the high-pressure strata, temperature gradients are normal but increase sharply below the geopressure interface, from $2.3^{\circ} \mathrm{C} / 100-\mathrm{m}\left(1.3^{\circ} \mathrm{F} / 100-\mathrm{ft}\right)$ to $3.8^{\circ} \mathrm{C} / 100-\mathrm{m}\left(2.1^{\circ} \mathrm{F} / 100-\mathrm{ft}\right)$ (Schmidt, 1973) and from $2.7^{\circ} \mathrm{C} / 100-\mathrm{m}\left(1.5^{\circ} \mathrm{F} / 100-\mathrm{ft}\right)$ to $5.5^{\circ} \mathrm{C} / 100-\mathrm{m}\left(3.0^{\circ} \mathrm{F} / 100-\mathrm{ft}\right)$ (Dorfman and Deller, 1976). Temperatures range from below $200^{\circ} \mathrm{F}$ to above $300^{\circ} \mathrm{F}$.

Shale beds are essentially impermeable. Porosity varies within a single shale bed, but generally decreases from the shale's central zone to its outer contacts with sand aquifers. Permeability of the sands averages 29-md (Papadopulas et a1., 1975) while porosity ranges from $12-22 \%$ by volume.

In the Gulf Coast, most of the hydrocarbon originates in the Cenozoic shales. The hydrocarbons in the geopressure fluids are nearly all natural gases, primarily methane; but ethane and propane are present in minute amounts. There is little or no evidence of hydrogen sulfide $\left(\mathrm{H}_{2} \mathrm{~S}\right)$ or other contaminants and only minimal concentrations of heavier hydrocarbons (Dorfman and Deller, 1976). Natural gas is presumed to exist at saturation levels in the reservoirs. Quantities range from $.2-\mathrm{m}^{3}\left(7-\mathrm{ft}^{3}\right)$ per barrel of fluid to $1.13-\mathrm{m}^{3}\left(40-\mathrm{ft}^{3}\right)$ per barrel. 
The sand lenses act as excellent reservoirs for geopressured fluids because of their porosity, permeability, and enclosure by shales or faults. Reservoir fluids are high in methane but vary in salinity when compared to the composition of formation fluids above the geopressured zone. In the geopressured zone, dissolved solids may range to and above 100,000 ppm. Figure A-13 shows the subareas of geothermal potential on the Gulf coast. Table A-5 gives the characteristics of each of the subareas of the Gulf coast area. Table A-6 compares the water composition between a geopressured formation and a normally pressured formation in southwest Louisiana.

\subsection{Hydrology and Water Use}

\subsubsection{Groundwater Hydrology and Use}

\subsubsection{Horizontal and Vertical Extent of Aquifers}

The groundwater resources of the coastal plain of Texas and Louisiana are contained in gulfward dipping and thickening wedges of Quaternary and Tertiary age sediments ranging in composition from clay and silt to sand and gravel. The sediments increase in age from Recent along the coast to Eocene inland. Generally, the sedimentary wedges are coarsest inland becoming thicker and grading to silt and clay some distance gulfward. The aquifers are recharged by precipitation inland at the elevated outcrop areas. From here fresh water flows under the force of gravity downdip to discharge areas near the coast. The movement of fresh water into the aquifer displaces the saline water originally deposited with the aquifer to a position of equilibrium nearer the coast. Thus, at some distance downdip all the aquifers contain only saline water. Flushing of saline waters from coastal aquifers has been most complete where recharge areas are highest, recharge water (precipitation) is most abundant, and aquifers are most 


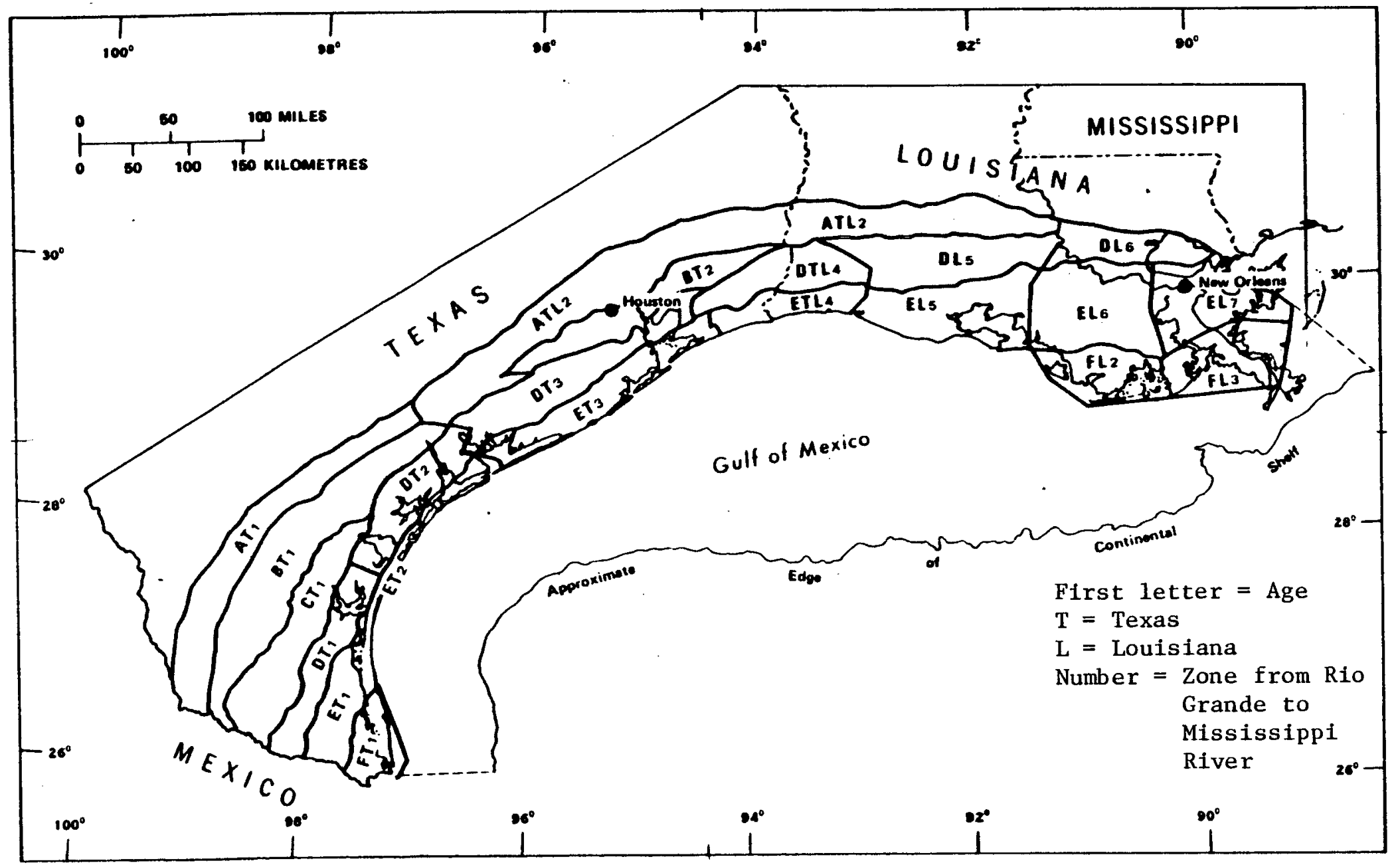

Fig. -13 Location map showing the extent of the assessed geopressured zones and their division into subareas (After Papadopulas et a1., 1975). 
Table A-5. Areal Extent and Average Pressure, Temperature, and Salinity Conditions in Each Subarea (After Papadopulas et a1. , 1975).

\begin{tabular}{|c|c|c|c|c|c|c|c|c|}
\hline Subarea & $\begin{array}{l}\text { Areal } \\
\text { Extent } \\
\qquad \mathrm{km}^{2}\end{array}$ & $\begin{array}{c}\text { Average } \\
\text { depth } \\
\text { to top of } \\
\text { geopressure } \\
\mathrm{km}\end{array}$ & $\begin{array}{l}\text { Average } \\
\text { depth } \\
\text { to } \\
\text { midpoint } \\
\text { km }\end{array}$ & $\begin{array}{c}\text { Average } \\
\text { pressure } \\
\mathrm{MN} / \mathrm{m}^{2}\end{array}$ & $\begin{array}{c}\text { Average } \\
\text { temperature } \\
\text { C }\end{array}$ & $\begin{array}{l}\text { Avera } \\
\text { salin }\end{array}$ & $\begin{array}{l}\text { ge } \\
\text { ity }\end{array}$ & $\begin{array}{l}\text { Methane } \\
\text { content } \\
\text { std. } \mathrm{m}^{3} / \mathrm{m}^{3}\end{array}$ \\
\hline $\begin{array}{l}\mathrm{AT}_{1} \\
\mathrm{ATt}_{2} \\
\mathrm{BT}_{1} \\
\mathrm{BT}_{2} \\
\mathrm{CT}_{1} \\
\mathrm{DT}_{1} \\
\mathrm{DT}_{2} \\
\mathrm{DT}_{3} \\
\mathrm{DTL}_{4} \\
\mathrm{DL}_{5} \\
\mathrm{DL}_{6} \\
\mathrm{ET}_{1} \\
\mathrm{ET}_{2} \\
\mathrm{ET}_{3} \\
\mathrm{ETL}_{4} \\
\mathrm{EL}_{5} \\
\mathrm{EL}_{6} \\
\mathrm{EL}_{7} \\
\mathrm{FT}_{1} \\
\mathrm{FL}_{2} \\
\mathrm{FL}_{3}\end{array}$ & $\begin{array}{r}8,948 \\
20,965 \\
13,588 \\
5,595 \\
8,230 \\
4,861 \\
5,155 \\
7,425 \\
5,102 \\
7,015 \\
3,729 \\
5,400 \\
1,938 \\
7,496 \\
3,461 \\
8,144 \\
8,849 \\
6,249 \\
2,269 \\
4,707 \\
6,139\end{array}$ & $\begin{array}{l}2.36 \\
2.47 \\
1.82 \\
2.32 \\
2.47 \\
2.92 \\
2.68 \\
2.41 \\
2.62 \\
3.01 \\
3.05 \\
2.96 \\
2.63 \\
2.37 \\
2.63 \\
3.66 \\
3.32 \\
2.99 \\
3.11 \\
3.76 \\
3.88\end{array}$ & $\begin{array}{l}4.18 \\
4.23 \\
3.91 \\
4.16 \\
4.23 \\
4.46 \\
4.34 \\
4.20 \\
4.31 \\
5.01 \\
5.02 \\
4.48 \\
4.32 \\
4.19 \\
4.31 \\
5.33 \\
5.16 \\
5.00 \\
4.55 \\
5.38 \\
5.44\end{array}$ & $\begin{array}{r}82.4 \\
78.5 \\
74.6 \\
81.4 \\
81.4 \\
88.3 \\
86.3 \\
80.4 \\
83.4 \\
102.0 \\
104.0 \\
83.4 \\
83.4 \\
80.4 \\
87.3 \\
106.9 \\
105.0 \\
100.1 \\
86.3 \\
105.0 \\
110.8\end{array}$ & $\begin{array}{l}186 \\
156 \\
170 \\
150 \\
172 \\
172 \\
169 \\
153 \\
141 \\
164 \\
160 \\
168 \\
166 \\
146 \\
140 \\
165 \\
159 \\
146 \\
171 \\
148 \\
151\end{array}$ & $\begin{array}{r}- \\
- \\
362 \\
50 \\
20 \\
95 \\
2 \\
67 \\
18 \\
222 \\
14 \\
34 \\
24 \\
65 \\
14 \\
39 \\
87 \\
9 \\
5 \\
46 \\
11\end{array}$ & $\begin{array}{l}16^{*} \\
20^{*} \\
30 \\
38 \\
24^{+} \\
23 \\
33 \\
28 \\
46 \\
65^{* *} \\
55^{++} \\
34^{+} \\
17^{+} \\
27^{+} \\
52 \\
90^{* *} \\
83 \\
26^{+} \\
15^{+} \\
84^{++} \\
45^{++}\end{array}$ & $\begin{array}{r}11.0 \\
8.4 \\
9.5 \\
7.5 \\
8.9 \\
9.1 \\
9.2 \\
8.0 \\
7.3 \\
8.0 \\
8.3 \\
8.8 \\
9.4 \\
7.8 \\
6.7 \\
8.0 \\
7.7 \\
8.5 \\
10.2 \\
7.3 \\
8.2\end{array}$ \\
\hline Total & כ2 & & & & & & & \\
\hline
\end{tabular}

* Estimated; samples not available.

+ Salinity as NaCl calculated from spontaneous potential of well logs; number of samples refers to number of well logs.

** Only few samples from deep zones are included.

+ No samples from deep zones are included. 
Table A-6. Geopressured Manchester Field Compared with Normal Pressured Hackberry Field

\begin{tabular}{lll}
\hline & Calcasieu Parish & Acadia Parish \\
\hline Field: & Manchester & Hackberry \\
Well Name: & No. I W.H. McBurrey & No. 51 Gulfland \\
Depth: & $12,670-12,677$ & 11,500
\end{tabular}

Chemical Composition (ppm):

$\begin{array}{lrr}\mathrm{Na} & 6,580 & 49,100 \\ \mathrm{Ca} & 138 & 5,850 \\ \mathrm{Mg} & 18 & 903 \\ \mathrm{~K} & 86 & 309 \\ \mathrm{CI} & 9,950 & 92,100 \\ \mathrm{HCO}_{3} & 1,330 & 286 \\ \mathrm{SO}_{4} & 175 & 37 \\ \mathrm{CO}_{3} & & \\ \mathrm{Li} & 3.1 & 4.5 \\ \mathrm{Rb} & 0 & 0.6 \\ \mathrm{Cs} & & 0 \\ \mathrm{Sr} & 5.3 & 569 \\ \mathrm{Br} & 33 & 183 \\ \mathrm{I} & 27 & 5.3 \\ \mathrm{Ba} & 0 & 23 \\ \mathrm{SiO}{ }_{2} & & 149,000 \\ \mathrm{TDS} & 18,300 & \end{array}$

Source: Schmidt, 1973 and Schmidt et a1., 1976. 
permeable. The deepest fresh water resources are in the northeast Texas and Louisiana areas. The coastward dipping aquifers are confined by clay layers above and below creating artesian conditions. Thus in wells tapping these aquifers, water rises above the confining layers in the wells. Unconfined aquifers (water table conditions) exist only along the major river valleys and at the outcrop areas.

Dominant structural features which interrupt the continuity of coastal deposits include (1) down-to-the-coast, growth faults which are generally parallel to the coast and (2) salt diapirs, which uplift and penetrate overlying sediments and are most prominent in the northeastern two-thirds of the Texas coastal plain and in Louisiana. Growth faults tend to act as hydrologic barriers blocking flow in aquifers (Kreitler, 1977). Thus they can compartmentalize effects of groundwater development located between bounding faults. Salt domes also cause faulting and, where they penetrate fresh groundwaters, can cause natural saline contamination of aquifers (Wesselman, 1972).

The important geologic and hydrologic units of the Texas and Louisiana coastal plains are 1isted in Table A-7. In this assessment the aquifer names adopted by Wood, Gabrysch, and Marvin (1963) are used for the Texas coast areas southwest of Brazoria and Fort Bend counties. Northeast from Brazoria and Fort Bend counties into southwest Louisiana the names adopted by Wesselman (1971) are used. However, in the map of aquifer outcrops (Plate 5) the more detailed nomenclature of southwest Texas is extended to the Louisiana border to provide maximum detail in the areas of aquifer recharge. Although the aquifer names vary along the coast, the sequence and nature of aquifers is rather uniform. Descriptions of 
Table A-7. Geologic and Hydrologic Units of the Texas and Louisiana Coastal Plain.

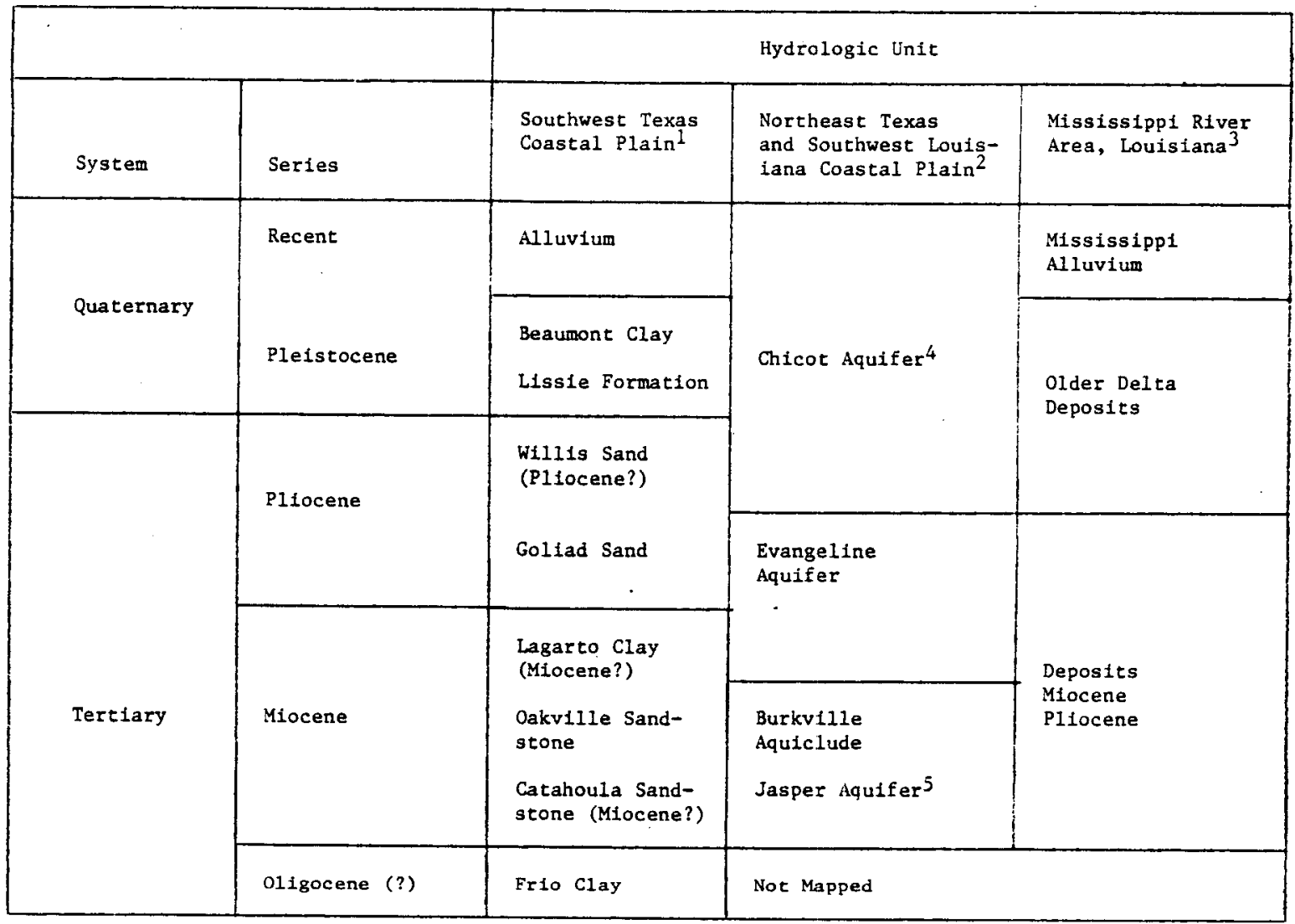

1Wood, Gabrysch and Marvin, 1963.

Wesselman, 1971 .

4 Becomes Chicot-Atchafalaya Aquifer in Southcentral

Louisiana (Harder and others, 1967).

Swesselman, 1972 . 
important aquifers, including information concerning thickness, 1ithology, and water bearing characteristics, are given in Tables $A-8$ and $A-9$.

In Texas the Goliad Sand, Willis Sand, and the Lissie Formation are the major coastal aquifers (Wood, Gabrysch, and Marvin, 1963). These sands are best developed and yield the largest quantities of fresh water in the northeastern three-fifths of the Texas coast. The Lagarto Clay, Oakville Sandstone, and Catahoula Sandstone are thinner, less important aquifers yielding water of greater chemical variability. The northeastern portion of the coast is also the area where these sands are best developed. The Beaumont Clay is an important aquifer from the Nueces County area to the Sabine River. The Alluvium is the principal aquifer of the Rio Grande Valley and is also developed in other river valleys of the Texas coast.

Outcrop areas for the important fresh water aquifers of the Texas and Louisiana coastal plain are shown on Plate 5. Coastal artesian aquifers receive recharge in their inland outcrop areas. Large areas of the Texas and Louisiana coasts are covered with relatively impermeable deposits of Recent alluvium and Pleistocene terraces. In these areas precipitation can only recharge near-surface water table aquifers. Major streams crossing these areas are in hydraulic contact with alluvial aquifers and, in some cases, with deeper artesian aquifers. Thus, even though surface deposits prevent recharge by precipitation, aquifers can receive important amounts of recharge from these streams.

In Texas the major areas of recharge are the outcrop belts of the Goliad, Willis, and Lissie formations. Caliche soils in these formations in southwest Texas may. 
Table A-8. Geologic Formations and Their Water-bearing Characteristics in the Texas Coastal Region (After Wood et al., 1963).

\begin{tabular}{|c|c|c|c|c|c|}
\hline System & Ser1es & Unit & $\begin{array}{l}\text { Thickness } \\
\text { (feet) }\end{array}$ & \begin{tabular}{|l|} 
Lithologic \\
Description
\end{tabular} & Water-bearing Characterlstics \\
\hline & \multirow[t]{2}{*}{ Recent } & Alluvium & $0-300$ & $\begin{array}{l}\text { Unconsolidated gravel, } \\
\text { sand, s1lt and clay. }\end{array}$ & $\begin{array}{l}\text { Yelds only small quantities of water } \\
\text { except in the lower reaches of the } \\
\text { Rio Grande and Brazos River Valleys } \\
\text { where moderate to large quantities of } \\
\text { water are obtained for public supply, } \\
\text { industry and Irrigation. }\end{array}$ \\
\hline & & Eolian Deposits & $0-50+$ & Unconsolidated sands. & $\begin{array}{l}\text { Yields only small supplies of water } \\
\text { locally. }\end{array}$ \\
\hline \multirow[t]{2}{*}{ Quaternary } & \multirow[t]{2}{*}{ Pleistocene } & Beaumont Clay & $0-1,500$ & $\begin{array}{l}\text { Unconsolidated, light- } \\
\text { colored sands, silts } \\
\text { and clays In upper } 200 \\
\text { feet. Predominantly } \\
\text { varicolored clays and } \\
\text { thin sand lenses in } \\
\text { lower part except for } \\
\text { a thick basal sand, the } \\
\text { Alta Loma of Rose } \\
\text { (1943), occurring in } \\
\text { the eastern part of } \\
\text { the region. }\end{array}$ & $\begin{array}{l}\text { Yields small to moderate supplies of } \\
\text { water for public supply, Industry and } \\
\text { irrigation throughout most of the cen- } \\
\text { tral and eastern parts of the region. } \\
\text { Most extensively developed in Galveston } \\
\text { and Orange Counties and southeastern } \\
\text { Harris County where it ylelds large } \\
\text { supplies of water from the Alta Loma } \\
\text { Sand of Rose (1943). A poor source of } \\
\text { fresh to slightly saline water south of } \\
\text { the Nueces River. }\end{array}$ \\
\hline & & $\begin{array}{l}\text { Lissie } \\
\text { Formation }\end{array}$ & $0-1,600$ & $\begin{array}{l}\text { Alternating thin to } \\
\text { thick beds of light- } \\
\text { colored sand, gravel, } \\
\text { sandy clay, and clay. } \\
\text { Extensive caliche beds } \\
\text { in the central and } \\
\text { southern parts of the } \\
\text { region. }\end{array}$ & $\begin{array}{l}\text { Yields small to large supplies of water } \\
\text { for public supply, lndustry and irriga- } \\
\text { tion throughout the length of the region } \\
\text { Extensively developed in the central and } \\
\text { eastern parts of the region. }\end{array}$ \\
\hline $\begin{array}{l}\text { Tertlary } \\
\text { (?) }\end{array}$ & P1focene (?) & W1111s Sand & $0-400$ & $\begin{array}{l}\text { Sand and gravel inter- } \\
\text { bedded with silt and } \\
\text { clay. }\end{array}$ & $\begin{array}{l}\text { Ylelds small to large supplies of water } \\
\text { for munfctpal, industrial and agricul- } \\
\text { tural uses. Extensively developed in } \\
\text { the eastern part of the reglon. }\end{array}$ \\
\hline
\end{tabular}


Table A-8. Geologic Formations and Their Water-bearing Chatacteristics in the Texas Coastal Region (After Wood et al, 1963). Continued,

\begin{tabular}{|c|c|c|c|c|c|}
\hline System & Series & Unit & $\begin{array}{l}\text { Th1ckness } \\
\text { (feet) }\end{array}$ & $\begin{array}{l}\text { Lithologic } \\
\text { Description }\end{array}$ & Water-bearing Characteristics \\
\hline & Pliocene & Gollad Sand & $0-500$ & $\begin{array}{l}\text { Sand, gravel and } 11 \text { me- } \\
\text { cemented sandstone } \\
\text { interbedded with } \\
\text { variegated clay and } \\
\text { silt. Callche beds } \\
\text { present in the south- } \\
\text { ern part of the region. }\end{array}$ & $\begin{array}{l}\text { Yields small to moderate quantities of } \\
\text { fresh to slightly saline water for } \\
\text { public supply, industry, and irrigation. } \\
\text { Extensively developed in some areas of } \\
\text { the central and southern parts of the } \\
\text { region. }\end{array}$ \\
\hline & Mlocene (?) & Lagarto Clay & $0-1,000$ & $\begin{array}{l}\text { Dominantly massive clay } \\
\text { and sandy clay inter- } \\
\text { bedded with sand and } \\
\text { sandstone. }\end{array}$ & $\begin{array}{l}\text { Yields moderate quantities of water for } \\
\text { public supply, industry, and irrigation } \\
\text { east of Bee County. In the southern } \\
\text { part of the region, the formation yields } \\
\text { only small supplies for domestic and } \\
\text { livestock use. }\end{array}$ \\
\hline \multirow[t]{4}{*}{ Tert1ary } & Mlocene & $\begin{array}{l}\text { Oakville } \\
\text { Sandstone }\end{array}$ & $0-1,650$ & $\begin{array}{l}\text { Dominantly sand and } \\
\text { sandstone finterbedded } \\
\text { with clay and silt. }\end{array}$ & $\begin{array}{l}\text { Yields moderate quantities of fresh to } \\
\text { slightly saline water for municipal, } \\
\text { industrial and agricultural purposes on } \\
\text { outcrop and several miles downdip } \\
\text { throughout the length of the region. }\end{array}$ \\
\hline & Miocene (?) & $\begin{array}{l}\text { Catahoula Sandstone } \\
\text { (eastern part) } \\
\text { Catahoula Tuff } \\
\text { (central and } \\
\text { southern part) }\end{array}$ & $0-1,500$ & $\begin{array}{l}\text { Volcanic ash, tuffa- } \\
\text { clous clay, clay, and } \\
\text { sandstone. }\end{array}$ & $\begin{array}{l}\text { Yields moderate quantities of water on } \\
\text { outcrop and a few miles downdip for } \\
\text { municipal, industrial and agricul tural } \\
\text { uses. }\end{array}$ \\
\hline & Oligocene (?) & Frio Clay & $0-600$ & $\begin{array}{l}\text { Predominantly clay, } \\
\text { thin beds of sand and } \\
\text { silt. }\end{array}$ & Not an aquifer in the region. \\
\hline & Eocene & Jackson Group & $800-1,300$ & $\begin{array}{l}\text { Sand, silt, tuffaceous } \\
\text { sand and clay }\end{array}$ & $\begin{array}{l}\text { Yelds moderate quantities of water for } \\
\text { public and Industrial supply in Kames } \\
\text { and Polk Counties. The group is of minor } \\
\text { importance as an aquifer with in the } \\
\text { reglon except possibly in the eastern } \\
\text { part where its potential was not } \\
\text { determined. }\end{array}$ \\
\hline
\end{tabular}


Table A-9. Geologic Formations and their Water-Bearing Characteristics in the Mississippi River Area, Louisiana.

\begin{tabular}{|c|c|c|c|c|c|}
\hline System & Series & Unit & $\begin{array}{c}\text { Thickness } \\
\text { (feet) }\end{array}$ & $\begin{array}{l}\text { Lithologic } \\
\text { Description }\end{array}$ & $\begin{array}{l}\text { Water-Bearing } \\
\text { Characteristics }\end{array}$ \\
\hline \multirow[t]{2}{*}{$\begin{array}{l}\text { Quater- } \\
\text { nary }\end{array}$} & Recent & $\begin{array}{l}\text { Mississippi } \\
\text { Alluvium }\end{array}$ & $0-600+$ & $\begin{array}{l}\text { Upper } 50 \text { to } 100 \\
\text { feet is mainly } \\
\text { clay and silt. } \\
\text { Deeper deposits } \\
\text { are clay, sand, } \\
\text { and gravel. }\end{array}$ & $\begin{array}{l}\text { Moderate to large } \\
\text { quantities of water under } \\
\text { artesian conditions. Chem- } \\
\text { ical quality of water is } \\
\text { variable, but shallow water } \\
\text { is generally hard and high } \\
\text { in iron. Deeper water is } \\
\text { soft and low in fron. } \\
\text { Depth to saline water } \\
\text { highly variable }\end{array}$ \\
\hline & $\begin{array}{l}\text { Pleist- } \\
\text { ocene }\end{array}$ & $\begin{array}{l}\text { Older Deltalc } \\
\text { Deposits }\end{array}$ & $1000+$ & $\begin{array}{l}\text { Deltaic to sha1- } \\
\text { low marine dep- } \\
\text { osits. Clay, } \\
\text { silt, sand and } \\
\text { gravel. }\end{array}$ & $\begin{array}{l}\text { Important fresh water } \\
\text { supplies at Baton Rouge, } \\
\text { New Orleans and other } \\
\text { Mississippi River } \\
\text { communities }\end{array}$ \\
\hline Tertiary & $\begin{array}{l}\text { Pliocene } \\
\text { Miocene }\end{array}$ & $\begin{array}{l}\text { Miocene \& } \\
\text { Pliocene } \\
\text { Deposits }\end{array}$ & $\begin{array}{l}\text { undeter- } \\
\text { mined }\end{array}$ & $\begin{array}{l}\text { Sand, silt and } \\
\text { Clay. }\end{array}$ & $\begin{array}{l}\text { Principal sources of mod- } \\
\text { erate to large quantities } \\
\text { of fresh, soft ground- } \\
\text { water in Baton Rouge and } \\
\text { southeastern Louisiana. }\end{array}$ \\
\hline
\end{tabular}

Adapted from Cardwe11 and Ro11o, 1960 and Long, 1965. 
locally reduce the amount of water entering these aquifers. Eolian sand deposits in southwest Texas create highly permeable recharge areas but yield only small amounts of groundwater locally (Wood, Gabrysch, and Marvin, 1963). The broad belt of Beaumont Clay is generally an area of clayey soils permitting recharge only to shallow aquifers except where streams dissect this formation and are in contact with deeper aquifers.

In southwest Louisiana, only the southernmost portion of the surface recharge area of the Chicot and deeper artesian aquifers extends into the outcrop map (Plate 5). Gulfward, relatively impermeable Pleistocene terraces and coastal marsh deposits prevent recharge of these artesian aquifers. However, important hydraulic connections exist between the Chicot aquifer and major streams of southwest Louisiana that cut through the overlying sediments, including the Sabine, Calcasieu and Vermilion Rivers. Eastward, the Chicot aquifer joins the Mississippi alluvium which is in contact with the Mississippi and Atchafalaya Rivers. The artesian Pleistocene and Miocene aquifers of southeast Louisiana are recharged in outcrops north of the area into Mississippi.

In the coastal plain fresh groundwater is confined to the sands and clays of the Pleistocene and Pliocene age. The depth of occurrence of fresh to slightly saline water (near 0 to 1000 parts per million total dissolved solids) is shown graphically in Plate 6 and in cross-sections of the Tertiary formations of the Texas coast in Plate 6. Generally, fresh water is more abundant in Louisiana and the northwast Texas coast than in the southwest Texas coast. The maximum depth of fresh to slightly saline water within the region considered in this report is approximately $914 \mathrm{~m}$ (3000 ft) below sea level near Houston, Texas. In Louisiana the maximum depth 
of fresh water occurrence is approximately $610 \mathrm{~m}$ (2000 ft) below land surface in northern Calcasieu Parish. Generally, the depth of occurrence of fresh water increases inland from a minimum at the coast. Below the fresh water aquifers and downdip from the fresh water/saltwater interface in a given aquifer, saline water ranging from 10,000 ppm to $130,000 \mathrm{ppm}$ dissolved solids occurs. Below $2440 \mathrm{~m}$ to $3660 \mathrm{~m}$ ( $8000 \mathrm{ft}$ to $12,000 \mathrm{ft}$ ) in geopressure reservoirs the water usually decreases in salinity to below 10,000 ppm dissolved solids (Jones, 1969).

The total dissolved solids concentration of groundwaters from the surface to $3960 \mathrm{~m}(13,000-\mathrm{ft})$ in the Manchester and West Hackberry fields are representative of groundwater salinity variations with depth in south Louisiana (Figure A-14) (Schmidt, 1973). Note the fresh waters near the surface and the abrupt freshening in the geopressured zone below 3050-m (10,000-ft). Temperature versus depth relationships for the same area are shown in Figure A-15. Saline sands occurring beneath the fresh water zones are used for brine disposal by well injection in coastal Louisiana and Texas.

In Texas the largest center of groundwater development is the Houston area. This is one of the most heavily pumped areas in the United States (McGuinness, 1963). Groundwater is pumped from the Chicot and Evangeline aquifers at a rate estimated at about 2,176 million liters per day (575 million gallons per day) in 1975 (Jorgenson, 1975). Two important irrigation areas in Texas are the Rio Grande valley and a broad area between the Guadalupe and Sabine Rivers. In the Rio Grande valley, vegetables, citrus fruit and cotton are irrigated with water supplied from the river and wells in the alluvium. Between the Guadalupe and Sabine Rivers approximately 68,758 hectares $(417,000$ acres) of rice were 


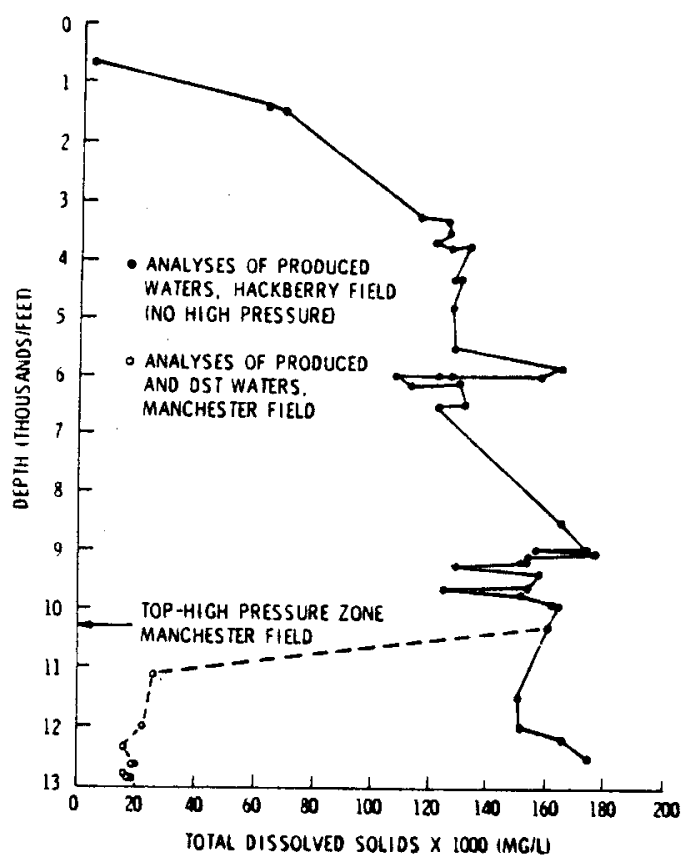

Fig. A-14. Changes in total dissolved solids concentrations of produced waters from sandstones with depth, from wells where high pressure is present and not present. (After Schmidt, 1973).

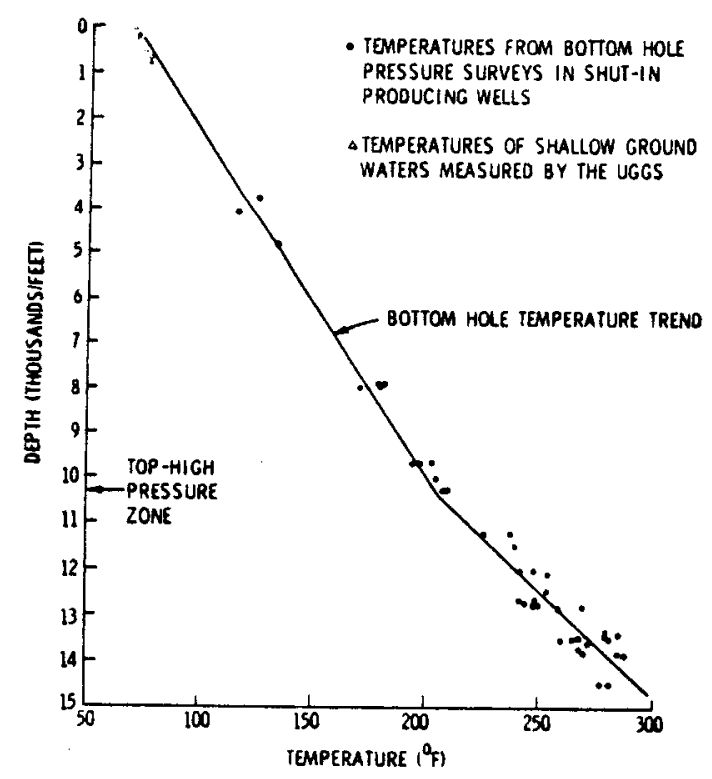

Fig. A-15. Plot of measured temperatures versus depth which shows increased temperature gradient at top of high-pressure zone (After Schmidt, 1973). 
irrigated in 1960 (Wood, Gabrysch, and Marvin, 1963). Approximately 40\% of the irrigation water came from groundwater sources.

In Louisiana the most important area of groundwater use within the report area is Lake Charles. Daily offtake in 1964 was $152 \mathrm{mgd}$ with $92 \%$ of a11 water pumped from the "500-ft" sand of the Chicot aquifer (Harder et al., 1967). In the parishes surrounding Lake Charles and to the east, approximately 242,817 hectares (600,000 acres) of rice land is irrigated for rice production. In 1960, approximately 74,909 hectares $(185,100$ acres) was irrigated using water from the Chicot and Evangeline aquifers (Kilburn and Whitman, 1962).

Two main problems are associated with groundwater development in the Gulf coast-saltwater encroachment and land subsidence. Saltwater encroachment results from the landward advance of saltwater, which exists downdip and near the coast in all aquifers, in response to fresh water withdrawals. In the absence of groundwater pumping the normal direction of groundwater flow is gulfward. When pumping begins, the potentio-metric surface (the level to which water rises in wells cased in the aquifer) is lowered and water flows to the lowest point, i.e., to the center of pumping. In some cases pumping has reversed natural groundwater flow directions and has resulted in the slow movement of saline water inland toward pumping centers. However, saltwater encroachment is not severe enough in coastal aquifers to require preventive measures such as are used to protect aquifers along the California coast.

Land subsidence due to groundwater withdrawals is a more significant problem. Subsidence due to groundwater use has been reported in Baton Rouge (Wintz, 
Kazmann, and Smith, 1970), New Orleans (Kazmann and Heath, 1968), and the Houston, Texas area (Gabrysch and Bonnet, 1975). Land subsidence in these areas is the result of compaction of aquifers and the surrounding fine-grained sediments as water pressure in the aquifer is lowered. Generally, maximum subsidence occurs near the centers of pumpage. In Houston, where the greatest subsidence has occurred, pumping has affected an area of about $12,945-\mathrm{km}^{2}\left(5000-\mathrm{m}^{2}\right)$ and the area of greatest subsidence, about 2.29-m (7.5-ft) measured between 1943 and 1973, is coincident with the location of greatest water level declines (Jorgensen, 1975). The first bi-monthly newsletter (May, 1977) of the recently formed HarrisGalveston Coastal Subsidence District reported the following costs due to subsidence in the area:

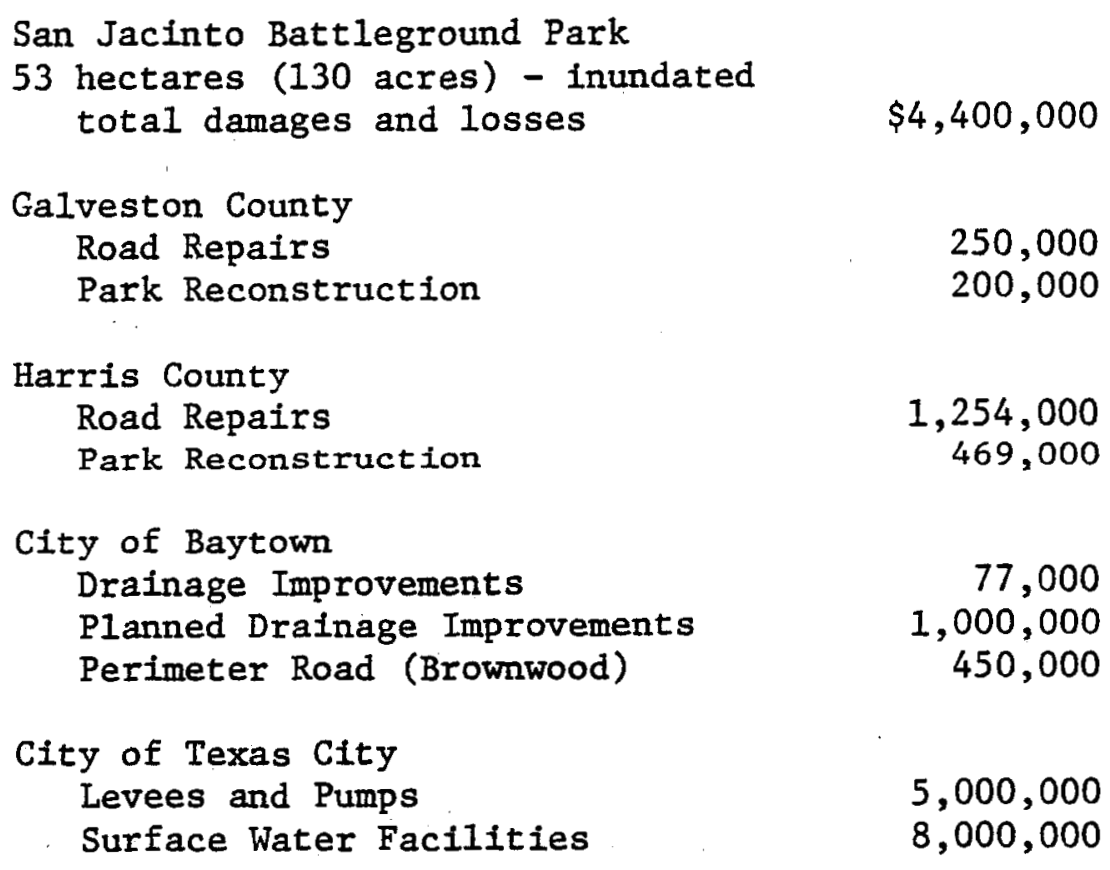

Consequences of subsidence include: (1) Increased areas subject to Innundation during floods and storms, (2) changes in surface water channel performance (canals, irrigations systems), (3) fault activation (Kreitler, 1977, Gustavson 
and Kreitler, 1976), and (4) damage to buildings, roads, utilities and other man-made improvements (Earle, 1975).

\subsubsection{Surface Water}

\subsubsection{General Hydrology}

Surface water in the Gulf coast geothermal region responds to several different influences because of the coastal location. Surface flow patterns are caused by a combination of elevation gradients, tides, and weather events.

A complex movement of water results, including channel flow in well-defined, large river systems and small streams, bayous, and canals; uncontained flow through fresh, brackish, and saline marshes; and indeterminate flow through poorly-defined drainage areas caused by lack of relief and interference by interconnecting tidal streams, lakes, canals, dikes, weirs, and spoil banks. The interaction of these various natural and cultural elements produces distinctly varied hydrologic processes and responses.

A gentle slope toward the Gulf throughout the region causes flow in that general direction. However, the gradient is small and the flow is sluggish and subject to distortion in lower river reaches and estuarine areas by effects of tides and weather conditions. Additionally, the various geomorphic zones along the coast affect the flow patterns. For example, hydrologic aspects of the Mississippi River delta zone and the smaller Texas river deltas (ColoradoBrazos, Rio Grande) where marshes and estuaries dominate are similar, but they differ in the sandy beach, lagoon and barrier island zones. (See the geomorphology section for a complete description of the zonation of the coasts.) The chenier plain zone also produces a distinctly different set of hydrologic characteristics because the lineation of the ridges produces flow parallel to the shoreline in places. 
In spite of these local differences, the surface hydrology can be characterized throughout the region by some aspects common to all the zones and sub-regions. Flow originates from precipitation in all parts of the basins, moves into the coastal zone where it inundates marshes and either disperses into estuaries or lagoons or debouches directly into the Gulf. Movement of water into these areas and the quality of that water is vital to natural processes and responses; fluctuating water levels and water qualities influence biological productivity because they mix fresh and saltwater, transport sediments, and export nutrients to adjacent coastal waters.

Water conditions within the coastal zones of the basins are one of the most important environmental factors affecting distribution of plants and animals. Vegetation and wildlife resources and soils adjust to a range of water quality conditions produced by fluctuating salinities and water levels. Figure A-16 shows the distribution of surface salinities in the Louisiana coastal zone. Although no such map is available for the entire Texas coastal zone, the distribution of soils and marsh types (salt, intermediate, or fresh water) serves as an adequate indication of normal water and salinity conditions in the coastal zone there. Table A-17 in the vegetation section outlines the soils upon which the marsh types occur. The distribution of these soils is shown on Plate 3.

Flushing action of tides, coastal winds, and river flooding keeps these waters in constant motion and determines water levels and qualities. Advance and retreat of the salt wedge in estuaries and rivers is the main transport system of many nutrients and pollutants - high flow transports them directly out into the Gu1f where they are dispersed and diluted, but with low flow they remain close to their source and may be transported back and forth in bottom slugs with the oscillation of the tidal prism. 


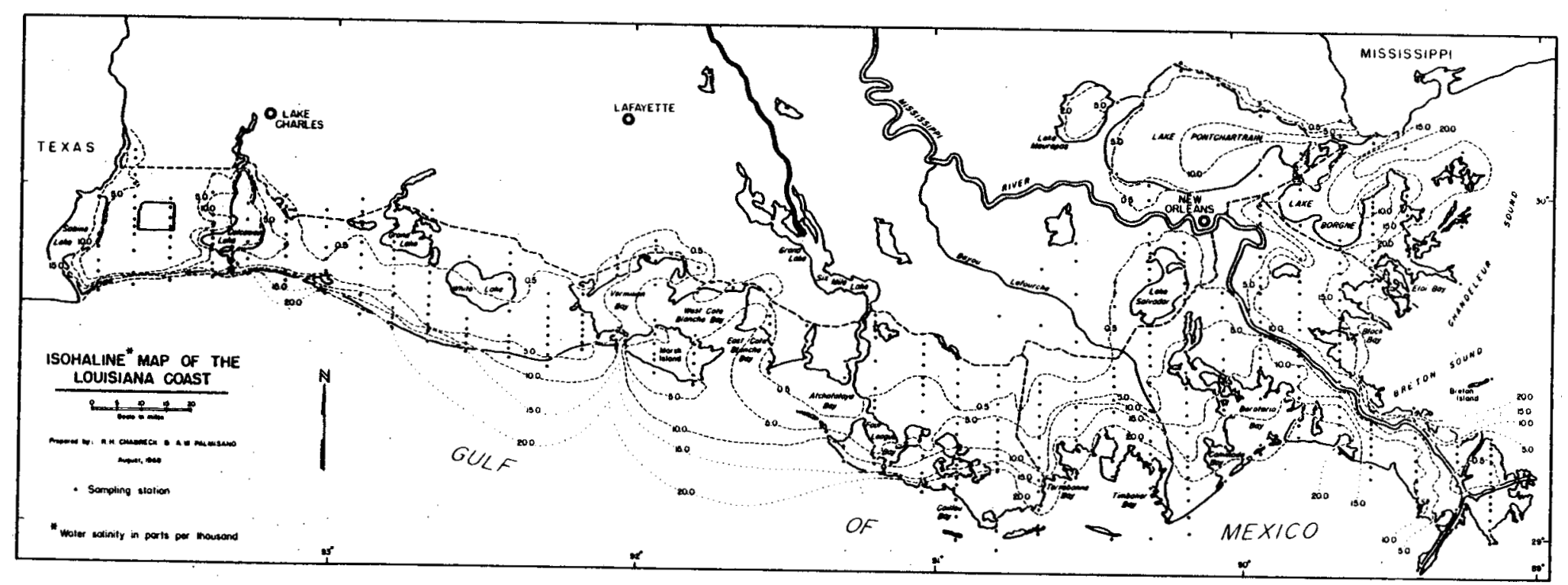

Fig. A-16. Isohaline map of the Louislana coast (After Chabreck, 1972). 


\subsubsection{Drainage Basins and Rivers}

Major hydrologic features of the geothermal region are delineated on Plate 7.

The 28 drainage basins mapped and the main streams draining each are listed in Table A-10.

Table A-10. Major Drainage Basins* and Rivers

\begin{tabular}{|ll|}
\hline \multicolumn{1}{|c|}{ Basin } & Main Stream \\
\hline Pearl & Pearl River \\
Pontchartrain - Borgne & Tangipahoa River \\
& Amite River \\
Mississippi & Mississippi River \\
Barataria & Bayou Des Allemandes \\
Terrebonne & Bayou Terrebonne \\
Atchafalaya & Atchafalaya River \\
Vermilion - Teche & Vermilion River \\
& Bayou Teche \\
Mermentau & Mermentau River \\
Calcasieu River & Calcasieu River \\
Sabine & Sabine River \\
Neches & Neches River \\
Neches - Trinity & Taylor Bayou \\
Trinity & Trinity River \\
Trinity - San Jacinto & Cedar Bayou \\
San Jacinto & San Jacinto River \\
San Jacinto - Brazos & Clear Creek \\
Brazos & Chocolate Bayou \\
Brazos - Colorado & Brazos River \\
Colorado & San Bernard River \\
Colorado - Lavaca & Colorado River \\
Lavaca & Tres Palacios Creek \\
Lavaca - Guadalupe & Lavaca River \\
Guadalupe & Garcitas Creek \\
San Antonio & Guadalupe River \\
San Antonio - Neuces & San Antonio River \\
Nueces & Mission River \\
Nueces - Rio Grande & Nueces River \\
Rio Grande & San Fernando Creek \\
& Los Olmos Creek \\
\hline & Rio Grande River \\
\hline & \\
\hline & \\
\hline &
\end{tabular}

*Drainage divides based on Hydrologic Unit Maps for Louisiana and Texas, 1974 (USGS, 1977 and 1976). 


\subsubsection{Precipitation and Runoff}

Precipitation patterns of the geopressured region are marked by a strong gradient from east to west (Figure $A-17$ ). The range is from about 60 inches average in the east to about 20 inches average in the western part of the region.

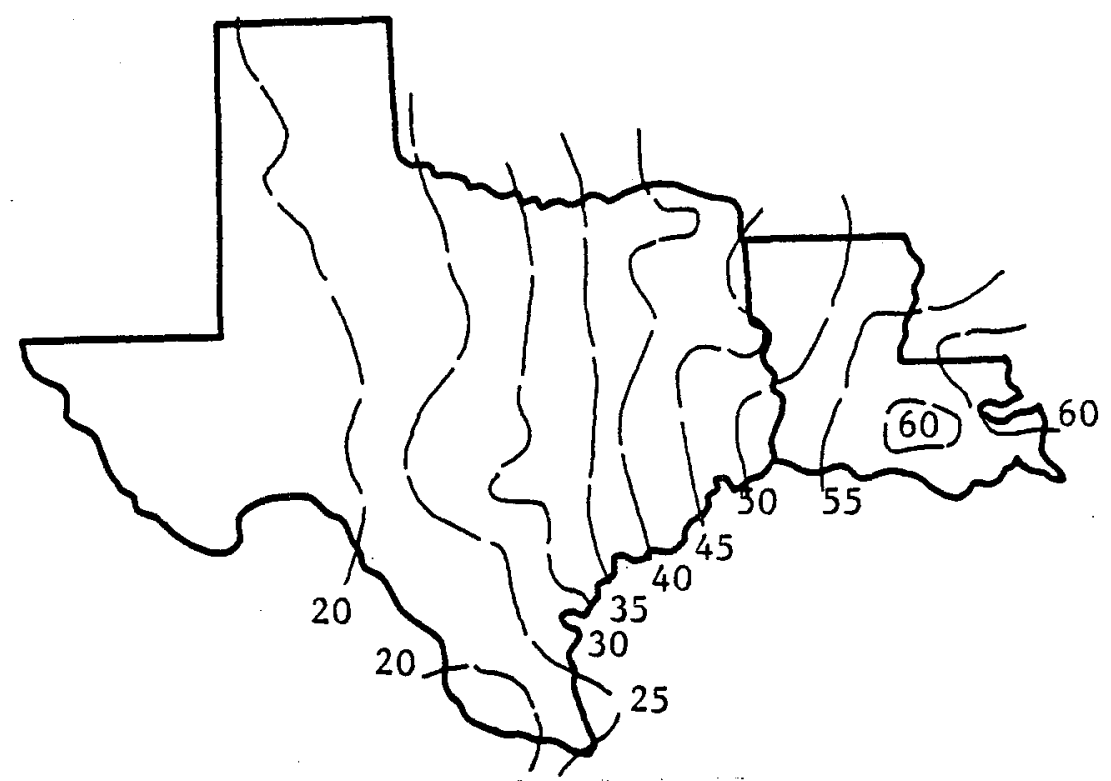

Fig. A-17. Average annual precipitation, inches (After Geraghty et al., 1973).

Surface runoff follows a similar distribution, with a concurrent gradient from east to west (Figure A-18). In the westernmost section of the region, runoff is exceeded by evaporation and transpiration 1osses. Because of the nature of the precipitation and terrain there, runoff is usually very small. About threefourths of the runoff in Texas originates in the eastern one-fourth of the state (Texas Water Development Board, 1968), whereas runoff in Louisiana is much more evenly distributed.

Runoff varies not only areally but also in response to temporal aspects of clinate. Wet and dry years produce quite different annual regimes. Severe storms and hurricanes (described in the climate section), though relatively 
rare, are a part of the climatic regime of the coastal region which can have great local influence on surface waters, Temperatures seldom fall below $0^{\circ} \mathrm{C}$ $\left(32^{\circ} \mathrm{F}\right)$ in winter, and dafly maxima above $32^{\circ} \mathrm{C}\left(90^{\circ} \mathrm{F}\right)$ are common in sumer. These climatic gradients and vagaries directly affect the occurrence and distribution of surface waters, their quality, and their uses across the geopressured region.

Runoff characteristics of basins are governed considerably by soil type, vegetation, and land use in the basin and the resulting types of surfaces. For instance, almost $100 \%$ of rain falling on paved surfaces runs off, but only 5-30\% runs off from forests, parks, and pastures. Table A-11 1ists the percent of precipitation expected as runoff from different surfaces. Reference to the soils type, vegetation, and land use sections of this assessment quickly point out the pertinence to runoff of these differences throughout the region.

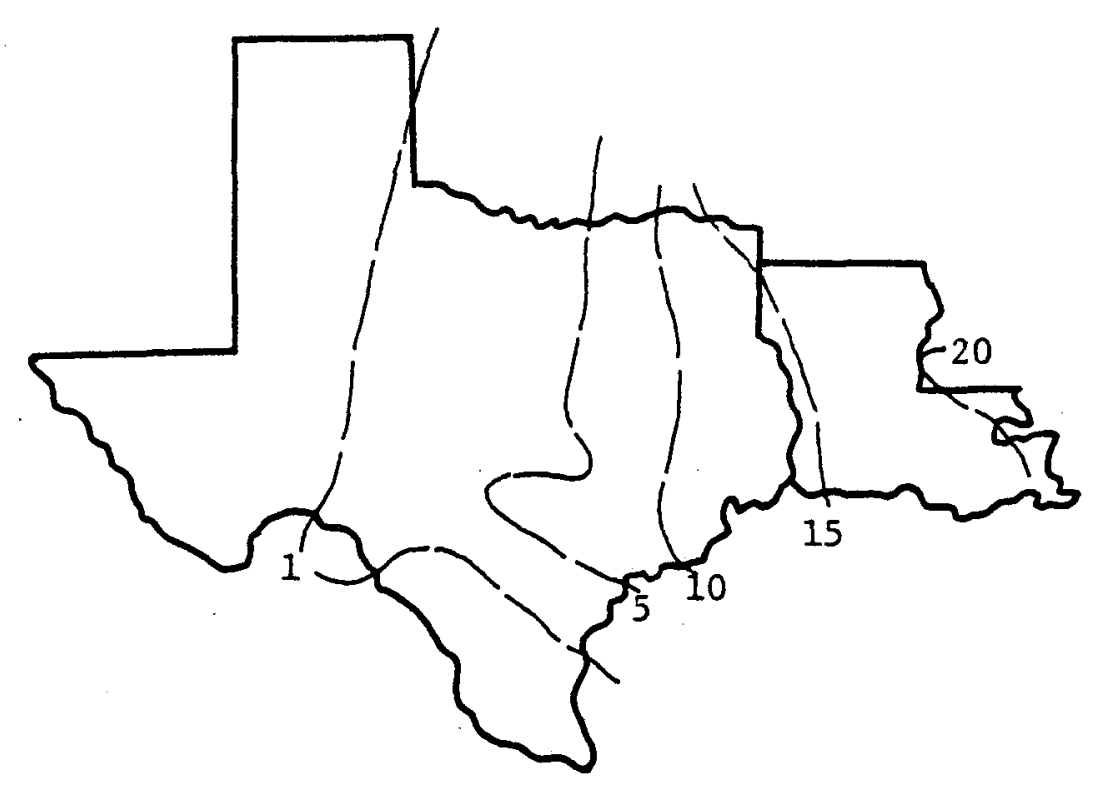

Fig. A-18. Normal annual runoff, inches (After Geraghty, et a1., 1973). 
Table A-11. Runoff as a Percent of Precipitation on Various Surfaces

\begin{tabular}{|cc|}
\hline Surface & $\%$ Runoff \\
\hline $\begin{array}{c}\text { Urban residential } \\
\text { single houses } \\
\text { garden apartments }\end{array}$ & 30 \\
Commercial and Industrial & 50 \\
Forested areas (depending & 90 \\
on soil) & $5-20$ \\
Parks, farm land, pasture & $5-30$ \\
Asphalt or concrete pavement & $85-100$ \\
\hline
\end{tabular}

Source: Linsley and Franzini, 1972

\subsubsection{Physical Characteristics of Regional Hydrology}

Physical characteristics of surface water in the region can be described relative to size of the basins, the quantity of water produced in the basins, and aspects of stream regime such as high and low sustained discharges and ranges of discharge. Data illustrating these characteristics emphasize the gradient in precipitation and runoff. Basins in the eastern part of the region produce more water than those in western parts, and the distribution through the year is more equitable in the east. As a general overview, streams in the eastern section have a higher base flow with very few of the streams ever failing to have some flow, whereas most of the farthest western rivers (Nueces-Rio Grande Basin) are strictly emphemeral streams dependent on preclpitation alone for their flow. Low flows typically occur in eastern Louisiana in October, in western 
Louisiana in August, in eastern Texas in October, and in western Texas in August; discharges are usually highest in Louisiana and eastern Texas during January, in central Texas during March, and in western Texas during May (Geraghty et al., 1973).

Selected hydrographs located on Plate 7 illustrate the preceding points. The Tangipahoa River (Pontchartrain-Borgne Basin) and Bear Head Creek (Calcasieu Basin), representative streams in Louisiana, contrast in seasonality and quantity with three Texas streams -- Chocolate Bayou (San Jacinto-Brazos Basin), Mission River (San Antonio-Nueces Basin), and Los Olmos Creek (Nueces-Rio Grande Basin). Drainage area and average discharge for these streams are displayed on the hydrographs to allow meaningful comparison. Available data on basin size and potential water production for all basins are summarized in Table A-12.

\subsubsection{Water Quality Characteristics}

All natural waters contain mineral constituents dissolved from rocks in the area through which the water flows. Differences in environment cause chemical character and dissolved solids concentrations to vary from stream to stream. Blakely and Kunze (1971) state that geology, patterns and characteristics of stream flow, and man's activities are the most important variables in surveying the quality of water in coastal basins.

Geology and climate determine the types and concentrations of dissolved constituents in streams under completely natural conditions. Plentiful rainfall (in excess of evaporation and transpiration) lessens the amount of mineralization that can occur in a basin, whereas more arid areas are capable of producing greater mineralization. Sedimentary rocks disintegrate relatively easily, so streams 
Table A-12. Physical Characteristics of Drainage Basins.

\begin{tabular}{|c|c|c|c|c|c|c|}
\hline \multirow{2}{*}{ Basin } & \multicolumn{2}{|c|}{ Size in $\mathrm{Km}^{2}\left(\mathrm{Mi}^{2}\right)$} & \multicolumn{2}{|c|}{$\begin{array}{l}\text { Average Annual } \\
\text { Precipitation in } \mathrm{mm} \text { (in) }\end{array}$} & \multicolumn{2}{|c|}{$\begin{array}{l}\text { Estimated }{ }^{*} \text { Average Ann } \\
\text { Runoff in } \mathrm{mm}^{3} / \mathrm{Km}^{2} \text { (A-F }\end{array}$} \\
\hline & $-\cdots--$ & $----\infty$ & 1524 & $(60)$ & --- & $-\infty-\infty$ \\
\hline Ponchatrain-Boyne & 45,066 & $(17,400)$ & 1524 & $(60)$ & 1.2 & $(945)$ \\
\hline Mississippi & 2,072 & $(800)$ & 1524 & $(60)$ & 0.9 & (724) \\
\hline Bavataria & 6,993 & $(2,700)$ & 1524 & $(60)$ & 1.5 & (1207) \\
\hline Terrebonne & 10,360 & $(4,000)$ & 1524 & $(60)$ & 1.2 & $(1014)$ \\
\hline Atchafalaya & 3,885 & $(1,500)$ & 1499 & (59) & 1.2 & $(1014)$ \\
\hline Vermilion-Teche & 8,806 & $(3,400)$ & 1473 & $(58)$ & 0.9 & $(703)$ \\
\hline Mermentau & 10,619 & $(4,100)$ & 1473 & $(58)$ & 1.2 & (989) \\
\hline Calcasieu & 10,360 & $(4,000)$ & 1422 & $(56)$ & 1.3 & $(1032)$ \\
\hline Sabine & 25,268 & $(9,756)$ & 1372 & (54) & 1.4 & $(1100)$ \\
\hline Neches & 25,928 & $(10,011)$ & 1372 & (54) & 1.2 & $(1,000)$ \\
\hline Neches-Trinity & 1,991 & $(769)$ & 1372 & (54) & 1.0 & $(850)$ \\
\hline Trinity & 46,540 & $(17,969)$ & 1321 & $(52)$ & 0.8 & $(650)$ \\
\hline Trinity-San Jacinto & 640 & $(247)$ & 1270 & $(50)$ & 0.7 & $(600)$ \\
\hline San Jacin to & 9,930 & $(3,834)$ & 1270 & $(50)$ & 0.7 & $(600)$ \\
\hline San Jacinto-Brazos & 3,730 & $(1,440)$ & 1219 & $(48)$ & 0.6 & $(500)$ \\
\hline Brazos & 115,617 & $(44,640)$ & 1168 & $(46)$ & 0.5 & $(400)$ \\
\hline Brazos-Colorado & 4,791 & $(1,850)$ & 1118 & (44) & 0.5 & $(400)$ \\
\hline Colorado & 108,166 & $(41,763)$ & 1016 & $(40)$ & 0.4 & $(350)$ \\
\hline Colorado-Lavaca & 2,434 & $(940)$ & 914 & $(36)$ & 0.4 & $(300)$ \\
\hline Lavaca & 6,239 & $(2,409)$ & 864 & $(34)$ & 0.4 & $(325)$ \\
\hline Lavaca-Guadalupe & 2,585 & $(998)$ & 813 & $(32)$ & 0.2 & $(200)$ \\
\hline Guadalupe & 15,721 & $(6,070)$ & 813 & (32) & 0.2 & $(200)$ \\
\hline San Antonio & 10,826 & $(4,180)$ & 762 & $(30)$ & 0.2 & (150) \\
\hline San Antonio-Nueces & 6,863 & $(2,650)$ & 711 & $(28)$ & 0.2 & $(150)$ \\
\hline Nueces & 43,900 & $(16,950)$ & 610 & (24) & 0.1 & $(100)$ \\
\hline Nueces-Rio Grande & 26,936 & $(10,400)$ & 508 & $(20)$ & 0.1 & $(50)$ \\
\hline Rio Grande & - & - & 406 & & $\ldots$ & \\
\hline
\end{tabular}

* Large portions of coastal basins are ungauged, making estimates necessary

(Source: Texas Water Development Board, 1968; Muller, 1975)

Runoff characteristics of basins are governed considerably by soil type, vegetation, and use in the basin and the resulting types of surfaces. For instance, almost $100 \%$ of rain falling on paved surfaces runs of $f$, but only $5-30 \%$ runs of from forests, parks, and pastures. Table lists the percent of precipitation expected as runoff from different surfaces. Reference to the soll types, vegetation, and land use sections of this assessment quickly point out the pertinence of these differences to runoff throughout the region. 
draining such areas can have high concentrations of minerals. Mean annual precipitation along most of the northern Gulf coast exceeds 25 inches, and consequently leaching assures good quality for most of the natural waters in the region.

Concentrations of dissolved solids vary inversely with discharge. Minimum concentrations occur during flood and sustained high flows, while maximum concentrations usually occur during low flow periods. Groundwater effluent (base flow contribution), owing to prolonged contact with minerals, generally contains high concentrations of dissolved solids and usually contributes greater amounts of chemical constituents than surface runoff.

Man's activities in the study area usually degrade the quality of surface waters. Examples are depletion of flow by diversion and consumption; irrigation return flows which include agricultural chemicals, groundwater, and water imported by canals from other basins; and industrial and municipal waste discharges. $0 i 1$ is produced in all the basins covered by this report, and many streams have been affected by brines and other wastes. For example, prior to January, 1969, the Mission River (San Antonio-Nueces Basin) received oil field brine routinely -the dissolved solids concentration exceeded $70,000 \mathrm{mg} / 1$ (Blakely and Kunze, 1971). The suggested tolerance level is $500 \mathrm{mg} / 1$ (Environmental Protection Agency, 1976).

Water quality monitoring stations of the National Stream Quality Accounting Network are located throughout the geopressured region (Ficke and Hankenson, 1975). Table A-13 sumarizes available information on various water quality paramenters, using selected streams to illustrate distribution of average discharges, total dissolved solids, dissolved chlorides, dissolved sulfates, and 
Table A-13. Water Quality Characteristics of Selected Streams in the Study Area.

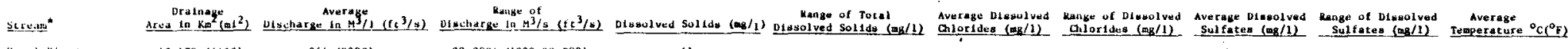

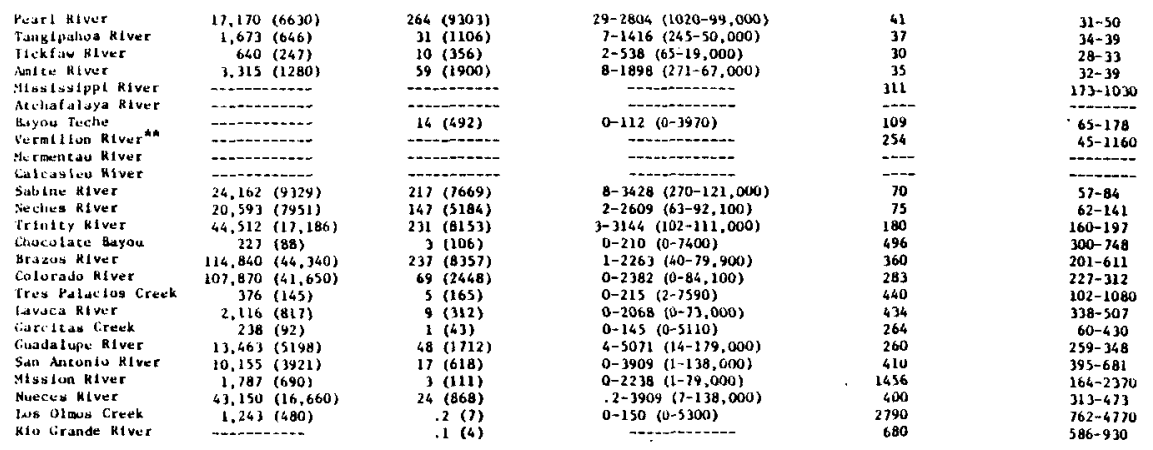

6.3
6.3
4.5
5.5
75
91
16
101
193
1933
15
11
22
125
86
46
128
128
38
28
70
704
91
708
140
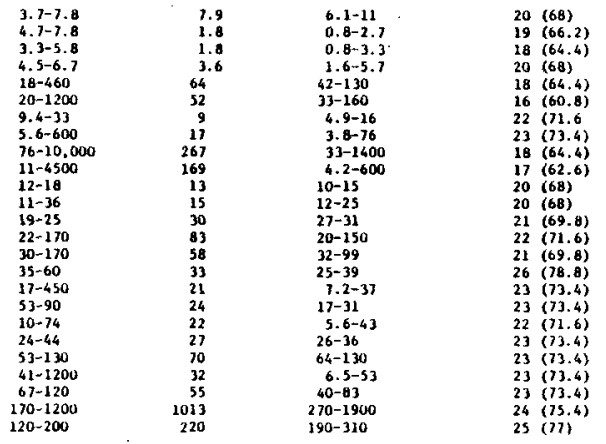

ciangina lociation on plaste 1

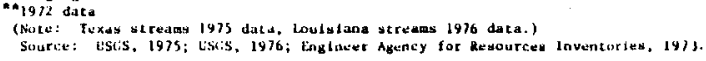


water temperatures. Range of discharges of the streams and range of concentrations of the dissolved constituents are also shown. Streams in the eastern section. of the region are of extremely good quality (Pearl, Tangipahoa, Tickfaw, Amite Rivers). Concentrations increase markedly in the Mississippi River and other streams, with chlorides and sulfates being highest in the Vermilion, Mermentau, Calcasieu, Mission and Rio Grande Rivers, Chocolate Bayou, Tres Palacios and Los Olmos Creeks. Total dissolved solids concentrations and water temperatures increase westward, reflecting the changing character of the geomorphic and climatic factors. Average discharges are a function of drainage area and are thus not comparative for some purposes. They do, however, relate to the assimilative capabilities of the streams. Range of discharge is comparative across the region, and illustrates that streams in the eastern section have less variability and fewer low flow extremes than those in the western areas, producing better assimilative and dilution capabilities in the eastern section streams.

Table A-14 gives Environmental Protection Agency suggested standards against which levels of various water quality parameters are compared to judge suitability of the water for certain uses. The standards given in the table apply for drinking water and for sustaining aquatic life.

Solids dissolved in water above the concentrations produced by natural circumstances are generally referred to as "pollutants." As Kazmann (1972) points out, however, if these substances create no costs or problems with use, the word "pollutant" is too harsh. Natural composition of water varies widely across the coastal region, and water that is unsuitable for an industry because of its dissolved constituents can be potable without any processing at all, and brackish 
water that is undrinkable is totally adequate to sustain fish life including shellfish.

Table A-14. Water Quality Criteria for Selected Variables

\begin{tabular}{|lc|}
\hline \multicolumn{1}{|c|}{ Parameter } & Tolerance Level \\
\hline Total Dissolved Solids & $500 \mathrm{mg} / 1$ \\
Chlorides & $250 \mathrm{mg} / 1$ \\
Sulfates & $250 \mathrm{mg} / 1$ \\
Temperature & $1^{\circ} \mathrm{C}\left(1.8^{\circ} \mathrm{F}\right)$ increase in \\
& average, not to exceed \\
& summer maximum* \\
\hline
\end{tabular}

* Summer maximum varies with location. Texas Water Quality Board (1976) reports a maximum for coastal waters in south Texas of $35^{\circ} \mathrm{C}\left(95^{\circ} \mathrm{F}\right)$ and for streams $2.8^{\circ} \mathrm{C}\left(5^{\circ} \mathrm{F}\right)$ above ambient temperature. Louisiana Stream Control Commission (1973) reports respective maxima of $35^{\circ} \mathrm{C}\left(95^{\circ} \mathrm{F}\right)$ and $2.2^{\circ} \mathrm{C}$ $\left(4^{\circ} \mathrm{F}\right)$ Oct.-May, $0.8^{\circ} \mathrm{C}\left(1.5^{\circ} \mathrm{F}\right)$ June-Sept.

Source: Environmental Protection Agency, 1976.

Pollution is widespread in coastal marshes, estuaries, and streams of the geopressured region. $0 i l$ and grease are spilled and leaked from wells, barges, pipelines, and pumps. Access canals increase saltwater intrusion interfere with water exchange and mixing, destroy fisheries' habitat, and increase turbidities. Construction of water control projects for navigation and flood control distorts hydrologic regimes and thereby increases pollution from municipal and industrial discharges by destroying the natural flushing action of the surface waters.

Both Louisiana and Texas state governments have identified their most polluted streams and the major causes of the pollution (Office of Water Planning and 
Standards, 1974). Louisiana stream segments identified are:

(1) Calcasieu River-from Oakdale to Gulf of Mexico - most acute in the state; oxygen depletion, high coliform count, and oily matierals;

(2) Mississippi River from Huey P. Long Bridge to Head of Passes - high coliform count from upriver discharges and extremely heavy barge and ship traffic;

(3) Lake Pontchartrain - New Orleans drainage canals discharge sewage and storm runoff;

(4) Bayou Terrebonne - sugar mill effluent, raw sewage, seafood processing; and

(5) Vermilion River - sugar mill effluent, raw sewage, menhaden processing and shrimp packing cause seasonal oxygen depletion and chronic bacterial problems.

Texas has many pollution problems with the potential for developing more. Because of aridity, much water reuse for irrigation is necessary, causing high levels of salinity, nutrient loading, and sediment loading. Additionally, an increased rate of industrial development, home building, feed lot expansion and poor treatment facilities are resulting in increasing toxic levels and nutrient and sediment loads. The Houston Ship Channel is listed as one of the 10 "dirtiest" streams in the United States (Geraghty ex al., 1973). The Brazos River has been identified as having the hardest water of 22 major streams surveyed in the nation, and both the Brazos and Rio Grande Rivers are higher in turbidity, dissolved solids, and phosphorous than the other major waterways. Information in Table A-13 shows that some smaller Texas streams contain greater concentrations of pollutants than either the Brazos or Rio Grande, but that none of the Louisiana streams do. Both states have published standards for individual 
streams within the states, and the criteria vary with the streams' natural conditions (Louisiana Stream Commission, 1973; Texas Water Quality Board, 1976). Those water bodies with designated water quality problems are mapped and shown on Plate 7.

\subsubsection{Water Resource Development}

Economic development and water resource development are closely intertwined. The natural setting produces abundant water of sufficient quality for municipal, industrial, agricultural, transportation, and recreation uses in most parts of the geopressured region, though the farthest western parts experience perpetual shortages for these uses. As use of water resources has increased, development has increased to control saltwater intrusion, flooding, and erosion, and to provide efficient drainage systems. In addition, surface water supplies, though still available, are fast becoming committed by appropriation permits in many parts of the Texas coastal zone. Water use in Texas is governed by both riparian and appropriation doctrines; riparian doctrines alone predominate in Louisiana.

Uses of the surface waters in the region have been surveyed in some detail for many, but not all, of the basins. Available information is summarized in Table A-15. The great dependence on groundwater supplies for municipal and industrial use in Texas is evident. Specific lists of municipal and industrial users, streams they withdraw from, and amounts of water they use, are available for each Texas county in the coastal zone and for a few of the Louisiana coastal river basins (Texas Water Development Board, 1970; Engineer Agency for Resources Inventories, 1973). Amounts of surface water used for irrigation are available for each of the Texas coastal basins and for three water resource planning areas in Louisiana which include the coastal basins (Texas Water Development Board, 
1975; Lower Mississippi Region Comprehensive Study Comission, 1974). Stream segments used for domestic raw water supply, the highest classification of water use regarding water quality criteria as designated by the respective state agencies, are indicated on Plate 7. The distribution of surface supply sources emphasizes the heavy use of groundwater in the coastal region.

Table A-15. Surface Water Uses in $\mathrm{hm} 3 / \mathrm{yr}$ (A-F/yr.)

\begin{tabular}{|lccl|}
\hline & Municipal & Industrial & Irrigation \\
\hline Texas Coastal Zone* & $199(161,091)$ & $1,744(1,414,315)$ & $2,575(1,088,317)$ \\
La. Coastal Zone** & $259(210,000)$ & $13,125(10,644,827)$ & $1,051(852,310)$ \\
\hline
\end{tabular}

$* 1968$ data
$* * 1970$ data

Source: Texas Water Development Board, 1970; LMR Comprehensive Study Commission, 1974.

Point sources of discharge, municipalities and industrialdischargers, amount of effluent, streams affected, and principal pollutants discharged are available in detail for both Louisiana and Texas (Office of Water Planning and Standards, 1974). Major types of industries discharging effluent into surface waterways are listed in Table A-16.

Recreational use of the surface waters in the region includes primary and secondary utilization in all segments. There are a total of 84 surface reservoirs across the region which are used for multiple purposes including recreation and wildlife management (Texas Water Development Board, 1968; Blakely and Kunze, 1971; U.S. Department of Agriculture, 1974). Wild, natural and scenic, and recreation waterways have been designated in each state (Louisiana Wild Life and 
Fisheries Commission, 1976; Texas Parks and Wildlife Department, 1973). Those streams so designated in the geothermal region are indicated on Plate 7.

Table A-16. Type and Number of Major Industrial Discharges by State

\begin{tabular}{|lrr|}
\hline \multicolumn{1}{|c}{ Industry } & Louisiana & Texas \\
\hline Oil and Gas Mining & 354 & 373 \\
Non-metallic Mineral Mining & 9 & 22 \\
Preserved Fruits and Vegetables & 13 & 4 \\
Sugar and Confecticnary Products & 42 & 1 \\
Seafood Products & 25 & 1 \\
Miscellaneous Food and Beverages & 15 & 5 \\
Lumber and Wood Products & 19 & 12 \\
Paper and Allied Products & 19 & 11 \\
Chemicals and Allied Products & 80 & 107 \\
Petroleum and Coal Products & 19 & 47 \\
Stones, Clay, Glass Products & 46 & 40 \\
Electric and Gas Utilities & 74 & 95 \\
Water and Sanitary Services & 38 & 10 \\
Government & 18 & 86 \\
& 771 & 814 \\
\hline
\end{tabular}

Source: Office of Water Planning and Standards, 1974 .

\subsection{Terrestrial Ecology}

The distribution of coastal vegetation of Louisiana and Texas is a result of both geologic events and historic and current land uses. Before man's influence the Pleistocene and older deposits were mainly covered with shortleaf pine, longleaf pine, hardwoods and prairie associations. Recent deposits were covered with hardwoods, swamps and marshes (Penfound, 1944). In historic times the shortleaf and longleaf pines have decreased in favor of the loblolly pine-hardwoods forest type. The prairies have been largely replaced with agricultural and range lands. Therefore, an attempt is made in this report to correlate vegetation types with 
geological and soil formation. The large variety of habitats encompassed by our study area provides for considerable diversity of wildlife species. On the accompanying vegetation map (Plate 8 ), the areas that have been changed to intensive human uses such as agriculture, range, or urban centers, are blank and are discussed in Section 2.6, Land Use. Endangered fauna are indicated on Plate 9. All other lands are divided into the appropriate vegetation type and a discussion follows in Sections 2.3 and 2.4. The speciescomposttion and soils of the vegetation types are summarized in Table A-17.

\subsubsection{Wetlands}

Deciduous Forest - The deriduous forests in the study area are found on Pleistocene terraces, alluvial ridges, cheniers, beach ridges, salt domes, Indian middens, and spoil areas. Those associated with Pleistocene sediments will be discussed in Section 2.3.2.

Bottomland hardwoods are deciduous forests found on better-drained alluvial areas with moist soil near seasonally flooding streams and on some abandoned river courses. They thrive in areas with short, occasional flooding. The hydroperiod and soil moisture conditions determine what kind of vegetation will be present. It is a highly productive ecosystem (Conner and Day, 1976).

The white-tailed deer (Odocoileus virginianus) is the principal big game of the bottomland forest because these provide the best deer habitat. According to the U.S. Department of Agriculture, 1976, deer carrying capacities vary inversely with basal area, stocking, and crown cover, and vary directly with rotation age and soil fertility. The same source gives a carrying capacity of one deer per 6 hectares (15 acres) of ungrazed bottomland forest habitat. Loblo1ly-shortleaf pine was 
rated at one deer per 14 hectares (35 acres) and longleaf-slash pine at one per 20 hectares (50 acres), both ungrazed. Range, a classification indluding both prairie and marsh, was rated at one deer per 81 hectares (200 acres) (U.S. Department of Agriculture, 1974).

The swamp rabbit (Sylvilayus aquaticus) occupies bottomland forests and marshes (Lowery, 1974a). They are taken indiscriminantly by hunters along with the cottontails as "rabbits" and kill surveys do not allow us to examine the relative harvest by species. Ranges of the Eastern cottontail and the Audubon cottontail overlap along the south Texas coast and Lower Rio Grande valley. The range of the swamp rabbit extends westward encompassing only the upper two-thirds of the Texas coast.

Bottomland hardwoods support more squirrels per unit of area than any other habitat type. Populations of from 1.5 to 2.5 squirrels per 0.4 hectare ( 1 acre) were estimated for southwest Louisiana bottomlands (U.S. Department of Agriculture, 1974). Two squirrel species are classed as game in this area of Louisiana and Texas. They are the Eastern gray squirrel (Sciurus carolinensis) and the fox squirre1 (Sciurus niger) (Davis, 1974, and Lowery, 1974a). They require trees as a component of their habitat and so are absent from the extensive marshes, prairies and brushlands. The Louisiana Department of Wildlife and Fisheries reveals that more hunting tri-ps are made annually for squirrels than for deer.

The woodcock (Philohela minor), while classed as a shorebird, is a bird of thicket by day and does nocturnal feeding in fields at night (Lowery, 1974b). It is a prized game bird in the Eastern United States. Severe winters often cause a good many woodcock to push all the way down to the beach ridges near the Gulf 
where they concentrate until the weather moderates. Since much of their food is comprised of earthworms which are obtained by probing in soft ground with their specialized beak, frozen ground greatly inhibits their feeding.

Bald cypress (Taxodium distichum) and water tupelo (Nyssa aquatica) occur mixed with blackgum (Nyssa triflora), sweetgum (Liquidambar styraciflora), maple (Acer rubrum var. drummondii), and oaks (Quercus sp.) to make up more than $50 \%$ of the stand in particularly molst areas. On the natural levees next to streams, live oak (Quercus virginianus), cottonwood (Populus heterophylla), willow (Salix sp.), elm (Ulmus, spp.), and maple (Acer spp.) are found (Table A-17). Where light penetrates the canopy there is a dense groundcover of herbs and vines. The deciduous forest vegetation may also occur in scattered localities within a swamp or marsh. Their presence marks an elevation rise of perhaps only a few inches. These rises were formed by a variety of physical and human processes. Scattered mounds mark former habitation sites of Indians who built up areas with shells to form middens. Other scattered and often circular rises were formed by the diapiric movement of salt domes. In western Louisiana, the process of storms and changing Mississippi River courses formed parallel ridges and islands which are remants of former dune ridges. In Texas, similar processes formed fluvial and distributary sand bodies called the strandplain. Farther south, the elevation rises are the basis for the oak mottes. All o: these elevated areas are the base for a live oak association of limited diversity which contrasts sharply with surrounding marshes or prairies. Most of these areas are of too small a scale to show up on the vegetation map (Plate 8). While small in area, these elevation rises are important to wildlife, such as raccoons and deer, that forage in the marsh and seek shelter in the forest. 
The deciduous forest is related to the water courses which formed it. The yearly floods provide nutrients and a sediment supply. Plant germination and growth is dependent upon a change in water levels. Human activities which permanently impound or drain the forest will cause a succession in plant types. Since the upland soils and levees are raised above the marsh they have historically been popular for human settlement. Pines were planted on many areas from which timber had previously been harvested. Thus there are many human activities which have altered this habitat. Large areas of bottomland hardwood and swamp such as the Mississippi River valley and Atchafalaya floodway are being irreversibly changed by leveeing and channelization.

Swamp Forest - Baldcypress once occurred in almost pure stands in the wetter alluvial river bottoms in Louisiana and Texas. Cypress was extensively logged in the early $1900^{\prime}$ 's leaving an expanse of rotting stump and logs which provided a base for germination of red maple (Acer ruburm), pumpkin ash (Fraxinus tomentosa), and water tupelo (Nyssa aquatica). The resultant forest was a more diverse association of cypress, tupelogum, and maple. The main floral components of this system are listed in TableA-17. In Texas, dwarf palmetto (Sabal minor), elms (Ulmus spp.), and mulberry (Morus spp.) became an important part of the flora. Below Matagorda Bay, cypress is an insignificant part of the canopy (McGowen et al., 1967a). Near the Rio Grande, montezuma cypress (Taxodium mucronatum) becomes part of the assemblage (Little, 1971).

Dynamic aspects of the swamp are controlled mainly by water regimes and sunlight. Rain and river waters naturally inundate low-lying swamps. Natural levees and ridges channel the flood waters into the backswamp to slowly drain toward the Gulf. Where artificial levees have restricted river flow, only rainfall now affects water 
Thble A-17. Vegetation of the Study Area.

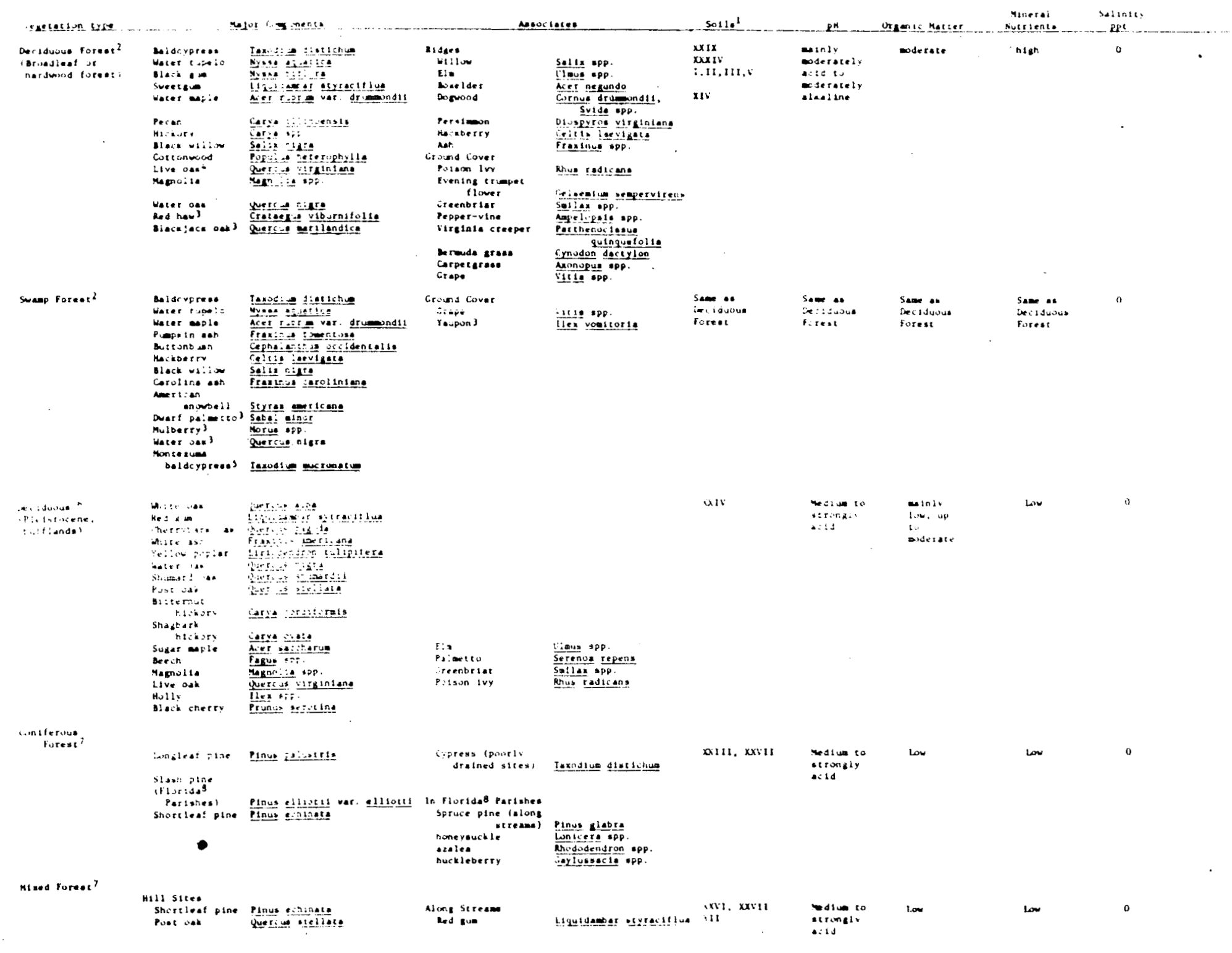


Table A-17. Vegetation of the Study Area, Continued,

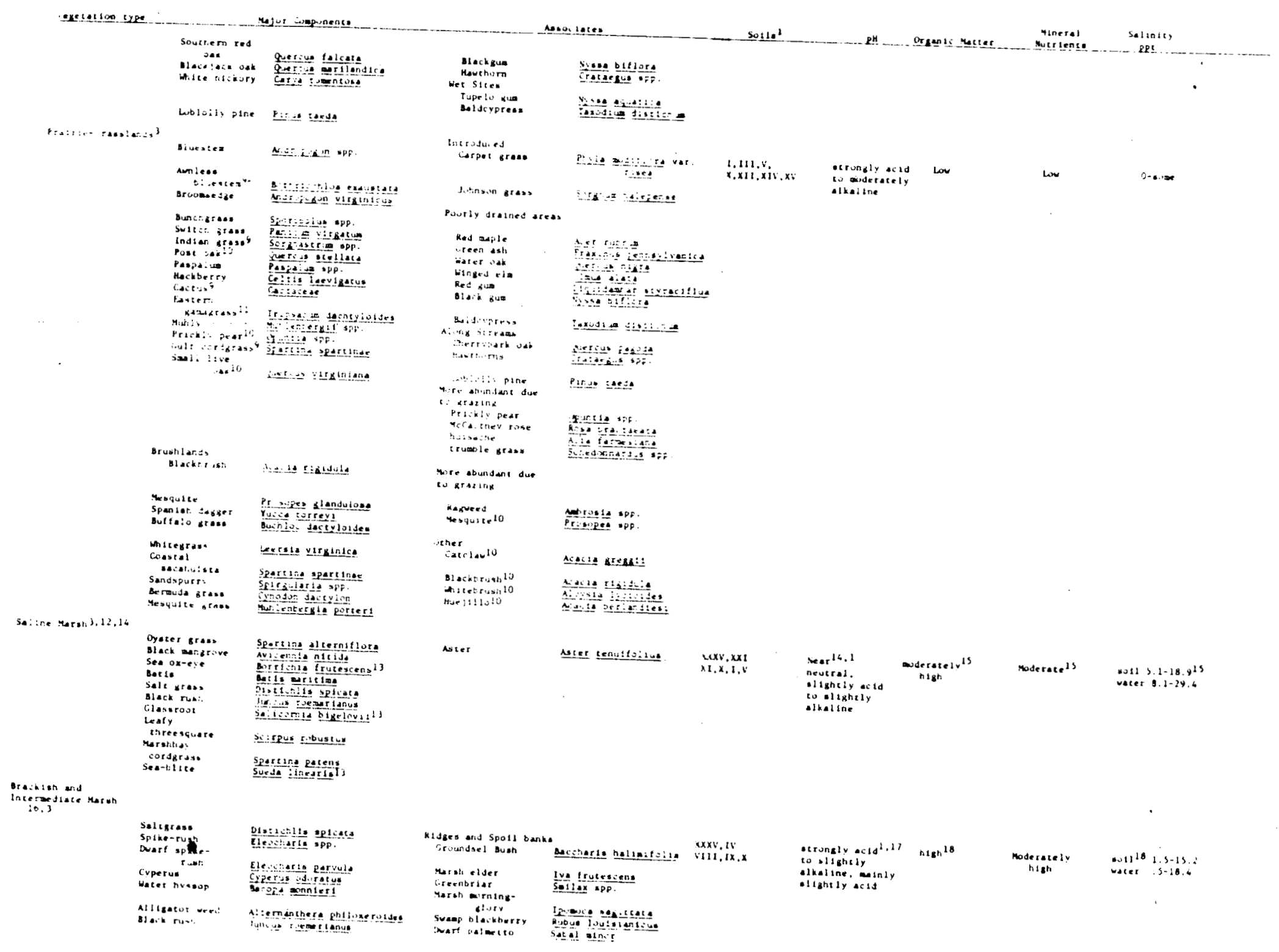


Table A-17. Vegetation of the Study Area, Continued,

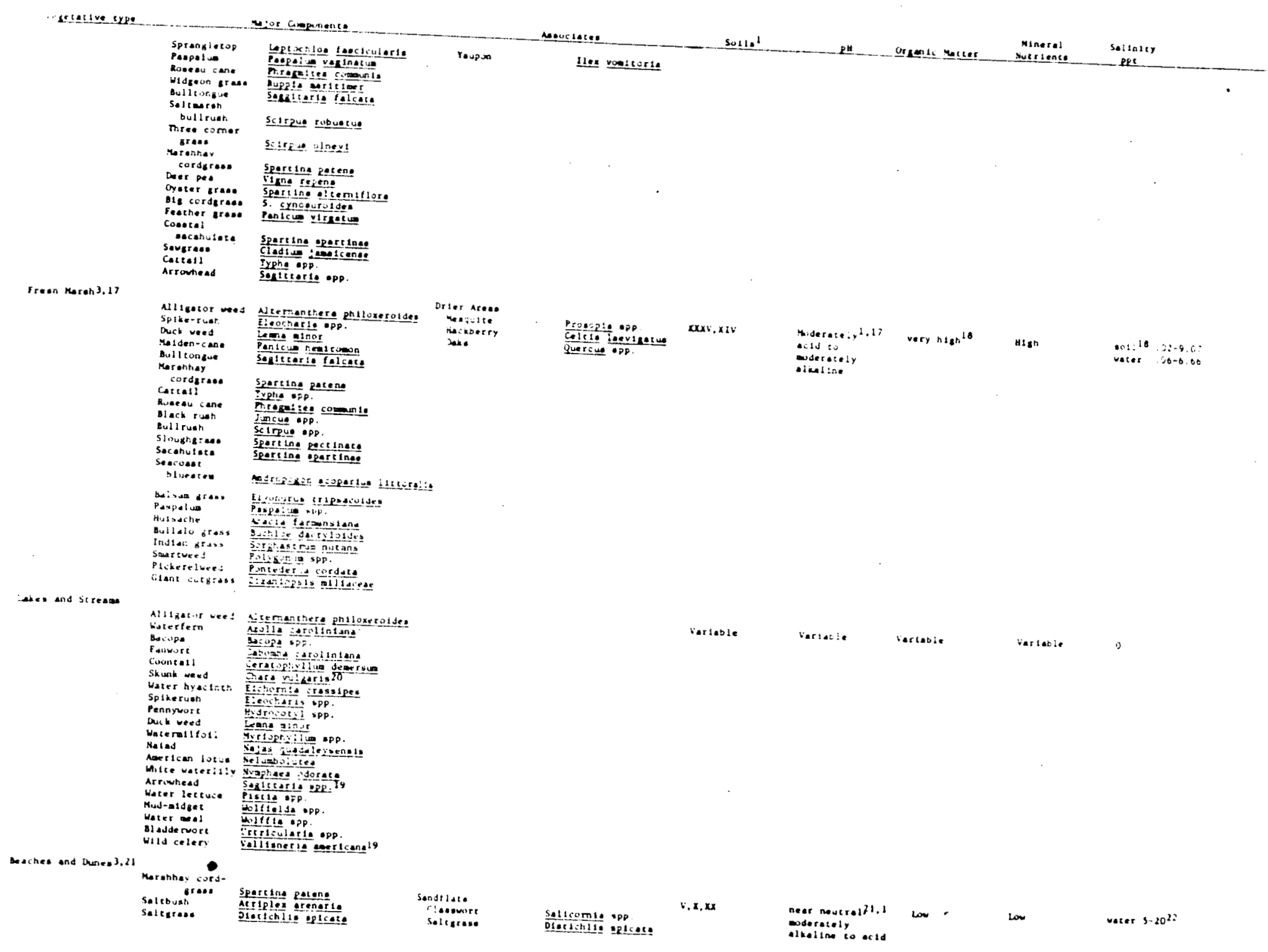


Table A-17. Vegetation of the Study Area. Continued.

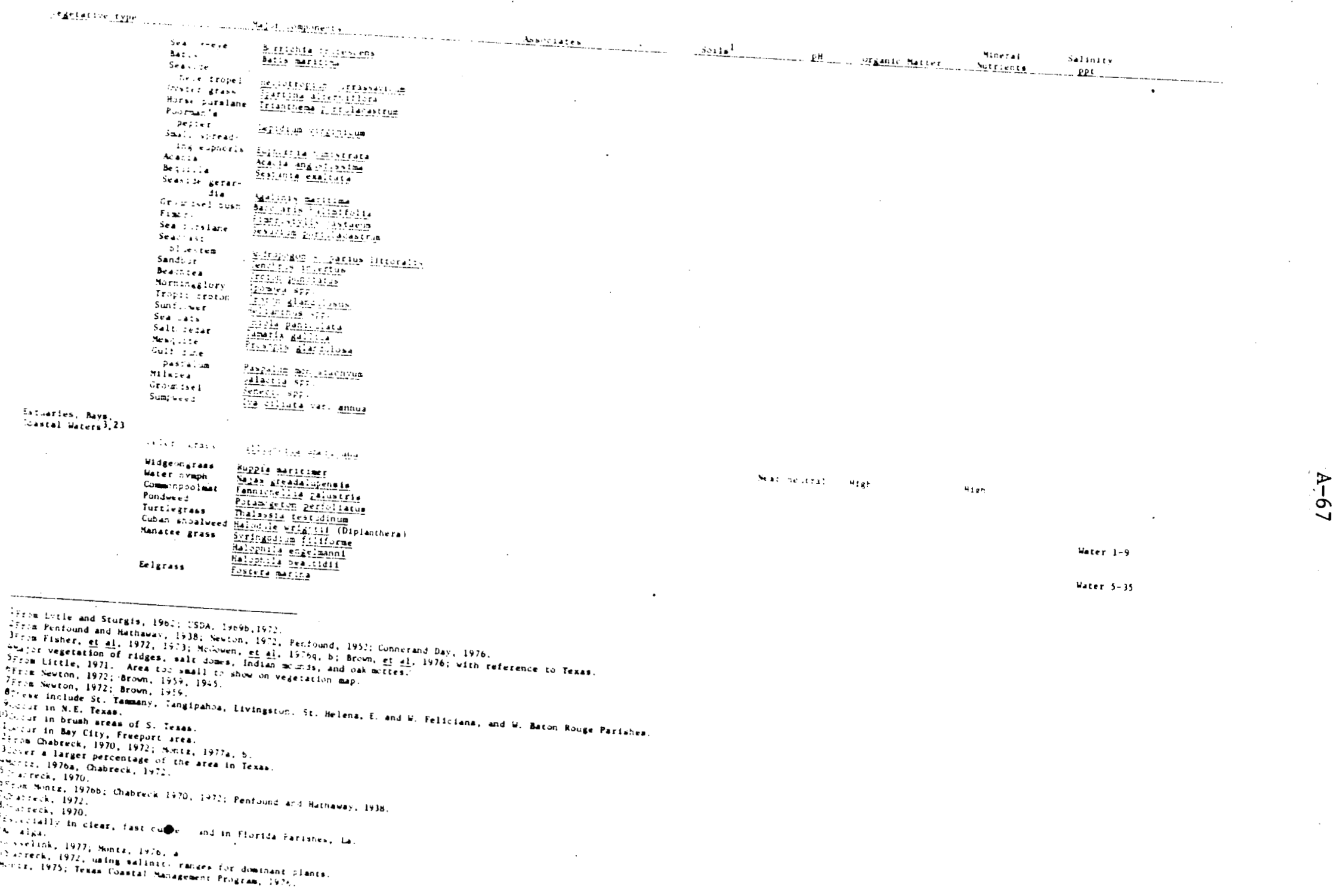




$$
\text { A-68 }
$$

levels. Canals within the swamp have allowed an accelerated drainage of some areas while leaving nearby areas permanently impounded. Wildlife are abundant in this vegetation area, especially crawfish, mink, raccoons, shorebirds, colonial nesting water birds, deer and alligators.

\subsubsection{Pleistocene}

Deciduous Forest - Only a small portion of the deciduous forest in the study area would be considered upland hardwoods or blufflands. This type occurs in western Livingston, East Baton Rouge, St. Landry, and Lafayette Parishes. It is found on the Mississippi terrace and Loessial hill soils, a brown, silty loam. Its unique association is characterized by a highly diverse flora of which over $50 \%$ of the species present are upland oak and hickory (Carya spp.) (U.S. Department of Agriculture, 1969a). Other common associates include gum, elm, and maple, with an understory of palmetto (Serenoa repens), greenbriar (Smilax spp.), and poison ivy (Rhus radicans) (TableA-17). Much of this vegetation type has been converted to farmland or pasture.

Coniferous Forest - Longleaf pine (Pinus palustris) and slash pine (Pinus elliotti var. elliottii) make up more than $50 \%$ of the stand and are associated with other southern pines, oak, and gum. Coniferous forest occurs on coastal plain or flatwoods soils which are sandy loams or sandy clay loams, medium to strongly acid and low in organic matter. The association grows best on soils with poor surface drainage.

When left unchanged by management practices or frequent fires this forest will change to a hardwood association. Hardwoods are favored by wildlife while pines are valuable for their saw timber and pulpwood resources. This has led to 
management practices such as controlled burning or selective harvest to generally enhance timber production and sometimes to influence wildlife habitat. Heavy grazing has influenced forest composition in some instances. While not as extensive as most of the other ecosystems in the study area, this type is nonetheless very valuable from a renewable resource standpoint. The largest area occurs in St. Tammany Parish, Louisiana.

Mixed Forest - The mixed forest in Louisiana and northeast Texas is a loblolly pine (Pinus taeda) - shortleaf pine (Pinus echinata) forest, which is associated with hardwoods, brushy understory and grasses. It occurs on acid clayey and loamy soils such as Mississippi terrace and flatwoods and it colonizes disturbed areas. Of the pines, loblolly prefer moist sites. Over $50 \%$ of the stand is made up of loblolly, shortleaf, and other southern pines, the remaining trees are mainly oak, hickory and gum (TableA-17).

Pines are less shade-tolerant than the associated hardwoods. This forest type is a mid-successional type. If an area becomes clear, pines will invade. The soil moisture conditions determine the kind of pine that will invade. As they grow and develop a canopy, the hardwoods form an understory. Hardwoods may photosynthesize more efficiently in lower sunlight than pines. Shading from the overstory prevents further germination of pines. Left undisturbed the final product would be a hardwood forest. But fire, grazing, lumbering, and clearing may arrest or change the pattern. Frequent fire and grazing reduces the hardwood understory and favors a pine forest. Selective lumbering of the pines for pulpwood may speed the transition into a hardwood climax. Clearcutting returns the forest to its initial stages of succession. In clearcut mixed pine-hardwood forest, hardwoods tend to dominate the next stage because of their rapid regeneration from coppice sprouts. 
Many wildife species occur in this forest type. It is the preferred habitat of the turkey (Meleagris spp.) which occurs in the eastern part of the study area from the Pearl River Wildlife Management Area across the pine flatwoods and to the pine-hardwoods of the terrace lands. They are absent from the Lake Maurepas-Blind River swamp system and across the lower Mississippi-Atchafalaya floodplain. They have been recently established in Calcasieu Parish and are expanding throughout the southwest Louisiana pinelands and stands of stream bottom hardwoods (Dan Dennett, 1977, personal communication). Turkeys are absent from the heavily industrialized upper Texas coast but again become important in the brushland adjacent to the lower coast (Oberholser, 1974).

The turkey native to the terrace lands of east Texas and to Louisiana is the Eastern wild turkey (Meleagris gallopavo sylvestris), while the lower portion of our area is inhabited by the Rio Grande turkey (Meleagris gallopavo intermedia, Oberholser, 1974). Habitat destruction or deterioration, poaching and disturbance during nesting have all proven detrimental to the turkey.

While squirrels occur in this habitat and are more abundant here than in the coniferous forest, they do not reach comparable concentrations to those in the bluffland deciduous and bottomland hardwood habitat.

Prairie-Grasslands - Prairies once occupied extensive areas of western Louisiana and coastal Texas. They occurred on coastal prairie soils which are a silt loam or silty clay surface soil with underlying silty clay, moderate organic matter and neutral to slight acidity. Original species included bluestem (Andropogon spp.), broomsedge (Andropogon virginicus), and switch grass (Panicum virgatum) (Table A-17). Most of this association has been converted to crops and pasture. 
Rice, soybeans, cotton and sugarcane have replaced much of the prairie. Overgrazing has caused a shift in species and many less desirable plants such as ragweed (Ambrosia spp.), tumblegrass (Schedonnardus spp.), broomsedge (Anropogon spp.) and mesquite (Prosopis spp.). There is no native prairie left in Louisiana.

Towards the west the climate is drier and this is reflected in the vegetation. In Texas, prickly pear cactus (Opuntia spp.), mesquite and huisache (Acacia farmesiana) becomes part of the association. Below Nueces County, the inland portions of the coastal counties are part of the south Texas plain vegetation area (Texas Agricultural Extension Service, 1975). This area is known as brush country or chaparral. The principle plants are mesquite, small live oak, prickly pear cactus, catclaw (Acacia greggii), huisache, blackbrush (Acacia rigidula). Originally, this area was warm season bunchgrass (Sporobolus spp.), in post oak (Quercus stellata), live oak, and mesquite savannas. But years of cattle grazing have caused brush to predominate. Untouched grasslands are a vanishing type. They are being quickly converted to human uses.

The Eastern cottontail (Sylvilayus floridamus) and the Audubon cottontail (Sylvilayus auduboni) occupy different niches of this region. The Eastern cottontail occurs in every county and parish and prefers brushy or weedy cover interspersed with grassy openings. The Audubon cottontail occurrs only in the southern end of the study area and appears in habitats ranging from grasslands to creosote brush and cactus deserts (Davis, 1974).

The bobwhite quail (Colinus virginiana) is present around agriculture, in pine and oak-pine forests, on many of the beach ridges, as well as in the uncultivated prairies and the brushlands. They have a high breeding potential and can tolerate 
heavy annual harvest so long as their habitat conditions remain favorable (Lowery, 1974b). More efficient farming, pine monoculture, the absence of fire and conversion of habitat to urban developments have been detrimental to quail.

Both the mourning dove (Zenaida macroura) and white-winged dove (Zenaida asiatica) occur in our study area. The mourning dove occurs in both states and is absent only from dense forest, swamps, and marshes. The white-winged dove is only a casual fall or winter visitor to the upper Texas coast or to the state of Louisiana but is a common breeding bird in the southwestem part of the study area. Adult waterfowl hunters in Texas, during a three-year survey period, 1966-67 and 1968-69, bagged an average of 178,656 white-winged dove (Zenaida asiatica) (U.S. Department of the Interior, 1971).

Two birds that are humted as game occur only in the southern part of the study area. The chachalaca (Ortalis vetula) is a pheasant-sized, small-headed, longtailed bird of brushlands and forests. The ring-necked pheasant (Phasianus colchicus), a native of Asia, has been established in many parts of the United States and was legal game in Hidalgo and Matagorda counties during the 1976-77 hunting season (Texas Parks and Wildlife, 1976).

Two species of birds occur in the prairie-grassland habitat which might be considered unique or important because of their restricted range. They are Audubon's caracara (Caracara cheriway) and the black francolin (Francolinus francolinus asiae).

The Audubon's caracara is a common bird near the middle and lower coasts of Texas (Oberholser, 1974) but is known as a Louisiana breeding bird only from Gum Cove, Cameron Parish (Lowery, 1974a, Murry, personal communication). Caracaras are members of the falcon family but subsist largely on carrion. 
The black francolin (Francolinus francolinus asiae) is well-established as a breeding bird on the Gum Cove ridge and 16-km to 24-km (10-mi to 15-mi) from the initial release area (Palermo and Doster, 1970). According to Murry (personal communication) this bird has withstood considerable adversity in becoming established and appears to have found a niche in that particular habitat.

\subsection{Aquatic Ecology}

\subsubsection{Wetlands}

Louisiana and Texas have a large percentage (estimate 3 ) of the marsh and estuarine area of the United States. These highly productive marshes are responsible for making Louisiana the leading state in commercial fisheries yield (poundage). The marshes are dominated by grasses, sedges and rushes (Palmisano, 1971, Chabreck, 1970). The marsh community composition reflects the age of the marsh and its soil and water environment. The classification system used in this report corresponds to that of Chabreck, 1970, 1972, after Penfound and Hathaway, 1938.

Physical gradients are characteristic of marsh systems, with salinity and elevation being the most apparent gradients. Water ranging from fresh to saline connects the marsh types. Salinity is determined by the level and frequency of flooding from both the upland fresh waters and the Gulf saltwater. An east to west precipitation gradient also exists. which affects the annual water surplus and, thus, the areal extent of the coastal marshes.

The tides, winds, rainfall, waves, original substrata, and topography determine the supply of surface water. Major marsh functions are controlled by the interaction of surface water and solar energy. Since the flooding waters bring a supply of sediment, salts, detritus, and nutrients and carry away detritus and waste 
products, the elevations, soil types, and organic matter accumulation rates are, in turn, related to the water regime. This water-dominated or wetland system is highly productive. Any alterations in the water quality, quantity, or timing brought about by channels, levees, ditches, water pumpage, wastes inputs or nutrient discharge, river course changes, sediment supply changes or climatic changes have profound effects on the marsh system which is in equilibrium with external forces.

The coasts of Louisiana and Texas are to a great extent composed of nutrient-rich estuarine waters which, with the surrounding marshes, provide organisms with food, habitat, favorable growth conditions and protection from predators. Important resources include waterfowl, mammals, alligators, fin and shellfish as well as unique and specialized species that are wetland dependent.

Lowery (1974b) lists 377 species of birds as occurring in Louisiana and Peterson (1960) claims 487 "basic":species that have been recorded for Texas five or more times. Besides these birds' beneficial feeding habits, they have a tremendous value in their role in providing outdoor recreation. Birding is growing in popularity and coastal ridges and coastal wetlands are excellent places to view birds during migration or living in specialized wetland niches that are largely unavailable near the domicile of the birder. Many migrant birds go south of the United States through Louisiana or Texas and cross our study area.

The study area comprises the terminal ends of two of the major administrative "flyways." Louisiana is in the Mississippi Flyway and Texas is in the Central Flyway. While many birds that use these flyways spend portions of the winter south of the United States border, the wetlands, especially the coastal wetlands, play a major role in the maintenance of the continental waterfowl population. 
Waterfowl that regularly nest along the coast or inland swamps of both states include the mottled duck (Anas fulvigula), wood duck (Aix sponsa), hooded merganser (Lophodytes cucullatys), and the fulvous tree-duck (Dendrocygna bicolor). Not known as a breeding bird in Louisiana, the black-bellied tree-duck (Dendrocygna autumnalis) summers and nests on the Texas coast. These birds migrate to the south during the winter as does the fulvous tree-duck.

Diving ducks make heavy use of bays, lakes, and near-shore waters. The lesser scaup (Aytha affinis) is the principal diving duck of coastal Louisiana and the upper Texas coast, with Lake Pontchartrain and Lake Borgne major concentration areas. The redhead (Aythya americana) is more important in the diving duck harvest along the lower Texas coast (U.S. Department of the Interior). Of the estimated 560,000 redheads in North America, 300,000 winter in the Laguna Madre of Texas (Bellrose, 1976).

Dabbling ducks: greatly outnumber diving ducks in the total kill for the coasts of both states but the ratio between divers and dabblers changes drastically along the coast. The ratio between divers and dabblers by groups of counties and parishes going from west to east is indicated in Table A-18. The total duck kill as well as the largest percentage of dabbling ducks is in the chenier plain portion of coastal counties and parishes (Table A-18).

Geese winter along the coasts of both Louisiana and Texas with lesser snow goose (Chen caerulescens) the most numerous. Snow geese are typically marsh birds that grub for roots and rhizomes of marsh plants. They are especially attracted to recent burns (0'Neil, 1949). 
Table A-18. Distribution of Diving and Dabbling Ducks as Indicated by Harvest Trends, Louisiana and Texas Coasts - 1961-1970 1

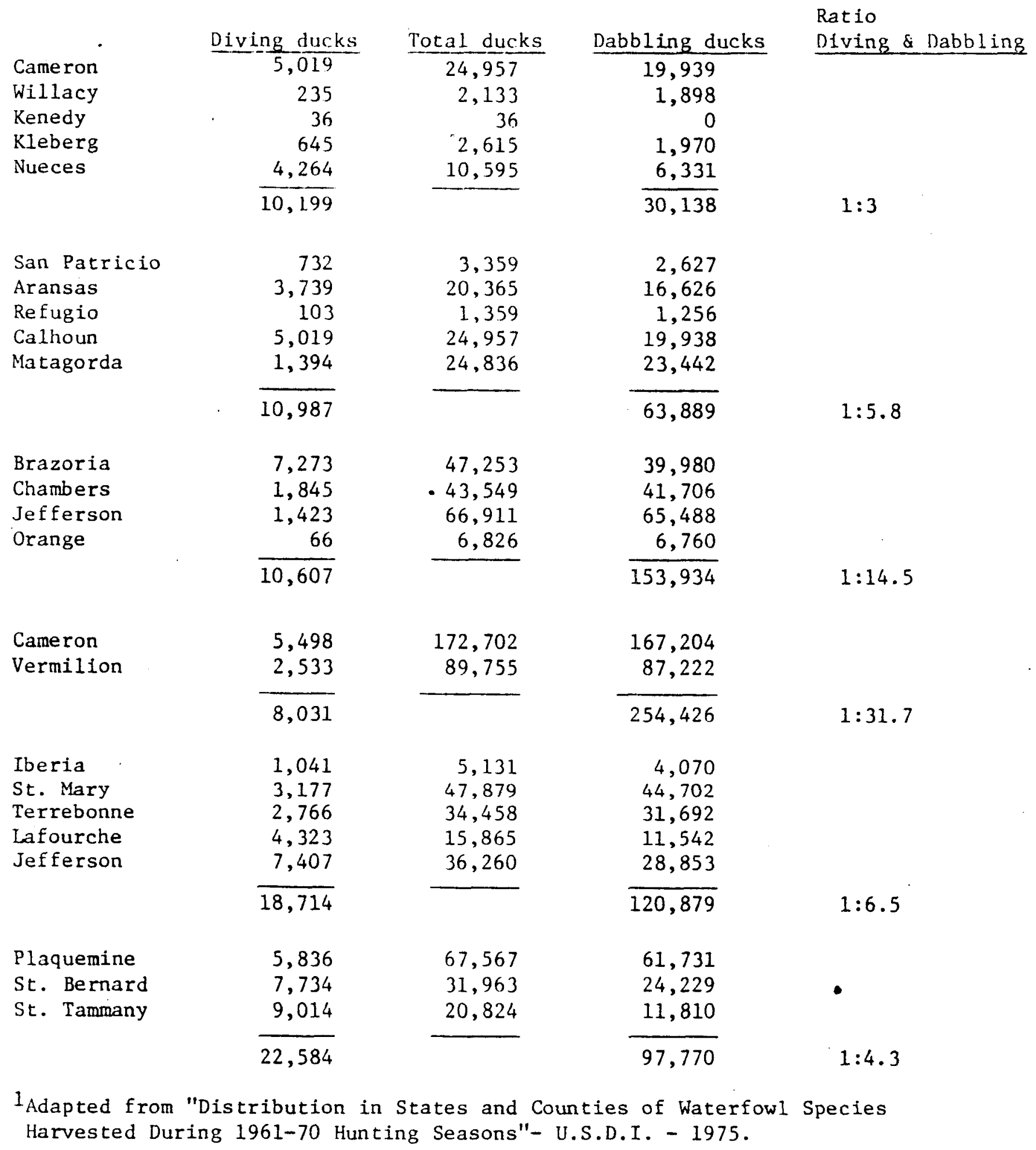


The white-fronted goose (Anser albifrons) and the Canada goose (Branta canadensis) are more associated with agriculture than are snow geese (Bellrose, 1976). While white-fronts are hunted in both states, the Canada goose, whose numbers in Louisiana have been diminished by changes in migration patterns, has enjoyed protection from legal hunting since the early 1960's (Lowery, 1974b). A resident population has been established on and around the Rockefeller Refuge in Cameron Parish (Lowery, 1974b).

The average bag of various geese by counties and parishes is indicated on Table A-18. The differential harvest by species as well as by color phase in the case of the snow goose is shown.

Rails include the clapper rail (Rallus longiros) of saline marshes, the king rail (Rallus elegans) of fresh or intermediate wetlands, the Virginia rail (Rallus Iimicola), a migrant that utilizes salt marshes, and the small sora rail (Porzana carolina), also a migrant but who frequents both fresh and saline marshes (Lowery, 1974b). Despite liberal hunting regulations on the preceding birds, the hunting for rails in Louisiana is relatively light (U.S. Department of Agriculture, 1974). However, as light as gunning may be "...Louisiana, Florida and New Jersey stand out as important rail hunting states," according to U.S. Fish and Wildlife Service surveys (U.S. Department of the Interior, 1971) where 5.99 rails are bagged per hunter per season.

Both the common gallinule (Gallinula chloropus) and the purple gallinule (Porphyrula martinica) are present and classed as game birds in Louisiana and Texas. Virtually all of the gallinule harvest in each state comes from along or near the coastal wetlands. Gallinules are considered to be 1ightly hunted in Louisiana with an annual harvest of 10,000 estimated (U.S. Department of Agriculture, 1974). Most purple gallinules migrate southward in winter and some common 
gallinules also migrate. The purple commonly nests in rice fields while the common prefers marshes (Lowery, 1974b).

The common snipe (Capella gallinago) is a regular winter resident of wet meadows and marshes (Lowery, 1974b). The highest kill by adult waterfowl hunters during a five-year survey period was 111,481 in Louisiana and 21,008 in Texas. Some of the kill represented by these estimates occurred outside our area of interest (U.S. Department of the Interior, 1971).

Colonial Sea and Wading Birds - Coastal sea and wading bird rookeries in Texas and Louisiana were surveyed during the 1976 breeding season. Approximate locations for concentrations of colonies are indicated on Plate 9. Areas with high densities of bird colonies are circled. The Texas and Louisiana surveys were done independently of each other.

Mammals - The fur resources of coastal Louisiana and the upper Texas coast are very valuable. Two major coastal species, nutria (Myocastor coypus), and the common muskrat (Ondatra zibethicus), lead in value. During the 1974-75 trapping season in Texas, 12,197 nutria pelts worth $\$ 30,248.50$ and 16,622 muskrat pelts worth $\$ 41,223$ were estimated to have been harvested (Boone, 1975). Louisiana, with a larger acreage of wetlands, reported $1,502,617$ nutria pelts worth $\$ 7,264,394$ and 300,214 muskrat pelts worth $\$ 1,050,695$ (O'Neil and Linscombe, 1975).

More recent data from Louisiana reflect both an increased harvest and higher prices to push the total value, to the trappers, for nutria and muskrat, pelts and meat combined, to $\$ 19,148,925$ for the 1976-77 trapping season (Louisiana Department of Wild Life and Fisheries, 1977). Muskrats reach maximum density in intermediate (brackish marshes while nutria prefer fresh marshes (Palmisano, 1972b). 
The northern raccoon (Procyon lotor) ranks third in number and in value in the coastal areas of Louisiana (Louisiana Department of Wild Life and Fisheries, 1977). In Texas the raccoon surpasses both nutria and muskrat in numbers and in value and provides approximately one-half the total fur catch of Texas. Available Texas data do not allow a breakdown by regions of the state so the importance of the raccoon fur take in the coastal regions can not be precisely evaluated.

The river otter (Lutra canadensis) occurs across the entire coast of Louisiana (Lowery, 1974a) and along the upper and middle coasts of Texas (Davis, 1974). This animal has shown a considerable increase in Louisiana during the past two decades according to catch records. Boone (1974) cites field observations from Texas biologists to indicate a healthy population in remaining habitats there, despite the attempts of fur trappers to heavily exploit them.

Several other fur-bearers are listed in Louisiana and Texas catch records in the coastal area of one or both states. These are North American mink (Mustela vison), Virginia opossum (Didelphis virginiana), Eastern spotted skunk or "civet" (Spilogale putorius), striped skunk (Mephitis mephitis), American beaver (Castor canadensis), red fox (Vulpes fulva), gray fox (Urocyon cinereoargenteus), coyote (Canis 1atrans) (Lowery, 1974a, and Davis, 1974), and in Texas only, the ringtail (Bassariscus astutus), and badger (Taxidea taxus) (Davis, 1974).

Of the four members of the cat family, Felidae, indigenous to the area, only one, the bobcat (Lynx rufus) occurs from the Pearl River system to the Rio Grande. The cougar (Felis concolor stanleyana) has recently ranged from about Galveston Bay north and westward. According to Davis (1974) this animal should receive 
protection by being classed as legal game. The cougar that was once endemic to the Louisiana - East Texas portion of the study area, the Florida panther (Felis concolor coreyi) is classified as endangered by the U.S. Fish and Wildlife Service and is no longer found in this area (Lowery, 1974a). The jaguarundi (Felis jagouaroundi) occurs only in Cameron, Hidalgo, Starr and Willacy Counties of Texas in dense brush. This cat is very rare in the United States (Davis, 1974).

The ocelot (Felis pardalis) has been recorded from several coastal counties of Texas. It is most numerous in the dense chaparral thickets of the brushland adjacent to the lower Texas coast. While not on the Federal endangered list, the ocelot is classified as "endangered" by Texas designation and is given full protection of state law (Davis, 1974).

The American black bear (Ursus americanus) occurs in the Atchafalaya basin of Louisiana (Lowery, 1974a) and has been reported from Willacy and Kleberg Counties of south Texas (Davis, 1974). During the 1976-77 hunting seasons bear were not legal game anywhere in the Louisiana portion of the study area but bear hunting with a season bag limit of one bear was allowed in a number of south Texas counties. The collared peccary or javelina (Pecari tajecu) occurs and is hunted as a game animal in the southern part of the study area (Davis, 1974, and Texas Parks and Wildlife, 1976).

Table A-19 is a list of the mammals occurring in the study area. Alligators - The American alligator (Alligator mississippiensis), recently classed as "endangered" throughout its range, has been reclassified as "threatened" in portions of its range including the entire coastal area of Louisiana and Texas (Federal Register, 1977, Vol. 42, No. 6, pp. 2071-2077). 
Table A-1:9

Mammals Occurring in Study Area of Louisiana and Texas (Excluding Marine Mammals)

From W. B. Davis, 1974 and George W. Lowery, Jr., 1974

Common Name

Virginia opossum

Eastern mole

Short-tailed shrew

Least shrew

Desert shrew

Leaf-chinned bat

Georgia bat

Big brown bat

Hoary bat

Red bat

Seminole bat

Greater yellow bat

Lesser yellow bat

Evening bat

Southereastern myotis

Rafinesque's big-eared bat

Pallid bat

Guano bat

Big free-tailed bat

Brizilian free-tailed bat

Nine-banded armadillo

Black bear

Northern raccoon

Coati

Ringtail

Long-tailed weasel

Mink.

River otter

Eastern spotted skunk

Striped skunk

Gulf coast hog-nosed skunk

Badger

Red fox

Gray fox

Coyote

Red wolf

ocelot

Cougar

Bobcat

Thirteen-lined ground squirrel

Mexican ground squirrel
Scientific Name

Didelphis virginiana

Scalopus aquaticus

Blarina brevicauda

Cryptotis parva

Natiosorex crawfordi

Mormoops megalophylla

Pipistrellus subflavus

Eptesious foscus

Lasiurus cinereus

Lasiurus borealis

Lasiurus seminolus

Lasiurus intermedius

Lasiurus ega

Nycticeius humeralis

Myotis austroparius

Plecotus rafinesquii

Antrozous pallidus

Tadarida mexicana

Tadurida macrotis

Tadarida brasiliensis

Dasypus novemcinctus

Ursus americanus

Procyon lotor

Nasua narica

Bassariscus astutus

Mustela frenata

Mustela vison

Lutra canadensis

Spilogale putorius

Mephitis mephitis

Conepatus leuconotus

Taxidea taxus

Vulpes fulva

Urocyon cinereoargenteus

Canis latrans

Canis rufus

Felis pardalis

Felis concolor

Lynx rufus

Spermophilus tridecemlineatus

spermophilus mexicanus 
Table A-19

(Contifined):
Common Name

Spotted ground squirrel

Eastern gray squirrel

Fox squirrel

Eastern flying squirrel

Plains pocket gopher

South Texas pocket gopher

Merriam pocket mouse

Hispid pocket mouse

Ord kangaroo rat

Beaver

Short-tailed grasshopper mouse

Fulvous harvest mouse

Dwarf harvest mouse

Pigmy mouse

Deer mouse

White-footed mouse

Cotton mouse

Northern rice rat

Coves rice rat

Hispid cotton rat

Florida wood rat

Gray wood rat

Muskrat

House mouse

Roof rat

Norway rat

Nutria

California jackrabbit

Eastern cottontail

Audubon cottontail

Swamp rabbit

White-tailed deer
Scientific Name

Spermophilus spilosoma
Sciurus carolinensis
Sciurus nigra
Glaucomys volans
Geomys bursarius
Geomys personatus
Perognathus merriami
Perognathus hispidus
Dipodomys ordil
Castor canadensis
Onychomys leucogaster
Reithrodontomys fulvescens
Reithrodontomys humulis
Baiomys taylori
Peromyscus maniculatus
Peromyscus leucopus
Peromyscus gossypinus
Oryzomys palustris
Oryzomys couesi
Sigmodon hispidus
Neotoma floridana
Neotoma micropus
Ondatra zibethicus
Mus musculus
Rattus rattus
Rattus norvegicus
Myocastor coypus
Lepus californicus
Sylvilagus floridanus
Sylrilagus auduboni
Sylrilagus aquaticus
Odocoileus virginiana

Adapted from range maps and texts of The Mammals of Texas by William B. Davis, 1974 and The Mammals of Louisiana and Its Adjacent Waters by George H. Lowery, Jr., 1974 
The alligator occurs in fresh to brackish marsh habitats and river swamp systems (0'Beil and Linscombe, 1975). The total coastal population of Louisiana and Texas is estimated at about 214,000 alligators, with 100,000 of these found in Calcasieu, Cameron, and Vermilion Parishes, Louisiana (U.S. Department of the Interior, 1977). Carrying capacity for the coastal marshland of Cameron and Vermilion Parishes is estimated as one alligator per 2 hectares (5 acres) of fresh marsh, one per 3.2 hectares ( 8 acres) of intermediate marsh, and one alligator per 8.1 hectares (20 acres) on brackish marsh (Nichols et al., 1976).

Mortality factors operating against small alligators include desiccation from extended drought and cannibalism. These are increased as receding water levels concentrate populations into remaining water bodies (Nichols et al., 1976). The same authors report that marsh flooding during June through August destroys a high percent of alligator nests.

The most important foods for small alligators are crawfish (Procambarus spp.) in fresh habitats and blue crabs where salinities are higher. Adult alligators eat a variety of foods including small mammals such as muskrat and nutria according to their availability (Valentine et al., 1972).

Reptiles and Amphibians - Examination of range maps in the most recent field guide to reptiles and amphibians (Conant, 1975) reveals that there are 160 species of amphibians and reptiles occurring along the Gulf coasts of Texas and Louisiana. This total includes 20 species of salamanders, 3 spadefoot toads, 8 "true" toads, 25 frogs, 1 crocodilian (American alligator), 28 turtles, 22 lizards, and 58 snakes. 
About $42 \%$ of these species are restricted in their range to the extreme southern (Rockport south) or extreme eastern (east of the Mississippi River) portions of the study area. Habitat preferences of salamanders (Bishop, 1947), frogs and toads (Wright and Wright, 1949), turtles (Carr, 1952), lizards (Smith 1946; Dendee and Rossmann, unpublished manuscript), and snakes (Wright and Wright, 1957; Dendee and Rossmann, unpublished manuscript) are such that there is a general increase in species' richness as one progresses inland from the Gulf. This effect is pronounced in the central portion of the study area (Hebrard, unpublished data).

Selected Commercial Fisheries - According to Gunter (1967), estuarine-dependent species comprise $97.5 \%$ of the total commercial catch of the Gulf States. For the majority of these species, the estuary serves primarily as a nursery into which they enter in larval form and from which they emerge as sub-adults (Dunham, 1972).

The shrimp fishery is the most economically valuable single fishery in LouisianaTexas coastal waters, followed by menhaden (Brevoortia spp.), oysters (Crassostrea spp.), and blue crabs (Callinectes spp.) (Table A-20). These four species account for $96 \%$ of the total weight and $97 \%$ of the total value of all fishery products landed in Louisiana and Texas. Menhaden and shrimp (Penaeus spp.) occupy estuaries for a large portion of their life cycles; the oyster and blue crab fisheries are almost entirely inshore or estuarine. In addition to providing for the major commerclal species, these estuaries support hundreds of organisms which have no immediate economic value, but are important in the food chain upon which commercial species depend. 
Table A-20. Average Annual (1970-1973) Louislana and Texas Landings from Marine and Coastal Waters. Landings are in Live Weight Except for Mollusks Which are in Weight of Total Meat. Shrimp are in Heads-on Weight. (1) denotes Less Than 5001 bs (225 kg) or $\$ 500 . \quad M=1000$ (After USDC, 1976).

\begin{tabular}{|c|c|c|c|c|c|c|c|c|c|}
\hline \multirow[b]{2}{*}{ ish } & \multicolumn{3}{|c|}{ Louisiana } & \multicolumn{3}{|c|}{ Texas } & \multicolumn{3}{|c|}{ Totals (La. \& Tex.) } \\
\hline & Kgs. (M) & Lbs. (M) & $S(M)$ & Kgs. (M) & Lbs. (y) & $\$(M)$ & Kgs. (M) & Lbs. (M) & $\$(M)$ \\
\hline Blue f ish & (1) & (1) & (1) & $-\infty$ & - & - & (1) & (1) & (1) \\
\hline Bowf in & 4 & 9 & (1) & $-\infty$ & -- & -- & 4 & 9 & (1) \\
\hline Buffalofish & 258 & 569 & 79 & 4 & 10 & 2 & 262 & 579 & 81 \\
\hline Cabio & 4 & 8 & (1) & 8 & 18 & 2 & 12 & 26 & 2 \\
\hline Carp & 12 & 26 & 1 & -- & -- & - & 12 & 26 & 1 \\
\hline Catfish \& Bullheads & 1,735 & 3,821 & 1,101 & 1 & 2 & (1) & 1,736 & 3,823 & 1,101 \\
\hline Croaker & 153 & 337 & 44 & 38 & 85 & 5 & 191 & 422 & 49 \\
\hline Drum & 636 & 1,402 & 201 & 1.250 & 2,754 & 568 & 1,886 & 4,156 & 769 \\
\hline Flounder & 196 & 433 & 77 & 160 & 353 & 92 & 356 & 786 & 169 \\
\hline Garfish & 178 & 392 & 36 & 6 & 13 & (1) & 184 & 405 & 36 \\
\hline Grouper & 2 & 5 & (1) & 45 & 99 & 11 & 47 & 104 & 11 \\
\hline Herring-thread & 423 & 931 & 15 & - & -- & - & 423 & 931 & 15 \\
\hline Jewf ish & 2 & 4 & (1) & -- & -- & -- & 2 & 4 & (1) \\
\hline King Whiting & 177 & 390 & 29 & 39 & 86 & 7 & 216 & 476 & 36 \\
\hline Sackerel & 31 & 68 & 6 & - & -- & $\therefore$ & 31 & 68 & 6 \\
\hline Senhaden & 456,280 & $1,005,022$ & 22,862 & 12,030 & 26,498 & 488 & 468,310 & $1,031,520$ & 23,350 \\
\hline Mullet & 19 & 41 & 2 & 41 & 90 & 4 & 60 & 131 & 6 \\
\hline Paddlef ish & - 1 & 2 & (1) & -- & -- & -- & 1 & 2 & (1) \\
\hline Pompano & 11 & 25 & 23 & 1 & 3 & 2 & 12 & 28 & 25 \\
\hline Sawf ish & 1 & 1 & (1) & -- & -- & -- & 1 & 1 & (1) \\
\hline Sea Catfish & 37 & 82 & 7 & 20 & 44 & $\therefore$ & 57 & 126 & 11 \\
\hline Sea Trout & 761 & 1,677 & 449 & 697 & 1,535 & 421 & $1, \div 58$ & 3.212 & 870 \\
\hline Shark & 1 & 2 & (1) & - & - & - & 1 & 2 & (1) \\
\hline Sheephead & 182 & 401 & 34 & 93 & 204 & 17 & 275 & 605 & 51 \\
\hline Snapper & 117 & 258 & 9? & 456 & 1,004 & 462 & 573 & 1,262 & 554 \\
\hline Spot & 11 & 25 & 2 & -- & -- & -- & 11 & 25 & 2 \\
\hline Swordfish & 2 & 4 & 4 & -- & -- & -- & 2 & 4 & 4 \\
\hline Tripletail & 3 & 7 & 1 & -- & -- & -- & 3 & 7 & 1 \\
\hline for food & & & & 54 & 119 & 8 & 5 & 10 & 8 \\
\hline For bait, Reduction & & & & & 119 & 8 & 34 & 119 & 0 \\
\hline and Nimal food & 11.584 & 25,515 & 484 & 61 & 135 & 7 & 11,645 & 25,650 & 491 \\
\hline rish Totals & 472.921 & $1.041,453$ & $\$ 25,546$ & 15,004 & 33,051 & $\$ 2,101$ & 487,825 & $1,074,504$ & $\$ 27,647$ \\
\hline
\end{tabular}


Table A-20. Average Annual (1970-1973) Loulsiana and Texas Landings from Marine and Coastal Waters. Landings are in Live Weight Except for Mollusks Which are in Weight of Total Meat. Shrimp are in Heads-on Weight. (1) denotes Less than $5001 \mathrm{bs}(225 \mathrm{~kg})$ or $\$ 500 . \quad M=1000$ (After USDC, 1976). Continued.

Shellfish, et al.
Blue Crab
Crawfish
Shrimp
Conches
Oysters
Squid
Terrapin
Turtles
Frogs
Total Shellfish,
et al.
Grand Totals

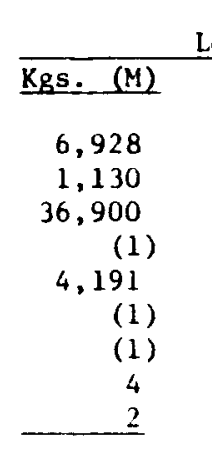

Lbs. (Y)

15,260$$
\begin{array}{r}
2,488 \\
81,276
\end{array}
$$$$
\begin{array}{r}
81,276 \\
(1) \\
9,231
\end{array}
$$$$
.231
$$

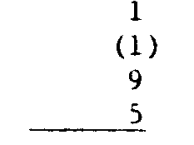

49,156

$$
108,272
$$

$521,975 \quad 1,149,725$

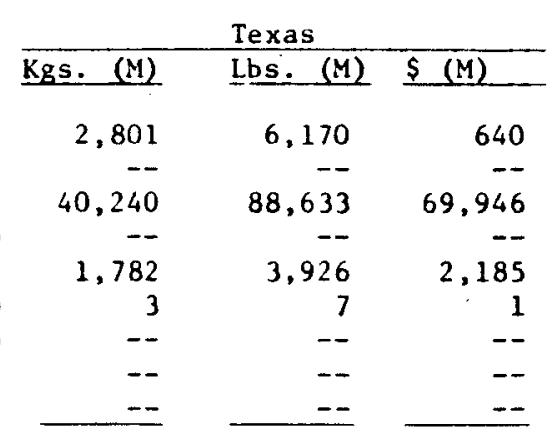

\subsection{5}$$
\begin{array}{r}
541 \\
42,369
\end{array}
$$$$
\begin{array}{r}
(1) \\
4,568
\end{array}
$$
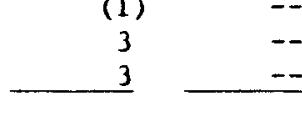

44,940

98,986

72,771

131,786

$\$ 74,872$

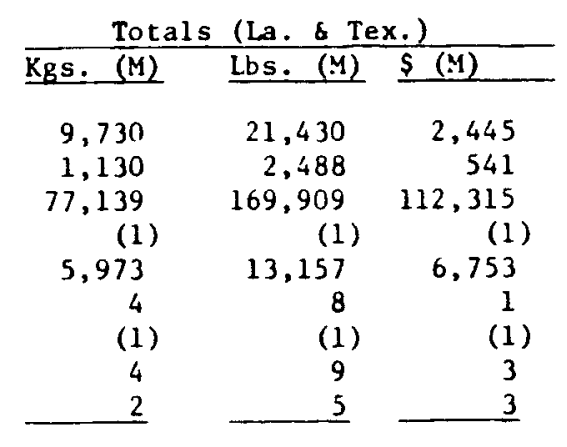

$p$
1
$\infty$ 
Annual averages for commercial fisheries catch from 1970 through 1973 in Louisiana and Texas are listed in Table A-20. During this time period Louisiana led the nation in percentage of all landings with $23 \%$ in $1970,28 \%$ in 1971 , $22 \%$ in 1972 , and $21 \%$ in 1973 . Factors generally believed to contribute to the high level of productivity of coastal Louisiana and Texas are the small range of the diurnal tides, which results in slow flushing rates, the shallowness of the estuaries, rendering them relatively high in oxygen content and penetrable to light, large expanses of vegetation bordering the estuaries, vast quantities of nutrient-laden fresh waters which regularly empty into these estuaries (particularly in Louisiana), and the high level of marsh-water interface. During the peak flood year of 1973, the estimated amount of selected nutrients $\left(\mathrm{NO}_{3}-+\mathrm{NO}_{2}^{-}+\right.$organid $-\mathrm{N}, \mathrm{PO}_{4}^{-3}-\mathrm{P}, \mathrm{Si} \mathrm{O}_{2}$, and Organic $-\mathrm{C}$ discharged from the Mississippi and Atchafalaya Rivers into Louisiana's coastal area was 43 billion pounds (19 billion kilograms) (Ho and Barrett, 1975).

Catch concentrations of estuarine-dependent species vary to a large extent on a seasonal basis and are a function of habitat type. Of the four major commercial species, all are found throughout the coasts of Louisiana and Texas.

Two species of shrimp comprise the bulk of shrimp caught in Louisiana and Texas, brown shrimp (Penaeus actecus) and white shrimp (Penaeus setiferus). Shrimp fishing zones are found in Figure A-19, and percentage catch by zone in Table A-21. In inshore waters, the area of greatest concentration for both species is the Timbalier-Terrebonne Bay complex in Louisiana. The offshore fishery is concentrated offshore from Vermilion Bay in Louisiana for white shrimp, and south of Matagorda Bay in Texas waters for brown shrimp. 


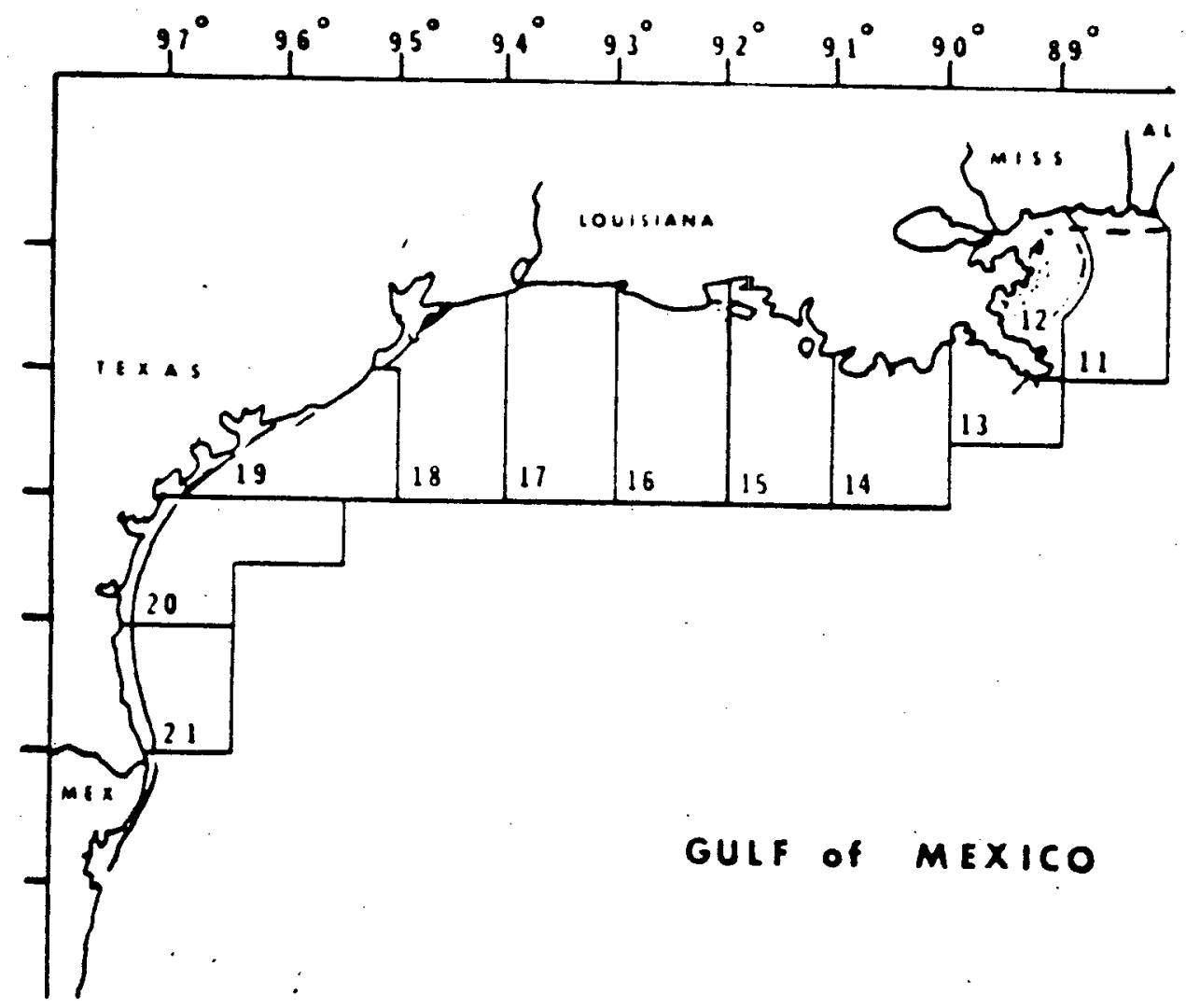

Fif. A-19. Gull of Mexico shrimp fishing zoncs (After Juh1, 1976). 
Table A-21. Areas of Marsh and Water with Percentages of the Northern Gulf Shrimp Catch by Fishing Zones. Refer to Figure A-19 for Zone Locations. Table Taken from Barrett and Ratph, 1977 -- in press.

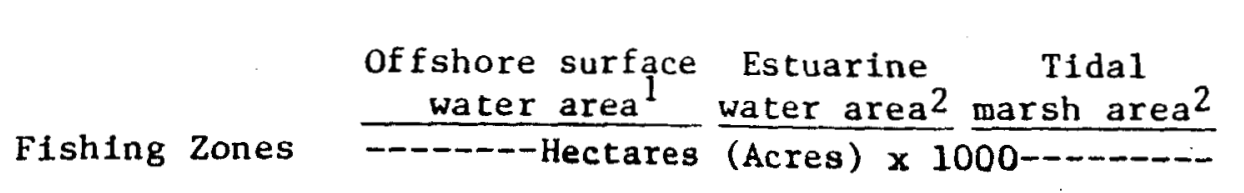

13
14
15
16
17
18
19
20
21

699
1,155
1,462
1,704
1,865
1,597
1,207
1,342
841

$$
(1,727)
$$$$
(2,852)
$$$$
(3,610)
$$$$
(4,207)
$$$$
(4,604)
$$$$
(3,944)
$$$$
(2,981)
$$$$
(3,314)
$$$$
(2,076)
$$

13
136
617
635
145
2230
145

$132(325)$

(337) 243

$(520)$
$(600)$

(320)

$61(150) \quad 126 \quad(310)$

$\begin{array}{rrrr}61 & (150) & 126 & (310) \\ 63 & (156) & 142 & (350) \\ 145 & (358) & 94 & (231)\end{array}$

$\begin{array}{llll}45 & (358) & 94 & (231) \\ 23 & (550) & 77 & (190)\end{array}$

$90 \quad(221)$

145 (358)

$\begin{array}{ll}69 & (170) \\ 51 & (125)\end{array}$

\begin{abstract}
Average annual percent (1965-1975)
of northern Gulf Shrimp catch Inshore offshore Inshore offshore
Intere
\end{abstract}

$\begin{array}{rrrr}7.1 & 4.9 & 5.5 & 6.4 \\ 8.7 & 4.1 & 10.6 & 3.5 \\ 0.5 & 3.4 & 1.8 & 14.3 \\ & 2.6 & & 9.5 \\ 0.4 & 4.0 & 1.7 & 8.7 \\ 0.9 & 6.8 & 5.5 & 6.1 \\ 1.0 & 17.5 & 6.3 & 7.4 \\ 0.2 & 10.5 & 0.7 & 1.6 \\ & 9.1 & & 0.5\end{array}$

1 Patella, Frank, 1975.

2 Acreages were approximated for Texas from Diener, 1975; and for Louisiana from Barrett, 1970.

3 Catch percentages were calculated from Gulf Coast Shrimp Data, 1965-19.75. 
Perret eㅗ al. (1971) reported menhaden in all of Louisiana's major estuarine systems, but found them most abundant in waters adjacent to the west side of the Mississippi River. After menhaden spawn in coastal waters, their larvae are transported into estuarine habitats where they metamorphose into juveniles, grow rapidly throughout the late summer, and return to the ocean in the fall as young adults (Jeffries, 1975).

The American oyster (Crassostrea virginica) inhabits estuarine waters for the entire duration of its life cycle. Oysters have been found in all major estuarine areas in Louisiana and Texas. In Louisiana, they concentrate in the southeastern coastal areas. As a result of its benthic development and feeding behavior, this organism is extremely sensitive to fluctuations in hydrological conditions. Peak spawning occurs in May, and is highly sensitive to temperature change. Salinities infringe upon both the reproductive capability of oysters and mortalities via predation; whereas low salinities reduce reproductive capability in oysters, they also prove detrimental to organisms destructive to the oyster such as the oyster drill (Van Sickle et al., 1976).

The blue crab (Callinectes sapidus) occupies virtually all available habitat in Louisiana from saline water in excess of thirty parts per thousand to the fresh waters of the Atchafalaya River system. Mating generally occurs inshore; once the eggs hatch, growth is generally rapid, especially at higher salinities, and juveniles may be found from November through May. Salinities and temperatures during summer months usually result in young crabs moving from very shallow waters to larger bays and estuaries (Adkins, 1972). 
Sport Fishing Resources - Fresh water sport fishing is provided by-several species of fish. Varlous bream (Lepomis spp.), crappie (Poxomis spp.), and bass (Micropterus spp.) are all popular with sport fishermen. Bream and crappie are foind in waters ranging from fresh to slightly brackish. Largemouth bass (Micropterus salmoides) inhabit lakes, ponds, fresh-to-slightly-brackish estuarine areas, overflow swamps and rivers of the area. Spotted bass (Micropterus punctulatus) inhabit the flowing streams that bisect the terrace lands and are taken along with largemouth bass. While the largemouth occurs throughout the study area the range of the spotted bass extends southwestward only to the middle Texas coast. Durlng 1974, over thirty-five million fresh water fishing days participation were estimated for all of Louisiana (Louisiana Department of the State, 1977).

Saltwater resources are considerable with the spotted seatrout or speckled trout (Cunoscion nebulosus), red drum or redfish (Sciaenops ocellata), and the Atlantic croaker (Micropogon undulatus), as three of the most important saltwater sportfish. Each is estuary-dependent and provides fishing in the marsh bayous and canals, the estuarine bays, and in the Gulf itself. The blue crab (Callinectes sapidus) provides a great deal of sport crabbing. In Louisiana, in 1975, over eight million crabbing and nearly thirteen million saltwater sportfishing efforts were estimated (Louisiana State of State, 1977).

Saline Marsh - Saline marsh is found on the borders of saline bays, lagoons, bayous, and lakes. The principal vegetation is a combination of oyster grass (Spartina alterniflora), black rush (Juncus roemerianus), batis (Batis maritima), black mangrove (Avicennia nitida), and saltgrass (Distichlis spicata). This is the least diverse marsh type. 
Soil salinities range from 5.1 to $18.90 / 00$, while the overlying waters range from 8.1 to $29.40 / 00$. Organic matter content in Louisiana averages around $17 \%$ (Chabreck, 1970). The amount of inorganic matter may be related to the degree of tidal flushing. Those areas receiving Gulf waters laden with riverine sediments build up inorganic sediments on their banks. This lowers the percentage of relatively lighter organic matter. Also, the increased flushing near open waters increases the detrital export, further decreasing the organic matter accumulation. A lower organic matter content than in fresher marshes does not mean that saline marshes are less productive, merely that detrital export is greater. On the contrary, those sites nearest streams or bays are the greatest producers, possibly due to the tidal energy subsidy or from the increased inorganic nutrient inputs. The clapper rail reaches maximum abundance in saline marshes.

As one moves westward, marshes become less dominated by oyster grass and have a greater percentage of sea ox-eye (Borrichia frutescens), saltgrass, sea bite (Suaeda spp.), and glasswort ( frequent clumps, but are limited by cold temperatures.

Intermediate Marsh - Intermediate marsh occurs between the fresh and saline marsh or bordering medium salinity bays and tidal lakes and includes both the brackish and intermediate types of Chabreck (1970). It occupies the majority of the marsh area of Louisiana. Soil salinities range from 1.5 to 15.2 0/00 (Chabreck, 1970). The amount present is related to a surface water salinity range of .5 to $18.50 / 00$ (Chabreck, 1970), the duration of flooding, and elevation. Community composition is determined by the salinity ranges and yearly regime. 
In the more saline areas, marsh cord grass (Spartina patens), big cord grass (Spartina cynosuroides), saltgrass, and widgeon grass (Ruppia maritima) predominate.

Sedges such as saltmarsh bulrush (Scirpus robustus) and three-corner grass (Scirpus olneyi) occur here and provide food for ducks and geese. Three-corner grass sometimes occurs in extensive stands and supports dense muskrat populations.

The fresher areas are generally more diverse and include the above association plus deer pea (Vigna repens), arrowhead (Sagitarria spp.), and roseau cane (Phragmites communis). The once common sawgrass (Cladium jamaicense) died off extensively in the late 1950's (Valentine, 1974). These marshes are important for their role in the production of muskrat.

These marshes are subject to some tidal flushing. Organic carbon in the soil averages around $30 \%$, less than in the fresh marsh, for more of the detrital material is exported with tides.

West into the chenier plain and along the Texas coast, coastal sachuista (Spartina spartinae) becomes part of the association. Species more often associated with saline or fresh marshes may often occur mixed with the brackish marsh.

Fresh Marsh - Fresh marsh occurs between the brackish and intermediate marshes to the south and the coastal prairie or river alluvium to the north. It receives no salinity flux and is primarily dependent on upland runoff, streams, and rainfall input for water supply. Principal species present are maiden cane 
(Panicum hemitomon), bulltongue (Sagittaria falcata), roseau cane, pickerel weed (Pontederia cordata), and paspalum (Paspalum spp.) (Table A-17). This marsh type can be extremely productive.

When the plant matter dies it falls and is either consumed, washed away with infrequent floods or tides, or incorporated into the soil which averages $50 \%$ organic matter (Chabreck, 1970). Most of the species in this association will not tolerate salinity, although some intermediate marsh species may be interspersed in a fresh marsh. Plant species are more diverse here than in brackish or saline marshes (Palmisano, 1971). These marshes are more productive of alligators and nutria and winter large numbers of dabbling ducks.

The Louisiana-Texas coastal area can be divided into a number of zones. The active delta zone of Louisiana contains a roseau cane-alligator weed (Alternanthera philoxaroides) association; the inactive delta, a maiden cane association; and the chenier plan, a bull tongue-alligator weed association (Palmisano, 1970). Texas can be divided into the coast from Louisiana to Matagorda Bay and then the southern section generally bordered by barrier islands. The northermmost fresh marshes are predominantly black rush, bulrush (Scirpus spp.), cattail (Typhas spp.), and slough grass (Spartina pectinata). Below Matagorda Bay they become a mix of coastal sacahuista, seacoast bluestem (Andropogon scoparius), balsam grass (Elyonurus tripsacoides), paspalum, and huisache. In the drier areas of the marsh there is mesquite, hackberry (Celtis laevigata), and oaks.

Lakes and Streams - The vegetation of lakes and streams is closely related to the chemistry of the water (see Section 2.2.2). In shallow waters with a current and low nutrient levels, submergent and emergent attached grasses predominate. 
Fresh water phytoplankton are found in deeper waters and where currents are greater. If an area becomes heavily polluted, green algae, blue-green algae, duckweed (Lema minor), water hyacinth (Eichornia crassipes), or alligator weed predominate and may cause further deterioration of water quality due to the oxygen demand of decomposing organic matter and respiration. Much of the sport fishing of the study area takes place in these lakes and streams.

Other common plants found in the area are wild celery (Vallisneria americana), skunk weed (Chara vulgaris), water lettuce (Pistia spp.), arrowhead, coontail (Ceratophyllum demersum), bladderwort (Urtricularia spp.), fanwort (Cabomba spp.), duckweed, pennywort (Hydrocoty1 spp.), white water lily (Nymphaea odorata), and waterfern (Azolla caroliniana). Diving ducks utilize the vegetation and animal matter in the lakes. Some dobblers such as the wigeon (Anas americana) and gadwall (Anas strepera) make heavy use of the shallow sumerged aquatic vegetation.

Beaches and Dunes - Beaches and dunes is a broad classification which includes sandy beaches, dunes, barrier flats, sandflats, eolian ridges, berms along bay margins, and subaerial or slightly inundated mud flats. In Louisiana, the barrier islands such as the Chandeleur Islands, Timbalier and Isles Dernieres Islands, and Grand Terre and Grand Isle have beach and dune habitat, although the area of these that is covered with beach and dune vegetation is too small to be detectable on the vegetation map (Plate 8). In Texas the beach and dune areas are more extensive and appear on the vegetation map. While some birds nest here, the area is more important as a resting area during migration. 
The dominant vegetation of beaches and dunes is marsh hay cordgrass, saltgrass, oyster grass, sea ox-eye, batis, camphorweed (Heterotheca subaxillaris), morning glory (Ipomoea spp.), seaside heliotrope, sedge (Cyperaceae), poor-man's pepper (Lepidium virginicum), and saltbush (Atriplex arenaris). The sand flats have a sparse cover of glassworts and saltgrass. Other vegetation which joins the association in Texas includes seacoast bluestem, sandbur (Cenchrus incertus), beach tea (Croton unctatus), salt cedar (Tamarix gallica), seaside croton (Croton maritima), and mesquite.

Estuaries, Bays, and Coastal Waters - Estuaries, bays, and coastal waters is another broad classification which includes medium-salinity bays, slightly brackish to nearly saline estuaries, transitional bays, tidal creeks, restricted bays and hypersaline lagoons. In general, medium-salinity bays run perpendicular to the coast while restricted and hypersaline bays run parallel to the coast. The salinity range experienced in any location is the reslut of fresh water runoff, coastal morphology, and climatic conditions which affect the degree of tidal mixing and residence times.

Phytoplankton are the basis of the foodchains in the deeper, well-mixed bays. Shallow areas have brackish and marine submergent grasses such as celery grass, widgeon grass, eelgrass (Fostera marina), turtle grass. (Thalassia tosatudinum), manatee grass (Syringodium filiforme), Cuban shoal weed (Halodule wrightii), and water nymp (Najas guadalupensis). This vegetation follows a yearly cycle and experiences a winter die-back, at which time algae, especially red algae (Rhodophyta), become more abundant. The trapping and binding effect of the submergent grass beds is important in determining sedimentation patterns. 
Hypersaline lagoons experience a very wide range of temperature, $\mathrm{pH}$, and salinity. Blue-green algae mats are the dominant vegetation along with turtle grass and Cuban shoal weed. Along the lower Texas coast these provide the most important reahead wintering area on the continent. Less saline bays on the eastern end of the study area are very important for wintering lesser scaup.

\subsection{Endangered Species}

\subsubsection{Terrestrial}

\section{VEGETATION}

Species that are either endangered or threatened are listed in Table A-22 (Federal Register, 1975). Information on location, habitat preference, status; state where the status is in effect and references are included. Those species whose present location is a very restricted geographic area are also indicated on the vegetation map (Plate 8 ).

\section{ANIMALS}

Table $A=23$ lists the endangered or threatened species for Louisiana.

Before widespread human settlement, the red wolf (Canis rufus) was common in North America from central Texas eastward through Florida and northward into Indiana (Figure A-20) (Riley and McBride, 1972). Due largely to habitat alteration and human harassment, the red wolf's range was reduced. By 1900, the wolf was absent from the northern and southeastern portions of its historic range (Nowak, 1974).

Since 1900, the red wolf population has decline drastically and it is now listed as endangered by the United States Fish and Wildlife Service. Currently, wild red wolves are found only in the coastal area of extreme southeast Texas and southwest Louisiana (New release, June 30, 1977, U.S. Fish and Wildlife Service). 
Table A-22. Terrestrial Vegetation - Proposed Endangered Species.

\begin{tabular}{|c|c|c|c|c|}
\hline Spectes & Location & Habitat Preference Sta & tatus (Stace) & Reference \\
\hline Amson 1a glaberima & $\begin{array}{l}\text { Welsh, Jefferson Davis } \\
\text { Parish, La. } \\
\text { Greensburg, St. Helena } \\
\text { Parish, La. }\end{array}$ & Low Prafries & $T(L a)$ & $\begin{array}{l}\text { Defilipps, } 1977 \\
\text { Missouri Botanica } \\
\text { Garden, } 1936 . \\
\text { Federal Register, } \\
\text { 1975. }\end{array}$ \\
\hline$\frac{\text { Ilex }}{\text { (Sarvis holly) }}$ & St. Tammany Par1sh, La. & $\begin{array}{l}\text { Bottomland hardwood } \\
\text { Margins of cypress, } \\
\text { blackgum swamps. }\end{array}$ & $T(\mathrm{La})$ & $\begin{array}{l}\text { USACOE, } 1973 . \\
\text { Federal Register } \\
\text { I975. }\end{array}$ \\
\hline Platanthera leucophaea & No exact data, La. & $\begin{array}{l}\text { Wet prairfes, swamps } \\
\text { bays, shores. }\end{array}$ & $T(L a)$ & $\begin{array}{l}\text { Defilipps, } 1977 . \\
\text { Federal Register } \\
1975 .\end{array}$ \\
\hline$\frac{\text { Bothriochloa }}{\text { (Awnless bexaristata }}$ & $\begin{array}{l}\text { No exact data, La. and } \\
\text { Texas. }\end{array}$ & Low, open ground. & $T(L a$, Texas $)$ & $\begin{array}{l}\text { Correll and } \\
\text { Johnston, } 1970 . \\
\text { Federal Register, } \\
\text { 1975. }\end{array}$ \\
\hline Platanthera integra & $\begin{array}{l}\text { Beauregard Parlsh, } 10 \mathrm{mi} \text {. } \\
\text { s. of DeR1dder. }\end{array}$ & Boggy soll in prairle. & $T(L a)$ & $\begin{array}{l}\text { Defilipps, } 1977 . \\
\text { Federal Register, } \\
1975 .\end{array}$ \\
\hline$\frac{\text { Machaeranthera }}{\text { (Houston machaeranthera) }}$ & Near Houston. & $\begin{array}{l}\text { Prairle-grasslands, } \\
\text { open areas. }\end{array}$ & $E$ (Texas) & * \\
\hline$\frac{\text { Hoffmanseggia }}{\text { (S1ender rushpea) }}$ & Nueces and Klebert Cos. & Prairle & $E$ (Texas) & $\star$ \\
\hline Manthot walkerae & HAdalgo Co. & $\begin{array}{l}\text { Caliche Cuestas } \\
\text { near the Rio Grande. }\end{array}$ & $E$ (Texas) & * \\
\hline$\frac{\text { Ambrosia }}{\text { (Gray ragweed) }} \frac{\text { folla }}{\text { (Gra }}$ & San Patriceo Co. & Prairle, clay sol1. & $\mathbf{E}$ (Texas) & * \\
\hline$\frac{\text { Justicia }}{\text { (Runyon junyonif }}$ & Cameron Co. & Prairfe & $E$ (Texas) & * \\
\hline$\frac{\text { Dyschoriste }}{\text { (Wavy dischoristate) }}$ & $\begin{array}{l}\text { Cameron, Hidalgo, Willacy } \\
\text { Cos. }\end{array}$ & $\begin{aligned} & \text { Chapparral, brush- } \\
& \text { lands. }\end{aligned}$ & $E$ (Texas) & * \\
\hline$\frac{\text { Chloris }}{\text { (Texas windmillgrass) }}$ & $\begin{array}{l}\text { No exact data, near R1o } \\
\text { Grande, S.E. Texas. }\end{array}$ & Prairie. & $T$ (Texas) & $\star$ \\
\hline 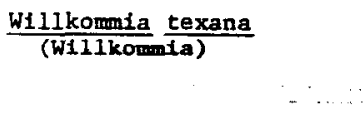 & Coastal Bend Cos. Texas. & $\begin{array}{l}\text { Coastal prafrte, } \\
\text { calcareous clay } \\
\text { loam. }\end{array}$ & $T$ (Texas) & * \\
\hline Scutellarla thiereti1 & $\begin{array}{l}\text { Pecan Island and Redfish } \\
\text { Point, Vermillion Parish, } \\
\text { Cameron Parish, La. }\end{array}$ & $\begin{array}{l}\text { Shell ridges and ridges } \\
\text { in brack1sh marsh. }\end{array}$ & $T(L a)$ & $\begin{array}{l}\text { Defilipps, } 1977 . \\
\text { Shinners, } 196 . \\
\text { Federal Register, } \\
1975 .\end{array}$ \\
\hline$\frac{\text { Sarricenla psittacina }}{\text { (Parrothead }}$ & $\begin{array}{l}\text { Abita Springs, St. Tammany } \\
\text { Parish, La. }\end{array}$ & Fresh marsh. & $T(I a)$ & $\begin{array}{l}\text { U.S.A.C.O.E., } 1974 . \\
\text { Eederal Register, } \\
1975 .\end{array}$ \\
\hline$\frac{\text { Atriplex }}{\text { (Kleberg }} \frac{\text { klebergorum }}{\text { saltbush) }}$ & Kleberg Co., Texas & $\begin{array}{l}\text { Clayey soils, saline } \\
\text { areas. }\end{array}$ & $\mathrm{E}$ (Texas) & 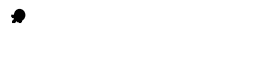 \\
\hline$\frac{\text { Sesuvium }}{\text { (Texas } \frac{\text { tranthemoldes }}{\text { sea-purslane) }}}$ & Kenedy Co., Texas & Dunes. & $E$ (Texas) & $\star$ \\
\hline$\frac{\text { Polygonum striatulum }}{\text { (Kleberg knotweed) }}$ & Klebert Co., Texas & Fresh Marsh. & $E$ (Texas) & $\star$ \\
\hline
\end{tabular}

*A11 of these references R.P.S.C., 1974; Corre11 and Corre11, 1975; Correll and Johnston, 1970; Dannis Brevonik, pers. conm.; Federal Register, 1975. 


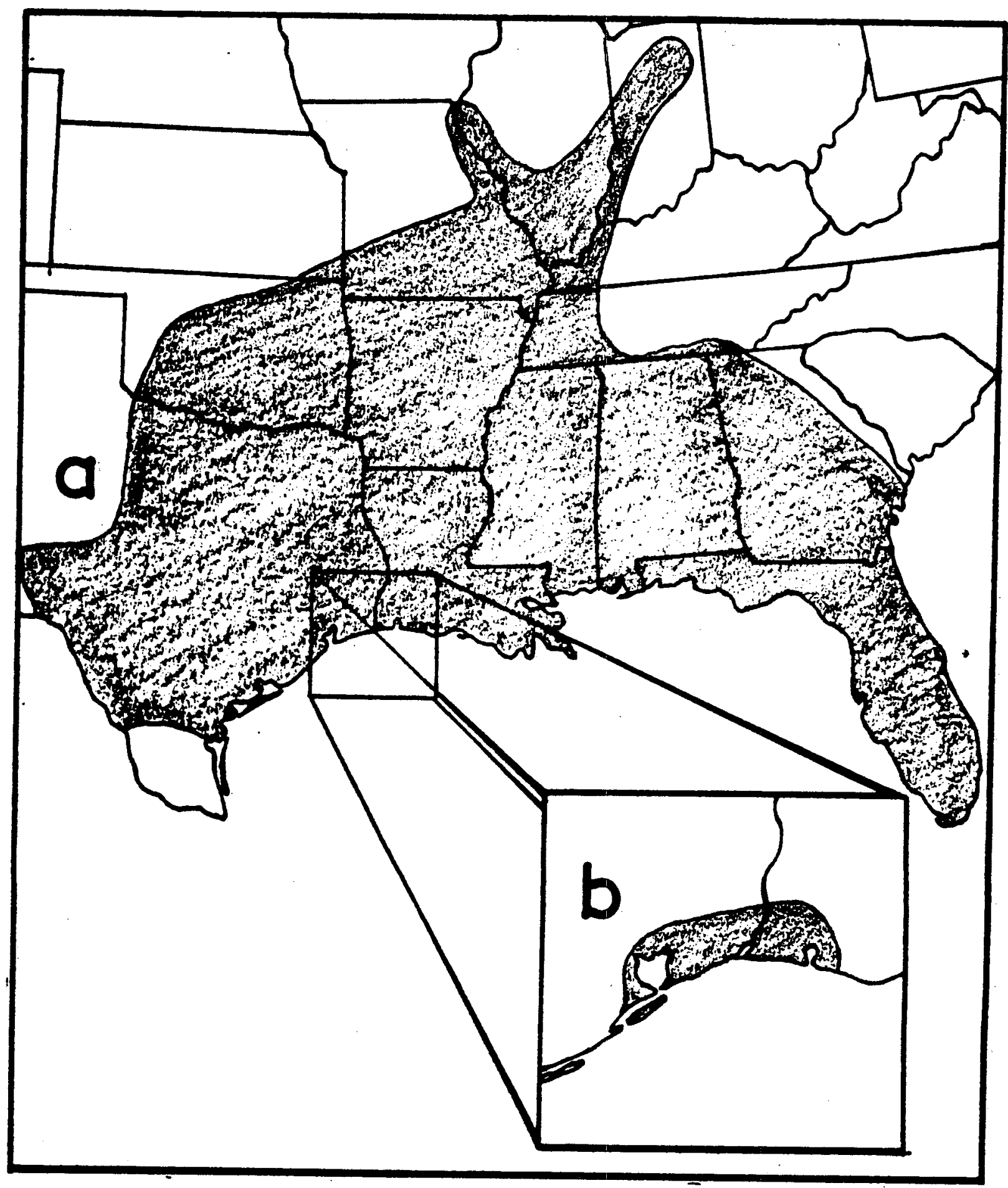

Fig. A-20. Historic range (a) and present known range (b) of the red wolf (Canis rufus) (After Riley and McBride, 1972). 
Table A-23. Endangered or Threatened Species List of coastal Louisiana and Texas.

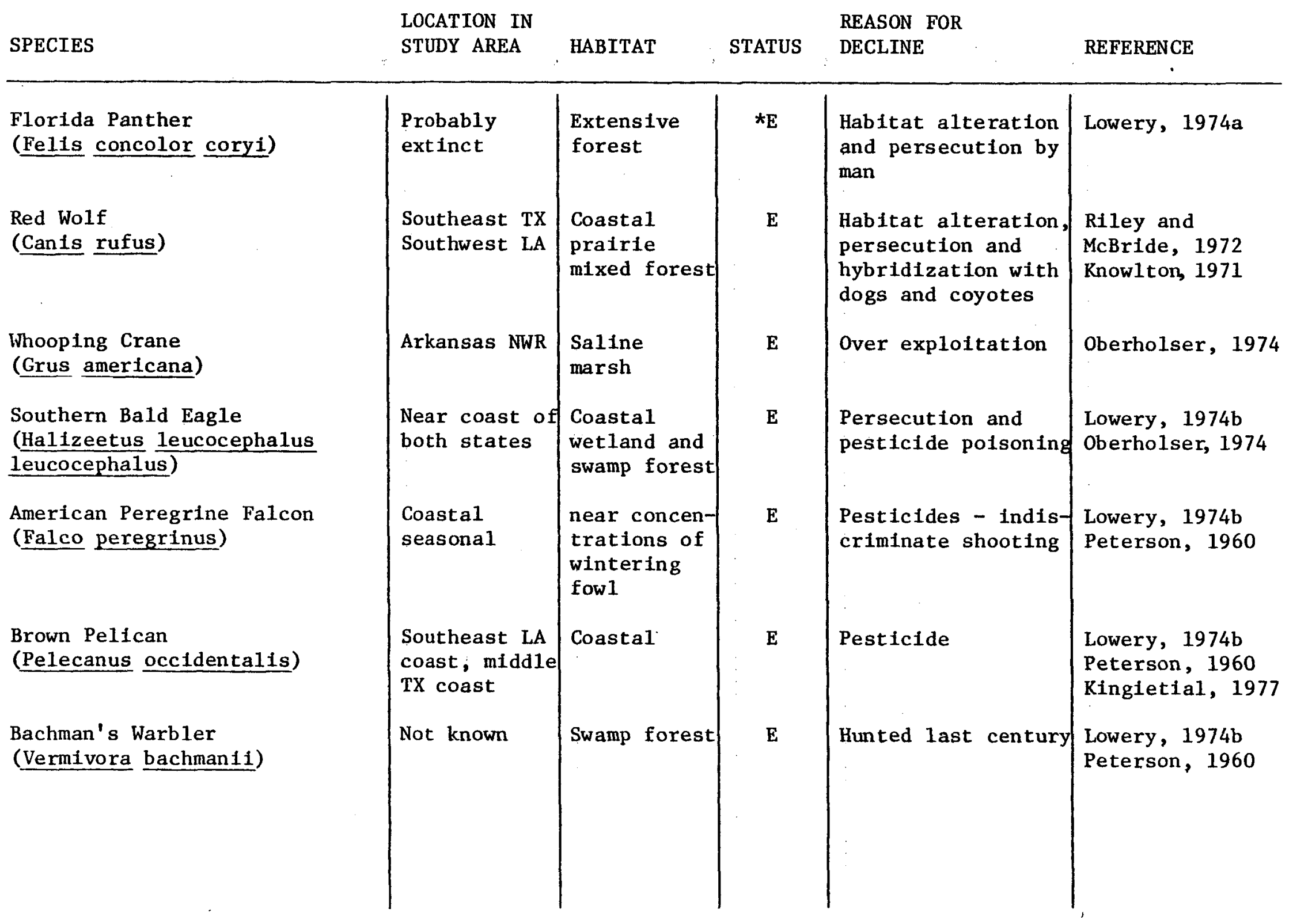


Table A-23. Endangered or Threatened Species List of coasta1 Louisiana and Texas. (continued)

\begin{tabular}{|c|c|c|c|c|c|}
\hline \multirow{2}{*}{ SPECIES } & \multicolumn{3}{|l|}{ LOCATION IN } & \multicolumn{2}{|l|}{ REASON FOR } \\
\hline & & HABITAT & STATUS & DECLINE & REFERENCE \\
\hline $\begin{array}{l}\text { Ivory-Billed Woodpecker } \\
\text { (Campehilus principalis) }\end{array}$ & $\begin{array}{l}\text { Lower } \\
\text { Atcha falaya } \\
\text { Floodway??? }\end{array}$ & $\begin{array}{l}\text { Bottomland } \\
\text { forest }\end{array}$ & $\mathbf{E}$ & Habitat alteration & Lowery, $1974 \mathrm{~b}$ \\
\hline $\begin{array}{l}\text { Red-Cockaded Woodpecker } \\
\text { (Dendrocopus borealis) }\end{array}$ & $\begin{array}{l}\text { Southeast } \\
\text { and south- } \\
\text { west LA }\end{array}$ & $\begin{array}{l}\text { Mature pine } \\
\text { forest }\end{array}$ & $\mathbf{E}$ & Habitat alteration & $\begin{array}{l}\text { Lowery, } 1974 \mathrm{~b} \\
\text { Peterson, } 1960\end{array}$ \\
\hline $\begin{array}{l}\text { Attwater's Prairie Chicken } \\
\text { (Tympanuchus cupio attwateri) }\end{array}$ & $\begin{array}{l}\text { TX coastal } \\
\text { plain - } \\
\text { (scattered } \\
\text { locations) }\end{array}$ & Prairie & $\mathrm{E}$ & Habitat alteration & $\begin{array}{l}\text { Peterson, } 1960 \\
\text { Johnsgard, } 1973\end{array}$ \\
\hline $\begin{array}{l}\text { American Alligator } \\
\text { (Alligator Mississipplensis) }\end{array}$ & $\begin{array}{l}\text { A11 of LA } \\
\text { and to cen- } \\
\text { tral } \mathrm{TX}\end{array}$ & Wetlands & $* * \mathrm{~T}$ & $\begin{array}{l}\text { Over exploitation } \\
\text { and habitat } \\
\text { destruction }\end{array}$ & $\begin{array}{l}\text { Joanen, } 1974 \\
\text { Conant, } 1975\end{array}$ \\
\hline $\begin{array}{l}\text { Atlantic Ridley Turtle } \\
\text { (Lepidochelys kempii) }\end{array}$ & $\begin{array}{l}\text { Gulf of } \\
\text { Mexico }\end{array}$ & Marine & $\mathbf{E}$ & Over exploitation & $\begin{array}{l}\text { Federal Register } \\
\text { October } 27,1976\end{array}$ \\
\hline $\begin{array}{l}\text { Hawkbill Turtle } \\
\text { (Eretmochelys imbricata) }\end{array}$ & $\begin{array}{l}\text { Gulf of } \\
\text { Mexico }\end{array}$ & Marine & $\mathbf{E}$ & Over exploitation & $\begin{array}{l}\text { Federal Register } \\
\text { October } 27,1976\end{array}$ \\
\hline $\begin{array}{l}\text { Leatherback Turtle } \\
\text { (Dermochelys corlacea) }\end{array}$ & $\begin{array}{l}\text { Gulf of } \\
\text { Mexico }\end{array}$ & Marine & $\mathrm{E}$ & Over exploftation & $\begin{array}{l}\text { Federal Register } \\
\text { October } 27,1976\end{array}$ \\
\hline $\begin{array}{rr}* & \text { Endangered } \\
* * & \text { Threatened }\end{array}$ & & & & & \\
\hline
\end{tabular}


In Texas, a maximum of 300 red wolves occurred in Chambers and Jefferson Counties (Nowak, 1974). Probably fewer wolves exist in the Louisiana parishes of Cameron (Russel1 and Shaw, 1971) and Calcasieu (New release, July 1, 1977, U.S. Fish and Wildlife Service). An important factor in the decline of the red wolf on the western part of its historic range and a problem receiving much current attention is hybridization with coyotes (Canis latrans), (Know1ton, 1971; Nowak, 1974; Russe1l and Shaw, 1971). Forest-clearing and agricultural development of red wolf habitat has abetted hybridization by making many areas more favorable to the coyote.

Attwater's prairie Chicken (Tympanvchus cupide atturateri) was once abundant on over 6,000,000 acres of Gulf coast prairie from about Rockport, Arkansas County, Texas, to near Abbeville in Vermilion Parish, in southwestern Louisiana (Lehmann and Mavermann, 1963). This bird has undergone drastic reductions in population numbers and range due to the destruction of native grassland communities in its historic range (Johnsgard, 1973). The Attwater was extirpated from its range in Louisiana in about 1919. By 1937, approximately 8700 of the birds were present in Texas. Attwater's prairie chicken is currently listed as endangered by the U.S. Fish and Wildlife Service. In 1972, approximately 1600 prairie chickens inhabited 13 counties in the Texas coastal plain (Plate 9) (Jurries and Dodd, 1973; and Oberholser, 1974).

\subsubsection{Aquatic}

VEGETATION

Threatened and endangered plant species which are located in wetlands environments are listed on Table A-24. Any species of very restricted range also appears on the vegetation map (P1ate 8 ). 
Tab1e A-24. Aquatic Vegetation - Proposed Endangered Species.

\begin{tabular}{|c|c|c|c|c|}
\hline Species & Location & Habitat Preference & $\begin{array}{l}\text { Status } \\
\text { (State) }\end{array}$ & Reference \\
\hline Scutellaria thieretil & $\begin{array}{l}\text { Pecan Island and Redfish } \\
\text { Point, Vermilion Parish, } \\
\text { Cameron Parish, La. }\end{array}$ & $\begin{array}{l}\text { Shel1 ridges and ridges } \\
\text { in brackish marsh }\end{array}$ & $\mathrm{T}(\mathrm{La})$ & $\begin{array}{l}\text { Defilipps, } 1977 \\
\text { Shinners, } 1964 \\
\text { Federal Register } \\
1975\end{array}$ \\
\hline $\begin{array}{l}\text { Sarricenia psittacina } \\
\text { (Parrothead pitcher- } \\
\text { plant) }\end{array}$ & $\begin{array}{l}\text { Abita Springs, St. Tammany } \\
\text { Parish, La. }\end{array}$ & Fresh marsh & $\mathrm{T}(\mathrm{La})$ & $\begin{array}{l}\text { U.S.A.C.O.E, 197 } \\
\text { Federal Register } \\
1977\end{array}$ \\
\hline$\frac{\text { Atriplex }}{\text { (Kleberg }} \frac{\text { klebergorum }}{\text { saltbush) }}$ & Kleberg Co., Texas & $\begin{array}{l}\text { Clayey soils, saline } \\
\text { areas }\end{array}$ & $\mathrm{E}(\mathrm{Tex})$. & * \\
\hline$\frac{\text { Sesuvium }}{\text { (Texas sea-purslane) }}$ & Kenedy Co, , Texas & Dunes & $\mathrm{E}(\mathrm{Tex})$. & * \\
\hline$\frac{\text { Polygonum }}{\text { (K1eberg knotweed) }}$ & Kleberg Co., Texas & Fresh Marsh & $\mathrm{E}(\mathrm{Tex})$, & * \\
\hline
\end{tabular}

* All of these references R.P.S.C., 1974; Correll and Correll, 1975; Corre11 and Johnston, 1970; Dannis Brevonik, personal communication; Federal Register, 1975

$\mathrm{T}=$ Threatened

$E=$ Endangered 


\section{ANTMALS}

Five species of reptiles are currently classified by the U.S. Fish and Wildife Service as "endangered" or "threatened," including the American alligator (Alligator mississippiensis), Atlantic Ridley turtle (Lepidochelys kempii), Hawksbill turtle (Eretmochelys imbricata), leatherback turtle (Dermochelys coriacea), and the Houston toad (Bufo houstonensis), (U.S. Department of the Interior, 1976a). The Sabine map turtle (Graptemys pseudogeographica sabinensis), a distinctive subspecies confined to the drainage of the Sabine, Calcasieu, and Mermentau Rivers, was being considered for inclusion on the endangered species list, but has recently been withdrawn (Dr. C. K. Dodd, Jr., U.S. Fish and Wildlife Service, personal communication). Also to be considered is the black pine snake (Pituophis: melanoleucus lodingi), a melanistic subspecies that just enters the study area along the Pearl River on the Louisiana-Mississippi border (Dr. C. K. Dodd, Jr., personal communication). The Atlantic green turtle (Chelonia mydas), and the Atlantic loggerhead (Caretta caretta), have been proposed to receive "threatened" status because of the similarity of their appearance to the other endangered sea turtles (U.S. Department of the Interior, 1976b).

A brief discussion of four of the five endangered species follows (the American alligator is discussed elsewhere):

Houston Toad (Bufo houstonensis)-This toad was first described by Sanders (1953), who gives its range as Harris County west to Colorado County, northwest to Burleson County and east to Liberty County. The species is apparently closely associated with loblo1ly pine areas, and probably numbers "in the dozens" at most localities, reaching maximum abundance in Bastrop and Buesches State Parks (Honegger, 1970). 
Atlantic Ridley Turtle (Lepidochelys kempii) - This sea turtle is known to occur in the Gulf of Mexico along the Texas and Louisiana coasts, but there are apparently no recent records (Brown, 1948; D. A. Rossmann, Louisiana State University, Museum of Zoology, personal communication).

Atlantic Hawksbill Turtle (Eretmochelys imbricata) - The status of this species in the study area is virtually the same as that of the Atlantic Ridley (Brown, 1948; D. A. Rossmann, personal communication).

Atlantic Leatherback Turtle (Dermochelys coriacea) - Known to occur along the Texas and Louisiana coast, this species has been most recently reported near the Chandeleur Island chain, where a single individual was seen by a fisherman (Brown, 1948; D. A. Rossman, personal communication).

The brown pelican (Pelecanus occidentalis), once occurred on all coasts of North America below the latitude of $36^{\circ} \mathrm{N}$. Large numbers were year-around residents along the northern Gulf of Mexico. Large scale mortalities and reproduction fallures have caused widespread alarm about the welfare of these birds (Allen, 1935; King et al., 1977; Simmons, 1974; Winn, 1975). The brown pelican is listed as endangered by the U.S. Fish and Wildlife Service.

In our area of interest, successful reproduction is reported for a few pairs each year along the Texas coast between Corpus Christi Bay and San Antonio Bay (King et al., 1977; Texas Parks and Wildlife Department, 1976). Since more subadults are seen fishing in these areas than can be accounted for by observed nesting, it is assumed that immature birds from Mexico join with the Texas pelicans to swell the local population to slightly below 100 birds. 
Approximate locations for southern bald eagle (Haliaeetus leucocephalus) nests observed in Louisiana and Texas during 1977 are shown on Plate 9. Bald eagles will often change nest sites year-to-year and utilize a nest which may have gone unused for one or more previous breeding seasons. Therefore, care should be taken to preserve currently inactive nests. A total of nine active eagle nests were observed in Louisiana in 1977 (Ray Aycock, U.S. Fish and Wildlife Service, Baton Rouge, personal communication), and in Texas seven nests were recorded from six different counties (William Brownlee, Texas Parks and Wildlife Department, personal communication).

The whooping crane (Grus americana) once nested over a wide area from Lake Michigan to the Peace River area in Alberta, Canada, with scattered colonies throughout the Mackenzie River system and northward to the Arctic coast (Canada Wildlife Service, 1968). Their winter range extended from north Mexico to the Louisiana coast (Figure ).

Currently, the breeding range of the whooping crane occupies $1300-\mathrm{km}^{2}\left(500-\mathrm{mi}^{2}\right)$ in Wood Buffalo National Park in Northwest Territories, Canada. Their present winter range is 1imited to about $40-\mathrm{km}^{2}\left(15-\mathrm{mi}^{2}\right)$ in the Aransas National Wildlife Refuge located on the Blackjack Penninsula in Aransas County, Texas. The whooping crane is presently on the endangered species list of the U.S. Fish and Wildlife Service.

Whooping cranes have probably never been numerous. In 1850, their population was estimated to be 1500 . Serious declines have occurred since that time. Starting in 1938, exact counts of the birds have been made (Zinn and Fryling, 
1977). The lowest recorded population since that time occurred in 1941 , when only 15 whoopers were observed (Canada Wildlife Service, 1968).

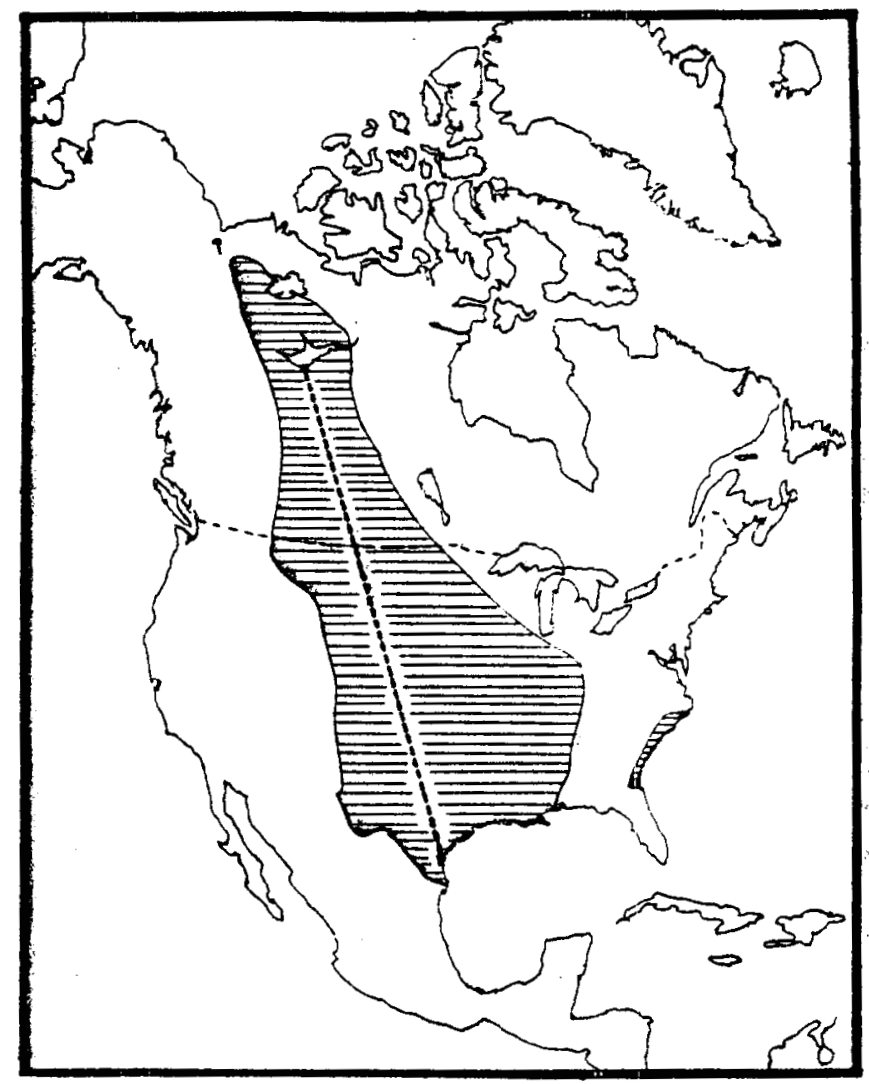

Fig. A-21. Migration route of whooping crane (After Canadian Wildlife Service, 1968).

In the spring of 1977, 69 whooping cranes left Aransas National Wildlife Refuge, the largest number recorded since 1938 (Zinn and Fryling, 1977). Population increases in recent years have been linked to a stabilized death rate, although the birth rate has decreased slightly (Miller et al., 1974).

On its winter range, the whooping crane inhabits a coastal salt marsh where it feeds on blue crabs, crayfish, mullet and various aquatic insects (Canada WildIife Service, 1968). Each pair of cranes requires a winter territory of about 
160 hectares (400 acres). It has been suggested that the carrying capacity of its wintering area on the Texas coast may eventually limit population growth of this species (Miller et al., 197.4).

The ivory-billed woodpecker (Campephilus principalis) was last confirmed in Louisiana in 1942, and in Texas in 1904. Based on photographs, Lowery (1974) belleves that a pair of birds were present in an unspecified location "...south of U.S. Highway $90, \ldots$ " in 1971.

Bachman's warbler (Vermivora bachmanni) was apparently fairly numerous in the eastern part of the study area during the latter part of the nineteenth century. Today it is the rarest warbler in this country and is to be looked for in heavily wooded swamp areas.

The peregrine falcon (Falco peregrinus) is a regular winter visitor to the coastal area. During its sojourn here it is highly mobile and tends to locate near concentrations of sandpipers, coots, ducks, or other prey species.

The red-cockaded woodpecker (Dendrocopos borealis), is classified as endangered because of a population decline related to modern forest management practices that favors vigorous younger trees on sites managed for pine. This highly specialized woodpecker requires pines that are infected with a fungus called "red heart" that occurs only in older, heavily-stressed pines, primarily longleaf.

\subsection{Land Use}

Existing land use along the Louisiana and Texas coast is illustrated on Plate 10. Five general categories have been designated which encompass the major land use 
types of the region. The categories which are discussed below include developed land, agricultural land, woodlands, swamps, and marshes. Oil fields occur under all 1and uses and therefore are not treated as a separate category (Overlay and Plate 10).

Developed land includes residential, commercial, industrial and extractive uses. Cultivated land, orchards, pasture and acreage presently out of cultivation have been grouped together as agricultural land. Wooded land is characterized by deciduous and hardwood forests which may be present either on Pleistocene soils or on floodplains of modern streams. Continually wet forested floodplains are designated as swamp lands. Saline, brackish, and freshwater marshes, as well as other coastal features such as barrier islands and some spoil areas have all been included in the marsh category. Parks, refuges, federal highways and major waterways are presented separate from the other land uses on Plates 1 and 11.

The statistics on land uses in Louisiana parishes and Texas counties is presented in Tables $\mathrm{A}-25$ and $\mathrm{A}-26$. For Louisiana, these data represent land use in square kilometers for every parish that lies either totally are partially within the study region. Land use for the entire parish has been included even if only a portion of it falls within the project area boundarles. In Texas counties, the information included reflects only those areas covered in the Environmental Geologic Atlas, Texas Coastal Zone, mapped by the Bureau of Economic Geology at the University of Texas in Austin. This atlas covers only those countles or portions of counties which are considered to be in the coastal zone. Therefore, data in Table A-26 represent 1and use information for partial counties as well as whole counties.

Figure A-22 illustrates the total breakdown of land use in the study area in each of the five different land use categories. Values for this figure were obtained 
Tab1e A-25. Areas of Land Use in Louisiana Parishes in the Study Region

\begin{tabular}{|c|c|c|c|c|c|c|c|c|c|c|}
\hline \multirow[b]{2}{*}{ Parish } & \multicolumn{2}{|c|}{ Developed } & \multicolumn{2}{|c|}{ Agricultural } & \multicolumn{2}{|c|}{ Wooded } & \multicolumn{2}{|c|}{ Swamp } & \multicolumn{2}{|c|}{ Marsh } \\
\hline & $\mathrm{Mi}^{2}$ & $\mathrm{Km}^{2}$ & $\mathrm{Mi}^{2}$ & $\mathrm{Km}^{2}$ & $\mathrm{Mi}^{2}$ & $\mathrm{Km}^{2}$ & $M i^{2}$ & $\mathrm{Km}^{2}$ & $\cdot M t^{2}$ & $\mathrm{Km}^{2}$ \\
\hline Acadia & 25.47 & 65.97 & 523.33 & $\overline{1355.42}$ & 57.50 & 148.93 & 42.84 & 110.96 & .77 & 1.99 \\
\hline Allen & 7.72 & 19.99 & 211.11 & .75 & 485.12 & 1256.46 & 56 & 46.93 & 0 & 0 \\
\hline Ascension & 13.12 & 33.98 & 142.80 & 369.85 & 54.80 & 141.93 & 78.73 & 203.91 & 2.70 & 6.99 \\
\hline Assumption & 34.35 & 88.97 & 118.90 & 307.95 & 0 & 0 & 182.93 & 473.79 & 0 & 0 \\
\hline Beauregard & 16.60 & 42.99 & 287.70 & 745.14 & 795.03 & 2059.13 & 65.22 & 168.92 & .77 & 1.99 \\
\hline Calcasieu & 81.43 & 210.90 & 556.90 & 1442.37 & 248.16 & 642.73 & 87.60 & 226.88 & 95.71 & 247.89 \\
\hline Cameron & 17.37 & 44.99 & 166.70 & 431.75 & 0 & 0 & 2.70 & 6.99 & 1314.50 & 3404.56 \\
\hline East Baton Rouge & 88.38 & 228.90 & 206.10 & 533.80 & 145.11 & 375.83 & 8.88 & 23.00 & 2.70 & 6.99 \\
\hline Evangeline & 8.10 & 20.98 & 359.30 & 930.59 & 270.16 & 699.71 & 32. & 82 & 4.25 & 11.01 \\
\hline Iberia & 45.15 & 116.94 & 171.40 & 443.93 & 3.09 & 8.00 & 191.81 & 496.79 & 125.43 & 324.86 \\
\hline Iberville & 19.68 & 50.97 & 163.30 & 422.95 & 20.45 & 52.97 & 7.72 & 19.99 & 424.53 & 1102.12 \\
\hline Jefferson & 142.80 & 369.85 & 5.80 & 15.02 & 5.79 & 15.00 & 41.30 & 106.71 & 126.97 & 328.85 \\
\hline Jeff Davis & 10.42 & 26.99 & 531.80 & 1377.36 & 49.79 & 128.96 & 49.01 & 126.94 & 3.47 & 8.99 \\
\hline Lafayette & 28.96 & 74.98 & 213.80 & 553.74 & 6.18 & 16.01 & 5.02 & 13.00 & .39 & 1.01 \\
\hline Lafourche & 167.11 & 432.81 & 188.70 & 488.73 & 5.40 & 13.99 & 191.68 & 496.45 & 557.68 & 1444.39 \\
\hline Livingston & 13.89 & 35.98 & 78.70 & 203.83 & 435.65 & 1133.51 & 103.43 & 267.88 & 0 & 0 \\
\hline Orleans & 71.40 & 184.93 & .40 & 1.04 & 8.88 & 23.00 & 10.42 & 26.99 & 91.08 & 235.90 \\
\hline Plaquemines & 103.43 & 267.88 & 37.40 & 96.87 & 10.42 & 26.99 & 20.07 & 51.98 & 684.27 & 1772.26 \\
\hline Point Coupee & 5.65 & 14.40 & 284.40 & 736.60 & 213.81 & 600.81 & 41.30 & 106.97 & 1.16 & 3.00 \\
\hline St. Bernard & 12.74 & 33.00 & 3.90 & 10.10 & 16.21 & 41.98 & 6.56 & 16.99 & 408.32 & 1057.55 \\
\hline St. Charles & 47.08 & 121.94 & 34.00 & 88.06 & 3.09 & 8.00 & 84.24 & 218.18 & 114.24 & 295.88 \\
\hline St. James & 10.03 & 25.98 & 86.80 & 224.81 & 12.35 & 31.99 & 124.65 & 322.84 & 0 & 0 \\
\hline St. John the Baptist & 6.56 & 16.99 & 43.60 & 112.92 & 6.95 & 18.00 & 127.36 & 329.86 & 27.40 & 70.97 \\
\hline St. Landry & 25, & 66.98 & 553.10 & 1432.53 & 289.45 & 749.68 & 48.24 & 124.94 & 0 & 0 \\
\hline St. Martin & 63.68 & 164.93 & 211.10 & 546.75 & 20.45 & 52.97 & 445.37 & 1153.51 & 34.35 & 88.97 \\
\hline St. Mary & 114.62 & 296.87 & 133.90 & 346.80 & 1.16 & 3.00 & .32 & .82 & 206.48 & 534.78 \\
\hline St. Tammany & 52.10 & 134.94 & 147.00 & 380.73 & 390.18 & 1010.57 & 191.04 & 494.79 & 89.15 & 230.90 \\
\hline Tangipahoa & 18.90 & 48.95 & 260.90 & 675.73 & 397.90 & 1030.56 & 44.38 & 114.94 & 61.75 & 159.93 \\
\hline Terrebonne & 176.80 & 457.91 & 86.50 & 224.04 & 33.19 & 85.96 & 140.87 & 364.85 & 874.15 & 2264.05 \\
\hline Vermilion & 18.90 & 48.95 & 670.40 & 1736.34 & 11.58 & 29.99 & 44.38 & 114.94 & 419.13 & 1085.55 \\
\hline West Baton Rouge & 5.00 & 12.95 & 80.30 & 207.98 & 56.35 & 145.95 & 45.15 & 116.94 & 0 & 0 \\
\hline Totals & 1453.29 & 3763.79 & 6560.04 & 16990.48 & 4056.20 & 10552.61 & 2682.98 & 6948.61 & 5671.35 & 14691.38 \\
\hline
\end{tabular}

Source: Louisiana office of State Planning, 1972. 
Table A-26. Areas of Land Use in Texas Counties in the Study Region.

\begin{tabular}{|c|c|c|c|c|c|c|c|c|c|c|}
\hline \multirow[b]{2}{*}{ Counties } & \multicolumn{2}{|c|}{ Developed } & \multicolumn{2}{|c|}{ Agricultural } & \multicolumn{2}{|c|}{ Wooded } & \multicolumn{2}{|c|}{ Swamp } & \multicolumn{2}{|c|}{ Marsh } \\
\hline & $\mathrm{Mi}^{2}$ & $\mathrm{Km}^{2}$ & $\mathrm{Mi}^{2}$ & $\mathrm{Km}^{2}$ & $\mathrm{Mi}^{2}$ & $\mathrm{Km}^{2}$ & $\mathrm{Mi}^{2}$ & $\mathrm{Km}^{2}$ & $\mathrm{Mi}^{2}$ & $\mathrm{Km}^{2}$ \\
\hline Newton & 10.9 & 28.23 & 13.00 & 33.67 & 71.50 & 185.19 & 3.0 & 7.77 & 0 & 0 \\
\hline Jasper & 2.1 & 5.44 & 26.40 & 68.38 & 54.00 & 139.86 & .3 & .78 & 0 & 0 \\
\hline Hardin & 13.1 & 33.93 & 33.00 & 85.47 & 123.50 & 319.87 & 7.0 & 18.13 & 0 & 0 \\
\hline Orange & 36.30 & 94.02 & 86.50 & 224.04 & 184.00 & 476.56 & 20.0 & 51.80 & 49.00 & 126.91 \\
\hline Jefferson & 177.20 & 458.95 & 600.20 & 1554.52 & 108.00 & 279.72 & 6.0 & 15.54 & 80.80 & 209.27 \\
\hline Chambers & 64.80 & 167.83 & 460.90 & 1193.73 & 52.10 & 134.94 & 8.3 & 21.50 & 76.90 & 199.17 \\
\hline Liberty & 19.20 & 49.73 & 216.00 & 559.44 & 144.90 & 375.29 & 17.5 & 45.33 & 3.50 & 9.07 \\
\hline Harris & 158.40 & 410.26 & 229.90 & 595.44 & 3.60 & 9.32 & 5.3 & 13.73 & 41.00 & 106.19 \\
\hline Galveston & 64.20 & 166.28 & 283.80 & 735.04 & 8.90 & 23.05 & 0 & 0 & 41.90 & 108.52 \\
\hline Fort Bend & 34.40 & 89.10 & 294.00 & 761.46 & 87.10 & 225.59 & 2.0 & 5.18 & 0 & 0 \\
\hline Brazoria & 211.10 & 546.75 & 809.10 & 2095.57 & 331.80 & 859.36 & 7.5 & 19.43 & 30.60 & 79.25 \\
\hline Matagorda & $223: 70$ & 579.38 & 198.30 & 513.60 & 43.00 & 111.37 & 3.0 & 7.77 & 36.90 & 95.57 \\
\hline Wharton & 86.00 & 222.74 & 387.30 & 1003.11 & 74.30 & 192.44 & 1.0 & 2.59 & 0 & 0 \\
\hline Jackson & 119.50 & 309.51 & 461.60 & 1195.54 & 84.70 & 219.37 & 0.3 & .78 & 0.3 & .78 \\
\hline Victoria & 72.40 & 187.52 & 377.70 & 978.24 & 56.50 & 146.34 & 1.0 & 2.59 & 5.0 & 12.95 \\
\hline & 1.30 & 3.37 & 92.80 & 240.35 & 7.40 & 19.17 & 0.3 & .78 & 0.3 & .78 \\
\hline Refugio & 40.20 & 104.12 & 733.80 & 1900.54 & 35.30 & 91.43 & 0.5 & 1.30 & 15.8 & 40.92 \\
\hline Bee & 19.90 & 51.54 & 99.90 & 258.74 & 9.40 & 24.35 & 0 & 0 & 0 & 0 \\
\hline San Patricio & 130.30 & 337.48 & 498.30 & 1290.60 & 21.00 & 54.39 & 0 & 0 & 19.00 & 49.21 \\
\hline Nueces & 360.50 & 933.70 & 602.80 & 1561.25 & 6.50 & 16.84 & 0 & 0 & 4.50 & 11.66 \\
\hline Jim Wells & 0 & 0 & 1.30 & 3.37 & 0 & 0 & 0 & 0 & 0 & 0 \\
\hline Kleberg & 144.90 & 375.29 & 729.10 & 1888.37 & 0 & 0 & 0 & 0 & 15.0 & 38.85 \\
\hline Kenedy & 147.00 & 380.73 & 987.40 & 2557.37 & 216.00 & 559.44 & 0 & 0 & 0 & 0 \\
\hline Brooks & 0 & 0 & 11.60 & 30.04 & 0 & 0 & 0 & 0 & 0 & 0 \\
\hline Wi1lacy & 5.60 & 14.50 & 595.90 & 1543.38 & 0 & 0 & 0 & 0 & 95.70 & 247.86 \\
\hline Hidalgo & 57.70 & 149.44 & 1603.20 & 4152.29 & 0 & 0 & 0 & 0 & 0 & 0 \\
\hline Cameron & 51.30 & 132.87 & 870.30 & 2254.08 & 0 & 0 & 0 & 0 & 113.40 & 293.71 \\
\hline Aransas & 121.00 & 313.39 & 129.30 & 334.89 & 13.40 & 34.71 & 0 & 0 & 24.10 & 62.42 \\
\hline Ca1houn & 144.90 & 375.29 & 387.90 & 1004.66 & 13.30 & 34.45 & 0 & 0 & 58.40 & 151.26 \\
\hline Totals & 2517.90 & 6521.39 & 1821.30 & 30617.18 & 1750.20 & 4533.03 & 83.00 & 215.00 & 712.10 & 1844.35 \\
\hline
\end{tabular}

Source: Bureau of Economic Geology, 1971-1977. 
from Tables $\mathrm{A}-25$ and $\mathrm{A}-26$. The dominant land use in the region is clearly agricultural. Approximately $49 \%$ of the land is either presently used for crops and range lands or has recently been under cultivation. Range land vegetation is similar to that found in prairie grasslands and is described in section 2.3 of this report.

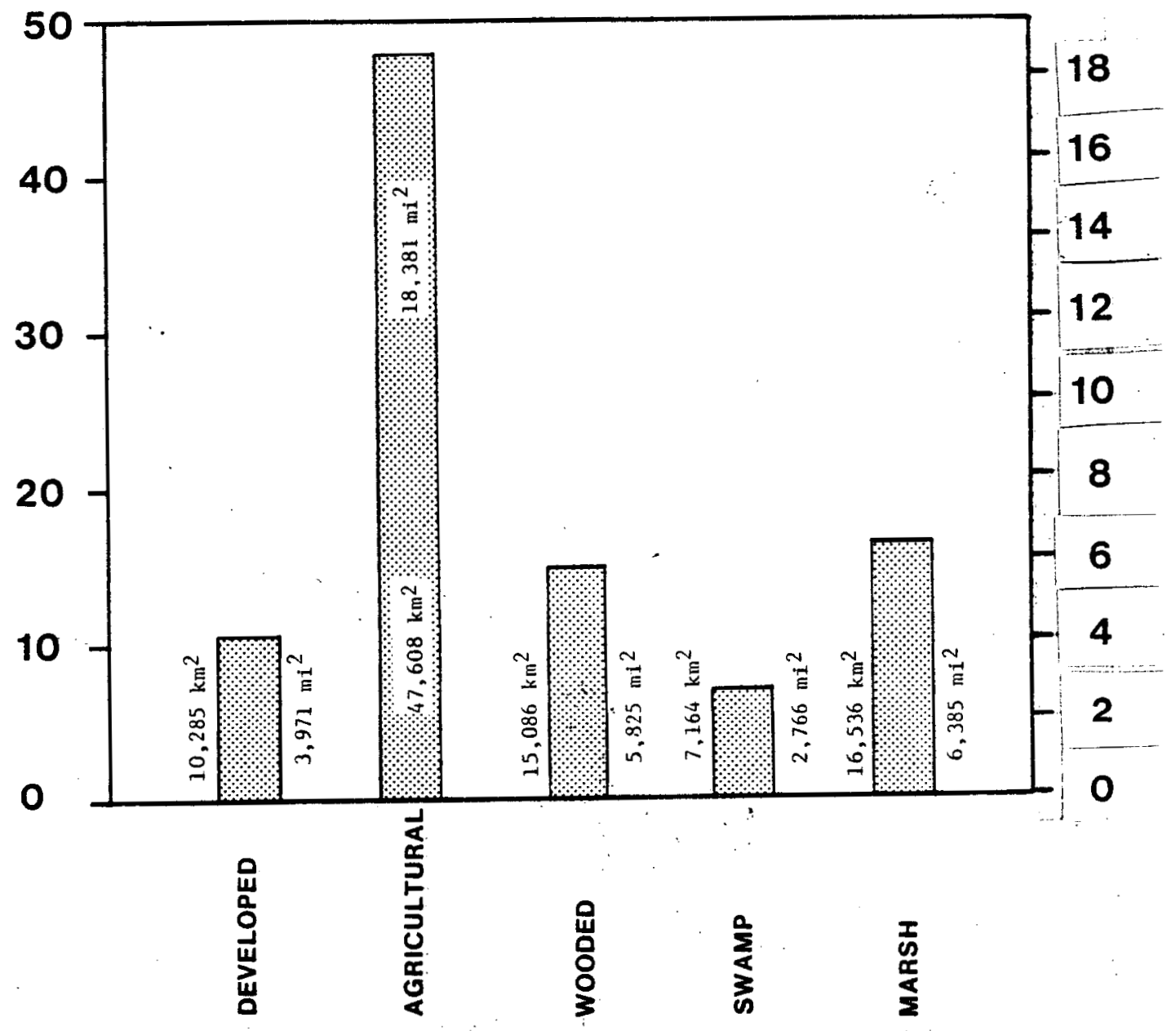

Fig. A-22. Breakdown of land use types within the study area. (After Loulsiana Office of State Planning, 1972; Bureau of Economic Geology, 1971-1977).

Agricultural lands extend over a large part of the Texas coast and continue into Louisiana along the Pleistocene terrace as far as the Atchafalaya Basin. Other 
agricultural land in Louisiana is along the fertile natural levees of the rivers and bayous.

Major regions of developed land in the study area include the urban and industrial areas associated with Corpus Christi, Galveston, the southern part of Houston, Beaumont, and Port Arthur in Texas; and Lake Charles, Lafayette, New Orleans, and Baton Rouge in Louisiana. Other urban and industrial areas in Texas mainly occur along major highways and railroads and inland waterways. In southern Louisiana the secondary developed areas tend to follow the higher land along the natural levees of bayous and rivers.

Extensive wooded areas in the Texas coastal region occur west of Boffin Bay as oak mottes, and in the Brazos River Basin and near the Texas-Louisiana border. These forests of eastern Texas continue into Loulsiana north of the marshes and prairies. More forested areas in Louisiana occur in the uppermost parts of the Atchafalaya Basin.

Nearly all of the swamp and marsh land in the two stateregions falls in Louisiana. Swamp land comprises $7164-\mathrm{km}^{2}\left(2765-\mathrm{mi}^{2}\right)$ of the land in the study area. Approximately $97 \%$ of the total swamp land is within Louisiana, mostly in the Atchafalaya Basin and west of Lake Ponchartrain. The major part of the marsh area also occurs in Louisiana. A total of $16,536-\mathrm{km}^{2}\left(6385-\mathrm{mi}^{2}\right)$ along the Louisiana coast has been categorized as marsh land. Only $1844-\mathrm{km}^{2}\left(710-\mathrm{mi}^{2}\right)$ of the marsh land in the study area occurs in Texas. Primary uses are for grazing, open space, and wildlife. State and federal lands in the study region include numerous parks, refuges, and management areas along the coast (Plate 11). 
Because of the volume of oil products and freight moving through the numerous ports and harbors along the Gulf coast, an extensive network of highways, rail 1ines, and waterways has developed to connect the major ports with inland areas (Plate 1). The Texas coastal zone presently has $19,308-\mathrm{km}(12,000-\mathrm{mi})$ of highways and 4809-km (2990-mi) of main-line tracks. In the coastal area of Louisiana, there are $9700-\mathrm{km}(6025-\mathrm{mi})$ of non-rural roadways and in 1970 there were 6900-km (4290-mi) of main-1ine tracks. The highway transportation system is supplemented by the intracoastal waterway and various other canals and navigable streams and rivers.

State and Federally owned lands in the region include numerous parks and refuges along the coastal zone (Plate 11). The names and sizes of the coastal state parks in Louisiana and Tecas are listed in Table A-27. The National Park Service administers the Chalmette National Historic Park in St. Bernard Parish, Louisiana, and the Padre Island National Seashore. This seashore extends $129-\mathrm{km}$ (80-mi) along Padre Island from Corpus Christi to near the mouth of the Rio Grande and occupies 54,420 hectares $(22,040$ acres).

The U.S. Fish and Wildife Service administers six National Wildiffe Refuges in coastal Louisiana and another five such refuges along the Texas coast. These refuges are 1isted in Table A-28. State wildlife and management areas in Louisiana and Texas are more numerous than the National Wildlife Refuges and vary somewhat in their management goals. These state refuges are listed in Table A-29 along with their locations and sizes. Private wildlife refuges administered by the National Auduborn Society are listed in Table 'A-30. 
Table A-27. State Parks in the Louisiana and Texas Study Area

Louisiana State Parks

$\begin{array}{lr}\text { Fort Macomb } & 7 \\ \text { Fort Pike State } & \\ \quad \text { Monument } & 51 \\ \text { Longfellow-Evangeline } & 64 \\ \text { Bogue Falaya Wayside } & \\ \quad \text { Park } & 5 \\ \text { Fontainebleau } & 1,115 \\ \text { Sam Houston } & 432 \\ \text { St. Bernard } & 145\end{array}$

$\begin{array}{lr}\text { Edward Douglas } & \\ \text { White State Monument } & 2 \\ \text { Fairview Riverside } & 41 \\ \text { Nibletts Bluff Confed. } & \\ \text { Memorial } & 13 \\ \text { Grand Isle } & 57 \\ \text { Cypremort Beach } & 75 \\ \text { Rutherford Beach } & \text { N/A } \\ \text { Sabine Pass SCA } & 18 \\ \text { Port Hudson State } & \\ \text { Commemorative Area } & 256\end{array}$

Proposed Louisiana State Parks

Lake Fausse Point

State Park

Isle Dernieres State

Preservation Area

Tickfaw State Park

McElroy Swamp State

Preservation Area

Jean Lafitte State Park

Lae Des Allemando

State Park

Lake Verret State Park

Pearl River Waterway

Chappepeela

Texas State Parks

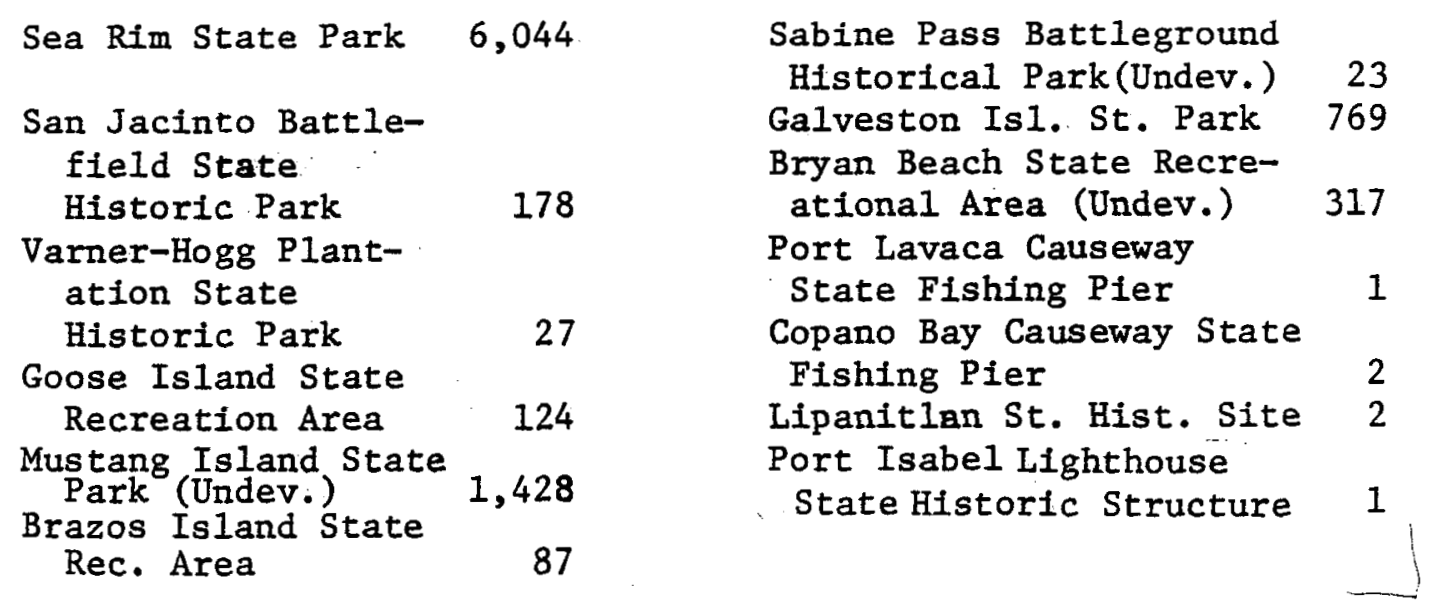

Source: Louisiana State Parks and Recreation Commission, n.d.: Louisiana State Parks and Recreation Commission, 1974; Loulsiana Office of State Planning, 1975 
Table A-28. National Wildlife Refuges in Coastal Louisiana and Texas

Louisiana

Name of Area

Delta Breton

Delta Section

Lacassine

Shell Keys

Sabine

East Timbahir Island
Texas

\begin{tabular}{r} 
Hectares \\
\hline 1,824 \\
19,749 \\
12,856 \\
20 \\
57,809 \\
136
\end{tabular}

Name of Area

Anabuac

Brazoria

San Bernard

Aransus

Laguna Atacosa
Hectares

4,023

3,857

6,038

22,190

18,272

Source: Louisiana State Parks and Recreation Commission, n.d.; Louisiana State Parks and Recreation Commission, 1974; Louisiana State Office of Planning, 1975.

Table A-29.: State Wildlife Management Areas and Preserves

Name of Area

County Location

Louisiana

Pearl River

St. Tammany

Biloxi

Bohemia

Pass-A-Loutre

Wismer

Salvador

Pointe au Chien

Rockefeller

Louisiana State

Marsh Island

Manchac

St. Tammany (Parish)
St. Tammany
St. Bernard
Plaquemines
Plaquemines
Lafourche
St. Charles
Lafourche
Cameron
Vermilion
Tberia
St. John the Baptist

St. John the Baptist
Hectares

10,812

526

16,019

6,475

26,710

8.750

11,129

11,430

33,185

6,070

31,971

2,129

Texas
J. D. Murphee
Jefferson
3,401
Sheldon
Harris
1,013
Las Palomas
283
Longoria Unit Cameron:
Voshe11 Unit Cameron
Fredricks Unit Willacy

Source: Louisiana State Parks and Recreation Commission, 1974

Texas Parks and Wildlife Dept., 1974. 
Table A-30. National Audubon Society Sanctuaries in Texas and Louisiana

Name of Area

Louisiana

Paul J. Rainey
Hectares

10,587

\section{Texas}

Vingt-et-un Islands of Galveston, Turtle, and East bays

Matagorda Island on Wynns Ranch across from Arkansas

Green Island and Three Island

Tracts in Laguna Madre

Bird Island and North Deer Island in Chocolate and West Bay and the Southwest part of Galveston Bay Lydia Ann Island, portions of Harbor Island and small tracts in Copano, St. Charles, Aransas, and Red Fish bays

Tract portions of the second chain of islands in San Antonio Bay
2,315

304

Source: Texas Parks and Wildlife Department; 1974.

\subsection{Climate and Air Quality}

\subsubsection{Climate}

From Pearl River, Louisiana, to the Rio Grande, Texas, there are significant variations in climate both from north to south and from east to west. The climate of southern Louisiana and upper Texas coasts east of Galveston may be classified as humid subtropical. Climate is influenced to a large degree by the many water surfaces provided by lakes and streams and by the proximity of the Gulf of Mexico. Throughout the year, these water areas modify the relative humidity and temperature regime by decreasing the range between extremes. During periods of southerly wind flow, these effects are increased, imparting the characteristics of a marine climate. Temperatures seldom fall below $0^{\circ} \mathrm{C}\left(32^{\circ} \mathrm{F}\right)$ in winter, and daily maxima above $320 \mathrm{C}\left(90^{\circ} \mathrm{F}\right)$ are common in sumer. 
The climate of south Texas west of Houston-Galveston is also subtropical but grading toward the west becomes progressively drier and more continental. Along the Rio. Grande annual rainfall drops off to less than 500-ml (20-in), with very low humidities, and the region is characteristically semf-desert in nature. Annual rainfall along the Texas coast varies significantly from north to south. Compare Houston's 1150-mI (45.26-in) annually, and Brownsville's 678.5-ml (26.75-in) (see Figure 2-17). More detailed information about climate in the study area is given in Orton (1964), about local wind regimes in Hsu (1969, 1970), and their relationship to air quality in Hsu (1977).

Tropical cyclones (hurricanes) are the largest and most destructive storms affecting the study area. They form between June and October over the warm waters of the Central Atlantic, Caribbean Sea, and Gulf of Mexico (Browner et a1., 1972). Figures A-23 and A-24 show the probability of hurricane occurrence along the length of the study area. Early in the season, hurricanes generally approach land from the southeast, while later in the season they tend to approach more from the south. As the tropical storm approaches land, sea level rises as a response to wind driven storm surge; wind velocities increase to in some cases an estimated $324-\mathrm{km} / \mathrm{hour}$ (200-mi/hour), precipitation increases in intensity and amount, more than 50-cm (20-in) in 24 hours; and barometric pressures in the eye of the storm may drop as 10 as $68-\mathrm{cm}$ (26.5-in) of mercury (McGowen et al., 1970; and U.S. Army Corps of Engineers, 1973). Damage from hurricanes results from storm surge along the coastal areas and from flooding resulting from precipitation in the more inland areas. Depth of flooding from storm surge depends on the configuration of the coast, the bottom topography and the intensity of the storm. In some cases, surge heights may exceed 10-m (33-ft) and reach $160-\mathrm{km}$ (100-mi) inland. Wind damage is common to inland and coastal 


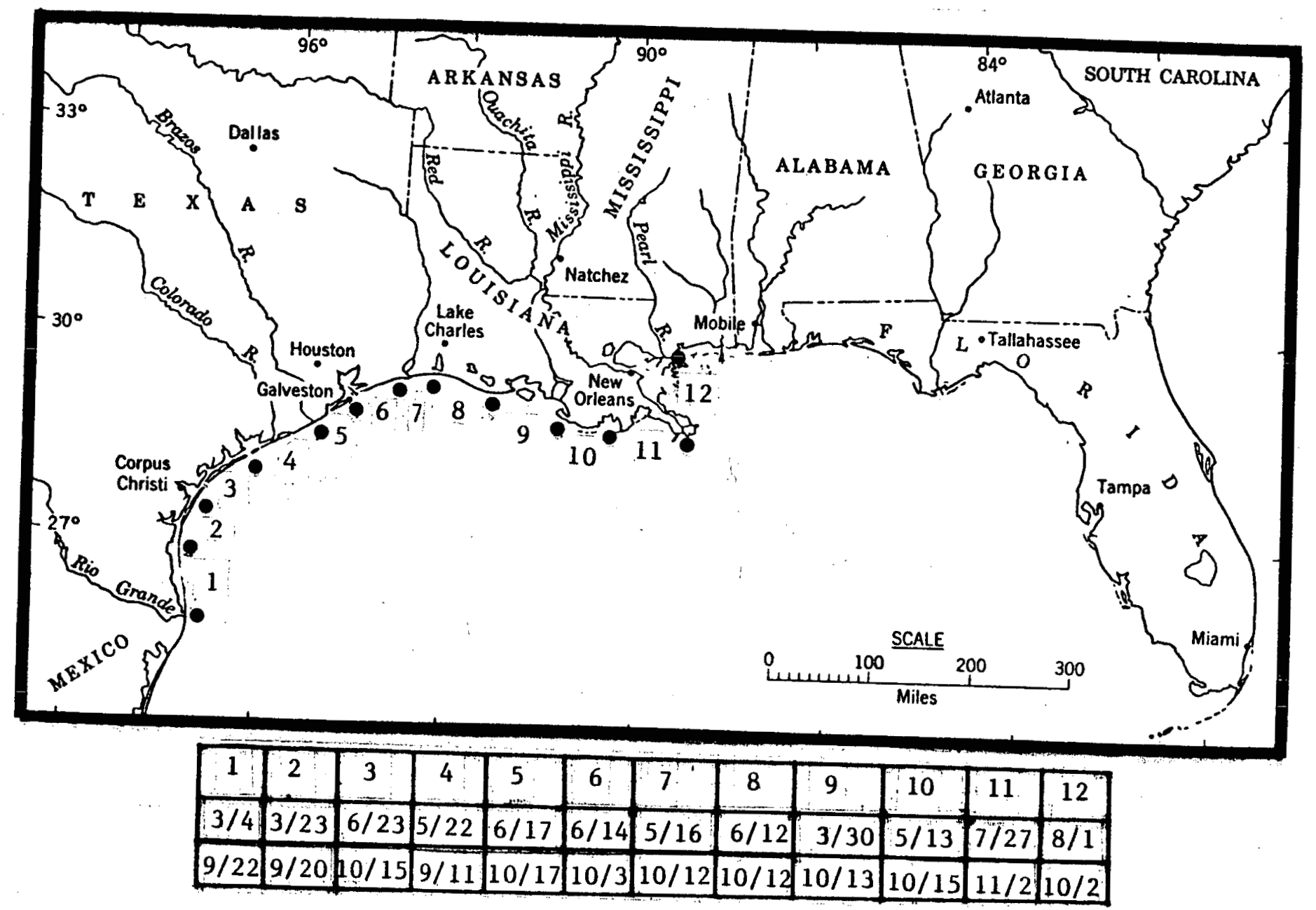

Fig. A-23. Earliest and latest tropical cyclone occurrences for the period 1886-1970. Numbers within boxes are the month and date of earliest and latest 1andfalls
for the Indicated coastal segment for the Indicated coastal segment (After Simpson and Lawrence, 1971). 
areas, but is less a cause of damage than is water. Wind damage may be intense in isolated zones impacted by tornadoes which precede the eye of the storm.

This histogram and table shows the probability (percentage) that a trepical storm, hurricane, or great hurricane will occur in any one year in a 50 mile segment of the coast line.

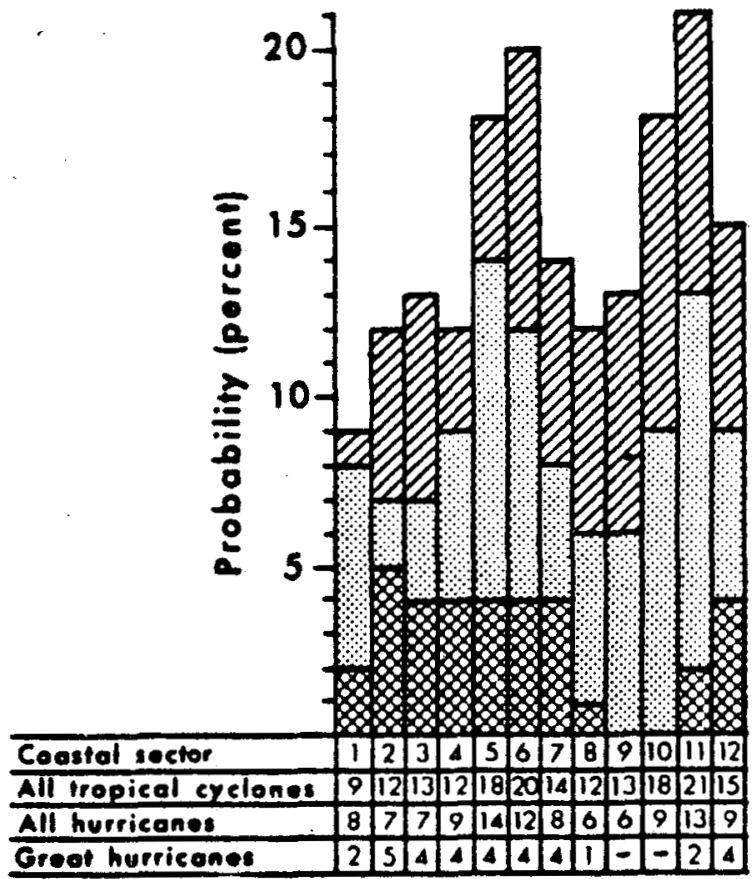

Fig. A-24. Cyclone probabilities for coastal sector along Gulf and Atlantic Seaborad (After Simpson and Lawrence, 1971). (See Figure 2-23 for geographic locations of each coastal sector.)

\subsubsection{Regional Air Quality}

From Pearl River to the Rio Grande, several pollutants were measured simultaneous1y. To compare these measurements with national standards, Table A-31 1ists a summary of National Ambient Air Quality Standards. Since the most recent and uniform data acquisition and presentation made by the Environmental Protection Agency (EPA) was in 1974 (EPA, 1976), Table A-32 lists all available data from that year. 
Table A-31. Summary of National Ambient Air Quality Standardsa

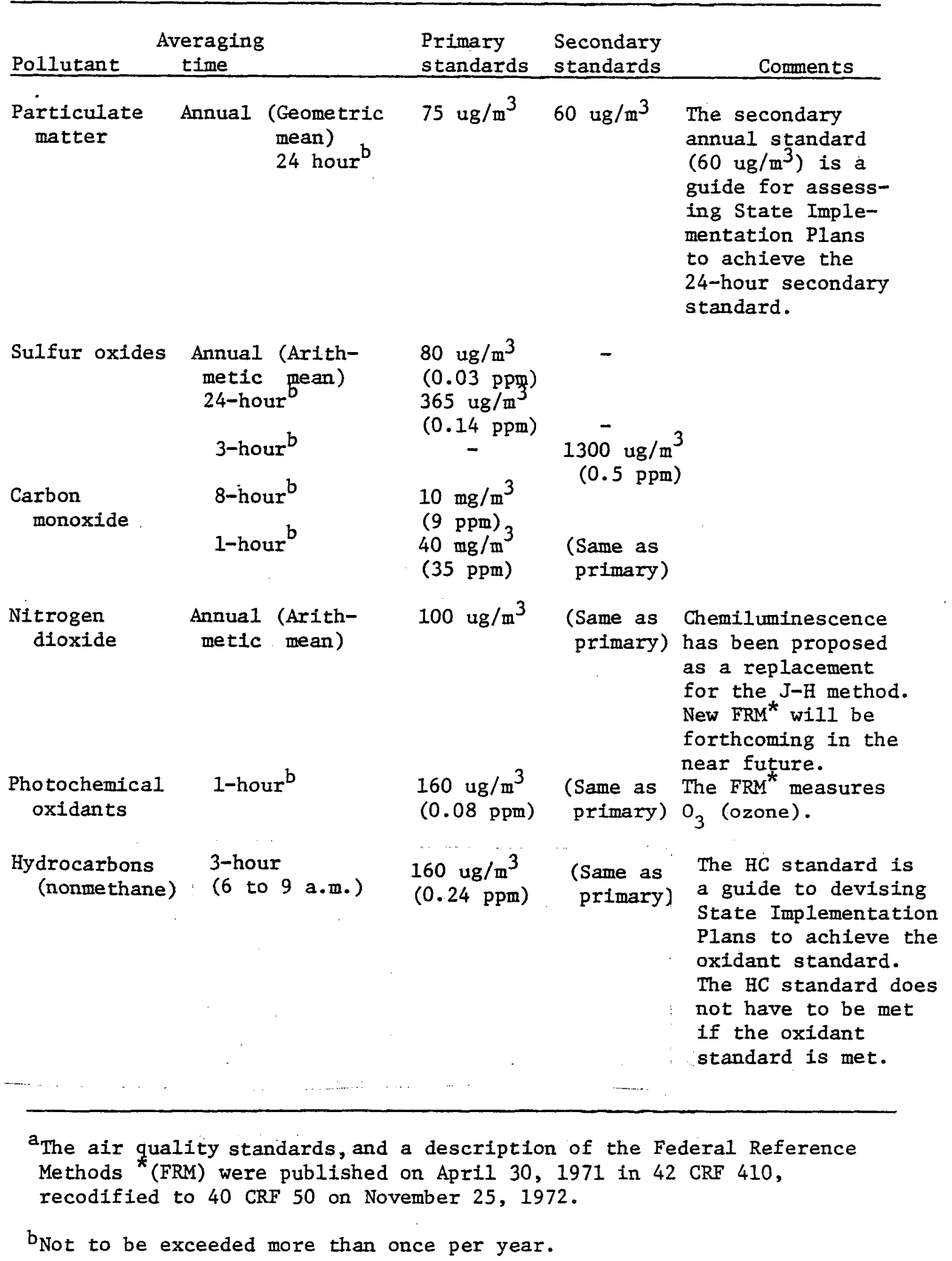


Table A-32. Air Quality Data for Particulate, Micrograms per Cubic Meter (25C) HI-VOL Gravimetric, 24 hours - 1974 Annual Report

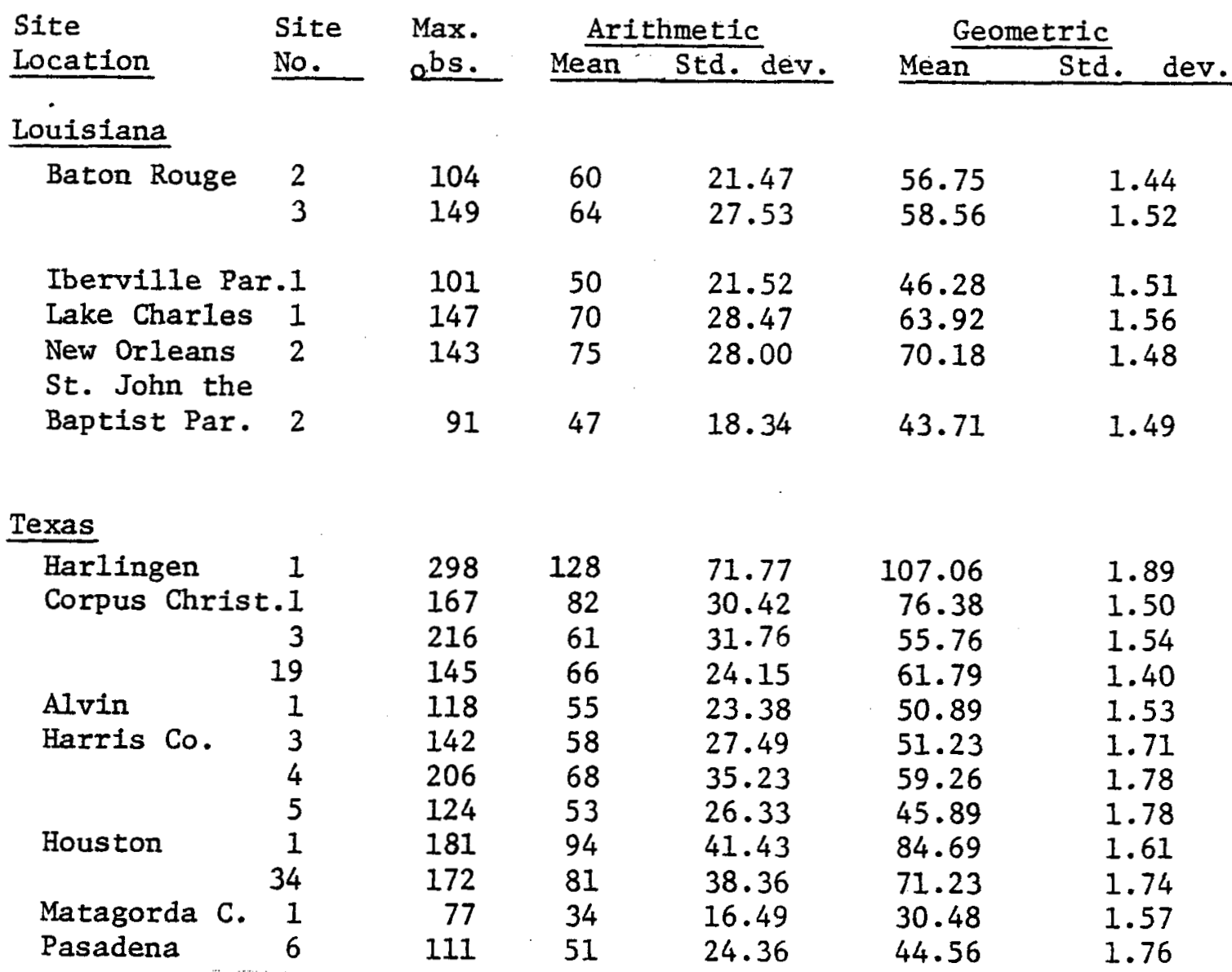

SULFUR DIOXIDE: $\mathrm{Mg} / \mathrm{M}^{3}$ (25C)

Gas Bubbler Pararosaniline - Sulfamic Acid, 24 hrs

Site 1974 Annual Report

Location Louisiana Site Max. Arithmetic No. obs. Mean Std. dev. BatonRouge 2101 $3 \quad 42$

14
7

Donaldson-

$\begin{array}{llr}\text { ville } & 1 & 31 \\ \text { Harvey } & 1 & 34 \\ \text { Iberville Par. } 1 & 21 \\ & 2 & 18 \\ \text { Lake Charles } & 1 & 8 \\ & 2 & 23 \\ \text { Metairie } & 2 & 138 \\ \text { New Orleans } & 2^{*} & 56 \\ & 2^{* *} & 38 \\ \text { Westlake } & 2 & 10\end{array}$

4
7
5
5
3
3
11
9
8
3

25.93
8.18
5.01
6.44
5.26
4.25
1.10
3.20
26.46
9.86
8.34
1.04
Mean

Geometric 
Table A-32, SULFUR DIOXIDE, $\mathrm{Mg} / \mathrm{M}^{3}$

Gas Bubbler Pararosaniline - Sulfamic Acid, 24 hrs 1974 Annual Report (Continued)

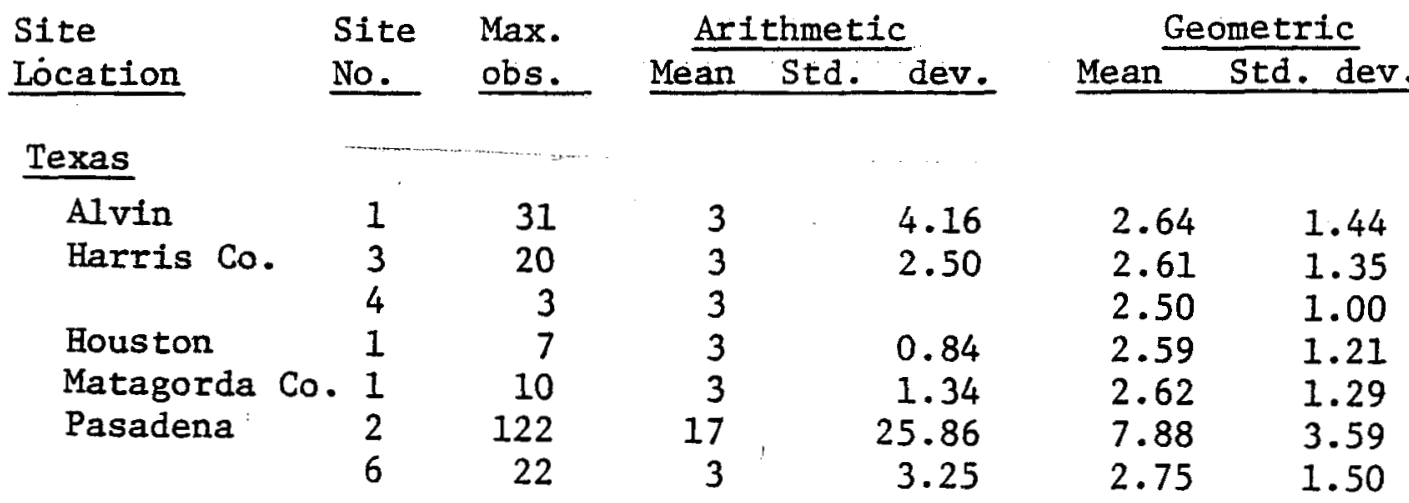

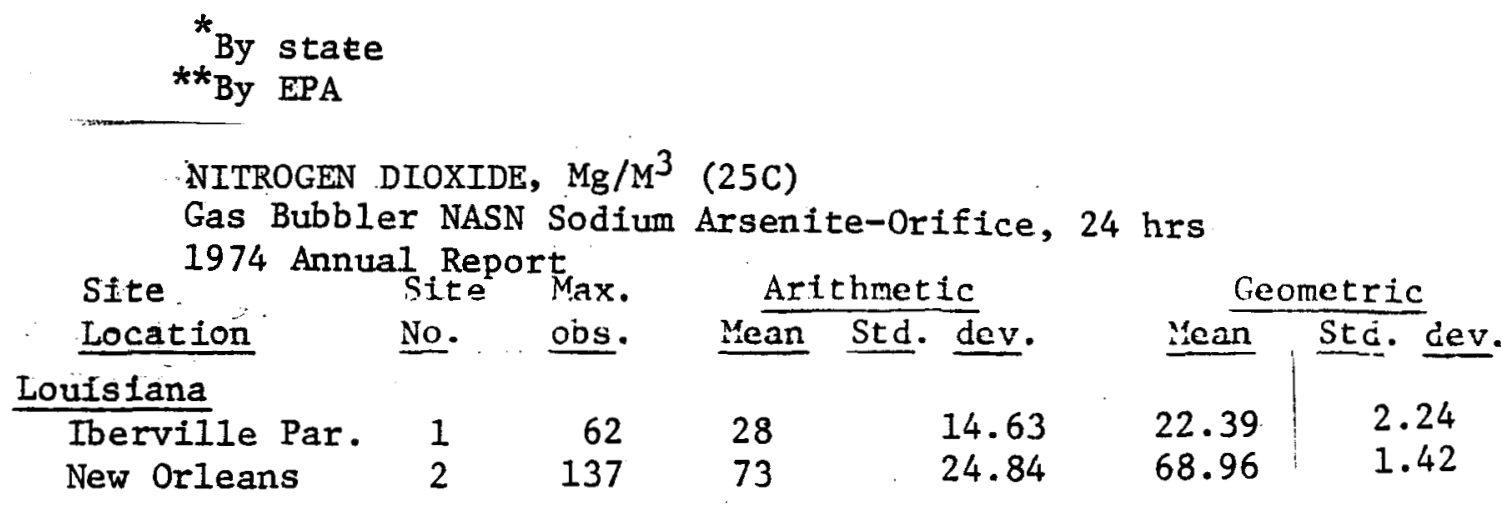

Texas

$\begin{array}{lrrrrrr}\text { Houston } & 1 & 124 & 68 & 24.16 & 64.42 & 1.42 \\ \text { Matagorda Co. } & 1 & 87 & 20 & 22.91 & 12.10 & 2.74 \\ \text { Pasadena } & 2 & 105 & 50 & 27.44 & 41.63 & 2.01\end{array}$

OZONE $\mathrm{Mg} / \mathrm{M}^{3}(25 \mathrm{C})$

Instrumental Chemiluminescence, $1 \mathrm{hr}$ 1974 Annual Report

Site Site Max. Arthmetlc

Location No. obs. Mean Std. dev. hean Std. dev.

Texas

$\begin{array}{llllllll}\text { Corpus Christ1 } & 19 & 247 & 41 & 32.64 & 30.57 & 2.23 \\ \text { Houston } & 34 & 429 & 41 & 45.51 & 25.08 & 2.64\end{array}$

Source: Environmental Protection Agency, 1976. 
Comparisons between Tables A-26 and A-27 show that on the average:

(1) for particulate matter, two areas, namely Harlingen and Houston, exceeded national standards in geometric mean, one area in Harlingen exceeded the maximum observation which is not to be exceeded more than once per year.

(2) for sulfur dioxide, there were no areas in our study region which exceeded national standard both in arithmetic and maximum value not to be exceeded more than once per year.

(3) for nitrogen dioxide, measurements showed that they were all below national standard.

(4) for ozone, from sparse data from Corpus Christi and Houston, both areas exceeded maximum value of $160 \mathrm{mg} / \mathrm{m}^{3}$ for one hour readings, not to be exceeded more than once per year.

It is concluded from air quality measurements in the study area from Pearl River to Rio Grande, that except in Houston (for particulate and $0_{3}$ ), Corpus Christi (for $\mathrm{O}_{3}$ ), and Harlingen (for particulate), the measurements did not exceed national standards.

\subsubsection{Atmospheric Stability Classes}

For a given distribution of sources of pollution, the concentration of pollutants in the atmosphere depends primarily on two factors, the vertical variation of temperature and the direction and strength of the wind. The vertical variation of temperature controls the rate at which the contaminants spread upward and clean air fromabove is mixed downward into the polluted air. The wind speed determines how much air the pollution is initially mixed into, and the 
irregularities of wind speed and direction govern the rate at which the pollution spreads horizontally as it is carried downwind.

Atmosphere stability classes and their associated wind speed have been measured in two places in our study area, by the Louisiana Power and Light Company and Houston Lighting and Power Company, respectively. These results are compiled in Tables A-33 and A-34. Note that stability Class A represents extremely unstable conditions; $B$, unstable; C, slightly unstable; D, neutral; E, slightly stable; F, moderately stable; and G, extremely stable (Slade, 1968). It can be seen from Tables A-28 and A-29 that neutral and slightly stable conditions (D and E) existed about $60 \%$ of the year. Furthermore, on the average, from both locations, stability classes D, E, and F describe approximately $75 \%$ of the time per year.

Table A-33. Stability Classes and Wind Speed Measured Near Taft, Louisiana from May 1972 through April 1973*

Stability Class Percent Frequency Average Wind Speed (M/S)

$\begin{array}{lrr}\text { A } & 10.33 & 3.72 \\ \text { B } & 1.72 & 3.83 \\ \text { C } & 2.37 & 4.17 \\ \text { D } & 29.43 & 3.74 \\ \text { E } & 29.61 & 2.81 \\ \text { F } & 14.48 & 1.56 \\ \text { G } & 12.06 & 0.98\end{array}$

* The site is for the Waterford Steam Electronic Station located on the West bank of the Mississippi River in St. Charles Parish, near the town of Taft, La. The results are taken from the Louisiana Power and Light Company (1974). 
Table A-34. Stability Classes and Wind Speed Measured Near Houston, Texas, from August 1972 through July 1973*

\begin{tabular}{|c|c|c|}
\hline Stability Classes & Percent Frequency & Average Wind Speed (M/S) \\
\hline A & 2.49 & 4.25 \\
\hline B & 3.15 & 4.71 \\
\hline C & 7.20 & 4.25 \\
\hline D & 34.95 & 4.38 \\
\hline E & 29.13 & 3.17 \\
\hline F & 14.14 & 1.80 \\
\hline G & 8.94 & 1.64 \\
\hline
\end{tabular}

The site is for the Allens Creek Nuclear Generating Station located in southern Austin County, Texas, immediately west of the Brazos River and about 45 miles west of the center of Houston. The results are taken from Houston Lighting and Power Company (1974).

\subsubsection{Atmospheric Inversion Potential}

While the temperature normally decreases with height, inversions are not infrequent, especially near the ground. They occur particularly at night, when the ground is cooled because of the outgoing radiation not being compensated by incoming radiation from the sun. The needed information on inversion frequencies for pollution dispersion computations is shown on Figures $A-25$ and $A-26$. It is clear that in our study area from the coastal region to inland, the gradient of these inversion frequencies is large. In general, however, there is slightly less frequency (40\% vs. $50 \%$ during nightime and $25 \%$ vs. $30 \%$ for total hours) for the inversion to form between Galveston and Corpus Christi than other regions in our study area. 

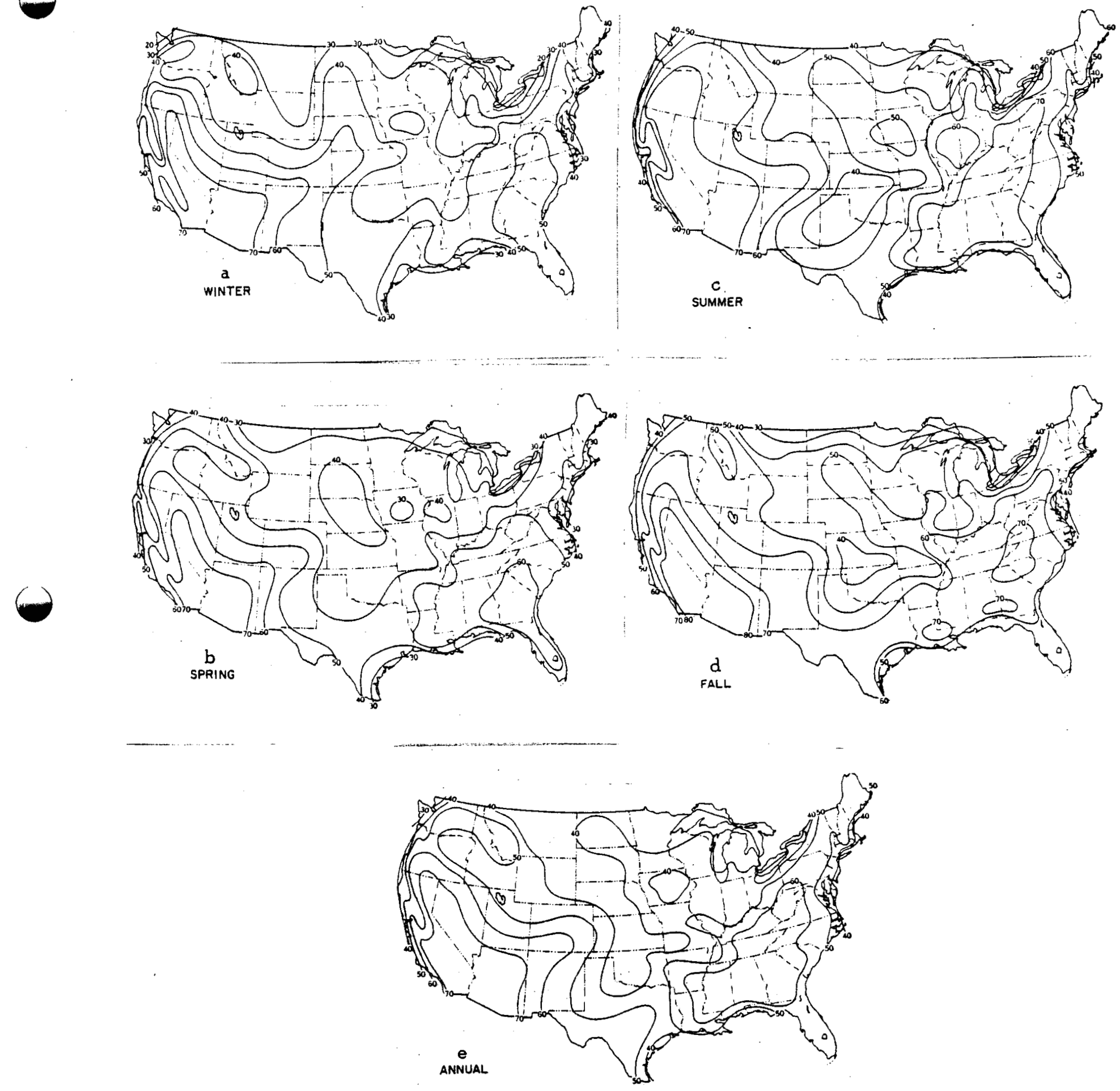

Fig. A-25. Isopleths of nighttime [ (percent cloud cover $\leq 3 / 10)+$ (percent wind speed $\leq 7$ m.p.h.) ]/2: (A) Winter, (B) Spring, (C) Summer, (D) Fall, (E) Annual (After Hosler, 1961). 

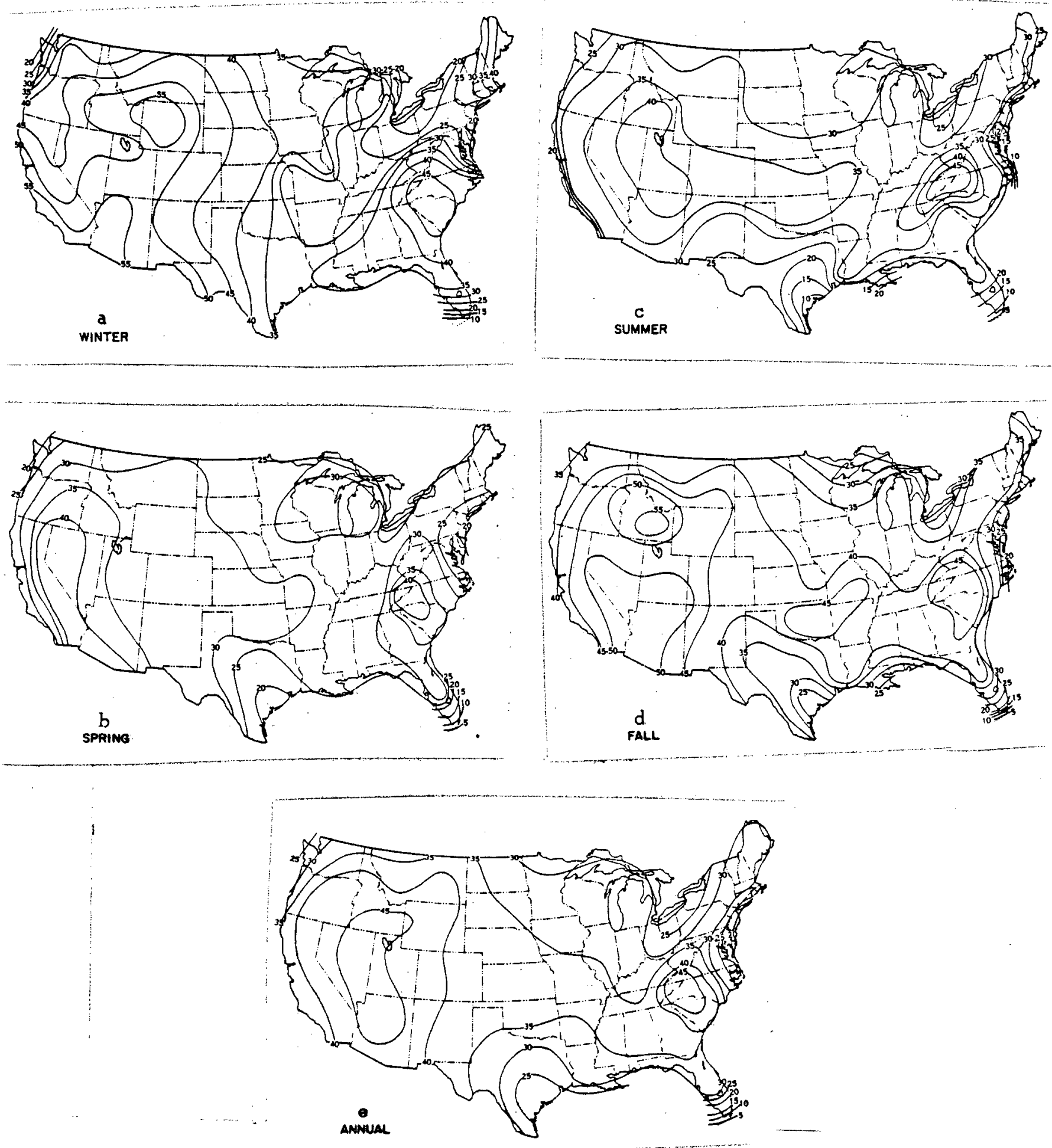

Fig. A-26. Inversion frequency (percent of total hours): (A) Winter, (B) Spring, (C) Summer, (D) Fall, (E) Annual (After Hosler, 1961). 


\subsubsection{Emission Inventory}

Natural emissions density maps have been compiled for the United States (Bach and Daniels, 1975). In the study area (Figure A-27), density of suspended particates decreases from east to west. Sulphur dioxide, nitric oxides, hydrocarbons, and carbon monoxide are highest in the north Texas Gulf coast air quality control region. The density of input decreases to the east and west from this region with the south and central Texas coast having the lowest pollution levels in the study region. The suspended particles, $\mathrm{NO}_{\mathbf{x}}$ emissions, and $\mathrm{SO}_{\mathrm{x}}$ emissions are largely the result of industrial and power plants in the heavily populated areas. Hydrocarbon and carbon dioxide are the result of transportation facilities and industrial processes. Bach and Daniels (1975) issue a word of caution on using these maps:

Finally, a word of caution is appropriate when interpreting these emission density maps. It is clear that the magnitude of the emission density is critically dependent not only upon the magnitude of the emission tonnage, but also upon the size of the area to which it is related.

The maps show the relative differences between areas.

\subsection{National Landmarks}

The National Landmarks program is a result of the Historic Sites Act of 1935. Its purpose is to "preserve for public use historic sites, buildings, and objects" (Greenburg, 1976:vi). In 1966, Congress passed the National Historical Preservation Act; the National Register of Historic Places was a part of this Act. The National Register includes "nationally significant properties and historic areas administered by the National Park Serve to include districts, sites, buildings, structures, and objects of State and local significance" (Greenburg, 1976:vi). All National Landmarks are in the National Register. 


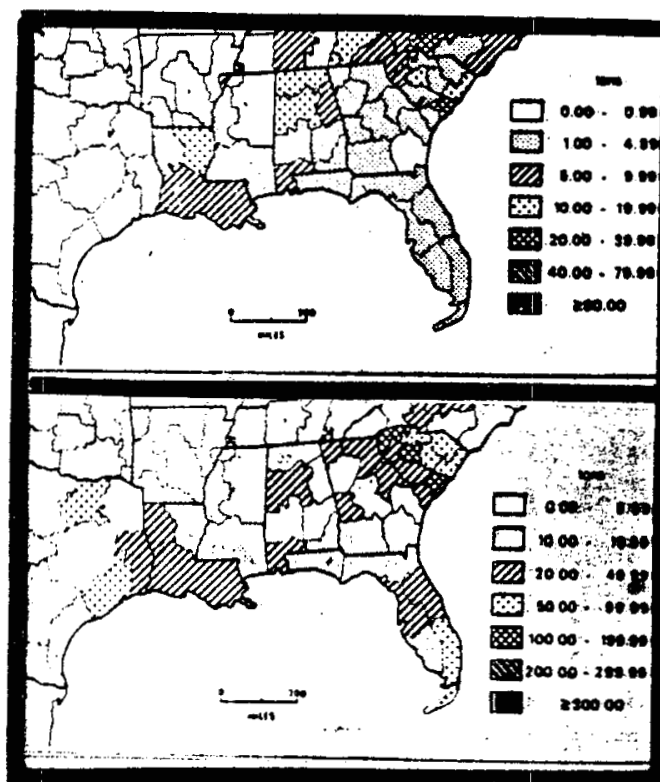

Suspended Particulates

Carbon Monoxide

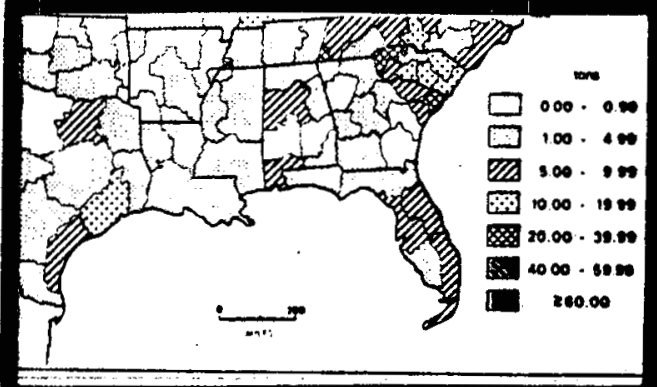

Nitric Oxide

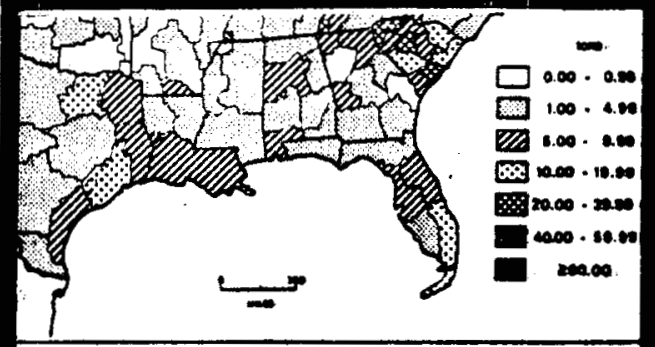

Hydrocarbon

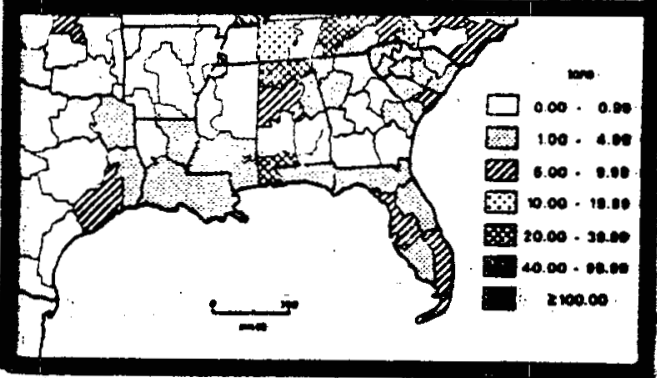

Sulfur Dioxide

Fig. A-27. U.S. emission density maps for various parameters (After The National Air Monitoring Program, 1973). 
Executive Order 11593, which was issued May 13, 1971, states that projects funded, licensed, or executed by Federal agencies must have the determination of eligibility of properties for inclusion in the National Register. This requires a survey, or surveys, to identify the sites and nominate them to the National Register.

The Archeological and Historical Preservation Act of 1974-Moss Bennett Act directs that any properties that would be irreparably damaged by any project using Federal funds must be preserved or excavated. Part of the Federal funds can be used for either of these alternatives. There are several other Federal laws concerning archeology but these are the most relevant to the proposed action.

The National Register sites on the cultural resource map (Plate 12) were taken from the National Register of Historic Places (Greenburg, 1976). The Louisiana sites have been updated to June, 1977, and Texas to December, 1976. Sites that have been nominated but not yet approved are not listed.

\subsubsection{State Landmarks}

A State Landmark in Louisiana is a "geographical area situated on State-owned lands, excluding public lands, private lands, or a combination thereof, which is accepted and approved for inclusion by the Louisiana Archaeological Survey and Antiquities Commission in the "Registry of State Archaeological Landmarks" "Rules and Regulations of the Louisiana Archaeological Survey and Antiquities Commission, 1977:10). Only two Louistana State Landmarks are in the project area, One of these, Bayou Jasmine (16 SJB 2), is also in the National Register (number 59 on Plate 12). Acadiana Park (16 LY 14) is in Lafayette Parish. A permit must be obtained from the Louisiana Archaeological Survey and Antiquities Commission 
before there is any work on a State Landmark. In Texas the Landmarks include:

all sites, objects, buildings, pre-twentieth century shipwrecks and locations of historical, archeological, educational or scientific interest including, but not Iimited to, prehistoric and historic American Indian or aboriginal campsites, dwellings and habitation sites, archeological sites of every character, treasure embedded in the earth, sunken or abandoned ships and wrecks of the sea, or any part of the contents thereof; maps, records, documents, books, artifacts, and implements of culture in any way related to-the inhobitants, prehistory, history, natural history, govermment, or culture in, on, or under any of the lands of the State of Texas, including the tidelands, submerged lands, and the bed of the sea within the jurisdiction of the State of Texas (Texas Antiquities Comnittee, 1969:.003).

In Texas, any archeological or historical site belonging to any "county, city, or other political subdivision ....are State Archeological Landmarks and may not be taken, altered, damaged, destroyed, salvaged, or excavated, without a permit from the Texas Antiquities Committee" (Texas Antiquities Committee, 1969:.003).

\subsubsection{Cultural Resources}

Archeology in Louisiana and Texas includes prehistoric and historic Indian sites, historic European sites, and shipwrecks. The sites date from 10,000 B.C. to c.A.D. 1900. Although there are concentrations of different cultures within the project area there is also a scattering of sites representing all time periods throughout the area. The circles on Plate 12 represent concentrations of sites. A concentration is five or more sites within a small area. On the map is a number next to each concentration representing the approximate number of sites within the area, The concentrations do not reflect the true site distribution within the area since they have usually been located through small, local surveys or they are in presently easily accessible locales. In addition, the location of many of the sites in Louisiana have been masked due to the subsidence of the land 
Most of the sites are on high ground that is located near water. These landforms are called high probability areas; other high probability areas include modern and relict natural levees, crevasse channels in backswamp areas, and floodplains and stream confluences.

Many archeological and historical sites are National Landmarks, or are in the National Register of Historic Places, or are Louisiana or Texas State landmarks.

\subsubsection{Survey Standards}

Executive Order 11593 which was issued May 13, 1971, requires a survey to identify and nominate sites to the National Register. Both-Texas and Louisiana have developed survey standards so the Federal Regulations will be followed in an orderly manner.

The Louislana Archaeological Council, an advisory body of professional archeologists, composed the survey standards for the State Art Historical and Cultural Preservation Agency and the Louisiana Archaeological Survey and Antiquities Commission. There are three levels of survey work, Level $I$ is the Assessment and Preliminary Field Review. At this level a review of the site records, literature, maps, aerial photographs, and other resource materials is required. On-the-ground inspection of high probability areas is necessary unless the Principal Investigator submits evidence that the inspection is impossible. limited testing to determine the extent of the site also occurs at this level. A report must then follow that lists sites that are being nominated to the National Register and recommendations for further work. 
The Intensive Field Survey, Level II, is a complete on-the-ground survey; subsurface testing and screening is required in high probability areas. Emphasis is on obtaining samples for dating and testing to determine site dimensions, cultural sequence, and eligibility for inclusion in the National Register of Historic Places. The report that follows this level must include an analysis of the artifacts.

Mitigation, Level III, occurs when a site will be destroyed by the proposed work. Excavation is then necessary to recover information in situ. Excavations are also necessary at sites determined elgible for inclusion in the State Landmarks Program and the National Register.

The Council also has qualifications for the Principal Investigator and the other archeologists working on the project. The Principal Investigator is responsible for the report which also must meet certain standards.

The Texas Antiquities Committee has rules and regulations similar to those in Louisiana. Their Cultural Resource Reconnaissaince is a record review, literature search, and on-the-ground survey of selected areas. Testing may be required at this stage. A Cultural Resource Survey is an intensive on-the-ground survey to determine the extent of the resources, the importance of the cultural resources and the estimated cost of investigating, excavating, and preserving the site and artifacts. The General Rules of Practice and Procedure stresses that excavation should only occur when it is absolutely necessary. Like Louisiana, Texas has certain requirements for the Principal Investigator and other archeologists working on the project. 
All efforts should be made to follow the standards in both states since the failure to do so could result in the rejection of the report and the subsequent postponement or denial of a Federal permit. A complete copy of The General Rules of Practice and Procedure can be obtained from the Texas Antiquities Committee, P. O. Box 12276, Capitol Station, Austin, Texas 78711. The Draft Standards for Cultural Resource Surveys can be obtained from the Louisiana Archaeological Survey and Antiquities Commission, 1645 Nicholson Drive, Baton Rouge, Louisiana 70802 .

\subsection{Socioeconomic Characteristics}

\subsubsection{Employment}

The major employment categories, agriculture, mining, construction, and manufacturing, and the number of people employed in each of these groups by county (parish) are listed in Table A-35. Both Louisiana and Texas are below the 1970 national per capita income of $\$ 3,910$. The Texas 1970 per capita income was $\$ 3,515$ (U.S. Bureau of the Census, 1973) while the Louisiana 1973 per capita income level was $\$ 3,825$ (U.S. Bureau of Mines, 1976). For comparison within the project area, the median family income is listed for each county or parish within the area Table A-36. Also for reference, the median number of years of school for each county (parish) is listed Table A-37.

\subsubsection{Economy}

The economy of the project area is diversified. Agriculture, mining, construction, and manufacturing are the four largest employers, but retailing, medical services, as well as other occupations, are also important, especially in urban areas. 
Table A-35: Total Employment and Employment in Selected Occupations

County

Aransas

Bee

Brazoria

Brooks

Calhoun

Cameron

Chambers

Fort Bend

Galveston

Golidad

Hardin

Harris

Hidalgo

Jackson

Jasper

Jefferson

Jim Wells

Kenedy

Kleberg

Lavaca

Liberty

Matagorda

Newton

Nueces

Orange

Refugio

San Patricio

Victoria

Wharton

Willacy
Tota1

Employed

$$
2,845
$$

6,345

39,811

2,233

5,835

40,178

4,291

17,887

65,011

1,548

10,061

711,749

52,073

4,529

7,790

89,848

10,453

298

9,656

6,280

10,884

9,679

3,033

81,305

24,428

3,471

14,947

19,356

13,114

4,168
Agri-

culture

217

605

1,475

337

521

4,730

587

1,579

1,033

304

150

5,666

9,418

715

191

1,030

927

179

639

937

785

1,168

112

2,171

200

369

1,731

863

2,080

1,446

\begin{tabular}{c} 
Mining \\
\hline 129 \\
429 \\
975 \\
130 \\
80 \\
103 \\
342 \\
447 \\
629 \\
44 \\
689
\end{tabular}

20,246

1,040

595

77

1,888

1,624

$-$

416

143

1,056

599

52

3,253

356

441

959

980

1,105

63
Construc- Manu-

tion facturing

273

649

5,303

241

758

2,817

507

1,917

6,390

203

1,047

63,348

3,183

484

721

6,416

883

-

935

534

1,518

1,006

405

7,175

2,491

257

1,536

1,567

1,016

160
295

210

11,765

54

1,589

4,579

521

4,160

13,156

35

2,904

143,039

3,791

392

2,375

25,325

444

9

844

1,320

1,442

1,279

1,118

8,973

8,827

198

1,818

3,196

1,153
106 
Table A-35. Total Employment and Employment in Selected Occupations Continued.

\begin{tabular}{|c|c|c|c|c|c|}
\hline Parish & $\begin{array}{l}\text { Total } \\
\text { Employed }\end{array}$ & $\begin{array}{l}\text { Agri- } \\
\text { culture }\end{array}$ & Mining & $\begin{array}{l}\text { Construc- } \\
\text { tion }\end{array}$ & $\begin{array}{l}\text { Manu- } \\
\text { facturing }\end{array}$ \\
\hline Acadia & 15,009 & 1,750 & 1,374 & 1,083 & 1,678 \\
\hline Ascension & 10,805 & 459 & 209 & 1,430 & 2,643 \\
\hline Assumption & 4,929 & 937 & 219 & 569 & 1,081 \\
\hline Calcasieu & 47,648 & 1,084 & 1,693 & 5,168 & 9,052 \\
\hline Cameron & 2,601 & 336 & 416 & 219 & 306 \\
\hline East Baton Rouge & 102,577 & 1,133 & 981 & 10,116 & 931 \\
\hline Evangeline & 8,386 & 1,316 & 585 & 613 & 931 \\
\hline Iberia & 17,346 & 1,090 & 2,673 & 1,076 & 2,242 \\
\hline Iberville & 8,018 & 548 & 363 & 1,088 & 1,361 \\
\hline Jefferson & 122,345 & 1,129 & 4,810 & 10,608 & 19,323 \\
\hline Jefferson Davis & 8,752 & 1,391 & 930 & 731 & 763 \\
\hline Lafayette & 37,569 & 1,380 & 3,568 & 2,926 & 2,030 \\
\hline Lafourche & 20,964 & 1,362 & 2,191 & 1,789 & 3,193 \\
\hline Livingston & 11,066 & 432 & 183 & 2,091 & 1,986 \\
\hline Orleans & 208,787 & 1,364 & 3,576 & 12,061 & 24,830 \\
\hline Plaquemines & 7,905 & 371 & 1,596 & 1,015 & 827 \\
\hline St. Bernard & 17,521 & 255 & 356 & 1,785 & 3,777 \\
\hline St. Charles & 8,910 & 205 & 261 & 723 & 2,881 \\
\hline St. James & 4,976 & 511 & 18 & 313 & 2,197 \\
\hline \multicolumn{6}{|l|}{ St. John the } \\
\hline Baptist & 6,321 & 312 & 94 & 660 & 2,293 \\
\hline St. Landry & 20,569 & 2,362 & 1,335 & 2,901 & 1,337 \\
\hline St. Martin & 8,301 & 991 & 696 & 1,316 & 717 \\
\hline St. Mary & 19,130 & 1,120 & 2,347 & 1,491 & 2,647 \\
\hline St. Tammany & 19,608 & 440 & 488 & 2,065 & 4,018 \\
\hline Tangipahoa & 19,294 & 2,007 & 292 & 1,939 & 3,063 \\
\hline Terrebonne & 22,958 & 1,036 & 4,255 & 1,465 & 2,698 \\
\hline Vermillion & 12,519 & 1,619 & 1,442 & 1,208 & 1,001 \\
\hline West Baton Rouge & 4,583 & 309 & 68 & 617 & 1,070 \\
\hline
\end{tabular}


Table A-36. Population, Median Family Income, and Median Number of School Years by Parish.

Parish
Acadia
Allen
Ascension
Assumption
Beauregard
Calcasieu
Cameron
East Baton Rouge
Iberia
Iberville
Jefferson
Jefferson Davis
Lafayette
Lafourche
Livingston
Orleans
Plaquemines
St. Bernard
St. Charles
St. James
St. John the
Baptist
St. Landry
St. Martin
St. Mary
St. Tammany
Tangipahoa
Terrebonne
Vermillion
West Baton Rouge

\section{Population}

52,109

20,794

37,086

19,654

22,888

145,415

8,194

285,167

57,397

30,746

337,568

29,554

109,716

68,941

36,511

593,471

25,225

51,185

29,550

19,733

28,813

80,364

32,454

60,752

63,585

65,875

79,049

43,071

16,864
Median Family Median Number of Income

$\$ 3,128$

3,335

3,877

2,817

3,148

5,167

4,466

5,830

4,329

3,125

6,016

3,795

4,483

4,330

3,825

4,807

2,486

6,028

5,289

3,659

4,079

2,480

2,518

4,686

3,868

2,917

4,831

3,354

4,037
School Years
8.3
9.0
10.3
7.5
11.1
11.7
9.4
12.3
9.4
8.7
12.1
9.2
11.7
8.5
10.5
10.8
9.8
11.0
10.9
9.6
9.9
7.8
7.5
9.9
11.9
9.6
9.6
8.3
10.1 
Table A-37. Population, Median Family Income, and Median Number of School Years by County.

County
Aransas
Bee
Brazoria
Brooks
Calhoun
Cameron
Chambers
Fort Bend
Galveston
Golidad
Hardin
Harris
Hidalgo
Jackson
Jasper
Jefferson
Jim Wells
Kenedy
Kleberg
Lavaca
Liberty
Matagorda
Newton
Nueces
Orange
Refugio
San Patricio
Victoria
Wharton
Willacy

\begin{tabular}{r} 
Population \\
\hline 8,902 \\
22,737 \\
108,312 \\
8,005 \\
17,831 \\
140,368 \\
12,187 \\
52,314 \\
169,812 \\
4,869 \\
29,996 \\
$1,741,912$ \\
181,535 \\
12,975 \\
24,692 \\
244,773 \\
33,032 \\
678 \\
33,166 \\
17,903 \\
33,014 \\
27,913 \\
11,657 \\
237,544 \\
71,170 \\
9,494 \\
47,288 \\
53,766 \\
36,729 \\
15,570 \\
\end{tabular}

Median Family Median Number of Income School Years

$\$ 6,661$

6,358

10,435

4,201

8,353

5,068

8,025

8,830

9,778

5,219

8,285

10,348

4,776

7,080

6,888

9,024

6,737

4,586

6,968

4,649

7,390

7,404

5,819

8,168

9,450

6,994

7,266

7,921

6,535

4,156
10.6

10.7

12.1

8.4

11.4

8.6

10.5

9.8

11.5

8.5

10.7

12.2

7.3

9.9

10.1

11.7

9.3

5.6

11.8

8.6

10.1

10.5

10.0

11.9

11.4

10.1

10.1

11.2

9.7

7.5 
Manufacturing and construction are two large employers. Manufacturing has not been broken into smaller categories but it does include oil and gas refining, as well as. chemical processing.

\subsubsection{Population, Demography, Ethnic Make-up}

Louisiana and Texas have a wide variety of ethnic and racial groups (Plate 13). Many small groups are scattered throughout the area but there are three large groups Table A-38.- These groups are Blacks, Mexican-Americans, and Acadian French. In Louisiana, Blacks constitute $33.3 \%$ of the population. This percentage is equalled or exceeded in eight parishes in the project area (Assumption, Iberville, Orleans, St. James, St. John the Baptist, St. Landry, St. Martin, and West Baton Rouge). The percentage of Blacks decreases in western Louisiana. In Texas, Blacks compose $12.5 \%$ of the population. This percentage is exceeded in Chambers, Fort Bend, Galveston, Hardin, Harris, Jasper, Jefferson, Liberty, Matagorda, Newton, and Wharton Counties. The percentage of Blacks decreases in south Texas (U.S. Bureau of Census, 1973).

Mexican-Americans and people with a Spanish sumame are the second large group. Spanish-speaking people make up $18.4 \%$ of the Texas population; this percentage is exceeded in 18 of the counties in the project area. Mexican-Americans compose over one-third of the population in Bee, Calhoun, Goliad, Jim Wells, Kleberg, Nueces, Refugio, San Patricio and Victoria; and over three-fourths of the population in Brooks, Cameron, Hidalgo, Kenedy, and Willacy. The small percentage of Spanish-speaking people in Louisiana (1.9\%) is exceeded only in Ascension, Jefferson, Orleans, Plaquemines, and St. Bernard. The populations in Louisiana are not necessarily Mexican-American (U.S, Bureau of Census, 1973). 
Table A-38. Total Population. Percentage of Population by Race and Also Percentage of Spanish Speakers by Parish

\begin{tabular}{|c|c|c|c|c|c|c|}
\hline & Population & $\begin{array}{l}\% \text { White } \\
\text { Non-Spanish } \\
\text { Speakers } \\
\end{array}$ & $\%$ Black & $\begin{array}{l}\% \text { Spanish } \\
\text { Speakers }\end{array}$ & $\%$ Indian & $\%$ Other \\
\hline Louisiana & $3,641,306$ & 70.0 & 29.8 & 1.9 & .1 & .3 \\
\hline Acadia & 52,109 & 80.0 & 19.9 & - & - & - \\
\hline Allen & 20,794 & 75.3 & 23.9 & - & .8 & - \\
\hline Ascension & 37,086 & 70.4 & 26.9 & 2.7 & .1 & .1 \\
\hline Assumption & 19,654 & 62.6 & 37.3 & - & - & .1 \\
\hline Beauregard & 22,888 & 79.3 & 18.6 & 1.8 & - & .2 \\
\hline Calcasieu & 145,415 & 77.3 & 21.6 & .9 & .1 & .1 \\
\hline Cameron & 8,194 & 93.1 & 6.6 & - & .1 & .2 \\
\hline East Baton Rouge & 285,167 & 69.6 & 28.7 & 1.5 & - & .3 \\
\hline Iberia & 57,397 & 71.0 & 27.8 & 1.0 & .1 & .1 \\
\hline Tberville & 30,746 & 52.4 & 47.4 & - & .1 & .2 \\
\hline Jefferson & 337,568 & 83.6 & 12.4 & 3.6 & .1 & .3 \\
\hline Jefferson Davis & 29,554 & 79.5 & 20.4 & - & .1 & .1 \\
\hline Lafayette & 109,716 & 77.1 & 21.7 & 1.0 & - & .2 \\
\hline Lafourche & 68,941 & 87.7 & 11.2 & .9 & .1 & .1 \\
\hline Livingston & 36,511 & 88.7 & 11.3 & - & - & .4 \\
\hline Orleans & 593,471 & 50.1 & 45.0 & 4.5 & .1 & .4 \\
\hline Plaquemines & 25,225 & 72.6 & 22.9 & 2.1 & 1.1 & 1.3 \\
\hline St. Bernard & 51,185 & 85.3 & 5.1 & 9.2 & .1 & .3 \\
\hline St. Charles & 29,550 & 73.6 & 26.3 & - & .1 & .1 \\
\hline St. James & 19,733 & 52.7 & 47.2 & - & - & - \\
\hline St. John the & & & & & & \\
\hline Baptist & 28,813 & 61.6 & 38.3 & - & - & .1 \\
\hline St. Landry & 80,364 & 58.1 & 41.3 & .5 & .1 & .1 \\
\hline St. Martin & 32,454 & 65.0 & 34.8 & - & - & .2 \\
\hline St. Mary & 60,752 & 70.5 & 28.1 & .9 & .4 & .1 \\
\hline St. Tammany & 63,585 & 79.3 & 18.7 & 1.6 & .1 & .2 \\
\hline Tangipahoa & 65,875 & 67.6 & 31.3 & .9 & - & .2 \\
\hline Terrebonne & 79,049 & 80.6 & 14.5 & 1.2 & 2.9 & .1 \\
\hline Vermillion & 43,071 & 86.4 & 13.5 & - & - & .1 \\
\hline West Baton Rouge & 16,864 & 56.9 & 43.1 & - & - & - \\
\hline
\end{tabular}


Table A-38. Total Population, Percentage of Population by Race and Also Percentage of Spanish Speakers by County. Continued.

\begin{tabular}{|c|c|c|c|c|c|c|}
\hline & Population & $\begin{array}{l}\% \text { White } \\
\text { Non-Spanish } \\
\text { Speakers }\end{array}$ & $\%$ BIack & $\begin{array}{l}\% \text { Spanish } \\
\text { Speakers }\end{array}$ & $\%$ Indian & $\%$ Other \\
\hline Texas & $11,196,730$ & 68.4 & 12.5 & 18.4 & .2 & .5 \\
\hline Aransas & 8,902 & 68.7 & 4.0 & 26.6 & .9 & .5 \\
\hline Bee & 22,737 & 57.4 & 2.5 & 39.1 & .2 & .8 \\
\hline Brazoria & 108,312 & 80.3 & 9.4 & 9.9 & .1 & .3 \\
\hline Brooks & 8,005 & 19.6 & .2 & 79.9 & - & .2 \\
\hline Calhoun & 17,831 & 61.2 & 4.4 & 33.4 & .1 & 1.0 \\
\hline Cameron & 140,368 & 22.7 & .4 & 76.2 & .1 & .6 \\
\hline Chambers & 12,187 & 75.5 & 20.4 & 3.8 & - & .2 \\
\hline Fort Bend & 52,314 & 56.0 & 17.0 & 26.6 & .1 & .5 \\
\hline Galveston & 169,812 & 67.8 & 19.6 & 12.0 & .1 & .5 \\
\hline Golidad & 4,869 & 50.5 & 11.6 & 37.6 & .2 & .1 \\
\hline Hardin & 29,996 & 84.5 & 13.8 & 1.6 & - & .1 \\
\hline Harris & $1,741,912$ & 68.4 & 20.1 & 10.7 & .2 & .6 \\
\hline Hidalgo & 181,535 & 20.1 & .2 & 79.1 & - & .6 \\
\hline Jackson & 12,975 & 70.1 & 11.9 & 17.7 & - & .3 \\
\hline *Jasper & 24,692 & 75.3 & 22.9 & 1.6 & - & .1 \\
\hline Jefferson & 244,773 & 70.3 & 25.0 & 4.5 & .1 & .2 \\
\hline Jim Wells & 33,032 & 34.8 & .8 & 64.0 & .1 & .4 \\
\hline Kenedy & 678 & 21.5 & - & 78.5 & - & - \\
\hline Kleberg & 33,166 & 50.8 & 4.2 & 43.9 & .1 & 1.0 \\
\hline Lavaca & 17,903 & 84.1 & 8.9 & 6.7 & .1 & .2 \\
\hline Liberty & 33,014 & 77.6 & 20.8 & 1.3 & .1 & .2 \\
\hline Matagorda & 27,913 & 61.6 & 19.2 & 18.5 & .1 & .6 \\
\hline${ }^{*}$ New ton & 11,657 & 67.7 & 28.9 & 3.4 & - & - \\
\hline Nueces & 237,544 & 50.6 & 4.6 & 43.6 & .1 & 1.0 \\
\hline Orange & 71,170 & 87.6 & 9.2 & 3.1 & .1 & .1 \\
\hline Refugio & 9,494 & 51.2 & 9.6 & 38.0 & - & .5 \\
\hline San Patricio & 47,288 & 48.7 & 1.6 & 49.1 & .1 & .5 \\
\hline Victoria & 53,766 & 60.4 & 7.8 & 31.5 & .1 & .3 \\
\hline Wharton & 36,729 & 60.8 & 19.8 & 18.8 & .1 & .5 \\
\hline Willacy & 15,570 & 22.0 & .4 & 76.8 & - & .8 \\
\hline
\end{tabular}

*Less than 400 Spanish Speakers in County, \% were figured with 400 Spanish Speakers. 
Agriculture includes forestry, wildlife, and fishing (U.S. Bureau of Census, 1973). The value of agricultural crops in Louisiana in 1974 was $\$ 1,193,722,000$, $55 \%$ of this came from southern Louisiana Table A-39. Rice and sugarcane are very important crops in south Louisiana since they cannot be grown in the rest of the state; citrus fruits and winter vegetables are important for the same reason. Soybeans are becoming increasingly more important (U.S. Bureau of Census, 1977). Texas had $\$ 3,292,627,000$ worth of agricultural products in $1974 ; 11 \%$ was from the project area. Cattle, cotton, and sorghum account for a large part of the crops in the project area. Rice and soybeans are grown in the coastal areas. South Texas has many fruit and vegetable farms; Cameron, Willacy, and Hildalgo produce $98 \%$ of the state's citrus crops (U.S. Bureau of Census, 1972) (Appendix

The fishing industry is very important in the project area. In Texas, 98 million pounds of fish and shellfish brought in $\$ 91$ million in 1973. Louisiana brought in 1,029. million pounds with a value of $\$ 95$ million in 1973 . In 1974, the value of shellfish was $\$ 253$ million in Loulsiana and $\$ 91$ million in Texas.

Minerals contribute much to the economy of both states. Petroleum, natural gas, sulfur, salt, and other minerals are mined in both states. The production of natural gas and petroleum is the most important in the project area. The value for natural gas alone in Loulsiana and Texas was $\$ 3,581,534,000$ in 1973 (U.S. Bureau of Mines, 1976). The importance of minerals can be seen in Table A-39. and Table A-40. Although Table A-39 and Table A-40 do not divide the occupation of mining, the census data shows that the natural gas and petroleum industry has the largest number of employees: Table A-39 and Table A-40, which show the minerals in order of value, again demonstrates the importance of the oil industry. 
Table:A-39. Value of Agricultural and Mineral Production in Louisiana by Parish

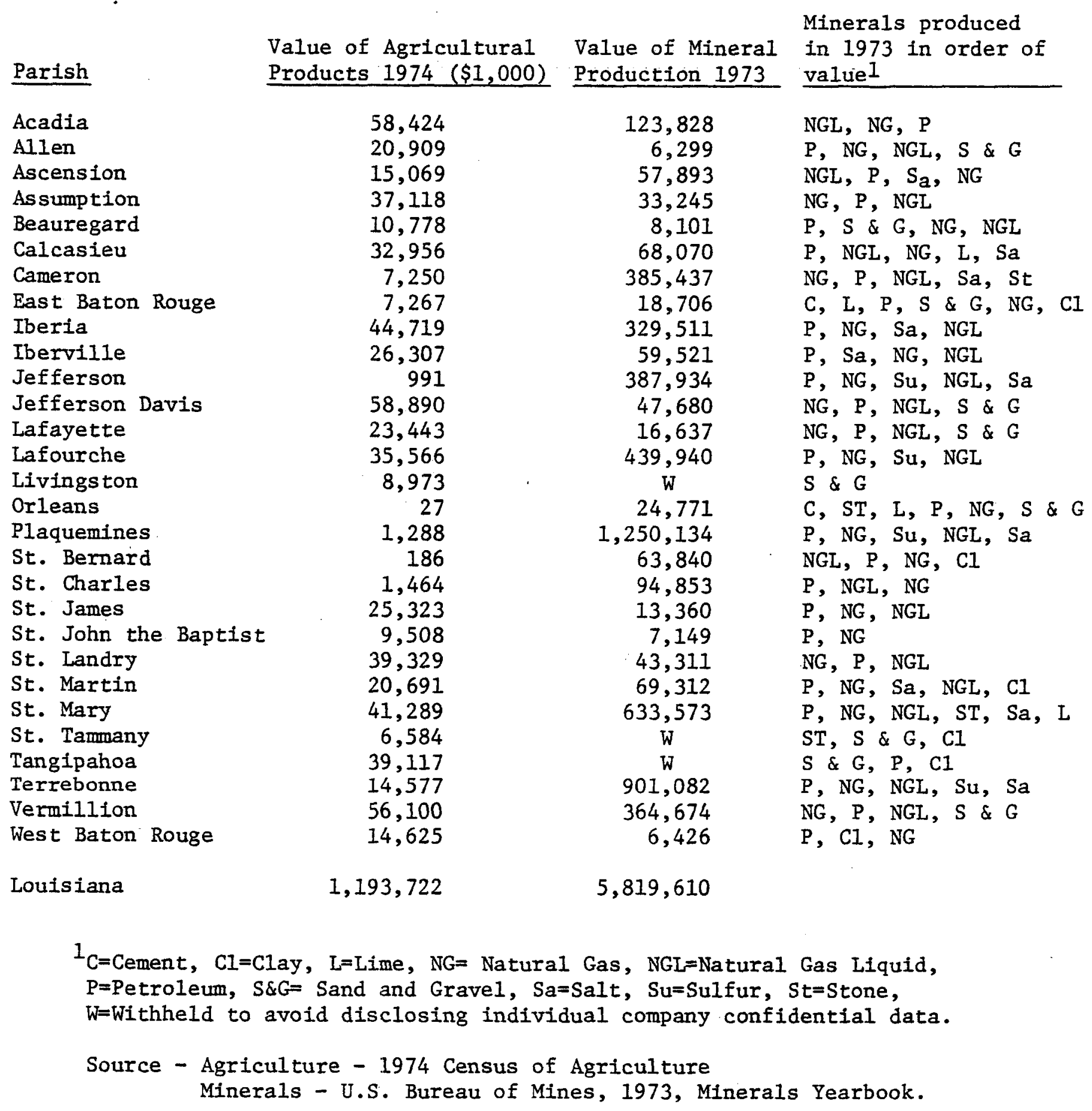


Table A-40. Value of Agricultural and Mineral Production in Texas by County.

\begin{tabular}{|c|c|c|c|}
\hline County & $\begin{array}{l}\text { Value of } 1974 \text { Agricul- } \\
\text { tural Products ( } \$ 1000)\end{array}$ & $\begin{array}{l}\text { Value of } 1973 \\
\text { Mineral Production }\end{array}$ & $\begin{array}{l}\text { Minerals Produced in } \\
1973 \text { in order of value } 1\end{array}$ \\
\hline Aransas & 445 & 12,622 & NG, $P, N G L$ \\
\hline Bee & 7,481 & 18,937 & $N G, P, N G L, S T$ \\
\hline Brazoria & 17,327 & 276,766 & $\begin{array}{l}\text { P, NG, MgCl, NGL, Sa, } \\
\text { Mg Comp, L }\end{array}$ \\
\hline Brooks & 3,489 & 61,845 & $\mathrm{NG}, \mathrm{P}, \mathrm{NGL}$ \\
\hline Calhoun & 5,337 & 24,701 & NG, ST, P, NGL, L \\
\hline Cameron & 27,573 & 2,955 & $\mathrm{NG}, \mathrm{P}$ \\
\hline Chambers & 11,507 & 139,842 & $\mathrm{P}, \mathrm{NG}, \mathrm{NGL}, \mathrm{Sa}, \mathrm{Cl}$ \\
\hline Fort Bend & 15,354 & 91,108 & $\mathrm{P}, \mathrm{Su}, \mathrm{NG}, \mathrm{Sa}, \mathrm{NGL}, \mathrm{Cl}$ \\
\hline Galveston & 4,508 & 57,723 & $\mathrm{P}, \mathrm{NG}, \mathrm{NGL}, \mathrm{Cl}$ \\
\hline Golidad & 8,082 & 11,570 & NG, $P$ \\
\hline Hardin & 804 & 26,859 & $P, N G, N G L, S \& G$ \\
\hline Harris & 24,082 & 217,896 & $P, C, N G L, N G, S a, L$, \\
\hline Hidalgo & 53,898 & 44,275 & $P, N G L, S T, S \& G$ \\
\hline Jackson & 15,069 & 104,646 & $P, N G, N G L$ \\
\hline Jasper & 2,936 & 1,441 & $\mathrm{P}, \mathrm{NG}$ \\
\hline Jefferson & 13,121 & 67,364 & $N G, P, S u, N G L, S a, C 1, S \& G$ \\
\hline Jim Wells & 12,000 & 94,330 & $P, N G, N G L$ \\
\hline Kenedy & 2,080 & 26,207 & NG, NGL, $P$ \\
\hline Kleberg & 5,708 & 225,194 & $N G, N G L, P, S T$ \\
\hline Lavaca & 16,644 & 12,464 & $N G, N G L, P$ \\
\hline Liberty & 11,642 & 39,526 & $P, S u, N G, N G L, S \& G$ \\
\hline Matagorda & 18,298 & 66,723 & NG, NGL, P, ST, Sa \\
\hline Newton & 2,149 & 5,421 & $P$, NG \\
\hline Nueces & 18,436 & 107,450 & $P, \underset{S \& G}{C,} N G L, G, N G, S T$, \\
\hline Orange & 1,226 & 12,707 & $\mathrm{C}, \mathrm{P}, \mathrm{NG}, \mathrm{CI}$ \\
\hline Refugio & 5,626 & 186,863 & $P, N G, N G L$ \\
\hline San Patricio. & 21,900 & 37,946 & $P, N G, N G L, S T, C I$ \\
\hline Victoria & 9,157 & 27,125 & $P, N G, S \& G, N G L$ \\
\hline Wharton & 29,974 & 60,473 & $\mathrm{Su}, \mathrm{P}, \mathrm{NG}, \mathrm{NGL}, \mathrm{Cl}$ \\
\hline Willacy & 12,358 & 13,443 & $P, N G$ \\
\hline Texas & $31,292,627$ & $8,442,494$ & \\
\hline
\end{tabular}

$1 \mathrm{C}=$ Cement, $\mathrm{Cl}=\mathrm{Clay}, \mathrm{G}=$ Gypsum, L=Lime, MgCl=Magnesium chloride, Mg Comp=Magnesium Compounds, NG=Natural Gas, NGL=Natural Gas Liquids, $\mathrm{P}=$ Petroleum, $S \& G=$ Sand and Gravel, $S a=S a l t, S T=S t o n e, S u=S u l f u r$

Source-Agriculture 1969 Census of Agriculture Minerals U.S. Bureau of Mines 1973, Minerals Yearbook. 
The third large group is the Acadian French. These people are centered in central and western Louisiana (Bertrand, 1976.) and eastern Texas (Nesmith, 1977). In Louisiana they compose over $30 \%$ of the population in Orleans, Terrebonne, Assumption, Iberia, and Cameron; over $48 \%$ in Lafourche, Lafayette, Acadia, Jefferson Davis and St. Landry; and over $63 \%$ but not over $80 \%$ in Evangeline, St. Martin, and Vermilion (Bertrand, 1976).

In Louisiana, two Indian reservations are located within the project area. The Chitimacha Reservation is centered at Charenton in St. Mary Parish and contains 115 hectares (283 acres). The Coushatta Reservation contains 58 hectares (143 acres) and is centered at Elton, Louisiana, in Allen Parish. Other Indian centers are Houma Alliance in Terrebonne, the Houma Tribe in Lafourche (Mora, 1977) and the Choctaws in St. Tammany (Bertrand, 1976). Only in Terrebonne and Plaquemines Parishes does the Indian population exceed 1\% (U.S. Bureau of Census, 1973). No Indian reservations or communities are located in Texas counties in the study area (Jordan, 1970).

Several European ethnic communities are located in the project area (P1ate 13). German communities are the most numerous, especially in Texas. Only one German community is in Louisiana nad it is located in Acadia Parish. In Texas, German communities are located in Jim Wells, Kleberg, Nueces, San Patricio, Golidad, Refugio, Bee, Victorla, Calhoun, Lavaca, Jackson, Matagorda, Wharton, Fort Bend, Brazoria, Galveston and Harris. Several of the counties have more than one community.

Swedish communities are located only in Texas in Harris, Wharton, Jackson, Calhoun, Bee and:Willacy Counties. The Czechoslovakians have settled throughout 
Texas. They are located in Liberty, Harris, Brazoria, Fort Bend, Wharton, Matagorda, Jackson, Victoria, Calhoun, Bee, and Nueces Counties (Jordan, 1970).

Several other ethnic groups are located in Texas. Polish communities are in Jackson, Victoria, Bee and Hidalgo. Danish communities are in Wharton and Matagorda. One Norwegian community is located in Bee and one Wendish community is in Nueces (Jordan, 1970).

Louisiana is dominated by ethnic groups different from these found in Texas. The Italians are concentrated in southeastern Louisiana in St. John the Baptist, Tangipahoa, and Lafayette Parishes. Italians have also settled along the Mississippi River from St. Bernard to St. John the Baptist. A DalmationSlovonian commity is located on the Mississippi River delta in Plaquemines Parish. A Spanish-speaking community is located on the border of Plaquemines and St. Bernard Parishes. Southeast Livingston Parish is the location of a Hungarian community. A Mennonite group is in central Beauregard Parish. Also in Beauregard is an endogomous community which extends from the southwestern part of the parish into the northwestern part of Calcasieu Parish (Bertrand, 1976).

Some of the most interesting communities in Louisiana are the racial hybrid communities. Often, these groups are a tri-racial mixture of Blacks, Whites and Indians. Very little is known about these groups because the people are very sensitive about their racial heritage (Bertrand, 1976).

The total population of Louisiana is $3,641,306 ; 62 \%(2,251,771)$ live in the project area. There are four Standard Metropolitan Statistical Areas (SMSA's) 
In south Louisiana. They are Baton Rouge $(285,167)$, Lafayette $(109,716)$, Lake Charles $(145,415)$, and New Orleans $(1,045,089)$. Seventy percent of the population lives in these four areas.

The Texas state population is $11,195,431 ; 30 \%(3,410,144)$ live in the project area. Eighty-five percent of the people in the project area live in the five SMSA's, Beaumont-Port Arthur-Orange $(315,943)$, Corpus Christi $(284,832)$, Galveston-Texas City $(169,812)$, Houston $(1,985,031)$, and Brownsville-Harlingen-San Benito $(140,368)$. 
APPENDIX B - POTENTIAL ENVIRONMENTAL IMPACT

\subsection{Installation and Maintenance of We11}

\subsubsection{Physical and Biological Issues}

Flora - Environmental impacts due to the installation and maintenance of geothermal wells are mitigated by the use of existing well sites. The reopenIng of an old site and possible drilling of a disposal well may involve building roads, dredging or redredging canals, disposing of spoil, building drill pads, transportation of on-site drill crews to and from the site, and building of a reserve pond to hold drilling wastes. The impacts upon the general vegetation types are presented in Table $3-1$.

The effects on the upland forest sites are compounded in hilly terrain, where cut and fill road building may be necessary. The area used for roads and covered with cinders or gravel will be semi-permanently or permanently altered with a resultant net loss of primary productivity. These areas of greater slope occur in the northern portion of the study area and locally along streams. These forest types will be slow to recover to their original association, and in some instances may be permanently changed because of changes in local drainage. The typical succession from grasses to shrubs and woody vegetation are likely to occur on areas not covered with cinders or gravel, such as the reserve pond and evaporation ponds once filled back in. The impermeable layer in these ponds may cause ponding of water leading to hydric vegetation. Where spoil or cut and fill earth are deposited, a plant communtty of annuals will develop initially that attracts doves. Return to original diversity and composition of vegetation may take twenty years or more.

Prairie-grasslands will undergo similar impacts to those stated above with. the distinction that slope will be less, eliminating the necessity for cut and fill, 
and that regeneration time will be greatly reduced. This vegetation type is relatively rare and care must be taken to preserve its natural character.

The marshes and swamp forest areas are where the greatest impact will be felt. They generally are too moist and soils too unstable for road construction. Canals will be dredged, redredged or modified to allow access. Direct impacts will be loss of production where new dredging occurs, temporary loss of benthic community due to turbidity and erosion of spoil and where redredging or modifications are made, and temporary loss of production where spoil is deposited. These spoil sites will probably be of greater elevation than the surrounding marsh and be colonized by ridge or high site vegetation. Any changes in local elevation may change flow patterns which will change salinities locally and affect productivity and composition of surrounding marsh vegetation.

It is not expected that the disposal well drill pad construction will require as much acreage in upland areas since it is likely that existing canal area will be used. The marshes, nevertheless, show a fairly high productivity loss due to their naturally high productivity levels. It is not expected, however, that an operation of the scale of the proposed testing will permanently alter marsh dependent estuarine fisheries along the Gulf Coast. The majority of necessary canals are already in existence since they are previously used sites, and salinity changes will already have occurred prior to well testing.

Impacts due to well installation and maintenance in streams and lakes are minimal, the majority of the land loss occurring in bordering ecosystems. Turbidity may temporarily lower phytoplankton, zooplankton, grass and fish production. 
Productivity changes to beach and dune habitats will probably be minimal since this is a very stressed system. However, the existing topography and stabilizing vegetation make up an important storm buffer for inland marsh, estuary and bay systems. Care must be taken to align roads parallel to dune ridges where possible because breaks across dunes may cause accelerated erosion leading to loss of storm buffer and possibly the making of a new pass or waterway. This could alter salinity levels and flushing rates of inland areas, especially in south Texas.

The major impact on estuarine bays would be in areas of submerged grass beds. Dredging might be necessary in the shallow waters where they grow and could result in the direct loss of highly productive vegetation. The trapping and binding action of grasses would be impaired and increased turbidity might result. In the case of Thalassia, the deep rhizome layer destruction of dredging could make recovery time long.

Other possible impacts occurring in the wetland habitats include turbidity increase due to dredging and boat traffic (short-term), resuspension of bottom sediment which may have been polluted due to previous oil operations (1ong-term), changes in flow patterns and drainage that might affect saltwater intrusion in marshes (long-term), and possible addition of pollutants into waters from runoff or waste from boats, rigs, personnel, etc.

High noise levels and air pollution and dust are not expected to be of high enough magnitude to cause environmental harm during site preparation. Many of the above-mentioned activities will not be necessary if a suitable disposal 
well already exists. It is assumed that waste products related to the construction and maintenance crew will be disposed of off the site.

Any of these activities would adversely affect the threatened or endangered species present. Given a choice among well sites, those for which impacts in Table 3-1 are less and which are not near endangered species (Plate 9) would be favored.

3.2 Normal Effluents from Operation of Well

3.2 .1 Biological Issues

Specific Biochemical Impacts - The normal effluents from operating.wells include air pollutants from motor vehicles and diesel-powered equipment, dust from movement of vehicles, noise, runoff from drill pad and boats, fluids contained in the reserve pond and, possibly, where allowed, brine water stored in evaporation or reserve ponds.

In the section treating climatology, it is stated that the possibility of air pollution is very small and restricted to the immediate vicinity of the drilling operation. For this reason it is not felt that normal operation of the well will adversely affect surrounding vegetation, and it will certainly have no greater effect than other oil and gas operations in the same area.

Dust and nolse may decrease wildlife use in the area but will probably not adversely affect the flora.

Runoff from the operation which is not routed into the reserve pond and boat effluents may affect local vegetation. They will probably contain olls, organic materials and detergents. Since the operation will be for a short period of time, It is expected that whatever adverse effects these have on vegetation and 
wildlife will be short-1ived. Long-term effects of petrochemicals on an area are determined largely by the physical and chemical nature of the sediments. Adsorptive capacity of sediments varies with organic matter content, clay type and content, mineral content, $\mathrm{pH}$ and $\mathrm{Eh}$. While small amounts of petrochemicals over a long period of time may not harm marine invertebrates under some conditions (Straughan, 1977), each site must be looked at as a specific case in terms of its soil profile and surface circulation. For instance, a spill with high concentration of petrochemicals may affect benthic organisms for a long period of time in one location (Krebs and Burns, 1977), while having no effect at another site. Also, while the adult benthic organisms, such as oysters, may not be adversely affected, the juvenile forms may be. This would only be apparent in a long-term experiment. Much more information is needed in regard to the effects of petrochemicals.

Fluids in the reserve pond may include fuel lubricants, acids, runoff from drill pad, and drill cuttings and drilling muds (Table 3-9). It is possible, but unlikely, that brine might be stored in the reserve pond. Those constituents of drilling muds which have the greatest possible detrimental impact to plants in the area are shown with an " $\mathrm{X}$ " in Table 3-9. Unless the reserve pond completely dries and particulate forms of the above constituents are made airborne, under normal conditions they pose no threat to the immediate environment. If they should be blown onto nearby vegetation, or waters, they may cause some local damage. For the probable distance, refer to the climatology section. Brine water disposal via drainage or evaporation ponds is considered unlikely. However, if it occurs, once dried the constituents of the brine with the most harmful environmental influence on the vegetation will probably be copper, zinc, 
lead, manganese and barium (Schieler, 1976). Effects of these on the vegetation will be discussed in section 3.3 .1 .

Flaring of $\mathrm{H}_{2} \mathrm{~S}$ and $\mathrm{CH}_{4}$ gases will locally increase $\mathrm{SO}_{2}$ and $\mathrm{CO}_{2}$ levels. If the $\mathrm{H}_{2} \mathrm{~S}$ is found to be of high concentration, it may lead to local acidification of water which in turn may solubilize the trace heavy metals (Schieler, 1976) due to the following reactions:

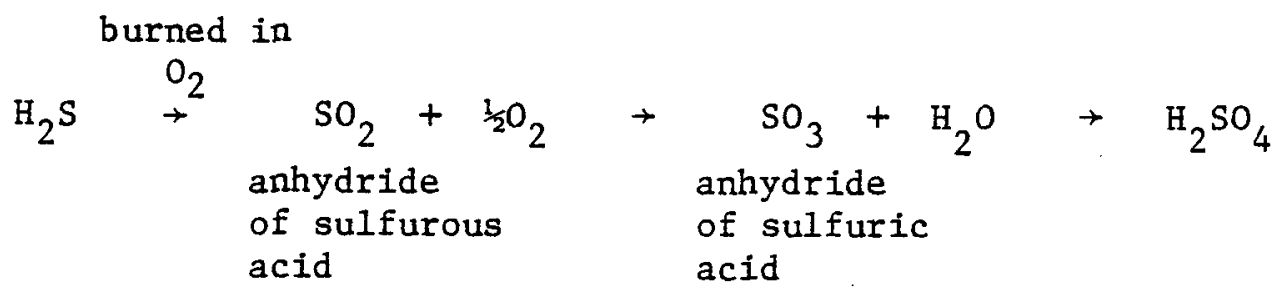

The $\mathrm{H}_{2} \mathrm{SO}_{4}$ will acidify surface waters. In saline and brackish areas this tendency will be well buffered by carbonate. But in soft fresh water and upland sites this could cause problems locally when atmospheric wind conditions were low. Plants have differing tolerances to $\mathrm{pH}$, but, for example, legumes will not grow below $\mathrm{pH}$ 4.5. The most critical areas will be those soils with already acidic tendencies (refer to Table A-17 in vegetation section to correlate acid soils and vegetation types). The short duration of the test should make this hazard very unlikely.

\subsection{Accidents}

3.3.1 Physical and Biological Issues.

Biological Issues with special reference to flora

Some of the types of accidents that could occur are a well blowout, evaporation or reserve pond leak, evaporation or reserve pond wash over-due to flooding or storms, vehicle or boating waste spill, plugging of injection aquifer and subse- 
quent breakage of well casings or blowout, fire, breakage of well casings or blowout due to physical conditions such as improper drilling mud pressure or seismic activity and subsidence, earthquakes, or fault reactivation.

of these, the well blowout will probably have the most detrimental effect on the surrounding vegetation.

Some of the constituents of geopressured brines are 1isted in Table 3-10. Comparison of concentrations in brines, seawater and acceptable standards are shown. Those ingredients whose level is higher than normal or standard are marked with an "X". Very few data are available on the heavy metals. Some of the values used were taken from Mayer and Ho, 1977, who sampled brines from the Leeville oilfield, Louisiana. The contributing formation was just above the geopressured layer, but since the conditions of formation of the layers are similar, it is expected that the heavy metal levels shown are appropriate to geopressured brines.

The first four elements in Table 3-10 are all necessary nutrients for plants. The sodium level is shown to be high for domestic use, but it is expected to be diluted as it enters streams or aquifers. If it goes over a vegetated area some scrubbing of these constituents is expected.

Chloride ion is the single highest anion in seawater and in brine. It can be detected by animals at low levels. Any increase in the salts, hardness or total dissolved solid levels in an area must be compensated for by the local 
flora and fauna. Excess total dissolved solids may cause plasmolysis in leaves and stems of vegetation. EPA, 1976, recommendations are for $10 / 00$ change from ambient. in areas with natural TDS levels of $0-3.50 / 00,20 / 00$ where natural levels are 3.5-13.5 0/00 (intermediate marsh; some estuaries and bays) and $40 / 00$ where natural levels are $13.5-35+0 / 00$.

The actual salinity changes experienced in an area if a blowout occurred would depend on TDS concentration in brine, flow rate, local circulation, wind conditions and duration of spill. The major impacts in upland areas would likely be within $300 \mathrm{~m}(1,000 \mathrm{ft})$ of the well. In wetland environments, the TDS would be diluted by surface waters. The main salt.wedge would probably sink due to increased density (a function of dissolved solids and temperature) to the bottom. The major effect would be on benthic plants, invertebrates and sediments. It might take up to two years to reseed or revegetate areas. Motile organisms could probably escape the initial effects of the spill. Residual effects would most likely be seen in clay sediments or soils with a high cation exchange capacity. Delayed effects may also be seem when motile organisms repopulated the affected area some time later, when the food organisms and sediments had an abnormally high mineral load.

Hardness ( $\mathrm{Ca}, \mathrm{Mg}$ ), while exceeding drinking water standards, may actually be a boon. Calcium and magnesium are necessary nutrients for plants. Water hardness also lowers the toxicity of many metals in plants and animals. 
Heavy metals levels in brine waters have been cited by many authors in the geothermal. field (Axtmann, 1975; Collins, 1975; Schieler, 1976; Balashove, 1975; Schmidt, 1975, Sabadel1 and Axtmann, 1975; and Koons et al., 1977). Unfortunately information concerning geopressured brines from the Gulf Coast is sketchy or absent. Table 3-10 summarizes what little is known and uses Mayer and Ho, 1977, as a data source even though the brine they tested was from a geologic formation directly over the geopressured zone but not in it.

Lead appears to be at safe levels (EPA, 1975; Saifullah, 1976; Brown and Newell, 1972). However, lead even at low levels may be concentrated by filter feeders such as Mytilus edulis (Schulz-Baldes, 1972). For this reason, mussels and other benthic invertebrate filter feeders can be used as integrators of lead pollution history in an area (Schulz-Baldes, 1973), and they may develop toxic levels of lead.

Gambrell et al. (1977a) reported that soil or sediment oxidation-reduction conditions had little effect on the chemical availability of lead; however, a decrease in $\mathrm{pH}$ to moderately acid levels was found to increase exchangeable lead. While a slight, but nonsignificant, linear relationship existed between marsh plant uptake of lead and its chemical availability, levels of watersoluble lead have been shown to be highly correlated with lead uptake by lowland rice (Gambrell et al., 1977b; Reddy and Patrick, 1977). Therefore, the pH of the different vegetation-soil associations must be taken into account when determining fate of lead. 
Zinc may be a pollution problem (EPA, 1976) 'although Brereton

et al., 1973, found it toxic to the Pacific oyster larvae at $0.2 \mathrm{ppm}$ even over a short period and at lower levels than recorded for geothermal brines (Table 3-10). Further testing may find it to be at an even greater concentration so that it may be incorporated into sediment or plant materials. The levels of zinc in soluble and exchangeable chemical forms and its availability to marsh plants and lowland rice have been reported to increase with a reduction in $\mathrm{pH}$ and an increase in oxidation-reduction conditions (Gambrell et al., 1977a; 1977b; Jugsujinda, 1975). Thus a given quantity of soil zinc derived from some contamination source might be expected to be more available to plants in well drained upland soils compared to reduced soils and sediments associated with marshes and estuarine bays. However, no research has been conducted to determine if reduced, near-neutral or alkaline sediments decrease the availability of zinc to bottom feeding benthic organisms. Since the saline waters will probably travel along the bottom and attached benthos cannot escape, it may prove to be harmful to local shellfisheries and fisheries feeding upon bottom invertebrates.

Copper levels in brine may prove to be toxic to plants and animals. There is only a slight direct relationship between copper uptake in plants and its chemical availability (Gambrell et al., 1977b), and soluble and exchangeable levels show no trends in availability with changes in $\mathrm{pH}$ or redox potential. But there is a strong affinity of sediment solids for copper (Gambrell et al., 1977a). If quickly diluted the copper may not be toxic to nearby vegetation or animals, but may become incorporated and concentrated into the food chain. 
Boron levels are very high in geothermal brines, roughly 19 to 75 times the maximum suggested by EPA, 1976. Its affects are ameliorated on neutral or alkaline soils of high absorption capacities (Biggar and Fireman, 1960). Thus, upland sites and especially croplands are most sensitive to boron additions from geothermal fluids.

Arsenic, chromium, mercury, nickel and cadmium have not been measured in Gulf Coast geopressured brines. Arsenic and chromium toxicities will be greater in sandy soils than in reduced or clay soils.

The factors affecting mercury solubility or absorption and subsequent plant uptake are dependent on the level of mercury present. Under low concentrations, mercury retention may be favored in moderate to weakly acid oxidized soils (like many upland sites) and in reduced and mildly alkaline soils (like saline or estuarine sediments). At high concentrations, an increased $\mathrm{pH}$ or a lowered redox potential favor adsorption to soil solids. Mercury generally complexes with organic matter present.

Mercury uptake by plants is reduced by increased salinity. Uptake is favored by Increasing pH being found under weakly alkaline conditions (Gambrell et al., 1977b). Seagrass beds may be very important in cycling of mercury once it reaches the estuary. 
Cadmium and zinc behave similarly. Cadmium adsorption to soil solids is favored by increasing $\mathrm{pH}$ and decreasing (reducing) redox potential. The maximum uptake in plants generally occurs under acid, oxidizing conditions for marsh plants, grasses and rice (see Table A-3 for these soil-vegetation associations). Cadmium uptake by Distichlis, on the contrary, was greatest under weakly alkaline oxidized conditions (Gambrell et al., 1977b).

Barium in geopressured brine was right at the critical level for aquatic and marine vegetation.

Particulate iron levels were found to be high in brine waters. Iron uptake in plants is greatest when they are flooded, or in a reduced environment. The soluble iron levels were not found to be at hazardous levels.

There is no information available on silicate levels.

Bromine may be at a high level, being almost four times as concentrated in brines as in seawater.

Ammonia toxicity will depend on its equilibrium with ammonium. It is most toxic in its unionized state, in contrast with heavy metals which are toxic in their free ionic state. 
Finally, $\mathrm{H}_{2} \mathrm{~S}$ gas as measured in the field near a geopressured site blowout was at toxic or harmful levels. This was probably only true within a short distance from the well.

Heavy metals may be present in geothermal brines. Whether they remain in a soluble, available state or are bound to sediment depends on the Eh, $\mathrm{pH}$ and constituents of soils or sediments. In general, a moderately low $\mathrm{pH}$ and redox potential level will favor the bioavailable soluble forms (Gambrell et al., 1976). However, the availability of different metals may respond differentiy, to a change in their physlochemical environment. Heavy metals may form metal sulfide precipitates in reduced soils and, thus, have limited mobility and availability. In oxidized environments they may complex with iron and manganese hydrous oxides and remain in the soil. Or, they may bind with organic matter.

Once in the soil, the $\mathrm{Eh}, \mathrm{pH}$ conditions regulate to a considerable extent their availability to plants and animals. The oxidized rhizosphere of plants may change the equilibrium and allow plant uptake even in reduced environments. Dredging may under some conditions release a pulse of metals to surface and subsurface waters. Plant uptake may be the first step in a chain of bioconcentration. Much research needs to be done to more accurately assess the environmental impact of geothermal brines, especially in regard to heavy metals. It appears that the intermediate marsh and submerged grass bed vegetation type with high organic matter content, moderately alkaline $\mathrm{pH}$ and proven plant uptake capabilities may be the most sensitive areas to heavy metal pollution. Rice agriculture, extensively practiced in the chenier plain area, may also be sensitive due to alternate flooding and drying of soils. 
In conclusion, there are many constituents in geopressured brines with possible detrimental impacts on the flora and fauna. Mackin, 1971, has shown that the majority of the effects are felt in the benthic communities, and some of these. are outlined above. It is apparent that long-term effects may occur if the soil or sediment is subsequently disturbed. Toxicities are further accentuated by high salt concentration of brines (Schneider, 1972) and by high temperatures (Anderson, 1973), both of which cause toxicity to occur at lower concentrations than under normal conditions. Evaporation pond and drainage ditch leaks; breaks or washovers will have the same effect as a blowout, but in a more localized area.

Leaks, breaks or washovers of reserve ponds and vehicle or boating waste spills will introduce oils, drilling muds and metal shavings into the environment. The main materials present in the reserve pond were listed in Table 3-9. The more toxic ingredients will be the oils and sulfonated oils. It has been shown that partially refined or refined oils such as used in these operations are more toxic to benthic organisms (oysters) than crude oil. If the spills are only of small levels it will probably not adversely affect most biota on a long-term basis (Marum, 1974; Fish et al., 1974; Kritzler, 1974). A temporary lowering of local plant productivity and foram, nematode and polychaete diversity may be noted. Other benthos affected, such as filter feeders, will temporarily have a higher tissue content of oils (Anderson, 1973; Stegeman and Teal, 1973̣), but will go back to normal levels after stress is abated. Bacteria present in the marine and brackish environment can utilize oil as an energy source. The most sensitive areas to these types of accidents will be upland sites.

Subsidence, earthquakes and fault reactivation are considered very unlikely to occur and are covered in section 2.1 . 
Fire will cause the least damage in the wetland environments where if it occurs in the wet season will not cause root or rhizome damage. In general, $\bullet$

fire will have increasing impact toward the west because of increasing arid conditions. If fire occurs in a fresh or brackish marsh when it is not flooded, it has a high probability of burning the rich peat deposits and causing permanent loss of habitat. These areas would change to open water, as has been seen in many areas in the chenier plan (Gosselink and Beck, 1976). Fire could have severe impact on dry grassland. Fire in upland forests will tend to reduce understory but will not be damaging unless it occurs in a dry area that has been artificlally protected from fire previously. In those areas, high litter buildup may feed a very hot fire that could permanently damage even larger trees and root layers. Normally, fire is a natural event and a management practice that selects for a pine forest.

This section has tried to outline possible accidents and give an indication of the relative impact each type of accident would have in the different soilvegetation associations. It goes without saying that any of these accidents would be highly detrimental to the threatened and endangered species and care should be taken to protect local populations. 


\subsection{Biological Issues}

\subsubsection{Biological Issues}

Impact control programs and site restoration such as building reserve ponds with berms and impervious linings, pumping reserve pond fluids back down well or taking off the site and covering over reserve ponds and reseeding them and possibly drill pad sites have both positive and negative impacts on the flora.

The reserve ponds protect surrounding areas but also restrict surface water flow. This could change local flora due to soil moisture and salinity changes. After cleaning the pit, filling it in and reseeding, what impacts occur? If the pit is filled with material dredged from canal, lake or stream bottoms in a reduced condition, putting it in an upland site above the water table may result in sediment oxidation and subsequent mobilization and release of heavy metals (Gambrell et al., 1977a). These can be translocated through vegetation to the food chain.

If the site is not returned to a condition level with surroundings, especially in the marsh, it may not help to reseed it as its increased elevation may cause spoil bank vegetation to out-compete marsh grasses and sedges.

If the site is filled with sandy soil, it may take years for organic matter content to build up and succession, especially to upland forest, may take a very long time.

Since the pit and channels are impervious, they may serve as holding ponds in areas that were once recharge sites. This could cause a local hydric vegetation to develop. 
If contaminants have not been completely removed from the pits, they may be mobilized in the soil and roots and become a surface hazard.

If careful cleaning, return to same elevation and breaks in the impervious lining were made, the areas would have the best chance for a rapid recovery.

Seeding of drill pads may or may not prove successful. If soils have been compacted by weight of equipment and traffic and covered with a layer of gravel or cinders, they may be slow to revegetate.

It might be noted that the extremely productive submerged grass beds reproduce minly by vegetative growth in this area. Any channels or dredging may take a long time to recolonize, and seeds are not generally available (Godcharles, 1971).

Clean up and restoration of the site, once the testing is completed, would allow successional changes to begin to turn the site back towards its former level of productivity. 
APPENDIX C - COORDINATION WITH FEDERAL, STATE, REGIONAL AND LOCAL GOVERNMENTS

Drilling operations in Texas and Louisiana are subject to regulation

at the Federal and state levels of government. Regulation for oil and gas operations are well established, but regulations on geothermal activities are in the embryonic stage of development. As a result, the permitting requirements are evolving as research adds new dimensions to the knowledge of the geothermal resource. This section presents the existing policies, regulations, and permitting requirements for drilling activities and geothermal development in the study area of coastal Texas and Louisiana. A 11st of Federal agencies contacted regarding coordination of the proposed action is included as Table $\mathrm{C}-\mathrm{I}$.

\subsection{Federal Regulation and Permitting Requirements}

Not all Federal lands are available for geothermal leasing. The following Federal lands are removed from geothermal leasing because of conservation and environmental matters:

$$
\begin{aligned}
& \text { National Parks, National Recreation Areas, Fish } \\
& \text { Hatcheries, Wildlife Refuges, Wildlife Ranges, } \\
& \text { Game Ranges, Wildlife Management Areas, Waterfowl } \\
& \text { Production Areas, lands acquired or reserved for } \\
& \text { the protection and conservation of fish and wildlife } \\
& \text { that are threatened with extinction }
\end{aligned}
$$

In addition, tribally or individually owned Indian trust or restricted lands, within or without the boundaries of Indian reservations, are removed by Congress from geothermal leasing (P1ate 11).

Special permission must be obtained from department heads when leasing will take place on lands withdrawn or acquired as part of the function of the Department of Agriculture. An example of this would be leasing of National Forest 
Table C-1. List of Federal Agencies Contacted Regarding Coordination of the Proposed Action

Federal Agencies - Regional Offices

Department of Housing \& Urban Development

National Parks Service

Geological Survey

National Marine Fisheries Service

Fish \& Wildlife Service

U.S. Fish \& Wildlife Service Regional Office

Regional Agencies - State of Texas

Lower Rio Grande Valley Development Council

Coastal Bend Council of Governments Golden Crescent Council of Governments

Houston-Galveston Area Council

Southeast Texas Regional Planning Commission

$\underline{\text { Regional Agencies - State of Louisiana }}$

Regional Planning Comnission for Jefferson, Orleans, St. Bermard and St. Tammany Parishes

Capitol Region Planning Commission

South-Central Planning and Development Commission

Acadiana Planning and Development District

Imperial Calcasieu Regional Planning and Development Commission
State Agencies - State of Louisiana

Louisiana Office of State Planning

Louisiana State Department of Commerce and Industry

Louisiana Wildlife and Fisheries Commission

Louisiana Department of Transportation \& Development, Office of Public Works

Office of the Governor, Governor's Council on Environmental Quality

Louisiana State Mineral Board

Louistana Geological Survey

Louisiana Stream Control Commission

Louisiana Air Pollution Control Cormission

Loulsiana Department of Conservation

Louisiana State Land Office

Loulsiana State Parks and Recreation Commission

State of Louisiana Department of Urban and Commity Affairs

State Department of Art, Historical and Cultural Preservation

Loulsiana Advisory Commission on Coastal and Marine Resources

State Agencies - State of Texas

Texas Railroad Commission

Texas Water Quality Board

Texas Parks and Wildlife Department

Texas Office of the Governor Interagency Council on Natural Resources and the Environment 
Table $\cdot \mathrm{C}-1$

(Continued)

$\underline{\text { Parish Agencies - State of Louisiana }}$

Jefferson Parish Planning Department St. Bernard Parish Planning Commission St. Tammany Parish Planning Commission Ascension Regional Planning Commission Iberville Parish Regional Planning Commission

Tangipahoa Parish Planning Commission West Baton Rouge Parish Planning Commission

East Baton Rouge Parish Planning Commission

Assumption Parish Planning Commission

Central Lafourche Regional Planning Commission

Houma-Terrebonne Planning and Zoning Commission

South Lafourche Regional Planning Commission

St. Charles Parish Planning and Zoning Commission

St. John the Baptist Planning Commission Acadia Parish Development Board

Evangeline Parish Planning Commission Iberia Regional Planning Commission Lafayette Regional Planning Commission St. Landry Parish Regional Planning Commission

St. Martin Parish Planning Commission

St. Mary Regional Planning Commission 非

St. Mary Regional Planning Commission 非 Beauregard Parish Planning Commission Cameron Parish Planning Commission 
lands. In the case of lands under the jurisdiction of the Federal Power Commission, permission must be granted by the Commission and activities are subject to use conditions.

For all activities which have a potential for adversely affecting the environment, there are several Federal programs which regulate some aspect of the activity (Table $\mathrm{C}-2$ ). The Environmental Protection Agency (EPA) issues permits for the discharge of effluents into waters of the United States and pollutants into the air. Each state may establish its own National Pollutant Discharge Elimination System (NPDES) permitting program provided it complies with the guidelines of the Federal Water Pollution Control Act (FWPCA) and is approved by EPA. To prevent degradation of water quality, EPA requires a permit for discharges under Section 306, Point Sources of Pollution, as it may apply to geothermal well test activities. The FWPCA does not now require NPDES permits for non-point source discharges. The State of Texas NPDES has not yet been approved by EPA, thus under present regulations EPA controls all discharges under NPDES in the State of Texas, and anyone who wishes to discharge fluid wastes into surface waters must apply to EPA for a permit as well as complying with Texas effluent discharge permit requirements. In Louisiana, these duties are held by the Louisiana Stream Control Commission. (See also state requirements.)

In the case of hazardous air pollutants including asbestos, beryllium and mercury, EPA has the ultimate permitting authority. No national standards have been set for the following air pollutants 11kely to be released in connection with geothermal resources: $\mathrm{H}_{2} \mathrm{~S}$ (Hydrogen Sulfide), $\mathrm{CO}_{2}$ (carbon dioxide) and radon. Noise pollution control is primarily the responsibility of state and local governments though the Environmental Protection Agency has the 
Table C-2. Matrix of Eederal and State Actions on Geopressure-Geothermal Well Testing Activities and Related 011 Activities

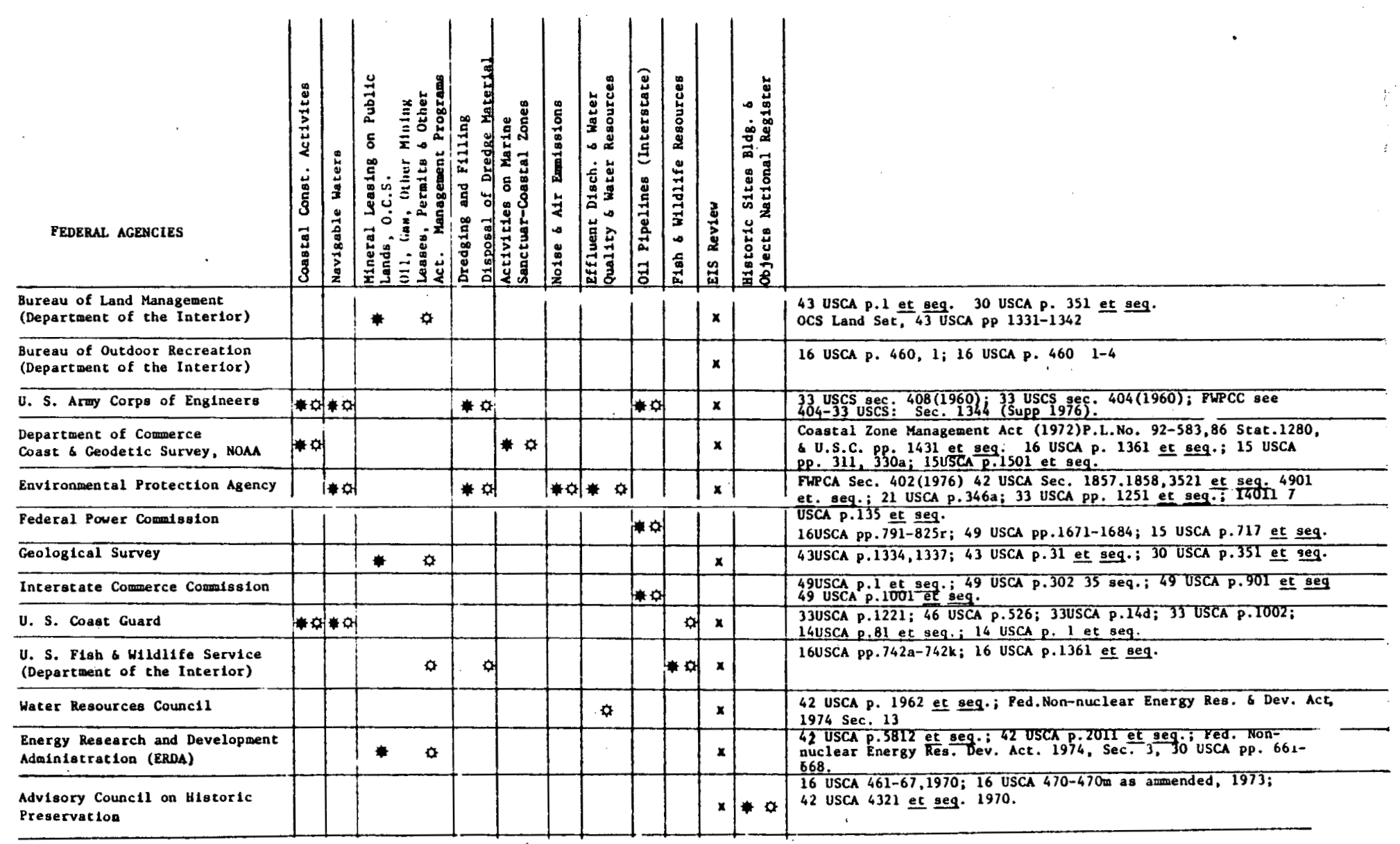

- Agency Requires Permits
Agency has Rules and Regulations
Applying to Action
* Agency Reviews EIS and EA or Reviews Applications 
Table C-2. Matrix of Federal and State Actions on Geopressure-Geothermal Well Testing Activities and Related 011 Activities. Continued.

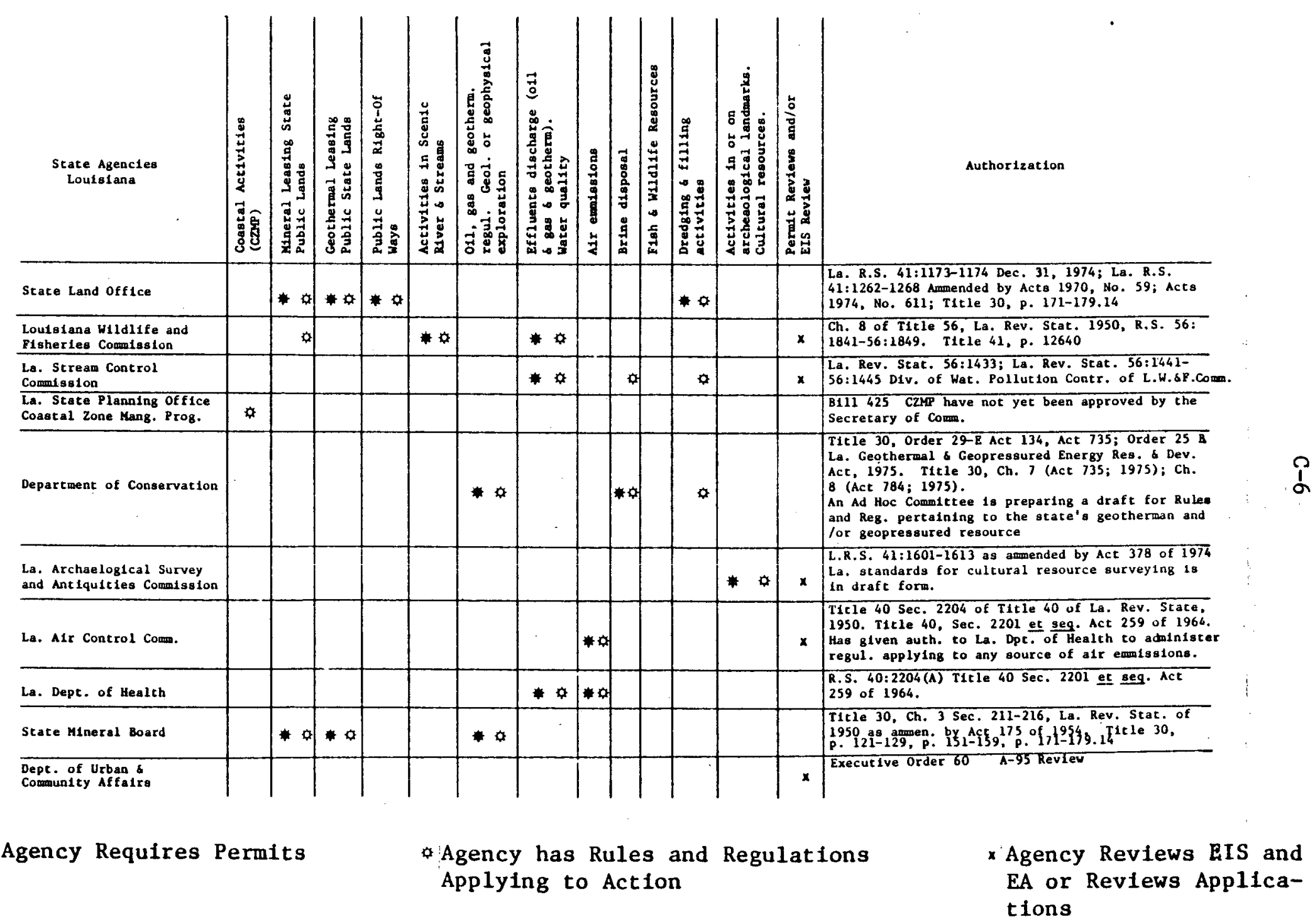


Table C-2, Matrix of Federal and State Actions on Geopressure-Geothermal Well Testing Activities and Related 011 Activities. Continued.

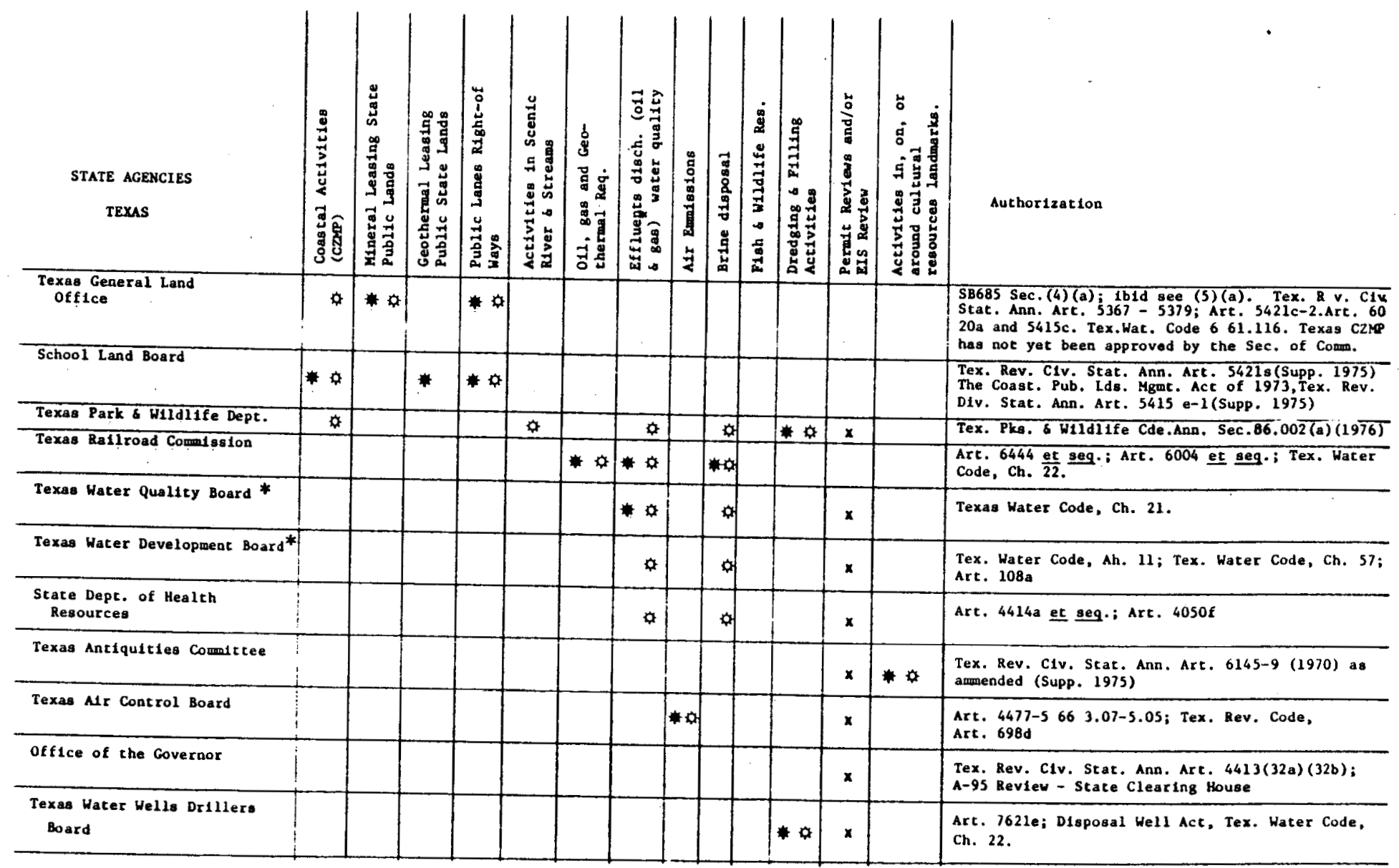

- Agency Requires Permits

* These two agencies plus the Texas Water Rights Commission have become the Texas Department of Water Resources
- Agency has Rules and Regulations Applying to Action
×Agency Reviews EIS and EA or Reviews Applications 
responsibility of conducting research on noise and its impact on people's health. Noise emission standards for construction equipment are published in Title 40 of the Code of Federal Regulations.

The passage of the Safe Water Drinking Act (SWDA) gave regulatory jurisdiction over injection wells to EPA in December, 1974. The act states that any underground injection is prohibited unless authorized by permit by December, 1977. Those authorized by permit must comply with specified inspection, monitoring, record-keeping, and reporting regulations. These rules and regulations "establish minimum requirements for effective State programs to protect existing and potential underground sources of drinking water from endangerment from underground injection of fluids". (SWDA, 1974).

The Bureau of Land Management is responsible for the leasing of mineral resources in the states of Texas and Louisiana. Federal mineral reservations may be for all minerals (including geothermal resources) or for some partial fraction of the mineral estate. No drilling on Federal mineral rights is allowed without a lease, or without consent of the present lease holder. Permits for drilling and other mineral developments are issued by the Geological Survey with the advice of other Interior Bureaus (FR 40, No. 23I, 1975).

Any activities related to oil, gas and geothermal resources exploration, development and production, requiring an environmental impact assessment, should identify park and recreation areas in the vicinity of the proposed action and address possible impacts, Impacted recreation areas funded with Land and Water Conservation Fund monies will require identification and coordination with the states involved. No changes in land use are permitted on lands acquired or 
developed for public outdoor recreation uses with assistance from the fund, without the consent of the Secretary of the Interior. In any such case, where approvat of conversion of uses is necessary, the State Liaison officer (SLO) should be informed to solicit the Secretary of the Interior's approval. The SLO in Texas is Clayton T. Garrison, Executive Director, Texas Parks and Wildlife Department, 4200 Smith School Road, Austin, Texas 78744. The SLO in Louisiana is Sandra S. Thompson, Secretary of the Department of Culture, Recreation and Tourism, P. O. Drawer 1111, Baton Rouge, Louisiana 70821.

The United States Army, through the Corps of Engineers, administers several permitting programs to protect and regulate the use of navigable waters. Any residential, commerical or industrial development activity in areas under the definition of navigable waters and unprotected flood areas is required to have a permit from the Corps of Engineers. A permit must be obtained from the Corps of Engineers appropriate district office before a structure is constructed, reconstructed, or renovated in, on, or under a navigable water. Exceptions are structures which require a permit from other authority such as in the case for bridges, causeways and aids to navigation constructed by the United States Coast Guard [see 33 C.F.R., Sections $209.120(\mathrm{c})(1), 209.120(\mathrm{~g})(14)(1975)$ for activities which are exempted]. Any channel or canal connection to navigable water requires a permit, as also do improvements to any navigable stream.

Dredging and filling activities also require a Corps of Engineers permit if the work is in or affects navigable waters. Under Section 404 of the Federal Water Pollution Control Act Amendments of 1972, P.I. 92-500, any discharge of dredge or fill material in navigable waters requires a permit issued by the Secretary of the Army, acting through the Chief of Engineers, after notice and opportunities 
for public hearings. Guidelines pertaining to these activities can be found in the Federal Register of July 25, 1975, Vo1. 40, Number 144, "Permits for Activities in Navigable Waters or Ocean Waters," published by the Corps of Engineers in accordance with the Environmental Protection Agency (EPA).

The Coast Guard issues permits regarding construction of bridges or causeways over navigable waters (including tidal wetlands). It also requires permits for handling explosives or dangerous cargo within contiguous waterfront facilities and for deepwater ports. The Coast Guard also has regulations pertaining to fixed islands or other fixed structues in offshore areas.

The Department of the Interior, Fish and Wildlife Service, reviews and comments on environmental assessments (EA) and environmental impact statements (EIS) of proposals for work and activities in or affecting navigable waters that are sanctioned, permitted, assisted or conducted by the Federal government:

These review functions delegated to the Service by the Secretary of the Interfor are prescribed by the Fish and Wildife Coordination Act (16 U.S.C. 661667 e; 48 Stat, 401, as amended), the National Environmental Policy Act of 1969 (42 U.S.C. 4321-4347; 83 Stat. 852), the Estuary Protection Act (16 U.S.C. 1224; 82 Stat. 627), the Department of Transportation Act (49 U.S.C. 1653(f); 82 Stat. 825), the Federal Afd Highway Act (23 U.S.C. 138; 82 Stat. 823), the Airport and Airway Development Act of 1970 (49 U.S.C, 1712 (c) and (f), 1716 (c) (4); 84 Stat. 222, 227), the Watershed Protection and Flood Prevention Act (16 U.S,C. 1008; 72 Stat. 567), and the Endangered Species Act of 1973 (16 U.S.C. 1536; 87 Stat. 892). The Service also has advisory and consulting roles under the Coastal Zone Management Act of 1972 (16 U.S.C. 1451) and the Marine Protection, Research, and Sanctuaries Act of 1972 (33 U.S.C. 1401), as well as basic and other authorities, (Federal Register, 1975) 
Coastal states with a Coastal Zone Management Program approved by the Department of Commerce (National Oceanic and Atmospheric Administration) in concurrence with the Department of the Interior have rules and regulations as well as legal controls for implementation affecting coastal activities, uses and development. Any activity in the coastal zone of such a state which requires a Federal permit or license must be accompanied by a state's approval of the proposed activity certifying its compliance with its coastal zone management plan. Neither Texas or Louisiana has yet instituted a coastal management program approved by the Secretary of Commerce.

If a project is within a marine sanctuary a certification is needed [see 33 CFR Section $204.120(\mathrm{~g})(3-4)$ (1975)] stating that the proposed activity is in compliance with the Marine, Protection, Research and Sanctuaries Act [16 U.S.C.S. Section 1432 (f) (Supp. 1976)].

Any geothermal activity which requires considerable amounts of water must conform to Section 5 of the Federal Non-nuclear Energy Research and Development Act of 1974 (Public Law 93-557, 88 Stat, 1878) which states:

Any program for the development of a technology which may require significant consumptive use of water after: the technology has reached the stage of commercial application shall include thorough consideration of the impacts of such technology and use of water resources pursuant to the provisions of Section 13.

This section makes the Water Resources Council responsible for undertaking "assessments of water resource requirements and water supply availability for any nonnuclear energy technology and any probable combinations of technologies which are the subject of federal research and development efforts authorized by this Act, and the commerical development of which would have significant impacts on water resources." 
The Geothermal Energy Research Development, and Demonstration Act of 1974 (Public Law 93-410, 88 Stat. 1079) requires that in the pursuance of any activities related to its programs, the protection and safety of the environment and the people on properties affected by the proposed actions be assured.

The Endangered Species Act of 1973. (Public Law 93-205, 87 Stat. 884) has as its main objective to "provide a means whereby the ecosystems upon which endangered spectes and threatened species depend may be conserved, and to provide a program for the conservation of such endangered species." Any activity related to the exploration, extraction or production of mineral resources including geothermal resources should state in its impact assessment the possible impacts (if any) to endangered species or to its habitat, the extent of the impact, and any proposed mitigation procedures.

The Antiquities Act of 1906 (Public Law 209, 16 U.S.C. 431-33, 1970) provides for the protection of all historic and prehistoric ruins or monuments on Federal lands. It authorizes the granting of permission of the Secretary of the department having jurisdiction. The Historic Sites Act of 1935 (Pub1ic Law 44-292, 16 U.S.C. $461-67,1970)$, declares as national policy the preservation for public use of historic sites, buildings, and objects. It gives the Secretary of the Interior the power to make historic surveys, to secure and preserve data on historic sites, and to acquire and preserve archeological and historic sites.

The National Historic Preservation Act of 1966 (Public Law 89-665, 16 U.S.C. 470-470m, as amended, 1973.) and the Archaeological and Historic Act of 1974 (Public Law 93-291) both have statutes and rules which establish environmental review procedures to ensure preservation of significant historic and 
archeological sites. The Advisory Council on Historic Preservation has established procedures ( $36 \mathrm{CFR} 800$ ) for compliance with the National Historic Preservation Act of 1966, Executive Order 11593, and the National Environmental Policy Act (Public Law 91-190, 42. U.S.C. 4321 et seq, 1970) requirements regarding historic preservation. According to Executive Order 11593, issued May 31, 1971, "projects funded, licensed or executed by Federal agencies must have the determination of eligibility of properties for inclusion in the National Register. This requires a survey, or surveys, to identify the sites and nominate them to the National Register." (See National Landmarks and the National Register, and Survey Standards Section of this report.)

Any proposed action which might affect properties with histroic, architectural, archeological or cultural value listed in the National Register of Historic Places (including National Landmarks) should follow the procedures established by the Advisory Council on Historic Preservation and the National Park Service. In order to comply with the Archaeological and Historic Preservation Act, the State Historic Preservation Officer should be consulted. In Louisiana, the State Preservation Officer is Ms. Sandra S. Thompson, Secretary of the Department of Culture, Recreation and Tourism. In Texas, Mr. Truett Latimer, Texas Historical Commission, is the Texas Preservation Officer.

The following Federal guidelines and procedures should be taken into account when undertaking Federally required cultural resources surveys:

Procedures of the Advisory Council on Historic Preservation (36 CFR Part 800)

National Register of Historic Places - Nominations by State and Federal Agencies. (36 CFR Part 60) 


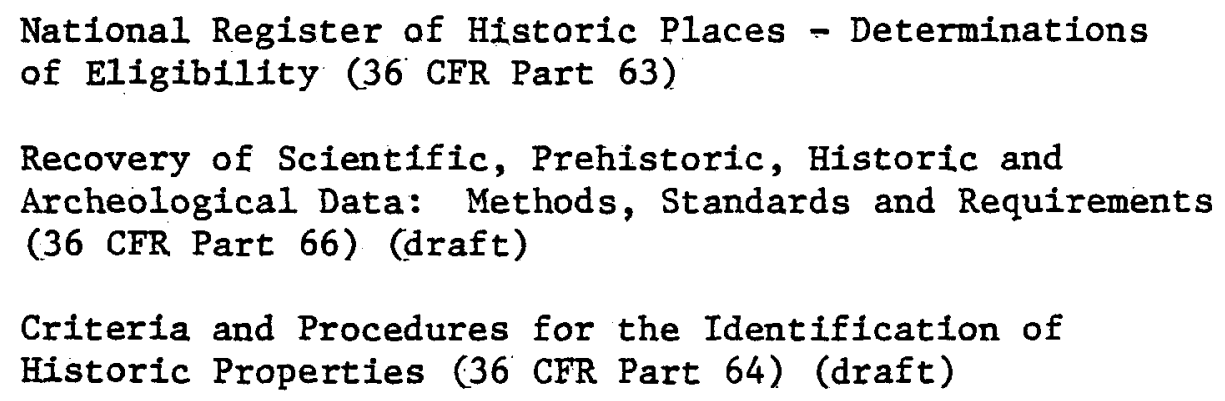

Several programs are available which offer matching funds for professional excavations and restoration of sites listed on the National Register. (See 1977 Catalog of Federal Domestic Assistance.)

The Office of Management and Budget Circular No, 9-95 is a regulation in which the main objective is maximum coordination of Federal and Federally assisted projects and programs with each other, as well as with state, regional and local projects and programs, The A-95 review system is also a way to assure state and local inputs to environmental impact statements as required by Section $102(2)$ (c) of the National Environmental Policy Act.

In the State of Texas the Office of the Governor as the State Clearinghouse serves as the state coordinating agency as prescribed in Office of Management and Budget, Circular A-95. The Council of Governments is also required as a regional agency to review certain Federally funded programs under 0.M.B. Cir. A-95 (rev.). In the State of Louisiana the Department of Urban and Community Affairs contains the Office of State Clearinghouse:

\subsection{State Plans and Policies.}

The states of Texas and Louisiana both play a leading role in the development and production of their mineral resources. Regulations and permitting procedures in 
these states are intended to help maintain the quality of their environment as oil, gas and geothermal resources development continues.

\subsubsection{State Land Use Plans - Parks, Refuges, etc.}

In Louisiana the Registrar of State Lands maintains in the State Land Office a list showing "the lands and improvements thereon and all royalty or mineral rights belonging to or under the control of the state, whether or not held directly in the name of the state or in the name of any state board, commission, department or agency." These include school board lands, wildlife management areas, refuges, and other similar lands. Leases to these lands can be obtained from the appropriate agency which has title, custody or possession of it. The Registrar of the State Land office may lease the bottoms of any lakes, bays, coves or other navigable waters and beds thereof for activities associated with mineral exploration, exploitation and transportation, including drilling of any wells for injection or withdrawal of natural gas, or for injecting, storing and withdrawing of liquid hydrocarbons. If any fill will be made within navigable water, a permit is needed from the Registrar of the State Land Office and approved by the Commissioner of Conservation.

The Governor of the State of Louisiana and the Registrar of the State Land Office may grant rights-of-way across and through any public lands belonging to the State of Louisiana to any person or corporation doing business in the state, provided that adequate compensation is paid the state, A permit should be filed using the State Right-of-Way Form provided by the Land Office.

In the State of Texas, the General Land Office and the School Land Board regulate activities taking place on the public free school lands of Texas (including 
coastal public lands). The Commissioner of the General Land office may issue permits for surveys and other investigations in areas within tidewater limits, rights-of-way over public lands, and mineral leases. The School Land Board grants certain interests or permits in coastal public lands; it controls leases for public purposes, easement to the littoral owner, channel easements for a holder of a surface or mineral interest in coastal public lands for purposes associated with the use of the holder's interest, and permits and leases for geothermal energy and related resources by the Board, under the direction of the Commissioner. However, no special rules have been promulgated for exploration permits or research permits. Leases are handled by a bidding procedure.

The Parks and Wildlife Department ( $P \& W D$ ) which is under the policy direction of the Parks and Wildlife Commission is responsible for the management of the state's fish and wildiffe resources and for the development and maintenance of state parks. It also regulates the dredging of sediments, fill and shell materials from publicly owned waters.

The Texas Parks and Wildlife Department comments on U.S. Army Corps of Engineers Permit Applications:

The Texas Parks and Wildlife Department will provide objective comments on all applications submitted to the U.S. Army Corps of Engineers for permits in accord with Section 10 of the Rivers and Harbors Act of 1899 , Section 404 of the Federal Water Pollution Control Act of 1972 , and related Federal regulations,

Under Section 86.001 of the Texas Parks and Wildlife Code, a permit is required from anyone prior to removing sand, shell, gravel and/or marl from the beds of State-owned waters. However, the holds of an oil and gas lease executed by the State is not required to obtain approval to exercise any right granted under the lease or other laws of the state. 
The Department of Wildlife and Fisheries under the Wildlife and Fisheries Commission of the State of Loufsiana controls and supervises the wildlife of the state including all aquatic life, and enforces the laws enacted for the control and supervision of programs which relate to the management, conservation and protection of wildife, fish and aquatic life. The Louisiana Wildiife and Fisheries Commission through its Division of Water Pollution Control, regulates, implements and enforces regulations on waste disposal, both public and private, into any of the state's waters. The Department also comments on the applications submitted to the Corps of Engineers for permits in accordance to Section 10 of the Rivers and Harbors Act of 1899, Section 404 of the Federal Water Pollution Control Act of 1072, and related Federal regulations.

The system of natural and scenlc rivers in Louisiana has as its main objectives the protection and enhancement of streams considered to have special qualities. The agency in charge of administering the system is the Wildlife and Fisheries Commission. The latest 1ist of rivers in the system and its administering procedures are outlined in their booklet entitled Natural and Scenic Streams System. Activities which are prohibited include channelization, clearing and snagging, channel realignment and reservoir construction. The following activities would require a Class $B$ permit from the Wildlife and Fisheries Commission -- pipelining, tree cutting, building of bridges, bullding of camps, bulkheading, dredging, and canalling of adjacent lands.

In the State of Texas, the 62nd legislature commissioned the Texas Parks and Wildlife Department to conduct a study of Texas waterways in order to determine the feasibility of establishing a statewide system of waterways which will include a system of wild and scenic rivers. With these objectives two reports 
entitled Texas Waterways and Air Analysis of Texas Waterways were conducted by the Texas Parks and Wildlife Department which identify various sections of rivers, streams and bayous in the state having potential for inclusion in such a system.

\subsubsection{Coastal Zone Management Plans}

According to the Coastal Zone Management Act of 1972, the Congress of the United States has established a Federal program to aid participating states in developing programs for the protection and management of their coastal areas. The objective of the plan for coastal resource management is balancing conservation and development by encouraging reasonable and suitable uses of coastal areas. Regulations to implement the act have been developed by both the states of Texas and Louisiana. However, at the present time no state level coastal zone management regulations are in effect in these states, nor as neither state has instituted a coastal management program approved by the Secretary of Commerce. In the state of Louisiana, the state agency in charge of the development of a coastal zone management program is the Louisiana State Planning office. In the state of Texas, the General Land Office of Texas is the agency responsible to develop and improve coastal management process. As the Coastal Zone Management Program evolves in both states it will be necessary to keep abreast of new regulations, permitting procedures and assistance available from these programs which may influence geothermal activities,

\subsubsection{State Well Drilling Procedures}

In the state of Texas, the agency which determines production allowables for oil and gas, issues drill permits for petroleum wells, and regulates geothermal energy development is the Texas Railroad Commission. Rules and regulations 
pertaining to this subject are contained in a publication entitled The Railroad Commission of Texas, General Conservation Rules and Regulations of Statewide Application, State of Texas (1971). The TRRC issues permits for the discharge of water resulting from oil and gas activities. It requires permits for drilling, deepening, or plugging back exploratory, fluid injection, injection water source, oil, gas and geothermal resource wells. Before plugging a well drilled for oil, gas, or geothermal resource, the TRRC district office must be notified in writing. Authorization is also required before disposal of oil field brine, geothermal resources, or ather mineralized water, and for injecting fluid into a productive oil, gas, or geothermal reservoir. The Commission also regulates transportation of natural gas, storage tanks and pipelines and inspects completed wells with regard to safety and for compliance with pollution and waste criteria. Coordinating state agencies are: The Texas Water Quality Board, Texas Water Development Board, Texas Parks and Wildlife Department and the State Health Department.

The Department of Conservation, Louisiana Geological Survey, is the main regulatory agency for the drilling, production and operation of oil and gas wells in the state of Louisiana. Rules and regulations are contained in the Statewide Rules, State of Loulsiana (Title 30, Order No. 29-B, Order 29-E, Act. 134, Act. 735). These rules and regulations govern the drilling for and production of oil and gas or either of them, except when they conflict with orders issued by the Commissioner of Conservation on specific fields.

Act 735 of 1975 provides for participation by State, Federal, and private agencies; to authorize contracts in connection therewith; to provide for reports to the Governor and Joint Legisiative Committee on Natural Resources; to provide for funding and to provide otherwise generally and specifically thereto. Act 134 of 1976 is to amend and reenact Chapter 8 of Title 30 of the Louisiana Revised Statutes of 1950 to be comprised of R.S : 30:800 through R.S, 30:809 inclusive, relative to geothermal energy resources, 
to provide for policy and purpose; to provide for definitions; to provide for regulation of exploration, drilling, production and subsurface disposal; to provide for conservation and environmental protection; to provide for leasing procedures and terms, rentals and royalties on state-owned lands; to provide for regulatory control by the State Mineral Board and the Department of Conservation; to provide for records and funds, to preserve rights; and to provide for related matters.

At present, there is an Ad Hoc Committee appointed by R. T. Sutton, Commissioner of the State of Loulsiana, Department of Conservation, to prepare a draft for proposed rules and regulations pertaining to the state's geothermal and/or geopressured resources. The draft rules and regulations should be persented to the Commissioner by the end of 1977. In order for said rules to become effective according to Louisiana law, they would have to advertise, a public hearing would have to be held, and the final rules and regulations would then be published in the Louisiana Register.

Rules and regulations regarding the disposal of saltwater associated with oil and gas production are applicable to disposal of geothermal saltwater.

\subsubsection{State Archeological and Historic Survey Requirements}

The states of Louisiana and Texas have both set standards for cultural resource surveying in compliance with Federal regulations. In Louisiana, there are three levels of survey work. Level $I$ is the Assessment and Preliminary Field Review; Level II is a complete on-the-ground survey; and Level III involves mitigation of the proposed action or actions should the site be destroyed (see survey Standards Section of this report). Louisiana standards for cultural resource surveying are compiled in "The Draft Standards for Cultural Resource Surveys," 
Louisiana Archaeological Survey and Antiquities Comission. Texas rules and regulations concerning survey standards are similar to those in Louisiana and are contained in "General Rules of Practice and Procedure," Texas Antiquities Committee.

\subsubsection{State Environmental Requirements}

Surface and Subsurface Permitting Procedures at the State Level - In the state of Texas the main regulatory authorities for waste fluid disposal in association with geothermal resources and with the production of oil and gas in Texas are the Texas Water Quality Board (TWQB) and the Texas Railroad Commission (TRRC), and the Federal Environmental Protection Agency (EPA) at the Federal level. The necessary permits for surface or subsurface disposal of waste fluids are issued by these agencies.

Although the Texas Water Quality Board has a water pollution control program for the state of Texas, this program has not yet been approved by EPA because it is not entirely in conformance with the Federal NPDES, Section 402 of the FWPCAA. Under existing regulations anyone seeking approval to discharge fluid wastes into surface waters must apply to EPA for an NPDES permit, and also under Texas regulations, a permit is required from either the Texas Railroad Commission or the Texas Water Quality Board. The TRRC requires a permit for discharge of waste fluids for either surface or subsurface disposal resulting from oil or gas operations, as long as the discharge meets the state waterquality standards established by the TWQB. In order to obtain a permit for discharge of fluid waste from geopressured or geothermal development and production both agencies, the TRRC and the TWQB, should be contacted prior to any action, since the Texas Legislature has not clearly resolved yet which agency will have final permit authorization regarding the disposal of geothermal resource waste. 
Other Texas state agencies with specific water pollution control duties are consulted by either the TRRC or the TWQB as the case may be. These agencies are the Texas Water Development Board (TWDB) which is concerned with the quality of groundwater in the state; the Texas Parks and Wildlife Department (TPWD) whose interest is the affect of water pollution on aquatic life and wildlife; and the Texas Department of Health Resources (TDHR) which oversees the health aspects of water quality in the state of Texas.

In the state of Louisiana, the Louisiana Stream Control Commission is the principal state agency which regulates waste disposal into any of the state's waters. It implements its rules through the Division of Water Pollution Control of the Loulsiana Wildiffe and Fisheries Commission.

No action on any facility which will discharge industrial waste into state waters can be started until a certificate of approval has been issued by the Stream Control Commission certifying that the waste discharge is within the water quality standards adopted by the state of Louisiana. A general report concerning the proposed action prepared and approved by a professional engineer duly licensed in Louisiana must accompany the application. The application for a permit to discharge waste water may be submitted on either of the following forms: National Pollutant Discharge Elimination System (NPDES) Standard Form C [EPA Form 7550-23(7-73) Sections I, II and IIIJ plus Sections III and IV of Form SCC2; or Louisiana Stream Control Commission Form SCC2.

Brine Disposal Relating to the O1l Production Industry - The states of Texas and Louisiana regulate brine disposal activities. The U.S. Environmental Protection Agency (EPA) can, depending on the case, seek a civil action if brine pollution occurs. 
In the state of Texas, a permit is required for brine disposal prior to initiating the action. The permit is from the Railroad Commission of Texas, 011 and Gas Division. Several disposal methods are permitted by the state; these are: injection, no pits, and discharge into waters offshore and adjacent estuaries zone. A letter of approval from the Texas Quality Board is required before granting such permits, A permit must also be obtained for fluid injection into a productive oil, gas, or geothermal reservoir from TTRC. TWDB, TDHR, and the Texas Water We11 Drillers Board (TWWDB) are the main state agencies acting as coordinators on the granting of such permits.

In Louisiana, the agency regulating brine disposal is the Department of Conservation, Louisiana Geological Survey, 011 and Gas Division. Rules and regulations covering this matter are published in a publication entitled Underground Saltwater and Waste Disposal in Louisiana, State Regulations and Geological Concepts, June, 1974. The allowable methods of disposal are; injection, pits lined, pits unlined, and in tide-affected waters (waters unfit for human consumption or agricultural purposes).

Air Emissions, Regulatory and Permitting Procedures at State Level - According to the Texas Clean Air Act any person planning to construct or modify a facility that may release pollutants into the atmosphere must obtain a permit from the Texas Air Control Board (TACB) before taking action. Rules and regulations adopted by the TACB can be found in the "General Rules and Regulations Adopted by the TACB." 
To expedite permit applications the applicant may send copies of General Form PL-1 to the appropriate TACB regional office and the local city or county air pollution control program besides sending the required three copies to the Austin Office of TACB accompanied by three copies of Supplemental Form PL-2 containing appropriate engineering data.

In the state of Loulsiana the Louisiana Air Control Commission has given authority to the Louisiana Department of Health to administer regulations applying to any source of air emissions in the state.

Any facility which may release contaminants into the air must file for a permit to the Air Contro1 Commission accompanied by a report with a description and all pertinent data regarding the proposed action and prepared and/or approved by a professional engineer duly licensed in Louisiana.

Among other state environmental requirements in the state of Texas, the office of the Governor is responsible for reviewing and commenting on Federally assisted grant applications and plans, required by Federal law.

The Governor's Council on Environmental Quality in the state of Louisiana in a letter of response to Coastal Environments, Inc., indicated no objection to the proposed testing of geopressured and geothermal weils along the Frio Formation in the Louisiana coastal area.

\subsubsection{Other State Permitting Procedures}

In Louisiana the State Mineral Board has rules and regulations applicable to geophysical exploration conducted upon or relating to State-owned lands and 
water bottoms. An application shall be made to this agency for geological or geophysical exploration under Title 30, Chapter 3, Section 211-216, of the Louisiana Revised Statutes of 1950, as amended by Act 185 of 1954.

The Department of Transportation and Development in Louisiana would require a permit before engaging in any work being performed within their right-of-way, including pipeline crossings.

The Louisiana Department of Public Works would also require an application for approval of pipelines crossing waterways (navigable and non-navigable) within the limits of the state of Louisiana.

The Louisiana Health and Human Resources Administration, Division of Health, has been authorized by the Louisiana Air Control Commission to provide and administer air emissions regulations. The Division of Health also issues permits for the construction of water supply and sewerage systems, solid waste facilities, and other activities not related indirectly to oil and gas or geothermal resources exploration and production.

A list of State Agencies contacted by Coastal Environments, Inc., regarding coordination of the proposed action with their plans and regulations is included in Table C-1.

\subsection{Regional Plans and Policies}

At the Regional level, there are several regional agencies which have controls, rules, and regulations both in Texas and Louisiana. The Regional Planning Commissions oversee physical, social and economic trends on an area encompassing 
several counties or parishes. They participate as clearinghouses on A-95 reviews, and they also serve as advisors to local agencies.

Regional Planning Commissions both in Texas and Louisiana were contacted with the purpose of identifying any possible conflicts between existing and future land use plans and agencies' regulations and the proposed action.

None of the letters of response identified any foreseeable conflicts at present. However, the responding agencles and Planning Commissions would like to be notified at a later date of any specific site chosen for testing within their planning area before any action is taken. Table $\mathrm{C}-1$ includes a list of agencies contacted, as well as the letter and questionnaires sent.

\subsection{Local Plans}

Several planning bodies in Texas and Louisiana at the county or parish level as well as at the city and municipal levels of government have interest in any mineral resource development activities occurring within their area of jurisdiction. The majority of them have zoning ordinances, subdivision regulations and building and health codes which require permitting procedures prior to construction of bulldings and other structures.

Moreover, special entities such as port authorities, river authorities, levee boards, drainage districts and others have authority upon specific areas or activities. These local planning bodies and entities should be contacted once specific sites have been chosen for geopressured or geothermal well testing if they are under these agencies ' jurisdictional areas. 
of the several local planning bodies contacted, none of those that responded forsee any conflicts between their local land use plans and the proposed action. None of them described any specific local rules and regulations affecting drilling activities. Table $\mathrm{C}-1$ lists those local agencies contacted. 
Adkins, Gerald, A Study of the Blue Crab Fishery in Louisiana, Louisiana Wildlife and Fisheries Commission Technical Bulletin, No. 3, New Orleans, Louisiana, 1972.

Adkins, Gerald and Philip Bowman, A Study of the Fauna in Dredged Canals of Coastal Louisiana, Louisiana Wildlife and Fisheries Commission Technical Bulletin, No. 18, New Orleans, Louisiana, 1976.

Algermissen, S. T., "Seismic Risk Studies in the United States," in Fourth World Conference of Earthquake Engineering, Santiago, Chili, January 13-18, 1969.

Algermissen, S. T. and D. M. Perkins, A Probabilistic Estimate of Maximum Acceleration in Rock in the Contiguous United States, 1976.

Allen, R. P., "Notes on Some Bird Colonies on the Gulf Coast," Auk, vol. 52, p. 198-200, 1935 .

American Association of Petroleum Geologists, Geologic Highway Map of Texas, H. B. Renfro Memorial Edition, Tulsa, Oklahoma, 1962.

Anderson, R. D., Effects of Petroleum Hydrocarbons on the Physiology of the American Oyster, Crassostrea virginica, Gmelin, Ph.D. Dissertation, Texas A \& M University, College Station, Texas, 145 p., 1973. 
Anonymous, The Subsidence Update, Harris-Galveston Coastal Subsidence District, Houston, Texas, March, 1977.

Anonymous, "Update - Brown Pelicans," Audubon, vol. 79(4), 1977.

Antoine, J. S. et al., "Continental Margins of the Gulf of Mexico," in The Geology of Continental Margins, ed. by C. A. Burke and C. L. Drake, Springer-Verlog, New York, p. 683-693, 1974.

Atherton, R. W., E. J. Finnemore, M. L. Gillam, A. E. DeGance, G. P. Grimsrud, and R. B. Schainker, The Analysis of Subsidence Associated with Geothermal Development, Systems Control, Inc., Palo Alto, California, vol. 1-3, 1976.

Axtmann, R. C., "Environmental Impact of a Geothermal Power Plant," Science, vol. 187, p. 795-802, 1975.

Bach, W. and A. Daniels, Handbook of Air Quality in the United States, The Oriental Publishing Company, Honolulu, Hawaii, 1975.

Baker, R. C. and O. C. Dale, Ground-Water Resources of the Lower Rio Grande Valley Area, Texas, U.S. Geological Survey Water-Supply Paper 1653, 56 p., 1964. 
Balashov, L. S., "Rare Elements in Thermal Groundwater," in Proceedings 2nd United Nations Symposium on Development and Use of Geothermal Resources, vol. 3, San Francisco, California, May 20-29, 1975.

Barrett, B. B., Water Measurements of Coastal Louisiana, Louisiana Wildife and Fisheries Commission, 1970.

Barrett, B. B. and Ellen J. Ralph, 1977 Environmental Conditions Relative to Shrimp Production in Coastal Louisiana Along with Shrimp Catch Data for the Gulf of Mexico, Louisiana Department of Wildlife and Fisheries Technical Series (in press), 1977.

1976 Environmental Conditions Relative to Shrimp Production in Coastal Louisiana, Louisiana Wildlife and Fisheries Commission Technical Bulletin No. 21, 1976.

Bauer, Erwin A., The Bass Fisherman's Bible, Doubleday \& Company, Garden City, New York, 1961.

Bebout, D. G. and O. K. Agagn, "Depositional Framework of the Frio Formation (Olisocene) - Lower and Middle Gulf Coast," Transactions, Gulf Coast Association of Geological Societies, vol. 25, p. 44-61, 1975 . 
Bebout, D. G., M. H. Dorfman, and O. K. Agagn, Geothermal Resources Frio Formation, Middle Texas Gulf Coast, Bureau of Economic Geology, Geological Circular No. 75-8, University of Texas, Austin, Texas, 1975a.

- Geothermal Resources Frio Formation, South Texas, Bureau of Economic Geology, Geological Circular No. 75-1, University of Texas, Austin, Texas, 1975b.

Bebout, D. G., R. G. Loucks, S. C. Boschs, and M. H. Dorfman, Geothermal Resources Frio Formation, Upper Texas Gulf Coast, Bureau of Economic Geology, Geological Circular No. 76-3, University of Texas, Austin, Texas, 1976.

Bebout, D. G., P. E. Luttre1l, and J. H. Seo, Regional Tertiary Cross Sections Texas Gulf Coast, Bureau of Economic Geology, Geological Circular No. 76-5, University of Texas, Austin, Texas, 1976.

Bellrose, Frank C., Ducks, Geese and Swans of North America, Stackpole, 1976.

Bernard, H.A. and R.J. LeBlanc, "Resume of the Quaternary Geology of the Northwest Gulf of Mexico Province," Quaternary of the United States, edited by H.E. Wright, Jr., and D.G. Frey, Princeton University Press, Princeton, New York, p. 137-185, 1965. 
Bernard, Wm. J., "Reservoir Mechanics of Geopressured Aquifers" in Proceedings, First Geopressured Geothermal Energy Conference, (M. H. Dorfman and R. W. Deller, Eds.), Austin, Texas, p. 157171,1975 .

Bertrand, Alvin L., "The Demography of Louisiana: Some Implications for Future Planning," LSU Alumni News, vol. 52, p. 13-17, 1976.

Biggar, J. W. and M. Fireman, "Boron Absorption and Release by Soils," Soil Science Society American Proceedings, vol. 24, p. 115, 1960.

Bishop, S.C., Handbook of Salamanders, Comstock, Ithaca, New York, 1947.

Blakely, J.:F. and H. L. Kunze, Reconnaissance of the Chemical Quality of Surface Waters of the Coastal Basins of Texas, Texas Water Development Board Report 130, Austin, Texas, 1971.

Boone, Dan, An Investigation of the 1972-73 and 1973-74 Texas Fur Harvests with Respect to Future Research and Management, Texas Parks and Wildlife Department, 1974.

Boone, Dan, Data 1974-1975 Furtrapping Season, Texas Parks and Wildlife Department, 1975. 
Bowen, R. G., "Environmental Impact of Geothermal Development" in P. Kruger and C. Otte, Geothermal Energy, Stanford University Press, Stanford, California, 1973.

Boyd, D. R. and B. F. Dyer, "Frio Barrier Bar System of South Texas;" Transaction, GuIf Coast Association Geological Societies, vol. 14, 309-322.

Brereton, A. H., Lord, I. Thornton and J. S. Webb, "Effect of Zinc on Growth and Development of Larvae of Pacific Oyster Crassostrea gigas," Marine Biology, vol. 19, p. 96-101, 1973.

Brevonik, D., Personal Communication, Diana Stellar, Rare Plant Study Center, Austin, Texas, 1977.

Brinker, R. C., Elementary Surveying, Fifth Edition, International Textbook Co., Scranton, Pennsylvania, 1969.

Brooner, F. I., "Shale Diapirs of the Lower Texas Gulf Coast as Typified by the Louisiana Ward Diapir," Transaction, Gulf Coast Association of Geological Societies, vol. 17, p. 126-134, 1967.

Brower, W. A., J. M. Meserve and P. G. Quayle, Environmental Guide for the U.S. Gulf Coast, National Oceanographic and Atmospheric Association, Environmental Data Service, National Climatic Center, Ashville, North Carolina, 1972. 
Brown, B. C., An Annotated Checklist of the Reptiles and Amphibians of Texas, M.S. Thesis, Texas A \& M University, College Station, Texas, 419 p., 1948.

Brown, B. E. and R. C. Newell, "The Effect of Copper and Zinc on the Metabolism of the Mussel Mytilus edulis," Marine Biology, vol. 16, p. 108-118, 1972 .

Brown, Clair A., Louisiana Trees and Shrubs, Louisiana Commission of Forestry, Baton Rouge, Louisiana, 1945.

Brown, Clair A., Commercial Trees of Louisṭana, Louisiana Forestry Commission, Baton Rouge, Louisiana, 1959.

Brown, L. F., J. L. Brewton, J. H. McGowen, T. J. Evans, W. L. Fisher and C. G. Groat, Environmental Geologic Atlas of the Texas Coastal Zone - Corpus Christi Area, Bureau of Economic Geology, University of Texas, Austin, Texas, 123 p., 1976.

Bureau of Economic Geology, Energy Resources of Texas, A Map, Scale: 1:1,000,000, University of Texas, Austin, Texas, 1976.

Bureau of Economic Geology, Environmental Geologic Atlas of the Texas Coastal Zone: Map-Environments and Biologic Assemblage Map, L. F. Brown (Ed.), University of Texas, Austin, Texas, 1971-77. 
Bureau of Land Management, U.S. Department of the Interior, Environmental and Socio-Economic Baseline on the Gulf of Mexico Coastal Zone and Outer Continental Shelf-Current and Recent Research on Environmental Processes and Conditions in the Gulf of Mexico Region, vo1. 1, 2 and 3, $1974 \mathrm{a}$.

Bureau of Land Management, Final Environmental Impact Statement for East Texas, Outer Continental Shelf, Sale No. 34, U.S. Department of the Interior, 2 vols., $1974 \mathrm{~b}$.

Bureau of Land Management, Final Environmental Impact Statement for Louisiana, Outer Continental Shelf, Sale No. 36, U.S. Department of the Interior, 2 vols., $1974 \mathrm{c}$.

Bureau of Land Management, Final Environmental Impact statement Proposed 1977 Outer Continental Shelf Oil and Gas Lease Sale, Sale No. 47, U.S. Department of the Interior, 2 vols., 1977.

Bureau of Mines, Minerals Yearbooks 1973, Vol. II Area Reports, Domestic, U.S. Government Printing Office, Washington, D.C., 1976 .

Burk and Associates, Louisiana Coastal Vegetation, for Louisiana State Planning Office, Map, 1976a. 
Burk and Associates, Unique Ecological Features of the Louisiana Coastal, for Louisiana State Planning Office, Map, $1976 \mathrm{~b}$.

Burk and Associates, Inc., Recreational Potential Along the Louisiana Coast Proposed New and Expanded Sites for Recreation, Prepared for the Louisiana State Planning Office, Coastal Resources Program, 1977.

Butler, T. J., Aquatic Metabolism and Nutrient Flux in a Southern Louisiana Swamp and Lake System, M.S. Thesis, Louisiana State University, Baton Rouge, Louisiana, 1975.

\section{Canadian Wildlife Service, The Whooping Crane (Grus americana), Canadian Wildlife Service, Ottawa, Canada, 1968.}

Cardwell, G. T. and Rollo, J.R., Interim Report on Ground-Water Conditions Between Baton Rouge and New Orleans, Louisiana, Departments of Conservation and Public Works and Louisiana Geological Survey, Water Resources Pamphlet No. 9, 44 p., 1960.

Carr, A., Handbook of Turtles, Comstock, Ithaca, New York, 1952.

Chabreck, R. H., Marsh Zones and Vegetative Types in the Louisiana Coastal Marshes, Ph.D. Dissertation, Louisiana State University, Baton Rouge, Louisiana, 112 p., 1970. 
Chabreck, Robert H., "The Foods and Feeding Habits of Alligators from Fresh and Saline Environments in Louisiana," Proceedings, 25th Conference Southeast Association, Game and Fish Commission, p. 117-124, 1971 .

Chabreck, R. H., Vegetation, Water and Soil Characteristics of the Louisiana Coastal Region, 'Louisiana State University Agricultural Experimental Station, Bulletin No. 664, 72 p., 1972.

Coastal Environments, Inc., An Environmental Assessment of Proposed Geothermal Well Testing in the Tigre Lagoon Oil Field, Vermilion Parish, Louisiana, prepared for Energy Research and Development Administration, Washington, D. C., 1976.

Coastal States Gas Producing Company (CSGPC), Tiger Lagoon Field Sales to Trunkline Sampled at a Meter Run in the Field, $\mathrm{H}_{2} \mathrm{~S}$ in Grains per 100 Cubic Feet, 1970.

Coffman, J. L. and C. A. van Hake, Earthquake History of the United States, U.S. Department of Commerce, National Oceanographic and Atmospheric Administration, Pub. 41-1, revised edition, 1973.

Collins, A. G., "Geochemistry of Oilfield Waters Development" in Petroleum Science, vol. 1, Elsevier Scientific Publishing Co., New York, 1975. 
Conant, R., A Field Guide to Reptiles and Amphibians of Eastern and Central North America, Houghton Mifflin, Boston, Massachusetts, 1975.

Conner, W. H. and J. W. Day, Productivity and Composition of a FreshWater Swamp in Louisiana, Center for Wetland Resources, Louisiana State University, Baton Rouge, Louisiana, 30 p., 1976.

Conner, W. H., Wetland Use Practices Fishing and Trapping, Center for Wetland Resources, Louisiana State University, Baton Rouge, Louisiana, 1977.

Correll, D. S. and M. C. Johnston, Manual of the Vascular plants of Texas, Texas Research Foundation, Renner, Texas, 1970.

Corre11, D. S. and H. B. Corre11, Aquatic and Wetland Plants of Southwestern United States, Stanford University Press, Stanford, California, vol. 1 and 2,1975 .

Coupland, R. T., "Productivity of Grassland Ecosystems," in Productivity of World Ecosystems, National Academy of Science, Washington, D. C., 1975. 
Davis, William B., The Mammals of Texas, Texas Parks and Wildlife, Bulletin 41, 1974 .

Day, J. N, W. G. Smith, P. R. Wagner, W. C. Stone and C. Wilmer, Community Structure and Carbon Budget of a Salt Marsh and Shallow Bay Estuarine System in Louisiana, Center for Wetland Resources, Louisiana State University, Baton Rouge, Louisiana, Publication No. LSU-SG-72-04, 1973.

Day, J., T. Butler and W. Conner, "Productivity and Nutrient Export Studies in a Cypress Swamp and Lake System in Louisiana," Estuarine Processes, Vol. II, p. 255-269, 1977.

Defilipps, R. A., Letter Concerning Rare and Endangered Plants of Louisiana, June 10, 1977, Endangered Flora Project, Smithsonian Institution, 1977.

DeLaBretonne, Larry, Jr. and James W. Avault, Jr., "Movements of Brown Shrimp (Penaeus aztecus) and White Shrimp (Penaeus setiferus) over Weirs in Marshes of South Louisiana," Proceedings 25th Annual Conference Southeast Association Game and Fish Commission, p. 651-654, 1971 .

Dickey, P. A., C. R. Shiram and W. R. Paine, "Abnormal Pressures in Deep Wells in Southwestern Louisiana," Science, vol. 160, pp. 609-615, 1968. 
Dickinson, G., "Reservoir Pressures in Gulf Coast, Louisiana," Bulletin, American Association of Petroleum Geologists, vol. 37, p. 410-432, 1953 .

Diener, Richard A., Cooperative Gulf of Mexico Estuarine Inventory and Study--Texas: Area Description, National Oceanographic and Atmospheric Administration Technical Report, NMFS Circ-393, 1975.

Dorfman, M. H., "Water Required to Develop Geothermal Energy," American Water Works Association Journal, vol. 68(7), p. 370-375, 1976.

Dorfman, M. H. and R. W. Deller, "Summary and Future Projections," Proceedings of the Second Geopressured Geothermal Energy Conference, vol. I, University of Texas, Austin, Texas, 1976.

Dundee, H. A. and D. A. Rossman, Amphibians and Reptiles of Louisiana, (in preparation).

Dunhan, Fred, A Study of Commercially Important Estuarine-Dependent Industrial Fishes, Louisiana Wildlife and Fisheries Commission Technical Bulletin No. 4, 1972. 
Earle, D. W., Land Subsidence and Maintenance Costs to Homeowners in East New Orleans, Louisiana, unpublished dissertation, Louisiana State University, Department of Marine Sciences, Baton Rouge, 1975.

Elmer, Donald B., "State Laws and Regulations, Geothermal Resources," Proceedings Second Geopressured Geothermal Energy Conference, University of Texas, Austin, Texas, in Geothermal Energy Magazine, vol. 4, No. 9, September 1976.

Engineer Agency for Resources Inventories, Inventory of Basic Environmental Data, South Louisiana, Mermentau River Basin to Chandeleur Sound, with Special Emphasis on the Atchafalaya Basin, U.S. Army Engineer Topographic Laboratories, Washington, D. C., 1973.

Energy Research and Development Administration, A National Plan for Energy Research, Development and Demonstration: Creating Energy Choices for the Future-Volume 1: The Plan, ERDA-48, June 1975.

Energy Research and Development Administration, Definition Report: Geothermal Energy Research, Development and Demonstration Program, ERDA-86, Division of Geothermal Energy, Washington, D. C., 1975.

Energy Research and Development Administration, Environmental Assessment of the Geopressure Subprogram of the Division of Geothermal Energy, draft, 1976 . 
Environmental Protection Agency, Conference Proceedings, Environmental Aspects of Chemical Use in Well-Drilling Operations, (May, Houston, Texas), Office of Toxic Substances, Washington, D.C., 1975.

Environmental Protection Agency, Air Quality Data--1974 Annual Statistics, Publication No. EPA-450/2-76-011, Research Triangle Park, North Carolina, 1976 a.

Environmental Protection Agency, Quality Criteria for Water, EPA440/9-76-023, Washington, D. C., $1976 \mathrm{~b}$.

Environmental Protection Agency, Estuarine-Pollution Control and Assessment, Proceedings of a Conference, Office of Water Planning and Standards, Washington, D. C., 2 vols., 1977.

Federal Register, vol. 40, No. 127 and 188, Tuesday, July 1, List A, p. 27874-27880; vol. 41, No. 117 and 208; vol. 42, No. 6, 1975 a.

Federal Register, vol. 40, No. 144, July 25, 1975 b.

Federal Register, vol. 40, No. 137, September 5, 1975 c.

Federal Register, vol. 40, No. 231, December 1, 1975 d. 
Federal Register, vo1. 41, No. 252, December 30, 1976.

Ficke, J. F. and R. O. Hawkinson, The National Stream Quality ACCounting Network (NASQUAN), Some questions and Answers, Geological Survey Circular 719, U.S. Geological Survey, Reston, Virginia, 1975.

Finnemore, E. J., "Potential Land Subsidence at Geothermal Development Sites," Geothermal Energy Magazine, vol. 5, No. 5, p. 35-39, May 1977.

Fish, A. G., L. L. Massey, J. R. Inabinet, and P. L. Lewus, A Study of the Effects of Environmental Factors Upon the Distribution of the Selected Sandy Beach Organisms of Timbalier Bay, Louisiana, Gulf University Research Consortium, Galveston, Texas, 1974.

Fisher, W. L., J. H. McGowen, L. F. Brown and C. G. Groat, Environmental Geologic Atlas of the Texas Coastal Zone - Galveston-Houston Area, Bureau of Economic Geology, University of Texas, Austin, Texas, 1972 .

Fisher, W L., L. F. Brown, J. H. McGowen and C. G. Groat, Environmental Geologic Atlas of the Texas Coastal zone - Beaumont-Port Arthur Area, Bureau of Economic Geology, University of Texas, Austin, Texas, 1973. 
Frazier, D. E., "Recent Deltaic Deposits of the Mississippi River: Their Development and Chronology," Transaction, Gulf Coast Association of Geological Societies, vol. 17, p. 287-315, 1967.

Gabrysch, R. K. and C. W. Bonnet, Land-Surface Subsidence in the Houston-Galveston Region, Texas, Texas Water Development Board Report 188, 19 p., 1975.

Gahagan, D. I., Dickinson, Gillock and South Gillock Fields, Galveston County, Texas, Guidebook, AAPG-SEPM-SEG, Joint Annual Meeting, Houston, p. 110-113, March 1953.

Gaidry, Wilson J., III, and Charles J. White, Investigations of Commercially Important Penaeid Shrimp in Louisiana Estuaries, Louisiana Wildlife and Fisheries Commission, Technical Bulletin No. 8, 1973.

Gambrell, R. P., R. A. Khalid, M. G. Verloo and W. H. Patrick, Transformations of Heavy Metals and Plant Nutrients in Dredged Sediments as Affected by Oxidattion-Reduction Potential and pH. Volume II: Materials and Methods/Results and Discussion, Contract Report D-77-4, U.S. Army Engineer Waterways Experiment Station, Vicksburg, Mississippi, 1977a. 
R-18

Gambrell, R. P, V. R. Collard, C. N Reddy and W. H. Patrick, Jr., Trace and Toxic Metal Uptake by Marsh Plants as Affected by Oxidation-Reduction Conditions, $p H$, and Salinity, Preliminary report submitted to Dredged Material Research Program, Waterways Experiment Station, U. S. Army Corps of Engineers (Contract No. DACW-39-73-C-0108), $1977 \mathrm{~b}$.

Gambrell, R. P., R. A. Khalid, and W. H. Patrick, Jr., "Physicochemical Parameters that Regulate Mobilization and Immobilization of Toxic Heavy Metals," in P. A. Krenkel, J. Harrison, and J. C. Burdick III (Eds.) Proceedings of the Specialty Conference on Dredging and Its Environmental Effects, American Society of Civil Engineers, New York, p. 418-434, 1976.

General Land Office of Texas, Present Authority, Texas Coastal Management Program, Austin, Texas, September 1974.

General Land Office of Texas, Texas Coastal Management Program, Current Permitting Processes in State and Federal Natural Resource Agencies, vols. I and II, Austin, Texas, June 1976.

Geraghty, J. J., D. W. Miller, F. Van Der Leeden, F. L. Troise, Water Atlas of the United States, Water Information Center, Port Washington, New York, 1973.

Godcharles, M. F., A Study of the Effects of a Commercial Hydraulic Clam Dredge on Benthic Communities in Estuarine Areas, Department of Natural Resources, State of Florida, St. Petersburg, Florida, 51 p., 1971. 
Goldberg, E. C., "Minor Elements in Sea Water," in J. P. Riley and G. E. Skinow (Eds.), Chemical Oceanography, vol. I, Academic Press, New York, 1965.

Gosselink, J. G. and R. Beck, Ecological Characterization of the Chenier Plain of Southwestern Louisiana and Southeaster Texas, Pilot Study Report: The Calcasieu Drainage Basin, Contract No. 14-16-008-2052, U.S. Department of the Interior, U.S. Fish and Wildlife Service, 1976.

Gosselink, J. G., An ECological Characterization of the Chenier Plain, Center for Wetland Resources, Louisiana State University, Baton Rouge, Louisiana, 1977.

Gould, H. R. and J. P. Morgan, "Coastal Louisiana Swamps and Marshlands," in Geology of the Gulf Coast and Central Texas and Guidebook of Excursions, edited by E. H. Rainwater and R. P. Zingula, Houston Geological Society, 1962 Annual Meeting of the Geological Society of America, p. 287-341, 1962.

Grigg, R. P., Jr., "Key to the Nodosaria Embayment of South Louisiana," Transaction, GuIf Coast Association of Geological Societies, vol. 6, p. 55-62, 1956 . 
Gulf Coast Association of Economic Geology, Tectonic Map of Gulf Coast Region, U.S.A., in cooperation with American Association of Petroleum Geologists, 1971.

Gunter, Gordon, Some Relationships of Esturaries to the Fisheries of the Gulf of Mexico, Gulf Coast Research Laboratory, Ocean Springs, Mississippi, 1967.

Gustavson, T. C. and C. W. Kreitler, "Environmental Concerns Arising from the Production and Disposal of Geothermal Waters," Geological Circular 76-7, Bureau of Economic Geology, University of Texas, Austin, Texas, 35 p., 1976.

Guthery, F. S., "Whoopers in Idaho," National Parks and Conservation Magazine, vol. 50(10), p. 18-21, 1976.

Halbouty, M. T., Salt Domes, Gulf Region, United States and Mexico, Gulf Publishing Co., Houston, Texas, 425 p., 1967.

Hammond, W. W., Jr., Ground-Water Resources of Matagorda County, Texas, Texas Water Development Board Report 91, 1969.

Harder, A. H., The Geology and Ground-Water Resources of Calcasieu Parish, Louisiana, U.S. Geological Survey Water-Supply Paper 1488, 102 p., 1960. 
Harder, A. H., Chabot Kilburn, H. M. Whitman and S. M. Rogers, Effects of Ground-Water Withdrawals on Water levels and SaltWater Encxoachment in Southwestern Louisiana, Louisiana Department of Conservation, Geological Survey, and Department of Public Works, Water Resources Bulletin No. 10, 56 p., 1967.

Hardin, G. C., "Notes on Cenozoic Sedimentation in the Gulf Coast Geosyncline, U.S.A.," in Geology of the Gulf Coast and Central Texas and Guidebook of Excursions, edited by E. H. Rainwater and R. P. Zingula, Houston Geological Society, 1962 Annual Meeting of the Geological Society of America, 1962.

Hebrard, J. J., Distributions by Habitat of Amphibians, Reptiles, Birds and Mammals of the Chenier Plain Region of Texas and Louisiana, unpublished data.

Herrin, E. and T. Goforth, "Environmental Problems Associated with Power Production from Geopressured Reservoirs," in Proceedings of the First Geopressured Geothermal Energy Conference, edited by M. H. Dorfman and R. W. Deller, The Center for Energy Studies, University of Texas, Austin, Texas, p. 311-318, 1975.

Herrin, Eugene, Tom Goforth and David Pheasant, Development of Geothermal Reservoirs from Overpressured Areas Beneath the Gulf Coastal Plain of Texas: Final Technical Report to the Air Force Office of Scientific Research, Contract No. 72-2395, 1973. 
Ho, Clara L. and Barney Barrett, Distribution of Nutrients in. Louisiana's Coastal Waters Influenced by the Mississippi River, Louisiana Wildlife and Fisheries Commission Technical Bulletin No. 17,1975 .

Holcomb, C. W., "Frio Formation of Southern Texas," Transaction, Gulf Coast Association of Geological Societies, vol. 14, p. 23-33, 1964.

Honegger, R. E., Red Data Book III: Amphibia and Reptilia, International Union for the Conservation of Nature and Natural Resources, Marges, Switzerland, 1970.

Hosler, C. R., "Low-Level Inversion Frequency in the Contiguous United States," Monthly Weather Review, vol. 89, p. 319-339, 1961.

Houston Lighting and Power Co., Environmental Report, vol. 1, for Allen Creek Nuclear Generating Station, Units $I$ and 2, 1974.

Hsu, S. A., Mesoscale Structure of the Texas Coastal Sea Breeze, Report No. 16, Atmospheric Science Group, College of Engineering, University of Texas, Austin, Texas, 237 p., 1969.

Hsu, S. A., "Coastal Air Circulation System: Observation and Empirical Model," Monthly Weather Review, vol. 98, p. 487-509, 1970. 
Hsu, S. A., Atmospheric Dispersion Characteristics in the Louisiana Coastal zone, Coastal Studies Institute Technical Report No. 229, Louisiana State University, Baton Rouge, Louisiana, 1977.

Jeffries, H. P., Diets of Juvenile Atlantic Menhaden in Three Estuarine Habitats as Determined from Fatty Acid Composition of Gut Contents, University of Rhode Island Marine Reprint No. 40, 1975.

Joanen, Ted and Larry McNease, "Population Distribution of Alligators with Special Reference to the Louisiana Coastal Marsh Zones," Symposium of the American Alligator Council, 12 p., 1972.

Joanen, Ted, Population Status and Distribution of Alligators in the Southeastern United States, Southeastern Regional Endangered Species Workshop, 1974.

Johnsgard, P. A., Grouse and Quails of North America, University of Nebraska Press, Lincoln, Nebraska, 1973.

Jones, P. H., "Geochemical Hydrodynamics-A Possible Key to the Hydrology of Certain Aquifer Systems in the Northern Part of the Gulf of Mexico Basin," XXIII International Geological Congress, Proceedings of Symposium II, vo1. 17, p. 113-125, 1968a. 
Jones, P. H., "Hydrodynamics of Geopressure in the Northern Gulf of Mexico Basin," Society of Petroleum Engineers, American Institute of Mechanical Engineers, SPE 2207, also Journal of Petroleum Technology, vol. 21, No. 7, p. 803-810, 1968b.

Jones, P. H., "Hydrodynamics of Geopressure in the Northern Gulf of Mexico Basin," Journal of Petroleum Geology, vol. 21, p. 803-810, 1969a.

Jones, P. H., Hydrology of Neogene Deposits in the Northern Gulf of Mexico Basin, Bulletin GT-2, Louisiana Water Resources Research Institute, Louisiana State University, Louisiana, 105 p., 1969b.

Jones, P. H., "Geothermal Resources of the Northern Gulf of Mexico Basin, Geothermics (Special Issue 2), vol. 2(1), p. 14-26, 1970a.

Jones, P. H., "Hydrology of Quaternary Delta Deposits of the Mississippi River,"International Association of Science Hydrology, Symposium of Bucharest, Publication No. 90, p. 49-63, $1970 \mathrm{~b}$.

Jones, P. H., "Geothermal and Hydrodynamic Regimes in the Northern Gulf of Mexico Basin," in Proceedings of the Second U.N. Symposium on the Development and Use of Geothermal Resources, San Francisco, California, 3 vols., May 1975. 
Jones, Paul H., A. N. Turcan, Jr., Herbert E. Skibitzke, "Geology and Ground-Water Resources of Southwestern Louisiana," Louisiana Department of Conservation, Geological Bulletin No. 30, 285 p., 1954.

Jones, P. H. and R. H. Wallace, "Hydrogeologic Aspects of Structural Deformation in the Northern Gulf of Mexico Basin," in Structure of the Gulf Basin, Part I, New Orleans Geological Society, p. $89-115,1973$.

Jordan, Terry G., Annals Map, Supplement Number Thirteen: Population Origin Groups in Rural Texas, Annals of the Association of American Geographers, vol. 60, p. 404-405, 1970.

Jorgensen, D. G., Analog-Model Studies of Ground-Water Hydrology in the Houston District, Texas; Texas Water Development Board Report NO. 190,84 p., 1975.

Jugsujinda, Aroon, Growth and Nutrient Uptake by Rice Under Controlled Oxidation-Reduction and $\mathrm{pH}$ Conditions in a Flooded Soil, $\mathrm{Ph} . \mathrm{D}$. Dissertation, Louisiana State University, Baton Rouge, 1975.

Juhl, Rolf, Oceanic Resource Surveys and Assessment Task, Status Report, National Marine Fisheries Service, Southeast Fisheries Center, Pascagoula, Mississippi, October 1976.

Jurries, R. and J. Dodd, "The Attwater Can Be Helped," Texas Parks and Wildlife, vol. 31(5), p. 12-14, 1973. 
Kazmann, R. G., Modern Hydrology, Second Edition, Harper and Row Publishers, New York, 1972.

.

Kazmann, R. G. and M. M. Heath, "Land Subsiderice Related to GroundWater offtake in the New Orleans Area," Transactions, Gulf Coast Association of Geological Societies, vol. XVIII, p. 108-113, 1968.

Kendrick, P. J., "Deep Well Injection-Sweeping the Problem Under the Carpet?" in Journal Water Pollution Control Federation, vol. 49, p. 187-189, February 1977 .

Ketchum, B. H., Statement Before the Subcommittee on Oceans and Atmosphere of the Committee on Commerce, U.S. Senate, 93rd Congress, Ist Session, Hearing on S-1067 held June 12-14, 1973.

Kilburn, Chabot and Harry M. Whitman, Water-Levels in Southwestern Louisiana, April 1960 to April 1961, With a Discussion of WaterLevel Trends from 1950 to 1960, Louisiana Department of Conservation, Geological Survey, and Department of Public Works, Water Resources Pamphlet No. 11, 21 p., 1962.

King, K. A., E. L. Flickinger and H. H. Hildebrand, "The Decline of Brown Pelicans on the Louisiana and Texas Gulf Coast," The Southwestern Naturalist, vol. 21(4), p. 417-431, 1977. 
Kleeman, W. T., Kingsley E. Haynes and Thomas F. Freeland, "Technical Assessment of the Impact of Geopressure Development in the Corpus Christi Area of Texas," in Proceedings, Second U.N. Symposium on the Development and Use of Geothermal Resources, San Francisco, California, 3 vols., p. 2389-2403, May 20-29, 1975.

Knowlton, F., Scent Posts of Canis rotos, Bureau of Sport Fisheries and Wildlife, San Antonio, Texas, 13 p., 1971.

Kolb, C. R. and J. R. van Lopik, Geology of the Mississippi Deltaic Plain, Southeastern Louisiana, U.S. Army Corps of Engineers, Waterways Experiment Station Technical Report 3-482, 2 vols., Vicksburg, Mississippi, 1958.

Koons, C. B., C. D. McAuliffe and F. T. Weiss, "Environmental Aspects of Produced Waters from Oil and Gas Extraction Operations in Offshore and Coastal Waters," Journal of Petroleum Technology, vol. 29 , p. $723-729,1977$.

Krebs, C. T. and K. A. Burns, "Long-Term Effects of an $0 i 1$ Spill on Populations of the Salt-Marsh Crab Uca pugnax," Science, vol. 197, p. 484-488, July 29, 1977.

Kreitler, C. W., "Fault Control of Subsidence, Houston, Texas, Ground Water, vol. 15, No. 3, p. 203-214, May-June 1977. 
Kritzler, H. Oil Production and Polychaetous Annelids in a Louisiana Estuary, Gulf University Research Consortium, Galveston, Texas, 1974.

Kutkuhn, Joseph H., The Role of Estuaries in the Development and Perpetuation of Commercial Shrimp Resources, Fisheries Society Special Publication No. 3, p. 16-36.

Landes, K. K., Petroleum Geology of the United States, Wiley-Interscience, New York, 1970.

Larrick, Walter D., Jr, and Robert H. Chabreck, "Effects of Weirs on Aquatic Vegetation Along the Louisiana Coast, "Southeastern Association of Game and Fish Commissioners, Thirtieth Annual Conference, 1976.

Lehmann, V. W. and R. G. Mavermann, "Status of Attwater's Prairie Chicken," Journal of Wildlife Management, vol. 27, p. 713-725, 1963.

Lieth, H., "The Role of Vegetation in the Carbon Dioxide Content of the Atmosphere," Journal of Geophysical Research, vol. 68(13), p. 3887-3898, 1963 . 
Lindsey, R. K. and J. B. Franyim, Water Resources Engineering, Second Edition, McGraw-Hill Book Company, New York, 1972.

Little, Elbert L., Atlas of United States Trees, Vol. 1, "Conifers and Important Hardwoods," U.S. Department of Agriculture Forest Service Miscellaneous Publication No. 1146, 1971.

Lofgren, B. E. Analysis of Stresses Causing Land Subsidence, U.S. Geological Survey Professional Paper 600-B, B219-B225, 1968.

Lofgren, Ben E., Background Studies for Appraising Subsidence in the Texas GuIf Coast Region, U.S. Geological Survey Open-File Report 77-412, Sacramento, California, 1977.

Long, Richard A., "Ground Water in the Geismar-Gonzales Area, Ascension Parish, Louisiana," Department of Conservation, Geological Survey, and Department of Public Works, Water Resources Bulletin, No. 7, 1965.

Louisiana Advisory Commission on Coastal and Marine Resources, "Louisiana Wetlands Prospectus, 1973.

Louisiana Air Control Commission, Air Control Regulations, New Orleans, Louisiana, August 1, 1974. 
Louisiana Archaeological Council, Draft Standards for Cultural Resource Surveys, Louisiana Archaeological Survey and Antiquities Commission, Baton Rouge, Louisiana, 1977.

Louisiana Cooperative Wildlife Unit, Final Report 1977: Colonial Sea and Wading Bird Survey, U.S. Fish and Wildlife Service Contract No. 14-16-0008-1187, 1977.

Louisiana Department of Commerce and Industry, Louisiana Air and Water Pollution Control Regulations, Baton Rouge, Louisiana, n.d.

Louisiana Department of Conservation, "Statewide Rules, State of Louisiana, Order No. 29B, Adopting Rules for Drilling, Production and Operation of $0 i 1$ and Gas Wells in the State of Louisiana, Effective August 1, 1943, as Amended by Order (No number), Effective February 13, 1951, Order No. 29-B-6, Effective January 1, 1954, Orders (no numbers), Effective March 1, 1955, August 1, 1958, July 21, 1959, Supplemented to Order No. 29-B, Effective January 1, 1963, Orders (No numbers), Effective December 1, 1963, and March 1, 1967, and Ammendments to Order No. 29-B, Effective January 1, 1973, May 1, 1973, and March 1, 1974. Order No. 29-B Supersedes Order No. A-1, Effective August 25, 1939, as Amended by Order No. A-2, Effective September 8, 1939, and Order No. 29-A, effective May 20, 1942," Baton Rouge, Louisiana, April 1974. 
Louisiana Department of Conservation, Title 30. Louisiana Revised Statutes of 1950, Baton Rouge, Louisiana, 1950.

Louisiana Department of Conservation, Underground Salt water and waste Disposal in Louisiana, State Regulations and Geological Concepts, Baton Rouge, Louisiana, June 1974.

Louisiana Department of Conservation, Summary of Field Statistics and Drilling Operations, Louisiana, 1975.

Louisiana Geological Survey, Interstate Gas Map of Louisiana, published by Department of Conservation, Baton Rouge, Louisiana, March 1974.

Louisiana Office of State Planning, unpublished Land Use Maps for Louisiana, 1972 .

Louisiana Office of State Planning, Environmental Assessment: Elements of a Growth Conservation Policy, Baton Rouge, Louisiana, June 1974.

Louisiana Office of State Planning, Louisiana Coastal Resource Inventory, Volume 1, Geographic Areas of Particular Concern, Baton Rouge, Louisiana, June 1975.

Louisiana Office of State Planning, Louisiana 1977, State of the State, Baton Rouge, Louisiana, 1977. 
Louisiana Power and Light Co., Preliminary Safety Analysis Report Waterford Steam Electric Station Units No. 3 and 4, vol. 1, 1974.

Louisiana State Parks and Recreation Commission, Louisiana State Parks Plan, 1975-1990, Baton Rouge, Louisiana, n.d.

Louisiana State Parks and Recreation Comission, "Outdoor Recreation in Louisiana 1975-1980," Louisiana State Comprehensive Recreation Plan, Baton Rouge, Louisiana 1974.

Louisiana Stream Control Commission, State of Louisiana Water Quality Criteria, The Commission, Baton Rouge, Louisiana, 1973.

Louisiana Wildlife and Fisheries Commission, Comparative Takes of Fur Animals in Louisiana, 1 page mimeographed supplement to Fur Division Records, 1940-1977, New Orleans, Louisiana, 1977.

Louisiana Wildlife and Fisheries Commission, Compilation of Louisiana Laws Pertaining to Wildlife and Fisheries, Louisiana Revised Statutes of 1950 Containing the Acts through the 1975 session of the Legislature, New Orleans, Louisiana, 1975.

Louisiana Wildlife and Fisheries Commission, Louisiana's Natural and Scenic Streams System, The Commission, New Orleans, Louisiana, 1976. 
Louisiana Wildlife and Fisheries Commission, Hunting, Fishing and Trapping Regulations, 1976-77, New Orleans, Louisiana, 1976.

Lower Mississippi Region Comprehensive Study Coordinating Committee, Appendix C, Volume I: Regional Climatology, Hydrology and Geology, Lower Mississippi Region Comprehensive Study, U.S. Army Corps of Engineers, New Orleans, Louisiana, 1974.

Lowery, George H., Jr., Louisiana Birds, Third Edition, Louisiana State University Press, Baton Rouge, Louisiana, $1974 a$.

Lowery, George H., Jr. The Mammals of Louisiana and Its Adjacent Waters, Louisiana State University Press, Baton Rouge, Louisiana, $1974 b$.

Lytle, S. A. and M. B. Sturgis, General Soil Areas and Associated Soil Series Groups of Louisiana, Agricultural Experiment Station, Louisiana State University, Baton Rouge, Louisiana, May 1962.

Mackin, J. G., A Study of the Effect of Oil Field Brine Effluents on Biotic Communities in Texas Estuaries, Texas A \& M Research Foundation, Project 735, College Station, Texas, 1971.

Marum, J. P., Effects of Long-Term Drilling and Production on the Zooplankton of Louisiana Coastal Waters, Gulf University Research Consortium, Galveston, Texas, 1974. 
Maslan, Frank, Theodore J. Gordon and Lillian Deitch, "Economic and Social Aspects of Geothermal Energy Resource Development," in Proceedings, Second U.N. Symposium on the Development and Use of Geothermal Resources, San Francisco, California, 3 vols., p. 23252331,1975 .

Mayer, J. F. and C. L. Ho, Trace Metals in Sèlected Aquatic Environments of Louisiana Coastal Zone, Coastal Studies Institute, Louisiana State University, Baton Rouge, Louisiana, 1977.

McGowen, J. H., C. V. Proctor, L. F. Brown, T. J. Evans, W. L. Fisher and G. G. Groat, Environmental Geologic Atlas of the Texas Coastal Zone-Port Lavaca Area, Bureau of Economic Geology, University of Texas, Austin, Texas, 1976(a).

McGowen, J. H., L. F. Brown, T. J. Evans, W. L. Fisher and C. G. Groat, Environmental Geologic Atlas of the Texas Coastal zone-Bay CityFreeport Area, Bureau of Economic Geology, University of Texas, Austin, Texas, 1976(b).

McGowen, J.C., C. G. Groat, L. F. Brown, W. L. Fisher and A. J. Scott, Effects of Hurricane "Celia"-A Focus on Environmental Geology Problems of the Texas Coastal zone, Geological Circular 70-3, Bureau of Economic Geology, University of Texas, Austin, Texas, 1970 . 
McGuiness, C. I., The Role of Ground water in the National water Situation, U.S. Geological Survey Water-Supply Paper 1800, 1973.

McKay, Roy, Personal Communication, Atlantic Richfield Oil Company, 1976.

Miller, R. S., D. B. Botkin, and R. Mendelssohn, "The Whooping Crane (Grus americana) Population of North America," Biological Conservation, vol. 6(2), p. 106-111, 1974.

Missouri Botanical Garden, Amsonia glaberrima Woodson, Bulletin Torry Botany Club, vol. 63, 1936.

Montz, G. N., The Submerged Vegetation of Lake Pontchartrain, Louisiana, U.S. Army Corps of Engineers, New Orleans, Louisiana, 1975.

Montz, G. N., A Vegetative Study of the Timbalier and Isles Dernieres Barrier Islands, U.S. Army Corps of Engineers, New Orleans, Louisiana, 1976(a).

Montz, G. N., Vegetational Studies Conducted in Atchafalaya Bay, Louisiana, U. S. Army Corps of Engineers, New Orleans, Louisiana, $1976(\mathrm{~b})$. 
Montz, G. N., A Vegetational: Study Conducted Along Southwest Pass in the Mississippi River Delta, Louisiana, U. S. Army Corps of Engineers, New Orleans, Louisiana, $1977(a)$.

Montz, G. N., A Vegetative Study of the White Lake and Vermilion Bay, Louisiana Area, U.S. Army Corps of Engineers, New Orleans, Louisiana, $1977(b)$.

Mora, Pete, Personal Communication office of Indian Affairs, Baton Rouge, Louisiana, 1977.

Muller, R. A., "Freshwater Potential in the Louisiana Coastal Marshes and Estuaries," Geoscience and Man, vol. XII, p. 1-7, School of Geoscience, Louisiana State University, Baton Rouge, Louisiana, 1975.

Murray, G. E., Geology of Atlantic and Gulf Coastal Province of North America, Harper and Brothers, New York, 1961.

Myers, B. N. and 0. C. Dale, Ground-Water Resources of Bee County Texas, Texas Water Development Board Report 17, 1966.

National Marine Fisheries Service, Fishery Statistics of the United States 1970-1973, Statistical Digest Nos. 64, 65, 66 and 67, 1974. 
National Marine Fisheries Service, Gulf Coast Shrimp Data, Annual Summaries 1965-1975, 1976.

Natural Resources Defense Council, Inc., Who's Minding the Shore? A Citizen's Guide to Coastal Management, prepared for the U.S. Department of Commerce, Nationa1 Oceanic and Atmospheric Administration, Office of Coastal Zone Management, August 1976.

Neill, W. T., "The Occurrence of Amphibians and Reptiles in Salt-water Areas, and a Bibliography," Bulletin on Marine Science, Gulf and Caribbean, vol. 8(1), p. 1-97, 1958.

Nesmith, Sam, Personal Communication San Antonio Institute of Texan Cultures, July 8, 1977.

News Release, New Red Wolf Pair to Arrive at Cape Romain National Wildlife Refuge, South Carolina, U.S. Fish and Wildife Service, 17 Executive Park Dr., N.E., Atlanta, Georgia 30329, June 30, 1977.

News Release, Substitute Pair of Red Wolves Shipped to Cape Romain National Wildlife Refuge, South Carolina, U.S. Fish and Wildlife Service, 17 Executive Park Dr., N.E., Atlanta, Georgia 30329, July 1,1977 .

Newton, M. B., Atlas of Louisiana, A Guide for Students, School of Geoscience, Louisiana State University Miscellaneous Publication $72-1,1972$. 
Nichols, James D. Lynn Viehman, Robert H. Chabreck and Bruce Penderson, Simulation of a Commercially Harvested Alligator

- Population in Louisiana, Louisiana State University Agricultural Experimental Station, Bulletin No. 691, 1976.

Nowak, R. M., "Red Wolf: Our Most Endangered Mammal. "The Rare Red Wolf is Endangered by Hybridization with Coyotes," National Parks Conservation Magazine, vol. $48(8)$, p. 9-12, 1974.

O'Ne1l, Ted, The Muskrat in the Louisiana Coastal Marshes, State of Louisiana, Department of Wildlife and Fisheries, 1949.

O'Neil, Ted and Greg Linscombe, The Fur Animals, The Alligator, and The Fur Industry in Louisiana, Louisiana Wildlife and Fisheries Commission, Wildlife Education Bulletin No. 106, 1975 (revised 1977).

Oberholser, H. C., The Bird Life of Texas, The University of Texas Press, Austin and London, 2 vols., 1974.

Odum, E. P., Fundamentals of Ecology, W. B. Saunders Co., Philadelphia, Pennsylvania, 1971.

Odum, H. T. and C. M. Hoskins, Comparative Studies on the Metabolism of Marine Waters, Institute of Marine Science, University of Texas, Austin, vol. 5, p. 16-46, 1958. 
Office of Air and Water Programs, The National Air Monitoring Program: Air Quality and Emission Trends Annual Report, Vol. II, EPA-450/173-001-b, Research Triangle Park, North Carolina, 1973.

Office of Management and Budget, Office of Management and Budget Circular No. A-95. What It Is. How It Works. A Handbook. July $1,1976$.

Office of Water Planning and Standards, National Water Quality Inventory-1974, Report to the Congress, Environmental Protection Agency, Washington, D. C., 1974 .

0lson, J. S., "Productivity of Forest Ecosystems," in Productivity of World Ecosystems, National Academy of Sciences, Washington, D.C., 1975.

Orton, R. B., The Climate of Texas and the Adjacent Gulf Waters, Weather Bureau, Department of Commerce, Washington, D. C., 1964 .

Palermo, Raymond J. and Gary L. Doster, "A Comparison of the Late Winter Foods and Parasites of Bobwhite Quail and Black Francolin in Southwestern Louisiana," Proceedings of the 24th Annual Conference of the Southeast Association of Game and Fish Commissioners, p. 206-212, 1970 . 
Palmisano, A. W., Commercial Wildlife work Unit Report to Fish and Wildlife Study of the Louisiana Coast at the Atchafalaya Basin, Volume I, Louisiana Wildlife and Fisheries Commission, New Orleans, Louisiana, 1971a.

Palmisano, A. W., Ibises in Louisiana; Louisiana Wildlife and Fisheries Commission, Wildlife Technical Report No. 71-1, 1971b.

Palmisano, A. W., "Habitat Preference of Waterfowl and Fur Animals in the Northern Gulf Coast Marshes," Proceedings of the Coastal Marsh and Estuary Management Symposium, Louisiana State University, p. $163-190,1972(a)$.

Palmisano, A. W., "The Distribution and Abundance of Muskrats (Ondatra zibethicus) in Relation to Vegetative Types in Louisiana Coastal Marshes," Proceedings of the 26 th Conference of the Southeast Association of Game and Fish Commissioners, 1972 (b)

Petella, Frank, "Water Surface Area within Statistical Subareas Used in Reporting Gulf Coast Shrimp Data," Marine Fisheries Review, Vo1. 37, No. 12, Marine Fisheries Service, December 1975.

Papadopulas, S.S., et al, Assessment of onshore Geopressured Geothermal Resources in the Northern Gulf of Mexico Basin, U.S. Geological Survey, USGS Circular 726, 1975. 
Penfound, W. T. and E. S. Hathaway, "Plant Communities in the Marshlands of Southeastern Louisiana," Ecology Monogram, vol. 8, p. 1-56, 1938. •

Penfound, W. T., "Plant Distribution in Relation to the Geology of Louisiana," Proceedings of the Louisiana Academy of Sciences, vol. 8, p. 25-34, December 1944.

Penfound, W. T., "Southern Swamps and Marshes," The Botanical Review, vol. 18, No. 6, p. 413-466, 1952.

Perret, W. S., Cooperative Gulf of Mexico Estuarine Inventory and Study, Louisiana, Phase IV, Biology, Louisiana Wildlife and Fisheries Commission, 1971.

Peterson, Roger Troy, A Field Guide to the Birds of Texas and Adjacent States, Houghton Mifflin Company, Boston, 1960.

Petitt, B. M., Jr. and A. G. Winslow, Geology and Ground-Water Resources of Galveston County, Texas, U.S. Geological Survey Water Supp1y Paper 1416, 1957.

Poland, J. F. and G. H. Davis, "Land Subsidence Due to Withdrawal of Fluids," in D. J. Varnes and G. Kiersch (Eds.) Reviews in Engineering Geology II, Geological Society of America, Boulder, Colorado, p. 187-269, 1969. 
Qasim, S. Z. and P.M.A. Bhattalhiri, "Primary Production of a Seagrass Bed on Kavaratti Atoll (Laccadivis)," Hydrobiologia, vol. 38(1), p. 29-38, 1971 .

Rare Plant Study Center (R.P.S.C.), Rare and Endangered Plants Native. to Texas, University of Texas, Austin, Texas, 1974.

Reddy, C. N. and W. H. Patrick, Jr., Effect of Redox Potential and pH on the Uptake of $C d$ and $P b$ by Rice Plants, 1977 (in press).

Reichle, D. E., B. E. Dinger, N. T. Edwards, W. F. Harris and P. Sollins, "Carbon Flow and Storage in a Forest Ecosystem," in G. M. Woodwell and E. V. Pecan (Eds.) Carbon in the Biosphere, Proceedings of Symposium, Brookhaven National Laboratory, Upton, New York, U.S. Atomic Energy Commission CONF-720510, p. 345-365, May 1972.

Reid, G. W., L. E. Streebin, L. W. Canter, J. R. Smith, Brine Disposal Treatment Practices Relating to the oil Production Industry, Office of Research and Development, U.S. Environmental Protection Agency Contract No. 14-12-873, Project 14020 FVW, Prog. Element 1BB040, EPA 600/2-74-037, 1974 .

Riley, G. A. and R. T. McBride, A Survey of the Red wolf (Canis rufus), U.S. Fish and Wildlife Service Special Science Report-Wildlife No. $162,1972$. 
Rodin, L. E., N. I. Bazilevich and N. N. Rozov, "Productivity of the World's Main Ecosystems," in Productivity of World Ecosystems, National Academy of Sciences, Washington, D. C., p 13-26, 1975.

Rogers, K. E. and A. W. Oberbeck, The Geopressured Geothermal Resources of Texas. Regulatory Controls over water Pollution, "The Center for Energy Studies, University of Texas, Austin, Texas, July 1, 1977.

Rogillio, Howard E., An Estuarine Sportfish Study in Southeastern Louisiana, Louisiana Wildlife and Fisheries Commission Fisheries Bulletin No. 14, 1975.

Russe11, Dennis N, and James H. Shaw, "Distribution and Relative Density of the Red Wolf in Texas," Proceedings of the 25th Annual Conference of the Southeast Association of Game and Fish Commissioners, p. 131-137, 1971a.

Russe11, D. N. and J. H. Shaw, Notes on the Red Wolf (Canis tufus) in the Coastal Marshes and Prairies of Eastern Texas, presented at the Texas Academy of Sciences, Nacoydoches, Texas, March 12, $1971 b$.

Sabade11, J. E. and R. C. Axtmann, "Heavy Metal Contamination from Geothermal Sources," Environmental Health Perspectives, vol. 12, p. $1-7,1975$. 
Saifullah, S. M., "Effect of Lead on Dinophyceae," Proceedings of the International Symposium on Marine Pollution Research, January 1976, Gulf Breeze, Florida, U.S. Environmental Protection Agency, P. 120$132,1976$.

Sandeen, W. M. and J. B. Wesselman, Ground-Water Resources of Brazoria County, Texas, Texas Water Development Board Report 163, 1976.

Sanders, 0., "A New Species of Toad, with a Discussion of Morphology of the Bufonid Skull," Herpetologica, vol. 9, p. 25-47, 1953.

Schafer, G. H., Ground-Water Resources of Aransas County, Texas, Texas Water Development Board Report No. 124, 1970.

Schafer, G. H., Ground-Water Resources of Neuches and San Patricio Counties, Texas, Texas Water Development Board Report No. 173, 1968.

Shafer, G. H. and E. T. Baker, Jr., Ground-Water Resources of Kleberg, Kenedy, and Southern Jim Wells Counties, Texas, Texas Water Development Board Report No. 173, 1973.

Schieler, L. Geothermal Effluents, Their Toxicity and Prioritization, in Proceedings of the First Workshop on Sampling Geothermal Effluents, October 20-2I, Las Vegas, p. 36-66, EPA-600/9-76-011, 1976. 


$$
\mathrm{R}-45
$$

Schmidt, G. W., "Interstitial Water Composition and Geochemistry of Deep Gulf Coast Shales and Sandstones," American Association of Petroleum Geologists Bulletin, vol. 57, No. 2, p. 321-337, 1973.

Schneider, J., "Nierdere Pilze als Testorganismen fur Schadstoffe im Meerund Brackwasser. Die Wirkung von Schoermetallverbindungen und Phenol auf Thraustockytrium striatum," Marine Biology, vol. 16, p. 214-225, 1972 .

Schulz-Baldes, M., "Toxizitat und Anreicherung von Blei beider Mies Muschel Mytilus edulis im Laborexperiment," Marine Biology, vol. 16 , p. 226-229, 1972 .

Schulz-Baldes, M. "Die Musmuschel Mytilus edulis als Indicator fur die Bleikonzentration im Weserastuar und in der Deutschen Bucht," Marine Biology, vol. 21, p. 98-102, 1973.

Seglund, J. A., "Collapse Fault Systems of Louisiana Gulf Coast," American Association of Petroleum Geologists Bulletin, vol. 58, p. $2389-2397,1974$.

Shaw, D. R., "The Toxicity of Drilling Fluids, Their Testing and Disposal," Proceedings, Conference on Environmental Aspects of Chemical Use in Welldrilling Operations, Environmental Protection Agency Office of Toxic Substances, Washington, D.C. 1975. 
Shinners, I. H., Scutellaria thieretii (Labiatae), A New species from Coastal Louisiana, SIDA 1 (4): 251-252.

Simmons, G., "Brown Pelicans on the Brink," National Parks Conservation Magazine, vo1. 48(12), p. 21-23, 1974.

Simpson, R. H. and M. B. Lawrence, Atlantic Hurricane Frequencies Along the U.S. Coastline, National Oceanographic and Atmospheric Administration Technical Memo NWS SR-58, Southern Region, Fort Worth, Texas, 1971 .

Singleton, J. R., Texas Coastal Waterfowl Survey, FA Report Series No. 11, Texas Game and Fish Commission, 1953.

Slade, D. H. (Ed.), Meteorology and Atomic Energy, U.S. Atomic Energy Commission, 1968.

Smith, H. M., Handbook of Lizards, Comstock, Ithaca, New York, 1946.

Stegeman, J. J. and J. M. Teal, "Accumulation, Release and Retention of Petroleum Hydrocarbons by the Oyster Crassostrea virginica," Marine Biology, p. 37-44, 1973. 
Straughan, D., "The Sublethal Effects of Natural Chronic Exposure to Petroleum on Marine Invertebrates," Proceedings, Conference on Prevention and Control of Oil Spills, American Petroleum Institute, New Orleans, Louisiana, 1977, 563-568.

Taylor, R. E., Chemical Analyses of Ground Water for Saline Water Resources Studies in Texas Coastal Plain Stored in National Water Data Storage and Retrieval System, U.S. Geological Survey Report 75-79, vols. I and II, 1975.

Texas Agricultural Extension Service, Texas Plants - A Checklist and Ecological Summary, MP-585, 1975.

Texas Antiquities Committee, General Rules of Practice and Procedure, Texas Antiquities Committee, Austin, Texas, n.d.

Texas Coastal Management Program, Report to the Governor and the 65th Legislature, Appendices, General Land Office of Texas, 1976.

Texas Governor's Energy Advisory Council, The Impact of State and Federal Law on Development of Geothermal Resources in Texas, 1974.

Texas Highway Department, "The Houston Toad Bufo hustonensis Sanders," Environmental Brief No. 74-12-02, 1974 . 
Texas Water Development Board, A Water Inventory of the Texas Coastal zone, The Board, Austin Texas, 1970.

Texas Water Development Board, "Inventories of Irrigation in Texas: 1958, 1964, 1969 and 1974," Texas Water Development Board Report 196, The Board, Austin, Texas, 1975.

Texas Water Quality Board, A Ready-Reference on Major Texas Water Pollution Control Legislation. The Texas Water Quality Act. The County Solid Waste Control Act. The Solid Waste Disposal Act. The Disposal Well Act. A Discussion of state Participation in the Matching Grants Program, January 1976.

Texas Water Quality Board, Texas Water Quality Standards, The Board, Austin, Texas, February 1976.

Texas Parks and Wildlife Department, Analysis of Texas Waterways, A Report on the Physical Characteristics of Rivers, Streams and Bayous in Texas, Austin, Texas, n.d.

Texas Parks and Wildlife Department, Texas Waterways--A Feasibility Report on a System of Wild, Scenic and Recreational Waterways in Texas, The Department, Austin, Texas, 1973. 
Texas Parks and Wildlife Department, Comprehensive Outdoor Recreation on the Texas Gulf Coast, Texas Outdoor Recreation Plan, (preliminary draft), Austin, Texas, vol. 4, p. 27, 1974.

Texas Parks and Wildlife Department, $A$ Guide to Texas Hunting and Sportfishing Regulations, 1976-77, 1976.

Texas Parks and Wildlife Department, Job Performance Report--Job No. 40: Fish-eating Bird Survey, W. C. Brownlee, Program Leader, Federal Aid Project No. W-103-R-6, November 26, 1976.

Texas Railroad Commission, Rules and Regulations of the Texas Railroad Commission Oil and Gas, Austin, Texas, 1973.

Texas Water Development Board, The Texas Water Plan, Texas Water Development Board, Austin, Texas, 1968.

Thompson, C. R. and G. Kats, "Effects of Continuous $\mathrm{H}_{2} \mathrm{~S}$ Fumigation on Crop and Forest Plants," submitted to Science and Technology, 1977.

U.S. Army Corps of Engineers, Report on Gulf Coast Deep. Water Port Facilities-Texas, Louisiana, Mississippi, and Alabama, Lower Mississippi Valley Division, Vicksburg, Mississippi, 1973. 
U.S. Army Corps of Engineers, Inventory of Basic Environmental Data, South Louisiana, prepared by Engineer Agency for Resource Inventories, U.S. Army Engineer. Topographic Laboratories, Washington, D.C., 1973.

U.S. Army Corps of Engineers, Inventory of Basic Environmental Data, New Orleans-Baton Rouge Metropolitan Area, prepared by Engineer Agency for Resource Inventories, U.S. Army Engineer Topographic Laboratories, Washington, D.C., 1975.

U.S. Bureau of Census, 1969 Census of Agriculture, Volume I, Part 37, Section 1, U.S. Government Printing Office, Washington, D.C., 1972.

U.S. Bureau of Census, Census of Population: 1970, Vo1. 1, "Characteristics of the Population," Part 45, Texas, Section 1, U.S. Government Printing Office, Washington, D.C., 1973.

U.S. Bureau of Census, Census of Population: 1970, Vol. 1, "Characteristics of the Population," Part 20, Louisiana, Table 34, p. 20-101102, Table 129, p. 20-373-374, U. S. Government Printing Office, Washington, D.C., 1973

U.S. Bureau of Census, 1974 Census of Agriculture, Vol. 1, Part 18, Washington, D.C., U.S. Government Printing Office, 1977. 
U.S. Code of Federal Regulations, section $120(\mathrm{~g})(3-4), 1975$.

U.S. Code of Federal Regulations, section 209.120(e)(1), section 209 . $120(\mathrm{~g})(14), 1975$

U.S. Congress, Historic Sites Act of August 21, 1935, Public Law 74-292; 16 U.S.C. $461-67,1970$.

U.S. Congress, National Historic Preservation ACt of 1966, Public Law $89-665 ; 16$ U.S.C. $470,1966$.

U.S. Congress, National Environmental Policy Act, Public Law 91-190; 42 U.S.C. 4321 , et seq, 1970.

U.S. Congress, Archaeological and Historic Act of 1974, Public Law 93-291, no U.S.C. given, 1974 .

U.S. Congress, Geothermal Energy Research, Development and Demonstration ACt of 1974, Public Law 93-410, September 3, 1975.

United States Department of Agriculture, Southwest. Louisiana River Basin Study--The Calcasieu, Mermentau and Teche-Vermilion River Basins, by Soil Conservation Service, Economic Research Service and Forest Service, 1974. 
U.S. Department of Agriculture, Forest Atlas of the South, Southern Forest Experiment Station, New Orleans, Louisiana, 1969a.

U.S. Department of Agriculture, Comprehensive Study and Plan of Development Lower Rio Grande Basin, Texas, in cooperation with The Texas Water Development Board, The Texas Soil and Water Conservation Board and the Texas Water Rights Commission, Soil Conservation Service, U.S. Department of Agriculture, 1969b.

U.S. Department of Agriculture, Texas Coastal Basins, vol. 2, Appendix A, "Soils of the Texas Coastal Basin," in cooperation with The Texas Water Development Board, The Texas State Soil and Water Conservation Board, Interagency Council on Natural Resources and the Environment; Soil Conservation Service, U.S. Department of Agriculture, July 1972.

U.S. Department of Commerce, Fishery Statistics of the United States, Statistical Digest No. 67, U.S. Government Printing office, Washington, D.C., 1976.

U.S. Energy Research and Development Administration, Division of Geothermal Energy, Washington, D.C., Guidelines to the Preparation of Environmental Reports for Geothermal Development Projects, February 1977. 
U.S. Geological Survey, Port Arthur, Louisiana; Texas Land Use N2900-W9200 and Lake Charles, Louisiana; Texas N3000-W9200,

. $1: 250,000$ Maps.

U.S. Geological Survey, Water Resources Data for Texas-Water Year 1975, U.S. Geological Survey, Reston, Virginia, 1975.

U.S. Geological Survey, Hydrologic Unit Map, 1974, State of Texas, Reston, Virginia, 1976.

U.S. Geological Survey, Water Resources Data for Louisiana-Water Year 1976, U.S. Geological Survey, Reston, Virginia, 1976.

U.S. Geological Survey, Hydrologic Unit Map, 1974, State of Louisiana, Reston, Virginia, 1977.

U.S. Department of the Interior, "Endangered and Threatened Wildlife and Plants," Federal Register, vol. 41 (10-27-76), No. 208, Government Printing office, Washington, D.C., 1976.

U.S. Department of the Interior, Final Environmental statement for Geothermal Leasing Program, 4 vols., 1975.

U.S. Department of the Interior, National Survey of Hunting, Fishing and Wildife Associated Recreation, conducted by National Analysts, Division of Booz, Allen \& Hamilton, Inc., 1975. 
U.S. Department of the Interior, The National Register of Historic Places, U.S. Government Printing Office, Washington, D.C., 1976.

U.S. Department of the Interior, "Proposed Rules--Sea Turtles," Federal Register, vol. 41 (6-16-76), No. 208, U.S. Government Printing Office, Washington, D.C., 1976.

U.S. Department of the Interior, Final Environmental Impact Statement Proposed 1977 outer Continental Shelf Oil and Gas Lease Sale Gulf of Mexico, ocs Sale No. 47, prepared by the Bureau of Land Management, Volume 1 of $2,1977$.

U.S. Department of the Interior, "Most U.S. Alligators Come Off Endangered List," News Release, Atlanta, Georgia, January 14, 1977.

U.S. Department of the Interior, Trends in Harvest of Migratory Game Birds Other Than Waterfowl, 1964-65 to 1968-69, Special Scientific Report No. 142, 1971.

Valentine, Jacob M., Jr., John R. Walther, Keith M. McCartney and Larry M. Ivy, "Alligator Diets on the Sabine National Wildlife Refuge, Louisiana," Journal of Wildlife Management, vo1. 36, No. 3, p. 809-815, July 1972 .

Valentine, Jacob.M., Jr., The Vegetation of the Calcasieu Lake Marsh, Cameron Parish, Louisiana, unpublished manuscript, 1974. 
Van Sickle, Virginia R., Barney B. Barrett, Ted B. Ford and Lewis J. Gulick, Barataria Basin: Salinity Changes and Oyster Distribution, Louisiana Wildlife and Fisheries Commission Technical Bulletin No. 20,1976 .

Wallace, R. H., "Abnormal Pressures and Potential Geothermal Resources in the Rio Grande Embayment, Texas," Second Symposium on Abnormal Subsurface Pressure, Louisiana State University Proceedings, p. $87-116,1969$.

Weinstein, David, Theodore J. Gordon and Frank Maslan, "Legal Aspects of Geothermal Energy Development," in Proceedings, Second U.N. Symposium on the Development and Use of Geothermal Resources, San Francisco, California, vols. 3, p. 2447-2455, 1975.

Wesselman, J. B., Ground-Water Resources of Chambers and Jefferson Counties, Texas, Texas Water Development Board Report 133, 1971.

Wesselman, J. B., Ground-Water Resources of Fort Bend County, Texas, Texas Water Development Board Report 155, 1972.

White, Charles J., Effects of River Flood Waters on Brown Shrimp in Louisiana Estuaries, Louisiana Wildlife and Fisheries Commission, Technical Bulletin No. 16, 1973. 
Winn, B. "Pesticides Decimate Transplanted Pelicans," Audubon, vol. 77, p. 127-129, 1975 .

Wintz, W. A., Jr., R. G. Kazmann and C. G. Smith, Jr., Subsidence and Ground-Water offtake in the Baton Rouge Area, Louisiana Water Resources Research Institute Bulletin 6, 1970.

Wood, Leonard A., R. K. Gabrysch and Richard Marvin, Reconnaissance Investigation of the Ground-Water Resources of the Gulf Coast Region, Texas, Texas Water Commission Bulletin 6305, 1963.

Woodbury, H.0., et al., "Pliocene and Pleistocene Depocenters, Outer Continental Shelf Lower Texas," Bulletin, American Association of Petroleum Geologists, vol. 57, p. 2428-2439, 1973.

Wright, A. H. and A. A. Wright, Handbook of Frogs and Toads of the United States and Canada, Comstock, Ithaca, New York, 1949.

Wright, A. H. and A. A. Wright, Handbook of Snakes of the United States and Canada, Comstock, Ithaca, New York, 1957.

Zinn, K. and L. Fryling, "Barred Owl," Audubon Newsletter, Baton Rouge, Louisiana, July 15, 1977. 